BRUNO Di DOTTO

\title{
NEGÓCIOS DA COMPANHIA COM AÇÕES DE SUA EMISSÃO
}

Dissertação de Mestrado

Orientador: Professor Doutor Erasmo Valladão Azevedo e Novaes França

FACUldADE DE DiREITO DA UNIVERSIDADE DE SÃo PAULO

SÃo PAUlO 
BRUNO Di DotTo

\section{NEGóCIOS DA COMPANHIA COM AÇÕES DE SUA EMISSÃo}

Dissertação apresentada à Faculdade de Direito da Universidade de São Paulo, para obtenção do título de Mestre em Direito Comercial.

Orientador:

Professor Doutor Erasmo Valladão Azevedo e Novaes França

FACUldade de DiREITo da UniVERsidAde de SÃo PAUlo

SÃo PAUlO 


\section{Agradecimentos}

Como (eterno) aluno, meus profundos agradecimentos ao meu mestre, Prof. Erasmo Valladão Azevedo e Novaes França, pelo apoio, pelos valiosos comentários, pela paciência e, sobretudo, pelo exemplo.

Aos meus pais, pelo incentivo e apoio.

Aos amigos (e companheiros) que me ajudaram - e suportaram -, meus sinceros agradecimentos: Artur Seixas, Bruno Soares Novo, Evandro Fernandes de Pontes, Luiz Eduardo Malta Corradini, Luis Felipe Spinelli, Maria da Glória Ferraz de Almeida Prado. 
"Se é certo que a mentalidade humana resiste, quanto pode, às inovações, não é menos certo que todo degrau subido de evolução se conta como definitivo, o que dá ao desenvolvimento e ao destino humanos certo sentido unívoco e certa segurança. Marcha-se, ascende-se. De degrau subido é difícil descer-se. Os povos que descem, morrem. Ou ficam como pontos do passado, que contemplassem o correr do tempo". Pontes de Miranda, Tratado de Direito Privado, Vol. 34, p. 5. 


\section{RESUMO}

DOTTO, Bruno Di. Negócios da Companhia com Ações de sua Emissão. 2014. 327 p. Dissertação (Mestrado em Direito Comercial), Faculdade de Direito da Universidade de São Paulo, São Paulo, 2014.

Depois de mais de 30 anos da edição da Lei 6.404, de 15 de dezembro de 1976 e da publicação da Instrução CVM 10, de 14 de fevereiro de 1980, volta novamente o regulador brasileiro a sua atenção para os benefícios e perigos dos negócios da companhia com ações de sua emissão. Tal se torna evidente pela publicação, em outubro de 2013, do Edital de Audiência Pública SDM 11/13, por meio do qual a Comissão de Valores Mobiliários pretende substituir a antiga regra aplicável às companhias abertas por uma nova, de conteúdo mais moderno e aderente à nova realidade.

Desenvolveu-se durante o século XX e XXI o estudo dos negócios da companhia com as suas ações, admitindo-se cada vez mais numerosas exceções ao inicialmente duro e absoluto preceito proibitivo - positivado originalmente pela Aktienrechtsnovelle alemã de 1870. O estudo das finanças sociais e o aprimoramento dos mecanismos de salvaguarda dos interesses protegidos no decorrer do século XX e XXI forçaram (e ainda forçam) a redefinição dos seus contornos jurídicos.

No que diz respeito a estes negócios, ressaltam como interesses escudados aqueles dos credores, dos acionistas e do mercado de capitais (e os investidores que nele atuam) os grupos de referência (Bezugsgruppen) do direito societário. É na proteção de seus interesses que se fundamentam as normas que os regem: a utilização de saldo de lucros tutela os credores, o princípio do tratamento equitativo protege os acionistas e as regras de prevenção a atos manipulativos e de repressão ao insider trading salvaguardam o mercado e seus investidores. É, portanto, no confronto com tais interesses que se deve avaliar a legalidade ou ilegalidade de cada um desses negócios, e não na simples (in)existência de uma exceção legal expressa ao conceito proibitivo geral. O art. 30 da Lei das S.A. estipula condições de validade dos negócios com ações próprias, e não meramente um rol de exceções taxativas.

Palavras-Chave: recompra de ações; sociedade anônima; sociedade comercial; capital social; programas de recompra; mercado de capitais; tratamento equitativo; manipulação de mercado; insider trading. 


\begin{abstract}
DOTTO, Bruno Di. Transactions by the Company in its Own Shares. 2014. 327 p. Dissertação (Mestrado em Direito Comercial), Faculdade de Direito da Universidade de São Paulo, São Paulo, 2014.
\end{abstract}

Thirty years after the enactment of Law 6.404, of December 15, 1976 and CVM Instruction 10, of February 14, 1980, once again have the transactions of the company in its own shares gained the attention of the Brazilian regulatory authority, especially in consideration of the benefits and perils arising from them. This is evidenced by the publication, in October 2013, by the Comissão de Valores Mobiliários of Public Hearing SDM 11/13, the purpose of which is to replace the old rule applicable to public companies by a new one, containing a more modern approach on the subject and a more reality-driven concept.

The studies about the transactions a company is allowed to perform in its own shares have had a great academic and empiric development during the XX and XXI centuries, the result of which has been the gradual acceptance of an ever-increasing list of possible exceptions to the inititally absolute prohibition - originally stated by the german Aktienrechtsnovelle of 1870. The study of financial economics and the improvement of the legal protective measures designed over the last century have forced (and continue to force) a broad redefinition of these transactions' legal boundaries.

In respect to these transactions, the interests of creditors, shareholders and the capital market itself (including the investors which act in it) arise in the center of the legal protective framework - they have been denominated as the reference groups of Corporate Law. Safeguarding their interests is the main purpose of the rules revolving around them: the use of profits and profit reserves safeguards creditors, adherence to the principle of equitable treatment adresses shareholder interests and the rules preventing manipulative acts and insider trading practices sponsor the interests of the capital market and its investors. Therefore, it is mandatory that any interpretation on the legality or ilegality of any given transaction by the company in its own shares be preceded by the examination of these concrete interests; this legal analysis cannot be limited to the verification of an express exception to the general rule. Article 30 of Law $6.404 / 76$ must therefore be read as containing a general validity framework, and not merely an exaustive list of exceptions.

Key-Words: share repurchase; corporation; corporate law; legal capital; repurchase plans; capital market; equitable treatment; market manipulation; insider trading. 


\section{Índice}

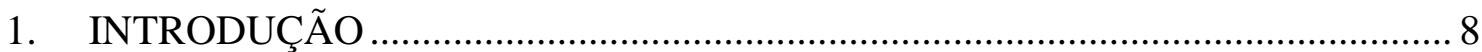

2. FUNDAMENTOS TEÓRICOS E DOGMÁTICOS ............................................ 22

2.1. A Visão Estruturalista de Herbert Wiedemann sobre o Fenômeno Societário como

Ponto de Partida.

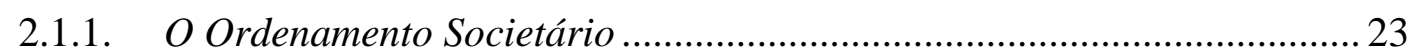

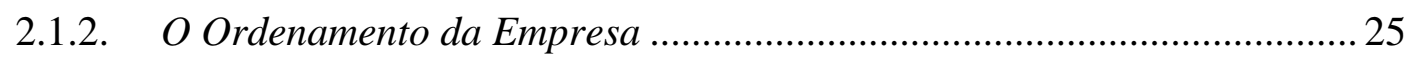

2.1.3. Sociedades de Pessoas e Sociedades de Capitais...................................... 26

2.1.4. O Ordenamento Patrimonial ................................................................... 29

2.2. A Evolução Histórica da Disciplina dos Negócios com as Próprias Ações...........36

2.2.1. Direito Europeu (Comunitário e Interno) .................................................39

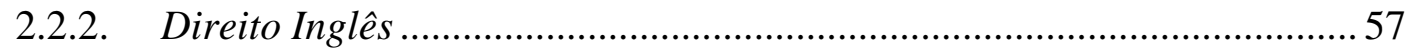

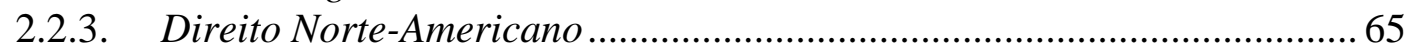

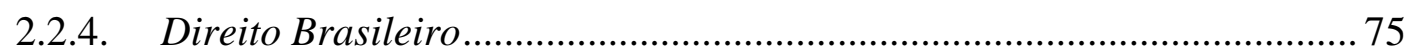

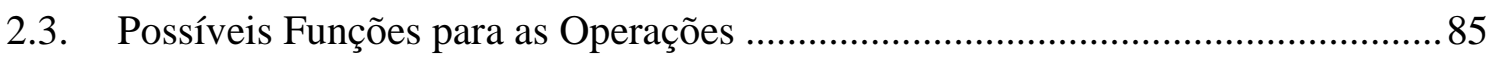

2.3.1. Facilidades na Redução de Capital ........................................................... 85

2.3.2. Gerenciamento Financeiro da Companhia: Liquidez, Política de Dividendos

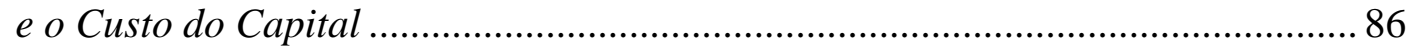

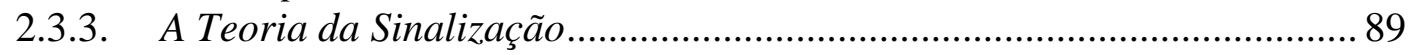

2.3.4. Gerenciamento da Estrutura Societária ................................................... 96

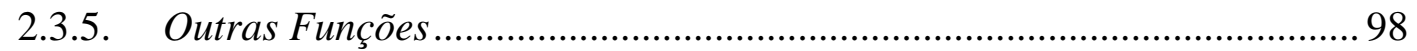

2.4. Do Caráter Exemplificativo dos Negócios Permitidos ..........................................99

3. ASPECTOS PATRIMONIAIS: O INTERESSE DOS CREDORES ....................... 101

3.1. Os Grupos de Referência do Direito Societário: Credores .................................. 101

3.2. Negócios com as Próprias Ações e Ordenamento Patrimonial da Sociedade:

Funções e Disfunções do Capital Social como Garantia dos Credores .......................... 103

3.2.1. Função de Garantia ............................................................................... 103

3.2.2. Negócios com as Próprias Ações como Devolução Ilegítima das

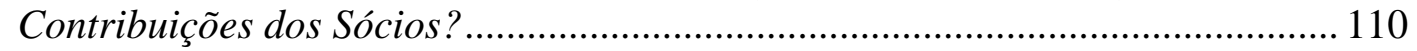

3.2.3. Críticas à Função de Garantia do Capital Social ................................... 111

3.3. Análise Crítica do Artigo 30 da Lei das S.A.................................................... 118

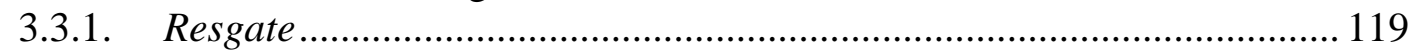

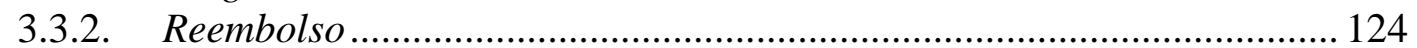

3.3.3. Amortização: Ações de Fruição Sujeitas ao Regime do art. 30 da Lei das S.A. 128

3.3.4. Aquisição para Permanência em Tesouraria ou Cancelamento ............. 131

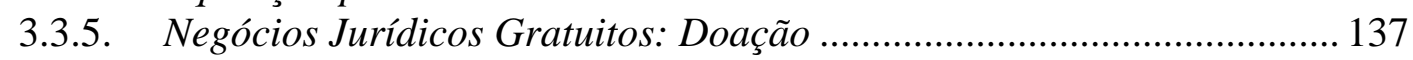

3.3.6. Aquisição das Próprias Ações para Redução de Capital......................... 139

3.3.7. Negócios em Nome elou no Interesse Alheio ........................................... 142

3.3.8. Acionista Remisso, Ações Caducas e Ações Caídas em Comisso ........... 146

3.3.9. Sucessão Universal: Incorporação, Fusão e Cisão............................... 148

3.3.10. Compra e Venda com Pacto de Retrovenda ou Reporte ......................... 150

3.3.11. Instituições Financeiras........................................................................ 155

3.4. Regime Contábil das Ações em Tesouraria ..................................................... 159

3.5. Consequências Civis das Operações da Anônima com Ações de Seu Capital em

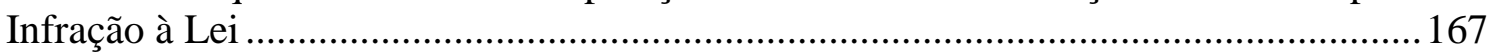

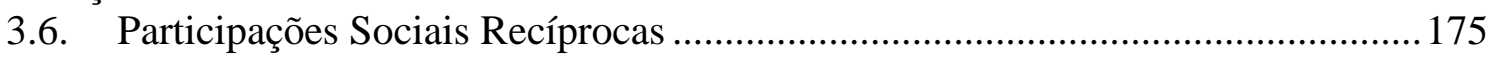

4. ASPECTOS ORGANIZATIVOS: O INTERESSE DOS ACIONISTAS ............ 178 
4.1. A Sociedade Sócia de Si Mesma........................................................................ 179

4.1.1. Da Estrutura para a Função: da Incompatibilidade Absoluta para a Teoria da Confusão 180

4.1.2. Superando a "Confusão”: a Teoria da Ineficácia ou Suspensão dos Direitos 185

4.1.3. A Sociedade sem Sócios 186

4.2. Tratamento Igualitário dos Acionistas 191

4.2.1. Considerações Gerais. 191

4.2.2. O Preço como Fonte de Discriminação: As Formas de Aquisição como Mitigadores 194

4.2.3. Aquisições Privadas...... 198

4.2.4. Alienações Privadas: Vendas, Operações Societárias, Planos de Opção de Compra, Doações 201

4.3. Esvaziamento do Poder de Supervisão da Assembleia Geral de Acionistas ......210

4.4. Influência da Administração na Composição Societária 212

4.5. Regime Jurídico das Ações em Tesouraria: o Fenômeno da Concentração de Direitos e não da Titularidade do Capital Social.

4.5.1. Cálculo de Quóruns de Instalação e Votação ........................................... 214

4.5.2. Direitos das Ações em Tesouraria ........................................................... 219

5. ASPECTOS DE MERCADO: INTERESSES DOS INVESTIDORES ................2234

5.1. Defesa contra Ofertas Hostis de Aquisição de Controle Societário.....................237

5.1.1. Eficácia das Recompras como Tática de Defesa ......................................240

5.1.2. Conveniência das Recompras de Ações como Tática de Defesa: Recompras a Mercado vs. Ofertas Públicas Concorrentes ...................................................... 243

5.1.3. A Rule 13e-1 vs. Rule 13e-4 ............................................................ 248

5.1.4. Algumas Conclusões ............................................................................. 251

5.2. Manipulação de Mercado, Insider Trading e Transparência ...............................253

5.2.1. A Doutrina da Imputação do Conhecimento: a Companhia como Insider de Si Mesma.... 253

5.2.2. Recompras e Manipulação de Mercado 263

5.2.3. EUA: Porto Seguro para Recompras sob a Visão da Manipulação de

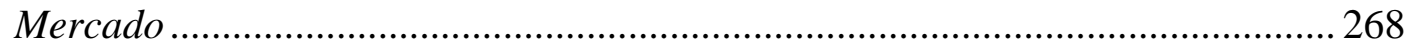

5.2.5. Brasil: Política de Negociação de Ações de Companhias Abertas e Insider Trading 276

5.2.6. Outros Períodos de Restrição para os Quais a Política não é Defesa

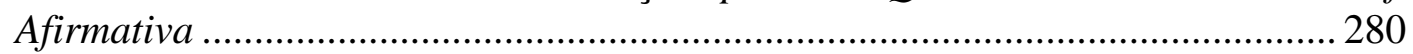

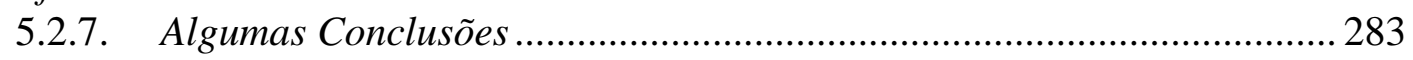

5.3. As Ações Próprias e as Modernas Estruturas e Instrumentos Financeiros ..........286

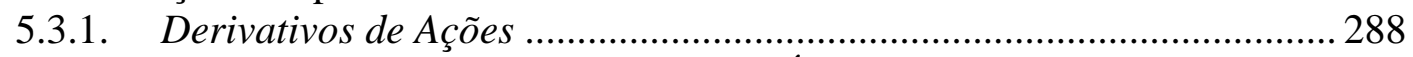

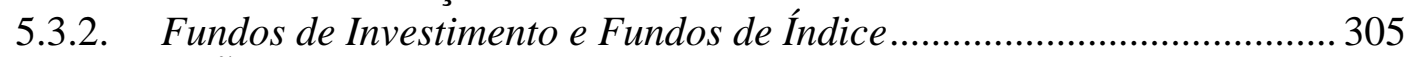

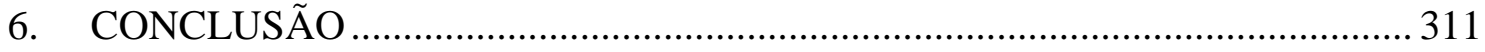

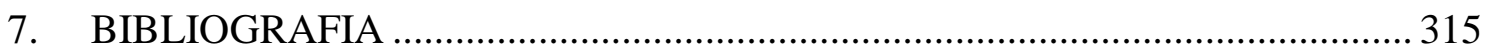




\section{INTRODUÇÃO}

O tema deste trabalho é o das negociações, pela companhia, com ações de sua própria emissão, nos termos do artigo 30 da Lei 6.404, de 15 de dezembro de 1976 ("Lei das S.A." ou "Lei 6.404/76").

O intuito é contribuir para a atualização dos escritos doutrinários sobre este assunto, considerando-se que a última monografia publicada sobre ele data já de 1965, quando o ilustre e saudoso mestre Philomeno J. da Costa escreveu sobre as operações, pela companhia, com ações de seu capital, em sua tese de cátedra para a Faculdade de Direito da Universidade de São Paulo ${ }^{1}$. Afora o óbvio fato de que essa monografia foi escrita antes mesmo da entrada em vigor da atual Lei das S.A. (e que, portanto, já careceria de uma atualização, ao menos, legislativa), não se pode olvidar que "o destino das leis sobre sociedades por ações é serem modificadas sem cessar: seja a pedido do público, que reclama insuficiente proteção contra a fraude, cujos aspectos proteiformes e meios de ação aperfeiçoados frequentemente conduzem ao insucesso dos atos normativos mais bem estudados; seja a pedido do alto comércio e da finança, que entendem poderem se desenvolver sem entraves inúteis, e adaptar suas empresas, sem risco de contrariar proibições em desuso, às formas e novas combinações que o progresso faz surgir incessantemente",2.

Apesar da aparente aberração que configura uma sociedade adquirir as próprias ações e, com isso, ser sócia de si mesma, é igualmente verdade que os países permitem essas negociações em maior ou menor grau, especialmente pelas companhias abertas, permitindo, inclusive a manutenção dessas ações no patrimônio da sociedade emitente na forma de ações em tesouraria. $\mathrm{O}$ instituto tem, em que pesem os diversos potenciais problemas que suscita, diversas finalidades. Dentre elas, podemos mencionar a aquisição para redução de capital (operação permitida nos termos do artigo 30, §1 , "d" da Lei das S.A.), a defesa contra perigos externos (como defesa na hipótese de oferta hostil de tomada

\footnotetext{
${ }^{1}$ Philomeno José da Costa, Operações da Anônima com as Ações de seu Capital, Tese de Cátedra da Faculdade de Direito da Universidade de São Paulo, São Paulo, 1965. Muito embora tenhamos vivenciado a elaboração de dissertações monográficas sobre o tema mais recentemente, consideramos que nunca é demais aprofundar as discussões sobre ele, considerando o estado de evidente negligência em que se encontrou durante muitos anos e a sua inegável complexidade. Talvez as análises mais detalhadas acerca do assunto tenham começado a ser feitas na década de 1990 e no decorrer dos anos 2000 pela Comissão de Valores Mobiliários, sendo que a doutrina passou a ocupar-se mais do assunto em anos bem mais recentes. Cf. Gabriela Bonini Codorniz, Aquisição por Companhias Abertas de Ações de sua Emissão, Dissertação (Mestrado em Direito), Faculdade de Direito da Universidade de São Paulo, 2013; Livinston M. Bauermeister, Aquisição das Próprias Ações pela Companhia Emissora, Dissertação (Mestrado em Direito), Pontifícia Universidade de São Paulo - PUC-SP, 2008.

${ }^{2}$ In Lamy Filho e Bulhões Pedreira, A Lei das S.A., Renovar, Rio de Janeiro, 1992, p. 82.
} 
de controle) ou mesmo a indicação, ao mercado, de que o preço das ações em bolsa é inferior ao seu valor justo (tipping effect ou signalling). Com efeito, todos os objetivos acima interagem com determinados interesses societários ou extrassocietários, mas todos tutelados pelo direito.

É até compreensível que, no Brasil, o assunto não tenha ainda merecido a atenção que requer em todos esses prismas, até porque nosso mercado acionário não é ainda desenvolvido quando comparado com o mercado de capitais de países como os Estados Unidos ou a Inglaterra, não obstante sua evolução recente, especialmente após 2004, de modo que as preocupações atinentes aos reflexos do instituto do ponto de vista dos investidores e do mercado de capitais ainda não foi foco de nenhuma análise aprofundada e recente. Por aqui, o pouco que se escreveu dedicou-se à análise das consequências patrimoniais da operação, tendo em vista o risco de prejudicarem-se os interesses dos credores. Como veremos, todavia, o instituto abrange outros centros de interesses igualmente relevantes para o direito societário e que merecem uma análise específica. Em outros países, ele é amplamente utilizado, especialmente nos Estados Unidos, na Inglaterra e na Alemanha, onde existe rica e abundante doutrina sobre o assunto.

Como se percebe, o instituto é filho natural das sociedades anônimas, o que não significa que não seja relevante para outros tipos de sociedades, mas, para elas, com importância distinta. Nosso intuito será o de tratá-lo sob a perspectiva da sociedade anônima (o que se dirá sobre as anônimas, vale igualmente para as em comandita por ações no tocante às participações dos sócios comanditários, mas a limitada importância prática desse tipo societário torna injustificada uma menção específica), pois abrir o leque de análise também a outros tipos societários, especialmente às sociedades limitadas (e apenas a elas, pois o instituto do capital social como forma de garantia dos credores apenas nestas duas sociedades faz sentido, sendo inútil com essa função nas demais, como veremos), pecaria pelo excesso de generalização. Até porque existem determinados objetivos possíveis apenas nas sociedades anônimas, como, por exemplo, influenciar a cotação dos valores mobiliários em bolsa, o que não ocorre, obviamente, com as quotas de uma sociedade limitada. Não será nosso objetivo, portanto, mencionar o regime de aquisição das próprias quotas de sociedades limitadas ou de qualquer outra forma associativa ${ }^{3}$.

\footnotetext{
${ }^{3}$ Para uma análise destes negócios sob a perspectiva da sociedade limitada, cf. José Alexandre Tavares Guerreiro, Aquisição de Quotas pela Própria Sociedade, in Revista de Direito Mercantil, Industrial, Econômico e Financeiro, n. ${ }^{\circ}$ 36, RT, São Paulo, 1979. Veja-se igualmente sobre o tema Mauro Brandão Lopes, Aquisição das Cotas Sociais pela Sociedade, in Revista de Direito Mercantil, Industrial, Econômico e Financeiro, n. ${ }^{\circ} 25$, RT, São Paulo, 1977, pp. 55 e ss.
} 
A nossa atual lei societária proíbe, genericamente, a companhia de negociar com as ações em que dividido o respectivo capital. Um dos grandes fatores de sucesso da sociedade anônima está no fato de que seus sócios não respondem pelas dívidas sociais, exceto até o limite do valor de subscrição ou aquisição das suas ações e, também, no fato de que o estado de sócio está cristalizado em títulos participativos padronizados (as ações) livremente negociáveis, de modo que as compras e vendas de ações, que transferem, qualitativamente, mais do que um bem, mas sim uma situação jurídica, têm em vista o objeto e não os sujeitos do contrato. Impessoalizam-se, desta forma, as transações com ações ${ }^{4}$. Em uma análise simplista deste fenômeno, poder-se-ia dizer, então, fundamentando-se na diferença entre a esfera jurídica da sociedade e de seus sócios, que à companhia poderia ser permitida a compra e venda de ações de sua emissão.

No entanto, isto é categoricamente proibido pela lei, e o grau da proibição é tão severo que o Código Penal (Decreto-Lei 2.848, de 7 de dezembro de 1940) tipifica como crime de administração fraudulenta de sociedades por ações, no artigo $177, \S 1^{\circ}$, IV, a compra ou venda por diretor da sociedade, por conta dela, de ações por ela emitidas, salvo, naturalmente, nas situações em que a lei o permite, reprimindo a conduta por meio da sujeição dos diretores à pena de reclusão de 1 a 4 anos. No inciso $\mathrm{V}$ do mesmo artigo, também é caracterizado como ilícito penal a aceitação, em garantia de créditos sociais, de ações de emissão da sociedade emitente-credora. Afirma-se, genericamente, que essa proibição severa se dá em "consequência do respeito ao principio da integridade do capital social das anônimas". Nas legislações estrangeiras abrem-se exceções, em maior ou menor grau, ao preceito proibitivo, mas, em geral, cuidam elas de resguardar os devidos limites legais dentro dos quais ocorrem essas operações. As exceções e limites são bastante variados entre os diversos países, mesmo entre aqueles que deveriam estar razoavelmente coordenados por conta da sua integração comunitária (como é o caso dos países membros da União Europeia), o que torna a avaliação comparada do instituto uma tarefa bastante

\footnotetext{
${ }^{4}$ Philomeno J. da Costa, op. cit., p. 2. É esta impessoalização e padronização, que permitem, inclusive, a estrutura de negociação bursátil, onde os adquirentes e vendedores das ações desconhecem a sua contraparte: as declarações de vontade são dirigidas ao mercado de negociação como um todo.

${ }^{5}$ Philomeno J. da Costa, op. cit., p. 3 e também, 255; Tullio Ascarelli, Questões a Respeito das Sociedades Coligadas, in Problemas das Sociedades Anônimas e Direito Comparado, Bookseller, Campinas, 2001, pp. 700 e ss, Trajano de Miranda Valverde, Sociedades por Ações, Vol. I, Forense, Rio de Janeiro, 1959, p. 159 e Waldemar Ferreira, Tratado de Sociedades Mercantis, vol. 4, Ed. Nacional de Direito, Rio de Janeiro, 1958, p. 1053. Afirma o próprio Philomeno, mais à frente, que "[é] mesmo [a proteção do capital social] a base principal da regulamentação das exceções que, em maior ou menor número, existem a respeito". In op. cit., p. 24.
} 
desafiadora, tanto quanto reveladora dos princípios e formas sob as quais cada país enxerga esses negócios jurídicos.

Mas não é só. Os negócios realizados pela companhia com ações de sua emissão têm consequências para diversos grupos de interesses que orbitam em torno da sociedade anônima. Elas podem influenciar o valor das ações cotadas em bolsa, significando uma manipulação de preços ou criação artificial de demanda ou oferta e, aí, atingem os interesses dos investidores e do mercado de capitais; podem, também, contribuir para o desequilíbrio das forças intrassocietárias e para privilegiar determinados acionistas, e, aí, atingem os interesses dos próprios acionistas. Podem, ainda, é claro, significar uma perda patrimonial inescusável para a companhia, atingindo, nessa frente, o interesse dos credores sociais (e, em certa medida, até dos próprios acionistas minoritários). Salta aos olhos, desde logo, a linha mestra que nos guiou na estruturação deste trabalho, consubstanciada no fato de que os negócios da companhia com as ações de seu capital constituem um tema poliédrico, podendo, portanto, ser encarado sob diversos pontos de vista. Guiaremos a nossa visão sobre o instituto a partir desses diversos prismas de interesse, quais sejam, o dos credores, dos acionistas e dos investidores ${ }^{6}$ e, com base nesta repartição de interesses tutelados é que vamos classificar as respectivas normas e enquadrá-las na categoria protetiva que lhes seja aplicável. Longe de tentar esgotar cada um dos temas específicos, nossa intenção é, claramente, a de mapear as interações dos negócios da companhia com ações de sua emissão sob todos os enfoques que lhes podem ser dados, colacionando as principais discussões acerca de cada um dos assuntos e identificando como tais problemas relacionam-se com uma esfera de interesses protegidos pelo direito. Trata-se, verdadeiramente, de uma perspectiva de interesses não rigidamente alternativos entre si, mas que podem integrar-se no exame do estudioso e concorrer para uma explicação completa acerca do fenômeno.

Entendemos que a separação das nossas considerações conforme os grupos de interesse em jogo é útil, especialmente quando lembramos que a nossa doutrina, até hoje, pouquíssima atenção tem destinado às efetivas funções que as operações da anônima com as ações de seu capital possuem na realidade das coisas. Muito se fala sobre a proteção dos credores, ignorando-se os demais prismas em que a análise pode, e deve, ser feita para

${ }^{6}$ Paolo Ferro-Luzzi, em saboroso texto, defende que existem "tre ottiche preferenziali, non sempre chiaramente rese esplicite" quando a doutrina e a jurisprudência se referem ao instituto das ações próprias. Tais óticas, listadas pelo eminente autor, correspondem perfeitamente à lógica dos interesses que utilizamos para estruturar os capítulos desta dissertação. Cf. Paolo Ferro-Luzzi, L'〈<antropofagia〉> societaria; riflessioni sulla natura e sulle vicende delle azioni proprie in portafoglio, in Rivista delle Società, Vol. 46, n. 5, setembro-outubro 2001, pp. 1277 e 1278. 
entender a fenomenologia do assunto em sua inteireza. É, ademais, consequência da inegável evolução do Brasil e de sua inserção no ambiente econômico e no mercado de capitais mundial. Analisaremos, assim, diversas questões de relevo para a compreensão do instituto sobre diferentes ângulos, não apenas enfocando o interesse dos credores, mas também dos próprios acionistas e dos investidores. O estudo será dialético e multifacetado.

Antes de seguirmos delineando a estrutura do estudo e sua fundamentação, gostaríamos de traçar poucas linhas acerca da terminologia utilizada. O título desta dissertação utiliza o termo "negócios" pela companhia com ações "de sua emissão", de maneira diversa, portanto, do que o faz a própria Lei da S.A, onde se lê que é proibido à companhia "negociar com as próprias ações", termo que foi responsável por popularizar, na literatura jurídica, a expressão "negociação" com as próprias ações. Entendemos que a letra da lei é imprecisa em alguns aspectos. Em primeiro lugar, pela utilização da expressão “próprias ações”, que pode englobar aquelas ações que, não sendo de emissão da companhia, lhe pertencem, são "próprias" pois que de sua propriedade ${ }^{7}$. Naturalmente que a lei não quer vedar que a companhia negocie com ações que lhe pertençam e de emissão de outras sociedades, pois esta vedação nada tem a ver com os interesses que o artigo 30 da Lei da S.A. visa a proteger e, daí, entendemos ser mais precisa tecnicamente a utilização da expressão "ações de sua emissão" para melhor designar o objeto da proibição. Em segundo lugar, o termo "negociação" tampouco nos pareceu o mais adequado para integrar o título do trabalho. Na realidade, não é a negociação, no sentido de entendimentos prévios à conclusão do negócio em si, que se quer vedar, mas os negócios jurídicos específicos, quaisquer que sejam e sob qualquer forma que se manifestem, exceto obviamente se permitidos pela lei. Waldemar Ferreira, referindo-se à redação da legislação anterior, critica a utilização dessa expressão (ao contrário de Philomeno J. da Costa, que a elogia) dizendo que "negociação é expressão de muita amplitude, e de sentido destoante do objetivo do preceito" ${ }^{\prime 8}$. Pontes de Miranda também enxerga o assunto da mesma forma, comentando a lei antiga, afirmando que o termo "negociar" foi empregado no sentido técnico que lhe atribui a doutrina jurídica: “a sociedade por ações não pode figurar, direta

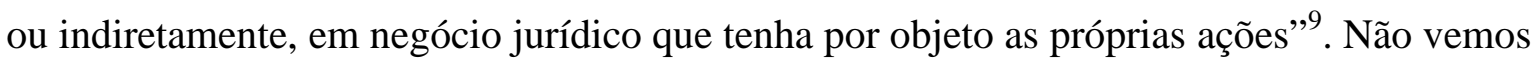

\footnotetext{
${ }^{7}$ No mesmo sentido, Philomeno J. da Costa, op. cit., p. 37.

8. Cf. Tratado de Sociedades..., cit., p. 1053 e 1054. Cf. também Maria Victória Rodrigues Vaz Ferreira da Rocha, Aquisição de Acções Próprias no Código de Sociedades Comerciais, Almedina, Coimbra, 1994, p. 21.

${ }^{9}$ Cf. Pontes de Miranda, Tratado de Direito Privado, Parte Especial, Tomo L, $3^{\circ}$ ed., Borsoi, Rio de Janeiro, 1972, p. 89. Sem razão, a nosso ver, Gabriela Codorniz, que considera, com base em parecer de José Luiz Bulhões Pedreira e Alfredo Lamy Filho, o termo negociar como envolvendo apenas negócios jurídicos
} 
na redação um sentido destoante, como afirma Waldemar Ferreira, mas apenas uma imprecisão técnica, já que negociação não é negócio jurídico, que é a única forma pela qual a companhia pode prejudicar os interesses que a lei visa a resguardar.

Menos preciso ainda, tecnicamente, seria a utilização da expressão "aquisição" ou "recompra" das próprias ações. O contrato de compra e venda é um negócio jurídico regulado pelo Código Civil, mas é apenas uma espécie de negócio e, como já dissemos, a lei visa a impedir qualquer negócio jurídico apto a infringir os preceitos e os princípios de tutela que ela regula. Daí ser muito estreita a utilização da expressão "aquisição" já que ela representa apenas um negócio específico. A expressão "recompra", a nosso ver, é a mais atécnica entre elas, já que parece indicar que a companhia as vendeu originalmente, com pacto de retrovenda, o que soa absurdo ao leitor cuidadoso. A emissão de ações não é um contrato de compra e venda, pois se regula, mormente, por princípios societários e organizativos e não faz qualquer sentido dizer-se que há uma emissão de ações pela companhia com pacto de retrovenda (situação economicamente semelhante ao resgate de ações, de que trataremos abaixo, mas juridicamente distinta).

Sem prejuízo dessas considerações terminológicas, utilizaremos no texto, por vezes, a expressão "negociação com as próprias ações" no sentido que aqui lhe queremos atribuir, de "realização de negócios jurídicos, pela companhia, com as ações de sua emissão". Similarmente, usaremos a expressão "recompra de ações" quando formos nos dirigir às aquisições pelas companhias abertas de ações de sua emissão. "Aquisição" e "recompra" serão utilizadas indiscriminadamente no sentido de "compra e venda".

Retomando a exposição, do ponto de vista de estrutura do estudo e de sua metodologia, cabem, ainda, algumas palavras adicionais.

Para viabilizar essa análise dialética do instituto, precisa-se, também, constatar que ele envolve a análise de questões fundantes do direito societário. Cada capítulo será estruturado de modo a introduzir a análise de cada conjunto de regras por meio do exame genérico da proteção dada ao interesse abstrato-coletivo sob tutela jurídica. Desse modo, por exemplo, quando tratarmos dos aspectos patrimoniais envolvidos nesses negócios jurídicos, exporemos, antes da análise de alguns negócios em espécie, os fundamentos teóricos da proteção dos interesses dos credores no direito societário, por meio do exame, v.g., da relação existente entre o ordenamento patrimonial da sociedade, o capital social e suas funções e os negócios com ações próprias da companhia. Assim seguiremos 
sucessivamente em cada capítulo, iniciando com uma breve análise do telos da proteção de cada grupo de interessados na vida da sociedade. Isto permitirá termos uma base teórica e técnica para a avaliação de cada conjunto de normas.

Entendemos útil elaborar, igualmente, um capítulo introdutório reservado aos fundamentos teóricos e dogmáticos gerais da disciplina que estudaremos, abrangendo questões relevantes para todas as esferas de interesses a serem examinadas nos capítulos seguintes. Com esse intuito, e como forma de fazer uma aproximação geral do instituto, possibilitando melhor análise das soluções do direito positivo, é que nos dispomos a tratar, antes de tudo, de alguns aspectos estruturais do direito societário, como fundamental ponto de partida.

Para isto, utilizaremos a teoria estruturalista concebida por Herbert Wiedemann que, neste aspecto, possui uma das visões mais globais e descritivas sobre o fenômeno associativo de que temos notícia. Sua obra guiará, portanto, o pensamento que trataremos de expor no primeiro capítulo, onde faremos, inclusive, uma breve apresentação de sua teoria $^{10}$, discorrendo sobre a disciplina dos ordenamentos societário, da empresa e patrimonial da sociedade. Além disso, faremos algumas observações quanto aos grupos de referência do direito societário, que representam os interesses considerados juridicamente relevantes para tutela do próprio direito societário, e também quanto às sociedades de pessoas em contraposição às sociedades de capitais, estas últimas de maior interesse para nosso estudo.

Será aqui, igualmente, que analisaremos a evolução histórica do instituto, perfilando-lhe o caminho, com o objetivo de tentar visualizar em que momento, e sob quais fundamentos, começam os negócios, pela companhia, com suas ações, a serem objeto de escrutínio jurídico e rejeição dogmática generalizada. Faremos um paralelo com legislações estrangeiras, especialmente (seja por força das raízes comuns com o nosso direito, seja porque a regulação por lá é extremamente avançada neste aspecto) a alemã, mas também um breve paralelo com as legislações de outros países, como a italiana, inglesa, norte-americana, portuguesa e espanhola. A análise do conteúdo histórico desta disciplina afigura-se-nos de maior importância, mas não se trata aqui, evidentemente, de um exercício de mera erudição: o desenvolvimento e a racionalização desta matéria

\footnotetext{
${ }^{10}$ Herbert Wiedemann é professor catedrático da Universidade de Colônia, na Alemanha, da qual foi reitor, e escreveu em 1980 a sua obra "Gesellschaftsrecht - Band I - Grundlagen", onde, em uma visão extremamente clara e dialética sobre o fenômeno societário, examina os seus aspectos estruturais, separandoos em uma descrição do (i) ordenamento societário stricto sensu; (ii) ordenamento da empresa; e (iii) ordenamento patrimonial. O último será nosso ponto focal, os demais, descreveremos em poucas linhas, apenas para concatenamento lógico do pensamento.
} 
decorreu em grande parte das respostas dos reguladores a crises de confiança no ordenamento pré-vigente. A história dos países e de suas crises, como as vividas pelos Estados Unidos em 1929 e pela Europa no mesmo período e nos pós-guerra nos dá valiosos subsídios para avaliar a racionalidade das normas positivas em consequência dessas crises, e que procuraram endereçar aqueles problemas que a opinião pública rapidamente tratou de atribuir às operações com as ações próprias. Assim, é de interesse notório conhecermos a fundo a história desse "problema" jurídico e qual o caminho trilhado até chegarmos a atual (complexa e fragmentada) legislação sobre o tema. Esta incursão histórica, igualmente, será de utilidade contundente para avaliarmos as razões fundamentais que levaram os sistemas jurídicos anglo-saxônicos, mais notadamente o norte-americano, e os da Europa continental, a diferirem radicalmente sobre a forma de tratar a regulamentação destes negócios, e a forma de classificar os riscos deles decorrentes. As razões para esta disparidade de fundamentos jurídicos serão examinadas a seu tempo.

Não deveriam existir preconceitos no direito. Não é o que ocorre, contudo, quando o assunto se volta a determinados "dogmas" jurídicos, verdadeiros tabus teóricos. Um desses tabus é, definitivamente, os negócios da companhia com as próprias ações. Será impossível tentarmos chegar a uma conclusão razoável sobre o tema, sem conseguir expor ao leitor as vantagens, os intuitos, as razões pelas quais a realização de determinados negócios jurídicos pela companhia com as ações de seu capital é útil e necessária. Nesta linha, exporemos no capítulo introdutório uma lista de fatores que justificam a realização destes negócios, como necessário contraponto à dureza das regras proibitivas. Ao final de contas, apenas será possível realizarmos um sopesamento jurídico válido, se soubermos exatamente o que colocar em cada prato da balança. Caso contrário, qualquer conclusão a que cheguemos (e que longe de avaliarmos como paradigmáticas, pretendem apenas contribuir com um outro ponto de vista, mais funcional, a respeito do assunto) estará mal fundamentada.

O objetivo desta parte inicial é, antes de um exercício de refinamento do conhecimento, levantar as bases históricas e conceituais necessárias para elucidar se as razões tradicionalmente levantadas pela doutrina nacional como fundamento para a proibição genérica das negociações com as próprias ações pela companhia emissora permanecem válidas, ou se, por outro lado, merecem algum relaxamento.

O capítulo seguinte utilizará todas as premissas e pressupostos levantados no capítulo anterior para discorrermos sobre o primeiro grupo de interesses atingidos pelo 
instituto que ora discutimos: os interesses dos credores. $O$ objetivo será, indubitavelmente, de verificar os aspectos patrimoniais envolvidos nos negócios da companhia com ações de seu capital, aspectos estes que, via de regra, justificam as duras limitações a eles impostas. Iniciaremos, portanto, pormenorizando a relação existente entre os negócios que ora são objeto de nossa atenção e o ordenamento patrimonial da sociedade, com uma análise imprescindível da doutrina sobre o capital social e de sua quase mística função de garantia dos credores, posteriormente referindo críticas doutrinárias acerca dessa concepção. Nossa finalidade é analisar criticamente o capital social enquanto garantia dos credores, pois é este o fundamento patrimonial dado tradicionalmente às proibições de que cuidamos. Não vislumbramos ser possível a compreensão do instituto, sem entender a fundo os fundamentos de sua proibição.

Passaremos, também, pelos negócios em espécie, tratando de abranger o maior leque possível de operações com ações de uma companhia emissora em que ela própria figure em um dos polos da relação jurídica. Algumas operações, até mesmo por constarem do texto legal expressamente, são facilmente lembradas, como o resgate, a amortização, o reembolso e as aquisições para manutenção em tesouraria. Outras estruturas são menos óbvias, mas devem igualmente constituir objeto de estudo detalhado, assim para os negócios nos quais a companhia opere no interesse e/ou nome alheios ou nos quais um terceiro esteja agindo em nome ou no interesse da companhia.

Analisaremos, também, e no que for aplicável, as disposições atinentes às companhias abertas para as quais, além das disposições da Lei das S.A., ainda temos outras específicas, que se empregam por força do seu artigo $30, \S 2^{\circ}$. Esse parágrafo dispõe que a aquisição das próprias ações pela companhia aberta obedecerá, sob pena de nulidade, às normas expedidas pela Comissão de Valores Mobiliários (“CVM”), que deu curso ao comando legal contido nesse dispositivo normatizando a "compra de ações emitidas pela própria companhia e a alienação das ações em tesouraria”, por meio da edição da Instrução n. ${ }^{\circ} 10$, de 14 de fevereiro de 1980 ("Instrução CVM 10") "), com base na competência que lhe fora atribuída já pelo artigo 22, $\$ 1^{\circ}$, III da Lei n. ${ }^{\circ} 6.385$, de 07 de dezembro de 1976 (“Lei 6.385/76").

Muito cogitamos a elaboração de um capitulo inteiro dedicado às participações sociais recíprocas. Ao final, decidimos apenas esboçar alguns breves elementos acerca

\footnotetext{
${ }^{11}$ Posteriormente alterada pelas Instruções CVM n. ${ }^{\circ}$ 268, de 13 de novembro de 1997 e n. ${ }^{\text {3 }} 390$, de 8 de julho de 2003. Adicionalmente, a CVM editou, no mesmo dia em que foi publicada a Instrução CVM 10, a Nota Explicativa n. ${ }^{\circ} 16$, de modo a complementá-la e esclarecer o mercado sobre as disposições desse mecanismo.
} 
deste assunto dentro do capítulo dedicado à proteção dos credores, pois essas participações nada mais representam do que uma forma específica, ainda que indireta, de uma negociação com as próprias ações pelas companhias envolvidas na estrutura. Da constatação da existência desse paralelismo entre os dois assuntos, derivou a necessidade de discorrermos brevemente sobre ele dentro deste capítulo, sem qualquer intuito de efetuar uma análise completa do instituto que demandaria uma dissertação monográfica por si só, dada sua evidente complexidade teórica, prática e financeira.

O capítulo seguinte tratará, de maneira semelhante ao anterior, dos negócios realizados pela companhia com as ações de sua emissão sob a perspectiva dos interesses dos acionistas e, pode-se afirmar com convicção, da própria sociedade enquanto organização. Neste capítulo, cuidaremos de expor o assunto privilegiando o olhar sobre consequências organizativas muitas vezes negligenciadas nos escritos sobre o tema. Começaremos, portanto, por elucidar as regras de tratamento igualitário entre os acionistas da companhia, tendo em vista determinar as regras que regem o seu estado de sócio como normas fundamentais da convivência societária. Na medida em que à companhia seja permitido, em maior ou menor amplitude, a realização de negócios com as próprias ações, é possível que se verifiquem, desde logo, tratamentos não igualitários entre os acionistas, privilegiando-se, por exemplo, o acionista controlador ou determinado grupo de acionistas em prejuízo de outros. Temos convicção de que esta matéria levanta grandes discussões doutrinárias, até porque é bastante difícil conceituar-se o tratamento de igualdade nos casos concretos e, ademais, porque não há uma fonte normativa positiva expressa que atribua esse "direito" aos acionistas. Ainda assim, procuramos elaborar uma teoria para o caso dos negócios com ações próprias (aquisições e alienações), mormente em se tratando de negócios privados, que não enrijeça desnecessariamente a companhia e, ao mesmo tempo, que busque endereçar os problemas comumente levantados quanto ao prejuízo de acionistas decorrentes de sua não participação no negócio jurídico do qual a companhia é parte, envolvendo ações de sua emissão. Neste item serão avaliados, também, diversos casos interessantes julgados pelo Colegiado da CVM envolvendo as múltiplas possibilidades de utilização das ações em tesouraria em negócios privados e como, em nosso entender, foram garantidos os direitos de tratamento justo e igualitário entre os acionistas.

Discorreremos, também, sobre a intrigante questão da sociedade sócia de si mesma, para estudarmos os fundamentos estruturais que levaram os pensadores do século XIX a considerar vedadas as operações, não por conta dos riscos concretos que acarreta e traz 
consigo, mas por uma avaliação de incompatibilidade teórica entre a pessoa jurídica (na época, inclusive, conceito incipiente e de teorização bastante confusa) e aquisição das ações de sua emissão. Trataremos de expor como a visão do estudioso passou de um sentimento de estigmatização, de tabu, como falamos, para um sentimento de racionalização da matéria, tendo os argumentos de caráter funcional passado a dominar o discurso sobre a possibilidade teórica da sociedade ser sócia de si mesma e as consequências da manutenção de ações em tesouraria no tocante aos direitos e deveres oriundos das ações. Por exemplo, é possível falarmos no instituto da confusão? Qual é o instituto jurídico que se aplica à "morte" dos (ou de alguns dos) direitos das ações em tesouraria - seria o caso de uma ineficácia? Também nos pareceu importante retomar a discussão (já introduzida no Brasil por Calixto Salomão Filho em 1998) da possibilidade teórica da sociedade sem sócios: temos uma visão pouco contratualista da sociedade, e mais organizativa, de forma que não nos parece absolutamente inconcebível a existência de uma sociedade sem sócios, muito embora nos seja forçoso reconhecer que diversos entraves práticos provavelmente não a viabilizaram na atual conjuntura do direito posto.

Por último, avaliaremos as consequências que resultam dos negócios com as próprias ações para algumas instâncias societárias, especialmente aquelas envolvendo o exercício de direitos dos minoritários, cálculo de quóruns e regime jurídico das ações em tesouraria (argumentando sobre quais direitos efetivamente estão sujeitos aos limites da Lei das S.A. e da Instrução CVM 10). O ponto principal deste item será a avaliação do fenômeno da concentração dos direitos patrimoniais e políticos das ações remanescentes após a recompra, mas não da titularidade do capital social total emitido (eis que as ações em tesouraria são inegavelmente ações emitidas).

A terceira viga mestra do nosso estudo será a avaliação do tema sobre o prisma dos aspectos de mercado que ele suscita, ou seja, em que termos os interesses dos investidores e do mercado de capitais podem ser atingidos e são, portanto, tutelados pelo direito. Começaremos, logicamente, por brevemente recordar as razões pelas quais existem as normas jurídicas acerca do mercado de capitais, e qual a função a que elas se destinam dentro da ordem jurídica, sem nos aprofundarmos muito (mas mencionando quando necessário) as fundamentais noções de finanças societárias exigidas para uma boa compreensão das regras de controle e limitações.

Após essa reflexão inicial, iniciaremos as nossas discussões pela avaliação da utilização das recompras de ações próprias como técnica de defesa contra ofertas hostis de 
aquisição do controle societário. Não o Brasil ${ }^{12}$, mas outros países convivem com o mecanismo da recompra de ações como uma das formas pelas quais a companhia pode defender-se de ofertas não previamente negociadas de aquisição de seu controle. Assim, no momento de anúncio de uma oferta pública de aquisição do controle, a companhia alvo, como se costuma denominá-la, por expressa permissão estatutária, pode começar a lançar ofertas de recompra das próprias ações no mercado (em bolsa, via de regra), atingindo simultaneamente dois resultados que podem inviabilizar a oferta de aquisição em andamento: escalada vertiginosa do preço de mercado das ações, por conta do repentino aumento da demanda por elas (regra básica de formação de preço) e, também, pela diminuição das ações em circulação livre no mercado (i.e., diminui-se a base de acionistas que poderiam votar afirmativamente à oferta). Analisaremos, aqui, a eficácia das recompras de ações como forma de defesa e quais as formas que elas podem assumir (recompras a mercado vs. ofertas públicas de aquisição das próprias ações), comparando-as também com o regime norte-americano (aliás, o regime dos Estados Unidos da América "EUA" será o único utilizado como forma de comparação neste capítulo, dado o desenvolvimento óbvio do mercado de capitais desse país). Muito embora este tópico tenha intrínseca ligação com o interesse dos acionistas, houvemos por bem alocá-lo no capítulo referente ao interesse dos investidores, tendo em vista que é um mecanismo disponível apenas para companhias abertas e que tem evidente impacto no funcionamento do mercado de capitais. Como dissemos, será impossível realizar uma separação estanque entre operações vis-à-vis apenas um interesse digno de tutela: normalmente todos os centros de interesse são tutelados em todos os negócios de que falaremos.

Trataremos, em seguida, das formas sob as quais as ações próprias e as recompras são inseridas dentro do contexto de análise das manipulações de mercado (conforme a definiremos oportunamente) e da negociação das ações com base em informações relevantes e não públicas (chamadas de "privilegiadas") que sejam de conhecimento de

\footnotetext{
${ }^{12}$ Quem melhor enfocou a questão dos negócios com as próprias ações do ponto de vista dos interesses organizativos envolvidos, no Direito brasileiro, foi Fábio Konder Comparato. O autor visualiza estes negócios sob o ângulo do reforço do poder de controle - diferentemente do que é comum nos demais comentários da doutrina, que se limitam a elucidar aspectos patrimoniais da operação -, e ensina que "dentre as razões da proibição, em princípio, de negociação da sociedade anônimas com as ações que emitiu, avulta a de se evitar que os controladores reforcem com isso o seu poder, utilizando-se dos fundos sociais". O autor também nota, mesmo que brevemente, a função de técnica de defesa contra aquisições hostis de controle. Verifica-se um avanço na discussão, com a obra de Comparato, na medida em que não se refere o autor simplesmente à suspensão do direito de voto (regime jurídico das ações em tesouraria, assunto para o qual dedicaremos um item do trabalho) e garantia dos credores (aspectos patrimoniais), fazendo referência a intuitos subjacentes, como a organização do controle societário e a proteção contra aquisição hostil do controle. Cf. Fábio Konder Comparato e Calixto Salomão Filho, O Poder de Controle na Sociedade Anônima, $4^{\mathrm{a}}$ ed., Forense, Rio de Janeiro, 2005, pp. 208 - 213.
} 
algumas pessoas - e, como veremos, da própria companhia. O item abordará intrigantes questões como as relacionadas à teoria da imputação do conhecimento da informação privilegiada à companhia, assim como as regras de manipulação de mercado e as formas sob as quais é possível criar um quadro de proteção para as companhias exercerem seus programas de recompra sem serem alvo de alegações de manipulação: afinal, a mera interferência da companhia no mercado de suas ações não geraria demanda artificial e modificações no preço? Discorreremos sobre o atual formato das políticas de negociação de ações de companhias abertas previstas na Instrução CVM 358, de 03 de janeiro de 2002 (“Instrução CVM 358”) e de que modo essa política protege a companhia que recompra seus papeis de imputações de insider trading. Para ambas as regras (manipulação de mercado e insider trading), traremos a comparação com as respectivas regras norteamericanas, avaliando a posição do direito vigente no Brasil. Também elucidaremos quais os períodos considerados de vedação absoluta à negociação pelas normas da CVM.

Por último, mas não menos importante, convém, necessariamente, analisarmos também outras estruturas que não tão obviamente se enquadram na proibição legal de negócios com as ações próprias. Eis a motivação para que estudemos como o arcabouço regulatório atinente a tais negócios conversa com o desenvolvimento do mercado de capitais, com o surgimento de novas estruturas financeiras (como os fundos de investimento e os fundos "passivos" de investimento em índice de ações) e com o surgimento inexorável de novos instrumentos financeiros de gerenciamento de risco no mercado financeiro e de capitais (swaps, opções e outros derivativos referenciados em ações de emissão da própria companhia geram peculiar perplexidade). Parece cristalino, desta forma, que as disposições do direito societário sobre este assunto são, em última análise, altamente influenciadas por inovações de instrumentos financeiros, que lhes impõem novos e intrincados desafios. Chegaremos a eles em seu devido tempo.

O último capítulo será dedicado à conclusão e ao teste, não propriamente de uma tese, mas de uma suspeita. Considerando o inegável amadurecimento dos mercados financeiro e de capitais e da economia brasileira em geral, parece-nos salutar reavaliar se as normas atualmente vigentes (editadas, como vimos, sob uma realidade absolutamente distinta como era a das décadas de 1970 e 1980) continuam cumprindo o desejado papel ou se, ao contrário, essas proibições (ou os fundamentos sob os quais se baseiam) tendem a não mais refletir a realidade do Brasil e, portanto, merecem modificações, o que nos levará a tentar responder a seguinte inquietação: sopesando-se os objetivos e as soluções atuais do direito positivo, tendo em vista os fundamentos em que se baseiam, é possível que o 
enfoque excessivo no capital social e na proteção dos interesses dos credores nos coloque em uma situação de restrições legais desnecessárias e que prejudicam o desenvolvimento do nosso mercado de capitais e da nossa economia? É recomendável ou útil a sugestão de normas mais flexíveis acerca deste instituto, de modo a contrabalancear eventuais vantagens de sua utilização contra os riscos que ele carrega? Do ponto de vista do mercado de capitais, em que pese a inegável (e tão bem exercida!) função estabilizadora da CVM, em que medida as normas sobre o assunto poderão ser aperfeiçoadas ${ }^{13}$ ?

Por fim, cumpre novamente salientar que não nos dispusemos a esgotar todos os assuntos tangenciados neste estudo. Como afirmamos, o espectro de conceitos e institutos jurídicos atingidos pela análise aprofundada dos negócios da companhia com ações de sua emissão é muito amplo, apesar de o assunto ter merecido apenas um artigo da Lei das S.A. Por isso, objetivamos, acima de tudo, um mapeamento racional sobre eles, evidenciando as discussões acerca de cada um e dando nossa opinião acerca do estado da arte do direito brasileiro sobre cada ponto. Naturalmente, muitos desses assuntos poderiam ser objeto de monografia específica, o que inclusive incentivamos, de forma que seria presunçoso pretender refletir e esgotar todos os temas.

\footnotetext{
${ }^{13} \mathrm{O}$ autor desde já deixa consignada a coincidência: após mais de 30 anos de positivação, a CVM pretende revogar a Instrução CVM 10 e substituí-la por outra, de conteúdo mais moderno e atualizado, conforme estabelecido no Edital de Audiência Pública n. ${ }^{\circ} 11 / 13$, da Superintendência de Desenvolvimento com o Mercado da CVM, publicado em 30 de outubro de 2013. Exporemos no capítulo final e/ou nas nossas conclusões, de que maneira a minuta de nova instrução da CVM endereça algumas das preocupações que levantamos no decorrer de nosso estudo, mas, considerando o prazo da audiência pública (que vai até 03 de fevereiro de 2014), será impossível a este autor incorporar as suas normas ao texto de maneira definitiva, já que a instrução final será positivada pela CVM muito depois do depósito desta dissertação.
} 


\section{FUNDAMENTOS TEÓRICOS E DOGMÁTICOS}

\subsection{A Visão Estruturalista de Herbert Wiedemann sobre o Fenômeno Societário como Ponto de Partida.}

O objetivo declarado de Herbert Wiedemann quando da publicação do volume 1 de sua obra foi o de providenciar uma visão global do ramo do direito que veio a ficar conhecido como "Direito Societário", ramo este que teve notável desenvolvimento científico na Alemanha com o final da Segunda Guerra Mundial. Para isto, o autor subdivide a sua análise em duas grandes vertentes: os princípios estruturais e os princípios valorativos do Direito Societário, sendo que todo o seu exame tem como intuito revelar ao estudioso várias facetas de um único fenômeno da vida ("die verschiedene Aspekte ein und desselben Lebensvorganges bewußt zu machen"14).

Wiedemann parte do pressuposto de que o Direito Societário é, antes de tudo, um "Direito Organizativo" ou "Organisationsrecht", e, como todo ramo do direito que visa a criar e assegurar a manutenção no tempo de uma organização, ele contém, também, várias decisões valorativas (Wertungsentscheidungen). Com isto em mente, Wiedemann enxerga nas regras estruturais dos fenômenos associativos, três grandes conjuntos que, apesar de distintos, acham-se dialeticamente enredados ${ }^{15}$ na complexidade do Direito Societário ${ }^{16}$. A grande vantagem de entender-se o Direito Societário nesta perspectiva estrutural e dialética é que muitos dos problemas enfrentados pela doutrina passam a ter uma explicação na própria estrutura das regras societárias, que partem de decisões valorativas muitas vezes diferentes das do direito civil comum.

\footnotetext{
${ }^{14}$ In Herbert Wiedemann, op. cit., p. 23.

15 "As disciplinas apresentadas não se excluem mutuamente e também não proporcionam uma visão absolutamente única dos fenômenos sociais que o Direito Societário regula. Muitos dos problemas do Direito Societário atingem tanto o ordenamento societário, quanto o patrimonial e o da empresa" ou, no original, "Die dargestellten Sachbereiche schließen sich gegenseitig nicht aus und stellen keine abschließende Beschreibung der vom Gesellschaftsrecht geregelten Lebensvorgänge dar. Viele gesellschafstsrechtliche Fragen betreffen sowohl die Verbandssphäre als auch die Vermögens- und Unternehmensordnung". Cf. Herbert Wiedemann, op. cit., p. 23.

${ }^{16}$ Erasmo Valladão Azevedo e Novaes França, com o apoio em Edmur de Andrade Nunes Pereira Neto, traça interessante paralelo com a teoria da empresa de Alberto Asquini. Enquanto Asquini via no complexo do fenômeno da empresa, quatro perfis distintos (subjetivo, a empresa enquanto empresária ou sociedade empresária; objetivo ou patrimonial, enquanto estabelecimento; funcional, enquanto atividade e corporativo, enquanto instituição), Wiedemann sugere a visualização desses mesmos perfis, mas sob as "lentes do direito societário". Para mais, ver Alberto Asquini, Profili dell'impresa (Perfis da empresa), publicado na Rivista del Diritto Commerciale, 1943, v.41, I; tradução de Fábio Konder Comparato na Revista de Direito Mercantil vol. 104, p. 109. Ver também Erasmo Valladão Azevedo e Novaes França (coord.), Direito Societário Contemporâneo I, Quartier Latin, São Paulo, 2009, pp. 11 e 12.
} 
É o caso, por exemplo, da explicação jurídica da sociedade unipessoal. Inicialmente, ao discorrer sobre o conceito de sociedade (Begriff der Gesellschaft), Wiedemann aponta que ela é, genericamente, uma associação de pessoas para, logo em seguida, trazer uma já tradicional exceção à regra, que é exatamente a sociedade unipessoal, por faltar-lhe o elemento de pluralidade de pessoas. E ele explica: "A permissibilidade de uma sociedade unipessoal pode ser fundamentada do ponto de vista da teoria societária, como do ponto de vista ético. Quando todas as participações societárias de uma sociedade de capitais pertencem a um só membro da associação, é verdade que não existirá mais uma reunião de pessoas, mas a organização patrimonial e a organização da empresa [criadas por meio do vínculo societário] permanecem intocadas. Também o ordenamento societário permanece simplesmente descontinuado [stillgelegt]; de forma latente, permanece existente a comunhão de pessoas, já que as participações societárias não foram unificadas entre si. Pela transmissão de uma ação ou quota da sociedade limitada, pode ser trazida de volta à vida, a qualquer tempo, a sociedade" - grifos nossos ${ }^{17}$. Wiedemann aponta, neste trecho, que os três grandes conjuntos de regras que regulam a estrutura do fenômeno associativo podem explicar com mais facilidade determinados problemas, já que eles interagem dialeticamente um com o outro, mas podem ser visualizados de maneira autônoma.

Pois bem, quais são, então, para Wiedemann, os três grandes conjuntos de regras que podem ser encontradas na legislação societária sobre a estrutura organizacional dos fenômenos associativos? São elas as regras sobre a organização do: (i) ordenamento societário em sentido estrito, (ii) ordenamento da empresa, e (iii) ordenamento patrimonial.

\subsubsection{O Ordenamento Societário}

\footnotetext{
17 No original: "Die Zulässigkeit der Einmanngesellschaft kann rechtstheoretisch wie rechtsethisch begründet werden. Wenn alle Gesellschaftsanteile einer Kapitalgesellschaft einem einzigen Mitglied gehören, gibt es zwar keine Personenvereinigung mehr, die bestehende Vermögens- und Unternehmsnorganisation bleibt aber von dem Mitgliederwechsel unberührt. Auch der Gesellschaftsverband bleibt stillgelegt; latent bleibt die Vereinigung existent, da die einzelnen Gesellschaftsanteile nicht verschmolzen werden. Durch Übertragung einer Aktie oder eines GmbH-Anteils läßt sich die Gesellschaft jederzeit wiederbeleben". Cf. Herbert Wiedemann, Gesellschaftsrecht - Band I - Grudlagen, München, Beck, 1980, pp. 6 e 7.

Notamos, também, que esta visão de Wiedemann reflete, na realidade, uma forma distinta, mas não necessariamente inovadora, de encarar o fenômeno societário. Para tanto, basta lembrarmos que o conceito de criação de uma organização "latente" já era de certo modo direcionado tanto pela teoria do Contrato Plurilateral de Tullio Ascarelli, quanto pela teoria dos contratos associativos de Ferro-Luzzi. Para mais, ver Paolo Ferro-Luzzi, I Contratti Associativi, $3^{\mathrm{a}}$ ed., Giuffrè, Milão, 2001 e Tullio Ascarelli, Problemas das Sociedades Anônimas e Direito Comparado, Bookseller, Campinas, 2001.
} 
Como fenômeno que tem como base a associação de pessoas e a criação de uma organização perene no tempo, orientada para a persecução de uma finalidade comum em torno da qual se vincularam os membros da coletividade (Verbandszweck), é função primordial das regras societárias a regulamentação da vida social ${ }^{18}$. Quando se analisa em profundidade qual é o conteúdo dessas normas regulamentadoras da vida coletiva, verificase que elas dispõem sobre: a definição da finalidade social, a organização societária e o estado de sócio (status socii ou Mitgliederstatus).

A finalidade comum buscada pelas pessoas associadas é, nas palavras de Wiedemann, a "estrela polar" do universo societário, em torno da qual gravitam todos os órgãos sociais e na direção da qual devem atuar os sócios ${ }^{19}$. Esta cláusula é vital para o bom funcionamento da organização coletiva, pois os sócios "coletivizam" seus interesses individuais apenas na medida do necessário para atender ao fim comum, para a persecução do qual voluntariamente se associaram. Em outras palavras, o objeto social ${ }^{20}$ delimita e constrói as fronteiras entre a esfera coletiva e a esfera individual dos sócios ${ }^{21}$.

\footnotetext{
18 "A associação, como qualquer outro sistema social, é organizada, no plano cultural, por sistema jurídico que regula a sua estrutura interna, as relações externas, as ações dos membros e órgãos sociais e a manifestação da vontade coletiva". In Alfredo Lamy Filho e José Luiz Bulhões Pedreira, A Lei das S.A., Renovar, Rio de Janeiro, 1992, p. 29 e também, sobre o assunto, p. 73. Apenas ressalvando que, no trecho, os autores utilizam a expressão "associação" em sentido amplo, englobando fenômenos associativos em geral.

19 "A cláusula do objeto - também chamada de cláusula de finalidade do estatuto social constitui a "estrela polar' do mundo social, sobre a qual devem-se orientar todos os órgãos e sócios". No original: "Die Gegenstands- oder Zweckklausel des Status bildet den 'Polarstern' der Verbandswelt, an dem sich alle Organe und Mitglieder orientieren müssen". In Herbert Wiedemann, op.cit., p. 17. O objeto social é, inclusive, parâmetro para limitação do poder da maioria. Ver Lamy Filho e Bulhões Pedreira, A Lei das S.A., cit., p. 86 .

${ }^{20}$ Wiedemann utiliza a palavra "Zweck" (que, literalmente, significa "objetivo" ou "finalidade") nas expressões "Verbandszweck" ou " Gesellschaftszweck" em sentido mais amplo do que o sentido que se atribui no Brasil ao conceito de "objeto social" - enquanto atividade exercida pela sociedade -, englobando tanto esse sentido (de atividade) quanto o sentido de objetivo social (que, nas sociedades, é sempre a distribuição de lucros). Erasmo Valladão já observou essa diferença cf. Erasmo Valladão Azevedo e Novaes França, Temas de Direito..., cit., p. 627, referenciando a página 155 do livro de Wiedemann, página na qual o autor esclarece os termos (Herbert Wiedemann, op. cit., p. 155). No nosso texto, a expressão tem o significado usado por Wiedemann.

21 "As disposições aplicáveis do estatuto cumprem, então, duas funções simultâneas, por meio da definição da máxima orientativa [Leitmaxime] e do raio de ação da associação". No original: "Die einschlägigen Vorschriften im Statut erfüllen also zwei grundlegende Aufgaben zugleich, indem sie die Leitmaxime und den Aktionsradius der Vereinigung festlegen". Aqui cumpre um breve parêntese de esclarecimento terminológico da língua alemã e que facilitarão a compreensão de certos excertos que traremos neste estudo: Verband é um termo plurívoco em alemão; em sentido estrito designa as associações que perseguem finalidades políticas ou associações de categorias profissionais ou econômicas; já em sentido amplo engloba o termo também as associações propriamente ditas (Verein) e as sociedades (Gesellschaft) (Herbert Wiedemann, op.cit., p. 4). Utilizaremos, portanto, para Verband ou para Vereinigung a tradução de "associação" em sentido amplo, que funciona como "tipo-quadro" geral do fenômeno associativo, sendo o genus, do qual são espécies a sociedade e a associação em sentido estrito. Nossa conclusão sobre esta visão unitária do fenômeno associativo, em paralelo com a doutrina alemã, baseia-se na redação do artigo $44, \S 2^{\circ}$ do Código Civil, que dispõe serem aplicáveis subsidiariamente às sociedades as normas das associações. Ou seja, "[n]a Parte Geral, portanto, são disciplinadas as associações como modelo genérico que compreende as sociedades, reguladas na Parte Especial”. In Erasmo Valladão A.N. França (coord.), Direito Societário Contemporâneo..., cit., p. 12.
} 
Em seguida, as normas que regram a vida societária devem ocupar-se do método de constituição da vontade social e da forma pela qual essa vontade será concretizada perante terceiros. É importante lembrar, neste aspecto, que a sociedade enquanto fenômeno do gênio humano, não possui, por si só, características intrínsecas que lhe garantem autonomia e capacidade de direito, mas é em razão dos seus membros humanos e de uma determinada ordem normativa que se lhe é atribuída vontade e capacidade de direito. Nesse sentido, é função das normas societárias a definição de competências dos órgãos, quóruns de decisão em sede de assembleia, processo normativo de formação da vontade coletiva, forma de presentação da coletividade perante terceiros, etc.

O terceiro grupo de regras neste quesito é daquelas que regulamentam os direitos e deveres de cada sócio perante a sociedade e perante os demais sócios, ou seja, aos direitos e deveres inerentes ao seu estado de sócio, adquirido ipso iure, após a aquisição de uma ação ou quota da sociedade. "Entre os direitos, diferenciamos os direitos de coadministração (direito de voto, competências do administrador), os direitos patrimoniais (participação nos lucros, direitos de fruição), as prerrogativas de controle e acesso à informação, bem como, por fim, o direito de se desvincular da associação (direito de dissolução). Já para as obrigações, contam o dever de contribuir [ao patrimônio social], o dever de participar da administração e o dever de lealdade" ${ }^{, 22}$.

O ordenamento societário em sentido estrito será muito relevante, e a ele voltaremos em detalhes, quando formos analisar os aspectos organizativos decorrentes dos negócios com as próprias ações.

\subsubsection{O Ordenamento da Empresa}

Para as sociedades empresárias, existe um conjunto de regras que visa a regulamentar o exercício da empresa pela sociedade ${ }^{23}$. Wiedemann considera como parte

22 No original: "Bei den Rechten unterscheiden wir dabei die Mitverwaltungsrechte (Stimmrecht, Geschäftsführerbefugnis), die Vermögensrechte (Gewinnbeteiligung, Nutzungsrechte), die Auskunfts-und Kontrollbefugnisse sowie schließlich das Recht, aus dem Verband auszuscheiden (Lösungsrecht). Zu den Pflichten zählen die Beitragspflicht, die Pflicht zur Mitarbeit bei der Geschäftsführung und die Pflicht zur Binnenloyalität (Treuepflicht)". In Herbert Wiedemann, op. cit., p. 17.

${ }^{23}$ A relação entre o Direito Societário e o Direito de Empresa é, por assim dizer, controvertida. Na Alemanha, alguns autores mencionam tratar-se o Direito de Empresa e o Direito Societário, na realidade, do mesmo ramo da ciência jurídica, devendo o Direito de Empresa ser encarado muito mais como uma categoria sistemática do que material. As regras desse direito de empresa, enquanto categoria sistemática, aplicar-seiam a todas as formas societárias que exercessem a empresa e no que fosse pertinente à atividade empresarial em si (como o levantamento de demonstrações financeiras, as regras de publicidade e as regras atinentes aos grupos de empresas). Outros autores defendem ser o direito de empresa uma categoria materialmente distinta de regras, dentro do Direito Societário. Do nosso ponto de vista, entendemos que o Direito de Empresa e o 
das regras atinentes à disciplina da empresa, aquelas que dizem respeito à administração da sociedade (por exemplo, quantas instâncias serão competentes, quem deverá eleger e destituir os administradores, qual sua competência e autonomia dentro do círculo social, etc.). Também pertencente a este conjunto de regras acham-se aquelas que dizem respeito à forma de elaboração, divulgação, auditoria e publicação das demonstrações financeiras (Rechnungslegung) da sociedade, sendo que o próprio autor reconhece que esta disciplina, por força da inevitável proximidade que tem com outros ramos do conhecimento, acabou sendo a que mais se distanciou do Direito Societário para ingressar em ramos como a administração de empresas ou a contabilidade.

Nós gostaríamos, com base nessa última observação, de chamar a atenção para um fato importante. Quando formos analisar a efetividade da garantia indireta dos credores que se consubstancia nas regras de distribuição de lucros efetivos (ou seja, não à custa do capital social), analisaremos também em mais detalhes como funciona a contabilização do lucro neste ponto em específico, para determinarmos em que momento estará atendido o requisito de observância do capital social na apuração de dividendos ou de outras formas de participação nos lucros sociais. A interconectividade entre o Direito e a contabilidade neste assunto será patente.

\subsubsection{Sociedades de Pessoas e Sociedades de Capitais}

Pedimos certo cuidado ao leitor quando falarmos, neste estudo, da diferenciação entre "sociedade de pessoas" e "sociedade de capitais". Estamos utilizando, aqui, a diferenciação de Herbert Wiedemann, e não aquela tradicionalmente adotada pela doutrina $^{24}$. Ao dispor sobre os tipos ideais das sociedades (ideais, no sentido de que são as formas que o legislador genericamente coloca à disposição dos cidadãos, sem uma análise sociológica de sua utilização prática, que Wiedemann também faz quando analisa, então,

Direito Societário não se confundem, devendo ser encarados como materialmente distintos entre si. Isso porque nosso Código Civil possui um livro inteiro dedicado ao Direito de Empresa (anteriormente denominado de "Da Atividade Negocial" pelo professor Sylvio Marcondes, pois, evidentemente, não se podem subsumir às regras de "direito de empresa" aquelas atinentes às sociedades não empresárias), onde se inserem também regras de Direito Societário. Entendemos, portanto, que ao lado das regras puramente societárias que regulamentam a vida e o funcionamento da sociedade, traz o Código Civil regras exorbitantes do Direito Societário, como, por exemplo, as regras atinentes ao estabelecimento e ao empresário individual.

${ }^{24} \mathrm{Na}$ França, similarmente ao que ocorre no Brasil, societés des personnes e societés de capitaux diferenciam-se pela presença ou ausência de intuitus personae na constituição da sociedade, que é exatamente a diferenciação que se faz no Brasil e corresponde em certa medida, no estudo de Wiedemann, à diferença entre Personengesellschaft e Körperschaft. Herculano Marques Inglez de Souza, Direito Commercial, $4^{\text {a }}$ ed., Companhia Dias Cardoso, Juiz de Fora, 1926, p. 107 e 123 e ss. Paulo de Tarso Domingues, Do Capital Social, 2a ed., Coimbra, Coimbra, 2004, p. 17. 
os tipos reais das sociedades), Wiedemann inicia fazendo a contraposição entre as sociedades de pessoas (Personengesellschaften), de um lado, e as "Körperschaften", de outro. Em seguida, Wiedemann diferencia entre, de um lado, as sociedades pessoais (Personalgesellschaften) e as sociedades de capitais (Kapitalgesellschaften).

Como nos ensina Erasmo Valladão A. N. França, "[a] expressão Körperschaft é virtualmente intraduzível. As Körperschaften fazem um contraste com as sociedades de pessoas, mas o seu conceito é mais abrangente do que o de sociedade de capitais, pois as associações também constituem Körperschaften. A distinção está na dependência que a organização societária tem com relação às pessoas dos sócios. Tanto nas sociedades de capitais, como nas associações, não se levam em conta as qualidades individuais dos seus membros. A distinção encontra paralelo no direito anglo-saxão entre corporations e partnerships. (...)" - grifos nossos ${ }^{25}$. Complementando a lição do professor, temos, então, que a diferença entre as Personengesellschaften e Körperschaften reside exatamente no fato de que, nestas, a persecução do fim comum não foi pensada em dependência das pessoas que compõem a sociedade. $O$ ente coletivo aparece com tamanha força perante terceiros que ele praticamente corporifica o objeto social como se fosse um fenômeno social existente paralelamente aos próprios membros da organização societária. Em bela alusão, Wiedemann assim se expressa sobre esta diferença: "e não raro, torna-se tão independente a associação, que a ela é atribuído um interesse próprio que é, até mesmo, contraposto ao interesse dos membros; os membros da Körperschaft são, então, não mais os senhores, mas transformam-se em servidores de um objeto comum que se tornou autônomo" ${ }^{\text {26 }}$. Como consequência, nestas sociedades, é, via de regra, característica a livre circulação das participações sociais (que são divididas, por exemplo, em ações, títulos padronizados e que facilitam sua circulação, ou mesmo possibilitando os títulos ao portador).

Já a diferença apontada entre a sociedade pessoal (Personalgesellschaft) e sociedade de capitais (Kapitalgesellschaft) é outra, sendo que o próprio Wiedemann reconhece o uso plurívoco dessas expressões. Neste sentido atribuído por Wiedemann, as sociedades de capitais são aquelas para as quais é imprescindível a constituição e manutenção de um capital social (Eigenkapital), para o qual são estipuladas diversas

\footnotetext{
${ }^{25}$ In Direito Societário ..., op.cit., p. 17, nota de rodapé XV.

${ }^{26}$ No original: "und nicht selten verselbstständigt sich der Verband so weit, daß man ihm ein eigenes Verbandsinteresse zuspricht und dieses womöglich gegen das Interesse aller Mitglieder auspielt; die Angehörigen der Körperschaft sind dann nicht mehr Herren, sie werden Diener des autonom gewordenen Zwecks". In Herbert Wiedemann, p. 90.
} 
regras. A sociedade de capitais, portanto, possui um patrimônio afetado apenas à consecução de seu objeto social, que é autonomizado por meio da pessoa jurídica e separado formalmente do patrimônio dos sócios (esfera subjetiva). Já nas sociedades pessoais, a lei deixa ao arbítrio das partes a forma de constituição do patrimônio social (estruturado, na ausência da pessoa jurídica, pela Gesamthand), pois, em todas elas existe a previsão de que ao menos um dos sócios será pessoalmente responsável pelas obrigações do ente coletivo.

Wiedemann resume a discussão nos seguintes termos: “A utilização plurívoca do termo 'sociedade de pessoas'- de um lado fazendo referência à estrutura da associação como pequeno grupo de pessoas em contraposição à Körperschaft, e, de outro, fazendo referência à forma de organização do patrimônio social como Gesamthand em contraposição às sociedades de capitais - adicionada à não uniformidade da definição terminológica da sociedade de capitais em si, levam, frequentemente, a desentendimentos. Uma 'sociedade de pessoas capitalista' é uma sociedade de pessoas dominada pelos prestadores de capital (em sua maioria, sócios comanditários); a 'sociedade de pessoas estruturada como 'Körperschaft' é uma Gesamthand que, por força do grande número de seus membros, passou a ser estruturalmente tratada como uma Körperschaft; a 'sociedade de capitais personalista', por fim, é uma sociedade anônima ou uma sociedade limitada, formada, em sua grande parte, por pessoas físicas e cujo círculo social seja fechado" ${ }^{, 2}$.

A sociedade de capitais, para nós, é, portanto, aquela na qual existe uma pessoa jurídica titular de um patrimônio autônomo e destinado à consecução do objeto social, para cuja formação o ordenamento jurídico atribui diversas regras especiais, que visam a contrabalancear o fato de que, nelas, não há um sócio que responda, ex vi legis, pelas obrigações da organização societária. São, no mais, as únicas sociedades que nos interessam para fins do nosso estudo, pois, a princípio, nas organizações societárias desprovidas de capital social (na função de garantia), mas com a correspondente responsabilização pessoal de um ou de uma categoria de sócios pelas obrigações sociais,

\footnotetext{
${ }^{27}$ No original: "Die mehrdeutige Benutzung des Begriffs der 'Personengesellschaft' - einmal in Hinblick auf ihre Verbandsstruktur als Kleingruppe im Gegensatz zur Körperschaft, zum anderen in Hinblick auf ihre Vermögensbildung als Gesamthand im Gegensatz zur Kapitalgesellschaft - und die uneinheitliche Begriffsbildung bei der Kapitalgesellschaft selbst führen gelegentlich zu Mißverständnissen. Eine 'kapitalistiche Personengeselschaft' ist eine von den Kapitalgebern (meist Kommanditisten) beherrschte Personengesellschaft; die 'körperschaftliche Personengesellschaft' ist eine wegen der Vielzahl der Mitglieder körperschaftlich organisierte Gesamthand'; die 'personalistiche Kapitalgesellschaft' schließlich ist eine AG oder $\mathrm{GmbH}$, die sich überwiegend aus natürlichen Personen zusammensetzt und deren Mitgliederkreis geschlossen ist. (...)”. Cf. Herbert Wiedemann, op. cit., pp. 103 e 104.
} 
não faz sentido falar-se em tutela dos credores sociais por meio da vedação à distribuição disfarçada do capital social aos sócios.

\subsubsection{O Ordenamento Patrimonial}

Esta disciplina será, sem dúvida, uma das mais importantes para nosso estudo. Como trataremos de expor abaixo, a proibição às negociações com as próprias ações fundamenta-se em grande parte nas regras que regulam a manutenção do capital social. Para conseguirmos visualizar com clareza a função deste instituto, precisaremos percorrer um caminho um pouco mais longo, analisando, de antemão, o regramento patrimonial da sociedade, considerando, em primeiro lugar, que o capital social não é conceito fundamental à existência de sociedades, ao menos não na função de garantia de credores.

Ao lado da disciplina do ordenamento societário propriamente dito, contêm as regras societárias, em grande parte, conteúdo que regulamenta a organização do patrimônio social, por meio do qual deverá ser perseguido o objeto da sociedade.

Estas normas visam a determinar o maior ou menor grau de separação entre o patrimônio individual do sócio e o patrimônio social pertencente à coletividade e afeto à perseguição do objeto social, constituindo (na falta de uma pessoa jurídica para ser o centro de imputação desses direitos) certa "massa especial" (Sondervermögensmasse), que precisa de regras próprias. Naturalmente, também, que o significado para a organização societária das normas que regulam seu patrimônio, ganha maior ou menor relevância a depender do tipo de fenômeno associativo de que se esteja tratando. Quando se fala de associações em sentido estrito, que não perseguem fins econômicos, então as regras que regulam seu patrimônio aparecem mais como regras de caráter secundário ou subsidiário na vida social, e, ao contrário, em uma sociedade empresária, as regras de formação e manutenção do patrimônio social emergem no centro da regulação da vida social.

Dentro deste quadro, despontam regras que visam a endereçar questões de (i) competência para dispor do patrimônio social, (ii) transferência de patrimônio entre o sócio e a sociedade, além de (iii) responsabilidade nas relações internas e externas. Neste ponto, diferentemente do que ocorre com as sociedades de pessoas, existem inúmeras regras nas sociedades de capitais que visam a regulamentar a constituição e manutenção do capital social, que é conceito afeito tão somente a elas ${ }^{28}$.

\footnotetext{
${ }^{28}$ Isto não quer significar que as sociedades para as quais não se aplique o conceito de capital social, estritamente falando, não possuam regras que disciplinem seu ordenamento patrimonial. Nelas (sociedades de
} 
Em resumo, as regras que disciplinam o ordenamento patrimonial dos fenômenos associativos têm, em seu conjunto, a função de criar um direito real coletivo, diferente da mera comunhão de uma coisa entre indivíduos, como se um típico condomínio civil fosse. O Direito Societário precisa criar regras de imputação de uma coletividade de coisas, autonomizadas das esferas jurídicas das pessoas individuais que delas abriram mão em favor da coletividade (Vermögenseinheit), a uma coletividade de pessoas que passam a ser titulares desse patrimônio em comum. Wiedemann assim se expressa: "o Direito Societário deve, consequentemente, regular as suas próprias formas de imputação [em contraposição às tradicionais regras do condomínio civil, inaplicáveis ao patrimônio social], que determinarão quem será o titular do direito e quem poderá regularmente exercer as prerrogativas oriundas da propriedade, ou, em outras palavras, como as disciplinas do ordenamento societário interagem com a disciplina do ordenamento patrimonial"29.

Como necessário verso da mesma moeda, a disciplina do ordenamento patrimonial também cuida da legitimidade dos credores para exercerem seus direitos de crédito contra o patrimônio social, ou, vale dizer, contra quem os credores sociais devem exercer suas prerrogativas de crédito. É por isso que também correspondem às regras de disciplina do ordenamento patrimonial aquelas atinentes à responsabilidade pelas dívidas sociais. Obviamente, a sociedade responde, ela própria, pelas suas obrigações e pelos atos de seus órgãos (mesmo que ela não possua personalidade jurídica), mas a questão que permanece é como, e em que medida, os sócios devem responder por dívidas sociais e se essa responsabilidade é direta ou tão somente subsidiária. Caso a responsabilidade dos sócios seja, em regra, inexistente pela via normativa, então o ordenamento jurídico precisa conferir outras formas de assegurar os credores sociais, e aqui Wiedemann menciona as regras de constituição e manutenção do capital social (Kapitalaufbringung und Kapitalsicherung). Gostaríamos de chamar a atenção para este ponto, sobre o qual voltaremos a falar logo adiante.

\footnotetext{
pessoas), existem também várias regras que disciplinam a titularidade comum do patrimônio social pelos membros da associação, além das competências para administrá-lo e da responsabilidade dos sócios pelas obrigações contraídas em prol da coletividade. Para um refinamento terminológico entre sociedades de capitais e sociedades de pessoas, fazemos referencia ao item específico onde tratamos sobre o assunto.

${ }^{29}$ No original: "[d]as Gesellschaftsrecht mu $\beta$ folglich seine eigenen Zuordnungsformen finden, die angeben, wer als Rechtsträger anzusehen ist und wer die sachenrechtlichen Herrschaftsrechte verbindlich ausüben darf, das heißt wie Vermögens- und Verbandsorganisation ineinandergreifen sollen". Cf. Herbert Wiedemann, op. cit., p. 19.
} 
Na concretização desta disciplina do patrimônio comum, fornece o ordenamento jurídico duas grandes soluções: a pessoa jurídica e a Gesamthand" ${ }^{30}$ "Como forma de organização do patrimônio coletivo, o direito vigente acaba colocando à disposição dois institutos jurídicos: a Gesamthand e a pessoa jurídica. (...) Ambos os institutos desenvolvem a mesma função no direito vigente, qual seja, a de criar um 'direito real coletivo'. Eles tomam, na concretização desse objetivo, no entanto, diferentes rumos: a autonomização do patrimônio social em contraposição ao patrimônio dos sócios aparece em diversos graus de força" ${ }^{31}$. A pessoa (personalidade) jurídica serve apenas como método de análise da disciplina do patrimônio coletivo ${ }^{32}$ da sociedade. Como no direito brasileiro inexiste a figura da Gesamthand e, ademais, como por aqui quase todas as sociedades são personificadas (exceto a sociedade em comum e a sociedade em conta de participação), detalharemos um pouco mais apenas o ordenamento patrimonial da pessoa jurídica que servirá, posteriormente, para o estudo dos aspectos patrimoniais da nossa matéria.

É no final do século XVII que se iniciam as teorizações ${ }^{33}$ sobre o conceito de pessoa jurídica, em conexão com a criação do conceito de sujeito de direito. Como salienta

\footnotetext{
${ }^{30}$ O termo "Gesamthand", que literalmente se traduz como "mão comum ou coletiva" é um instituto de direito alemão desconhecido em outros Direitos (como reconhece o próprio Herbert Wiedemann: "a Gesamthand - um instituto de Direito Alemão desconhecido, nesta forma, fora dos limites dos países germânicos - já era, na Idade Média, uma forma difundida de organização de patrimônios coletivos pertencentes a comunhões de bens dos casados, comunhões entre herdeiros (Erbverbrüderungen) e coresidentes" ou, no original, "die Gesamthand - ein deutschrechtliches Institut und außerhalb der deutschen Sprachgrenzen in dieser Art unbekannt - war bereits im Mittelalter eine verbreitete Form mehrheitlicher Vermögenzuordnung für eheliche Gütergemeinschaften, Erbverbrüderungen und Lehensgemeinschaften") e que constitui espécie de condomínio. Diz Erasmo Valladão A.N. França que "pode-se fazer, com todas as reservas, um ligeiro paralelo, no Direito Brasileiro, com o patrimônio especial dos sócios na sociedade em comum (art. 988 do CC)" in Temas de Direito Societário, Falimentar e Teoria da Empresa, Malheiros, São Paulo, 2009, p. 631.

${ }^{31}$ No original: "Als Sondervermögensordnung stellt das geltende Recht zwei Rechtsinstitute zur Verfügung: die Gesamthand und die juristische Person. (...) Beide Rechtsinstitute erfüllen im geltenden Recht dieselbe Aufgabe, nämlich ein 'Kollektivesachenrecht' zu gestalten, sie schlagen bei der Verwirklichung jedoch getrennte Wege ein: der Grad der Verselbstständigung des Sondervermögens gegenüber den einzelnen Mitgliedern ist verschieden stark ausgeprägt". Cf. Herbert Wiedemann, op. cit., p. 19.

32 "Veremos, mais de uma vez, que personalidade jurídica e patrimônio separado constituem, afinal, instrumentos de técnica jurídica para a disciplina do comércio com responsabilidade limitada" - grifos nossos. A singeleza e polidez do pensamento impressiona. Cf. Tullio Ascarelli, Problemas..., cit., p. 460, à nota de rodapé 956, in fine. Quanto à terminologia, é importante, também, não confundirmos alguns conceitos. A personalidade jurídica nada tem a ver com a existência da sociedade, como a letra do próprio Código Civil deixa incontroverso (artigos 986 a 996 do Código Civil), pois ela serve como forma de organização (autonomização) de patrimônio, não como requisito de existência da organização societária. Mais abaixo no texto tratamos da diferença fundamental entre personalidade jurídica e limitação da responsabilidade.

${ }^{33}$ Há autores que defendem a presença, no direito privado romano, de um caráter de personalidade da sociedade (societas) distinto da personalidade das pessoas físicas que as compunham (körperschaftlichen Struktur), apontando-se, como exemplo, o caso das grandes societates publicanorum, destinadas ao exercício de certas funções e atividades públicas, como a arrecadação de impostos, o fornecimento de armas ao
} 
Herbert Wiedemann: "No final do século XVII, é Domat quem insere, ao lado das pessoas físicas, as Corporações como objeto do direito das pessoas; aproximadamente na mesma época, Pufendorf cria o conceito da persona moralis - contido na personnalité morale - e desenvolve, por meio da expressão conjunta das pessoas jurídicas e físicas, o conceito central de sujeitos de direito" - os itálicos são do original. No entanto, a grande discussão doutrinária sobre este conceito é filha do século XIX e inícios do século $\mathrm{XX}^{34}$.

A concessão de personalidade jurídica a um patrimônio especial, destinado a uma finalidade específica, tem por função permitir que tal patrimônio organizado e finalístico possa ser, ele próprio, titular de direitos e obrigações (passa de objeto para sujeito de direito) - sendo de se acentuar o caráter finalístico e instrumental da concessão da personalidade: ela é atribuída não em decorrência de uma autodeterminação, como a das pessoas físicas, mas apenas para a consecução de uma finalidade própria, daí a sua instrumentalidade. "A pessoa jurídica é, portanto, uma unidade de imputação de direitos e deveres autonomizada pela lei" ${ }^{, 35}$. Pela atribuição de personalidade, o ordenamento jurídico separa, formalmente, uma parcela do patrimônio das pessoas físicas componentes da pessoa jurídica para o patrimônio que passa a ser próprio desta última (princípio da

exército (heereslieferung) e a exploração de minas de ouro, prata e sal. Ignorando seus aspectos organizacionais (mais atinentes, nas nossas premissas estruturalistas, à disciplina do ordenamento societário), salienta Waldemar Ferreira que elas tendiam a se apresentar como um todo único, adquirindo caráter “corporativo". Cf. Waldemar Ferreira, Tratado de Sociedades..., cit., pp. 130 e ss. No entanto, mesmo que se admita algum resquício do que hoje seria a teoria de uma "pessoa jurídica" já nos entes públicos romanos ou em algumas formas privadas de associação, verdade é que os romanos, em si, não eram afeitos a teorizações abstratas ou metafísicas, de modo que qualquer um desses fenômenos teria sido apenas intuído, muito mais do que teorizado. Seguimos a opinião de Calixto Salomão Filho neste assunto, que afirma categoricamente que "primeiramente devem-se ainda fazer duas observações sobre o direito romano. Em primeiro lugar, ressaltar a total inexistência de um conceito de pessoa dissociável da noção de homo." - grifos nossos (Cf. Calixto Salomão Filho, "Societas" com Relevância Externa e Personalidade Jurídica, in Revista de Direito Mercantil, Industrial, Econômico e Financeiro, v. 81, 1991, p. 66 e ss.). No entanto, não faltam discussões e doutrina respeitável afirmando a existência de determinados resquícios históricos do que veio a ser conhecido com Pufendorf como "persona moralis". A. Santos Justo, citando D'Ors, afirma que "es totalmente contrario a la mentalidad jurídica romana que fines estrictamente comerciales puedan justificar el reconocimiento de la personalidad jurídica, como ocurre en el mundo moderno" in op. cit., p. 77, nota de rodapé 32. Waldemar Ferreira também reconhece que pessoas eram apenas os homens, mas dá mérito aos romanos por terem feito "brotar no espírito humano essa noção jurídica". In Tratado de Sociedades..., cit., p. 122.

34 “Am Ende des 17. Jahrhunderts stellt Domat erstmals neben der physischen Personen die Korporationen als Gegenstand des Personenrechts; etwa gleichzetig prägt Pufendorf den Begriff der persona moralis erhalten in der personnalité morale - und entwickelt mit diesem natürliche und juristische Personen zusammenfassenden Ausdruck den zentralen Begriff des Rechtsubjekts". As grandes teorizações são atribuídas à Savigny (System des heutigen Römischen Rechts, de 1840), pai da Teoria da Ficção, à Otto von Gierke (Deutsches Privat Recht, de 1902), pai da Teoria da Realidade e à Bekker (System des heutigen Pandektenrechts, de 1886) e Brinz (Pandekten, de 1884), que cunharam a Teoria do Patrimônio Especial (Sondervermögen). Para mais, Herbet Wiedemann, op. cit., p. 191.

35 "Die juristische Person ist also eine vom Gesetz verselbständigte Zuordnungs- und Zurechnungseinheit". Herbert Wiedemann, op. cit., p. 196. 
separação ou Trennungsprinzip) $)^{36}$. Consequentemente, este patrimônio autonomizado e afetado à consecução do objeto social é destinado a garantir os credores da sociedade (que não são, por via reversa, credores dos sócios e nem podem acessar, via de regra, o patrimônio destes - ao menos não diretamente) $)^{37}$.

Em outras palavras, o prius na teorização da pessoa jurídica é o patrimônio especial destinado pelos sócios à perseguição de um fim comum, que fica afetado a essa finalidade (Zweckvermögen $)^{38}$. Os métodos de gerenciamento desse patrimônio, formação da vontade coletiva, etc. são consequência, e não pressuposto, da sua autonomia. Em outras palavras, a organização societária não é pressuposto, mas consequência da atribuição de personalidade jurídica à sociedade, já que, concomitantemente com essa atribuição de personalidade, devem ser previstas as regras de atuação e formação da vontade coletiva, agora unificada pela pessoa jurídica. De uma coletividade de pessoas passa-se, então, a uma pessoa coletiva.

Outro ponto de fundamental importância diz respeito à inexistência de correlação lógica entre a atribuição de personalidade jurídica (que é, no fundo, uma opção do legislador) a uma determinada sociedade e a limitação da responsabilidade dos seus sócios pelas obrigações sociais: "a exclusão da responsabilidade dos sócios de uma associação

\footnotetext{
${ }^{36}$ Os sócios, originalmente detentores dos bens individualmente considerados, passam a deter apenas direito de participação (Mitgliedschaftsrechte, quotas ou ações) na pessoa jurídica criada, que detém o patrimônio vertido. O direito que essas pessoas possuíam sobre os bens individualmente considerados, passam a ser um direito proporcional ("quotal", por assim dizer) sobre o patrimônio total da pessoa jurídica no momento de sua liquidação, ou seja, ele não terá mais a prerrogativa de requerer de volta o bem específico originalmente coletivizado. Herbert Wiedemann, op. cit., p. 198.

${ }^{37}$ No fenômeno de criação dos grupos societários, a pessoa jurídica exerce fundamental importância, como se percebe quando uma empresa organiza parte de sua atividade por meio de subsidiárias integrais: a empresa é uma, a sua organização patrimonial é atomizada. Sobre o assunto, Lamy Filho e Bulhões Pedreira esclarecem: "na subsidiária integral o modelo de companhia serve de instrumento para personificar um patrimônio especial e definir suas relações com outras pessoas, mas as relações jurídicas internas próprias da sociedade somente passam a existir no momento em que há admissão de ao menos outro acionista”. Aqui, data venia, entendemos que não é unicamente o tipo societário da companhia que serve ao propósito apontado, mas a personalização jurídica de um patrimônio como forma de organização da empresa. Coincidentemente, a subsidiária integral vem regulada apenas na Lei das S.A. In Lamy Filho e Bulhões Pedreira, A Lei das S.A., cit., p. 79.

${ }^{38} \mathrm{O}$ acento tônico dado à função patrimonial da pessoa jurídica em nada é prejudicado pelos demais direitos que a ela são conferidos. De fato, de forma a possibilitar a individualização e a identificação, no trânsito jurídico, dessa organização patrimonial e societária é que o ordenamento estende à pessoa jurídica, também, alguns outros direitos inerentes à personalidade que sejam necessários para garantir a sua proteção e permitir que ela interaja economicamente com outros participantes do mercado (limitada igualdade de situação "begrenzte Gleichstellung"), como direitos processuais (legitimação ativa e passiva da sociedade em juízo), direitos reais, como a propriedade, e certos direitos pessoais, como nacionalidade e nome. Pelo mesmo fundamento, não são estendidos direitos inerentes à personalidade humana e que sejam absolutamente incompatíveis com esta função (proteção do patrimônio autonomizado e sua organização societária), como os direitos de família e determinadas direitos civis (como o voto). A dimensão de quais direitos devem ser classificados como inerentes exclusivamente à pessoa humana e quais podem ser atribuídos à pessoa jurídica depende do direito positivo vigente. Para mais, Herbert Wiedemann, p. 200 e também 208 a 210.
} 
personificada não é uma consequência lógica ou necessária do instituto jurídico [da pessoa jurídica]" - itálico do original ${ }^{39}$. Mesmo em situações onde o ordenamento jurídico garanta a personalidade jurídica de uma sociedade, é possível que ele também atribua, direta ou subsidiariamente, solidariamente ou não, a um (ou a uma categoria de) sócio ou a todos eles a responsabilidade pelas obrigações da pessoa jurídica. No ordenamento jurídico brasileiro, existem fáceis exemplos disto: (i) as sociedades em nome coletivo são personificadas e, ainda assim, determina a lei responsabilidade solidária e ilimitada dos sócios pelas obrigações sociais (artigos 1.039 e seguintes do Código Civil), (ii) as sociedades cooperativas também são personificadas, mas, nelas, a matéria é dispositiva, havendo a possibilidade de previsão de responsabilidade solidária e ilimitada (artigo 1.095, $\S 2^{\circ}$ do Código Civil), e (iii) nas sociedades em comandita simples (personificadas), o sócio comanditado é solidária e ilimitadamente responsável pelas obrigações sociais (artigo 1.045 do Código Civil). O conceito de limitação da responsabilidade dos (de todos os) sócios - pois que na comandita os comanditários têm responsabilidade limitada - é relativamente recente e apenas na segunda metade do século XVIII ${ }^{40}$ é que se desenvolveu como característica das sociedades anônimas e das sociedades de capitais em geral.

Ademais, o princípio da limitação da responsabilidade dos sócios não pressupõe o da livre circulação das participações sociais - i.e. a limitação da responsabilidade não pressupõe uma organização independente da pessoa de seus sócios - , como o demonstra a sociedade limitada, onde, conforme artigo 1057 do Código Civil, existem fortes restrições à saída e admissão de novos sócios. O mesmo não se pode afirmar, no entanto, quanto à relação inversa: a livre circulação das participações sociais pressupõe uma organização independente da qualidade individual de seus membros que, por sua vez, pressupõe a limitação da sua responsabilidade, pois a irrelevância da pessoa do sócio em relação à sociedade (estrutura de Körperschaft) só é possível em virtude de sua responsabilidade limitada, já que os credores sociais não negociam com a sociedade tendo em vista o patrimônio particular dos sócios, que responderão subsidiariamente: os credores sociais negociam com o patrimônio autonomizado e afetado à atividade social (independentemente

\footnotetext{
39 “[d]er Ausschluß der Haftung der Mitglieder eines rechtsfähigen Verbandes ist keine logische oder notwendige Konsequenz des Rechtsinstitus". Cf. Herbert Wiedemann, op. cit., p. 202.

${ }^{40}$ Cf. Herbert Wiedemann, op. cit., p. 203.
} 
dos seus sócios) que, por isso mesmo, merece (o patrimônio assim autonomizado) proteção diferenciada ${ }^{41}$.

Por outro lado, se é possível, como afirmamos, a existência de uma pessoa jurídica com sócios responsáveis, em maior ou menor medida, pelas obrigações sociais, então, ao revés, é impossível a completa limitação da responsabilidade destes sem o reconhecimento da pessoa jurídica e de regras de preservação do patrimônio destarte autonomizado: “a separação teórica do patrimônio especial vinculado ao exercício da atividade e a constituição de um capital apropriado constitui pré-condição para a completa desvinculação dos sócios quanto à sua responsabilidade" ${ }^{\text {42 }}$. Em outras palavras, a pessoa jurídica (com o consequente patrimônio separado e juridicamente tutelado) é apenas um "meio técnico" para que os sócios possam exercitar o comércio com responsabilidade $\operatorname{limitada}^{43}$, pois ela permite a separação formal e definitiva entre as esferas patrimoniais ${ }^{44}$. É exatamente por essa razão, também, que, em termos técnicos, não se deve confundir a existência de personalidade jurídica com a obrigatoriedade de manutenção de um capital social: este conceito apenas é aplicável naquelas sociedades onde inexiste, por via de lei, responsabilidade dos sócios (em maior ou menor grau) pelas obrigações sociais, pois ele serve, em teoria, como contrabalanceamento legal à inexistência dessa responsabilidade ${ }^{45}$. Em outras palavras, o capital social é conceito logicamente decorrente da limitação de responsabilidade dos sócios e não da personalidade jurídica - daí também ser ele (e seu

\footnotetext{
${ }^{41}$ Cf. Tullio Ascarelli, Problemas..., cit., p. 461. De fato, como conciliar a ideia de que a organização social dependa das características e qualidades individuais de seus membros com a noção de que eles podem mudar incessantemente e sem qualquer formalidade?

${ }^{42}$ No original: "die gedankliche Abgrenzung des unternehmensgebundenes Sondervermögens und die Aufbringung eines angemessenen Kapitals ist Voraussetzung der vollständigen Entlassung der Mitglieder aus ihrer Verantwortung". Cf. Herbert Wiedemann, op. cit., p. 203. O mesmo autor, na página 536, menciona que a limitação da responsabilidade dos sócios cria uma muralha da China entre o patrimônio social e particular.

${ }^{43}$ Cf. Tullio Ascarelli, Problemas..., cit., p. 465. Afirmativamente também Philomeno J. da Costa, op. cit., p. 42.

44 “O problema da limitação da responsabilidade, nas sociedades comerciais, tem a ver com a constituição de um patrimônio separado ou autônomo, que passará a suportar com exclusividade a ação dos credores, nos limites de sua constituição, de acordo com a disciplina legalmente estabelecida para preservar sua integridade. A separação patrimonial pode ter como consectário a limitação da responsabilidade, na medida em que permite a circunscrição de uma massa de bens responsáveis; por tal motivo, patrimônio separado e responsabilidade limitada se conjugam em unidade permanente e indissolúvel, tal como 'irmãos siameses', segundo a feliz expressão de Sylvio Marcondes”. Cf. Mauro Rodrigues Penteado, Aumentos de Capital das Sociedades Anônimas, Saraiva, São Paulo, 1988, p. 13.

${ }^{45}$ Escrevendo em 1888, Dídimo Agapito da Veiga Junior assim se manifestou: “[a] crise financeira de 1838, si desacreditou o regimen da autorização governativa, sob o qual se operara, revelou também a que perniciosas consequências podia levar a responsabilidade limitada, quando explorada pela fraude, que encontra nella fácil meio de illudir os direitos de credores e engodar a ambição e cubiça de prestadores de capitaes pouco experientes." Cf. Dídimo Agapito da Veiga Junior, Sociedades Anonymas - Commentarios, Imprensa Nacional, Rio de Janeiro, 1888, p. 94.
} 
regime jurídico) aplicável, na Alemanha, apenas às sociedades limitadas e às por ações, que são as únicas onde há limitação da responsabilidade de todos os sócios ${ }^{46}$.

Graficamente, teríamos a seguinte linha lógica, onde as setas direcionais indicam que o elemento da esquerda pressupõe o da direita (ou que o da direita é pressuposto do da esquerda): livre circulação das participações sociais » organização social independente de seus membros (estrutura de Körperschaft, sociedade de capitais, no Brasil) » limitação da responsabilidade dos membros (sócios) » pessoa jurídica. Em decorrência da limitação da responsabilidade (e não da pessoa jurídica, daí a ausência da seta direcional), também será necessária a constituição e manutenção do capital social ${ }^{47}$, à variabilidade das pessoas dos sócios contrapõe-se a fixidez do capital social.

Em resumo, a legitimidade da limitação da responsabilidade dos sócios depende, em tese, da constituição e da manutenção de um fundo de garantia aos credores, separado formalmente da esfera subjetiva dos sócios, objetivos que são atendidos por meio da pessoa jurídica e da tutela jurídica do capital social na sua função de garantia de credores, um dos pressupostos chave do nosso estudo. Um dos objetivos do nosso trabalho será analisar se, como e em que medida, ele cumpre esse papel para, depois, verificarmos a sua função na regulamentação das negociações com as próprias ações. Disto, trataremos oportunamente.

\subsection{A Evolução Histórica da Disciplina dos Negócios com as Próprias Ações}

Temos afirmado que a disciplina da negociação com as próprias ações envolve a análise de diversos centros de interesse. Cumpre, neste momento, avaliarmos a partir de

\footnotetext{
${ }^{46}$ Dizemos, aqui, conceito de capital social em sentido técnico-jurídico, como forma de garantir os credores. Sem prejuízo deste conceito de capital social, que serve como garantia de credores (e veremos em que medida isso é verdadeiro), existe também outra noção de capital, que é aquela aplicável às sociedades onde haja sócios ilimitadamente responsáveis: nestas sociedades, por inutilidade do capital social como garantia de credores (pois que nelas os credores possuem prerrogativa de executar os bens particulares dos sócios), o conceito adquire outra função, a de ser o valor destinado à atividade (função de produção) do capital. $\mathrm{O}$ conceito, nestas sociedades onde existe responsabilidade dos sócios, adquire, naturalmente, diverso alcance e daí não haver perplexidade quando o artigo 997 do Código Civil exige que conste no contrato social o “capital da sociedade”. Cf. Paulo de Tarso Domingues, Do Capital..., cit., p. 203. Também Lamy Filho e Bulhões Pedreira (coords.), Direito das..., cit., p. 1347.

${ }^{47}$ Já, por outro lado, em sociedades onde não haja limitação completa da responsabilidade dos sócios pelas dívidas sociais, a pessoa jurídica não é pressuposto, mas, ainda assim, serve como técnica de organização do patrimônio social, facilitando a visualização das esferas pessoais e coletivas. "Nessas sociedades com sócios ilimitadamente responsáveis, os credores sociais não perdem a possibilidade de executar os bens particulares daqueles; conservam-na, entretanto, apenas subsidiariamente, acabando, de outro lado, por ser como privilegiados sobre os bens sociais". Daí também ser, nelas, necessário o regime de publicidade. O regime do capital social em sentido técnico, no entanto, perde força. Cf. Tullio Ascarelli, Problemas..., cit., p. 465, à nota de rodapé 962 e, mais adiante à página 480 .
} 
qual centro de interesses foi derivada a regra proibitiva. Como parece intuitivo, ao menos para fins de ordenamentos jurídicos de origem continental europeia (especialmente o brasileiro, onde não existiu, de forma substanciosa, mercado de capitais até poucos anos atrás), essas regras são uma consequência quase que natural da evolução da disciplina do capital social. Essa herança se reflete constantemente nos escritos sobre o tema, raramente abertos ao exame de outros aspectos do instituto que não o patrimonial.

Quando verificamos o passado do direito comercial e societário, percebe-se que, ao mesmo tempo em que evoluiu o conceito de limitação da responsabilidade dos sócios pelas dívidas sociais, firmou-se, em contrapartida, o princípio da intangibilidade do capital social como forma de garantir os credores sociais (formando o que hoje se conhece como o "regime jurídico" do capital social). "A intocabilidade do capital social tinha que impor a proibição às companhias de negociação com as suas ações" ${ }^{\text {, }}$, diria Philomeno J. da Costa. A evolução histórica do instituto, no entanto, não demonstra um paralelismo tão óbvio com o desenvolvimento do regime do capital social.

Com a Revolução Industrial no século XVIII, os comerciantes individuais da era mercantilista se viram diante dos mesmos problemas enfrentados pelos soberanos quase dois séculos antes, durante a exploração das colônias: o investimento em tecnologia (máquinas a vapor), a transformação da economia para uma economia capitalista de mercado, a especialização do trabalho, a produção em massa para sujeitos indeterminados (empresa) com o consequente aumento acirrado da concorrência requeriam cada vez mais vultosos e fixos aportes de recursos por aqueles que quisessem assumir a função de titulares da empresa. Como sói acontecer, estes agentes do mercado passam a utilizar, na organização de sua atividade empresarial, os instrumentos jurídicos que o ordenamento lhes proporciona: no caso, aqueles oriundos do direito romano ${ }^{49}$ e do direito medieval ${ }^{50}$, como a sociedade em conta de participação e a comandita simples (além, é claro, da sociedade em nome coletivo, que não tinha, porém, sócios investidores; era uma sociedade de empresários).

Logo viram que, para possibilitar os gigantescos empreendimentos que agora eram possíveis, como a construção das estradas de ferro, seria necessária outra forma de acesso

\footnotetext{
${ }^{48}$ Philomeno J. da Costa, op. cit., p. 7.

${ }^{49}$ Para uma boa análise da estrutura da societas romana e seus antecedentes históricos, ver Franz-Stefan Meissel, Societas. Struktur und Typenvienlfalt des römischen Gersellschaftsvertrages, vol. 3, Peter Lang, Frankfurt am Main, 2004 e, também, Vincenzo Arangio-Ruiz, La Società in Diritto Romano, Eugenio Jovene, Nápoles, 1982.

${ }^{50}$ É na Idade Média que os fenômenos associativos entre pessoas para o exercício do comércio florescem, formando-se os primeiros tipos de sociedades dedicadas a essa atividade: "[c]om efeito, a Idade Média, segundo Diurni, é a idade da associação”. Cf. Lamy Filho e Bulhões Pedreira, A Lei das S.A., cit., p. 33.
} 
ao capital dos poupadores. Passaram, então, a clamar acesso àquele instituto que tão bem servira aos Estados na época colonial ${ }^{51}$. Os anos entre 1800 e 1870 foram, sem dúvida, os mais marcantes da história primitiva das companhias, significando o triunfo dos princípios do liberalismo econômico em matéria de sociedades anônimas, com significativas evoluções ocorrendo na Espanha, em Portugal, na Itália, na Alemanha, na Inglaterra e na França.

Com a promulgação do Código Civil francês de 1807, garante-se acesso público às sociedades por ações, dependendo, apenas, de uma autorização do Estado (e não mais de um privilégio legal) para a sua constituição, sendo livre a criação de comanditas por ações, devido ao fato de que, nestas, há um sócio solidariamente e ilimitadamente responsável pelas dívidas sociais, enquanto, naquelas, a regra passou a ser a da limitação completa da responsabilidade (artigo 33 do Código Civil francês de 1807). Nenhuma referência havia, nesse momento, aos lucros e sua forma de apuração, nem às demonstrações financeiras, o que colocava em grande risco os credores sociais, perdendo de um lado o acesso ao patrimônio pessoal dos sócios, mas não ganhando contrapartida legal em defesa de seus interesses ${ }^{52}$. Essa situação foi alterada por meio da edição de Lei de 17.07.1856, que dispunha sobre as comanditas por ações ${ }^{53}$, da Lei de 16.5.1863, que reproduziu esse conteúdo para uma nova forma de sociedade por ações denominada "sociedade de responsabilidade limitada”, acrescentando novas normas às sociedades por ações que hoje

\footnotetext{
${ }^{51}$ A passagem da Idade Média para a Era Moderna, com os descobrimentos da América e do caminho das Índias pelos navegadores portugueses, espanhóis, franceses e ingleses, marcou o desenvolvimento de novas formas de associação. Diferentemente do que ocorria no comércio privado em geral (que continuava utilizando as formas societárias medievais, ainda satisfatórias às suas necessidades), também em desenvolvimento na época pela produção industrial de pequena escala, as navegações marítimas e a exploração e domínio das colônias requeria um enorme volume de capital com o qual os recém-formados Estados Nacionais não podiam arcar sozinhos. A junção de elevados custos com o alargamento do tempo de maturação do investimento (entre o aporte de capitais e a aferição do lucro) levou à necessidade de formação de um novo tipo de associação dos titulares de capital. Com o surgimento da Companhia Holandesa das Índias Orientais, em 1602, cristaliza-se esta nova forma de associação, que Waldemar Ferreira classificou como acontecimento de "projeção verdadeiramente ímpar e de incalculáveis resultados na vida econômica do mundo, bem assim na ordem política e social". In Tratado de Sociedades..., cit., p. 226. Cf. também Trajano de Miranda Valverde, Sociedades..., cit., pp. 10 e ss.

${ }^{52}$ In Lamy Filho e Bulhões Pedreira, A Lei das S.A., cit., pp. 59 e ss.

${ }^{53}$ Essa lei incluiu algumas normas que "visavam assegurar a fixidez, realidade e integridade do capital social (...): exigência de valor nominal mínimo de 100 a 500 francos, conforme o capital social fosse menor ou maior do que 2.000 francos (art. $1^{\circ}$ ); subscrição de todo o capital social, com integralização de, no mínimo, $25 \%$, como requisito para a constituição da sociedade (art. $1^{\circ}$ ); obrigatoriedade da forma nominativa das ações até sua integralização (art. $2^{\circ}$ ); proibição de negociação das ações antes de realizados 4/5 do seu valor (art. $3^{\circ}$ ); responsabilidade do subscritor pela integralização das ações, mesmo após a cessão da ação não integralizada (art. $3^{\circ}$ ) (...)”. In Lamy Filho e Bulhões Pedreira, A Lei das S.A., cit., p. 63.
} 
são fundamentais pilares de seu regime jurídico ${ }^{54}$ e da Lei de 24.7.1867 que introduziu uma completa e complexa disciplina da sociedade anônima e vigeu, com diversas modificações, até o advento do Código de Sociedades Comerciais de $1966^{55}$.

Nestes diplomas franceses surgem, portanto, a maior parte das regras atinentes à formação, manutenção e integridade do capital das companhias, ingressando, ainda que intuitivamente, os interesses dos credores na esfera dos grupos de referência do direito societário de que falamos acima. Contudo, ainda seria necessário desenvolvimento teórico para possibilitar a existência de discussões concretas sobre a vedação dos negócios com as próprias ações. Saliente-se que, até a metade do século XIX, nenhuma lei reconhecia às companhias capacidade jurídica para possuir ações, “o que era considerado impróprio e perigoso" ${ }^{56}$, quanto menos as próprias ações. A ideia de Philomeno J. da Costa, portanto, de que a evolução do regime do capital social "impôs" a necessidade de vedação destes negócios jurídicos é imprecisa.

A primeira norma a tratar da questão específica das ações próprias foi a lei alemã de 1870 (Erste Aktienrechtsnovelle), muito tempo depois, portanto, do surgimento das primeiras regras de proteção aos credores da companhia, já presentes na época da constituição das primeiras companhias de navegação, e quase 70 anos após a promulgação do Código Civil francês de 1807.

\subsubsection{Direito Europeu (Comunitário e Interno)}

Atualmente, quase todas as leis de sociedades por ações na Europa partem, no tocante à disciplina jurídica dos negócios com ações de emissão própria, de um preceito proibitivo, sendo esses negócios vedados genericamente, exceto nos casos em que as leis, em maior ou menor medida, excetuam a proibição ${ }^{57}$. Por lá, o preceito proibitivo surgiu historicamente em decorrência, em parte, de razões dogmático-estruturais (atreladas à impossibilidade teórica, vislumbrada pelos pensadores, de uma companhia tornar-se sócia

54 Princípio da maioria nas deliberações sociais, formalidades para alteração do estatuto, inclusão de referência à "responsabilidade limitada" na denominação da companhia, dissolução em caso de perda de mais de $3 / 4$ do capital social, etc.

55 “De instrumento jurídico 'excepcional', a sociedade anônima passou a constituir uma forma jurídica 'normal' da empresa econômica e a sua adoção se espalhou pari passu com a industrialização dos vários países”. Cf. Tullio Ascarelli, Problemas..., cit., p. 459. Cf., de maneira entusiasmada, Dídimo Agapito da Veiga Junior, Sociedades Anonymas..., cit., pp. 13 e 14.

${ }^{56}$ A possibilidade de uma companhia adquirir ações de outra foi genericamente reconhecida pela primeira vez nos Estados Unidos no final da década de 1860 e somente veio a ser admitida na Europa continental por decisão jurisprudencial francesa de 1878. Cf. Lamy Filho e Bulhões Pedreira, A Lei das S.A., cit., pp. 77 e ss.

${ }^{57}$ Seguiremos de perto, no essencial e resumidamente, a exposição de Maria Victória Rodrigues, op. cit., pp. 48 e ss., que, por sua vez, baseou-se em Velasco San Pedro. 
de si mesma - sobre o que discorreremos em item específico) e, também, em decorrência dos riscos que as operações trazem consigo, como teremos oportunidade de aprofundar (riscos de redução oculta do capital social, especulação com o valor das ações em mercado, consolidação ou concentração do poder societário, etc.). Na medida em que se desenvolveu o estudo sobre a matéria, alterou-se a fundamentação da proibição, passando um raciocínio de cunho econômico-funcional a prevalecer na discussão doutrinária.

$\mathrm{Na}$ origem histórica europeia, a primeira regra proibitiva positivada de que se tem notícia adveio, como se disse, com a lei alemã de 11 de junho de 1870, conhecida como Erste Aktienrechtsnovelle, que determinava, no seu $§ 215,3$, que a sociedade anônima não podia adquirir (nem amortizar, salvo autorização estatutária) as próprias ações ${ }^{58}$. Mas mesmo antes da regra de 1870, as companhias alemãs já se utilizavam da operação, mormente em decorrência da ausência completa de regulação (ou proibição). Conforme relata Alexander Kitanoff, citando Renaud, a razão da recompra de ações próprias era a de possibilitar o aumento de valor das ações remanescentes, já que o patrimônio social ficaria dividido por número menor de ações, assim como o pagamento de dividendos ficaria concentrado em menor número de ações ${ }^{59}$. A Gesetz über die Aktiengesellschaften für die Königlich Preussischen Staaten, de 09 de novembro de 1843, proibia genericamente às sociedades por ações, nos $\S \S 15$ e 17 , a devolução pela sociedade das entradas de capital dos sócios, inclusive por meio de pagamentos. "Apesar de, do ponto de vista estritamente conceitual, podermos subsumir a recompra de ações como devolução de capital nos termos dos mencionados dispositivos, era considerada a recompra de ações majoritariamente como permitida" ${ }^{\prime 60}$. Interessantíssimo notarmos que, já antes de 1870, as primeiras companhias da época constituíam as chamadas "reservas de amortização" (amortisationsfonds), não por força legal, mas por previsão estatutária, com recursos oriundos de lucros da companhia e cuja destinação era a recompra de ações. Com isso

\footnotetext{
58 “A sociedade por ações não pode adquirir suas próprias ações. Ela tampouco pode amortizar as próprias ações, exceto se o estatuto social original, ou uma deliberação dos acionistas modificativa deste, assim o permitir." No original: "Die Aktiengesellschaft darf eigene Aktien nicht erwerben. Sie darf eigene Aktien auch nicht amortisiren, sofern dies nicht durch den ursprünglichen Gesellschaftsvertrag oder durch einen, den letzteren abändernden, vor Ausgabe der Aktien gefaßten Beschluß zugelassen ist". A palavra "amortisiren" consta no texto original do Norddeutsches Bundesgesetzblatt de 1870 com essa grafia, ao contrário da sua atual forma: "amortisieren".

${ }^{59}$ Cf. Alexander Kitanoff, Der Erwerb eigener Aktien - Aktienrückkäufe und Interessen der Gläubiger, Aktionäre und des Kapitalmarkts, Peter Lang, Frankfurt, 2008, p. 16.

${ }^{60}$ No original: "Obwohl man rein begrifflich den Rückkauf von Aktien als Rückzahlung unter die genannten Vorschriften subsumieren könnte, wurde der Rückkauf von Aktien überwiegend für zulässig erachtet". Cf. Alexander Kitanoff, op. cit., p. 16.
} 
(utilização de lucros na recompra de ações) entendia-se não atingido o preceito proibitivo dos $\S 15$ e 17 anteriormente mencionados ${ }^{61}$.

Na Itália, a proibição surgiu como direito positivo com o Codice di Commercio del Regno d'Italia de 1882, no seu artigo 144. A legislação italiana de 1882 é interessante, pois ela indica não só o preceito proibitivo, como também estipula as condições sob as quais as aquisições seriam permitidas (a legislação alemã de 1870 não continha exceções). A redação dessa norma italiana era a seguinte: "gli amministratori non possono acquistare le azioni della società per conto di essa, salvo il caso in cui l'acquisto sia stato autorizzato dall'assemblea generale, e sempreché si faccia con somme prelevate dagli utili regolarmente accertati e le azioni siano liberate per intero. In nessun caso essi possono accordare sulle azioni stesse alcuna anticipazione". Esta configuração normativa era fruto de anseios da prática comercial, em especial tendo por base decisões das câmaras de comércio de Milão e de Torino ${ }^{62}$. Segundo a doutrina italiana, essa norma foi positivada justamente em decorrência do receio de que essas operações tivessem consequências negativas para os credores ("avrebbe inciso negativamente sulla garanzia oferta ai creditori sociali del capitale sociale") e poderia abrir espaço para uma influência ilegítima da administração na esfera societária ("avrebbe potuto offrire agli amministratori uno strumento per influire indebitamente sulle deliberazioni della assemblea e sul corso delle proprie azioni" $)^{63}$. O descumprimento da regra já era uma sanção penal, pelo artigo 247 do mesmo diploma (apesar de não haver disciplina clara quanto às consequências civis da sua violação).

O Código de Comércio italiano de 1882 estabelecia já os três requisitos básicos que seriam adotados pela legislação italiana posterior na regulação da temática, e que perduram até o direito hoje vigente: (i) autorização pela assembleia geral, (ii) utilização do saldo de lucros (utili regolarmente accertati) e (iii) ações $100 \%$ integralizadas, demonstrando certo avanço do pensamento italiano à época.

\footnotetext{
${ }^{61}$ A alteração radical de posicionamento pode ter tido influência na crise da bolsa de Viena de 1869, onde as ações próprias parecem ter tido papel relevante, apesar de, na Alemanha, não haver experiência semelhante no período. Cf. Alexander Kitanoff, op. cit., pp. 16 a 18. Barbara Pozzo relata que a crise do megaempresário das ferrovias prussianas Henry Bethel Strousberg, na primeira metade do século XIX, deveu-se em parte também a negócios com ações das suas companhias. Cf. Barbara Pozzo, L'acquisto di Azioni Proprie - La Storia di um Problema in un'Analisi di Diritto Comparato, Giuffrè, Milano, 2003, p. 5.

${ }^{62}$ Cf. Barbara Pozzo, op. cit., p. 24. Para uma exaustiva análise histórica do surgimento do art. $144 \mathrm{em}$ comento, confira-se o excelente estudo de Scotti Camuzzi, Acquisto delle Proprie Azioni, Utile e Utile d'Esercizio, in Rivista delle Società, Vol. 15, n. ${ }^{\circ} 3 / 4,1970$, pp. 617 e ss.

${ }^{63}$ Cf. Barbara Pozzo, op. cit., p. 181.
} 
$\mathrm{Na}$ Espanha, duas leis de 1856 proibiram que as instituições financeiras concedessem empréstimos tomando como garantia as próprias ações, proibição que parece ter tido origem nos escândalos financeiros de 1845-1846, relatando a doutrina que o banco de Isabel II em determinado momento havia aceitado mais de metade das próprias ações em garantia ${ }^{64}$. A proibição veio a ser consagrada expressamente no Código de Comércio espanhol de 22 de agosto de 1885 , no artigo $166^{65}$, que proibia genericamente as aquisições, exceto no caso de amortização.

O regime europeu foi sofrendo diversas transformações no decorrer do tempo, especialmente tomando em conta as circunstâncias econômico-sociais de cada época, passando-se gradativamente a adotar uma atitude mais pragmática. Os medos exagerados das épocas originárias foram gradativamente sendo sopesados à luz das potencialidades das operações. Maria Victória Rodrigues discorre sobre três etapas visíveis na evolução teórica europeia e que nós transformaríamos em quatro.

O primeiro período é o da proibição tendencialmente absoluta, que tem seu nascimento no último terço do século XIX com o surgimento das legislações comerciais europeias de cunho liberal, conforme tivemos a oportunidade de apontar nos parágrafos acima. Neste período, a vedação ou era absoluta, como, por exemplo, na Aktienrechtsnovelle alemã de 1870, que sequer a amortização das ações permitia, ou as exceções tendem a ser em pequeno número, como nos códigos espanhol e italiano (neste, o sistema não era de "exceções específicas", mas de "condições de validade" - o que, aliás, nos parece conceito extremamente útil de tratamento da matéria, ainda nos dias de hoje), vimos acima. O único país do período a ter uma legislação mais flexível neste ponto era a Suíça, cujo Código de Obrigações de 1881 pregava um critério mais amplo. O artigo 628 do Schweize Obligationenrecht continha um regime bastante complexo sobre a questão. Esse artigo determinava, primeiramente, que a companhia não poderia adquirir suas próprias ações. No entanto, o mesmo artigo já listava quatro exceções, muitas das quais continuaram sua trajetória até os dias atuais, que eram: (1) para possibilitar uma amortização estabelecida nos estatutos; (2) para possibilitar o reembolso de capital, observados os requisitos para a redução do mesmo; (3) aquisições em via executiva,

\footnotetext{
${ }^{64}$ Cf. Velasco San Pedro, La adquisición por la sociedad emisora de sus proprias acciones, Valladolid, Editorial Lex Nova, 1985 apud Maria Victória Rodrigues, op. cit., p. 50.

${ }^{65} \mathrm{O}$ texto do art. 166 era o seguinte "Las compañias anónimas únicamente podrán comprar sus proprias acciones con los beneficios del capital social para el solo efecto de amortizarlas. En caso de reducción del capital, cuando procedirse conforme a las disposiciones de este Código, podrán amortizarlas también con parte del mismo capital, empleando al efecto los medios legales que estimen convenientes." No artigo 167, proibia-se a elas de receberem as próprias ações em garantia, de maneira absoluta.
} 
quando necessárias para satisfazer um crédito da sociedade; e (iv) aquisições ligadas ao objeto estatutário da sociedade ${ }^{66}$. Cabe salientar, ainda, que foi a legislação suíça a primeira do mundo a preocupar-se com a criação de mecanismo de controle a posteriori da operação e com a previsão de um regime jurídico diferenciado para as ações assim adquiridas pela sociedade. Dessa forma, o mesmo artigo 628 determinava (i) o cancelamento obrigatório das ações adquiridas para amortização ou reembolso, não sendo possível a sua recolocação no mercado; (ii) a obrigação de revender as ações recebidas em via executiva ou no cumprimento do objeto social o mais rápido possível; (iii) a obrigação de informar todas as aquisições e alienações de ações próprias ocorridas durante o exercício social; (iv) a proibição de que as ações adquiridas pela sociedade fossem representadas em assembleia geral. Todo este regime diferenciado coloca a Suíça, sem dúvidas, entre os países pioneiros a respeito da matéria.

A rigidez do regime neste primeiro período foi contrabalanceada por um período de intensa discussão doutrinária e jurisprudencial, o que levou, se não a nível positivo, ao menos a nível de teoria jurídica, a determinadas flexibilizações que puderam, posteriormente, ser incorporadas por ocasião das reformas dessas primeiras leis. Assim aconteceu, por exemplo, com a promulgação da Zweite Aktienrechtsnovelle alemã de 1884, que incorporou ao seu texto algumas exceções discutidas no período de vigência da legislação de 1870 (como, por exemplo, a permissão jurisprudencial para a aquisição de ações próprias no âmbito de reduções de capital, o que era formalmente proibido pela lex absoluta consubstanciada na Erste Aktinrechtsnovelle ${ }^{67}$ ), no que foi seguido pelo Handelsgesetzbuch de 1897, que pouco alterou o regime da segunda Aktienrechtsnovelle ${ }^{68}$.

66 O artigo 628 do Código das Obrigações Suíço de 1881 tinha a seguinte redação: "(1) Die Aktiengesellschaft darf eigene Aktien nicht erwerben. (2) Von diesem Verbote findet eine Ausnahme statt: 1. Wenn die Erwerbung zum Zwecke einer in den Statuten selbst vorbehaltenen Amortisation vorgenommen wird; 2. Wenn die selbe in Gemässheit des Artikel 670 Absatz 1 und 2 zum Zwecke der teilweisen Rückzahlung des Grundkapitals vorgenommen wird; 3. Wenn dieselbe in Executionswege zur Befriedigung einer Forderung der Gesellschaft erfolgt; 4. Wenn dieselbe mit dem Betriebe eines nach den Statuten zum Gegenstande des Unternehmens gehörigen Geschäftszweiges verbunden ist. (3) In den Fällen 1 und 2 sind die zurückerworbenen Aktien sofort für jede weitere Veräusserung unbrauchbar zu machen. In den Fällen 3 und 4 müssen die erworbenen Aktien mit thunlichster Beschleunigung weiter veräussert und die im Laufe des Jahres erfolgten Erwerbungen und Veräusserungen von eigenen Aktien im Jahresberichte ersichtlich gemacht werden. (4) Die durch die Gesellschaft zurückerworbenen Aktien dürfen in den Generalversammlungen nicht vertreten sein".

${ }^{67}$ Cf. Alexander Kitanoff, op. cit., p. 19.

68 Segundo o $\$ 215 \mathrm{~d}$ da Zweite Aktienrechtsnovelle: "Die Aktiengesellschaft soll eigene Aktien im geschäftlichen Betriebe, sofern nicht eine Kommission zum Einkauf ausgefüht wird, weder erwerben noch zum Pfande nehmen. Sie darf eigene Interimsscheine im geschäftlichen Betriebe auch in Ausführung einer Einkaufskommission weder erwerben noch zum Pfande nehmen. Eine Amortisation der Aktien ist zulässig, sofern sie unter Beobachtung der für die Zurückzahlung oder Herabsetzung des Grundkapitals maßgebenden Vorschriften erfolgt. Ohne Beobachtung derselben darf die Gesellschaft ihre Aktien nur aus dem nach der jährlichen Bilanz sich ergebenden Gewinne und nur in dem Falle amortisiren, daß dies durch den 
Nesse sentido, a legislação alemã de 1884 incorporou, influenciada pelo seu próprio pensamento jurídico e pela legislação suíça de 1881, diversos pontos de exceção, como, por exemplo: (i) pondo fim à discussão em torno do diploma anterior, a amortização passou a ser permitida, desde que obedecidas as disposições sobre redução de capital; (ii) permitiu também o uso de lucros acumulados para a realização de amortização de ações, abrindo caminho para o núcleo moderno do regime, que orbita em torno dos saldos contábeis de lucros e reservas de lucros; (iii) além disso, a expressão "im geschäftlichen Betriebe" que traduzida significa "na exploração dos negócios" é entendida como uma expressão que autoriza os negócios com as próprias ações de forma gratuita e as aquisições decorrentes de um processo de execução para satisfazer crédito da sociedade, (iv) excetuou-se a aquisição de ações próprias quando realizada em decorrência de um contrato de "comissão de compra" ("Kommission zum Einkauf" $"$ "), atendendo-se a pedidos dos bancos para serem permitidas essas operações, (v) alterou-se a consequência jurídica da nulidade da operação para a responsabilidade civil da administração da sociedade, respondendo a clamores de injustiça decorrentes de operações de bolsa, em que o vendedor não teria como saber que sua contraparte era a companhia, e via sua operação submetida à nulidade absoluta ${ }^{70}$.

O Handelsgsetzbuch (Código Comercial) alemão de 1897 (HGB) seguiu de perto esta regulamentação, com ligeiras variações (alterações estas que visavam mais do que modificar o substrato normativo, apenas adequar a linguagem do texto à do Código Civil Alemão), mas a incompletude do dispositivo acabou por esvaziar o conteúdo da vedação, tendo graves consequências durante a Grande Depressão. Noticia-se que "não existe dispositivo normativo mais conhecido e tão amplamente ignorado como o $\$ 226$ do $\mathrm{HGB}^{, 71}$.

ursprünglichen Gesellschaftsvertrag oder durch einen, den letzteren vor Ausgabe der Aktien abändernden Beschlu $\beta$ zugelassen ist". Cabe, neste ponto, a mesma observação quanto à grafia da palavra "amortisiren" que já fizemos em momento anterior.

${ }_{69} \mathrm{O} \$ 383$, Abs. 1, do Handelsgesetzbuch (Código Comercial Alemão de 1897) atualmente define um "Komissionsgeschäft" da seguinte forma: "Comissário é aquele que se compromete a adquirir ou vender, em nome próprio, mas no interesse de terceiro (o comitente), mercadorias ou valores mobiliários". No original: "Kommissionär ist, wer es gewerbsmäßig übernimmt, Waren oder Wertpapiere für Rechnung eines anderen (des Kommittenten) in eigenem Namen zu kaufen oder zu verkaufen". O contrato equivale, certamente, ao nosso contrato de comissão, cuja definição, no artigo 693 do Código Civil, é substancialmente igual a essa: "Art. 693. O contrato de comissão tem por objeto a aquisição ou a venda de bens pelo comissário, em seu próprio nome, à conta do comitente".

${ }^{70}$ Cf. Maria Victória Rodrigues, op. cit., p. 52, nota de rodapé 107. Ver também Alexander Kitanoff, pp. 19 e 20.

${ }^{71}$ No original: "Es gibt keinen Paragraphen, der so allgemein bekannt und so allgemein ignoriert wird, wie § 226 HGB". Notícia veiculada no Berliner Tageblatt de 1931, citada por Schön apud Alexander Kitanoff, op. cit., p. 20, nota de rodapé 33 . 
O início da segunda etapa evolutiva pode ser situado em 1931, data em que foi promulgada na Alemanha uma lei alterando o Handelsgesetzbuch de 1897, denominada de pequena reforma acionária (kleine Aktienrechtsreform). A Lei alemã de 19 de setembro de 1931 (Notverordnung do então presidente Hindenburg) foi promulgada em reação aos níveis alarmantes de especulação que os negócios com as ações próprias tomaram durante a crise de 1929/1931, em parte pelo regime jurídico do Handelsgesetzbuch de 1897, o que tornava a sua revisão assunto de pauta urgente na Alemanha. Nesse período, a Alemanha, que já passava por uma grave situação econômica após a perda da Primeira Guerra Mundial, viu-se atingida com brutalidade pela queda dos níveis mundiais de comércio, não só na indústria, como também no setor financeiro. As instituições financeiras alemãs, ainda altamente dependentes de capital estrangeiro, viram-se em meio a uma crise de liquidez que culminou com uma crise bancária no verão de 1931. No período que a antecedeu, muitos bancos utilizaram o instituto com o intuito primordial de alterar a cotação de seus papeis, usando-o em níveis muito maiores do que as companhias industriais ${ }^{72}$. A nova redação do Handelsgesetzbuch e o novo regime criados por essa lei assentaram os aspectos fundamentais do sistema alemão sobre ações próprias como hoje o conhecemos: apesar de não haver uma volta ao quadro da proibição absoluta de 1870, vê-se claramente que as operações passam a ser submetidas a rigorosos limites e controles. A título de curiosidade, é neste momento que surge o famoso limite de $10 \%$ do capital social para as ações em tesouraria, disposição que até hoje vige, não apenas por lá, como no Brasil ${ }^{73}$.

A segunda fase, portanto, é marcada por um aperfeiçoamento técnico da proibição, ora incorporando ao regime das exceções aqueles casos julgados de menor perigo, ora apertando o controle das operações onde efetivamente o temor se justificava (por exemplo, ao definirem-se melhor as condições sob as quais as ações em tesouraria seriam mantidas, e os direitos que seriam a elas assegurados, além da introdução do regime de participações recíprocas). Cabem aqui, também, menções à Aktiengesetz de $1937^{74}$, na Alemanha, a

\footnotetext{
${ }^{72}$ Cf. Alexander Kitanoff, op. cit., p. 23.

73 A origem do limite de $10 \%$ é controversa, mas entende-se que o legislador tenha se baseado no então projeto de lei das sociedades por ações, que viria a ser promulgado em 1937, o qual continha o dispositivo no $\$ 215$, Abs. 1, S. 2. No entanto, há outras opiniões. Cf. Alexander Kitanoff, op. cit., pp. 23 e 24, nota de rodapé 52 .

${ }^{74}$ Admite-se, a partir dela, a aquisição para evitar um dano grave à sociedade desde que as ações adquiridas não ultrapassem 10\% do capital social; a aquisição pela sociedade, mas em nome de terceiro, desde que as ações estejam totalmente integralizadas; a aquisição para redução de capital; e as aquisições gratuitas de ações integralizadas, entre outras autorizações inovadoras. As ações em tesouraria ficam com todos os seus direitos suspensos. A redação da Aktiengesetz de 1937 é praticamente a mesma introduzida pela reforma de 1931, com pequenas modificações. Ver Alexander Kitanoff, op. cit., p. 24, nota de rodapé 53.
} 
revisão do Código das Obrigações da Suíça de 1936, a promulgação do Codice Civile italiano de 1942 e a Lei de Sociedades Anônimas da Espanha de 1951.

A redação original do Codice Civile de 1942, art. 2.357, não inovou muito em relação ao disposto no Código Comercial de 1882. As modificações que efetivamente conseguiram galgar o caminho para a positividade foram introduzidas em decorrência de clamores por maior precisão conceitual, estabelecendo-se, em primeiro lugar, que a proibição deveria ser endereçada à companhia, e não a seus administradores, como era feito na redação anterior. Outra alteração foi a de definir os "utili" como "utili netti",75. No geral, o Codice Civile manteve o sistema de "condições de validade", submetendo a permissão da operação àquelas mesmas três condições de 1882: aprovação da assembleia geral, utilização de saldo de lucros (agora "líquidos") e envolvimento apenas de ações totalmente integralizadas. Por outro lado, foram introduzidas algumas melhorias, especialmente ao ter sido inserida norma que suspendia o exercício do direito de voto dessas ações (e somente desse direito) ${ }^{76}$.

O terceiro período começa com a promulgação da Aktiengesetz de 06 de setembro de 1965 (§71), e caracteriza-se pelo rejuvenescimento da teorização sobre as aquisições das próprias ações, agora sob o ponto de vista do pragmatismo e da evolução dos mercados financeiro e de capitais, com o desenvolvimento de novos produtos e técnicas de gerenciamento de risco e alocação de recursos entre os agentes econômicos. O regime jurídico trazido pela Aktiengesetz de 1965 reflete o pensamento criado pela Aktiengesetz de 1937 que, por sua vez, remonta à reforma de 1931: desse modo, o regime atual, na Alemanha, claramente tem suas raízes no regime instituído em 1931. É importante destacarmos este fato, pois, como vimos, a reforma de 1931 foi uma resposta apressurada a uma grave crise e sobre a qual não há registros de discussão legislativa (lembrando-se que foi uma norma de caráter emergencial do presidente Hindenburg). A interpretação dos dispositivos da lei atual deve levar isto em consideração.

O traço fundamental que caracteriza este período é o de perseguir duas tendências, aparentemente contraditórias entre si, mas em realidade perfeitamente compatíveis: de um lado, considerando-se a necessidade de pensar cuidadosamente sobre o regime de flexibilização, possibilitando a inclusão de cada vez mais numerosas exceções à proibição, naquelas hipóteses em que se considera haver um interesse legítimo ou uma vantagem a ser

\footnotetext{
${ }^{75}$ Confira-se, novamente, Scotti Camuzzi, para um profundo exame sobre a forma de cálculo contábil desse conceito. In Acquisto delle..., cit., especialmente pp.643 e ss.

${ }^{76}$ Cf. Barbara Pozzo, op. cit., p. 188.
} 
perseguida pelos agentes econômicos e, por outro lado, tornando mais rigoroso e controlado o regime proibitivo naquelas hipóteses em que efetivamente as operações importem riscos.

Pertencem também ao início deste período a promulgação da lei de sociedades francesa de 1966, a $2^{\text {a }}$ Diretiva do Conselho das Comunidades Europeias sobre sociedades por ações e sobre capital social, de 13 de dezembro de 1976 (" $\underline{\underline{a} \text { a Diretiva" ou "Segunda }}$ Diretiva" $)^{77}$ - fortemente influenciada pelo direito alemão, como se nota pela adoção do limite de $10 \%$ do capital social para ações em tesouraria - e as leis editadas para possibilitar a internalização dessas normas nos países membros, como, por exemplo, o Código das Sociedades Comerciais de Portugal de $1986^{78}$.

Foi também em decorrência da $2^{\mathrm{a}}$ Diretiva que houve, por meio de lei de 13 de dezembro de 1978, a primeira modificação do regime das ações próprias estabelecido na Aktiengesetz de 1965 - foi também a primeira lei nacional a implementar a $2^{\text {a }}$ Diretiva em nível nacional. Apesar de ter servido de inspiração à mencionada diretiva, a Aktiengesetz de 1965 foi alterada em alguns pontos substanciais ${ }^{79}$. Até este momento, como vimos, a Aktiengesetz tratava do assunto em um único parágrafo, o $§ 71$. Com esta lei, o instituto passa a ser regulado pelo $\$ 71$, remodelado, e adicionado dos $\$ 71 \mathrm{a}$ a $\$ 71 \mathrm{e}$, ainda hoje vigentes. A mudança na Alemanha decorreu, em parte, de adaptações materiais às normas e, em parte, de um intuito organizativo - de dar maior clareza às disposições. Do ponto de vista de estilo, os novos parágrafos da Aktiengesetz seguem a mesma orientação da redação anterior: as aquisições das próprias ações somente são possíveis dentro de uma das hipóteses especificamente mencionadas pela lei (em decorrência de grave dano, em decorrência de sucessão, em decorrência de uma redução de capital, etc.). Ainda não havia sido introduzida a possibilidade genérica de aquisições desprovidas de uma causa subjacente. De fato, a justificativa dada ao Projeto de Lei que se transformou posteriormente na Lei de 1978, dizia que "particularmente, o projeto de lei abdica do

\footnotetext{
${ }^{77}$ A primeira redação da diretiva já havia sido feita em 1965 e foi apresentada para discussão do Conselho das Comunidades Europeias em 1970, mas aprovada apenas em 1976, refletindo a dificuldade de elaborar um texto apto a ser aplicável a todos os países membros, em um tema tão delicado quanto este e em um ambiente legislativo heterogêneo. Cf. Maria Victória Rodrigues, op. cit., p. 59, nota e rodapé 117.

${ }^{78}$ Em Portugal, antes da promulgação do Código das Sociedades Comerciais em 1986, a legislação sobre o assunto era vaga e indefinida. Para detalhes, cf. Maria Victória Rodrigues, op. cit., pp. 70 a 74.

${ }^{79} \mathrm{O}$ principal deles foi a obrigatoriedade de todos os negócios com ações próprias darem-se com os saldos oriundos de reservas de lucros disponíveis da sociedade. Até então, a lei alemã permitia que os pagamentos fossem feitos com o saldo de ativos vinculados (capital social e reservas indisponíveis), desde que observado o limite de $10 \%$ do capital social. Para alguns autores, houve um exagero na "infeliz cumulação desses dois mecanismos de proteção" ("verunglückte Kumulation von Schutzinstituten"). Cf. Alexander Kitanoff, op. cit., p. 74.
} 
sistema permitido a outros Países-Membross pelo art. $19, \S 1^{\circ}$ da Diretiva, segundo o qual as aquisições das próprias ações podem ocorrer sem a presença de uma motivação específica. Muito por força do duvidoso valor que essa possibilidade de aquisição genérica das próprias ações tem, é que o Direito Alemão não deve fazer uso dessa permissão da Diretiva" $" 80$.

A Alemanha teve ainda duas importantes alterações no regime das ações próprias na década de 1990. Citamos duas: (i) a Zweites Finanzmarktförderungsgesetz, de 1994, que permitiu aos bancos alemães, sob determinadas circunstâncias, a negociação de ações de sua própria emissão em decorrência de sua atividade bancária e (ii) a liberalização do regime, pela Gesetz zur Kontrolle und Transparenz im Unternehmensbereich (KonTrag) de 1998, que permitiu a aquisição de ações próprias sem motivo predeterminado em lei, mas apenas sujeita à aprovação da assembleia geral (hoje §71, Abs. 1, Nr. 8 da Aktiengesetz de $1965)^{81}$.

Na Itália, a $2^{\text {a }}$ Diretiva foi convertida em lei nacional (com notevole calma, nos dizeres da doutrina italiana ${ }^{82}$ ) apenas em 1986, por meio do Decreto del Presidente della Republica 30, de 10 de fevereiro de 1986. Esse artigo desmembrou o antigo artigo 2.357 em três novas disposições (o artigo 2.357, 2.357-bis e 2.357-ter), e agregou, ainda, uma nova disposição (o artigo 2.357-quater). Vemos também a reformulação do artigo 2.358, agora sob o título "outras operações com as próprias ações”, além do 2.359, que introduz o regime das participações sociais recíprocas e de outros artigos, como os que alteraram o grau de publicidade dessas operações no balanço patrimonial (nova redação do artigo

\footnotetext{
${ }^{80}$ No original: "Insbesondere sieht der Entwurf davon ab, entsprechend dem in Artikel 19 Abs. 1 der Richtlinie zugelassenen System anderer Mitgliedstaaten der EG einen Erwerb eigener Aktien ohne Vorliegen eines besonderen Grundes nur aufgrund einer Ermächtigung durch die Hauptversammlung zuzulassen. Schon wegen des zweifelhaften Wertes, den die Möglichkeit des Erwerbs eigener Aktien ganz allgemein hat, sollte von dieser Möglichkeit der Richtlinie im deutschen Recht nicht Gebrauch gemacht werden". Cf. Gesetzentwurf der Bundesregierung - Entwurf eines Geseztes zur Durchführung der Zweiten Richtlinie des Rates der Europäischen Gemeinschaften zur Koordinierung des Gesellschaftsrechts, BT Drucksache 8/1678, 31 de março de 1978, p. 14.

${ }^{81}$ A alteração legislativa surtiu efeito, tendo crescido o volume de operações com ações próprias na Alemanha a partir de 1998. O Deutsches Aktieninstitut, que inclusive apoiou as modificações trazidas pelo projeto, fez um levantamento com 337 companhias abertas, que responderam a um questionário enviado em fevereiro de 1999. Considerando a data de corte da pesquisa, 77 companhias abertas já possuíam autorizações das assembleias gerais (conforme modificação introduzida pela KonTrag) para as aquisições, sendo que 10 delas já haviam realizado uma aquisição. Comparando, à época, o volume dos programas de recompra das companhias alemãs (30 bilhões de marcos alemães) vis-à-vis a capitalização de mercado das companhias, o índice na Alemanha chegou a 1,6\%, quase igual ao dos Estados Unidos da América, na época de 1,9\%. A aceitação do instituto foi muito alta. Cf. Deutsches Aktieninstitut (DAI), Der Erwerb Eigener Aktien in Deutschland - Ergebnisse einer Untersuchung des Deutschen Aktieninstituts zum Rückkauf eigener Aktien durch die Gesellschaft, Frankfurt a.M., junho de 1999.

${ }^{82}$ Cf. Mario Stella Richter Jr, Novo e Novissimo Regime dell'Acquisto delle Proprie Azioni, in Studi in Onore di Umberto Belviso, Cacucci, Roma, 2011, p. 809.
} 
2.424 e inclusão do art. 2.429-bis). Segundo a doutrina italiana, o critério inspirador da adequação da lei local à regra comunitária parece ter sido o da manutenção da sua tradição sobre a matéria, especialmente no tocante ao sistema de não elencar as operações permitidas expressamente, mas de arrolar apenas as condições às quais são submetidos todos os negócios para fins de sua validade ${ }^{83}$.

Assim é que o artigo 2.357 do Codice Civile alterado elenca as condições que devem ser atendidas para que seja reputado válido o negócio: (i) ações totalmente integralizadas, (ii) utilização do saldo de lucros e reservas disponíveis, (iii) prévia aprovação assemblear, que deverá conter alguns requisitos mínimos e não poderá ser superior a 18 meses (cf. regra da $2^{\text {a }}$ Diretiva). Adicionalmente, foi introduzida a limitação dos $10 \%$ do capital social.

A Itália também teve uma pequena alteração na redação do artigo 2.357 em 1994, apenas para acrescentar que, no limite dos $10 \%$ consideravam-se também as ações da controladora detida pela companhia controlada. Em 2003, o país passou por uma extensiva reforma de seu direito societário, por meio do Decreto n. ${ }^{\circ}$ 6, de 17 de junho de 2003. Na disciplina das ações próprias, as principais alterações introduzidas em 2003 ao Codice Civile foram: (i) acrescentou-se a hipótese de cisão entre aquelas operações especiais listadas no artigo 2.357-bis, em adição aos casos de fusão e de outras operações por sucessão universal, (ii) foi introduzida a possibilidade de que a assembleia geral autorizasse genericamente, nos termos da lei, compras e vendas sucessivas de ações (o trading com as próprias ações, conforme também havia sido introduzido na Alemanha em 1998) - artigo 2.357-ter-, e, especialmente, (iii) a possibilidade de a assembleia geral autorizar os administradores da companhia a exercerem o direito de preferência com relação às ações em tesouraria por ocasião de um aumento de capital (artigo 2.357-ter) ${ }^{84}$.

Pela importância da $2^{\mathrm{a}}$ Diretiva, assim como pelo papel fundamental que exerceu (e a continua a exercer, agora modificada) na regulação do objeto de que tratamos, entendemos valiosa a análise do quadro regulatório original por ela introduzido, para

\footnotetext{
83 "Per quanto concerne l'acquisto, viene altresì confermata la tecnica di non subordinare l'ammissibilità a specifiche ragioni dell'acquisto stesso. Questa tecnica tuttavia - fatta propria anche dalla legge inglese - è solo apparentemente meno rigorosa di quella opposta, tradizionalmente adottata dale leggi francese e tedesca". A referência ao modelo alemão é aquele da listagem de operações especificamente excluídas da proibição. Cf. Barbara Pozzo, op. cit., p. 341.

${ }^{84}$ A doutrina italiana considerava difícil a conciliação dessa possibilidade de subscrição primária de novas ações pela companhia com o texto da $2^{\text {a }}$ Diretiva, que as veda por completo. Cf. Barbara Pozzo, op. cit., p. 524. Em 2010, inclusive, a mais recente reforma do direito italiano excluiu essa previsão (cf. Decreto Legislativo n. 224, de 29 de novembro de 2010).
} 
depois avaliarmos as alterações de 2006. Com a alteração da $2^{\mathrm{a}}$ Diretiva, inclusive, se inicia o que entendemos ser o quarto período evolutivo do instituto.

\subsubsection{Direito Comunitário: a $2^{\mathrm{a}}$ Diretiva}

No texto original da $2^{\mathrm{a}}$ Diretiva, o tema é tratado nos artigos 18 a 24, que contêm uma disciplina pormenorizada da subscrição, aquisição e aceitação em garantia pela sociedade, das ações de sua emissão, bem como dos financiamentos concedidos a terceiros para que adquiram ações, estabelecendo as normas básicas sobre o tema. A leitura da norma nos mostra um regime complexo, sem fronteiras óbvias entre transações permitidas ou vedadas em qualquer caso. O grande desafio do legislador comunitário era o de tentar harmonizar, em todos os Estados-Membross, uma disciplina que não era uniforme entre os países, tendo cada um deles regulado alguns ou todos os assuntos tratados na $2^{\mathrm{a}}$ Diretiva de formas variadas.

Interessante notar que muitas das regras imperativas concedem, não obstante, a faculdade de os Estados-Membross afastarem a aplicação do regime da $2^{\mathrm{a}}$ Diretiva em diversos aspectos, de acordo com os usos e costumes de cada país, especialmente levandose em conta as finalidades que essas operações desempenham em cada um desses mercados.

O artigo $18,{ }^{\circ}{ }^{\circ}$, estabelece o princípio geral de que uma sociedade não pode subscrever as próprias ações, proibição esta que, na falta de detalhamento, aplica-se tanto ao momento de constituição da sociedade, quanto ao momento de subsequentes aumentos de capital. O artigo ainda veda a subscrição, por terceiro, em nome próprio, mas por conta da sociedade, prescrevendo, como consequência ao descumprimento da regra, não a sua anulabilidade ou nulidade, mas, sim, que o subscritor será considerado o acionista para todos os fins e efeitos (alteração da eficácia subjetiva do negócio jurídico). O artigo 18, n. ${ }^{\circ}$ 3 , estipula que os fundadores (pessoas físicas ou não) e, em casos de aumento de capital, os membros do órgão de administração, fiquem responsáveis por alienar as ações irregularmente subscritas pela sociedade, o que reforça o entendimento de que as consequências jurídicas do descumprimento não estão, aqui, tipicamente ligadas a sanções de invalidade, mas sim, a outros mecanismos que visam melhor tutelar os terceiros envolvidos e a estabilidade dos negócios sociais.

Já as aquisições derivadas de ações de emissão própria não são proibidas pelo texto da $2^{\text {a }}$ Diretiva, mas apenas sujeitas a uma série de condicionantes mínimas que cada país 
precisa impor (nota: caso sejam admitidos esses negócios, o que não é obrigatório pela norma) e que são quatro, listadas nas alíneas do artigo 19. A alínea (a) impõe uma condição de forma: a aquisição deve ser precedida de autorização da assembleia geral, que fixará o numero, o valor, as modalidades de aquisição visadas, a duração da autorização (que não poderá exceder 18 meses) e, no caso de aquisições onerosas, as contrapartidas mínimas e máximas. A alínea (b) insere o percentual de $10 \%$ do capital subscrito como limite objetivo da possibilidade de aquisições de ações próprias pela sociedade, aí computadas todas as ações previamente em tesouraria e as novas a serem adquiridas em determinado momento. A alínea (c) prescreve a regra de ouro de que nenhuma aquisição poderá tornar o patrimônio líquido da sociedade inferior ao valor do capital social, somado com o das reservas indisponíveis da sociedade (em outras palavras: a aquisição não pode se dar em prejuízo do capital social). Por último, a alínea (d) impede que existam aquisições envolvendo ações não totalmente integralizadas ${ }^{85}$.

O primeiro requisito é a prévia autorização assemblear, o que significa submeter as operações, e, portanto, a competência da administração, à previa deliberação dos acionistas, representando uma situação de exceção ao princípio geral de que os administradores são competentes para praticar quaisquer negócios pela companhia ${ }^{86}$. A submissão da operação à prévia deliberação da assembleia geral não era algo harmonioso nos ordenamentos locais da Europa, sendo um requisito necessário desde sempre na Itália, mas inaplicável, por exemplo, na Alemanha ou na Inglaterra (onde o caso Trevor $v$. Witworth vedava qualquer operação, e a assembleia não poderia suprir essa regra, como veremos mais adiante). A ratio dessa previsão é a de que, apesar de ser estruturalmente um

\footnotetext{
${ }^{85}$ Isso porque permitir-se à companhia a realização de negócios com acionistas titulares de ações não integralizadas (uma compra para manutenção em tesouraria, por exemplo) seria o mesmo que dispensar o acionista da sua obrigação maior de contribuir ao capital social. Ele receberia da companhia o valor das suas ações (seja que valor for esse, considerando que elas estão, de certa forma, vazias de conteúdo até que sejam integralizadas) e retirar-se-ia da sociedade sem nunca ter contribuído ao capital social. "Atendendo ao princípio de integridade do capital social, deve ser lembrado que não pode a companhia adquirir ações não integralizadas, uma vez que tal operação resultaria em diminuição automática do valor do capital". Cf. Modesto Carvalhosa, Comentários..., Vol. 1, cit., p. 312. "Com a exigência de que apenas ações totalmente integralizadas podem ser adquiridas (\$71, Abs. 2, S. 3 AktG) está-se querendo evitar que os créditos de integralização da companhia contra seus acionistas sejam perdidos", o que ocorreria, segundo Kitanoff, devido à confusão. No original: "Mit dem Gebot, nur voll bezahlte Aktien zurückzukaufen (\$71, Abs. 2, S. 3 $A k t G)$, soll verhindert werden, dass Einlageforderungen der Gesellschaftgegen ihre Aktionäre verloren gehen". Cf. Alexander Kitanoff, op. cit., p. 92.

86 "Si tratta di uno dei rari casi in cui l'assemblea delibera su atti di gestione, ma non v'è deroga al principio della competenza generale degli amministratori per gli atti di gestione: la delibera à autorizzativa, non vincula gli amministratori, I quali sono obbligati a chiedere il consenso dell'assemblea ma non ad eseguirne la volontà; possono quindi rinunciare ad effetuare l'acquisto deliberato, che rimane un atto di gestione di loro competenza e de quale essi sono responsabili". Cf. Antonio Albanese, Operazioni Sulle Azioni Proprie (e Leveraged Buy Out) nel Nuovo Diritto Societario, in Contratto e Impresa - Dialoghi com La Giurisprudenza Civile e Commerciale, Vol. 23, n. ${ }^{\circ}$ 2, Cedam, 2007, p. 357.
} 
negócio jurídico como qualquer outro, as operações envolvendo ações próprias incide inevitavelmente na composição acionária, modificando-a. Como a assembleia geral é o órgão mais apropriado para a prestação de informações aos acionistas, escolheu o legislador europeu esse fórum para o debate das condições em que aquisição pode se processar, determinando inclusive o conteúdo mínimo desse debate (prazo, volumes, preços, etc.).

A própria $2^{\mathrm{a}}$ Diretiva abre espaço para que os Estados-Membross excetuem a regra da prévia autorização assemblear. Assim, o artigo 19, $\S 2^{\circ}$, permite que um Estado-Membro derrogue a obrigação de prévia aprovação da assembleia (conforme alínea (a) descrita acima), quando tal aquisição seja necessária para evitar um prejuízo grave e iminente à sociedade - inspirando-se o legislador europeu evidentemente na legislação alemã quanto a este ponto (a regra já constava na redação original da Aktiengesetz de 1965 e está mantida até hoje na lei alemã). Efetuada a aquisição sob este manto, deverá a administração informar à assembleia geral imediatamente seguinte os motivos das aquisições efetuadas, 0 número e o valor das ações objeto de aquisição e a contrapartida paga. Outra exceção ao requisito de prévia aprovação assemblear nos dá o artigo 19, n. ${ }^{\circ} 3$, que permite à sociedade adquirir as próprias ações para distribuí-las, no prazo máximo de 12 meses, aos seus funcionários (incluindo funcionários das sociedades a ela coligadas).

O segundo requisito é a imposição do limite quantitativo de 10\%. A introdução desta regra, também de inspiração nitidamente alemã, teve como princípio não apenas a proteção do capital social enquanto tal (que é resguardado já pela obrigação de utilização do saldo de lucros e reservas), mas também como forma de se evitar danos ao mercado de capitais, já que qualquer intervenção da companhia no mercado de suas próprias ações pode ser mecanismo idôneo a falsear o curso dos papeis e, de forma geral, a manutenção de ações entesouradas diminui a quantidade de ações sendo negociadas, ou seja, as recompras de ações tendem a diminuir a liquidez das ações no mercado ${ }^{87}$. É claro que anular esses riscos é algo apenas possível mediante a proibição absoluta dos negócios: “l’imposizione di um limite alla quantitá di azioni proprie che una società può detenere in portafoglio è una soluzione che, al massimo, potrà raggiungere l'effetto di arginare disfunzioni

\footnotetext{
${ }^{87} \mathrm{Em}$ verdade, o que é importante enfatizar é que o limite percentual ora mencionado não tem por função a proteção dos credores (que advém da utilização do saldo de lucros e reservas), mas evitar o enxugamento da liquidez das ações e abrir menos espaço para manobras manipulativas com as ações próprias, objetivos dignos, por sis ó, de tutela regulatória. "Si vuole inoltre limitare, sopratutto lle società di più grandi dimensioni, la possibilità di influenziare le quotazioni dei propri titoli o di favorire l'ingresso di soci graditi alla maggioranza". Cf. Antonio Albanese, Operazioni..., cit., p. 359.
} 
macroscopiche, ma non quello di garantire l'assoluta correttezza dell'operazione ${ }^{, 88}$. O limite, com isso, é uma tentativa de evitar não apenas a perda patrimonial da sociedade que era a ratio inspiratrice da regra alemã - mas também o de limitar o escopo de atuação da companhia no mercado de suas próprias ações.

Já o artigo 20, n. ${ }^{\circ}$ 1, lista diversas exceções, totais ou parciais, ao regime estabelecido pelo artigo 19, tornando a aquisição, nas situações nele previstas, livres das condições ali estabelecidas ou, para todos ou alguns dos casos, excetuando um ou mais requisitos condicionantes, o que, na prática, dá certa flexibilidade aos Países-Membros para adaptarem as suas legislações dentro deste quadro básico, possibilitando o surgimento de regimes complexos em diversos países da Europa. As exceções listadas no artigo 20 da Segunda Diretiva são bastante heterogêneas, mas podemos enxergar um traço comum entre elas, qual seja, o de que, nesses casos, ou não há transferência de patrimônio (negócios gratuitos, por exemplo) ou a necessidade de proteção dos credores é reduzida (caso dos negócios efetuados por bancos, a título de comissão). Outro elemento de conexão entre as hipóteses encontra-se no fato de que essas operações podem ser encaradas não mais como sendo consequências de um ato do emissor das ações diretamente preordenado a esse escopo, mas apenas como um "elemento acidental" ou marginal dentro de uma operação com outro escopo (como a redução de capital ou uma incorporação de uma companhia por outra, por exemplo).

As hipóteses em que o regime condicionante do artigo 19 pode ser afastado são, resumidamente: (i) ações adquiridas para redução de capital ou resgate, (ii) ações adquiridas como resultado de transmissão de um patrimônio a título universal (como, por exemplo, numa incorporação), (iii) ações totalmente integralizadas, adquiridas a título gratuito ou por bancos e outras instituições financeiras a título de comissão de compra, (iv) ações adquiridas em virtude de determinação legal ou como consequência de uma decisão judicial que tutele minorias de acionistas (aparentemente este item foi derivado da prática inglesa $^{89}$ ), (v) ações adquiridas de acionista remisso, (vi) ações adquiridas para indenizar acionistas minoritários de sociedades coligadas, e (vii) ações totalmente integralizadas ou venham a ser arrematadas judicialmente a título de satisfação de crédito da sociedade contra o ex-acionista (o fato de serem ações totalmente integralizadas, neste inciso, nos

\footnotetext{
${ }^{88}$ Cf. Barbara Pozzo, op. cit., pp. 212 e 213.

${ }^{89}$ Cf. Barbara Pozzo, op. cit., pp. 228 e 229, relatando que a Section 5 do Companies Act de 1948, que tratava da necessidade de a alteração do objeto da companhia ser submetida à aprovação do Judiciário, poderia estar condicionada a que a companhia, com saldo de lucros e sem prejuízo do capital social, devesse recomprar as participações dos acionistas dissidentes.
} 
permite entender a diferença com relação à hipótese em que tratamos de um acionista remisso - o crédito de que trata este inciso refere-se a outro negócio entre a companhia e o acionista, não ao crédito pela integralização das ações).

O regime jurídico das ações em tesouraria ${ }^{90}$ vem estipulado no artigo 22 da $2^{\text {a }}$ Diretiva, que dispõe que as leis nacionais deverão prescrever, no mínimo: (i) que ficará suspenso o direito de voto das ações (artigo 22, n. $^{\circ}$ 1, alínea a), e (ii) se as ações forem contabilizadas no ativo da sociedade, que seja criada uma reserva indisponível no mesmo montante (artigo 22, n. ${ }^{\circ}$ 1, alínea b) ${ }^{91}$. O artigo 22 impõe, ainda, uma obrigação de informação, por meio da qual os administradores da companhia devem fazer constar de suas demonstrações financeiras os motivos das aquisições efetuadas durante o exercício, o valor das ações adquiridas e/ou vendidas, a fração do capital que representam e a contrapartida da operação, se houver (artigo 22, n. $^{\circ}$ 2).

O artigo 23, n. ${ }^{\circ} 1$ impede o adiantamento de fundos, concessão de empréstimo ou prestação de garantias pela sociedade para que um terceiro adquira ações de sua emissão, excetuando-se desta vedação aquelas operações da atividade ordinária de bancos e outras instituições financeiras e também aquelas aquisições destinadas aos trabalhadores da companhia, em qualquer caso desde que não sejam realizadas em prejuízo do capital social (artigo 23, n. ${ }^{\circ}$ 2).

Por fim, o artigo 24 equipara à aquisição de ações próprias, a aceitação dessas em garantia pela sociedade, exceto no caso das atividades ordinárias de bancos e outras instituições financeiras.

A $2^{\text {a }}$ Diretiva é omissa sobre a eventual responsabilidade civil ou penal dos administradores $^{92}$.

\subsubsection{Direito Comunitário: a Diretiva Alteradora}

Em âmbito comunitário, uma pequena reforma da $2^{\text {a }}$ Diretiva ocorreu em 1992, por meio da publicação da Diretiva 92/101/CEE, que introduziu o artigo 24a na $2^{\text {a }}$ Diretiva,

\footnotetext{
${ }^{90}$ Por amor ao detalhe, enfatize-se que a redação do dispositivo se refere apenas às ações em tesouraria decorrentes das situações permitidas pelas leis nacionais, mas a boa interpretação dita que esse regime deve ser estendido a qualquer ação em tesouraria, mesmo que adquiridas de forma ilícita. Cf. Maria Victória Rodrigues, op. cit., p. 64, nota de rodapé 125.

${ }^{91}$ Discorreremos mais a fundo sobre este ponto no item relacionado ao regime contábil das ações em tesouraria, abaixo, inclusive tecendo algumas críticas.

${ }^{92}$ O projeto original da diretiva (apresentado pela Comissão ao Conselho em 1989) sobre a sociedade anônima europeia copiava, em quase todos os termos, a $2^{\mathrm{a}}$ Diretiva. $\mathrm{O}$ regulamento efetivamente publicado (EC 2157/2001) retirou todo o regime jurídico dessa norma. Para detalhes, Maria Victória Rodrigues, op. cit., pp. 66 a 69.
} 
para tratar em maior detalhe da situação em que uma sociedade controlada detenha as ações da companhia controladora (participações recíprocas), e da qual se seguiram as respectivas leis nacionais (editadas em meados dos anos 90).

A $2^{a}$ Diretiva viria a ser alterada em maior substância pela Diretiva 2006/68/CE do Parlamento Europeu e do Conselho, de 6 de setembro de 2006 ("Diretiva Alteradora”), que institucionaliza no âmbito comunitário - permitimo-nos entender - o início do quarto período do instituto.

Este último período é marcado, de forma mais acentuada, pela busca da eficiência dos mercados, visando o legislador propiciar "regras do jogo" econômico mais flexíveis, dando à iniciativa privada, dentro de limites mais amplos e menos restritivos, maior competência para regular as próprias atividades e a gestão das companhias. Desta forma, a modernização do direito societário visava a garantir às sociedades "a possibilidade de, no que diz respeito ao volume, estrutura e propriedade do seu capital, reagir mais rapidamente e segundo um procedimento menos oneroso e menos longo às evoluções dos mercados que afectam essas sociedades. Consequentemente, esta proposta de modernização da Segunda Directiva deve contribuir para a promoção da eficiência e da competitividade das empresas sem reduzir a protecção proporcionada aos accionistas e credores (...)"93. Esta fase é certamente influenciada tanto pela anterior (em que a perseguição das já mencionadas "duas tendências" foi introduzida e agora continua, sem dúvida, como núcleo indutor do pensamento) quanto pela globalização e pelo aperfeiçoamento (e por que não dizer, pelo aumento da interdependência e da complexidade) dos mercados. Esta fase é identificada por críticas teóricas contundentes ao modelo do capital social como forma de garantia dos credores (substancialmente pelos escritores de origem anglo-saxônica), o que pressionou, se não a adoção de um novo modelo de teorização sobre a proteção aos interesses dos credores na Europa continental em substituição ao capital social (que continua sendo a sua viga mestra), ao menos uma revisão amenizadora do princípio ${ }^{94}$. É isto, a nosso ver, que a Diretiva Alteradora representa em seu contexto histórico: um pensamento muito mais amplo e direcionado para a avaliação da eficácia das regras de capital social como base para a aplicação das medidas protetivas aos credores.

\footnotetext{
${ }^{93}$ Cf. Exposição de Motivos exposta na proposta apresentada ao Conselho e ao Parlamento Europeu que viria a ser transformada posteriormente na Diretiva Alteradora.

94 "The issue here is not whether these protective mechanisms are needed, but rather whether linking them to the legal capital rules is an effective and satisfactory approach". Cf. Eddy Wymeersch, Reforming the Second Company Law Directive, WP 2006-15, University of Gent, novembro de 2006, p. 3.
} 
A origem da Diretiva Alteradora remonta, em primeiro lugar, ao resultado dos estudos conduzidos pelo grupo de trabalho "SLIM" sobre o direito societário concernente à simplificação da primeira e da segunda diretivas sobre matéria societária, que foram apresentados em 1999. Especificamente sobre o que nos interessa, a proposta 4 do Grupo SLIM continha algumas recomendações, como, por exemplo, a exclusão do limite de $10 \%$ da norma, sujeitando a aquisição apenas à existência de saldo de lucros ou reservas (já comentamos que alguns doutrinadores alemães entendiam, realmente, serem as duas normas aplicadas em conjunto um exagero injustificado) e o aumento do prazo da autorização assemblear de 18 meses para 5 anos. Posteriormente a essas recomendações, outro grupo de trabalho criado para estudar o direito societário apresentou suas conclusões: em 4 de novembro de 2002, o High Level Group of Company Law Experts on a Modern Regulatory Framework for Company Law in Europe publicou seu relatório final, conhecido como relatório Winter, em referência a Jaap Winter, presidente do grupo, que, inclusive, reforçou o entendimento do Grupo SLIM de que o limite de $10 \%$ estabelecido na $2^{\text {a }}$ Diretiva era arbitrário e inútil ${ }^{95}$.

O passo seguinte para a adoção da Diretiva Alteradora foi o reconhecimento pela Comissão Europeia de que as propostas do Grupo SLIM (1999) e do Grupo de Notáveis (2002) realmente trariam benefícios, o que foi feito em 2003 por meio da publicação de um plano de ação em matéria de modernização do direito societário. "The Commission considers that a simplification of the Second Directive on the basis of these proposals and recommendations would significantly contribute to the promotion of business efficiency and competitiveness without reducing the protection offered to shareholders and creditors. A proposal to amend the Second Directive along these lines is therefore regarded as a priority for the short term" 96 . Esse objetivo de curto prazo culminou com o envio da proposta da Diretiva Alteradora em 2004.

Ainda nesse plano de ação de 2003, mencionou-se a interessante e inovadora possibilidade de criação de um regime alternativo ao do capital social para fins de regulamentar as distribuições da companhia para seus acionistas, mormente baseado em uma declaração de solvência anterior ao pagamento da distribuição. No entanto, devido ao caráter largamente revolucionário da proposta, o plano de ação previa, antes de tudo e como objetivo de médio a longo prazo (2006 em diante), a criação de um grupo de trabalho

\footnotetext{
${ }^{95}$ Cf. Report of the High Level Group Of Company Law Experts on a Modern Regulatory Framework for Company Law in Europe, Bruxelas, 2002, pp. 84 e ss.

96 Commission of the European Communities, Modernising Company Law and Enhancing Corporate Governance in the European Union - A Plan to Move Forward, Bruxelas, 21 de maio de 2003, p. 18.
} 
específico para analisar a viabilidade desse regime alternativo e se ele realmente seria mais vantajoso do que a tutela conferida pelo regime do capital social.

A Diretiva Alteradora não modificou substancialmente a $2^{\mathrm{a}}$ Diretiva, apesar de ter tido esse objetivo, mas trouxe algumas inovações e alterações que merecem ser ressaltadas (i) em primeiro lugar, aumentou de 18 meses para cinco anos o prazo máximo da autorização da assembleia geral para a administração negociar com as próprias ações, (ii) expurgou a obrigatoriedade da existência do limite de $10 \%$ previamente existente, mantendo como regra geral que os valores utilizados na conclusão dos negócios jurídicos sejam provenientes contabilmente do saldo de lucros ou reservas disponíveis da companhia (apesar de, curiosamente, permitir que os Países-Membros mantenham essa previsão ${ }^{97}$ ), (iii) fez referência expressa à necessidade de observância do princípio do tratamento igualitário dos acionistas e das normas sobre manipulação de mercado, (iv) permitiu que os Países-Membros estipulem em suas condições de validade que a aquisição não poderá "prejudicar a satisfação dos direitos dos credores".

As modificações da Diretiva Alteradora foram deixadas praticamente a cargo dos Países-Membros. Nota-se, de parte deles, certa falta de vontade para alterar as suas leis nacionais após essa modificação em âmbito comunitário. Por exemplo, a Itália limitou-se a restringir o percentual limite de $10 \%$ para as companhias que obtivessem recursos via mercado de capitais por meio de alteração no artigo 2.357 do Codice Civile, passando a diferenciar o regime aplicável para companhias abertas e fechadas, como faz o Brasil desde 1976, nada mais (essa mudança deu-se por meio do Decreto Legislativo 142, de 4 de agosto de 2008). A manutenção desse percentual durou pouco tempo, pois outra Lei, desta vez a Lei 33 de 9 de abril de 2009 (de conversão do decreto-lei 5, de 10 de fevereiro de 2009), alterou novamente o artigo 2.357 do Codice Civile, aumentando o percentual para $20 \%$.

\subsubsection{Direito Inglês}

Resolvemos discutir a evolução do estudo no Reino Unido de forma separada dos demais países de origem europeia continental não porque o direito inglês tenha se aproximado, desde sempre, do modelo norte-americano (que veremos adiante), mas porque o direito inglês, curiosamente, foi bastante mais restritivo em relação a estes negócios do

\footnotetext{
${ }^{97}$ Esta manutenção foi criticada pela doutrina como não tendo coerência lógica. Cf. Mario Stella Richter Jr., op. cit., p. 813.
} 
que os países continentais. Mesmo depois de entrar na Comunidade Econômica Europeia, em 1973, o assunto ainda era objeto de vedações severas e nenhuma exceção: apenas depois do Companies Act de 1985 é que a matéria ganhou os contornos que lhe foi dada pela $2^{\text {a }}$ Diretiva.

No Reino Unido, o leading case é Trevor v. Withworth ${ }^{98}$, que data de 1887. De forma resumida, o caso envolvia a discussão entre um dos acionistas que, de acordo com a permissão do estatuto da companhia (articles of association), vendeu suas ações à companhia e, de outro lado, o liquidante da companhia, que via na operação um ato ultra vires. Os Lords foram unânimes em julgar nula a operação, trazendo à baila argumentos lógico-estruturais, no sentido de que seria inviável à sociedade ser sócia de si mesma. Esta proibição absoluta dos negócios com ações próprias, derivada do julgamento do caso Trevor v. Withworth, viraria uma regra quase inabalável no direito inglês.

São interessantes também as conclusões do estudo realizado no Reino Unido pelo Jenkins Committee, apresentado em 1962, que, dentre outros assuntos, avaliou a conveniência de o Reino Unido migrar para uma linha de regulamentação mais flexível e próxima do modelo norte-americano (que já naquela época era regido por regras conceitualmente bastante distintas). Naquela ocasião, avaliando uma série de dispositivos legais do Companies Act de 1948 de forma comparativa com o direito norte-americano, foi reportado pelo comitê que, apesar do leading case inglês (Trevor v. Whitworth) ter considerado a operação ilegal em termos absolutos, "[i]n the United States there is no general rule prohibiting limited companies from buying (...) own shares (...). In the opinion of our American witnesses the power enjoyed by companies in the United States has not led to abuse and it is useful for a number of purposes" $" 99$. No entanto, o Jenkins Committee reconheceu que o direito norte-americano adotava este conceito mais flexível, mas trazia consigo um contrapeso que não era tão evoluído no Reino Unido: um regime de responsabilidade da administração extremamente severo ${ }^{100}$. E, na ausência do contrapeso devido, a conclusão do comitê foi a de que deveria ser mantida a decisão de Trevor $v$.

\footnotetext{
98 (1887) Trevor v. Witworth, 12 App.Cas. 409, HL. Paul L. Davies (coord.), Gower and Davies, Principles of Modern Company Law, 8 a ed., Maxwell, Londres, 2008, p. 316.

${ }_{99}$ Cf. Report of the Company Law Committee, Her Majesty's Stationery Office, Cmnd. 1749, Londres, 1962, p. 60, item 167 e ss. Para uma descrição resumida do conteúdo desse "Green Paper" no contexto britânico à época, cf. Giuseppe Carcano, L'Acquisto delle Proprie Azioni in un Libro Verde Britannico, in Rivista delle Società, Vol. 25, n. ${ }^{\circ}$ 6, novembro-dezembro de 1980, pp. 1292 e ss.

100 "Secondo la chiave di lettura offerta dalla Jenkins Committee, la mancanza di un divieto all'acquisto de azioni proprie negli Stati Uniti trovava nella rigida disciplina relative alla responsabilità degli amministratoti un adeguato contraltare: I due aspetti venivano a combinarsi in modo da permettere - da un lato - l'acquisto de propri titoli, ma - dall'altro - di reprimerne gli eventuali abusi da parte degli amministratori”. Cf. Barbara Pozzo, op. cit. p. 129.
} 
Witworth: "[w] have therefore reached the conclusion that there is no justification for the general abrogation of the familiar rule that a limited company may not buy its own shares; indeed, we think that the rule should be expressly stated in the Act ${ }^{\text {"101 }}$. Ou seja, os ingleses rejeitaram mudar suas regras não com base em uma suposta complexidade da regulação, ou mesmo em função da possibilidade de abusos a que levaria o seu relaxamento, mas sob o argumento de que quase todos estariam felizes com o status quo jurídico.

Com a entrada do Reino Unido na Comunidade Econômica Europeia em 1973, o então projeto de diretiva que se transformaria na $2^{\mathrm{a}}$ Diretiva ganhou bastante atenção dos doutrinadores societaristas ingleses. Existiu muita discussão acerca da aplicação da $2^{\mathrm{a}}$ Diretiva sobre as public companies ou private companies, conforme eram definidas no então em vigor Company Act de 1948, além, naturalmente, das regras de criação e manutenção do capital social. Por exemplo, o Department of Trade do Reino Unido, estudando em 1977 justamente as medidas necessárias do ponto de vista legislativo para adaptar o ordenamento inglês à $2^{a}$ Diretiva (que já tinha sido publicada e precisava ser incorporada aos ordenamentos dos Países-Membros até dezembro de 1978) mencionava apenas três exceções constantes do Companies Act de 1948 à proibição de aquisição das próprias ações: no caso de ações resgatáveis (redeemable shares), no caso de uma ordem judicial (e, nestes dois casos, seguidos de cancelamento das ações) e no caso de forfeiture (instituto inglês semelhante às nossas ações caídas em comisso). O referido relatório, inclusive, dizia que não havia nenhuma intenção do direito inglês de alterar estas tradicionais exceções, apesar da regra europeia ser bem mais flexível na definição das condições e exceções à proibição da aquisição ${ }^{102}$. O Companies Act de 1980 seguiu esta linha defensiva, e não recepcionou o direito comunitário europeu neste quesito.

Nesse mesmo ano, o renomado professor Gower publicaria um Green Paper relatando as vantagens e desvantagens da operação de aquisição das próprias ações, tomando por base a moderna teoria das finanças corporativas, em franco desenvolvimento nos EUA e comparando o regime inglês ao de outros países, dentro e fora da Comunidade Econômica Europeia ${ }^{103}$. O relatório do professor Gower colocaria, pela primeira vez na história do Reino Unido, o tema sob uma perspectiva um pouco menos diabólica e mais funcional, mencionando as possíveis vantagens advindas das operações, tanto para as

\footnotetext{
${ }^{101}$ Cf. Report of the Company Law Committee, cit. p. 60, item 168.

102 Cf. Department of Trade, Implementation of the Second EEC Directive on Company Law - An Explanatory and Consultative Note, Londres, HMSO, 1977, pp. 16 e 17.

${ }^{103}$ Cf. Laurence C.B. Gower, The Purchase by a Company of its Own Shares - A Consultative Document, Cmnd. 7944, HMSO, 1980.
} 
public, quanto para as private companies, e defendendo um regime de "relaxation" de certas vedações. Muito embora tenha sido um documento moderno para o direito inglês, especialmente tratando o assunto de forma comparada, a sua leitura deixa transparecer claramente que o discurso ainda era de ceticismo com relação às operações em questão. $\mathrm{O}$ ilustre mestre referia apenas isoladas hipóteses de relaxamento das vedações britânicas, não defendia muitas das propostas que a própria Segunda Diretiva permitia, muito menos considerava válida a hipótese de manutenção de ações em tesouraria, tachando essa possibilidade quase de imoral, ao atribuir-lhe a denominação de "trafficking" : "[t]he EC Second Directive envisages that companies having power to repurchase their shares might then re-sell them. This would, in effect, introduce a practice alien to British notions (though common in the USA) namely that of public companies keeping their shares 'on tap' indefinetely. In none of the recent discussions on this subject has there been any advocacy of allowing companies to traffic in their shares (...)"104. De qualquer forma, com o Green Paper de 1980, aparenta superada aquela impostação feita pelo Jenkins Committee na década de 1960 no que diz respeito à carência de um efetivo interesse de parte das companhias britânicas em adquirir as ações de sua emissão.

Em 1985, vemos a publicação de um novo Companies Act, este, sim, contendo uma sistematização mais completa acerca do instituto e de suas exceções, no qual a regra geral proibitiva vinha prevista na Section 143(1), que, sem prejuízo das disposições que seguiam, vedava qualquer negócio das companies com as próprias ações "whether by purchase, subscription or otherwise". No entanto, a regra proibitiva passa a ter um caráter principiológico, considerando a introdução de uma multiplicidade de exceções a ela (mais em linha com a $2^{a}$ Diretiva) que redimensionaram, notavelmente, a regulação do instituto no Reino Unido. As exceções eram aquelas previstas na Section 143(3), incluindo permissões quanto a aquisições a título gratuito, com a finalidade de redução de capital e, especialmente, se estivessem de acordo com o capítulo VII dessa norma, que trazia efetivamente aquelas exceções previstas em âmbito comunitário (em conjunto com as regras sobre ações resgatáveis).

Efetivamente, a Section 162 da Companies Act de 1985 previa, antes de qualquer coisa, a autorização do estatuto para a aquisição. Observada essa condição, as aquisições seriam consideradas lícitas, caso (i) as ações fossem totalmente integralizadas (Section 162(2)), (ii) fossem usados os saldos de lucros ou um aumento de capital especificamente

${ }^{104}$ Cf. Laurence C.B. Gower, The Purchase by a Company..., cit., p. 25. 
destinado a essa finalidade (Section 160 (1) e (2)) e (iii) fossem observados um dos procedimentos previstos para a aquisição: off-market purchase ou market purchase. Ainda, para companhias de capital fechado (private companies), permitiam-se aquisições das próprias ações utilizando recursos considerados como capital social (falava-se em "repurchase or redemption out of capital" nas Sections 171 a 177, em que pesem as duras condições a que estavam submetidas).

As off-market purchases eram reservadas para ações não listadas em bolsa, estando portanto genericamente disponíveis apenas para companhias fechadas (Section 163), sendo que o conteúdo do contrato deveria ser aprovado previamente por uma special resolution da assembleia geral (que, de acordo com a Section 378 desse diploma, previa quórum qualificado de aprovação - 3/4 dos presentes). Já para companhias com ações listadas em bolsa de valores, o Companies Act de 1985 previa a modalidade do market purchase, que era obrigatoriamente precedida de uma autorização assemblear - ordinary resolution (Section 166(1)), que deveria conter, coerentemente com a $2^{\text {a }}$ Diretiva, um conteúdo mínimo (Section 166(3) a (5)). Essa aprovação, note-se bem, não era para os termos contratuais, mas para autorizar a prática dos negócios enquanto tais - há um tratamento mais relaxado para as aquisições em bolsa. O procedimento a ser seguido pela companhia na aquisição de suas ações, portanto, dependia da forma escolhida para a recompra.

Já no tocante à possibilidade dada às companhias fechadas (private companies) de realizar recompras em prejuízo da cifra do capital social, o Companies Act previa que, antes que ela pudesse realizar o pagamento com esse saldo contábil: (i) tal pagamento deveria ser aprovado por uma special resolution da assembleia geral (Section 173(2)), de acordo com os procedimentos da própria norma (Section 174), (ii) os administradores deveriam fazer um trabalho de verificação da situação financeira atual e prospectada da companhia e eram obrigados a, de acordo com a Section 173, fazer uma declaração formal (statutory declaration) confirmando a solvência da companhia.

Independentemente do método utilizado para a aquisição, as operações eram submetidas a um minucioso procedimento de publicidade, conforme Section 169 do diploma, que mirava garantir-lhes a devida transparência. Inclusive, curiosamente, os termos contratuais ou memorandos descrevendo as condições do negócio deveriam, em companhias abertas, ficar disponíveis para visitação e conferência na sede da companhia para qualquer pessoa (Section 169 (5)).

Em 2003, o Companies Act de 1985 sofreu uma relevante alteração. Intrigantemente, o Reino Unido - no que era um caso isolado na Europa - não permitia, até 
então, a existência de ações em tesouraria, possibilidade que foi criada justamente pela reforma promovida pelo Companies (Acquisition of Own Shares) (Treasury Shares) Regulations 2003, que introduziu o conceito na lei de 1985 e entrou em vigor em 01 de dezembro de 2003. Lembramos que a Section 162(2) c/c Section 160(4) do Companies Act de 1985 fazia com que todas as ações recompradas pela companhia fossem obrigatoriamente consideradas como canceladas, com diminuição do valor do issued share capital. A reforma de 2003 alterou a legislação e admitiu, pela primeira vez na história inglesa, que as companhias mantivessem ações em tesouraria: mas o fez com uma série de condições.

Passou a rezar a nova Section 162(2B) que "where a company makes a purchase of qualifying shares out of distributable profits under this section, section 162A applies to the shares purchased; and accordingly section 160(4) does not apply to those shares" grifos nossos. Traduzindo o significado do dispositivo, temos que, quando uma companhia adquira "ações elegíveis" com recursos oriundos de saldo contábil de lucros disponíveis, então essas ações seriam consideradas "treasury shares" sujeitas ao (detalhado) regime criado pela inserção das novas Sections 162A a 162G (todas elas tratando do regime jurídico das ações em tesouraria), ao invés de aplicar-se o regime do cancelamento (que continuou em vigor para as ações não elegíveis, ou caso os recursos fossem oriundos do capital social). Essa nova opção estava disponível apenas, contudo, para as public companies, já que as ações elegíveis eram definidas como sendo ações listadas no Reino Unido ou em mercado organizado e regulado na União Europeia (Section 162(4)).

Pela profundidade com que foi abordado o tema (especialmente considerando sua novidade no direito inglês) e pelo fato de que a legislação posterior adotou quase que idêntica redação, colhemos dessa norma alguns dispositivos interessantes: (i) o limite de $10 \%$ do capital veio previsto na Section 162B(1); (ii) nenhum direito, patrimonial ou político, era assegurado às ações em tesouraria, mas isso não incluía (e a lei mencionou expressamente), ações decorrentes de desdobramento ou bonificação ou o pagamento em dinheiro caso as ações em tesouraria fossem resgatáveis (Section 162C(5)); (iii) uma vez em tesouraria, era lícito à companhia ou não fazer nada com elas (hold), e ali mantêlas, ou vendê-las em troca de dinheiro (sell the shares for cash) - aqui compreendidos pagamentos em cheque, perdões de dívidas líquidas da companhia ou um pagamento a termo não maior do que 90 dias -, transferi-las em decorrência de um plano de participação de funcionários (transfer the shares pursuant to an employee share scheme) ou cancelá-las (cancel the shares), (iv) a nova redação das Sections 94 e 95 previa que a alienação de 
ações em tesouraria daria aos acionistas da companhia naquele momento um direito de preferência na compra desses papeis (preemption rights).

Em 2006, mesmo ano de publicação da Diretiva Alteradora, o Reino Unido publica o Companies Act de 2006, que regulou o assunto em diversos dispositivos - o que ora é nosso objeto vem tratado na Part 18 da norma, Section 658 e seguintes, que de forma geral, manteve em termos substancialmente equivalente o regime do Companies Act de 1985 e entrou em vigor apenas em 01 de outubro de 2009 - cf. The Companies Act 2006 (Commencement No. 8, Transitional Provisions and Savings) Order 2008 -. A regra geral continuou sendo a de vedação da aquisição de ações próprias pelas limited companies, e duas foram as principais alterações: (i) a partir de 2006, as operações eram permitidas, salvo se proibidas expressamente pelo estatuto (Section 690(1)), em sentido diametralmente oposto ao regime da lei de 1985, em que as operações eram proibidas, exceto se permitidas pelo estatuto, e (ii) foi substituída a statutory declaration requerida dos administradores das private companies para uma aquisição "out of capital" por um statement simples, em conformidade com a Section 714, mas, por outro lado, o statement passou a levar em consideração, para definir a situação financeira e solvabilidade da companhia, uma gama maior de passivos (Section 714) - a necessidade de aprovação por maioria qualificada permanece.

Essa permissão é apenas possível (i) para private companies (Chapter 5 da Part 18 inteiro), (ii) quando esgotados os saldos de lucros distribuíveis (permissible capital payment, cf. Section 710), (iii) se permitida por aprovação qualificada da assembleia geral (Section 716 - que é aprovação distinta daquela igualmente necessária para efetuar uma recompra privada prevista na Section 694(2)), e (iv) se acompanhada da declaração da administração e do parecer dos auditores. E ela é bastante peculiar, pois é a única norma europeia de que temos notícia que permite uma recompra de ações mesmo que a companhia (fechada apenas) não tenha saldo de lucros ou reservas em montante suficiente, desde que a administração assuma formalmente perante todos a responsabilidade por declarar que após "having made full inquiry into the affairs and prospects of the company" é de sua opinião que, logo após o desembolso do pagamento, e pelo período de um ano que se seguirá, não haveria fundadas razões para antever que a companhia ficasse inviabilizada de honrar com suas obrigações. (redação da Section 714(3)). A administração é obrigada a considerar, nessa avaliação, todos os passivos da companhia, atuais ou contingentes, sem critério de materialidade algum. Além disso, essa declaração deve vir acompanhada de uma carta dos auditores da companhia confirmando 
que nada nas estimativas da administração poderia ser considerada como unreasonable (Section 714(6)). O único elemento, a nosso ver, que sustenta esta modalidade de negócio com as próprias ações, em países em que o conceito de capital social se mantém - como no Reino Unido, mas certamente com menos entusiasmo do que nos países de origem continental - é um regime de responsabilização da administração extremamente severo. Na norma inglesa, dar uma declaração desta modalidade sem "reasonable grounds" é, por si só, crime, com pena de até 2 anos de prisão e multa.

A norma mantém substancialmente o regime das market purchases (disponível apenas para public companies, que são as únicas que presumivelmente terão ações elegíveis, conforme são definidas na norma e sujeitas à deliberação ordinária da assembleia) e das off-market purchases (disponíveis tanto para private quanto public companies, mas sujeitas também à aprovação qualificada da assembleia e com restrições de voto dos acionistas contratantes com a companhia), com uma regulamentação extensa para cada uma dessas modalidades. O regime jurídico das ações em tesouraria introduzido em 2003 foi mantido praticamente intacto na redação original da Companies Act de 2006.

Em 21 de julho de 2009, foi editado o Companies (Share Capital and Acquisition by Company of its Own Shares) Regulations 2009, que modificou o Companies Act novamente na matéria - antes mesmo dele estar em vigor! -, por força, agora sim, da conversão em lei nacional das previsões da Diretiva Alteradora. Basicamente, foram duas as adaptações: (i) aumento dos prazos de autorização da assembleia, seja para compras a mercado, seja para compras privadas, de 18 meses para 5 anos, e (ii) exclusão da Section 725 que tratava do limite de $10 \%$ para manutenção de ações em tesouraria.

Por fim, a matéria foi objeto de nova modificação em abril de 2013, no Reino Unido, com a publicação da The Companies Act 2006 (Amendment of Part 18) Regulations 2013, que entrou em vigor no dia 30 daquele mês. As principais alterações dessa norma foram (i) uniformizar as aprovações assembleares tanto para as recompras a mercado quanto para as recompras privadas, que passaram a ser aprovações simples (ordinary resolutions), o que era previsto até então apenas para as recompras a mercado - market purchases, alegadamente em decorrência do maior potencial conflito de interesses oriundo de uma recompra privada, (ii) inclusão de várias facilidades e um regime bem menos regulado para recompras de ações que forem realizadas em conexão com um plano de 
participação de funcionários (employee share scheme) ${ }^{105}$, (iii) foi, finalmente, estendida a possibilidade para as private companies deterem ações em tesouraria, que desde 2003 eram permitido apenas para as companhias públicas, tendo sido excluída a definição de “ações elegíveis" (nova redação da Section 724).

\subsubsection{Direito Norte-Americano}

Esta seção está subdividida em duas partes. Em um primeiro momento, avaliaremos o nascimento das regras consuetudinárias nos EUA no início e no decorrer do século XIX, entrando nas primeiras décadas do século XX. O segundo bloco de estudo será, então, o da avaliação do direito positivo norte-americano, consubstanciado em algumas leis nacionais publicadas pelos estados federados. A avaliação das normas federais de 1933/1934, editadas logo após o crash da bolsa de Nova Iorque em 1929, por sua pertinência temática com a tutela do mercado de capitais e dos investidores, será feito no capítulo referente aos a esses interesses.

O desenvolvimento de uma american rule acerca da possibilidade ou impossibilidade de uma companhia adquirir suas próprias ações, ou livremente negociar com elas, foi objeto de algumas importantes decisões nos EUA já no século XIX. Apesar de, obviamente, ter o judiciário americano se baseado na jurisprudência e legislação inglesas nesse início do desenvolvimento das corporations, a sua utilização não foi muito útil, especialmente considerando o rápido e majestoso desenvolvimento das empresas americanas no século XIX ${ }^{106}$.

O primeiro caso tido como o leading case americano sobre a matéria (ainda que alguns escritores mencionem como tal o caso Ex Parte Holmes, julgado pela Suprema

\footnotetext{
${ }^{105}$ A norma como um todo teve o objetivo declarado de simplificar o processo de recompras em conexão com os planos de opções e de participação no capital das companhias pelos funcionários, de forma a fomentá-la. Tal motivação fica clara quando vamos à origem da modificação, ligada a um desejo de alterar a forma pelas quais as companhias inglesas são administradas, alinhando interesses de mais longo prazo. Após solicitação do então Ministro do Trabalho do Reino Unido, Norman Lamb, Graeme Nuttall publicou um estudo independente sobre a participação acionária dos funcionários em empresas inglesas, que ficou conhecido como Nuttal Review of Employee Ownership. Segundo Norman Lamb: "we need to fundamentally change our economy to ensure long term growth is strong and more evenly balanced in the future. One of the centrepieces to creating this sustainable growth is to encourage more responsible and more diverse ways of running a business in Britain today. I want this to be the decade of wider employee ownership". Cf. The Nuttall Review of Employee Ownership, Julho de 2012, p. 1. Essas recomendações foram posteriormente colocadas em audiência pública sob o título de "Employee Ownership and Share Buy Backs", de outubro de 2012 e, finalmente, propostas e publicadas em abril de 2013.

${ }^{106}$ Cf Irving J. Levy, Purchase by a Corporation of its Own Stock, in Minnesota Law Review, Vol. XV, N. ${ }^{\circ}$ 1, 1930, p. 12, descrevendo com detalhes o desenvolvimento histórico primordial nos EUA.
} 
Corte de Nova Iorque em $1826^{107}$ ) é um julgamento da corte da Georgia, Hartridge v. Rockwell, do ano de 1828, envolvendo a possibilidade de um banco adquirir suas próprias ações, com a finalidade de revendê-las posteriormente, podendo, por essa via, aumentar a distribuição de dividendos para seus acionistas. No caso, os pontos fundamentais da disciplina foram levantados e discutidos, inclusive o perigo para os credores e para os acionistas, além do risco de que a administração se valesse dessas operações para se perpetuar no controle da companhia. É realmente surpreendente como um julgado de mais de 180 anos já tenha tido a visão de enfrentar o assunto da mesma forma que, basicamente, se o encara nos dias de hoje.

No final, os juízes entenderam que as aquisições das próprias ações eram um útil instrumento disponível para utilização dos administradores na sua avaliação dos melhores investimentos disponíveis para o capital da companhia no mercado, reconhecendo, assim, a sua legitimidade com base no fato de que o patrimônio social não sofreria diminuição (já que o dinheiro seria substituído por ações da companhia de igual valor) e uma vez que, se houvesse dano ao acionista, ele poderia valer-se de mecanismos de ressarcimento judicial. Com certos refinamentos ${ }^{108}$, a opinião da corte nesse caso passaria a ser a regra majoritária adotada no direito americano (o que vai frontalmente contra a posição originalmente adotada pelos tribunais ingleses) - muito embora tenha sido duro o embate da american rule contra a resistência e força argumentativa de uma posição minoritária de julgados coadunando-se com a interpretação inglesa (english rule) ${ }^{109}$. Agora, não obstante tivesse sido formada uma majority rule que considerava lícitas as operações, muito fragmentadas e diversas foram as justificativas e os argumentos usados pelas diversas cortes para fundamentá-las ${ }^{110}$, especialmente no tocante ao que constitui exatamente a extensão da proteção dos credores.

\footnotetext{
${ }^{107}$ Cf. E. Merrick Dodd, Jr. Purchase and Redemption by a Corporation of its Own Shares: The Substantive Law, in University of Pennsylvania Law Review, Vol. 89, 1941, p. 698.

${ }^{108}$ Não demorou muito tempo para a literatura veementemente criticar a opinião de que ações em tesouraria, adquiridas pela companhia, seriam um substituto adequado para o dinheiro que saiu do patrimônio social como contraprestação da aquisição e que daí não resultaria nunca prejuízo aos credores. Segundo alguns autores, isso seria mera verborragia: "It is mere verbiage to say the corporation has a new asset. What has happened is that the capital and assets have both been reduced in the amount of the purchase price, if the purchase was at par". Cf. Erwen Esser Nemmers, The Power of a Corporation to Purchase its Own Stock, in Wisconsin Law Review, 1942, p. 167. Deste tipo de consideração foram surgindo os mencionados refinamentos da american rule.

${ }^{109}$ Cf. Arthur Nussbaum, Acquisition by a Corporation of its Own Stock, in Columbia Law Review, Vol. 35, 1935, p. 977, relatando que a majority rule dos EUA "stands alone in the world of comparative law". Também em Erwen Esser Nemmers, op. cit., pp. 168 e ss.

110 "While the courts following the American rule usually have no difficulty in stating the rule, there is no unanimity in the application of certain phases of it". Cf. Leo G. Blackstock, A Corporation's Power To Purchase Its Own Stock and Some Related Problems, in Texas Law Review, Vol. 13, 1934/1935, p. 446.
} 
Em resumo, a majority rule criada nos EUA no início e meados do século XIX assumia formulação amplamente permissiva: contanto que fosse feita de boa-fé, não intencionada a defraudar credores (o que genericamente se entendia ser o caso quando a companhia ficasse insolvente) ou prejudicar os acionistas - e não houvesse uma vedação explícita na lei ou nos estatutos da companhia, a admissibilidade irrestrita de aquisição de ações próprias não poderia ser questionada (estes conceitos vagos, por sua vez, levaram àquela já mencionada profusão de opiniões sobre os aspectos concretos destas condicionantes).

Apesar de inicialmente terem sido bem divididos os Estados norte-americanos sobre qual tendência seguir e muito fragmentadas as explicações e justificativas tanto da permissão quanto da proibição, acabaram convergindo as legislações, na década de 1930/1940, para a adoção da regra majoritária e permissiva ${ }^{111}$, que terminou prevalecendo, ainda que sujeitando as companhias às mais variadas salvaguardas anti-fraud. Em resumo, a problemática inerente à admissibilidade de uma companhia adquirir suas próprias ações foi, desde a sua origem, o centro de um vivo debate, seja de parte da doutrina, seja de parte da jurisprudência norte-americanas do século XIX e até o início da década de 1940.

Assumindo a prevalência da regra permissiva no debate, as cortes passaram, então, a impor condições das mais diversas para que a regra fosse aplicável, condições estas que visavam a garantir a mencionada boa-fé e ausência de fraudes contra os credores e danos para os acionistas (alguns destes controles e testes já haviam sido sugeridos ou mencionados na jurisprudência anterior à promulgação de leis, que floresceram em larga escala a partir da década de 1930). Para verificar a existência ou não de fraude contra credores na realização da aquisição das próprias ações, segundo a majority rule, emergiram dois testes (como sói acontecer em termos de lei americana, os testes judiciais têm papel relevantíssimo no complemento das regras legais e consuetudinárias): o Solvency Test (Teste de Solvência) e o Surplus Test (Teste do Patrimônio Líquido).

O Solvency Test foi criado paralelamente ao outro e tinha como fundamento básico que o negócio da companhia com as suas ações seria permitido, desde que a companhia não estivesse insolvente (ou seja, incapaz de honrar as suas obrigações vencidas - conceito que não leva o patrimônio líquido em consideração) nem se tornasse insolvente após a

\footnotetext{
${ }^{111}$ Segundo Erwen Esser Nemmers, escrevendo em 1942, apenas 4 Estados norte-americanos adotavam a regra proibitiva originada do direito inglês, sendo que apenas New Hampshire era massivamente unânime em não aceitar a permissão. In op. cit., p. 181. Cf. também Leo G. Blackstock, op. cit., p. 442. Para uma tentativa de análise e explicação sobre por que as cortes americanas acabaram migrando para a regra mais relaxada, cf. E. Merrick Dodd, Jr., op. cit., pp. 700 e ss, que menciona, inclusive, o maior prestígio das cortes que assim julgaram, como a Suprema Corte de Nova Iorque em Ex Parte Holmes.
} 
conclusão do negócio ${ }^{112}$. O principal ponto controverso deste teste era o momento no qual deveria ser avaliada a solvência, se no momento no qual o contrato fosse aperfeiçoado ou se no momento do pagamento, o que era particularmente delicado no caso de pagamentos diferidos ou parcelados no tempo. A resposta majoritária a esse questionamento era a de que a companhia deveria estar solvente tanto no momento de celebração do contrato, quanto no momento do pagamento. O leading case citado como criador do Solvency Test foi In re Fechheimer Fishel Co., de 1914. Segundo a corte julgadora: "If the stockholder sells his stock to a corporation which issued it, he sells at his peril and assumes the risk of the consummation of the transaction without encroachment upon the funds which belong to the corporation in trust for the payment of its creditors. The rights of the creditors cannot be defeated by the fact that at the time the transaction was entered into the seller of the stock and the officers of the company who purchased it were acting in good faith and supposed that the corporation was solvent" - grifos nossos ${ }^{113}$.

Note-se a menção da corte, nos grifos no trecho acima, ao fato de que o acionista que vende à companhia, o faz sob sua conta e risco, considerando que o capital social estaria "held in trust" para os credores: a teoria ficou conhecido como Trust Fund Theory. Ela aproxima bastante os regimes norte-americano (nesta época) com o regime jurídico do capital social desenvolvido na Europa continental, e que acabou tornando-se a grande referência em matéria de aquisição das próprias ações no velho continente. Em um caso julgado em 1824, e que se tornou célebre, o magistrado Story, da Circuit Court do distrito de Maine, elaborou os contornos da teoria, assim descrita por Levy: "One of the deepseated principles of our law is the so-called 'trust fund' doctrine enunciated by Judge Story in 1824. Whatever criticism has since been levelled against the use of that frase to explain the legal limitations on the use of the capital of a corporation, the principle remains that it may not be returned to subscribers or shareholders so as to injure creditors" "114. A Trust Fund Theory é, portanto, se não idêntica, muito semelhante à teoria da manutenção do capital social na função a que se destina. Esta doutrina, inclusive, encontrou aplicação específica em alguns casos julgando aquisições das próprias ações

\footnotetext{
${ }^{112}$ Criticando a teoria da solvência, pelo fato de ela amparar-se muito na situação probatória da "condição de solvência", Arthur Nussbaum assim se pronunciou: "These cases in my opinion not only reveal that the majority rule is unsound in itself, but at the same time disclose a difficult problem of proof'. In op. cit., p. 982.

${ }^{113}$ Cf. Erwin Nemmers, op. cit., pp. 171 a 173.

${ }^{114}$ Cf. Irving Levy, Purchase..., cit., p. 19.
} 
pela companhia na década de $1910^{115}$, inclusive o caso In re Fechheimer Fishel Co. que mencionamos acima.

Nos muitos Estados onde a majority rule foi adotada, o teste de solvência acima não era, por vezes, visto como suficiente para que fosse considerada válida a aquisição da companhia dentro do conceito de que tais negócios deveriam ser feitos de boa-fé e sem prejuízo aos interesses dos credores e acionistas, e assim, foi condicionada essa validade também (ou apenas a, conforme o caso) outro critério: o Surplus Test. Ele surgiu já contando com uma série de interpretações diferentes sobre o que efetivamente consistiria o "surplus". Uma parte dos julgados entendia que o negócio seria possível desde que, após realizado, a companhia tivesse ativos que superassem os passivos, menos o capital social; enquanto outra corrente incluía no Surplus Test a cifra do capital ${ }^{116}$. Segundo Leo G. Blackstock, propondo-se a esclarecer a terminologia usada nos julgados como tentativa de refinar o Surplus Test, "a great deal of confusion existing in connection with these problems arises either from use of language which has no uniform meaning and application or from lack of a clear conception of the meaning of terms on the part of those speaking or writing on the subject" ${ }^{\prime 117}$. Em 1915, I. Maurice Wormser, também adepto da escola norte-americana, em contraposição à escola inglesa, defende que "[i]f the rights of creditors and the rights of stockholders are thus safeguarded, and if purchase be permitted from surplus alone as distinguished from capital stock, there would seem no valid reason for denying to a corporation the right to acquire shares of its own stock. On the contrary, to deny the right under such conditions and circumstances, would unduly hamper corporate activity and usefulness and the serviceability of the private corporation as a type of business organization" "118. O que retiramos desta discussão é que, de maneira geral, a preocupação dos doutrinadores e juízes norte-americanos lidando com o Surplus Test era o de justamente presumir válidas as aquisições quando fossem feitas com saldo contábil de lucros e reservas de lucros que, similarmente ao que acontece no regime do capital social europeu continental, significa um patrimônio líquido (ativos - assets - diminuídos os

\footnotetext{
${ }^{115}$ Cf. Barbara Pozzo, op. cit., p. 374.

116 "It would definitely be more correct to refer to only one test for surplus: excess of assets over liabilities, including capital stock. This is the accountant's concept. But the cases use "surplus" to convey various meanings". Cf. Erwen Esser Nemmers, op. cit., pp. 170, nota de rodapé 63. Também nesse artigo encontramse citações a muitas decisões judiciais apoiando esta tese mais "ortodoxa" do conceito de patrimônio líquido disponível.

${ }^{117}$ Cf. Leo g. Blackstock, op. cit., pp. 449 e ss.

${ }^{118}$ I. Maurice Wormser, The Power of a Corporation to Acquire Its Own Stock, The Yale Law Journal, Vol. 24, N. ${ }^{\circ} 3,1915$, p. 188.
} 
passivos - liabilities) disponível, ou superior ("surplus") ao capital social nominal (capital stock).

Como vimos, não só o interesse dos credores era alçado como digno de tutela. Também aquele dos acionistas deveria ser salvaguardado, para que o negócio fosse considerado como legítimo e válido. Os dois testes que acabamos de analisar eram bastante eficientes para assegurar a tutela dos credores, mas não enfrentavam a questão de que os acionistas da companhia poderiam sofrer um dano em decorrência da modificação basilar da estrutura social, do grupo de controle e da perpetuação da administração da companhia. O principal quesito a ser observado, de acordo com os julgados à época (início do século XX, até 1940) era o de que os acionistas deveriam ter um "equal treatment", sendo que a proposta de recompra pela companhia deveria ser acessível a todos os acionistas indistintamente, de maneira proporcional à sua titularidade no capital social ${ }^{119}$. O leading case que adotou firmemente esta linha de tratamento igualitário entre os acionistas foi o caso Hoops v. Leddy, da Corte de New Jersey, datado de 1936, que foi posteriormente seguido por outras cortes ${ }^{120}$.

Pois bem, analisada em breves palavras a história jurídica das cortes norteamericanas desde o início do século XIX, e os princípios que permitiam, de acordo com elas, a válida celebração deste tipo de negócio jurídico, chegamos ao momento de analisar como estes princípios e testes foram transpostos para o direito codificado, que floresceu nos EUA na década de 1930, tendo sido promulgadas leis sobre o direito das companhias em quase todos os Estados norte-americanos que, anteriormente, eram desprovidos de normas que regulassem a matéria ${ }^{121}$. Esse movimento codificador decorreu da necessidade de reavaliação de todo o direito societário por conta da crise de 1929 que abalou os EUA e fez com que os anseios da doutrina por uma revisão das normas societárias surgissem de forma ampla. Apesar do intuito comum, a forma como as leis dos Estados internalizaram essa regulamentação foi bastante diversificada, (i) tendo alguns (incluindo Delaware) permitido as aquisições desde que o capital "não fosse lesado" ("if the capital is not thereby impaired"), (ii) outros (incluindo o Estado de Nova Iorque) fizeram referência mais expressa à utilização necessária do saldo de lucros ("out of surplus"), (iii) outros poucos proibiram a aquisição (Wyoming e Kentucky). Em resumo, no início da década de

\footnotetext{
${ }^{119}$ Sobre o tema, cf. Erwin Nemmers, op. cit., pp. 175 e ss.

${ }^{120}$ Cf. Barbara Pozzo, op. cit., p. 383.

${ }^{121}$ Referimo-nos a Erwin Nemmers, op. cit., pp. 179 e ss.; E. Merrick Dodd, Jr., op. cit., pp. 704 e ss.
} 
1940, 34 Estados norte-americanos tinham codificações tratando da matéria, enquanto 5 Estados não continham regra alguma sobre o tema ${ }^{122}$.

Com o tempo, no entanto, o direito norte-americano foi se afastando da noção de legal stated capital (ou capital stock) como forma de proteção dos credores, de forma que a Trust Fund Theory do século XIX e início do século XX foi, lenta, mas inexoravelmente, perdendo força como teoria justificativa da proteção dos credores e, por consequência, como forma de regulamentar as condições sob as quais seria lícita ou não a aquisição das próprias ações pela companhia. Então, apesar de terem partido de um ponto razoavelmente comum, o direito europeu e o direito norte-americano começam a tomar rumos extremamente diversos a partir da década de 1940, tendo sido o primeiro passo neste distanciamento as leis que passaram a permitir a emissão de ações sem valor nominal, a contar do exemplo da New York Corporation Law de $1912^{123}$, de onde se seguiu uma extensa revisão pela doutrina americana sobre o conceito e o fundamento do regime do stated legal capital, que culminou com uma mudança definitiva de paradigma introduzida pela General Corporation Law da Califórnia, no ano de 1976.

Essa lei equiparou o pagamento de dividendos às recompras de ações, sob a rubrica de "distributions", além de ter revolucionado o regime de tutela dos credores, extirpando os conceitos de "stated capital" e "surplus". Afastou-se definitivamente o direito norteamericano do europeu a partir de então, caindo em descrédito o conceito de capital social e a função a que se propunha, tornando a Califórnia o Estado vanguardista acerca da matéria $^{124,125}$. Alguns autores, comentando a introdução da nova lei, em comparação com as disposições legais anteriormente vigentes na Califórnia, disseram que o regime da lei anterior utilizava a divisão do balanço da companhia para permitir os negócios, o que estava relacionado apenas a rubricas contábeis, sem manter coerência com índices

\footnotetext{
${ }^{122}$ Cf. Barbara Pozzo., op. cit., p. 386.

${ }^{123}$ Carlos L. Israels, Problems of Par and No-Par Shares: A Reappraisal, in Columbia Law Review, Vol. 47, 1947, pp. 1279 e ss.

124 "These new provisions have made California the first jurisdiction to abandon the fundamental but ineffectual doctrine of traditional legal accounting that the stated capital of a corporation forms a "trust fund" for creditors" - grifos nossos. Cf. Thomas C. Ackerman Jr. e James K. Sterret, II, California's New Approach to Dividends and Reacquisitions of Shares, in UCLA Law Review, Vol. 23, 1975/1976, p. 1052.

${ }_{125}$ "California's dividend provisions, enacted in 1977, marked a sweeping break with traditional dividend statutes. Until that time, the foundation of most statutes was a legal concept-stated capital. In contrast, the foundation of the California statute is a set of economic realities: retained earnings, asset-liability ratios, liquidation preferences, and an insolvency test". Cf. Melvin Aron Eisenberg, Corporations and Other Business Organizations - Cases and Materials, $8^{\text {a }}$ ed., Foundation, New York, 2000, p. 898.
} 
financeiros ou, de forma mais geral, sem coerência "to the realities of corporate finance ${ }^{126}$.

A General Corporation Law da Califórnia de 1976, nos termos do seu §500, criou um mecanismo duplo para permitir a realização dos negócios da companhia com as suas ações. Assim, poderia a companhia fazer uma "distribution" aos acionistas (i) com o saldo de "retained earnings", assim definidos nas normas contábeis aplicáveis de tempos em tempos, ou (ii) mesmo que o saldo de lucros acumulados não fosse suficiente, desde que fossem atingidos, cumulativamente, dois (complexos) índices contábeis - aparentemente refletindo a imposição de índices feitas por alguns credores de maior porte das companhias $^{127}$ - após realizada a aquisição, um deles relacionava ativos totais com passivos totais (e, portanto, considerava a alavancagem da companhia, sendo denominado de índice de solvência quantitativa) e o outro relacionava ativos circulantes com passivos circulantes (índice conhecido como índice de liquidez corrente - referindo-se, por óbvio, ao estado de liquidez da sociedade). No cálculo desses índices, diversos fatores contábeis eram levados em consideração pela lei, especialmente indicadores do valor contábil dos ativos (de onde eram deduzidos alguns itens, como os intangíveis) em relação aos passivos. A lei definia com minúcia o que deveria ser considerado na conta dos ativos e dos passivos da companhia, e como eles deveriam ser avaliados (por exemplo: em geral, ativos deveriam ser considerados a custo de aquisição - book value -, e não a valor de mercado, exceto para securities) ${ }^{128}$. Além disso, a nova lei elimina o conceito de ações em tesouraria (treasury shares), prevendo que, uma vez readquiridas pela companhia, as ações deveriam retornar ao estado de "authorized but unissued capital"129.

A norma teve como intuito a modernização da proteção dos credores, por meio da extinção do conceito de capital social e pela adoção, na lei, de conceitos contábeis e de princípios de finanças corporativas que eram entendidos como mais eficientes na proteção e tutela do interesse dos credores. Na revisão de 1979 da Model Business Corporation Act,

\footnotetext{
${ }^{126}$ Cf. Gilbert Dreyfuss, Distributions to Shareholders under the New California General Corporation Law, in Loyola of Los Angeles Law Review, Vol. 9, 1976, p. 842.

127 "In their place the new law has substituted the accounting notion of retained earnings and new financial tests modeled after typical restrictions placed on borrowers by institutional lenders. The result is that trade and other creditors have become the beneficiaries of concepts drawn from the experience of people whose business it is to loan money" - grifos nossos. Cf. Thomas C. Ackerman Jr e James K. Sterret, II, op. cit., p. 1053.

${ }^{128}$ Cf. Gilbert Dreyfuss, op. cit., p. 850 e, mais adiante, 852.

129 "In short, treasury shares represented an aberration in the statutory scheme that created unnecessary legal and accounting problems". Cf. Gilbert Dreyfuss, op. cit., p. 862.
} 
e com mais profundidade na revisão de 1984, esta liderada por Elliot Goldstein, o mesmo caminho foi seguido (inclusive com relação à equiparação das formas de "distribution" e a implantação dos testes de solvência), abandonando-se os conceitos que então passaram a ser vistos como anacrônicos ${ }^{130}$.

Na versão atual do Revised Model Business Corporation Act ("MBCA"), de 2002, a seção 6.31 (que tem a mesma redação desde a reforma de 1979) determina que as recompras de ações podem ser realizadas pela companhia, mas não serão consideradas ações em tesouraria, mas, sim, "authorized but unissued shares", algo semelhante ao capital autorizado porém não emitido do direito brasileiro. Isso vale exceto no caso de o estatuto social da companhia vedar a "reemissão" (reissue), situação na qual, de acordo com a mesma seção, as ações serão canceladas e o montante do "authorized capital" diminuído em valor correspondente.

Por serem consideradas como uma forma de "distribution" da companhia a seus acionistas (conforme definição que é dada a essa expressão pela seção 1.40 do RMBCA), determina a regra geral acerca de todas as formas de distribution que tal apenas pode ocorrer de acordo com determinadas regras comuns. A seção 6.40 do RMBCA, seguindo a tradição das reformas de 1979/1980, submete a legalidade de tais negócios a dois testes alternativos: (i) o Equity Insolvency Test, e (ii) o Balance Sheet Test ${ }^{131}$, que vêm previstos em termos substancialmente equivalentes aos anteriormente elaborados em 1976 pela Califórnia. Hoje, inclusive, o California Corporation Code replica, na sua essência, os testes previstos na RMBCA (cf. $§ 500$ e ss ${ }^{132}$ ).

\footnotetext{
130 "In 1980, amendments to the Model Act did away with concepts that were historically considered fundamental to the law of corporations, but, more recently, had come to be viewed as anachronistic. These amendments eliminated the concepts of par value, stated capital, and treasury shares. The 1984 revision made even further changes". Cf. Elliott Goldstein, Revision of the Model Business Corporation Act, in Texas Law Review, Vol. 63, 1984/1985, p. 1478.

131 De acordo com o Official Comment a essa seção, "[t]he reformulation of the statutory standards governing distributions is another important change made by the 1980 revisions to the financial provisions of the Model Act. It has long been recognized that the traditional 'par value' and 'stated capital' statutes do not provide significant protection against distributions of capital to shareholders. (...) The financial provisions of the revised Model Act, which are based on the 1980 amendments, sweep away all the distinctions among the various types of surplus but retain restrictions on distributions built around both the traditional equity insolvency and balance sheet tests of earlier statutes" - grifos nossos.

${ }^{132}$ Ressaltando que a lei da Califórnia não faz menção ao capital social para permitir o pagamento de dividendos (e, portanto, para admitir as recompras), Robert Clark assim se manifestou: "Note that this test does not depend on the concept of legal capital". Cf. Robert Charles Clark, op.cit., p. 623. Apenas lembramos que o direito societário norte-americano continua sendo de competência dos Estados federados, de forma que a adoção dos conceitos do RMBCA não é obrigatória. Inclusive, Estados relevantes, como o de Nova Iorque (cf. §513 e ss. da New York Business Corporations Law, falando em "out of surplus") e Delaware ( $\$ 160$ e ss. da Delaware General Corporation Law, falando em "if capital is not impaired"), continuam adotando os conceitos de stated capital e surplus. Estes últimos - e o regime anterior, portanto -,
} 
De maneira complementar, e vale aqui o comentário, o RMBCA prevê uma hipótese específica de responsabilidade da administração em caso de uma distribution em desconformidade com essas regras. A seção 8.33 estipula, de fato, que, nos dois anos subsequentes à distribuição, caso o administrador não tenha agido seguindo as normas de conduta a ele aplicáveis (good faith, reasonabe care, etc.), e tenha votado ou consentido com uma distribuição em desconformidade com as regras vistas acima, ele será, então, pessoalmente responsável por cobrir a diferença entre o que foi distribuído e o que poderia ter sido. Pela mesma regra, se existir concorrência de culpa com outros administradores a mesma sanção aplicar-se-á a eles, e os acionistas de má-fé que tiverem recebido a distribuição sabendo da sua irregularidade, deverão devolver os valores assim recebidos.

A conclusão dessa breve retrospectiva no direito dos EUA nos mostra que, a partir do final da década de 1970, boa parte da doutrina e das normas escritas dos Estados norteamericanos passa a adotar um regime totalmente diverso daquele que tem por base o regime do capital social e que, no limite, garante ampla flexibilidade às companhias para distribuírem seus ativos aos acionistas, seja com recursos oriundos de lucros, seja com saldo contábil de capital social ${ }^{133}$.

Se é verdade que os interesses dos credores foram objeto de grande e extensa intervenção do legislador dos EUA, conforme se depreende da análise que fizemos acima sobre as formas, condições e testes necessários para permitir a distribuição, em que medida interveio o legislador para salvaguardar os interesses dos acionistas em caso de negócios com as próprias ações pela companhia? Em parte por conta da filosofia societarista norteamericana, de cunho notadamente contratualista (a companhia como nexus of contracts refletindo-se no conceito de que o acionista que aceitou fazer parte da companhia assumiu voluntariamente os riscos da membridade e não deveria merecer tutela especial), os critérios de proteção com relação ao tratamento igualitário entre acionistas nestas operações deverão ser buscados em fontes diversas daquelas que são predispostas a tutelar os credores sociais. Aparentemente, a atenção do legislador norte-americano implicitamente reconhece que os interesses verdadeiramente dignos de tutela normativa são aqueles dos credores: a proteção dos acionistas deriva dos deveres fiduciários de conduta da administração (fiduciary duties doctrine), que está, ainda, intimamente relacionada com a business judgement rule. A interação entre essas duas teorias, como

estão longe de terem sido abandonados, considerando a relevância desses dois Estados para o direito societário norte-americano.

${ }^{133}$ Cf. também Barbara Pozzo, op. cit., p. 405. 
forma de garantir proteção judicial aos acionistas, é bastante flexível, por um lado (na medida em que a regra geral seja a de agir com probidade, boa-fé e no interesse da companhia, mas reconhecendo-se um campo de atuação discricionário dos administradores), e complexa, por outro lado (submetendo a matéria de tutela dos acionistas ao foro de competência probatória do judiciário) ${ }^{134}$.

Além de observarem as normas societárias do Estado onde sejam incorporadas, algumas companhias (basicamente as abertas), devem observar também as leis federais norte-americanas sobre o direito dos valores mobiliários e do mercado financeiro: o U.S. Securities Act of 1933 ("Securities Act”) e a U.S. Securities Exchange Act of 1934 ("Exchange Act"), que criou a Securities Exchange Commission ("SEC"), publicadas em decorrência da crise de 1929, e que miravam justamente complementar as regras da common law por meio da positivação de normas de transparência e tendentes a coibir os abusos e fraudes cometidos nas operações com valores mobiliários. A SEC, exercendo seu mandato de normatizar o mercado de valores mobiliários, de certa forma "federalizou" uma parte do direito societário norte-americano e passou a coexistir com as disciplinas orgânicas das companhias de cada Estado, criando um corpo de securities regulation robusto e extenso. Sobre as normas federais e aquelas publicadas pela SEC discorreremos no capítulo sobre a proteção dos interesses do mercado de capitais e dos investidores.

\subsubsection{Direito Brasileiro}

A proibição de a companhia emitente negociar com as suas próprias ações já constava, em textos mais ou menos lacunosos e vagos, de há muito no direito positivo brasileiro. Mas, contrariamente ao que se pode pensar, essa proibição não surgiu concomitantemente com a positivação da limitação da responsabilidade dos acionistas pelas dívidas sociais. Alguns diplomas antigos, como o próprio alvará de criação do Banco do Brasil de 12 de outubro de 1808, o Código Comercial e a legislação de $1860^{135}$, continham disposições acerca da limitação da responsabilidade, mas a proibição da negociação com as próprias ações veio a ser inserida (expressamente) no direito positivo brasileiro apenas com a edição da Lei 3.150/1882 (e a proibição expressa de existência de participações recíprocas como forma indireta desses negócios - muito depois - apenas com a Lei das S.A.).

${ }^{134}$ Cf. Luis Felipe Spinelli, Conflito de Interesses na Administração da Sociedade Anônima, Malheiros, São Paulo, 2012, pp. 55 e ss, com detalhada análise e extensa bibliografia.

${ }^{135}$ Como ficaram conhecidas. Ver Lamy Filho e Bulhões Pedreira, A Lei das S.A., p. 115. 
O Código Comercial (Lei 556, de 25 de junho de 1850), inspirado no Código Comercial francês de 1807 e no Código Comercial português de 1833, foi o primeiro diploma legal brasileiro a regular as sociedades mercantis ${ }^{136}$ e dedicava às anônimas apenas cinco artigos, introduzindo, em decorrência do clareamento das ideias jurídicas, alguns princípios basilares da regulação das companhias (como a limitação de sua responsabilidade ao valor das "ações ou do interesse por que se houverem comprometido" - art. 298) que lhe imprimem a sua fisionomia peculiar. As regras sobre o capital social, nesta época, ainda eram, no entanto, escassas e confusas. O artigo 297 do Código Comercial fazia referência à contribuição de cada sócio ao capital da anônima, e o artigo 289 previa que o sócio deveria "entrar para o fundo social" com o dinheiro ou os bens a que se obrigara, respondendo pela mora. O artigo 292 continha importante disposição, que já indicava certa separação patrimonial entre sócio e companhia, ao não permitir ao credor particular de sócio que executasse os "fundos líquidos" que esse sócio tivesse na companhia antes de esgotados os demais bens particulares desse sócio (artigo 292) ${ }^{137}$. Nenhuma menção à negociação, pela anônima, com ações de sua emissão era feita neste momento histórico, pois a proteção aos credores e a separação formal de esferas jurídicas entre sociedade e sócio ainda estava em fase embrionária de evolução.

Pouco depois disso, com a edição da Lei 1.083, de 22 de agosto de 1860, de iniciativa do então Ministro da Fazenda Angelo Moniz da Silva Ferraz, foram incorporadas algumas poucas novidades e um estrito regime de fiscalização governamental (esta lei foi dedicada em grande parte às companhias que exercessem atividade bancária). Aqui, encontramos, no artigo $1^{\circ}, \S 8^{\circ}$, o princípio de que "[s]ó poderão fazer parte dos dividendos dos Bancos e Sociedades Anonymas de qualquer natureza os lucros liquidos provenientes

\footnotetext{
${ }^{136}$ Esta informação procede. No entanto, como salientamos um parágrafo acima, o alvará de criação do Banco do Brasil, em 1808, apesar de não ter disciplinado a sociedade por ações, já chamava os sócios daquela instituição de "acionistas" e aquele banco pode, sem dúvida, ser considerado a primeira sociedade anônima brasileira. $\mathrm{O}$ artigo $5^{\circ}$ dos estatutos do Banco do Brasil previa que "toda e qualquer pessoa que quiser entrar para a formação deste côrpo moral, o poderá fazer sem exclusão alguma, ficando ùnicamente obrigada a responder pela sua entrada”. Cf. Trajano de Miranda Valverde, Sociedades..., cit., p. 17.

${ }^{137}$ Como se percebe, no entanto, a separação patrimonial entre sócio e sociedade, apesar de ter sido, de certo modo, prevista, não considerava ainda a existência de uma esfera jurídica de direitos e deveres autônoma, representada pela pessoa jurídica da sociedade, pois os credores dos sócios, a pesar de terem de observar o benefício de ordem imposto pela lei, tinham direito, ao final, de acessar os "fundos líquidos" desse sócio na companhia, significando, ao que parece, uma perda patrimonial à companhia. Situação diversa ocorreria se o credor particular detivesse prerrogativas de penhora da quota social ou das ações de propriedade do sócio. Existia, sim, uma noção de patrimônio afetado (coletivizado em favor do fim comum a que se associavam as pessoas), mas daí a dizer-se que havia pessoa jurídica é exagerado. Não obstante a letra da lei não indicar expressamente a existência da personalidade jurídica, a doutrina à época já se manifestava no sentido de que "seria absurdo suppôr que o que pertence á sociedade pertença a cada socio, do mesmo modo que seria absurdo suppôr que o que pertença a cada socio pertença á sociedade". Herculano Marques Inglez de Souza era adepto da teoria da realidade da pessoa jurídica. In Direito..., cit., p. 108 e 109.
} 
de operações effectivamente concluídas no respectivo semestre", o que, em conjunto com as disposições do Código Comercial, indica uma evolução na disciplina dos interesses dos credores, apesar de não haver indicação clara da forma de cálculo desse lucro líquido. Semelhantemente, a mesma lei, no artigo $2^{\circ}, \S 10^{\circ}$, passou a proibir aos bancos (que eram sociedades anônimas) a realização de empréstimos que tivessem como garantia as próprias ações do banco mutuante, uma forma de negociação com as próprias ações que até hoje vigora como princípio proibitivo. De qualquer maneira, a proibição, aqui, ainda não se apresenta com traços claros, mas apenas com indicações de que o regime de proteção ao capital social estava na mente do legislador imperial.

A Lei 3.150, de 4 de novembro de 1882 foi o diploma que, no Brasil, instituiu a fase moderna das sociedades por ações, prevendo diversas normas de regramento da vida societária, incluindo medidas como publicidade dos atos sociais ${ }^{138}$, normas sobre conflito de interesses entre administração e sociedade, funcionamento da assembleia geral, além, obviamente, de significar a vitória do movimento econômico liberal, garantindo-se a livre constituição de sociedades anônimas pelos particulares (regime das disposições normativas) ${ }^{139}$. Foi aqui, também, que surgiu pela primeira vez a regulamentação específica aplicável às sociedades em comandita por ações (artigos 35 a 41). A Lei $3.150 / 1882$ foi regulamentada pelo Decreto n. ${ }^{\circ} 8.821$, de 30 de dezembro de 1882 , em cujos 168 artigos foram detalhadas diversas normas regentes da vida societária.

Esta lei previa expressa limitação de responsabilidade dos sócios pelas dívidas sociais, no artigo $2^{\circ}, \S 2^{\circ}$, com idêntica disposição no Decreto n. ${ }^{\circ} 8.821 / 82$. Logo em seguida, no artigo $3^{\circ}$, vem estipulada uma norma atinente à constituição do capital da sociedade: ela não poderia constituir-se sem que subscrito todo o seu "capital social" (e aqui é esta mesma a expressão usada) e sem que tenham sido integralizados ao menos $10 \%$ do valor das ações ${ }^{140}$. Outras regras atinentes à proteção do capital social se fazem

\footnotetext{
${ }^{138}$ Importantíssimo mecanismo na sociedade anônima, apto a tornar públicos os atos da vida social, contrapondo-se, de certo modo, à limitação da responsabilidade dos sócios. "Em referencia aos terceiros seria de facto uma verdadeira emboscada [a limitação da responsabilidade dos sócios], si o sigillo presidisse a todos os actos da constituição e do funccionamento das sociedades anonymas”. Cf. Dídimo Agapito da Veiga Junior, Sociedades..., cit., p. 96 e 97.

${ }^{139}$ Este regime de livre acesso dos particulares às sociedades anônimas foi, sem dúvida, núcleo fundamental da promulgação dessa lei, que teve como paradigmas, a Lei Francesa de 1867 e a Lei Belga de 1873. Cf. Dídimo Agapito da Veiga Junior, Sociedades..., cit., p. 17.

${ }^{140}$ Aqui, permitimo-nos entender, o capital social ainda aparece com a função de produção e não de garantia, ao menos da forma como hoje se a concebe. É de se notar, naturalmente, que a mera subscrição e integralização (real) de capital não é garantia alguma de credores por si só, mas é o tratamento dado às retiradas feitas pelos sócios que garante que esse capital seja afetado à fond perdu. Inclusive, Dídimo Agapito era contrário à adoção deste dispositivo e preferia que fosse necessária subscrição de apenas metade do capital social. Cf. Dídimo Agapito da Veiga Junior, Sociedades..., cit., p . 115 e ss, especialmente em 118.
} 
encontrar: avaliação de bens conferidos ao capital por três "louvados" e com aprovação da assembleia geral $\left(\operatorname{art} .3^{\circ}, \S 2^{\circ}\right.$ ), responsabilidade solidária do cedente de ação não integralizada pela sua integralização (art. $7^{\circ}, \S 2^{\circ}$ ), regras acerca da distribuição de dividendos fictícios (art. 13, cujo parágrafo único repete a dicção do art. $1^{\circ}, \S 8^{\circ}$ da Lei $1.083 / 1860$ que transcrevemos acima $)^{141}$.

Foi por meio desta lei, também, que ingressou oficialmente no nosso direito positivo a proibição de a companhia negociar com as suas próprias ações e, desde então, já era esse comportamento reprimido com a cominação de uma infração penal ao seu descumprimento. Assim é que o artigo 31 da lei ora em comento, que não constava do projeto original enviado ao Congresso Nacional, mas foi incorporado ao projeto por emenda aditiva das Comissões Reunidas de Fazenda e Justiça do Senado ${ }^{142}$, previa que "E' prohibido ás sociedades anonymas comprar e vender as suas proprias acções”, exceto nos casos de amortização com "fundos disponíveis" (essa a redação do seu parágrafo único, cópia fiel da Lei belga de 1873) e o artigo 27, I considerava crime a violação desses preceitos. Também era considerada infração penal a distribuição fictícia de lucros (art. 27, II) e a aceitação de penhor das ações de emissão própria em garantia de créditos sociais (art. 27, IV). Todas as regras, em tese, destinadas à proteção do capital social, que, nesta lei, já possui regime jurídico bem delineado ${ }^{143}$.

No Decreto 8.821/1882, regulamentador da Lei 3.150/1882, o tratamento é semelhante, mas a redação é aprimorada. É assim que o artigo $19, \S 2^{\circ}$, proíbe a companhia de receber as próprias ações em penhor e o artigo 20, desenvolvendo e aprimorando a redação do artigo 31 da lei (que comentamos acima), afirma: "Não póde a sociedade

\footnotetext{
${ }^{141}$ Falava-se em lucro líquido efetivamente auferido no semestre. A noção de que esses lucros seriam apenas e tão somente aqueles que superassem a cifra do capital social era clara desde então: "ora, a distribuição de dividendos não consistentes em lucros provenientes de transacções faz-se à custa do capital (...)”. No entanto, as noções de demonstrações financeiras eram embrionárias de modo que, é evidente, pode haver lucro no exercício sem haver lucro no balanço (por conta de prejuízos de exercícios anteriores): neste caso estaria igualmente impedida a distribuição de dividendos. Cf. Dídimo Agapito da Veiga Junior, Sociedades..., cit., p. 378. Para uma análise do normativo sob o ponto de vista dos aumentos de capital, cf. Mauro Rodrigues Penteado, Aumentos..., cit., pp. 47 e ss.

${ }^{142}$ Emenda essa assim justificada na sessão do Senado de 17 de abril de 1882: "Há uma fraude muito comum e de que dão noticia diversos escritores. Consiste essa fraude em comprar o administrador com fundos sociais um grande número de ações da própria companhia, com intuito de provocar altas fictícias e oportunamente revendê-las. A dita fraude pode ter por fim a obtenção de lucros ilícitos para a sociedade, ou mesmo para o administrador, hipótese esta que ocorre quando este possui grande quantidade de ações e quer dispor delas. Os primeiros prejudicados com tal artifício são os compradores. Também sofrem-lhe as consequências os acionistas e os credores da sociedade, por virtude de desvio de parte do capital. As comissões reunidas propõem que uma semelhante pratica seja absolutamente proibida e nesse sentido redigiram o aditivo". Cf. Dídimo Agapito da Veiga Junior, op. cit., pp. 531 e 532. Interessante notar a justificativa de manipulação de preços usada pela comissão, já nos idos de 1880 .

${ }^{143}$ Cf. Dídimo Agapito da Veiga Junior, Sociedades..., cit., pp. 531 a 534.
} 
anonyma comprar e vender as suas acções. Nesta prohibição não se comprehende a amortização das acções, uma vez que seja realizada com fundos disponiveis e sem offensa do capital" - grifos nossos. A redação grifada foi acrescentada pelo Decreto e constitui inegável indicação de que essas normas visam a tutelar juridicamente os credores sociais, por meio da manutenção de regras rígidas acerca do capital social.

Com a república, surge o Decreto 434, de 4 de julho de 1891, que veio a compilar a legislação relativa às sociedades anônimas no Brasil (consolidação apressada, diria Valverde ${ }^{144}$ ) e que se limitou a copiar o regime que a este respeito instituía a Lei 3.150/1882 e seu decreto regulamentador. Neste sentido, enunciava-se nos artigos 39 e 40, que era proibido às sociedades anônimas aceitarem em penhor as próprias ações e, também, a elas era vedado "comprar e vender" as próprias ações. Nesta proibição não se compreendiam as operações de amortização de ações, realizadas sem ofensa ao capital social, e que dependeria de aprovação prévia da assembleia geral com quórum qualificado de aprovação de dois terços do capital total ${ }^{145}$.

O Anteprojeto de Código Comercial de Herculano Marques Inglez de Souza, datado de 30 de abril de 1912 (elaborado em cumprimento ao Decreto n. ${ }^{\circ} 2.379$, de 4 de janeiro de 1911) não acrescentou nada à matéria (regulada no artigo $107, \S \S 8^{\circ}$ e $9^{\circ}$ ), não tendo sido ela, inclusive, objeto de estudo especifico pelo autor do Anteprojeto, sequer havendo na exposição de motivos alusão especial ao assunto. Neste anteprojeto, a matéria vinha com alusão expressa apenas à proibição de "aquisição", e não de venda, como o fazia o Decreto 434/1891. Após emendas pela comissão especial do Senado, foi ele submetido ao exame da Câmara dos Deputados, onde (como sói acontecer no Brasil) ficou sem andamento durante anos seguidos, a ponto de ter sido preterido pelo projeto original de Clodomir Cardoso, apresentado em 1928, como veremos.

Após a revolução de 1930, foi constituída Comissão Legislativa para revisitar e consolidar toda a legislação e as normas atinentes às sociedades comerciais ficaram sob responsabilidade da $22^{\text {a }}$ Subcomissão, cujo relator era Gudesteu Pires ${ }^{146}$. No seu trabalho

\footnotetext{
${ }^{144}$ In Sociedades..., cit., p. 31.

145 Afirmativamente quanto a ter sido o regime do Decreto 434/1891 uma cópia quase literal da Lei 3.150/1882 e do Decreto 8.821/1882: Philomeno J. da Costa, op. cit., p. 35. Também Gudesteu Pires, falando ao jornal do Brasil em 06 de novembro de 1931, in Gudesteu Pires, Sociedades Anonymas - Subsidios para a Reforma da Lei, Jornal do Commercio, Rio de Janeiro, 1935, p. 15.

${ }_{146}$ Aqui cumpre corrigir uma pequena impropriedade. Não foi a $3^{\text {a }}$ Subcomissão, presidida por Gudesteu Pires por nomeação de Decreto de 30 de julho de 1931 e posterior designação da própria Subcomissão, que ficou responsável por analisar as normas atinentes às sociedades comerciais. Essa Subcomissão recebeu tarefa mais ousada, de avaliar a redação de um Código Comercial. Posteriormente, foi proposto ao Governo que desmembrasse a $3^{a}$ Subcomissão, criando-se uma destinada exclusivamente às sociedades comerciais, que era tarefa mais realista. Assim, por Decreto de 30 de setembro de 1932, criou-se a $22^{\text {a }}$ Subcomissão, esta,
} 
final $^{147}$, entregue ao Ministro da Justiça, Vicente Ráo, em dezembro de 1934, foi estipulada a matéria com a mesma redação e lógica que se lhe vinha atribuindo até então: o artigo 69 proibia à anônima a compra e venda de suas próprias ações, exceto no caso de amortização de ações. Não foi o assunto objeto de análise na justificativa do anteprojeto, o que nos parece uma injustificada falta, considerando que a base declarada do anteprojeto foi a redação original do projeto de Clodomir Cardoso de 1928, que ao tema dedicava extensa análise.

$\mathrm{Na}$ sequência cronológica, temos o Projeto Clodomir Cardoso, apresentado ao Senado Federal em $1936^{148}$, cujo artigo 87 dispunha sobre as situações nas quais seria lícito ou ilícito à anônima negociar com suas próprias ações (até aqui, em verdade, a palavra utilizada pela legislação era "compra" ou, apenas, "aquisição" pela sociedade de ações de sua emissão).

O texto é bem mais desenvolvido do que as redações anteriores e enfeixa uma série de operações anteriormente não contempladas de maneira expressa (como a possibilidade de compra pela companhia de ações de sua emissão para redução do capital social). Philomeno J. da Costa classificou o texto de Clodomir Cardoso como "prolixo", mas "organicamente bem concebido" ${ }^{449}$. Em nossa visão, o texto era bastante inovador com relação ao que até então se vinha praticando no Brasil, e, como dissemos, tratou da matéria de maneira muito mais detalhada: incluíram-se, pela primeira vez na história do Brasil, entre os negócios permitidos à anônima com as próprias ações, as situações de adjudicação

sim, com o objetivo de reavaliar as normas atinentes às sociedades comerciais apenas e da qual Gudesteu Pires era relator, mas não presidente (cargo incumbido ao Desembargador Collares Moreira). Ver Gudesteu Pires, Sociedades..., cit., p. 18.

Mais peculiar ainda é notar que, quando Gudesteu Pires foi nomeado presidente da $3^{\text {a }}$ Subcomissão, nessa função substituiu o professor Waldemar Ferreira. O entendimento histórico do desenvolvimento legislativo nacional dá um tom de poesia ao estudioso do assunto, ao notar que o livro de autoria de Gudesteu Pires consultado possui dedicatória exatamente ao Professor Waldemar Ferreira.

147 Novamente, por amor à precisão acadêmica, precisamos salientar que o trabalho, de verdade, não constituía uma versão final, eis que alguns capítulos não puderam ser submetidos à revisão dos membros da Subcomissão, por falta de tempo hábil. Revisou-se apenas até o quinto capítulo, inclusive. Ver Gudesteu Pires, Sociedades..., cit., p. 21.

${ }^{148} \mathrm{Na}$ realidade, o projeto original de Clodomir Cardoso foi entregue em 1928, mas ficou prejudicado pela eclosão da revolução de 1930. Este projeto foi a quarta versão elaborada por Clodomir Cardoso, ao contrário do que dá a entender a respectiva justificativa, onde menciona-se que essa (a de 1936) seria a segunda versão. Gudesteu Pires, no entanto, esclarece quais foram as três versões anteriores a essa (a original, de 1928, o substitutivo de 1930, prejudicado pela superveniência do movimento revolucionário com a consequente dissolução do Congresso Nacional, e a de 1934, que serviu de base para a $3^{\text {a }}$ Sub-Comissão, presidida pelo próprio Gudesteu Pires, como vimos, e que foi, inclusive, a responsável pela publicação da justificativa de Clodomir Cardoso ao anteprojeto de sua autoria). Clodomir Cardoso, Sociedades Anonymas - Projecto Organizado, Imprensa Nacional, Rio de Janeiro, 1932, p. V. Gudesteu Pires, Sociedades..., cit., p. 9. Philomeno J. da Costa, op. cit., p. 31, na nota de rodapé 48.

149 Op. Cit., p. 33. Trajano de Miranda Valverde assim se manifestou sobre o projeto: "entre muitas disposições úteis e aproveitáveis, (...), há muita coisa inútil e complicada”. Cf. Trajano de Miranda Valverde, Sociedades..., cit., p. 33. 
compulsória das próprias ações, resgate, aquisição para redução do capital social $^{150}$ e reembolso. Em nenhuma hipótese, no entanto, a sociedade poderia revender as próprias ações adquiridas, exceto no caso de adjudicação compulsória. Em todas as demais, reza o artigo 90 do projeto, ficariam sem efeitos e seriam inutilizadas as ações, o que significa que a mecânica das ações em tesouraria ainda não estava aqui presente ${ }^{151}$.

Por força de pressões sociais e políticas em prol da modernização da legislação sobre sociedades anônimas no Brasil, foi encaminhada pouco depois, em 30 de outubro de 1936, ao plenário da Câmara dos Deputados, pela Comissão de Constituição e Justiça, peça legislativa que viria a ficar conhecida como Substitutivo Waldemar Ferreira, em que este, como presidente da mencionada comissão, apresentou um projeto de Código das Sociedades Comerciais (Projeto de Lei 424), tomando por base, abertamente, o projeto de lei de sociedades anônimas de Gudesteu de Sá Pires ${ }^{152}$. O artigo 135 daquele diploma vedava à companhia a compra e venda de ações de sua emissão, salvo no caso de venda em bolsa em decorrência da mora de acionista (art. 132, §3º e permitia a amortização de ações. Também vedava à companhia receber suas ações em penhor, salvo para garantia de gestão de seus administradores. A redação era bem menos abrangente que aquela sugerida por Clodomir Cardoso.

Em junho de 1939, foi incumbido a Trajano de Miranda Valverde, pelo então ministro da justiça Dr. Francisco Campos, a elaboração de um anteprojeto de lei das sociedades por ações, que recebeu abundantes colaborações de juristas e associações de classe. Uma vez promulgado o DL 2.627/40, passou a matéria a ser regulada dentro do capítulo da lei dedicado às ações ${ }^{153}$, e lia-se, no artigo 15 , que “[a] sociedade anônima não pode negociar com as próprias ações”, redação que quebrou a tradição brasileira de limitar a vedação a operações de "compra e venda" ao ampliar o âmbito da proibição para

150 “Outras legislações, é certo, prohibindo, como o decreto n. 434, a amortização, a não ser por meio de lucros acumulados, declaram, por outro lado, possível a reducção do capital. Declaram-no, porém, expressamente, e são logicas, pois accrescentam: desde que se faça sem prejuízo dos credores; e estabelecem as regras destinadas a acautelar os direitos destes". In Clodomir Cardoso, Sociedades..., cit., p. 124.

151 "Assim, pois, a revenda das acções que a sociedade adquirir só será possível nas hypotheses previstas pela alínea $a$ do n. 2 do art. 87”. Clodomir Cardoso, Sociedades..., cit., p. 124.

${ }^{152}$ Este projeto de lei foi publicado no Diário do Poder Legislativo, ${ }^{\circ} 461$, já em $1^{\circ}$ de novembro de 1936 e recebeu diversas sugestões de emendas parlamentares, todas elas analisadas e estudadas por Waldemar Ferreira que, além do parecer sobre a conveniência de cada uma, apresentou uma exposição de motivos e um substitutivo ao projeto originalmente apresentado ao plenário, este, sim, em formato de código abrangente. O projeto de Waldemar Ferreira era ambicioso, exatamente porque excedeu a missão de apenas reformar a legislação vigente sobre sociedades anônimas (que ainda era o Decreto 434/1891), transmudando-o em Código das Sociedades Comerciais (como, posteriormente, o fariam a França em 1966 e Portugal em 1986). Ficou prejudicada a análise do projeto de lei por força do golpe de Estado de 1937. Cf. Waldemar Ferreira, Código das Sociedades Comerciais, Revista dos Tribunais, São Paulo, 1938, pp. 12 e ss.

${ }^{153}$ Curiosamente, como o fazem também outras legislações, o assunto é regulado no capítulo das ações e não do capital social. 
qualquer "negociação". O parágrafo único desse artigo excepcionava as operações de "resgate, reembolso, amortização ou compra", previstas em lei. Essa redação, com uma pequena modificação, era exatamente a que constava do anteprojeto apresentado por Trajano de Miranda Valverde ${ }^{154}$.

Até então, a tradição da legislação brasileira sobre o tema foi a de vedar, genericamente, a compra e venda, pela companhia, das ações de sua emissão e o recebimento por ela de ações de sua emissão em penhor, autorizando, desde logo, a operação de amortização. O DL 2.627/40 ampliou o rol de operações vedadas e também as exceções, incluindo o resgate e o reembolso, mas era omisso quanto a outras operações ligadas a este instituto e que haviam sido (ou que viriam a ser em um futuro breve) objeto de tratamento em outras legislações, como a alemã, a italiana e a espanhola: era omissa nossa legislação, entre outros assuntos, acerca (i) das participações sociais recíprocas entre sociedades sujeitas a um vínculo de interesse, como as sociedades controladoras e suas controladas ou entre sociedades coligadas ou sujeitas a controle comum; (ii) das operações com ações de emissão da própria companhia para evitar "grave perigo", cujo expoente era a legislação alemã (Aktiengesetz de 1937, §51), posteriormente seguida pela espanhola (Lei de 17 de julho de 1951, art. 47); (iii) das operações com ações da companhia a título gratuito e das operações de empréstimo, pela companhia, para aquisição de suas ações por terceiros, entre diversas outras situações (que, curiosamente, já haviam sido estudadas por Clodomir Cardoso, como vimos).

A omissão referente às participações recíprocas, por exemplo,decorria de uma interpretação restritiva (como toda interpretação de norma proibitiva ou restritiva de direitos deve ser), pela doutrina, do artigo 15 do DL 2.627/40, de modo que estariam excluídas da vedação as negociações pela controlada de ações de sua controladora (ou de duas sociedades não vinculadas entre si), já que, aí, haveria pessoas jurídicas distintas e nenhuma negociação com as "próprias ações", tecnicamente falando. Foi por essa razão que parte da doutrina não via nas modalidades de negociação com as próprias ações proibidas pelo artigo 15 uma proibição às participações recíprocas, como se depreende da lição de Cunha Peixoto, fazendo referência a Philomeno J. da Costa, para quem: “A lei italiana [Codice Civile de 1942, artigos 2.357 a 2.360] veda expressamente a sociedade

\footnotetext{
${ }^{154}$ A redação original do anteprojeto de lei de Valverde continha, ainda, uma expressão de que era proibido à companhia "especular" com as próprias ações, texto este que foi retirado da versão final do DL 2.627/40, por entender-se que o ato de "especular" já estaria contido no ato de "negociar", que foi o verbo que permaneceu. Philomeno J. da Costa, op.cit., p. 28. Assim se manifestou o autor do anteprojeto: "[a] sociedade anônima não deve negociar, comprar e vender, especular, enfim, com as próprias ações". Cf. Trajano de Miranda Valverde, Sociedades..., cit., p. 159.
} 
controlada de adquirir ações da controladora. (...) No Brasil, a conclusão é diferente. Sem lei expressa não é possível impedir tal transação. (...) Daí ter razão Filomeno J. da Costa, quando leciona: 'segundo decorre da extensão objetiva do disposto pelo artigo 15, fixador da regra geral da interdição de operações pelas companhias com as ações da respectiva emissão, aquela que fizer com as frações do capital da anônima controladora (holding company) não representa uma negociação com as próprias ações e constituem, sim, uma operação de ações do capital de 'outra' sociedade. Inexiste, então, proibição alguma'"155. De modo semelhante, não vislumbrando vedação alguma, se manifestou Arnoldo Wald, em parecer elaborado sob a vigência do DL 2.627/40: "Concluímos, pois, que, excluídas as hipóteses de fraude comprovada, a posição do direito brasileiro é de não confundir as empresas coligadas não vigendo, pois, quanto à sociedade controlada o impedimento de adquirir ações ou quotas da holding"156.

Já Tullio Ascarelli, com o brilhantismo que lhe era peculiar, tinha, desde então, como ilícita a "subscrição reciproca de ações", já que, para ele, a existência de uma sociedade não poderia servir para alcançar um escopo ilícito e, portanto, "a existência de uma coligação de sociedades não pode servir para burlar as normas e as obrigações que dizem respeito a uma das sociedades coligadas". Se as normas de proibição de negociação com as próprias ações, nos termos do artigo 15 do DL 2.627/40, tinham como fim proteger a integridade do capital social, constituiria modalidade de fraude se uma sociedade pudesse, indiretamente, adquirir ações próprias por interposta pessoa (jurídica). Esta seria, considerando seus outros estudos, uma modalidade de negócio indireto ${ }^{157}$. Na prática, permitimo-nos entender, o que avaliou Ascarelli, neste ponto, foi o substrato da pessoa jurídica, que possui caráter instrumental e, desse modo, é impossível sua visualização como um princípio absoluto. Sob pena de perniciosamente permitirem-se situações de fraude à lei é que existem limites à autonomia da pessoa jurídica ${ }^{158}$.

\footnotetext{
${ }^{155}$ Cunha Peixoto, Sociedades por Ações, volume 1, São Paulo, Saraiva, 1972, p. 163 e ss. Também Philomeno J. da Costa, op.cit., p. 24. É bom salientar, no entanto, que logo após Philomeno fazer essa afirmação, ele próprio defende que essa forma de atividade deveria ser vedada pela lei, por entender haver, aí, uma "feição tradutora de uma devolução verdadeira de capital pela sociedade filiada à sociedade matriz".

${ }^{156}$ Arnoldo Wald, op.cit., p. 6.

157 Tullio Ascarelli, Problemas..., cit., p. 701.

158 "Der Vorwurf des Rechtsmißbrauchs setzt voraus, daß jemand gesetzliche Gestaltungsmöglichkeiten formal korrekt, also unter Beachtung der gesetzlichen Voraussetzungen und Grenzen ausübt, mit dieser Verwendung jedoch entweder rechtswidrige Ziele verfolgt (intitutioneller) oder andere Personen treuwidrig schädigt (individueller Rechtsmißbrauch). Der Buchstabe des Gesetzes wird erfüllt, der Geist der Rechtsordnung aber verletzt." - itálicos do original, grifos nossos. Em tradução livre: "A ocorrência de um abuso de direito pressupõe que alguém observe as disposições formais da lei, ou seja, aja dentro dos limites e dos requisitos da lei, mas com este agir ou bem persiga um fim ilícito (abuso de direito institucional) ou
} 
Temos, ainda, como antecedente legislativo, a parte dedicada à atividade empresarial e às sociedades do então Anteprojeto de Código das Obrigações, parte essa que ficou sob a responsabilidade do brilhante Sylvio Marcondes (responsável, também, pelo Livro do Direito de Empresa do nosso atual Código Civil). O seu art. 154 refletia o conceito positivado pelo Decreto 2.627/40 e proibía às anônimas "negociar com ações de seu capital”, redação esta que, conforme mencionamos nos parágrafos introdutórios deste trabalho, é tecnicamente mais apurada que a redação do Decreto 2.627/40 e, mesmo, da atual Lei das S.A. Outra inovação em relação ao diploma então vigente era a inclusão das operações de "venda" na proibição - a venda pela companhia de ações de seu capital foi muitas vezes vedada e posteriormente readmitida na legislação nacional. Não havia consenso doutrinário sobre o caso, até porque a venda não representaria um decréscimo patrimonial à companhia emissora, apenas a aquisição teria esse problema. No entanto, se a proibição é de "negócios" com as ações de seu próprio capital, inegavelmente também estão abrangidas as vendas. A situação típica onde a companhia emissora aparece como vendedora das próprias ações é no caso de venda em bolsa por conta de mora do acionista (acionista remisso) - atual artigo 107, II, sobre o qual trataremos mais adiante neste estudo $^{159}$.

Por fim, com a promulgação da Lei 4.728, de 14 de julho de 1965 (“Lei 4.728/65”) foi acolhido um regime mais flexível sobre o capital social, tendo sido introduzido o conceito de capital autorizado no direito brasileiro, além de ter sido permitido, no artigo 47, às companhias com capital autorizado, a recompra de suas ações mediante utilização do seu saldo de lucros e reservas e sem redução do capital subscrito, ou, ainda por doação. $\mathrm{O} \S 1^{\circ}$ desse artigo mencionava que o "capital em circulação" da companhia corresponderia ao subscrito, menos as ações em tesouraria. Esse dispositivo adotava terminologia de origem claramente norte-americana (issued capital, authorized capital, treasury shares, etc.), sem precedentes no direito brasileiro e, ademais, passou a admitir, quase que imperceptivelmente, a existência de ações em tesouraria expressamente no texto legal. Além disso, previu a suspensão do direito de voto das ações em tesouraria no §2 do art. 47, enquanto não fossem recolocadas em circulação por meio de sua alienação pela companhia.

vise a lesar terceiros (abuso de direito individual). A letra da lei é observada, mas o espírito do ordenamento jurídico é contrariado". Cf. Herbert Wiedemann, op. cit., p. 227.

159 "Esta é a venda prevista no Anteprojeto, como uma das suas modalidades clássicas para a companhia compelir a integralização do capital contra subscritores das ações de sua emissão". In Philomeno J. da Costa, op. cit., p. 38. 
O diploma legal seguinte foi a atual Lei das S.A.

\subsection{Possíveis Funções para as Operações}

Os negócios realizados pela companhia com as próprias ações são particularmente complexos de avaliar, pois envolvem sempre vantagens e perigos. Além disso, esse tipo de negócio jurídico tem seus efeitos práticos, não raro, moldados ou diferidos no tempo: assim, alguns efeitos podem ser concomitantes à realização do negócio (como, por exemplo, uma influência na cotação das ações em bolsa ou a saída de um sócio alienante), enquanto outros podem manifestar-se durante o período em que as ações permanecerem em tesouraria (como o eventual reforço do poder de controle). Podem, ainda, manifestar-se somente na época da recolocação no mercado das ações entesouradas (por exemplo, a obtenção de um benefício econômico pela sociedade, dependendo do valor de venda das ações).

Enfim, categorizar e avaliar os riscos e as vantagens desse tipo de negócio é fundamental para conseguirmos ter um critério razoável de assunção de riscos e criação dos correspondentes limites. Neste ponto do estudo, o objetivo é compilar alguns benefícios, legítimas finalidades, que podem ser alcançados por meio de negócios com as próprias ações. Os perigos das operações, que não são poucos ou facilmente observáveis em todos os casos, serão detalhados em capítulos subsequentes, de acordo com o interesse que ameaçam de forma predominante.

\subsubsection{Facilidades na Redução de Capital}

O primeiro benefício da operação, usualmente apontado, é o de facilitar os procedimentos de redução do capital social. A aquisição de ações próprias, enquanto processo de realização de uma redução de capital regularmente deliberada, nunca foi alvo de muitas objeções por parte da doutrina, em decorrência do fato de que as ações adquiridas são, logo em seguida, canceladas. Não obstante, a utilização destas aquisições como forma de viabilizar uma redução de capital deliberada demonstra algumas vantagens: (i) a presença de um elemento de voluntariedade, que pode significar uma composição de interesses entre os acionistas desejosos de desfazerem-se de suas participações e aqueles que optem por mantê-las, (ii) a relativa simplicidade da operação, já que outros mecanismos - como a redução do valor nominal, cancelamento ou agrupamento - podem gerar alguns entraves ou dificuldades práticas, e (iii) um benefício que pode ser obtido pela 
sociedade, dependendo da cotação das ações em bolsa, tomada em comparação com o valor deliberado de restituição ${ }^{160}$.

\subsubsection{Gerenciamento Financeiro da Companhia: Liquidez, Política de Dividendos e o Custo do Capital}

A aquisição das ações próprias pode ter finalidades financeiras e de mercado. Esta forma de abordar as vantagens destas aquisições desenvolveu-se tardiamente na Europa, onde (como se disse) foram considerações de ordem lógico-estrutural e, em um segundo momento, de ordem funcional (passando a ser relevante o estudo da intangibilidade do capital social), que permearam a discussão. Por outro lado, a avaliação dos benefícios destes negócios do ponto de vista das finanças corporativas se desenvolveu com maior vigor nos países anglo-saxões, cujos mercados acionários são mais robustos, líquidos e maduros. Foi nesses países que surgiu a corrente doutrinária que vê nesses negócios um mecanismo útil de gerenciamento das finanças sociais, considerando especialmente a composição da estrutura de capital (entre capital "próprio" e de "terceiros") e a decisão sobre as formas de distribuição do lucro e da liquidez excessiva da companhia ${ }^{161}$.

Atende a essas finalidades de formas variadas. De maneira mais objetiva, o pagamento de dinheiro em troca das ações próprias significa, diretamente, uma redução nos níveis de liquidez (por vezes excessiva) da companhia - esta redução é comumente referida como "enxugamento". É possível que, em determinado momento, uma companhia detenha muito dinheiro em caixa, e não visualize investimentos rentáveis a serem feitos com ele. Nesta situação, é mais eficiente para a sociedade distribuir tais recursos aos acionistas, para que estes possam, individualmente, encontrar investimentos mais rentáveis em outras atividades. Conforme informa a doutrina norte-americana: " $g$ ] iven the existence of excess cash as we have defined it, a rational, profit-maximizing firm should make some kind of distribution. Typically the distribution takes the form of cash dividends, but today more and more corporate managers are turning to the method of share repurchases"162. Segundo esses autores, desconsiderando-se eventuais diferenças tributárias entre um mecanismo e outro (de forma que seria irrelevante para os acionistas a forma por meio da qual receberiam o dinheiro), as recompras de ações têm muitas vantagens (e, também,

\footnotetext{
${ }^{160}$ Cf. Maria Victória Rodrigues, op. cit., pp. 104 a 108.

${ }^{161}$ Cf. Barbara Pozzo, op. cit., p. 82.

${ }^{162}$ Cf. Donald H. Woods e Eugene F. Brigham, Stockholder Distribution Decisions: Share Repurchases or Dividends?, in The Journal of Financial and Quantitative Analysis, Vol. 1, N. ${ }^{\circ}$ 1, Proceedings of the First Annual Meeting of the Western Finance Association, 1966, pp. 20 e ss.
} 
algumas desvantagens) no gerenciamento de liquidez da companhia, quando contrapostas a outros métodos de distribuição, como o pagamento de dividendos ou a redução de capital. Exemplificamos com uma situação em que uma sociedade deseje fazer um enxugamento pontual em sua liquidez: se ela o fizer mediante aumento no volume de seus dividendos tradicionalmente distribuídos no período, é muito provável que ela não deseje manter esse novo patamar de dividendos no ano seguinte. Isso significa que haveria, inicialmente, um aumento seguido de uma retração no volume de dividendos pagos, o que pode ser visto negativamente pelo mercado como um sinal de fraqueza da companhia. Isso porque, de acordo com estudos empíricos, a política de dividendos tem uma característica de ser "pegajosa" (sticky) no curto prazo e a administração das companhias reluta em alterá-la caso não seja possível ou desejável manter o aumento nos dividendos no futuro. Já a adoção do mecanismo da recompra de ações tem por efeito a redução da disponibilidade de caixa da sociedade, mantendo, contudo, inalterado seu fluxo de dividendos. Assim, se o excesso de caixa é algo temporário, a administração tende a preferir "disfarçá-lo" na forma de recompras, ao invés de alterar a política de dividendos da companhia ${ }^{163}$.

Reconhece-se que, nos Estados Unidos da América, o Model Business Corporation Act da American Bar Association submete, desde 1979, a recompra de ações às mesmas regras da distribuição de dividendos, ambos tratados como formas de transferência patrimonial entre a companhia e o acionista. Reflete-se este entendimento, por exemplo, na redação do $\$ 1.40$ (6) do atual Revised Model Business Corporation Act, em que se define que qualquer transferência, direta ou indireta, de dinheiro ou bens da companhia para os seus acionistas, seja por meio de dividendos ou recompra de ações, é considerada genericamente como uma "distribution" duas situações.

Além disso, as ações em tesouraria podem significar um estratégico mecanismo de recomposição do caixa da companhia em momento de necessidade de liquidez de curto prazo, por meio de sua venda ao mercado (atuam as ações entesouradas, neste sentido, como reservas de refinanciamento - Refinanzierungsreserve ${ }^{165}$. Elas podem significar, igualmente, uma forma de a sociedade “emitir seu próprio dinheiro". Pode-se pensar em

\footnotetext{
${ }^{163}$ Cf. Donald H. Woods e Eugene F. Brigham, op. cit., p. 22.

164 “(6) 'Distribution' means a direct or indirect transfer of money or other property (except its own shares) or incurrence of indebtedness by a corporation to or for the benefit of its shareholders in respect of any of its shares. A distribution may be in the form of a declaration or payment of a dividend; a purchase, redemption, or other acquisition of shares; a distribution of indebtedness; or otherwise". Cf. também, relatando a experiência norte-americana, Barbara Pozzo, op. cit., p. 93.

${ }^{165}$ Cf. Alexander Kitanoff, op. cit., p. 29. Donald H. Woods e Eugene F. Brigham, op. cit., p. 22.
} 
uma situação de permuta de ações, em que uma companhia possa, em troca de uma determinada participação em seu próprio capital social, adquirir percentual de outra companhia ou absorvê-la por inteiro (incorporando-a). Essa permuta de ações (com o concomitante pagamento ou não de dinheiro) poderia ocorrer por meio da entrega de ações em tesouraria para acionistas da outra companhia, em troca das ações do capital social desta segunda ${ }^{166}$, ou como forma de completar a operação de incorporação societária, evitando o recurso ao aumento de capital. A permuta das ações poderia ocorrer, ainda, como contrapartida do recebimento de outros tipos de bens úteis à atividade social, como um estabelecimento comercial ou, até, em contraprestação de uma aquisição de parte ou da totalidade dos ativos de outras empresas ${ }^{167}$. Hoje, inclusive, essa utilização das ações em tesouraria é prevista expressamente na Alemanha, por força do $\$ 344,1$, da Aktiengesetz de 1965 (contendo redação semelhante ao §238, 1, da Aktiengesetz de 1937). Em que pese o silêncio da nossa lei, entendemos ser mecanismo bastante útil à sociedade e seus sócios: para estes, não há diluição de sua participação societária e, para aquela, há eficiente utilização das ações em tesouraria que, de outro modo, têm destinação muitíssimo limitada pela lei.

Ao mesmo tempo, a recompra de ações pode influenciar o balanceamento dos custos de capital ${ }^{168}$ da companhia. Como se sabe, a companhia possui basicamente duas fontes de recursos: a própria, consubstanciada nos aportes dos acionistas, e a de terceiros, que se realiza mediante crédito estendido à sociedade (por meio do sistema financeiro, por exemplo). Ambas possuem um determinado custo para a sociedade, de modo que o capital de terceiros (credores; capitale di debito) possui um custo decorrente dos juros cobrados pelo credor, enquanto o capital próprio (acionistas; capitale di rischio) "custa" à companhia a satisfação dos interesses econômicos dos acionistas, primordialmente na forma de dividendos e valorização dos papeis. Os acionistas possuem normalmente altas expectativas econômicas quando investem em ações, já que estão abdicando de uma rentabilidade praticamente isenta de riscos (ao não adquirirem títulos públicos) para direcionarem seus recursos a uma empresa: ao assumirem o risco financeiro da atividade desenvolvida pela companhia, esperam eles obter rendimentos do investimento, que se traduzem, do ponto de vista da sociedade, no seu "custo de capital próprio". Nessa linha,

\footnotetext{
${ }^{166}$ Este tipo de operação, inclusive, já foi avaliado pela CVM em alguns casos, tendo sido permitidos os negócios, conforme trataremos oportunamente.

${ }^{167}$ Cf. Maria Victória Rodrigues, op. cit., pp. 112 a 116. Cf. Alexander Kitanoff, op. cit., p. 29.

${ }^{168}$ Esclareça-se que o termo "capital", aqui empregado, não se confunde com "capital social", mas tem significado mais amplo, de "fonte de recursos". O "capital próprio", de que se falará, sim, corresponde ao conceito de capital social.
} 
os custos do capital próprio tendem a ser maiores do que os custos do capital de terceiros e existe uma complexa teoria financeira que procura calcular qual seria o ponto ótimo de equilíbrio entre ambas as formas de captação, que decorre do weighted average cost of capital ou WACC.

$\mathrm{Na}$ gestão de seu custo de capital, poderão ser adquiridas pela emissora determinadas classes de ações que representem um encargo financeiro muito alto ou indesejável para ela (especialmente se considerarmos ações preferenciais com dividendos fixos e cumulativos, emitidas em situação de crise financeira da companhia), como alternativa à sua amortização (outra alternativa, igualmente válida, seria o resgate dessas ações, mas essa saída poderia encontrar entraves procedimentais que a tornariam mais onerosa).

Uma companhia pode equilibrar o seu WACC, ainda, por meio da contratação de dívidas (dívidas bancárias ou por meio de debêntures, por exemplo) seguida de uma recompra de ações: diminui-se seu valor de capital próprio e aumenta-se o seu capital de terceiros, o que pode beneficiá-la do ponto de vista de gestão da sua estratégia financeira, considerando que o valor da empresa societária é tão maior quanto menor for o seu custo de capital. A substituição de capital próprio por capital de terceiros, especialmente em momentos de baixas taxas de juros no mercado, pode ser útil à companhia e à sua empresa $^{169}$. Esta função pode ser denominada de otimização da alavancagem financeira (optimizing financial leverage $)^{170}$.

\subsubsection{A Teoria da Sinalização}

Outro aclamado (e muito estudado) motivo que justifica a existência dos negócios com ações próprias é a possibilidade de sinalização, pela companhia, de que seus papeis estão subvalorizados no mercado (tipping effect ou signalling theory) ${ }^{171}$.

A teoria da sinalização parte necessariamente da constatação de que, por vezes, o preço de um determinado valor mobiliário no mercado não reflete todas as informações

\footnotetext{
${ }^{169}$ Para detalhes, ver Zvi Bodie, Alex Kane e Alan J. Marcus, Investments, $6^{\text {a }}$ ed., McGraw-Hill, New York, 2005. Também em Alexander Kitanoff, op. cit., p. 28.

${ }^{170}$ Cf. Donald H. Woods e Eugene F. Brigham, op. cit., p. 24.

${ }^{171}$ Sobre o efeito de sinalização advindo das recompras de ações por meio de ofertas públicas de aquisição lançadas pela própria companhia, com evidência empírica, ocuparam-se: Theo Vermaelen, Repurchase Tender Offers, Signalling, and Managerial Incentives, in The Journal of Financial and Quantitative Analysis, Vol. 19, N. ${ }^{\circ}$ 2, 1984, pp. 163-181; equiparando os dividendos às recompras de ações por serem ambas "desembolsos de caixa" cf. Donald B. Hausch e James K. Seward, Signalling with Dividends and Share Repurchases: A Choice between Deterministic and Stochastic Cash Disbursements, in The Review of Financial Studies, Vol. 6, N. ${ }^{\circ}$ 1, 1993, pp. 121-154.
} 
que a respeito dele ou de seu emissor são conhecidas. Em outras palavras, a teoria da sinalização pressupõe uma formação ineficiente de preços, o que pode ocorrer por razões das mais diversas, de maneira que os preços das ações cotadas nas bolsas de valores podem não refletir de maneira perfeita o seu valor "justo".

$\mathrm{Na}$ base destas considerações está, não podemos deixar de mencionar, a teoria dos mercados eficientes, ou efficient capital markets hypothesis (ECMH), que ganhou aceitação ampla no mercado norte-americano nas décadas de 1970 e 1980, influenciando fortemente a produção normativa e as decisões judiciais ${ }^{172}$. Essa teoria defende que, pressupondo condições perfeitas de mercado - essencialmente, a existência de investidores racionais, informação perfeita e a inexistência de custos de transação -, os preços dos valores mobiliários refletirão imediatamente todas as informações disponíveis sobre um ativo/emissor. Algumas críticas tachavam a teoria de "auto-evidente", levando outros autores a afirmar, no intuito de preservar a sua utilidade, que o mais importante na teoria, e o que faz dela algo não trivial, "is its prediction that, even though information is not immediately and costlessly available to all participants, the market will act as if it were" grifos do original ${ }^{173}$. Hoje, a prevalência da ECMH é altamente questionada pelo surgimento, na década de 1980, da teoria de finanças comportamentais (behavioral finance $)^{174}$. Os defensores dessa nova linha de pensamento encaram os estudos realizados nas décadas de 1970 e 1980, apontando evidências empíricas da ECMH, com um tom "somewhere between irony and condescension",175,176. A ECMH é importante para a

172 A bibliografia sobre a ECMH é muito vasta. Cite-se, por todos, Ronald J. Gilson and Reinier $H$. Kraakman, The Mechanisms of Market Efficiency, in Virginia Law Review, Vol. 70, N. ${ }^{\circ}$ 4, Fifty Years of Federal Securities Regulation: Symposium on Contemporary Problems in Securities Regulation, 1984, pp. 549-644.

${ }^{173}$ Ronald J. Gilson and Reinier H. Kraakman, The Mechanisms..., cit., p. 552.

${ }^{174}$ Para uma cuidadosa discussão a respeito desta escola de pensamento econômico, por todos, Donald C. Langevoort, Taming the Animal Spirits of the Stock Markets - A Behavioral Approach to Securities Regulation, in Georgetown University Law Center, 2002 Working Paper Series in Business, Economics, and Regulatory Law, Working Paper No. 305241, 2002.

${ }^{175}$ Ronald J. Gilson and Reinier H. Kraakman, The Mechanisms of Market Efficiency Twenty Years Later: The Hindsight Bias, 2003, p. 3, assumindo a influência da psicologia cognitiva na sua teoria elaborada 20 anos antes.

${ }^{176}$ No século XVIII, a teoria econômica clássica de Adam Smith, David Ricardo e Thomas Malthus buscava justificar o funcionamento do recém-surgido mercado capitalista com base em um modelo fundado na conduta individualista como centro do processo econômico. Nesta concepção, cuja principal referência é Adam Smith e seu famoso An Inquiry into the Nature and Causes of the Wealth of Nations de 1776, iniciouse a caracterização do mercado como um ambiente capaz de regular-se por meios próprios - a famosa imagem da mão invisível do mercado. Passando-se à teoria neoclássica, surge então a ideia de que os agentes de mercado são racionais e que, portanto, todas as operações de mercado tenderiam a obter os melhores resultados possíveis para todos, tendendo sempre a um equilíbrio ótimo. Com o tempo, foi verificado que as teorias clássicas e neoclássicas partiam de pressupostos irreais sobre o comportamento racional dos agentes (com o desenvolvimento, por exemplo, das teorias sobre a racionalidade limitada ou "bounded rationality"), devido ao fato de que, no mundo real, é impossível ser onisciente sobre todos os fatores que afetam uma 
definição da sinalização, pois caracteriza o mercado de capitais em função das informações públicas disponíveis sobre as companhias, o que dá relevância à pergunta sobre como os seus administradores decidem divulgar as suas informações. Se boas informações forem divulgadas ao mercado, a ECMH estabelece que elas serão inexoravelmente incorporadas ao preço das ações, fazendo com que ele aumente.

Com isso em mente, para que se fundamente uma teoria da sinalização, é forçoso reconhecer que a formação de preços, ainda que estruturada para ser objetiva, não está sujeita apenas à regra econômica clássica do equilíbrio perfeito entre oferta e demanda, nem mesmo pode se basear exclusivamente nos ideais da ECMH, uma vez que diversos fatores, exógenos e endógenos, influenciam a formação de preço em bolsa, como: (i) a instabilidade econômica externa, seja no país de listagem da ação, seja no mundo (graves crises nos mercados podem levar a uma aversão generalizada a riscos, influenciando a cotação de diversos papeis, independentemente da efetiva posição econômico-financeira das companhias), (ii) o estado psicológico dos operadores do mercado, (iii) a política fiscal, monetária, cambial ou tributária de um país (impondo benefícios para investimentos em ações, ou retirando-os), (iv) as taxas de juros (países com altas taxas de juros básicas na economia, como ainda é o caso do Brasil, tendem a estimular menos o crescimento dos investimentos em bolsa), (v) a própria cultura dos poupadores (no Brasil, o passado de inflação galopante criou uma cultura de aversão a riscos e de direcionamento da poupança popular para investimentos seguros e de renda fixa, como a caderneta de poupança).

Não seria muito incomum, portanto, imaginar que as cotações de uma determinada ação, em algum momento, sejam excessivamente baixas relativamente à consistência patrimonial e às perspectivas de rendimento da sociedade. Nessa situação, é justificável que a administração da companhia envie um sinal, por meio do qual "comunica" ao público a sua avaliação de que o valor das ações da companhia está abaixo do valor real (daí a companhia ter decidido comprá-las) ${ }^{177}$. A cotação dos títulos em bolsa possui significados não desprezíveis para as companhias, pois: (i) indica ao mercado em geral uma pujança financeira e patrimonial, (ii) o preço de mercado é um termômetro não apenas da ação, mas da saúde e das perspectivas da própria empresa social, (iii) a remuneração dos administradores e, muitas vezes, de funcionários, é, em parte, dependente dessa cotação, e

decisão perfeitamente racional, surgindo, com isso, a teorização das falhas de mercado, como a concentração do poder econômico, as assimetrias informacionais e as externalidades. Para uma ótima resenha sobre o assunto, ver Otávio Yazbek, Regulação do Mercado Financeiro e de Capitais, Elsevier, São Paulo, 2007, pp. 7 a 57.

${ }^{177}$ Cf. Maria Victória Rodrigues, op. cit., p. 109. 
(iv) uma alta cotação em bolsa dificulta a tomada hostil de controle por outras companhias. Empiricamente, a SEC conduziu um estudo, entre os dias 19 e 23 de outubro de 1987, por meio do qual conseguiu verificar numericamente que, dentre as companhias listadas no índice S\&P 500, o desempenho daquelas que haviam anunciado e/ou utilizado programas de recompra de ações foi melhor do que o daquelas que não o fizeram. Especificamente, "the staff found that stock repurchases by many $S \& P 500$ companies represented a significant proportion of the trading volume in their shares during the week. Purchasing activity had a favorable impact on price performance, and the effect of the announcement of a repurchase program also appeared to be positive" ${ }^{\text {178. }}$.

A razão pela qual é compreensível que uma companhia tenha esse "poder" de influenciar o preço de seus papeis se deve à natural assimetria de informações entre a administração da companhia, enquanto "insiders natos" e os demais participantes do mercado de capitais ${ }^{179}$. Os administradores da companhia, muitas vezes, terão informações sobre a atividade social que não estarão refletidas ainda no preço de mercado das ações. Por exemplo, os membros da administração podem saber ou suspeitar, com base em relatórios internos ou mesmo em sua experiência profissional, que os lucros da companhia subirão, ou que um novo produto será bem aceito no mercado consumidor. A administração da companhia é, portanto, a fonte de informações mais importante acerca dos negócios sociais, o que deriva de sua responsabilidade pelas operações cotidianas da empresa e íntimo envolvimento com as suas decisões estratégicas (investimentos, estrutura financeira, distribuições aos acionistas, etc.): analistas de valores mobiliários e administradores de carteira, além de fazerem suas avaliações independentes sobre o valor das ações e as perspectivas da companhia, dependem, em última análise, das informações divulgadas ao mercado pela companhia, por decisão de sua administração.

A sinalização ocorre, desse modo, quando uma pessoa em relação de assimetria de informação, como um membro da administração ou a própria

\footnotetext{
${ }^{178}$ U.S. Securities and Exchange Commission - Division of Market Regulation, The October 1987 Market Break, Fevereiro 1988, p. xxi e, mais adiante, no capítulo 6. Disponível em http://www.sechistorical.org. Mais de uma década antes, também no intuito de averiguar se as recompras de ações haviam tido efeito positivo na cotação das ações das companhias envolvidas, cf. Samuel, S. Stewart Jr., Should a Corporation Repurchase Its Own Stock?, in The Journal of Finance, Vol. 31, N. ${ }^{\circ} 3$, 1976, pp. 911-921. Apesar da evidência levantada, ressaltamos que o autor não recomenda a conclusão de "causa-efeito" com base em seus dados, já que "[w] ithout a complete theory of valuation, it is impossible to infer causation from the statistical correlation of two variables". Ibidem, p. 920.

${ }^{179}$ Em tom irônico, criticando o apoio irrestrito da teoria da sinalização, assim se pronunciou Robert Clark: "All of us can sympathize with the manager who thinks the brilliance and wisdom of his strategy for his company is simply not perceived by those thickheaded, uninspired stock market analysts". Cf. Robert Charles Clark, Corporate Law, Brown, Boston, 1986, p. 628.
} 
companhia, envia tais informações indiretamente a um terceiro, por meio de uma atividade que lhe imponha custos suficientes e que, consequentemente, tornam a informação crível. As três vias mais tradicionais para endereçar tais sinais ao mercado são: (i) a política de dividendos da companhia (quando ela decide distribuí-los, ou aumentá-los, sinalizando sua boa situação financeira), (ii) os desdobramentos de ações (por aumentarem o número de ações de cada acionista, e, simultaneamente, não reduzir os dividendos) e, é claro, (iii) as recompras de ações. A literatura empírica demonstra que, apesar de poder ser encarada como ato que diminui o valor da companhia, considerando o inevitável desembolso de caixa, o componente informacional das recompras de ações faz com que elas tenham um efeito positivo sobre a cotação dos papeis ${ }^{\mathbf{1 8 0}}$.

Ao mesmo tempo, a tese do "signalling" procura evidenciar que não apenas enviase um sinal positivo sobre a própria companhia, como concomitantemente lança-se um sinal negativo acerca das companhias competidoras, as quais, no intuito de evitar danos às suas cotações, tendem a mimetizar a atitude, efetuando também recompras de suas ações. Segundo os autores que sustentam esta hipótese, quando uma companhia anuncia um programa de recompras, e efetivamente adquire suas ações no mercado, ela gera a expectativa de que outras companhias do mesmo setor farão o mesmo. Se estas não seguirem essa mensagem, o mercado interpretaria essa omissão negativamente, atribuindo à companhia omissa uma pior perspectiva econômica. Isto induz as companhias concorrentes a recomprar suas ações, não por que elas necessariamente desejem enviar um sinal sobre o preço de seus papeis, mas simplesmente para corrigir essa percepção negativa de mercado, tendência mimética esta que varia de acordo com a concentração do mercado relevante em que atuam (que é um indicador da relação de interação estratégica entre ambas as atividades) ${ }^{181}$.

Definido que os sinais ao mercado são uma forma eficiente de enviar informações ao público, resta responder à pergunta de por que razões as companhias optam por utilizálos, ao invés de simplesmente tornar pública a informação que os motivou. Pelas explicações econômicas que pesquisamos, a teoria da sinalização é escolhida pela

\footnotetext{
${ }^{180}$ Cf. Robert Lawless, Stephen P. Ferris e Bryan Bacon, The Influence of Legal Liability on Corporate Financial Signaling, The Journal of Corporation Law, Vol. 23, 1998, p. 214 a 216.

181 "We study the tendency of firms to mimic the repurchase announcements of their industry counterparts. We argue that a firm, by repurchasing its shares, sends a positive signal about itself and a negative one about its competitors. This induces the competing firms to mimic the behavior of the repurchasing firm by repurchasing themselves." Este estudo é bastante peculiar, pois faz uma ponte entre a teoria das finanças corporativas e a estrutura organizacional da indústria em que operam. Cf. Massimo Massa, Zahid Rehman e Theo Vermaelen, Mimicking Repurchases, EFA 2005 Moscow Meetings Paper, 26 de fevereiro de 2005, pp. 1 e 2 e, mais adiante, 27 e 28.
} 
administração das companhias, pois os sinais (i) são apoiados sobre alguma forma de distribuição em dinheiro, o que torna a informação enviada mais fidedigna do que uma divulgação direta, (ii) são sempre prospectivos, enquanto declarações afirmativas da companhia são, no mais das vezes, retrospectivas, (iii) são simples e bastante visíveis, enquanto divulgações diretas tendem a ser mais confusas e complexas (por exemplo, como forma de transmitir uma informação aos acionistas e ao mercado, qual seria o mecanismo mais claro: um formulário de referência de 600 páginas ou um aumento na política de dividendos?), (iv) enviam informações ao público sem divulgar detalhes potencialmente proveitosos para concorrentes da companhia. Adiciona-se a essas uma quinta explicação, de natureza exclusivamente jurídica: a sinalização pode passar informações ou impressões sobre a performance futura da empresa social, de maneira velada, o que, portanto, faz recair sobre elas um menor grau de responsabilidade do que se houvessem sido tornadas públicas por meio de uma declaração aberta da administração sobre as perspectivas futuras da companhia. Em outras palavras, "the potential liabilities faced by managers under the relevant securities laws deter managers from making direct public statements that predict their firms' future economic performance. In contrast, signaling activity is left virtually unregulated, ${ }^{, 182}$.

Por exemplo, no Brasil, diversas normas da CVM impõem normas de conduta e responsabilidade à companhia, seus controladores e administradores, pelo conteúdo das informações divulgadas ao mercado. No caso de ofertas públicas de valores mobiliários, a Instrução CVM n. ${ }^{\circ}$ 400, de 29 de dezembro de 2003 (“Instrução CVM 400”), no art. 56, impõe responsabilidade ao ofertante pela veracidade, consistência, qualidade e suficiência das informações prestadas por ocasião do registro e daquelas fornecidas ao mercado durante a distribuição. Já os artigos 45 c/c 46 da Instrução CVM 480 impõem o dever aos administradores, controladores e à própria companhia pela prestação de todas as informações exigidas pela legislação e regulamentação do mercado de valores mobiliários. Também o artigo 14 dessa mesma norma prevê que o emissor deve divulgar informações verdadeiras, completas, consistentes e que não induzam o investidor a erro, considerando-se infração grave o descumprimento dessas regras. Também a Instrução CVM n 8, de 08 de outubro de 1979 (“Instrução CVM 8”), poderia ser invocada para penalizar um emissor pelo conteúdo da informação prestada ao mercado, sob a égide da vedação de operações fraudulentas ou condutas não equitativas. De forma mais

${ }^{182}$ Robert M. Lawless, Stephen P. Ferris e Bryan Bacon, op. cit., pp. 210 e 211. 
contundente, enfim, a Instrução CVM 480 prevê o modo que um emissor deve observar para divulgar projeções e estimativas sobre o futuro, a partir do artigo 20. Em primeiro lugar, impõe a instrução que tais projeções sejam incluídas no Formulário de Referência (e, portanto, sejam submetidas aos já mencionados critérios de veracidade, completude, consistência e probabilidade de indução do investidor a erro) e venham acompanhadas das premissas, parâmetros e metodologia adotados. Indo além, essas estimativas, suas premissas e metodologias, precisam sofrer acompanhamento constante da administração, com vistas à sua atualização (em prazo não superior a 1 ano), sendo que os resultados da companhia devem ser comparados trimestralmente com as projeções e estimativas dadas ao público. O que se depreende facilmente dessa leitura é que o arcabouço regulatório do Brasil vê com certa desconfiança a divulgação formal de projeções e estimativas sobre a rentabilidade futura da companhia, devido ao fato de que esses não são dados fatuais, são opiniões decorrentes da adoção de premissas pela administração, e podem induzir o investidor a erro. Daí o regime de responsabilidade previsto ser ainda mais acentuado, em nossa visão, quando falamos do conteúdo divulgado a título de projeções e estimativas futuras. Isso sem contar com a possibilidade de tipificação de conduta criminosa (fraudulenta), nos termos do artigo $27-\mathrm{C}$ da Lei 6.385/76 ${ }^{183}$.

Em resumo, existe um campo jurídico minado impondo severas penalidades à companhia, seus controladores e administradores, pela existência de conteúdo falso ou enganoso nas divulgações de informações feitas ao público. As projeções e estimativas sobre o futuro são campos particularmente férteis para que tal responsabilidade seja aplicada, o que pode incentivar as companhias a divulgar suas projeções de forma menos direta, por meio dos sinais, categoria que, como se disse, inclui a recompra de ações. Em nossa visão, a probabilidade de a companhia ser condenada pelo conteúdo da informação que transmitiu por meio de uma recompra de ações é bastante remota. Tendo em conta essa diferença, parece-nos evidente que o regime de responsabilidade irá influenciar a decisão da companhia e seus administradores de divulgarem projeções, estimativas e outras informações por meio de recompras de ações (ou de outros sinais), ao invés de utilizarem formas diretas de transparência ${ }^{184}$ (ou, ao menos, em conjunto com estas).

\footnotetext{
${ }^{183}$ Afirmativamente em relação a potencial subsunção de prestação de informações falsas ou tendenciosas ao mercado, com o objetivo de induzir alguém a negociar, como crime de manipulação de mercado, cf. Nelson Eizirik et al., Mercado de Capitais - Regime Jurídico, $2^{\mathrm{a}}$ ed., Renovar, Rio de Janeiro, 2008, p. 525.

${ }^{184}$ Em 1996, pesquisa empírica realizada com 80 companhias componentes da lista da Fortune 500 daquele ano, revelou que $80,2 \%$ dessa amostra tinham, nos cinco anos precedentes à pesquisa, utilizado alguma forma de sinalização (dividendos, recompras ou desdobramentos), sendo que as recompras de ações foram
} 
Aqui, cabe um parêntese importante. Dizer que a probabilidade de responsabilização pela atividade de sinalização em termos de "veracidade, completude e consistência" da informação transmitida em si é remota (o que efetivamente nos parece ser o caso), não significa que outras normas relevantes da CVM não estejam sendo descumpridas por meio do exercício dessa sinalização, gerando, então, a responsabilidade. É preciso muito cuidado com estas afirmações, pois a linha que divide o que é uma informação futura, não disponível ao mercado, mas que pode ser "sinalizada" mediante recompras de ações, daquelas que deveriam ser imediatamente tornadas públicas pela companhia, é bastante tênue. Se a informação não puder ser classificada como relevante ou concreta o suficiente para justificar a divulgação para todo o mercado - "soft information" - então a administração pode optar por enviar um sinal mais sutil indicando a subvalorização ${ }^{185}$. Agora, se a administração possuir informações que o público desconhece, mas que sejam relevantes, não públicas e concretas, não deveria ela ser simplesmente divulgada ao mercado para que este, então, atue sobre elas e equilibre os preços praticados? A resposta a esse questionamento impõe necessariamente diferenciar entre uma informação relevante, material, concreta e não pública (e, portanto, de divulgação obrigatória ao mercado), de outras informações, igualmente relevantes, mas ainda não concretas ou de materialização no longo prazo (como, por exemplo, uma visão sobre as perspectivas futuras da companhia), e que a administração pode entender como não sendo ainda de divulgação obrigatória. É apenas esta última que justificaria a sinalização, pois, na primeira situação, estaríamos diante de uma típica operação de insider trading, não permitida ${ }^{186}$. Como veremos mais adiante, a Instrução CVM 358 aplica-se também, e na mesma medida, para as próprias companhias emissoras no tocante às restrições de negociação com base em informação privilegiada. Retomaremos o ponto no item específico.

\subsubsection{Gerenciamento da Estrutura Societária}

Por outra vertente, ainda, poderá a companhia utilizar a aquisição de ações próprias como forma de gerenciamento da estrutura de poder dentro da sociedade. Assim, por

indicadas como a cateogria mais popular, com $60 \%$ da amostra tendo feito uso dela no mencionado período. Cf. Robert M. Lawless, Stephen P. Ferris e Bryan Bacon, op. cit., pp. 237 a 240.

${ }^{185}$ Cf. Alexander Kitanoff, op. cit., p. 31. Cf. também Jesse M. Fried, Insider Signaling and Insider Trading with Repurchase Tender Offers, in University of Chicago Law Review, Vol. 67, 2000, p. 442.

${ }^{186}$ Victor Brudney, Equal Treatment of Shareholders in Corporate Distributions and Reorganizations, California Law Review, Vol. 71, N. ${ }^{\circ}$ 4, 1983, pp. 1110 e 1111, questionando a legitimidade da presunção de que a sinalização é eficiente. 
exemplo, poderá ela adquirí-las para evitar a formação de um grupo de poder minoritário no seio da sociedade, cujo objetivo seja o de causar prejuízos a ela (pense-se em um concorrente da companhia adquirindo participação minoritária relevante via escalada em bolsa, por exemplo ou, ainda, de um minoritário desleal em uma companhia fechada). Nestes casos, além do objetivo de reforço do poder de controle, lícito, simultaneamente pode-se evitar um dano à sociedade, decorrente da presença de elemento "estranho" à boa continuidade das atividades sociais. É claro que esta finalidade de manutenção ou reforço do controle (ou de evitar a formação de uma minoria prejudicial) poderá ser lícita ou ilícita, a depender da motivação: ora se vislumbra o atendimento aos interesses somente dos acionistas controladores (e aí a operação será ilícita), ora aos da sociedade (e, então, será revestida de licitude). A definição, no caso concreto, entre uma e outra situação pode ser bastante complexa.

Ainda quanto às finalidades lícitas no gerenciamento da estrutura organizativa da sociedade, pode-se mencionar a sua utilidade no que diz respeito às ações distribuídas a administradores ou empregados como parte de sua remuneração ou como forma de aumentar seu engajamento no desempenho de suas funções (formas tradicionais de criar incentivos e vínculos de longo prazo entre a companhia e seus trabalhadores e administradores). Por um lado, quando essas pessoas perdem ou deixam os seus cargos, a existência de cláusulas que garantam o direito de preferência da sociedade para a aquisição, por ela, dessas ações, ou, ainda, de uma opção de compra compulsória por parte dela, poderão evitar a permanência indesejada deles no quadro societário. Por outro lado, no âmbito dos tradicionais planos de opção de compra de ações (outorgadas aos administradores e funcionários), é muito útil à sociedade poder entesourar ações em número suficiente para possibilitar a sua entrega no caso do exercício, pelos titulares, de suas opções. Ao manter essas ações em tesouraria, a companhia gerencia de forma prudente o risco a que está exposta em decorrência da existência dessas opções (negócio em que ela está sujeita à mandatória entrega de ações), decorrente da variação do valor, e da disponibilidade, dos papeis no mercado - a companhia protege-se destes riscos ao ter as ações em tesouraria desde a outorga da opção.

Por fim, são comuns operações de incorporação e aquisição, mesmo em companhias abertas, que envolvem a celebração de acordos de acionistas, ou outros arranjos contratuais/societários, contendo cláusulas de preferência ou opções mútuas entre as partes e a companhia (ou apenas entre os sócios contratantes), cuja finalidade é a de evitar que o desentendimento entre as partes possa levar uma delas a alienar sua 
participação social a um sócio indesejado (como, por exemplo, um concorrente), em prejuízo da companhia. Neste tipo de situação, pode-se visualizar na aquisição de ações próprias um mecanismo de proteção da sociedade contra o ingresso de acionistas estranhos ou perniciosos e, ainda, um mecanismo de garantia da existência de um comprador apto a viabilizar a saída do sócio alienante.

\subsubsection{Outras Funções}

Não é unânime a doutrina sobre a possibilidade de a companhia adquirir suas próprias ações como forma de investimento dos seus lucros excedentes. Alguns autores afirmam que esse seria um possível, e rentável, investimento feito por ela, considerando que não haveria ninguém em posição mais propícia para conhecer o verdadeiro valor das participações sociais da companhia do que os membros de sua administração. Outra parte da doutrina coloca sérias reservas a essa interpretação, uma vez que (como veremos) as ações em tesouraria não possuem um valor patrimonial próprio e que o fato de a companhia utilizar suas disponibilidades para comprar ações próprias poderia sinalizar que ela não encontrou outros investimentos rentáveis para alocar seus recursos. Nos EUA, ao analisarem a questão sobre se a recompra seria, em si, um (bom) investimento dos recursos sociais, West e Bierman afirmam que "[n] ormal investments keep the size of the firm intact or increase it, and either have no effect on the stockholders' equity balance or the number of shares outstanding, or increase them. A firm's acquisition of its own common stock, on the other hand, reduces the size of the enterprise. In particular, the cash balance is decreased, the stockholders' equity balance is reduced, and the number of shares outstanding is cut back. In short, repurchasing shares has few characteristics which identify it as a normal investment ${ }^{\prime 187}$. Na nossa visão, uma recompra de ações nunca poderá ser considerada um investimento da companhia, por mais que ela tenha como intenção obter algum lucro com a diferença de preço entre a ação adquirida e posteriormente alineada ao mercado: investimentos típicos (como a compra de uma planta industrial, ou a aquisição de um título público) não implicam a alteração da composição estrutural da sociedade. Isso sem contar que um investimento típico tem por consequência a manutenção, ou o aumento, do patrimônio social, enquanto uma recompra, ao menos no momento em que realizada e enquanto permanecerem as ações em tesouraria, provoca uma redução do patrimônio líquido, devido a sua obrigatória dedução contábil: as recompras,

${ }^{187}$ Cf. Harold Bierman Jr. e Richard West, The Acquisition of Common Stock by the Corporate Issuer, in The Journal of Finance, Vol. 21, N. ${ }^{\circ}$ 4, 1966, p. 689. 
evidentemente, têm poucas características que as tornam equiparáveis a um investimento comum.

Existem outras razões segundo as quais se justifica a utilização dos negócios com ações próprias, como no caso de um fechamento de capital de uma companhia aberta, em que o instituto pode ser particularmente útil.

\subsection{Do Caráter Exemplificativo dos Negócios Permitidos}

É inegável que existe uma vedação genérica para que a companhia realize negócios com ações de sua própria emissão. É igualmente inegável, no entanto, que a lei admite exceções a essa regra, cujo número foi sendo elevado com o passar do tempo, como se depreende da retrospectiva histórica feita acima. No passado, apenas a amortização era expressamente permitida no Brasil, mas, com a evolução do conhecimento jurídico, outras operações foram paulatinamente sendo acrescentadas ao rol dos negócios permitidos (o resgate e o reembolso, v.g., foram acolhidos posteriormente). O que se verifica é que a tendência histórica acerca do objeto deste estudo foi a de acrescentar exceções à regra: atualmente, convivemos com uma situação em que diversas estruturas e negócios jurídicos são desenvolvidos pelos agentes financeiros envolvendo as próprias ações, sem uma correspondente atualização do pensamento teórico sobre a sua disciplina.

A pergunta que se faz neste momento, portanto, é se a lista do artigo 30 da Lei das S.A. possui caráter taxativo ou meramente exemplificativo. Conquanto a doutrina nacional seja unânime em defender o caráter taxativo das exceções ${ }^{188,189}$, defendemos uma mudança de visão a respeito destas operações, que devem deixar de ser encaradas com o estigma da fraude, para finalmente serem pensadas de forma racional, sempre com vistas a proteger interesses legítimos que podem ser impactados, sempre que estejam efetivamente sendo ameaçados. Na nossa visão, precisam ser pensados os negócios jurídicos com as próprias ações sob o ponto de vista dos três principais grupos de referência tutelados, expostos ao longo deste trabalho: o dos credores, dos acionistas e do mercado. Estando atendidos os

\footnotetext{
${ }^{188}$ Philomeno J. da Costa era adepto da teoria de que a lista de operações permitidas pela lei seria taxativa: "[s]e numa proibição se declara que esta não abrange as hipóteses indicadas logo a seguir, todas as demais que não foram referidas, estão compreensivamente vedadas". In op. cit., p. 50, opinião com a qual não concordamos. O próprio autor, no entanto, reconhece que a norma (DL 2.627/40) não excepcionava, já naquela época e bem assim hoje, outras operações com ações próprias permitidas em outros artigos, o que, para ele, seria apenas uma imperfeição legislativa.

${ }^{189}$ Defendendo o caráter taxativo cf. Modesto Carvalhosa, Comentários à Lei de Sociedades Anônimas, Vol. 1, $5^{\text {a }}$ ed., Saraiva, São Paulo, 2007, p. 309; Darcy Arruda Miranda Jr., Breves Comentários à Lei de Sociedade por Ações, Saraiva, São Paulo, 1977, p. 46.
} 
requisitos delineados legalmente e se não houver claro intuito de fraude à lei, qualquer operação deveria ser permitida.

Afinal, é evidente que os requisitos de observância obrigatória criados pela Lei das S.A. e pela CVM têm o intuito de proteger justamente os interesses desses grupos: (i) a utilização do saldo de lucros e reservas salvaguarda o interesse dos credores, ao não possibilitar prejuízos ao capital social real, (ii) o princípio do tratamento igualitário entre acionistas (tópico espinhoso e a respeito do qual discorreremos à frente) visa a resguardar os acionistas, minoritários em sua maioria, de abusos perpretados pela companhia, seus administradores e controlador(es), e (iii) as normas de repressão ao insider trading, à manipulação de mercado e às práticas fraudulentas (inclusive com a criminalização de várias dessas condutas) são mecanismos eficazes de tutela dos investidores e do mercado de capitais.

Observadas essas condições de validade (e, aqui, a referência em Direito Comparado é com o Direito Italiano), defende-se veementemente que qualquer operação deveria ser permitida, dando um caráter exemplificativo à lista do artigo 30 da Lei das S.A. A cumulação dessas ferramentas jurídicas de cuidado deveria ser suficiente para que qualquer operação fosse considerada, a priori, lícita, e não o contrário. Hoje, mesmo que um negócio jurídico atendesse a todos esses princípio e limites, mas não estivesse listado expressamente na lei, seria, segundo a doutrina unânime, ilegal.

Ocorre que existem inúmeros negócios, sobre os quais refletiremos adiante, que não se encontram arrolados no art. 30 da Lei das S.A. Em primeiro lugar, esse artigo não arrola sequer todas as modalidades de negócios com as próprias ações previstas na própria lei. Veja-se, ad esempio, que não está inserida a possibilidade de a companhia alienar as ações de acionista remisso, estabelecida expressamente no artigo 107, II, do mesmo diploma, o que extrapola um mero erro legislativo: deve-se entender que o legislador apenas não cuidou de enumerar todas as opções em um único artigo. Outro argumento a favor desta tese, este de caráter mais político ${ }^{190}$, refere-se ao fato de que a adoção da interpretação segundo a qual as modalidades elencadas no art. 30 são taxativas engessaria sobremaneira o âmbito de atuação das companhias. Os tempos modernos impõem a necessidade de interpretações que, garantida a lógica protetiva do instituto, permitam o maior número possível de operações, tendo por objetivo fomentar o desenvolvimento de operações financeiras e de estruturas flexíveis que impulsionem a economia. Argumentar em favor do

\footnotetext{
${ }^{190}$ Interpretação "liberal” diria Philomeno J. da Costa (op. cit., p. 53).
} 
caráter taxativo das exceções significa proibir o recebimento das próprias ações em legado ou herança, por falta de previsão legal expressa, que menciona apenas a doação, o que visivelmente não se justifica, quando se recordam os três grupos de referência, cujos interesses são tutelados pelo regime: credores, acionistas e mercado. Veja-se um exemplo claro da incoerência com relação ao recebimento de ações pela companhia por legado: o negócio não é listado expressamente no artigo 30, mas a doutrina enxerga com bons olhos o negócio, por ser gratuito e não causar prejuízos aos credores ou aos acionistas. Qual o raciocínio aqui? Ora, certamente não é o de defesa do caráter taxativo da relação, já que se está admitindo outra hipótese além daquelas efetivamente contempladas. Parece-nos patente que a ratio interpretativa deve sempre considerar o risco de efetiva lesão aos interesses dos grupos de referência escudados: se nenhum deles é atingido ou afrontado, qual seria o fundamento jurídico da existência da proibição? Nenhum.

À vista disso, a lista de operações com ações próprias do art. 30 da Lei das S.A., cuja prática é autorizada para a companhia, deve ser encarada como meramente exemplificativa. Com isto, vale o reforço, não se defende que qualquer negócio pela anônima com ações de sua emissão seja admitido, mas, apenas, que é necessário avaliar sempre a existência efetiva de prejuízo para algum dos grupos de referência tutelados para que um negócio seja vedado.

\section{ASPECTOS PATRIMONIAIS: O INTERESSE DOS CREDORES}

\subsection{Os Grupos de Referência do Direito Societário: Credores}

Ponto fundamental a se esclarecer antes de entrarmos na análise do capital social é que as regras de comportamento veiculadas pelo Direito Societário não são direcionadas a pessoas individualmente consideradas, mas, sim, a coletividades de pessoas com algumas características homogêneas. As normas de Direito Societário, com raras exceções, são estruturadas em torno da proteção de determinados interesses coletivos, que possibilitam a sua divisão em grupos de referência (Bezugsgruppen), como, por exemplo, os sócios, os credores e os trabalhadores.

Entra como um dos grupos, cujos interesses é conveniente ${ }^{191}$ ao Direito Societário regular, o dos credores: "também os seus interesses são reconhecidos de uma forma

\footnotetext{
${ }^{191}$ Reconhece-se que são necessários limites na internalização de interesses extrassocietários. É preciso, de certa forma, admitir que determinados titulares de interesses coletivos são mais bem protegidos por meio de
} 
abstrata e coletiva" ${ }^{\prime 192}$. Como titulares de um interesse legítimo no correto funcionamento do aparato social, os credores são tutelados tanto na medida em que a lei confere responsabilidade pessoal (seja direta ou subsidiária) a um sócio ou a uma categoria de sócios pelas dívidas sociais, como na determinação de constituição e manutenção de um capital social que lhes sirva de garantia (Garantiekapital), naquelas sociedades onde essa responsabilização pessoal não seja prevista na lei. Estas normas, como se nota, não estão direcionadas a um credor específico, mas, sim, à proteção de uma coletividade abstrata de credores (Gläubigergesamtheit) ${ }^{193}$.

Os credores sociais são colocados, em quase todas as leis, em situação de preferência de recebimento em caso de falência da sociedade, sendo os sócios colocados em último lugar no ranking de credores. A proteção aos credores sociais, nestes termos, sejam eles bancos, fornecedores, consumidores, contrapartes contratuais, etc., se justifica do ponto de vista ético pelo fato de que são os sócios, por meio de suas decisões empresariais no seio da sociedade, que ditam os rumos desta, traçando, por isso, as condições do sucesso ou insucesso da atividade desenvolvida. Daí decorre o princípio de que eles, os sócios, devem assumir responsabilidade pelas suas decisões, por meio da colocação de seu capital próprio à fond perdu. Os credores sociais, por sua vez, são externos em relação ao desenvolvimento da atividade empresarial. Por mais que tentem se

um subconjunto distinto de regras, que não aquelas do Direito Societário, que pode, quando muito, trazer apenas determinadas normas específicas que tutelem esses interesses de maneira subsidiária e não central. Entre nós, Calixto Salomão Filho explorou em profundidade o ponto quando dissertou sobre a teoria do institucionalismo integracionista ou organizativo na definição do interesse social. Nas palavras de Calixto Salomão Filho: "Por solução orgânica ou estrutural quer-se significar a tentativa de resolver nos órgãos societários o problema de conflito, seja através da incorporação no órgão de todos os agentes que têm interesse ou sofrem as consequências, ou através da criação de órgãos independentes, não passíveis de ser influenciados pelos interesses conflitantes" - grifos nossos. A fundamentação jurídica desta teoria tem por base a ideia de que a sociedade é uma forma de solução de conflitos (em sua origem, conflitos capitaltrabalho, como dão a entender as Mitbestimmungsgesetze alemãs). Sendo assim, é de interesse da própria empresa a manutenção e a diminuição dos diversos conflitos de interesses existentes de maneira interna corporis, como forma de reduzir custos de transação, aumentando sua eficiência. In Calixto Salomão Filho, O Novo Direito Societário, $3^{\mathrm{a}}$ ed., Malheiros, São Paulo, 2002, pp. 90 a 104. Wiedemann, como afirmamos, é contrário à internalização irrestrita de interesses extrassocietários, considerando que eles podem, devem e de fato são mais bem regulados por outros ramos do direito, como o Direito do Consumidor, o Direito Ambiental e o Direito Antitruste.

192 No original: "auch ihre Interessen werden abstrakt-kollektiv wahrgenommen". Cf. Herbert Wiedemann, op. cit. p. 85. Se a proteção dos credores deveria ou não levar em conta a diversidade de credores (bancos, o Estado, o consumidor, os fornecedores) é questão diversa.

${ }^{193}$ Herbert Wiedemann, op. cit. p. 85. A observação que fazemos aqui com relação à presença destes centros de interesse juridicamente relevantes para o Direito Societário não é meramente classificatória, mas vai influir em diversas esferas do regramento societário, como, por exemplo, nas regras que definem as condições de interpretação dos estatutos e contratos sociais, que devem, em grande medida, diferenciar cláusulas estatutárias ou contratuais que atinjam os interesses destes grupos, em contraposição às cláusulas que digam respeito unicamente à organização interna da sociedade. No primeiro caso, recomendar-se-ia a utilização de uma interpretação objetiva, no segundo, subjetiva das disposições. Para mais detalhes, Herbert Wiedemann, op. cit., pp. 165 e ss. 
blindar contra o risco que isso lhes acarreta pela via contratual (a depender do tamanho e influência do credor), os atos sociais tomados em contrariedade a essas disposições resultam não em invalidade do ato societário, sobre o qual os credores não têm qualquer influência, mas apenas em perdas e danos por violação do contrato ${ }^{194}$ (ou execução deste, com suas eventuais garantias).

É óbvio que tanto os credores quanto os sócios participam do risco da atividade empresarial, mas cada um em diferente grau: o capital de terceiros (Fremdkapital), pela sua função, deve sofrer os prejuízos da atividade empresarial por último e com menor grau de probabilidade, sob pena de os sócios coletivizarem os prejuízos sociais, mas usufruírem isoladamente dos seus lucros: o risco empresarial é, por excelência, dos sócios e não dos credores e qualquer tentativa de inverter esta lógica contraria a ordem econômica. Para isso, o ordenamento jurídico cria regras organizacionais e patrimoniais que tentam equilibrar esses dois interesses ${ }^{195}$.

Na proteção do equilíbrio entre esses interesses, os países seguem diversos rumos.

No direito continental europeu, a constituição e a manutenção de um capital social (Grundkapital, na anônima, Stammkapital, na limitada) surge exatamente como uma das formas de se garantir os interesses dos credores naquelas sociedades onde eles não têm acesso ao patrimônio particular dos sócios (a responsabilidade dos sócios substitui a manutenção do capital social ${ }^{196}$ ). Aqui, é primordialmente a lei e não o contrato, que protege os credores sociais contra os comportamentos abusivos dos acionistas. A visão da doutrina europeia sobre o capital social, e o seu regime, sugere que a submissão a ele seja uma consequência da limitação de responsabilidade dos sócios. Para obterem esse privilégio, os acionistas devem fazer contribuições de capital à companhia e ela, por sua vez, não pode, em regra, devolver-lhas durante a sua vida.

\subsection{Negócios com as Próprias Ações e Ordenamento Patrimonial da Sociedade: Funções e Disfunções do Capital Social como Garantia dos Credores}

\subsubsection{Função de Garantia}

\footnotetext{
${ }^{194}$ Cf. Herbert Wiedemann, op. cit., p. 515.

195 "No direito comercial, a proteção dos credores é um princípio jurídico intrínseco à lei, que se deixa derivar, por indução, a partir de várias disposições específicas". No original: "Im Handelsrecht ist der Gläubigerschutz ein gesetztesimmanentes Rechtsprinzip, daß sich induktiv aus vielen einzelnen Bestimmungen ableiten läßt". Cf. Herbert Wiedemann, op. cit., p. 518. Interessante notar, neste aspecto, que o valor declarado pelos sócios como capital social, em uma sociedade anônima ou limitada, servirá como medida do risco assumido, no limite, pelos sócios. O restante será terceirizado aos credores. Cf. Paulo de Tarso Domingues, Do Capital..., cit., p. 219.

${ }^{196}$ Cf. Herbert Wiedemann, op.cit., p. 536.
} 
Como vimos acima, o capital social, e as normas que visam a resguardá-lo, decorre da limitação da responsabilidade dos sócios. O patrimônio social, tornado autônomo pela personificação, é, no entanto, naturalmente mutável, pois que afetado ao exercício de uma atividade a ser desenvolvida pela sociedade e que é exatamente a razão pela qual se associaram as pessoas. E como o patrimônio social está vinculado a uma atividade, sofre ele alterações diárias e não apenas excepcionais ou ocasionais.

Cumpre, portanto, ao direito, em decorrência da autonomia patrimonial da sociedade e da limitação da responsabilidade dos sócios, proporcionar aos credores meios de contrabalancear estas características, em prol de sua proteção, o que se dá exatamente pela publicidade da vida social, que lhes garante certa tutela a respeito da gestão societária, e pelas regras de proteção do capital social, que lhes garantem certa proteção contra a variação patrimonial irrestrita da sociedade ${ }^{197}$. Autores têm afirmado que o conceito de capital social é "noção central e fundamental no direito societário"198.

Neste ponto de nosso estudo, analisaremos apenas a função que se atribui ao capital social de ser garantia indireta dos credores. Importa-nos verificar como e em que medida se dá essa proteção ou se, ao contrário, ela não é tão evidente como se afirma. Não é nosso objetivo desacreditar a noção de capital social como um todo, pois que ela tem grande valia no seio da organização societária das sociedades de capitais, onde exerce funções das mais variadas, especialmente considerando a medição do poder politico (determinação do poder intrassocietário) dos sócios com base no valor de suas contribuições ao patrimônio social.

O capital social é conceito "não apenas funcional, mas fundacional"199 nas sociedades onde haja limitação da responsabilidade dos sócios, que são, por excelência, a sociedade anônima e sociedade limitada (no nosso direito, conforme artigos $1^{\circ}$ da Lei das S.A. e 1052 do Código Civil) ${ }^{200}$. Mas por quais razões? É ele fundamental ou mesmo

\footnotetext{
${ }^{197}$ Cf. Tullio Ascarelli, Problemas..., cit., p. 467.

198 Paulo de Tarso Domingues, Do Capital..., cit., p. 18. Para Wiedemann, outrossim, a noção de capital social constitui uma contribuição cultural de primeiro grau ("eine Kulturleistung ersten Ranges", op. cit., p. 558).

${ }^{199}$ Paulo de Tarso Domingues, Do Capital..., cit., p. 27.

${ }^{200} \mathrm{O}$ capital social não é conceito fundamental à noção de sociedade, fique claro, na sua função de garantia de credores. Obviamente, o conceito de que uma forma societária necessita de capital para que possa exercer sua atividade é intuitiva. Ou seja, o capital social passa a ser forma integrante e indissociável do fenômeno societário na sua função de produção, mas não necessariamente na sua função de garantia de credores. É neste sentido que diz José Alexandre Tavares Guerreiro que "o capital social constitui elemento necessário e indissociável, a integrar a própria realidade ontológica da sociedade comercial, sem o qual esta não logra sequer se constituir validamente, por falta de meio imprescindível à consecução de seus objetivos". Cf. José Alexandre Tavares Guerreiro, Regime Jurídico do Capital Autorizado, Saraiva, São Paulo, 1984, p. 1.
} 
idôneo por servir de garantia aos credores sociais ou por conta de outras funções que exerce no seio social? ${ }^{201}$

O capital social vem estudado em suas diversas acepções. Uma delas é a de que o capital social seria uma cifra contábil tão somente, constante do lado direito do balanço da sociedade. Esta visão é um pouco limitada, por duas razões: em primeiro lugar, porque nenhuma cifra contábil é unilateral, ou seja, se a "conta" do capital social está ao lado direito do balanço é porque ativos correspondentes foram contabilizados no lado esquerdo. Em segundo lugar, porque desconsidera as demais funções do capital, especialmente no tocante à formação interna do poder societário (voto). Esta noção, puramente considerada, de cifra contábil, não nos convence quando o assunto é garantia de terceiros. O capital social, sendo cifra do balanço, não tem como ser garantia dos credores.

Outra visão que se retira da doutrina é que o capital social corresponde à soma das entradas dos sócios. Esta concepção merece algumas críticas; em primeiro lugar, pois a fixação do montante do capital social antecede as entradas e não o contrário. Com isto quer-se dizer que primeiro se fixa o montante que determinará o mínimo que os sócios precisarão atribuir ao patrimônio social para depois distribuírem-se essas participações. Ademais, é sabido que os sócios podem ingressar com mais recursos do que a cifra do capital dispõe (a cifra seria o capital nominal ${ }^{202}$ ), servindo o restante como ágio na subscrição das ações, de onde se compreende que a identificação das entradas dos sócios com o capital social também fica prejudicada. No mais, o capital social pode estar previsto, sem que tenha havido entrada, o que ocorre quando o sócio se compromete a integralizar as ações subscritas em momento posterior à sua subscrição ou mesmo quando haja aumento de capital por capitalização de reservas (onde não há, ao menos diretamente, “entrada").

\footnotetext{
${ }^{201}$ Antes de prosseguirmos, vale ressaltar o óbvio: capital social não é patrimônio, nem patrimônio líquido. O patrimônio é, nos termos do artigo 91 do Código Civil, uma universalidade de direito, compreendendo, portanto, o complexo de relações jurídicas ativas e passivas, de conteúdo econômico, atinentes a uma mesma pessoa (física ou jurídica); o patrimônio líquido se obtém pela soma de todos os ativos, subtraídos todos os passivos de uma mesma pessoa e o capital social é uma cifra fixa carimbada no estatuto ou contrato social. Portanto, se o capital social não é conceito obrigatório nas sociedades, o patrimônio o é (seja pela soma de todos os bens aportados pelos sócios no patrimônio social ou comum, seja pelas relações jurídicas ativas e passivas em que a sociedade venha a figurar como parte).

${ }^{202}$ Basicamente, o capital social seria idêntico à multiplicação do número de ações pelo seu valor nominal (capital social nominal). Para Wiedemann, a cifra do capital social corresponde a um "Mindest-Sollbetrag" (valor teórico mínimo) do patrimônio social, ou seja, essa cifra representa o mínimo de recursos que os sócios se obrigam a verter ao patrimônio social, podendo, naturalmente, ultrapassá-lo, mas nunca lhe ser inferior. Cf. Herbert Wiedemann, op.cit, p. 556. "In der Regel ist das Ausgangsvermögen höher als die Nennkapitalziffer, weil die Mitgliedschaften über pari verkauft werden; (...)", ou "em regra, é o patrimônio de saída [da esfera subjetiva dos sócios] maior que a cifra nominal do capital, pois as participações sociais são vendidas acima do par [com ágio]". Cf. Herbert Wiedemann, op. cit., p. 557.
} 
Esta noção de capital social tampouco nos convence quando o assunto é garantia dos credores.

A terceira noção que se depreende é a de que o capital social é um nomen iuris, com existência meramente jurídica e não real, um valor abstrato e fixo no estatuto ou contrato social, que apenas em certas circunstâncias formais pode ser alterado. Tampouco esta noção nos convence de que o capital social seja garantia de credores, pois é óbvio que eles não podem ser garantidos por uma cifra abstrata plasmada no estatuto ou no contrato. Mesmo que o capital social seja amplíssimo, como cifra abstrata, é possível que o patrimônio líquido da sociedade seja nulo, ou mesmo negativo, uma vez que a companhia não só pode, como deve, utilizar os recursos aportados pelos sócios em sua atividade, colocando tais valores em risco.

$\mathrm{Na}$ tentativa de salvar a letra da lei, conceituou-se o capital social como um fenômeno uno, porém complexo ${ }^{203}$, atribuindo-lhe dois perfis ${ }^{204}$, um nominal (ou formal) e um real (ou material). Quer esta teoria significar que o conceito de capital social é utilizado pela lei em diversas noções, ora indicando seu sentido nominal ou formal - como nomen iuris, elemento fixo e constante mencionado nos estatutos da sociedade (é neste sentido que a expressão é utilizada nos artigos $5^{\circ}$ e $6^{\circ}$ da Lei das S.A.) -, ora indicando seu sentido real ou material - como massa concreta de bens (é neste sentido que a lei fala em “formação", no artigo $7^{\circ}$, e "perda" do capital social no artigo 173 da Lei das S.A.). Com este último sentido é que se diz que a companhia não pode utilizar o capital social para adquirir as próprias ações, no artigo $30, \S 1^{\circ}$, "b”, da Lei das S.A.

Assim vistas as coisas, observa Paulo de Tarso Domingues, "o capital social é não apenas a cifra, que consta do lado direito do balanço, mas igualmente aqueles bens da sociedade - qualitativamente não determinados mas contabilisticamente destinados a cobrir a referida cifra -, e que constituem a outra face, apelidada de capital social real"205 grifos nossos. Esse conjunto não individualizado de bens estaria afetado com um vínculo de indisponibilidade (Wiedemann fala em Vermögensbindung em contraposição ao conceito de capital social - Eigenkapital ${ }^{206}$ ), não podendo a sociedade deles dispor em favor dos sócios uti socii. Ressalte-se que esses bens não são qualitativamente

\footnotetext{
${ }^{203}$ Cf. Paulo de Tarso Domingues, Do Capital..., cit., p. 46.

${ }^{204}$ Técnica esta de grande valia ao direito, como se sabe. Ver também Alberto Asquini, Profili dell'impresa, in Rivista Del Diritto Commerciale, 1943, v. 41, I, in Fábio Konder Comparato (trad.), Revista de Direito Mercantil, Industrial, Econômico e Financeiro, Malheiros, São Paulo, $n^{\circ} 104$.

${ }^{205}$ Paulo de Tarso Domingues, Do Capital..., cit., p. 52. Philomeno J. da Costa diria que os ativos que excedem a cifra nominal do capital social seriam uma "plusvalia concreta que se dilui entre os bens da sociedade". In Philomeno J. da Costa, op. cit., p. 86.

${ }^{206}$ Cf. Herbert Wiedemann, op. cit., pp. 554 e ss.
} 
determinados, o que significa que eles não se identificam com os bens originalmente aportados pelos sócios ao patrimônio social. Apesar da variação do patrimônio como um todo, permanece fixo o volume de bens necessário a cobrir a cifra formal do capital social, sem identificarem-se quais bens a essa finalidade estão afetados ${ }^{207}$.

O grande trunfo deste último sentido é o de ser o único capaz de explicar, satisfatoriamente, o que se quer dizer quando se afirma que o capital social é garantia dos credores sociais, uma vez que seus interesses são tutelados por bens reais do patrimônio social e não por cifras aritméticas. Quando se afirma, comumente, que o capital social é garantia dos credores, está-se afirmando que a parcela líquida do ativo social (bens concretos, ou, melhor dizendo, seu equivalente valor financeiro) apta a cobrir a cifra nominal do capital social, e o regime específico de sua manutenção, é que são a garantia dos credores ou, em outras palavras, que o patrimônio líquido ${ }^{208}$ da sociedade deve sempre ser, no mínimo, igual ou superior à cifra nominal do capital social, antes da distribuição de qualquer soma aos sócios, a título de dividendos (o que somente pode ocorrer no caso de ser superior) ${ }^{209}$. Por se tratar de patrimônio líquido, o "vínculo de indisponibilidade" de que falamos funcionaria como um colchão de amortecimento (Verlustpolster) dos credores sociais abstratamente considerados, já que, além de todos os valores a eles já destinados (mais cedo ou mais tarde) e consubstanciados no passivo social - o cálculo do patrimônio líquido pressupõe esta conta - terão eles também mais ativos patrimoniais vinculados à atividade social e não aptos a serem distribuídos aos sócios.

Herbert Wiedemann se filia a este conceito, afirmando que: "A manutenção do capital social não ocorre in natura, já que os capitais ingressados na sociedade não devem ser investidos de determinada maneira, mas devem ser utilizados como patrimônio afetado à empresa; mais precisamente, criam as leis uma reserva [Sparstrumpf] técnico-contábil, criada por meio da contabilização do capital social no passivo do balanço. Um lucro líquido condizente com as demonstrações financeiras, que pode ser distribuído, existe

\footnotetext{
${ }^{207}$ Cf. Paulo de Tarso Domingues, Do Capital..., cit., p. 53. Cf. também Lamy Filho e Bulhões Pedreira (coords.), Direito das..., cit., p. 1331 e 1332; Maria Victória Rodrigues, op. cit., p. 80.

${ }^{208}$ Ressalte-se: o patrimônio aqui considerado é o líquido, e não o bruto. O patrimônio líquido, em sentido jurídico, equivale ao patrimônio bruto (soma de todas as quantidades de valor financeiro "contidas" nos bens patrimoniais do sujeito) diminuído do valor negativo das prestações das obrigações do mesmo sujeito. Isso é importante, pois "o valor (negativo) das prestações de obrigações informa a parte do valor financeiro existente no ativo que pertence a terceiros, no sentido de que mais cedo ou mais tarde deverá ser transferido para os credores do titular do patrimônio". Cf. Lamy Filho e Bulhões Pedreira (coord..), Direito das Companhias, cit., p. 1313.

209 'Nessas condições, o capital funciona, perante o patrimônio da sociedade, como uma 'cifra de retenção', prendendo no ativo bens suficientes para equilibrá-la; (...). Cf. Mauro Rodrigues Penteado, Aumentos..., cit., p. 14.
} 
apenas quando a soma de todos os ativos é maior que a soma de todos os passivos, incluindo o capital social" ${ }^{210}$. No mesmo sentido, José Luiz Bulhões Pedreira: "[a]s contas do patrimônio líquido apresentadas no lado passivo do balanço representam as quantidades de capital próprio da companhia, mas esse capital existe no ativo patrimonial, como quota-parte ideal do capital nele aplicado, e não no balanço nem nas contas da escrituração que o registram" 211 - grifos nossos.

Pois bem, passemos, então, à função de garantia dos credores que esse capital social deve exercer.

Para possibilitar uma vinculação patrimonial efetiva, que servirá como garantia dos credores sociais, em primeiro lugar é necessário que o capital declarado no estatuto ou contrato social seja efetivamente e regularmente constituído (Kapitalaufbringung): princípio da realidade do capital social.

Para que isto aconteça, é necessário que sua cifra nominal corresponda efetivamente ao volume (mínimo) de bens ou recursos que ingressou na sociedade, e isso ocorre tanto na constituição como em qualquer futuro aumento de capital: o valor nominal do capital social deve corresponder efetivamente ao (mínimo) que os sócios contribuíram para que ela possa exercer sua atividade. Se esses bens, posteriormente, se depreciaram ou não, não importa mais, pois passaram a fazer parte do patrimônio vinculado (capital social real) e, com isso, não são mais relevantes em sua individualidade. Em decorrência deste princípio é que, v.g., se proíbem emissões de ações abaixo do valor nominal (par value), em decorrência da qual ingressariam na companhia menos recursos reais do que a cifra formal indicaria. Igualmente, possibilitam-se à companhia modos eficazes de cobrar dos acionistas em mora o valor das contribuições a que se obrigaram e das quais não podem desistir ou renunciar.

Paralelamente às regras de constituição, encontramos as regras de manutenção do capital social (Kapitalerhaltung): princípio da intangibilidade (ou integridade) do capital social. Quer isto significar que os bens colocados à disposição da sociedade pelos sócios a título de capital social, destinados à sua atividade (função de produção), não podem ser a eles restituídos, exceto se observados procedimentos formais de redução do

\footnotetext{
${ }^{210}$ No original: "die Erhaltung des Einlagekapitals erfolgt nicht etwa in natura, denn das aufgebrachte Kapital soll nicht in bestimmter Weise angelegt, sondern als Betriebsvermögen eingesetzt sein; vielmehr ordnen die Gesetze einen 'bilanztechnischen Sparstrumpf' an, der durch Einstellen des unveränderten Grundkapitals unter die Passiva der Bilanz eingerichtet wird. Ein bilanzmäßiger Reingewinn, der verteilt werden kann, entsteht dann erst, wenn die Summe aller Aktiva höher liegt als die Schulden zuzüglich des Garatiekapitals". Cf. Herbert Wiedemann, op. cit., p. 557.

${ }^{211}$ Cf. Lamy Filho e Bulhões Pedreira, Direito das..., cit., p. 1342 e ss.
} 
capital ou na liquidação - i.e. aos sócios não poderão ser atribuídos bens nem valores que sejam necessários à cobertura do capital social ${ }^{212}$.

As normas a respeito das recompras de ações (e do pagamento de dividendos) são decorrência direta do princípio da intangibilidade. $O$ "princípio básico do regime legal do capital social, na sua função de proteção dos credores, somente permite à sociedade transferir bens para os sócios a título de distribuição de dividendos ou preço de aquisição ou resgate das próprias ações com a parte do patrimônio líquido que excede do valor do capital social fixado no estatuto" 213 .

Naturalmente, a relação entre patrimônio líquido, lucro líquido do exercício, capital social e recompras de ações é mais complexa, envolvendo uma série de regras contábeis sobre a forma de formação e destinação do lucro da companhia em determinado exercício. O relevante é que a companhia não poderá distribuir aos acionistas nenhum valor sem que ela tenha saldo contábil para tanto (lucro líquido no exercício ou existência de reservas de lucros no balanço, constituídas com lucros auferidos em exercícios passados), consubstanciado este na existência de ativos livres (patrimônio líquido) em valor suficiente para cobrir e ultrapassar a cifra do capital nominal ${ }^{214}$ : o regime do capital social é um regime de proteção contra a insuficiência do ativo. Não retira, obviamente, o risco empresarial (perda legítima dos ativos sociais), mas apenas protege os credores de descapitalizações ilegítimas motivadas pelos sócios, que acrescentariam a esse risco empresarial, outro, imprevisível, que consiste no comportamento destes últimos ${ }^{215}$.

As normas que regulam os negócios pela companhia com as ações de sua emissão ocupam um lugar de relevo neste contexto, já que tais negócios, potencialmente, podem significar um retorno indevido do capital social aos sócios. No exemplo mais simples do contrato de compra e venda, estes, na qualidade de proprietários das ações, é que figurarão

\footnotetext{
212 "É uma solução que se alcança obstando a que o patrimônio líquido da sociedade desça - por virtude da atribuição de bens aos sócios - abaixo do capital social (...)". Cf. Paulo de Tarso Domingues, Do Capital..., cit., p. 133. Uma alusão metafórica tradicional neste ponto, feita por Vivante, compara o capital social nominal com um vaso e os ativos patrimoniais como grãos, de forma que os grãos precisam encher o vaso e apenas os grãos que transbordarem é que podem ser distribuídos. Ver Erasmo Valladão Azevedo e Novaes França, A Proteção aos Credores e Acionistas nos Aumentos de Capital Social, in Temas de Direito Societário..., cit., p. 238.

${ }^{213}$ Cf. Lamy Filho e Bulhões Pedreira, Direito das..., cit., p. 1345.

${ }^{214}$ Cf. Lamy Filho e Bulhões Pedreira (coords.), Direito das..., cit. pp. 1681 e ss.

${ }^{215}$ Do ponto de vista econômico, "[a] restriction on the return of capital to shareholders can be understood as protecting creditors against the risk of opportunistic behavior by the shareholders. Distributions to shareholders reduce a company's net assets, making it more exposed to the risk of default. Creditor's interests can be harmed even if the company does not become insolvent. Such a transfer will still decrease the expected value of their claims, whilst commensurately enhancing the combined value of shareholders' private wealth and their stake in the firm". Cf. John Armour, Legal Capital - An Outdated Concept?, Centre for Business Research, University of Cambridge, Working Paper n. ${ }^{\circ}$ 320, March 2006, p. 5.
} 
como contrapartes vendedoras no negócio - por sua vez, o pagamento do preço de aquisição das ações, pela companhia-compradora, significa, em termos econômicos, uma transferência de riqueza da companhia para os acionistas, consubstanciada no pagamento do valor das suas ações, reduzindo, além de tudo, o patrimônio social (saída de caixa, na maior parte das vezes).

\subsubsection{Negócios com as Próprias Ações como Devolução Ilegítima das Contribuições dos Sócios?}

Um ponto importante que devemos tangenciar neste momento é de natureza filosófica: tecnicamente, poderia a recompra de ações ser considerada como um "retorno indevido das contribuições dos sócios" pela companhia (já que ela, como compradora, lhes pagou “o valor de suas ações"), similar, portanto, à redução de capital, ou deveria ela ser interpretada apenas como um ato de simples disposição (lícita) do patrimônio social, semelhante, na essência, aos dividendos, mas travestida de negócio jurídico de compra e venda? Esta discussão foi particularmente fértil na Alemanha e possui consequências jurídicas interessantes.

Naquele país, existiu intensa discussão a respeito de serem as saídas de recursos em contraprestação de uma aquisição de ações próprias um retorno das entradas dos acionistas (mesmo observando a regra de compra de ações próprias com saldo de lucros ou reservas, não haveria, ainda assim, um retorno disfarçado das entradas dos acionistas?) ou apenas uma forma alternativa de distribuição de lucros. O 557 , Abs.1, S. 2 da Aktiengesetz de 1965 tentou apaziguar a discussão ao criar uma ficção de que, em operações permitidas de recompra de ações, não estaria configurado qualquer retorno das entradas dos sócios $^{216}$. Esse dispositivo fez com que a doutrina alemã passasse a debater se o preço da aquisição das próprias ações, quando exacerbado ou inflado, poderia, então, ser uma operação ilegal de recompra de ações, sujeita ao regime da intangibilidade do capital social (a discussão sobre o valor das ações próprias para a companhia e, consequentemente, sobre as balizas de preço para sua aquisição serão discutidas em conjunto com seu tratamento contábil, pois são assuntos intimamente relacionados). A controvérsia gira em torno de dois pontos de vista: ou o ativo social é distribuído aos acionistas na forma da lei, obedecendo, portanto, a intangibilidade do capital social (os valores de tal forma entregues seriam oriundos de lucros da companhia, legitimamente pertencentes aos acionistas), ou

216 “\$57. 1. (...) Als Rückgewähr gilt nicht die Zahlung des Erwerbspreises beim zulässigen Erwerb eigener Aktien". 
ele é distribuído em contrariedade a ela e, neste caso, podem tais valores ser considerados um retorno ilegal de capital aos acionistas.

Na nossa visão, uma aquisição de ações pela companhia, se realizada na forma da lei, com o saldo de seus lucros e reservas contábeis disponíveis, não deve ser encarada nunca como uma forma de a companhia devolver o capital aos sócios: a operação assemelha-se, muito mais, a uma distribuição de recursos que já pertenceriam aos acionistas (pois que utilizados os saldos de lucros e reservas excedentes ao capital social, cf. a lógica do art. $202, \S 6^{\circ}$ da Lei das S.A.). Neste sentido, o mais correto é identificar nestas operações, do ponto de vista jurídico, uma distribuição de lucros semelhante aos dividendos, muito embora o tratamento contábil das ações em tesouraria possa levar ao entendimento de que há uma redução fictícia do capital (ver item sobre contabilização) esta é, na verdade, somente uma técnica contábil que visa a refletir o valor intrínseco das ações em tesouraria (após, portanto, sua aquisição) para a companhia.

Apesar de ser possível identificar diferenças, do ponto de vista econômico, o pagamento pela recompra das ações é muito semelhante à distribuição de dividendos, tanto do ponto de vista do acionista, que recebe o valor (com a diferença de que ele retira-se da sociedade, o que não ocorre com o pagamento dos dividendos), quanto dos credores sociais (que verão, de um ou outro ângulo, diminuído o patrimônio social - para eles pouco importa a forma da distribuição, apenas sua consequência). Mesmo porque, e disto trataremos mais abaixo no capítulo sobre o ordenamento societário, se considerarmos, ad argumentandum tantum, que a recompra das ações próprias é um "retorno das entradas", então as ações em tesouraria seriam juridicamente similares a ações não integralizadas, ou mesmo ações não emitidas (afinal, os recursos que ingressaram na integralização original foram "devolvidos" ao acionista vendedor, retornando a companhia ao status quo ante). Este raciocínio traria consigo algumas consequências jurídico-societárias graves (como veremos no capítulo específico) e com as quais não se pode concordar.

De forma mais abrangente, a operação envolve riscos para a companhia, seus acionistas e credores, pois ela representa, como já tivemos oportunidade de avaliar, um mecanismo de transferência patrimonial entre companhia e sócios (assim como os dividendos). Neste sentido, filiamo-nos à interpretação do direito norte-americano que identifica esta situação como uma "distribution", equiparável ao pagamento de dividendos, e não à redução de capital.

\subsubsection{Críticas à Função de Garantia do Capital Social}


Mencionamos, acima, que o capital social nominal é uma cifra que se reflete em um vínculo de indisponibilidade incidente sobre uma massa patrimonial amorfa que, deduzidos os passivos (patrimônio líquido), seja capaz de cobrí-la e que permaneça permanentemente afetada à atividade da sociedade. No entanto, o regime do capital social, nesses termos, não é idôneo para o desempenho da função de garantia dos credores (primitive regulatory technology) $)^{217}$, ou, ao menos, não consegue realizá-la de maneira totalmente satisfatória (European Union should abandon its inneficient approach) ${ }^{218}$ : isso resulta da composição dos ativos do balanço.

Existem diversos ativos contábeis que não são bens reais, concretos, aptos a serem penhorados ou arrecadados forçosamente (judicialmente, mesmo na falência), ou voluntariamente, da esfera patrimonial da sociedade para cobrir os créditos dos credores sociais (como, por exemplo, créditos tributários, ativos intangíveis ou diferidos) ${ }^{219}$. Tanto isto é verdade, acrescente-se, que, mesmo o patrimônio líquido sendo igual a zero (o ativo cobre exatamente o passivo) isso não significa nenhuma garantia aos credores sociais: os valores financeiros do ativo patrimonial podem ser absolutamente ilíquidos, intangíveis (i.e. não podem ser alienados separadamente da empresa como um todo) ou mesmo impossíveis de se monetizar, exceto no caso de uma venda da sociedade. A função de garantia dos credores, por estar afetada a valores financeiros de capitais aplicados no ativo patrimonial, e não a bens concretamente considerados, é fraca, pois em nada lhes garante a monetização desses valores, que são meros reflexos contábeis do seu valor intrínseco, decorrentes de uma avaliação subjetiva do observador (por mais verossímil que ela seja), de acordo com as normas contábeis.

Essa opinião ganha força quando se diferenciam os balanços de exercício do balanço de liquidação da sociedade. Enquanto no balanço de exercício a sociedade continua operacional e viva, no balanço de liquidação pressupõe-se a sua descontinuidade. Por isso, o balanço de liquidação considera como ativos apenas os "objetos de direito cujo valor possa ser realizado mediante troca no mercado, ou que tenham valor de extinção realizável no prazo previsto para a liquidação. Não são considerados, portanto, os

\footnotetext{
${ }^{217}$ Cf. John Armour, Legal..., cit., p. 15.

218 Cf. Luca Enriques e Jonathan R. Macey, Creditors Versus Capital Formation: The Case Against European Capital Rules, Cornell Law Review, n. ${ }^{\circ}$ 86, 2001, p. 1166.

${ }^{219}$ No máximo, poder-se-ia pensar que esses ativos, apesar de não serem imediatamente monetizáveis, geram valor à sociedade (à empresa social) como um todo, permitindo a sua alienação a terceiros e, assim, garantindo os credores. Não ignoramos este fato, mas, novamente, não seria aí o capital social a garantia e, sim, o patrimônio social e a empresa.
} 
intangíveis que não podem ser alienados separadamente da empresa nem as despesas do

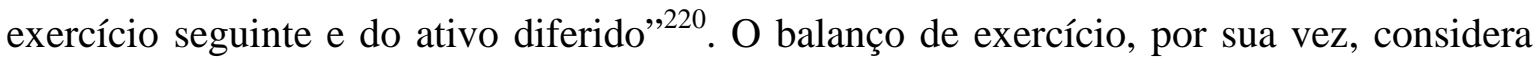
como ativos também aqueles bens que possam contribuir para a formação do lucro no futuro, o que inclui todas essas contas. Ora, entende-se, então, que o capital social no decorrer da vida da sociedade (com o perdão do anglicismo, "as a going concern") perde muito da sua função de garantia, pois a massa amorfa de ativos livres suficientes para cobrir a cifra nominal do capital pode ser representada, inclusive (ou apenas), por tais ativos intangíveis (ou, e nunca é demais enfatizar, por ativos imobilizados ou ilíquidos e que, na prática, não servem como conforto para o pagamento dos credores, pois são de difícil monetização no curto prazo). Nestes termos, o capital social ganha concretude como garantia dos credores tão somente na liquidação da sociedade (as a gone concern). Por essa razão, também, é que alguns autores defendem que a tutela dos credores, mais do que do regime do capital social, resulta da capacidade de geração de caixa da sociedade, que, a seu turno, garante a pontualidade dos pagamentos aos credores no decorrer da vida social.

Ainda sobre o assunto: é completamente plausível pensarmos em uma sociedade que esteja gerando prejuízos, e, portanto, diminuindo seu patrimônio, mas que tenha um massivo fluxo de geração de caixa, apto a gerar recursos para honrar suas obrigações. É razoável, também, imaginarmos uma sociedade com patrimônio líquido positivo, mas extremamente ilíquida, ou com dificuldade de geração de caixa. Um credor, por mais que a companhia devedora tenha ativos fixos ou imobilizados muito valiosos, sempre irá desejar que exista um robusto fluxo de caixa, pois a companhia dificilmente se desfará de seus bens imóveis ou intangíveis (muitas vezes vitais para a própria empresa) para pagar juros; isso ocorreria apenas em caso de falência ou como ultima ratio. Em geral, "la società tende a liquidare le situazioni debitorie sulla base del suo cash-flow, prima di chiudere del tutto $i$ battenti e quindi di rinunciare liquidandoli anche agli immobili e agli impianti che sono necessari al suo funzionamento" ${ }^{\text {221 }}$. Em nossa visão, é bastante razoável, dessarte, que um credor não se atenha apenas aos bens que compõem o ativo social na sua avaliação de crédito, mas, de forma mais categórica, avalie a sua liquidez e capacidade de geração de caixa $^{222}$.

\footnotetext{
${ }^{220}$ Cf. Lamy Filho e Bulhões Pedreira, Direito das..., cit. p. 1564.

221 Barbara Pozzo, op. cit., p. 87.

222 Comumente traduzida em uma fórmula de medição dessa produtividade: o LAJIDA (ou EBITDA na sigla em inglês), que significa lucros antes dos juros, impostos, depreciação e amortização, e que aponta aos credores sociais a quantidade de recursos que a companhia consegue gerar em um exercício social. A relação entre essa capacidade e o endividamento da companhia (índice LAJIDA/Dívida) é extremamente frequente na análise de crédito das sociedades. Afirmativamente, cf. Paulo de Tarso Domingues, Do Capital..., cit., p.
} 
Ademais, note-se que os bens e os recursos vertidos pelos acionistas quando da integralização do capital social já estão em risco $a b$ ovo: esses bens não constituem proteção aos credores, mas indicam a eles o volume de dinheiro próprio que os acionistas conferem à empresa social, servindo, neste sentido, como indicação aos credores da confiabilidade dos próprios acionistas no sucesso da empresa que perseguem. Este efeito de indicação não é de ser menosprezado e, tanto é assim, que os credores utilizam-se muitas vezes de um índice matemático para verificar a composição dos recursos da empresa: a divisão entre o valor do patrimônio líquido e as dívidas sociais (Net Equity/Debt). É importante perceber que o relevante, aí, não é o capital social (nem mesmo o patrimônio líquido individualmente considerado), mas, sim, a relação entre recursos dos acionistas e recursos de terceiros colocados no jogo da vida social - aos credores interessa saber se, enquanto donos da empresa, os acionistas estao dispostos a investir (e potencialmente a perder) dinheiro próprio.

O problema do capital social enquanto garantia de credores se acentua também quando verificamos a existência de ações sem valor nominal ou a possibilidade de emissão de ações com ágio, ambas as situações expressamente permitidas pela Lei das S.A. (artigos $11 \mathrm{c} / \mathrm{c} 14$, parágrafo único e $13, \S 2^{\circ}$, respectivamente).

Na hipótese de ações com valor nominal, mas emitidas com ágio (above par), a diferença entre o valor nominal e o preço de emissão será destinado à conta de reserva de capital, nos termos do artigo $13, \S 2^{\circ}$ da Lei das S.A. c/c artigo 182, §1 $1^{\circ}$. "a". Anteriormente à promulgação da Lei das S.A., a Lei 4.728/65 dispunha, no artigo 58, que os recursos recebidos pela companhia a título de ágio seriam contabilizados em reserva específica "enquanto não forem incorporadas ao capital da sociedade". A atual lei inova a este respeito, permitindo diversas destinações, nos termos do seu artigo 200, entre elas, inclusive, a compra das próprias ações (art. 200, II) e o pagamento de dividendos de determinadas ações preferenciais (art. 200, V).

O problema é ainda maior no caso das ações sem valor nominal. O artigo 14 da Lei das S.A. estabelece que o seu preço de emissão (por não conter valor nominal) será fixado, nos aumentos de capital, pela assembleia geral ou pelo conselho de administração da companhia. Parte desse preço de emissão poderá ser destinada, a critério dos acionistas, à

222. "Por outro lado, os credores habituais ou potenciais da companhia, como os fornecedores e as instituições bancárias, baseiam sua decisão de com ela operar em outros fatores, alguns internos à companhia, outros externos - como o grupo controlador; o grau de endividamento do patrimônio; o grau de liquidez; o setor da economia nacional (ou internacional) da empresa explorada pela companhia, etc.". Cf. Carlos Eduardo Bulhões, Opiniões Jurídicas, Forense, Rio de Janeiro, 2002, p. 32. 
conta de reserva de capital. E qual é esse critério? Não existe balizador na lei, ficando a repartição entre os valores a serem contabilizados como capital social - e, portanto, sujeitos ao seu regime jurídico - e como reserva de capital - e, assim, distribuíveis aos acionistas, inclusive por meio de compra das próprias ações pela companhia - sujeitos à vontade dos acionistas. Carvalhosa, afirmativamente, menciona que: “[e]xternamente, o montante do capital social deixa de constituir plena expressão de garantia dos credores, pela mesma razão de não representar mais o valor integral das entradas dos acionistas",223.

A diferença entre capital social e reservas resulta, obviamente, do fato de que estas, em geral, são distribuíveis aos acionistas, enquanto os valores contabilizados como capital social não o são ${ }^{224}$. Ademais, se é permitido aos acionistas, em maior ou menor intensidade, definir, a seu exclusivo critério, quais valores comporão o capital social e quais serão destinados à reserva de capital, então está muita enfraquecida a função de proteção de credores atribuída a este instituto ${ }^{225}$.

Mais recentemente, outra fonte de relativização da função de garantia dos credores foi acolhida na legislação pátria. O processo de convergência internacional das normas de contabilidade aplicáveis às companhias, por mais salutar e desejável que seja do ponto de vista de uniformização das informações contábeis, trouxe algumas disposições que não se compatibilizam, inteiramente, com o ordenamento jurídico brasileiro. Em 2007, com a promulgação da Lei 11.638, de 28 de dezembro de 2007 (“Lei 11.638/07”), iniciou-se, no Brasil, o processo de internalização dos padrões contábeis conhecidos como International Financial Reporting Standards, conhecidos pela sigla IFRS, que são princípios publicados pela International Accounting Standards Board (“IASB”). Estas regras são complementadas por aquelas elaboradas pelo Comitê de Pronunciamentos Contábeis ("CPC") e pelo Conselho Federal de Contabilidade (CFC), cujos pronunciamentos são

${ }^{223}$ E ainda critica os autores do anteprojeto, quando estes afirmam que se manteve na Lei das S.A. a plenitude da função do capital social de garantir credores. Cf. Modesto Carvalhosa, Comentários..., cit., p. 48. Também Lamy Filho e Bulhões Pedreira, A Lei das S.A., cit., p. 216.

${ }^{224}$ Assim Ascarelli: "[a]s reservas desempenham uma função substancialmente análoga à do capital social. A distinção entre 'capital' e 'reservas' ressalta, antes de mais nada, à vista das normas que visam à tutela dos terceiros, pois estas normas assentam justamente no 'capital' social e visam a impedir seja ele inferior ao patrimônio líquido social, ou seja distribuído entre os acionistas, prejudicando a terceiros. (...). A distinção entre capital e reservas, em princípio, não diz respeito aos direitos patrimoniais dos acionistas, mas à tutela dos terceiros credores; podem, com efeito, as reservas, ser distribuídas entre os acionistas (...) independentemente da observância daquelas normas que, ao contrário, respeitam à redução do capital social e que visam justamente a tutela dos terceiros”. Cf. Problemas..., cit., p. 470 e 471, na nota de rodapé 972.

225 "Whilst incorporators are not free to say whether or not they want this framework [capital social] to apply to their firms, they do have considerable flexibility in setting the conditions under which the maintenance of capital rules will restrict distributions. Their application will be determined by the size of a company's share capital [capital social nominal] and share premium account [reserva de capital], which - in the absence of a minimum capital requirement - the shareholders are free to set". Cf. John Armour, Legal..., cit., p. 6 e 7. 
tornados obrigatórios para companhias abertas pela CVM (por meio de deliberações, nos termos do art. $177, \S \S 3^{\circ}$ e $5^{\circ}$ da Lei das S.A.) e, para instituições financeiras, pelo Banco Central do Brasil (" $\underline{\mathrm{BCB}}$ ”).

De maneira simplificada, podemos dizer que alguns dos pronunciamentos técnicos do CPC, aprovados desde a entrada em vigor da Lei 11.638/07, contrariam o modelo da legislação societária nacional, ao previrem a contabilização da contrapartida de determinadas reavaliações de ativos e passivos, não na conta de ajuste de avaliação patrimonial, como manda a lei (artigo $182, \S 3^{\circ}$ da Lei das S.A.), mas diretamente a título de resultado do exercício. A internalização indiscriminada de regras criadas tendo por base outros ordenamentos - como é o caso exemplar das normas do IFRS, elaboradas em um contexto de legislação norte-americana - pode conflitar com determinadas disposições do ordenamento local. É por isso que a Lei das S.A. possui diversos artigos destinados a regular as demonstrações financeiras e a contabilidade das companhias, de modo que a elaboração das informações contábeis seja compatível com o restante desse diploma legal.

Ao menos três pronunciamentos técnicos do CPC, os de número 15, 28 e 29, contêm regras de contabilização que obrigam a avaliação de determinados ativos a preços “justos”, o que, por si só, não representa nenhuma contrariedade ao sistema da Lei das S.A., que também estipula este tipo de avaliação (art. 183, I, “a”), mas que - e este é o foco da divergência - impõem a contabilização das diferenças apuradas, para mais ou para menos, com relação ao valor originalmente contabilizado, não como ajuste de avaliação patrimonial, mas sim, como resultado do exercício em que apurada essa diferença.

A diferença entre uma e outra forma de proceder é significativa. Tullio Ascarelli assim se posiciona: “[v]isa-se, assim, à tutela dos terceiros, procurando impedir sejam distribuídos lucros que, por não terem ainda sido realizados, constituem apenas esperanças de lucros: esta distribuição, com efeito, poderia, na realidade, resultar numa distribuição de capital e, portanto, num prejuízo para os credores sociais" ${ }^{\text {226 }}$. No mesmo sentido se manifestou a CVM, por meio do parecer CVM/SJU/n. ${ }^{\circ}$ 052, de 22 de julho de 1985: "O valor registrado como reserva de reavaliação, no entanto, significa mera possibilidade de serem realizados econômica e financeiramente. Representa - vale repetir - lucros potenciais, mera expectativa de ganho (...) É a própria natureza destes lucros - a sua potencialidade - que fundamenta o princípio de que o valor registrado como reserva de reavaliação, enquanto não realizado econômica e financeiramente, não pode ter qualquer

${ }^{226}$ Cf. Tullio Ascarelli, Problemas das Sociedades..., cit., p. 608. 
destinação, vale dizer, não pode ser objeto de distribuição como dividendo ou participação nos lucros, capitalizado ou utilizado para absorver prejuízos contábeis".

É a lógica do artigo $182, \S 3^{\circ}$, que estabelece que esses valores fiquem contabilizados como ajustes de avaliação patrimonial "enquanto não computadas [as contrapartidas] no resultado do exercício". Na mesma linha, o artigo 189, paragrafo único, não permite a compensação de prejuízos do exercício com essa conta de ajuste de avaliação patrimonial, mas apenas com as contas oriundos de lucros (reservas de lucros) ou, ainda, reserva de capital. O também já examinado artigo 201 tampouco permite o pagamento de dividendos à conta de ajuste de avaliação patrimonial, apesar de ser ela igualmente uma conta de patrimônio líquido. Todos esses artigos preservam o conceito de que esses são valores expectados e potenciais, apenas, não permitindo uma distribuição de recursos aos acionistas com base nesses saldos. As normas do CPC, ao preverem a contabilização das contrapartidas da avaliação a preços justos como resultado do exercício, por outro lado, revertem a lógica da lei, ao permitirem que distribuições sejam feitas com base nesses valores ${ }^{227}$.

Nesse mesmo sentido crítico se posicionou José Luiz Bulhões Pedreira, em nota de 26 de dezembro de 2001, comentando o então projeto de lei 3.741, convertido posteriormente na Lei 11.638/07 que vimos analisando: “a 'harmonização' com as práticas contábeis internacionais, a que se propõe o projeto de lei, é uma cópia de normas que se justificam no quadro da legislação norte-americana, mas que conflitam com o sistema da lei brasileira",228.

Na doutrina anglo-saxã, por sua vez, o conceito de capital social enquanto proteção de credores já caiu em descrédito há algum tempo ${ }^{229}$, em parte pela influência que a doutrina da análise econômica do direito possui nesses países. Mesmo entre os autores de origem continental, contudo, há certo ceticismo quanto à eficácia do conceito do capital social como garantia de credores. Autores italianos, por exemplo, já afirmaram que o instituto reflete apenas uma tradição histórica, representando uma visão irreal e obsoleta

\footnotetext{
${ }^{227}$ Remetemos o leitor ao excelente e profundo estudo de Luiz Alberto Colonna Rosman, Capital Social Princípios da Realidade e da Intangibilidade - Funções e Disfunções (Aumento de Capital da Petrobrás em 2010 e Determinadas Regras do IFRS), in Alexandre Couto Silva, Direito Societário: Estudos sobre a Lei de Sociedade por Ações, Saraiva, São Paulo, 2013, pp. 61 - 117, onde são analisados em profundidade esses pronunciamentos técnicos, com referências, inclusive, de casos concretos onde eles tiveram consequências reais na saúde financeira de companhias.

${ }^{228}$ In José Luiz Bulhões Pedreira, Direito das Companhias, cit., pp. 1493 a 1499. Ressalvamos, apenas, que essas notas foram feitas em versão antiga do Projeto de Lei 3.741/00, não efetivamente sobre a versão que foi convertida em lei.

229 "Although not universally admired, it was not doubted that, in contrast to its obsolescence in North America, legal capital had a future in (continental) Europe”. Cf. John Armour, Legal..., cit., p. 1.
} 
sobre a realidade e que "tale dogma riflette anche l'assenza di uma suficiente analisi critica ${ }^{230}$. O crescente contato dos juristas continentais europeus com outras formas de pensamento, especialmente vindas dos sistemas de common law, certamente contribuíram para que fosse novamente pautado o problema na literatura jurídica da Europa a partir da década de 1980.

À luz do exposto, seria o capital social ainda a melhor maneira de amparar os interesses dos credores? "The European Union's legal capital rules are not justifiable on efficiency grounds and [this article] argues that the best way to reform this area of European Union Law would be to repeal the legal capital rules altogether" ${ }^{231}$. Quer-nos parecer, com base nas opiniões refletidas nas páginas precedentes, que a função do capital social enquanto garantia de credores perdeu muito de sua pujança ao longo dos anos. Hoje, remanesce o capital mais como um mecanismo de controle das forças intrassocietárias (efeito para o qual ele é particularmente bem estruturado), do que como uma garantia indireta de credores. Dificilmente visualizamos qualquer credor tomando por base o capital social para decidir se estende ou não crédito a uma determinada sociedade; existe uma análise mais funcional do que formal neste momento: os credores avaliarão a saúde financeira da sociedade como um todo, sua capacidade de geração de caixa, alavancagem, passivos de curto prazo e liquidez corrente. Enfim, o foco da proteção dos credores deveria passar a ser, assim, o da transparência e uniformidade das informações contábeis, com a consequente redução da assimetria de informações entre sociedade e credores, e não o capital social.

\subsection{Análise Crítica do Artigo 30 da Lei das S.A.}

Sem termos por objetivo esgotar a discussão em torno de cada uma das hipóteses de aquisição previstas (ou não previstas) no artigo 30 da Lei das S.A. - o que representaria, sem dúvida, uma extrapolação do objeto deste estudo -, pretendemos, abaixo, discorrer criticamente acerca da forma pela qual o artigo 30 vedou e abriu exceções aos negócios da companhia com ações de sua emissão, comparando-o com a legislação estrangeira, onde cabível.

Inserimos este item dentro do capítulo destinado aos interesses dos credores por razões históricas: no Brasil, a regulação dos negócios com ações próprias (e o artigo 30, por consequência) sempre visou, mais do que tudo, à proteção dos credores.

\footnotetext{
${ }^{230}$ Cf. Barbara Pozzo, op. cit., p. 77.

${ }^{231}$ Cf. Lucas Enriques e Johnathan R. Macey, Creditors..., cit., p. 1167.
} 


\subsubsection{Resgate}

O resgate de ações representa uma das mais traumáticas operações da vida societária, apesar dos poucos artigos que a lei a ele dedica. De outra parte, é um dos poucos negócios que tem sua definição dada por lei, conforme redação do artigo 44, $\S 1^{\circ}$, da Lei das S.A. ${ }^{232}$, e é também uma das exceções expressamente previstas para um negócio da companhia com as ações de sua emissão.

O resgate consiste, pela expressa definição legal, no pagamento ao acionista do valor de suas ações (ordinárias ou preferenciais, sem distinção), de modo a retirá-las definitivamente de circulação, com a redução ou da cifra nominal do capital social ou apenas do valor nominal de cada ação, se houver (mantida a cifra do capital social inalterada). A teor do que dispõe o caput do artigo 44 da mesma lei, esse pagamento deve se dar à custa do saldo de lucros ou reservas da sociedade, sendo a competência para a regulação do resgate outorgada aos estatutos ou à assembleia geral; o $§ 6^{\circ}$ do mesmo artigo, por sua vez, dispõe que, salvo previsão diversa no estatuto social, a deliberação da assembleia geral dispondo sobre o resgate de uma classe ou espécie de ações tem sua eficácia condicionada à aprovação, em assembleia especial, de ao menos metade dos titulares das ações atingidas ${ }^{233,234}$.

Pois bem, o resgate de ações foi introduzido no nosso direito pelo Decreto n. ${ }^{\circ}$ 21.536/1932, que passou a permitir ações preferenciais no Brasil e que dispunha expressamente que o estatuto social deveria prever as vantagens e restrições a que as ações preferenciais estariam sujeitas, incluindo, entre as restrições, a possibilidade de seu

\footnotetext{
${ }^{232}$ Três das operações que a companhia pode praticar com ações de sua própria emissão vêm definidas na lei. É bem verdade que, desde os romanos, a definição de conceitos ou institutos jurídicos era reservada à doutrina, sendo temerária a inclusão de definições na lei, já que a sua interpretação, com o passar dos anos, poderia mudar a natureza dos institutos. Até hoje são poucos os que são definidos pela norma; assim se pronunciou Valverde em 1939, em sua justificativa ao Anteprojeto do DL 2.627/40: “[d]efinem-se, para evitar confusões, as operações de resgate, amortização e reembolso". Cf. Trajano de Miranda Valverde, Sociedades..., cit., Vol. 3, p. 281.

${ }^{233}$ Cf. Carlos Fulgêncio da Cunha Peixoto, Sociedades..., Vol. 1, cit., p. 181.

${ }^{234}$ Marcelo Vieira von Adamek entende ser admissível a inserção, no estatuto social da companhia fechada, de uma disposição inspirada no art. 1.085 do Código Civil "prevendo que a totalidade das ações de cada uma das classes poderá ser resgatada pela companhia, quando acionistas, representando a maioria do capital social (ou do capital votante), entenderem que o titular das ações da classe a resgatar incorreu em falta grave dos seus deveres sociais (...)". O resgate, nesses termos e observadas certas condições expostas pelo autor, independeria de deliberação dos acionistas da classe atingida (art. 44, §6 ${ }^{\circ}$, da Lei das S.A.) e operaria como uma forma de exclusão de sócio nessas companhias. Cf. Marcelo Vieira von Adamek, Abuso de Minoria em Direito Societário (Abuso das Posições Subjetivas Minoritárias), Tese (Doutorado em Direito), Faculdade de Direito da Universidade de São Paulo, 2010, p. 325.
} 
resgate $^{235}$. A legislação anterior sobre as sociedades anônimas era omissa quanto à operação, tendo sido ela introduzida formalmente no diploma regulamentador das companhias com o DL 2.627/40, que, no seu artigo 16 e respectivo parágrafo único, dispunha, de maneira muito semelhante ao que a atual lei o faz, sobre o resgate.

Na sua essência, a operação se destinava a possibilitar à companhia um programa de financiamento flexível, de acordo com o qual ela poderia admitir acionistas preferencialistas que, em troca das preferências recebidas (usualmente na forma de dividendos mais altos ou mesmo fixos), eram considerados acionistas claramente temporários. Isso porque, depois de certo tempo - quando a companhia estivesse em período de prosperidade, por exemplo, que não mais justificasse o pagamento dos dividendos mais altos -, poderia cessar a simbiose por opção da companhia, sujeitando os acionistas atingidos ao poder que ela detinha de resgatar as ações nos termos do previsto no estatuto social ou na deliberação de assembleia geral de acionistas.

Segundo Philomeno J. da Costa, com apoio em Trajano de Miranda Valverde, o resgate tem natureza jurídica de uma compra compulsória das ações, para retirá-las de vez de circulação ${ }^{236}$. Waldemar Ferreira, igualmente, diz que, ao pagar o valor das ações com dinheiro oriundo dos "fundos disponíveis" da sociedade, ela, iniludivelmente, "mais não faz do que, em verdade, comprá-las" ${ }^{237}$. Haveria, segundo esses autores, uma compra e venda, irremediavelmente seguida do cancelamento das ações compradas. Existiriam, de acordo com esta visão, dois momentos distintos na operação de resgate: (i) paga-se o acionista e entram as ações para a conta de ações em tesouraria, para, ato contínuo, (ii) serem elas extintas com a respectiva anotação no livro ou registro próprio.

Segundo José Luiz Bulhões Pedreira, por outro lado, o resgate é negócio jurídico unilateral, no qual apenas uma manifestação de vontade existe: a da companhia. A eficácia dessa manifestação de vontade não depende do consenso de outra (Alfredo Lamy Filho diria que há exclusão de sócio, com a ruptura unilateral do contrato de sociedade ${ }^{238}$ ). Assim se manifesta o autor: "O efeito da deliberação de resgate adotada pela assembleia geral [tendo sido previstas as condições de resgate pelo estatuto] é a extinção da ação, e esse efeito decorre da deliberação, independentemente de sua comunicação ao acionista, ou

235 "O resgate é, na sua pureza, a operação para extinguir classes de ações preferenciais". Philomeno J. da Costa, op. cit., p. 83. De fato, o é apenas na sua pureza, uma vez que, atualmente, não há limitação no sentido de que apenas ações preferenciais podem ser objeto de resgate, pois qualquer classe ou espécie está sujeita ao procedimento.

${ }^{236}$ Philomeno J. da Costa, op. cit., p. 105.

${ }^{237}$ Cf. Waldemar Ferreira, Tratado..., cit., Vol. 4, p. 1055. No mesmo sentido, de caracterizar a operação como uma compra e venda, cf. Carlos Fulgêncio da Cunha Peixoto, Sociedades..., Vol. 1, cit., p. 188.

${ }^{238}$ Cf. Alfredo Lamy Filho e José Luiz Bulhões Pedreira, A Lei das S.A., cit., p. 396. 
de qualquer condição ou termo; mas como a deliberação que resgata ações implica alteração do estatuto social, seus efeitos dependem de arquivamento da ata da assembleia no Registro de Comércio. (...) Satisfeito esse requisito legal para a eficácia da deliberação da Assembleia Geral, a ação resgatada extingue-se e, por conseguinte, seu titular perde a qualidade de acionista e passa a ser credor da companhia pelo preço de resgate"239. A opinião tem consequências jurídicas importantes: a partir do arquivamento da ata deliberando o resgate, os acionistas, mesmo que não comunicados, não poderão mais participar de assembleias da companhia, nem mesmo receber dividendos - não possuem mais status socii. Alfredo Lamy Filho, em parecer, segue a mesma linha de raciocínio: “[o] resgate importa, pois, sempre, no cancelamento das ações resgatadas, com ou sem redução de capital - o que significa, para o detentor das ações resgatadas, a exclusão da sociedade. Trata-se de manifestação unilateral da companhia, contra a qual a lei não assegura recurso: todas as companhias têm, em princípio, o direito [quiçá o poder, pensaríamos nós] de proceder ao resgate de suas ações, e ao instituto (observadas, obviamente, as demais regras legais) estão sujeitos todos os acionistas"

Não nos restam dúvidas de que a razão está com os autores do anteprojeto de lei: o resgate é negócio jurídico unilateral ${ }^{241}$, no qual a única manifestação de vontade necessária é a da companhia, sendo a extinção das ações, juridicamente, operada ipso iure após o arquivamento da deliberação que a tenha aprovado ou após a ocorrência dos eventos de resgate previstos no estatuto social ${ }^{242}$. A obrigação de dar, consubstanciada no ato de pagar o valor de resgate, pela companhia, e a correspondente pretensão de cobrar do ex-acionista, advêm não de um contrato de compra e venda, mas, sim, de um negócio jurídico unilateral, o que é plenamente possível.

\footnotetext{
${ }^{239}$ Cf. Alfredo Lamy Filho e José Luiz Bulhões Pedreira, A Lei das S.A., cit., p. 392.

${ }^{240}$ Cf. Alfredo Lamy Filho e José Luiz Bulhões Pedreira, A Lei das S.A., cit., p. 399.

${ }^{241}$ Afirmativamente, Pontes de Miranda, cf. Tratado de Direito Privado, op. cit., p. 90.

${ }^{242}$ Vale detalhar o ponto. Existem três formas de legitimar o resgate: (i) a primeira se configura quando o estatuto tenha, na constituição da sociedade, estabelecido as condições de resgate de determinada classe de ações, (ii) a segunda se dá, quando, posteriormente à constituição da sociedade, delibera-se, em assembleia, a modificação do estatuto para incluir nova classe de ações, estas com cláusula de resgate, e (iii) na última, o resgate de ações já em circulação depende de deliberação da assembleia geral. Nos casos (i) e (ii), a compulsoriedade do resgate é evidente, considerando que não há necessidade de qualquer aprovação pelos acionistas atingidos, uma vez que as modificações e a fixação das condições do resgate se deram previamente à subscrição das ações (pacta sunt servanda). Já na situação (iii), a reforma de 1997 (seguindo entendimento anterior de Alfredo Lamy Filho) veio a acrescentar a necessidade de aprovação do resgate pelos acionistas atingidos, por maioria e em assembleia especial - o que de certa forma lhes garante veto sobre a deliberação. Ver também Alfredo Lamy Filho e José Luiz Bulhões Pedreira, A Lei das S.A., cit., pp. 400 e ss.
} 
Temos que um dos elementos principais do resgate é o de que a companhia paga ao acionista o valor das suas ações ${ }^{243}$, para retirá-las definitivamente de circulação: trata-se de um negócio jurídico da companhia emissora com o seu acionista, eis que é ela que deve efetuar o pagamento, com os seus próprios recursos. Significa dizer que as ações resgatadas são necessariamente extintas do quadro de ações emitidas pela sociedade, com a correspondente anotação no livro de Registro de Ações Nominativas, ou nos extratos da instituição custodiante das ações, da diminuição do número das ações (artigo 31 da Lei das S.A.). Não há qualquer possibilidade de que essas ações retornem à circulação: pelo menos o número das ações deve necessariamente diminuir ${ }^{244}$.

Dizemos que "pelo menos" o número de ações deve diminuir, por conta da redação inequívoca do artigo $44, \S 1^{\circ}$, que prevê expressamente a possibilidade de não redução da cifra do capital social e, neste caso, o resgate alteraria o número e o valor nominal das ações remanescentes, o que é óbvio ${ }^{245}$. Da maneira como for, seja com ou sem redução da cifra formal do capital social, será necessária sempre uma modificação estatutária deliberada em assembleia (seja para reduzir o número de ações, apenas - na hipótese em que elas não possuam valor nominal -, para reduzir esse número e aumentar seu valor nominal - para ações com valor nominal - ou para reduzir a cifra do capital social).

A redução da cifra nominal do capital social, portanto (ou, simplificadamente, a redução do capital), não constitui elemento essencial ao resgate. Muito pelo contrário, essa cifra deveria, via de regra, manter-se inalterada, dado que a lei determina o pagamento do valor dessas ações com "lucros ou reservas" da sociedade. Ora, se o pagamento se dá com lucros ou reservas ${ }^{246}$ da companhia, necessariamente faz-se o resgate sem que se atinja a massa de ativos reais e concretos que serve de lastro para a cifra nominal do capital social,

\footnotetext{
243 Dessa redação já se pode abstrair um conceito e uma dúvida importantes: o conceito é o de que esse pagamento deve necessariamente ser pelo valor total das ações (se fosse parcial, seria amortização, e não resgate, nos termos do artigo $44, \S 3^{\circ}$ da Lei das S.A., sobre o qual dissertaremos adiante) e a dúvida, igualmente relevante, consiste em saber como se define o valor dessas ações. Para mais, ver Philomeno J. da Costa, op. cit., pp. $80-83$.

${ }^{244}$ Philomeno J. da Costa, op. cit., p. 83. "O objetivo do resgate é, sem dúvida, diminuir o número de ações”, cf. Waldemar Ferreira, Tratado..., cit., vol. 4, p. 1062.

${ }_{245}$ Aritmeticamente, se mantido idêntico o produto da multiplicação (número de ações x valor nominal = capital social formal) e reduzido um de seus fatores (número de ações) o outro fator (valor nominal) necessariamente deve aumentar para manter a identidade do resultado.

${ }^{246}$ A redação do DL $2.627 / 40$ falava em "fundos disponíveis". Philomeno J. da Costa entendia que eram aquelas reservas que, pela lei, não teriam destinação ou finalidade específicas (e ficariam, portanto, contabilmente classificadas na extinta conta de "lucros acumulados"). Philomeno J. da Costa, op. cit., p. 84. Ver também, sobre fundos disponíveis, tratando com maestria os conceitos de capital social nominal e capital social real, Trajano de Miranda Valverde, Sociedades por..., cit., Vol I., p. 161 e 162. Ver também Carlos Fulgêncio da Cunha Peixoto, Sociedades..., Vol. 1, cit., p. 180.
} 
pois, caso contrário, não haveria nenhum lucro ou reserva. Não se pode efetuar o resgate "à custa do capital social", na já consagrada expressão.

Perguntamo-nos por qual razão, então, a lei veda, de um lado, a utilização de ativos "lastro" da cifra nominal do capital social para a realização do pagamento do valor do resgate, quando permite, de outro lado, a redução do capital social depois de realizada a operação. Não seria mais simples que tivesse permitido também o resgate à custa do capital social (como permite no reembolso) e, nesse caso, necessariamente seguido da redução da sua cifra nominal ${ }^{247}$

Waldemar Ferreira diria que a inadvertência do legislador na redação do dispositivo é manifesta (neste ponto, o texto do artigo 16, parágrafo único, do DL 2.627/40 é teleologicamente idêntico ao da Lei das S.A.): "No capital se não toca. Há de êle manterse, sempre e necessáriamente. O texto somente permite o resgate 'por meio de fundos disponíveis'. O capital, portanto, fica intacto. Intacto, por ser possível a operação sòmente à custa de fundos disponíveis" ${ }^{\text {248 }}$. Philomeno J. da Costa obtemperava que há uma parte exata e uma imprecisa no pensamento do mestre. Para ele: "[s]e o resgate se opera com fundos disponíveis, utilisam-se bens que permanecem no patrimônio social em relação a outros acima do valor nominal do capital; nunca se poderão transformar em dinheiro aquêles que desçam aquém do capital, pagando-se as ações resgatadas com êsse produto. Isto quer significar que sempre restam bens, cujos valôres de registro contábil equivalem ao montante do capital social; o resgate realisa-se com aquêles bens que se situam acima do capital e que não tenham destinação diversa como já vimos atrás (n. 22). O capital de fato não diminui; baixam os fundos disponíveis. Mas de direito, o capital pode ser diminuído. O legislador não atuou inadvertidamente." ${ }^{249}$ - os itálicos são do original.

Concordamos com Waldemar Ferreira e Cunha Peixoto ${ }^{250}$. Ou bem se estipula que o resgate não permite a redução do capital social, mesmo com a extinção de ações (que

\footnotetext{
${ }^{247}$ Esta curiosa característica do resgate já estava estipulada, em semelhantes termos, no DL 2.627/40.

${ }^{248}$ Waldemar Ferreira, Tratado de Sociedades..., cit., p. 1062.

${ }^{249}$ In Philomeno J. da Costa, op. cit., p. 94, nota de rodapé 105. Nessa nota de rodapé o autor ilustra um exemplo, em que a diminuição da cifra do capital social seria aconselhável: delibera-se a emissão de ações resgatáveis em parcelas, mediante sorteio, depois de certo período de tempo, pelo seu valor nominal. Acontece que, após cada resgate, o valor nominal das ações remanescentes aumentava, tornando a operação de resgate cada vez mais custosa para a sociedade. Neste caso, seria mais útil e aconselhável que se deliberasse também a redução do capital social, evitando o problema matemático. Isto, no entanto, não afasta, a nosso ver, a incongruência da norma: permita-se desde logo o resgate à custa do capital social, desde que, nesse caso, obrigatoriamente se reduza a sua cifra formal correspondentemente.

${ }^{250}$ Mencione-se também que o entendimento da CVM é o de que a redação é aparentemente contraditória (a utilização de lucros ou reservas vis-à-vis a possibilidade ou não de redução da cifra formal do capital social). Cf. Parecer/CVM/SJU/n. ${ }^{\circ}$ 91, de 28 de dezembro de 1982, especificamente no seu item 4. A argumentação
} 
representam, formalmente, "frações" dele), e, portanto, o valor a ser pago aos acionistas atingidos necessariamente deve ser oriundo de lucros ou reservas, ou bem se faculta o resgate com redução de capital, mas também se permite que os valores sejam pagos aos acionistas ainda que a companhia não tenha saldo de lucros ou reservas. Neste último caso, necessariamente deve-se reduzir a cifra do capital social ${ }^{251}$. A redação do dispositivo peca, não por facultar a redução do capital social, mas por não permitir que o resgate se efetue à custa dele.

\subsubsection{Reembolso}

O instituto do reembolso, de origem italiana (rimborso delle proprie azioni ${ }^{252}$ ), está situado entre aqueles que a lei define. Reza o artigo 45 da Lei das S.A. que o reembolso é a operação pela qual a própria companhia, nos casos previstos em lei, paga aos acionistas dissidentes de deliberação da assembleia geral o valor (total, sempre) de suas ações (o direito de recesso mediante reembolso é, inclusive, listado entre os direitos essenciais do acionista no artigo 109, V, da Lei das S.A.). Os “casos previstos em lei” mencionados pelo artigo 45 são aqueles listados no artigo 136, I a VI e IX c/c artigo 137 da Lei das S.A., que enumeram diversas situações. $\mathrm{O}$ artigo 137 dispõe sobre as condicionantes e os termos, verdadeiras regras complementares, de acordo com os quais será efetivado o resgate, além de detalhar o seu procedimento específico ${ }^{253}$.

da CVM, no entanto, decepciona: limita-se a afirmar que a redação é possivelmente contraditória, não argumentando a favor ou contra a disposição.

${ }^{251}$ Já na situação onde a companhia tenha saldo de lucros ou reservas para efetuar o pagamento, mas ainda assim deseje reduzir o capital, isso também poderá ser feito, mas será apenas uma faculdade da companhia, e não uma obrigação.

252 "De fato, enquanto quase todas as legislações então vigentes reduziam o número de modificações estatutárias, o art. 158 do Código Comercial italiano de 1882 permitiu amplas alterações e, para temperar esta concessão à maioria, outorgou-se ao acionista ausente ou dissidente o direito de retirada. O Código Unitário Italiano de 1942 conservou o princípio, embora reduzindo seu campo de aplicação”. Cf. Carlos Fulgêncio da Cunha Peixoto, Sociedades..., Vol. 1, cit., p. 189.

${ }^{253}$ Existem cinco outras hipóteses de direito de recesso, mediante reembolso do valor das ações, previstos na lei, e que não estão disciplinadas nos artigos 136 e 137, que são as seguintes: (1) a Lei das S.A., assim como o fez o DL 2.627/40, não previu na redação do artigo $136 \mathrm{c} / \mathrm{c} 137$, o direito de retirada no caso de transformação. Isso porque o artigo 136 determina casos de quórum qualificado de deliberação, por maioria absoluta das ações ordinárias, e a transformação exige unanimidade, nos termos do artigo 221 da Lei das S.A. (2) tampouco previu a lei o caso da incorporação de ações, nos termos do artigo 252 da Lei das S.A., que não se confunde com a incorporação do artigo 136, IV. (3) em terceiro lugar, foi deixada de fora da relação a hipótese de reembolso para acionistas dissidentes de deliberação de uma companhia adquirente do controle de outra, caso o preço deliberado de aquisição supere determinados valores que a lei estipula no artigo 256 e seus parágrafos. (4) menciona-se, igualmente, a situação na qual o poder público adquire ações de uma companhia por desapropriação, nos termos do art. 236, parágrafo único. (5) Por fim, não previu o caso de acionistas que discordem da vinculação da sociedade a uma convenção grupal, nos termos do artigo 270 , parágrafo único. De qualquer forma, são outros casos de reembolso do valor das ações, previstos em lei. E são apenas esses, o caráter continua sendo taxativo. Cf. Philomeno J. da Costa, op. cit., p. 115. 
Novamente, assim como no resgate, a operação de reembolso foi admitida no mundo das sociedades anônimas com o Decreto n. ${ }^{\circ} 21.536 / 32^{254}$, que o estabeleceu nos seus artigos $9^{\circ}$ (com seus três parágrafos) e $10^{\circ}$, que se limitavam, até pelo objeto do decreto, aos casos de acionistas preferenciais prejudicados por alteração nas regras de hierarquia ou nas vantagens entre classes de ações preferenciais. O Anteprojeto Miranda Valverde alargou o campo de sua aplicação ${ }^{255}$, no que foi seguido pela Lei das S.A., que acolheu outras importantes mudanças no seu regime jurídico ${ }^{256}$.

Pela leitura das normas, nota-se que esta é uma operação também de pagamento aos acionistas, inconformados com alguma deliberação social tomada, do valor de suas ações; mas, diferentemente do resgate, a finalidade da operação não é retirar essas ações definitivamente de circulação (mediante seu cancelamento compulsório). Pelo contrário, a lei prevê claramente que essas ações continuam existentes, podendo a companhia até mesmo buscar novos acionistas para comprá-las.

Uma vez tomada uma deliberação pela assembleia geral envolvendo uma das matérias elegíveis, e com a qual o acionista não concorde (mesmo que ausente da assembleia ou que tenha se abstido de votar, o que é uma inovação muito bem-vinda da Lei das S.A. ${ }^{257}$ ), tem ele o prazo de 30 dias, conforme artigo 137, IV, da Lei das S.A., contados da publicação da ata da deliberação, para comunicar à companhia que deseja exercer o seu direito de recesso ${ }^{258}$, mediante reembolso de suas ações. Já o artigo $45, \S 6^{\circ}$, prevê o prazo, para a companhia, de 120 dias a contar dessa mesma publicação, para encontrar novos acionistas para as ações que tenham sido reembolsadas à custa do capital social.

\footnotetext{
${ }^{254}$ Dizemos mundo das anônimas, pois o direito de recesso foi introduzido pelo Decreto n. ${ }^{\circ} 3.708 / 19$, que regulou por muitos anos as sociedades limitadas no Brasil e facultava, no seu artigo 15, o reembolso dos sócios que divergissem da alteração do contrato social.

${ }^{255}$ Cf. Trajano de Miranda Valverde, Sociedades..., cit., Vol. 3, p. 286.

${ }^{256}$ Cf. Alfredo Lamy Filho e José Luiz Bulhões Pedreira, A Lei das S.A., cit., p. 222 e, mais adiante, pp. 548 a 550 .

${ }^{257} \mathrm{Cf}$. artigo $137, \S 2^{\circ}$ da Lei das S.A. No direito anterior, o entendimento majoritário era não só o de que o acionista deveria comparecer à assembleia, como o de que ele deveria fazer constar sua opinião contrária, pois, na ausência de previsão expressa da lei, um acionista "dissidente" não podia ser confundido com um acionista "ausente" ou "abstinente": o acionista precisava comparecer, votar e ser vencido na deliberação. Ver Philomeno J. da Costa, op. cit., pp. 134 e 135. No mesmo sentido era a opinião de Trajano de Miranda Valverde, cf. Sociedades..., cit., Vol. 2, p. 242. Waldemar Ferreira entendia possível ao acionista ausente exercer direito de recesso, mas não tratou do acionista abstinente, cf. Tratado..., cit., Vol. 4, p. 1067. A Lei das S.A. alterou, conscientemente, este regime, cf. Alfredo Lamy Filho e José Luiz Bulhões Pedreira, A Lei das S.A., cit., p. 232.

${ }^{258}$ A redação, tanto do artigo 45, quanto dos artigos 109, 136 e 137, mencionam o direito do acionista de "retirar-se" da sociedade, mas a doutrina usa frequentemente a denominação "direito de recesso". Cf. Philomeno J. da Costa, op. cit., p. 134. Ver também Trajano de Miranda Valverde, Sociedades..., cit., Vol. 2, p. 42 e Waldemar Ferreira, Tratado..., cit., Vol. 4, pp. 1066, 1381 e 1382.
} 
Duas observações decorrem desse mecanismo: (i) a primeira é a de que as ações reembolsadas passam a ser propriedade da companhia emissora, e não são extintas automaticamente. Tanto isso é verdade, que o artigo $45, \S 5^{\circ}$, dispõe que as ações reembolsadas à custa de saldo de lucros ou reservas (exceto a legal) permanecerão em tesouraria, e sujeitar-se-ão, portanto, ao seu regime jurídico específico; e (ii) a segunda é a de que é permitido expressamente o pagamento do reembolso à custa do capital social, diferentemente do que ocorre, por exemplo, com o resgate (situação que já criticamos quando dissertamos sobre ele). Neste último caso (pagamento do reembolso à custa do capital), haverá redução do capital social depois de transcorridos os 120 dias de prazo após a publicação da ata da deliberação contra a qual tenha se insurgido o acionista, caso não tenham sido recolocadas as ações ${ }^{259}$.

A leitura desses dois parágrafos do art. 45 pode parecer confusa: as ações reembolsadas à custa do capital não permanecem também em tesouraria, até o decurso do prazo permitido para serem recolocadas no mercado (a redação do artigo 45, $5^{\circ}$, menciona apenas o caso de reembolso com recursos oriundos do saldo de lucros ou reservas)? A resposta é positiva: também no caso de reembolso à custa do capital social, considerando que as ações não são extintas (ao menos não antes de transcorrido o prazo de 120 dias), devem elas também ser submetidas ao regime das ações em tesouraria ${ }^{260}$.

Por outro lado, pergunta-se: as ações reembolsadas com recursos oriundos do saldo de lucros ou reservas elegíveis devem ser extintas (e/ou o capital social reduzido) caso não sejam encontrados novos acionistas após o prazo de 120 dias acima mencionado? A resposta deve ser negativa: neste caso, as ações podem permanecer por tempo indeterminado em tesouraria, mantido inalterado o capital social, considerando que o pagamento do reembolso foi realizado com "fundos disponíveis" que não possuem nenhum vinculo de indisponibilidade e podem ser distribuídos aos acionistas ${ }^{261}$. O reembolso, neste

\footnotetext{
${ }^{259}$ A explicação para que o reembolso possa ser feito também à custa do capital social está no fato de que ele é um direito do acionista, e não uma prerrogativa da companhia. Daí a impossibilidade de frustrar-se o exercício do direito pelo acionista sob o argumento de falta de saldo de lucros e reservas para seu exercício. Cf. Fran Martins, Comentários à Lei das Sociedades Anônimas, $3^{\text {a }}$ Ed., Forense, Rio de Janeiro, 1989, p.184 e Modesto Carvalhosa, Comentários..., cit., pp. 321 e 322.

${ }^{260}$ Cf. Trajano de Miranda Valverde, Sociedades..., cit., Vol. 1, n. 104-bis, pp. 161 e 162.

${ }^{261}$ Esta diferenciação, entre reembolso feito à custa de saldo de lucros ou reservas ou do capital social, não era conhecida do DL 2.627/40. Sob a vigência desse diploma, entendiam os doutrinadores que a redução do capital social era obrigatória caso não fossem encontrados novos acionistas para substituir os retirantes, independentemente da existência ou não de lucros e reservas elegíveis - os "fundos disponíveis" na linguagem do direito anterior. "Não se poderia, por exemplo, imaginar que o vácuo, não preenchido no capital, fosse preenchido diretamente com a mobilização de eventuais reservas acumuladas da sociedade, sob a aparência sugestiva de que elas se destinam bem a recompô-lo. Admitido o princípio de que, em algumas circunstâncias, pode o acionista minoritário retirar-se, resulta disto o desfalque correspondente do capital; é a
} 
caso, assemelha-se muito a uma compra e venda para permanência em tesouraria ${ }^{262}$, com uma diferença de causalidade ${ }^{263}$ : a entrega de recursos, pela companhia ao acionista, tão-só se revestirá como "reembolso" - e não como compra e venda - se houver uma deliberação sobre uma das matérias previstas na lei, a inconformidade do acionista e a realização de um minucioso processo jurídico. Na sua essência econômica, no entanto, são equivalentes.

Outro ponto interessante da estrutura, sob a ótica de proteção dos interesses dos credores em negócios com ações onde a companhia emitente seja parte, é o tratamento previsto para o caso de falência superveniente da companhia emissora. $\mathrm{O}$ artigo $45, \S^{\circ}$, da Lei das S.A. estipula que o pagamento do reembolso aos acionistas que seja feito à custa do capital social (e apenas por esta modalidade) entende-se feito com condição resolutiva: ocorrendo a convergência de três circunstâncias, operar-se-á a restituição do dinheiro, voluntariamente ou mediante ação. São elas: (i) superveniência da falência da companhia, após terem sido reembolsados acionistas à custa do capital social; (ii) a não concretização da recolocação das ações no mercado para novos acionistas; e (iii) a insuficiência dos ativos sociais para pagamento das dívidas existentes anteriormente à data da publicação da ata da assembleia que resolveu a matéria sobre a qual se rebelaram os acionistas dissidentes (é o que se entende por "créditos mais antigos" na redação da lei) ${ }^{264}$. A solução adotada pela lei, aqui, claramente se destina à satisfação do princípio da integridade do capital social e encontra um paralelo na situação das ações não integralizadas no caso de liquidação da sociedade, nos termos do artigo 210 , V, segundo o qual o liquidante deve exigir dos acionistas titulares destas ações, caso o ativo social não baste para saldar o passivo, a integralização dos valores por eles devidos à companhia.

Tem a operação a natureza de um negócio jurídico unilateral receptício, vez que o acionista tem o direito potestativo de requerer à companhia, obedecidos os termos da lei e se for de seu interesse, o reembolso de suas ações, para que ele possa retirar-se da

sua diminuição”. Cf. Philomeno J. da Costa, op. cit., p. 148. Data venia, razão não assiste ao autor: se há saldo contábil de patrimônio líquido superior à cifra do capital social, não há desfalque algum, há utilização de recursos de disponibilidade plena da companhia e, teleologicamente, de titularidade dos próprios acionistas. Bem andou a Lei das S.A. em alterar esta mecânica no reembolso.

${ }^{262}$ Afirmativamente, José Edwaldo Tavares Borba, Direito Societário, 6a ed., Renovar, Rio de Janeiro, 2001, p. 238.

${ }^{263}$ A discussão sobre a causalidade nos negócios jurídicos não é pacífica. Explica-se a causa final do negócio jurídico como o fim perseguido pelos que se vinculam. Por exemplo: a entrega de um bem qualquer de uma pessoa a outra poderá ter causas diversas, o que identificará o negócio jurídico desejado pelos contratantes, seja uma compra e venda, uma doação, um mútuo ou uma permuta. É a causa final que o caracteriza; assim também nos casos de negócios da companhia com ações de sua emissão. Cf. Paulo Luiz Netto Lôbo, Teoria Geral das Obrigações, São Paulo, Saraiva, 2005, pp. 30 a 32.

${ }^{264}$ Cf. Philomeno J. da Costa, op. cit., pp. 143 a 145. Trajano de Miranda Valverde, Sociedades..., cit., Vol. 2 , pp. 244 e 245. 
sociedade, sendo absolutamente desnecessária a concordância da companhia sobre essa manifestação de vontade. A retirada dos acionistas dissidentes efetiva-se, portanto, por atos unilaterais de suas vontades ${ }^{265}$. Diz-se que é um negócio jurídico unilateral de caráter receptício, pois o direito dos acionistas transforma-se, pela força da lei, de direito de sócio para um direito de crédito pelo valor do reembolso no momento em que a companhia recebe a notificação do exercício, pelo acionista, desse direito - surte o recebimento da notificação de pleno direito esse resultado ${ }^{266}$.

\subsubsection{Amortização: Ações de Fruição Sujeitas ao Regime do art. 30 da Lei das S.A.}

A amortização de ações é o terceiro negócio da companhia com as ações de sua emissão que figura no rol permissivo do artigo $30, \S 1^{\circ}$, "a", da Lei das S.A., tendo também sua definição prevista no artigo 44, $2^{\circ}$, dessa lei. À luz desse dispositivo, consiste a amortização na distribuição aos acionistas, a título de antecipação e sem redução do capital social, de quantias que lhes poderiam tocar em caso de liquidação da companhia.

É também o tipo de negócio mais antigo e conhecido, tendo sido excepcionado pela legislação brasileira do rol de proibições já pelo Decreto 434/1891, que a ela fazia referência no artigo 40, prevendo então suas linhas gerais e dizendo que a operação se daria com fundos disponíveis e sem ofensa do capital social ${ }^{267}$. Todas as peças normativas que se seguiram continham disposição semelhante, até que o instituto chegou à Lei das S.A., com as características que veremos abaixo.

O conceito de "amortização" é corrente em finanças (falamos, aqui, de instrumentos de dívida clássicos, como um contrato de mútuo, por exemplo) e denota o pagamento, pelo devedor ao credor, dos valores de principal (e não apenas de juros) do crédito tomado por ele: nessa situação, o devedor "amortiza a sua dívida", devolvendo ao credor parte do valor nominal que havia recebido a título de empréstimo. A descrição adequa-se ao que a amortização de ações é, mutatis mutandis. Esta alusão é apenas

\footnotetext{
${ }^{265}$ Waldemar Ferreira, Tratado..., cit., Vol. 4, p. 1067.

${ }^{266}$ Waldemar Ferreira, Tratado..., cit., Vol. 4, p. 1067. Afirmativamente, Alfredo Lamy Filho e José Luiz Bulhões Pedreira, A Lei das S.A., cit., p. 392 e também Carlos Fulgêncio da Cunha Peixoto, Sociedades..., cit., Vol. 3, p. 190.

${ }^{267}$ Carlos Fulgêncio da Cunha Peixoto observa que o instituto teria surgido no Brasil por meio do Decreto 1.746 , de 3 de outubro de 1869 , que autorizou o Governo a contratar a construção de diversos portos. Dizia esse normativo que a sociedade teria capital fixo e imutável, exceto se por autorização do Governo, mas que ela poderia criar um fundo de amortização para restabelecer-se o capital social aos sócios ao final da concessão pública. Cf. Sociedade por Ações..., cit., vol. 1, p. 199.
} 
ilustrativa, visto que não defendemos qualquer igualdade entre instrumentos de dívida e de capital, como é o caso das ações.

Pela redação do artigo $44, \S 5^{\circ}$, ocorrida a amortização integral das ações, com o pagamento aos acionistas do valor total que lhes incumbiria na liquidação da companhia, as suas ações (ordinárias ou preferenciais) poderão ser substituídas por ações de outro tipo, que são as de fruição. Significa, então, que a natureza da amortização, inicialmente, não se presta para cancelar as ações integralmente amortizadas, eis que a lei estipula como caminho natural que essas sejam substituídas por outras, as de fruição, com as restrições que o estatuto ou a assembleia lhe impuserem. Aliás, diga-se de passagem, a amortização, diferentemente do resgate e do reembolso, pode ser parcial: existe a figura das ações parcialmente amortizadas. Para mais, a própria Lei das S.A. estatui que a amortização de ações ocorre sem a redução do capital social, no seu art. $44, \S 2^{\circ}$.

O escopo da operação não é efetivamente de extinguir ações e/ou reduzir o capital social, mas conferir à companhia ainda mais um mecanismo de administração das suas finanças. No resgate, essa redução pode ou não ocorrer (mas o cancelamento das ações resgatadas, no mínimo, é obrigatório); no reembolso, a redução é obrigatória quando a companhia não consegue recolocar no mercado as ações reembolsadas à custa do capital social. Todavia, na amortização, a redução do capital social é proibida em qualquer hipótese. Equivale a dizer que a companhia paga aos acionistas valores equivalentes àqueles que lhes poderiam tocar na sua liquidação com recursos oriundos do patrimônio líquido que se situem acima do necessário para cobrir a cifra do seu capital nominal - não há possibilidade de deliberar a assembleia geral sua redução em decorrência da amortização.

Com referência à sua natureza jurídica, há debate entre os doutrinadores, justamente decorrente do fato de que o pagamento do adiantamento se dá com saldo de lucros e reservas e de que nunca poderá ser deliberada a redução do capital. É operação verdadeiramente curiosa da companhia com as suas ações, pois, na prática, quando a lei menciona que a companhia devolve aos acionistas parte daquilo que poderia lhes tocar na liquidação, faz aí uma apuração de haveres dos sócios antes do tempo, quase que uma liquidação ficta da sociedade ${ }^{268}$. Em uma situação de normalidade, o procedimento de liquidação da companhia, estipulado também na Lei das S.A., é o procedimento que culmina com o pagamento de todos os credores sociais e a distribuição entre os sócios, do

${ }^{268}$ Philomeno J. da Costa, op. cit., p. 167. 
que remanescer: é o cálculo final do patrimônio líquido da sociedade de titularidade dos acionistas e que lhes serão, então, distribuídos para possibilitar a extinção da sociedade. Segundo Philomeno J. da Costa, "o momento não desnatura ou modifica a essência do ato considerado abstratamente" ${ }^{269}$, afirmando, com isso, a natureza jurídica de liquidação ficta que mencionamos antes, com um consequente adiantamento aos acionistas daquilo que deveriam receber no futuro.

A operação, segundo outros autores, assemelha-se a uma distribuição de lucros extraordinários aos acionistas, já que a lei é incisiva ao afirmar que não pode ser diminuído o capital social. Este posicionamento entra em conflito com o fato de que, na liquidação final da sociedade, essas ações não concorrem no acervo líquido em condições de igualdade com as demais, recebendo apenas depois de pagas aquelas ações não amortizadas, nos termos do artigo $44, \S 5^{\circ}$, in fine.

Para nós, portanto, a soma paga a título de amortização representa uma verdadeira antecipação da restituição do capital social, que só deveria ser realizada quando da liquidação da sociedade ${ }^{270}$. Apesar desta devolução, o acionista não é excluído da sociedade, mas sua ação é substituída por outra, permanecendo ele com todos ou alguns dos direitos de sócio: tem-se, com isso, a figura de um sócio que não possui mais uma "fração" do capital social, já que sua contribuição original foi devolvida a ele antecipadamente $^{271}$. Neste ponto, é novamente necessária uma avaliação de causa do negócio: a saída de recursos da sociedade pode ser revestida de diversas roupagens jurídicas; a sua causa final, entendida como objetivo lícito a que se destina, é que lhe definirá as características.

Entendemos que a amortização nunca permite a redução do capital social, mesmo quando seja integral, porque, nessa situação, não haveria diferença entre a amortização e

\footnotetext{
${ }^{269}$ Philomeno J. da Costa, op. cit., p. 168.

${ }^{270}$ Cf. Carlos Fulgêncio da Cunha Peixoto, Sociedades por Ações, cit., p. 200.

${ }^{271}$ Para sermos precisos, há uma discussão doutrinária sobre se é obrigatória ou facultativa a substituição das ações integralmente amortizadas por ações de fruição, em decorrência da redação duvidosa do art. $44, \S 5^{\circ}$, que utiliza o verbo "poderão", do mesmo modo que fazia o DL 2.627/40. Escrevendo sobre o direito anterior, Philomeno J. da Costa se manifestou no sentido de que seria obrigatória a redução do número de ações quando, integralmente amortizadas, silenciavam os estatutos ou a assembleia deliberante, sobre a substituição. Cf. Philomeno J. da Costa, op. cit., p. 193. Trajano de Miranda Valverde e Carlos Fulgêncio da Cunha Peixoto se manifestaram em sentido contrário: se pudesse o acionista titular de ações integralmente amortizadas perder a qualidade de acionista, não haveria diferença entre amortização e resgate. Cf. Carlos Fulgência da Cunha Peixoto, Sociedades..., cit., p. 204 e Trajano de Miranda Valverde, Sociedades..., cit., Vol. 1, pp. 167 e ss. Temos que a solução destes últimos dois autores é a mais acertada. Na legislação vigente, Fran Martins defende que o acionista titular de ação integralmente amortizada não perde o status de sócio e que melhor seria, talvez, que as ações de fruição fossem sempre emitidas em substituição às ações amortizadas, para maior facilidade de movimentação das mesmas por parte do acionista. Cf. Fran Martins, Comentários..., cit., p. 266 e 268.
} 
uma efetiva redução de capital com restituição de dinheiro aos acionistas. Se for intenção da companhia reduzir o capital e restituir valores aos acionistas, que assim o façam nos termos da lei, e não por meio do instituto da amortização, que não tem essa finalidade.

Amortizadas integralmente as ações, e substituídas por ações de fruição, deveriam estas estar sujeitas ao regime jurídico do art. 30 da Lei das S.A.? A dúvida poderia surgir, tendo em vista que as ações de fruição são as que substituem as ordinárias ou preferenciais integralmente amortizadas, no sentido de que elas deixam de representar uma fração do capital social. Nesta situação, poder-se-ia pensar: as ações de fruição não devem ser submetidas ao regime proibitivo, eis que negócios envolvendo tais ações não colocam em risco o capital social de nenhuma forma, dado que a amortização previamente ocorrida, necessariamente e integralmente, efetivou-se com o saldo de lucros e reservas disponíveis da companhia, nos termos do artigo 44 da Lei das S.A. - uma vez amortizadas, teriam passado a não mais representar sequer uma "fração" do capital social.

$\mathrm{O}$ argumento, no entanto, não convence. Primeiramente, porque, mesmo que integralmente amortizadas nos termos da lei, a posterior aquisição ou realização de outro negócio pela companhia emitente com essas ações poderia prejudicar o capital social. Imagine-se que uma companhia decida adquirir, para manutenção em tesouraria, ações de fruição, não contando com saldo de lucros ou reservas suficientes para fazê-lo: nesta situação, haveria um desfalque dos bens submetidos ao vínculo de indisponibilidade do capital social real. Não diríamos que há um bis in idem (i.e. que o acionista recebeu duas vezes pela sua participação social), já que o critério de cálculo do valor da amortização, representando adiantamento de quantias potencialmente devidas na liquidação da companhia, e o valor residual das ações de fruição (que certamente refletirá o fato de que essas ações estão amortizadas), não devem ser confundidos: um representa a devolução do capital e o outro representa um valor residual pelos direitos que a ação de fruição confere, ainda que limitados. Por fim, as ações de fruição continuam conferindo o estado de sócio aos seus titulares de modo que não se pode dizer que não representem uma verdadeira ação emitida pela companhia, cujo conteúdo deverá ser, no mínimo, aquele estabelecido no artigo 109 da Lei das S.A. Assim, as ações de fruição, no direito brasileiro, estão igualmente abrangidas pelo âmbito objetivo da regra proibitiva.

\subsubsection{Aquisição para Permanência em Tesouraria ou Cancelamento}


A permissão mais geral e, ao mesmo tempo, mais relevante em termos de aplicação prática, é a aquisição para permanência em tesouraria, que foi permitida indistintamente somente com o advento da Lei das S.A. ${ }^{272}$, refletindo, de certa forma, uma evolução no pensamento acerca do instituto: passou-se a permitir que a companhia comprasse e vendesse suas ações independentemente de uma causa subjacente, desde que tivesse saldo de lucros e reservas acumulados em montante suficiente. Vale dizer: admite-se, a partir de então, que os administradores da companhia, por julgamento de conveniência própria, possam realizar as operações - a única exigência legal é que não haja desfalque do capital social, utilizando-se para a aquisição valores decorrentes de lucros e reservas disponíveis. As ações assim adquiridas podem permanecer no patrimônio da sociedade, ser canceladas (e, neste último caso, não ipso iure, como no caso do resgate, por exemplo, mas dependem de posterior deliberação da companhia) ou vendidas pela companhia (trading das próprias ações ${ }^{273}$ ). A inclusão desta possibilidade decorre da evolução do instituto, que, como se disse, ocorreu de maneira similar na Alemanha, país que viu essa alteração ser promovida pela KonTrag, em 1998, que modificou a Aktiengesetz de 1965 no tocante a esse tópico ${ }^{274}$.

A permissão do artigo 30, §1, "b”, da Lei das S.A. efetivamente institui a compra e venda desvinculada das próprias ações (pensamos que este termo é mais preciso que “desmotivada”). Entenda-se bem: é óbvio que toda decisão da administração de efetuar uma compra ou uma venda de ações próprias deverá ter uma razão, já que necessariamente houve um processo psicológico de tomada de decisão que culminou com a manifestação correspondente da vontade de realizar o negócio jurídico. A propagada "ausência de motivos" deve ser compreendida na medida em que a lei não vincula os negócios de compra e venda a determinadas e especificadas situações (como o faz na aquisição por conta de reembolso, na compra para redução de capital, etc.). Isso significa que ainda existem limites para a discricionariedade da administração, tanto nas companhias abertas como nas fechadas, incluídos como parte integrante dos deveres gerais atribuídos à

\footnotetext{
272 “A proibição [no DL 2.627/40], portanto, era quase absoluta, vedando-se rigorosamente a compra de ações pela sociedade para mantê-las em tesouraria”. Cf. Modesto Carvalhosa, Comentários..., Vol. 1, cit., p. 305. É de se notar que, para as companhias de capital autorizado, tal permissão foi introduzida pelo artigo 47 da Lei 4.728/65.

${ }^{273}$ Sobre o assunto, cf. Arturo Dalmartello, Ammissibilità del c.d. "Trading” di Azioni Proprie, in Rivista delle Società, Vol. 28, n. ${ }^{\circ}$ 3, maio-junho de 1983, pp. 649 e ss.

${ }^{274}$ Lá, a compra e venda sem motivação específica por companhias não financeiras (para estas, há regra específica) está estabelecida no §71, Abs. 1, Nr. 8, e deve ser precedida de autorização da assembleia geral, que deve discriminar alguns pontos, como os preços máximos e mínimos que podem ser pagos. Esses preços não precisam ser fixos, mas podem ser referenciados como um percentual do valor de bolsa. Observamos que a falta de "motivação", obviamente, não significa uma carta branca absoluta para os administradores, que continuam vinculados aos seus deveres fiduciários gerais. Cf. Alexander Kitanoff, op. cit., pp. 87 a 90.
} 
administração da companhia de sempre agir no interesse social, de forma diligente e cuidadosa (ver artigos 153 e ss da Lei das S.A.). Esses deveres da administração têm importância cabal na avaliação sobre os limites da discricionariedade que este item do artigo 30 outorga à companhia.

Complementarmente, para as companhias abertas, a Instrução CVM 10, logo no artigo $1^{\circ}$, limita a utilização da discricionariedade prevista na lei, ao estatuir que unicamente são permitidas as operações para aquelas companhias abertas cujo estatuto social atribua ao conselho de administração poderes para autorizar tal negociação. Ou seja, se o estatuto social originário não previr a autorização, então a assembleia geral deverá ser convocada para deliberar sobre a sua modificação, possibilitando a inclusão da outorga dessa prerrogativa ao conselho de administração. Uma vez autorizado pelo estatuto ou pela assembleia geral, o conselho de administração deverá, então, deliberar e autorizar a diretoria a praticar a recompra, devendo, no ato de autorização, delimitar o objetivo da companhia na operação (art. $8^{\circ}$, a da Instrução CVM 10), submetendo a ata da reunião à devida publicidade e comunicação à CVM (art. 10 e 11 da Instrução CVM 10). As finalidades da operação também devem ser explicitadas em nota explicativa às demonstrações financeiras (art. 21, “a”, da Instrução CVM 10).

A Lei das S.A. é omissa quanto a dois tópicos de alta importância. O primeiro deles é o preço de aquisição. Como buscaremos expor neste estudo (no capítulo sobre os aspectos organizativos), o estabelecimento de um preço excessivo no caso de aquisição de ações para permanência em tesouraria pode acarretar questionamentos quanto à existência de eventual tratamento privilegiado de determinados acionistas, e, concomitantemente, a um ilegítimo desfalque no patrimônio social. O segundo tópico, ainda mais relevante, consiste em definir e regular as formas pelas quais podem ser adquiridas e alienadas essas ações, e quais as disposições específicas que deveriam ser aplicáveis em cada situação evidentemente, a forma escolhida pela companhia para realizar suas recompras poderá influenciar de modo bastante decisivo o grau de ameaça posta aos grupos de referência.

A primeira maneira possível é admitida apenas para as companhias abertas, visto que são as únicas que possuem ações listadas: é a aquisição em bolsa. Em que pese estar disponível apenas para as companhias abertas, possui ela diversos benefícios: (i) as operações cursadas em bolsa são anônimas, no sentido de que as partes vendedoras e compradoras são desconhecidas umas das outras, e substituídas por uma contraparte central. Para a companhia aberta recomprando suas ações no mercado, isto significa que a ela não é possível, de antemão, recomprar as ações de um determinado acionista; (ii) as 
operações cursadas em bolsa tem preço objetivamente determinado e verificável, sendo que as ordens de compra e de venda são casadas de acordo com parâmetros de maximização de valor definidos pela bolsa de valores. Estas características têm importância esmagadora do ponto de vista de riscos aos interesses dos grupos de referência, uma vez que a impossibilidade de definição privada do preço do negócio, seja ele de compra ou de venda, cumulada com o desconhecimento prévio da contraparte do negócio, tornam praticamente impossível qualquer transferência ilegítima de patrimônio entre sociedade e acionista ou qualquer forma de tratamento não equitativo.

Naturalmente, existem também desvantagens nesta forma de negociar: (a) os papeis da companhia podem ser extremamente ilíquidos, dificultando o encontro de ordens de compra e venda, notadamente quando a intenção seja de recompra ou de venda de um lote significativo de ações, (b) apenas companhias abertas podem usufruir do mecanismo, (c) existe risco de a interferência da companhia no mercado de suas ações poder ultrapassar o limiar da legalidade e vir a ser caracterizada como forma de manipulação de preços ou de criação de condições artificiais de oferta e/ou demanda pelos papeis.

Como regra geral, as companhias abertas somente podem adquirir suas próprias ações em bolsa, nos termos do claríssimo artigo $9^{\circ}$ da Instrução CVM 10, que obsta qualquer tipo de operação privada. Além desta obrigação, que já garante determinados fatores de segurança, a CVM também impôs, por meio da Instrução CVM n. ${ }^{\circ}$ 168, de 23 de dezembro de 1991 (“Instrução CVM 168”), que as bolsas de valores adotem procedimentos especiais de negociação quando a quantidade ou o preço de uma operação for sensivelmente diferente da média dos últimos pregões, e, ainda, em situações específicas, como no caso de alienação de controle ou de solicitação do Judiciário. Entende-se por "procedimentos especiais" aqueles que visem ao oferecimento de condições adequadas à participação equitativa dos investidores nas operações realizadas em bolsas de valores, bem como a observância de procedimentos específicos exigidos na legislação para determinadas operações.

Fora do ambiente de bolsa de valores, menciona a doutrina, ainda no tocante às formas disponíveis às companhias abertas, a possibilidade de realização de ofertas públicas de aquisição das próprias ações, seja a preço fixo e previamente determinado (fixed price tender offer) ou cujo preço esteja sujeito a procedimento de verificação de intenções de alienação, para sua posterior definição (dutch auction ou "leilão holandês").

Nas ofertas públicas de aquisição a preço fixo, a companhia ofertante torna público a seus acionistas o desejo de adquirir ações de sua própria emissão a um preço por ela 
divulgado, necessariamente superior ao valor cursado em bolsa (gerando incentivo àqueles acionistas que não vislumbram maior valor à companhia, no longo prazo, do que aquele oferecido, a aceitarem a oferta e venderem suas ações). Comumente, estas ofertas de aquisição envolvem a divulgação, pela companhia, do volume de ações que aceita recomprar, a duração da oferta e, é claro, o preço de recompra que está disposta a pagar, deixando a critério dos acionistas a decisão de aceitar ou não a oferta. Na sua configuração teórica, esta forma de aquisição é particularmente útil para a teoria da sinalização de uma subvalorização dos papeis, pois a companhia pode, verdadeiramente, atribuir às ações um valor arbitrário que ela considere adequado, não guardando relação com os preços praticados no mercado. Há também que mencionar-se a grande utilidade deste mecanismo como tática de defesa contra ofertas hostis de tomada de controle, uma vez que o incentivo econômico incluído no prêmio de recompra - que faz com que o preço da oferta pública esteja certamente situado em patamares mais altos do que o de bolsa e também que o da oferta originalmente lançada -, induz os acionistas a desfazerem-se de suas ações, vendendo-as à companhia, e não ao terceiro ${ }^{275}$. Cuidaremos destes problemas posteriormente.

Nas ofertas públicas de aquisição sujeitas a procedimento de descoberta de preço (price discovery, Preisfindung), realizadas na modalidade conhecida como "leilão holandês" (dutch auction, bookbuilding), a companhia não divulga ao mercado o preço que está disposta a pagar pelas suas ações, apenas sua intenção em fazê-lo e o volume estimado: os acionistas que desejarem participar da oferta, demonstrarão, cada um, o volume e o preço pelo qual admitiriam alienar suas ações. A companhia fará, então, o cálculo do valor mínimo que será necessário pagar para adquirir a quantidade de papeis que tenha interesse.

No Brasil, todas as ofertas públicas de aquisição de ações são reguladas pela CVM. A Instrução CVM n. ${ }^{\circ}$ 361, de 05 de marco de 2002 (“Instrução CVM 361") regula a maneira pela qual todas elas se processarão. $\mathrm{O}$ artigo $2^{\circ}, \S 3^{\circ}$, dessa instrução dispõe que as ofertas públicas reguladas pela norma serão efetuadas fora do ambiente de bolsa de valores ou de entidade de mercado de balcão organizado, sendo certo que as ofertas de aquisição realizadas exclusivamente nesses recintos ou ambientes de negociação, continuam regidas pelas disposições a elas aplicáveis (Instrução CVM 168 e regras internas da

\footnotetext{
275 John C. Persons, ao estudar os dois mecanismos de forma comparativa, tendo em vista duas finalidades distintas (teoria da sinalização vs. defesa contra aquisições hostis de controle), argumenta que "fixed price repurchases are better suited to signaling undervaluation and dutch auctions are better suited to deterring takeovers". Cf. John C. Persons, Signaling and Takeover Deterrence with Stock Repurchases: Dutch Auctions Versus Fixed Price Tender Offers, in The Journal of Finance, Vol. 49, N. ${ }^{4}$, 1994, p. 1374.
} 
BM\&FBovespa S.A. - Bolsa de Valores, Mercadorias e Futuros "BVMF"), inclusive quanto à adoção dos procedimentos especiais.

Dessa forma, caso uma companhia aberta deseje recomprar suas ações por meio de uma oferta pública de aquisição, deverá fazê-lo em conformidade com a Instrução CVM 361. Entre as modalidades previstas na norma, a de que tratamos aqui se enquadra apenas como oferta pública de aquisição voluntária, não sujeita, portanto, a registro perante a CVM, mas submetida aos seus princípios básicos. Entre as principais características, enunciamos: (i) a oferta deve ser endereçada indistintamente aos titulares de ações da mesma espécie e classe daquelas que sejam objeto da oferta, impedindo favorecimento de acionistas e assegurando tratamento equitativo entre eles (art. $4^{\circ}$, I e II) (ii) a oferta será lançada sempre por preço uniforme (salvo a possibilidade de fixação de preços diversos conforme a classe e espécie das ações), o que não impede, a nosso ver, a realização da modalidade "leilão holandês" no Brasil - como veremos -; (iii) a oferta será efetivada em leilão em bolsa de valores ou entidade de mercado de balcão organizado.

Com isso, temos que a companhia aberta pode efetuar oferta pública de aquisição de suas próprias ações tanto por preço fixo, quanto na modalidade de leilão holandês, e desde que a oferta seja conduzida em leilão na BVMF. Dizemos que está permitida a oferta na modalidade de "leilão holandês", pois a Instrução CVM 361 não obriga a que o preço da oferta seja fixo, mas pede que ele seja uniforme para todos aqueles que a aceitarem. Por isso, entende-se que a companhia pode adotar um procedimento de descobrimento de preço, dado que, ao fim e ao cabo, ele resultará em um único e uniforme preço a ser pago por todas ações indistintamente (desde que sejam da mesma classe e espécie, naturalmente). Não se espera que muitas companhias optem por adotar esta modalidade, considerando a burocracia e os custos gerados pela observância obrigatória da Instrução CVM 361, cumulativamente, é claro, com as regras da Instrução CVM 10, no que for aplicável (utilização de saldo de lucros e reservas, etc.). A probabilidade maior, como se percebe no mercado brasileiro, é o da utilização de programas de recompra de ações em bolsa, nos termos das Instruções CVM 10 e 358.

Por fim, a companhia, aberta ou fechada, poderá adquirir ou vender suas próprias ações em negociação privada com determinado(s) acionista(s) (uma "negotiated repurchase" na expressão inglesa). Esta modalidade de negociação é particularmente delicada no que diz respeito às regras de proteção dos interesses dos acionistas, que se manifestam indiscutivelmente por meio da aplicação do princípio do tratamento igualitário entre eles. Como negócio jurídico privado bilateral, sujeitam-se eles a maior maleabilidade de seus 
termos negociais, como o preço e as condições da compra e venda, além de, incontestavelmente, ser possível impedir a participação de um, ou de um determinando grupo de, acionista(s) na celebração do contrato. O capítulo destinado à tutela dos interesses dos acionistas desenvolverá estes temas.

\subsubsection{Negócios Jurídicos Gratuitos: Doação}

Anteriormente à vigência da Lei das S.A., a admissibilidade da realização de negócios gratuitos pela companhia com as próprias ações era controversa, tendo em vista que a redação do DL 2.627/40 não continha nenhuma referência expressa a eles, mencionando simplesmente a compra e venda, negócio oneroso por natureza. Por esse motivo, Philomeno J. da Costa, ao incluir um item específico em sua tese acerca da aquisição das próprias ações em decorrência de um ato gratuito ${ }^{276}$, inovava em relação ao texto da lei que comentava. Observava aquele autor que "a companhia pode aceitar em doação ações do próprio capital porque a lei a proíbe de 'negociar', isto é, ela não pode fazer trato mercantil, não pode traficar, não pode exercer o comércio"277. Como a doação não consistiria em um "ato mercantil" estaria permitido à companhia receber as suas próprias ações em doação. Nitidamente, a visão do professor estava condicionada ao estado da arte do conhecimento jurídico em 1965, quando ainda vigorava, em sua plenitude, o Código Comercial de 1850 e suas definições sobre "atos do comércio". Atualmente, essa discussão está totalmente superada.

Por isso, concordamos, manifestamente, com a conclusão do notável jurista, mas não com a sua fundamentação ${ }^{278}$. O atual artigo $30, \S 1^{\circ}$, "b”, da Lei das S.A. permite textualmente o recebimento das próprias ações por doação, para manutenção em tesouraria. A razão pela qual a lei não proíbe este tipo de negócio jurídico é clara: não há saída de recursos do ativo social que pudesse prejudicar o capital social e os credores, pois a doação é contrato, quanto aos efeitos, unilateral: surgem obrigações, normalmente, apenas ao doador (exceto no caso de doação modal ou com encargos). Na Alemanha, todos os negócios jurídicos unilaterais estão incluídos no rol de "operações privilegiadas" da Aktiengesetz de 1965, já que a preocupação não é a existência das ações em tesouraria,

\footnotetext{
${ }^{276}$ In op. cit., pp. 41 a 43.

${ }^{277}$ In op. cit., p. 42.

${ }^{278}$ Ressaltando novamente que a linha de raciocínio do professor era muito precisa no contexto em que foi elaborada, na vigência do Código Comercial de 1850. Destaque-se, além disso, que o DL 2.627/40 não dispunha acerca da aceitação das próprias ações em doação, diferentemente do que o faz hoje a Lei das S.A. Para mais, ele próprio indica sua aceitação quanto ao que defendemos, ao argumentar que as companhias poderiam fazer tudo quanto "não represente um empobrecimento unilateral". In op. cit., p. 43.
} 
mas o esvaziamento do patrimônio social ${ }^{279}$. O legislador comunitário europeu resolveu adotar o exemplo alemão, incluindo na $2^{\text {a }}$ Diretiva a hipótese de negócios gratuitos dentro do elenco de operações excepcionadas do regime da prévia autorização da assembleia geral (art. 19) - em nenhuma das duas normas (comunitária ou alemã), no entanto, a permissão é limitada unicamente à doação: o preceito permissivo estende-se a qualquer negócio gratuito, assim entendido aquele em que não há, direta ou indiretamente, um esvaziamento patrimonial da sociedade.

A redação da Lei das S.A. não é primorosa (exatamente por não se referir a todos os negócios jurídicos gratuitos, mas apenas à doação), mas demonstra irrefutavelmente que, na proibição do art. 30, caput, não se compreendem os negócios nos quais a companhia receba as próprias ações em doação, sendo que a lei não distingue entre doação simples ou com encargos. No entanto, dependendo da natureza dos encargos impostos à companhia donatária, o negócio poderá significar um ônus potencial para o seu patrimônio e deveria, assim, estar sujeito às regras de proteção dos credores, especialmente no tocante à existência de lucros ou reservas (se isso for exigido, será necessário avaliar o caso concreto para se verificar a natureza do encargo e o impacto patrimonial que ele acarretaria à sociedade, para então se poder concluir qual regime aplicar-se-ia: o dos negócios onerosos, ou, ao contrário, o da doação pura).

Sempre cabe rememorar que nenhuma operação com as ações de emissão da companhia permitida pela Lei das S.A. pode ser realizada com ações não totalmente integralizadas. Precisa-se mencionar que as ações recebidas a título gratuito necessitam estar integralizadas, para evitar uma situação em que, disfarçado sob o pretexto de que a operação não causa prejuízos ao patrimônio social, um acionista possa ver-se desobrigado de contribuir ao capital ao doar suas ações não integralizadas à companhia.

Concluindo: (i) são permitidos todos os negócios jurídicos gratuitos, por meio dos quais a companhia receba ações próprias, inclusive por legado ou herança, sendo imprecisa a redação da Lei das S.A., (ii) as ações recebidas por qualquer negócio jurídico gratuito não prejudicam os acionistas ou os credores, exceto se a doação for modal ou com encargos, situação na qual deverá ser avaliado o impacto do encargo sobre o patrimônio social, para concluir-se sobre a aplicação ou não do regime comum dos negócios onerosos,

\footnotetext{
${ }^{279}$ O privilégio decorre da não observância de determinados requisitos da Aktiengesetz como, v.g., o limite de $10 \%$. "O motivo [do tratamento privilegiado] é que os perigos que decorrem das operações com ações próprias não são causados pela detenção das ações em tesouraria, mas pela distribuição de recursos aos acionistas". No original: "Der Grund ist, dass die Gefahren, die vom Erwerb eigener Aktien ausgehen, nicht im Halten der eigenen Aktien begründet sind, sondern in der Auszahlung von Kapital an den Aktionäre". Cf. Alexander Kitanoff, op. cit., p. 76.
} 
(iii) as ações a serem entregues gratuitamente devem estar totalmente integralizadas, e (iv) as ações recebidas gratuitamente, tanto quanto aquelas adquiridas pela companhia por meio de um negócio oneroso, serão consideradas ações em tesouraria - nesse ponto não se diferenciam.

A existência de eventual tributação não deve ser caracterizada como um encargo da companhia (ex.: imposto sobre doação ou imposto de transmissão mortis causa) - há que entender-se, inclusive, que a companhia poderia pagar tais encargos fiscais sem ter saldo de lucros e reservas, dado que seu benefício no recebimento das ações gratuitamente é potencialmente muito maior do que o valor do ônus tributário; a interpretação contrária não permitiria sequer que as doações, previstas textualmente na Lei das S.A., pudessem ser realizadas, eis que o imposto de transmissão sobre doação incidiria praticamente em todas elas.

\subsubsection{Aquisição das Próprias Ações para Redução de Capital}

Nos termos do art. 173 da Lei das S.A., a companhia poderá deliberar a redução do seu capital social em decorrência de perdas sociais ou se julgá-lo excessivo relativamente às necessidades de seu objeto social. O artigo 174 do mesmo diploma reza, de maneira complementar, que caso a redução de capital seja realizada com o pagamento aos acionistas de ao menos parte do valor das ações em dinheiro, então os credores quirografários terão 60 dias para oporem-se à redução, em claro dispositivo que corrobora a função de garantia inerente à cifra nominal do capital social.

Neste âmbito se insere outra das exceções à proibição da companhia figurar em negócios com ações de sua emissão, nos termos do art. 30, §1, “d”, da Lei das S.A., segundo o qual é lícito a ela comprar as ações de sua emissão quando, resolvida a redução do capital mediante restituição, em dinheiro ${ }^{280}$, de parte do valor das ações (art. 174 da mesma lei), o preço destas em bolsa for inferior ou igual à importância que deve ser restituída. A redação é muito semelhante àquela constante do art. 19 do DL 2.627/40, cabendo mencionar, no entanto, que os diplomas anteriores não faziam referência expressa a esta modalidade de negócio.

\footnotetext{
${ }^{280}$ E apenas em dinheiro; não é toda redução de capital que autoriza a compra das suas ações pela sociedade. A restrição justifica-se pelo fato de que é necessária uma comparação de preços: entre aquele deliberado para restituição aos acionistas e o das ações em bolsa (este deve ser menor do que aquele). A comparação do valor das ações (cuja cotação é sempre em dinheiro) com o valor de bens poderia levar a fraudes ou dificuldades de avaliação justa. Cf. Philomeno J. da Costa, op. cit., p. 223.
} 
Neste caso, no entanto, pode-se dizer que a companhia não tem pleno domínio sobre a concretização do negócio jurídico. No resgate e na amortização, ela detém, seguindo determinados procedimentos legais, o poder de resgatar ou amortizar as ações de sua emissão; no reembolso, apesar de a iniciativa ser do acionista, pode-se afirmar que a companhia detém o poder de ocasionar o reembolso, já que, inconformado o acionista com certas deliberações, poderá ela sempre rever a sua deliberação ou, caso decida não fazê-lo, pagará ela o valor das ações e partirá em busca de novos subscritores. No caso de que ora tratamos, de outra sorte, "a lei cria uma forma de negociação das próprias ações pela anônima, em que esta não a domina unilateralmente (...). Nas três espécies anteriores [resgate, amortização e reembolso] de negociação de ações pela própria sociedade emissora, esta rege-as. Na sua compra, ela vai até o ponto de obtenção da qualificação de candidata à negociação, como será observado mais adiante"281. A condição de legitimidade a que se refere Philomeno J. da Costa se justifica, pois trata-se, em verdade, de um contrato de compra e venda comum com determinadas condições de legitimidade, dependendo, portanto, do encontro da vontade da companhia de comprar com a do acionista de vender. A sociedade compra ações de sua emissão para possibilitar a diminuição da cifra de seu capital social, utilizando para tanto quaisquer recursos, mesmo que à custa do capital (afinal, o escopo da operação é justamente sua redução). É caso típico de autofagia.

Além das condições de legitimidade discutidas brevemente acima, entende a doutrina que a assembleia que deliberar a redução do capital social deve ser expressa em permitir que tal ocorra por meio da aquisição das ações em bolsa ${ }^{282}$.

Diz-se que este tipo de negócio é permitido como um meio de a sociedade reduzir vantajosamente o seu capital. Valverde diria que "a operação, evidentemente, não prejudica os acionistas, e é sempre favorável à companhia"283. São necessárias diversas ressalvas ao pensamento de Valverde. Em primeiro lugar, porque, caso o valor de bolsa for igual ao restituível, então não haverá vantagem nem prejuízo para a companhia; em segundo lugar, e ainda com mais nitidez, esta modalidade de redução pode, ao invés de beneficiar os acionistas, como se propagou na opinião do mestre Valverde, prejudicá-los: se uma das condições de legitimidade da compra de ações para redução de capital é a de que o preço delas em bolsa seja inferior ao valor que seria restituível de acordo com a deliberação da assembleia, então o acionista efetivamente receberá menos do que receberia

\footnotetext{
${ }^{281}$ Cf. Philomeno J. da Costa, op. cit., p. 221.

${ }^{282}$ Cf. Philomeno J. da Costa, op. cit., p. 224 e Modesto Carvalhosa, Comentários..., Vol. 1, cit., p. 322.

${ }^{283}$ Cf. Trajano de Miranda Valverde, Sociedades..., cit., Vol. 1, p. 173.
} 
do modo tradicional ${ }^{284}$ e, ainda, ficará destituído da sua condição de sócio. Na realidade, o acionista que se vir na situação de decidir entre receber seus haveres da maneira comum, inerente ao processo de redução de capital, ou por meio da venda das suas ações em bolsa à companhia, precisaria tomar uma decisão antieconômica para optar pelo segundo caminho. Nas palavras de Waldemar Ferreira: "para que, todavia, a compra das ações pela sociedade se efetue é indispensável que os acionistas prefiram, contra os seus próprios interesses, o que é inadmissível, em vez de receber o mais, que a assembleia geral lhes mandou restituir, o menos, produzido pela venda das suas ações em bolsa. De outro modo, a compra é impossível"285. Carlos Fulgêncio da Cunha Peixoto diria que, além de uma exceção à proibição de negócios da companhia com as ações de sua emissão, esse dispositivo (o artigo 19 do DL 2.627/40) seria também uma exceção ao princípio de hermenêutica de que não existem artigos inúteis em uma lei $^{286}$, já que o acionista nunca venderia suas ações nessas condições. Modesto Carvalhosa, enfaticamente, afirma que a manutenção da permissão na Lei das S.A. é fruto da desatenção ${ }^{287}$.

Finalmente, ainda com relação ao valor da restituição - e aqui temos um ponto de contato com os interesses dos investidores -, é natural que seja vedado à companhia manipular os preços das próprias ações no mercado, forçando sua baixa, para possibilitar a compra a preços menores. Este tipo de criação de condições artificiais de oferta e demanda é considerado ato ilícito pela Instrução CVM 8. A situação inversa, na qual o acionista força a alta das ações para impedir a compra (lembre-se que o valor das ações em bolsa precisa ser inferior ao valor por ação a ser pago aos acionistas, como condição para que possa realizar-se a redução mediante compra), também pode ser cogitada, sendo igualmente vedada nos termos da mesma instrução ${ }^{288}$.

\footnotetext{
${ }^{284}$ Cf. Philomeno J. da Costa, op. cit., p. 234, nota de rodapé 174.

${ }^{285}$ Cf. Waldemar Ferreira, Tratado..., Vol. 4, cit., p. 1081, n. 51.

${ }^{286}$ Cf. Carlos Fulgêncio da Cunha Peixoto, Sociedades..., cit., p. 212.

287 "A lesividade no caso é manifesta e inteiramente incompatível, portanto, com os princípios de resguardo institucional e contratual dos interesses patrimoniais dos acionistas-investidores de companhias abertas. A reiteração dessa faculdade na lei de 1976 somente pode ser fruto de descuido ou da falta de entendimento do seu caráter iníquo e espoliativo dos interesses da massa de acionistas". Cf. Modesto Carvalhosa, Comentários..., Vol. 1, cit., pp. 322 e 323. Na realidade, não vemos aí um princípio de "resguardo patrimonial", pois o acionista não é forçado a vender as ações nessas condições.

${ }^{288}$ É importante consignar que esta modalidade de negócio difere da possibilidade de cancelamento das ações que originalmente tenham sido adquiridas para permanência em tesouraria. Na situação em comento neste item (compra predeterminadamente realizada para possibilitar a redução do capital), a aquisição integra o procedimento comum previsto na Lei das S.A. (redução por força de perdas ou se o capital for julgado excessivo, cf. art. 173); na segunda hipótese que listamos, por outro lado, ela o precede. As duas situações possuem consequências diversas: "sono però tendenzialmente contrario, credo ciò̀ che la riduzione di capitale conseguente all'annullamento di azioni proprie già in portafoglio debba essere intesa come genere a sé, terzo nella aparentemente rígida dicotomia degli artt. 2445 e 2446, c.c., e per più concomitante ragioni" - grifos nossos. Cf. Paolo Ferro-Luzzi, op. cit., p. 1283. Sobre a mesma discussão, cf. Francesco
} 


\subsubsection{Negócios em Nome elou no Interesse Alheio}

A regra da Lei das S.A., em sua expressão literal, direciona a proibição apenas à companhia emitente das ações. Por outro lado, existem situações nas quais um terceiro, não pertencente ao grupo societário de uma companhia, adquire as suas ações (situação típica de heteroparticipação, portanto) não em nome e interesse próprio, mas em decorrência de estruturas contratuais que permitem a negociação em nome e/ou no interesse da companhia, de modo que os efeitos do negócio jurídico sejam a ela imputados - situação que se afigura, caso fosse amplamente permitida, como uma forma de violação indireta do regime jurídico dos negócios com as próprias ações. Existem, de outro lado, negócios nos quais a companhia pode estar agindo em nome e/ou no interesse de um terceiro, cujos exemplos mais fartos podem ser extraídos da prática financeira. Mais uma vez, o tema tangencia uma situação limítrofe, em que podem ser verificados abusos por parte dos agentes econômicos, ou excesso de zelo por parte da legislação. Como devem ser disciplinados os negócios jurídicos por meio dos quais a companhia celebra um acordo com um terceiro, para que este seja autorizado ou obrigado a adquirir ações em nome ou por conta da companhia? E a mesma pergunta vale para o sentido inverso: como devem ser regulados os negócios nos quais a companhia age em nome, ou no interesse, de um terceiro (não societariamente vinculado a ela)?

Iniciaremos a discussão pelos negócios em que a companhia age em nome ou no interesse alheios.

O caso clássico é o do contrato de comissão, que também foi discutido no âmbito da legislação europeia. A norma da $2^{\text {a }}$ Diretiva, influenciada, como se disse, pelo direito alemão (que já permitia a comissão constituída para a compra, como exceção ao regime geral proibitivo, desde 1884 - e assim também na redação original da Aktiengesetz de 1965), permite, no seu artigo $20, \S 1^{\circ}$, C, que os bancos e as instituições financeiras adquiram as suas próprias ações a título de comissão de compra. A lei comunitária foi apenas um pouco mais conservadora que a alemã, prevendo que a comissão de compra poderia ser efetuada apenas por bancos e instituições financeiras, enquanto que a Aktiengesetz permitia (até então, já que a reforma de 1978 adequou-a nesse ponto também) a comissão de compra a qualquer companhia, mesmo as não financeiras.

Carbonetti, Acquisto di Azioni Proprie e Patrimonio Sociale, in Rivista delle Società, Vol. 27, n. ${ }^{\circ}$, novembro-dezembro de 1982, p. 1133. 
Nestes contratos, de acordo com o nosso Código Civil, o comissário adquire ou vende, em nome próprio, mas à conta de um terceiro (o comitente), determinados bens, conforme redação inequívoca do artigo 693. Nesta estrutura contratual, o comissário fica diretamente e pessoalmente responsável perante as pessoas com que contratar, que não poderão opor suas pretensões e exceções contra o comitente (artigo 694). Ao mesmo tempo, o comissário não assume responsabilidade subsidiária pela solvência das suas contrapartes, exceto se vier estipulado em contrato (artigo 698).

Antes de tudo, é preciso esclarecer que, se houvesse saldo suficiente de lucros e reservas de lucros na companhia, a operação estaria plenamente permitida nos termos da ratio legis do artigo $30, \S 1^{\circ}$, "b", da Lei das S.A.: estando autorizada a adquirir suas próprias ações para mantê-las em tesouraria, desde que respeitado o capital social (i.e. utilizadas reservas de lucros), também poderia fazê-lo no contexto de uma comissão - com ainda mais razão -, uma vez que ela atuaria quase como intermediária de um terceiro, não assumindo os riscos do bem objeto da operação (que seriam direcionados, posteriormente, ao comitente). A pergunta que deve colocar-se, consequentemente, é se a operação de compra de ações próprias em comissão poderia ocorrer sem a observância dos requisitos da Lei das S.A., mormente o da utilização de saldo de lucros e reservas.

Philomeno J. da Costa entende que há de se diferenciar dois tipos de comissão (apesar de ele não utilizar esta denominação): uma situação na qual o comissário recebe previamente os recursos de que disporá para a aquisição dos bens e, outra, na qual ele não recebe esses recursos e os adianta, na forma de crédito contra o comitente. Para ele, quando se fala em aquisição das próprias ações no contexto de um contrato de comissão, apenas a primeira situação seria possível, pois, ali, a companhia recebeu previamente os recursos destinados a essa finalidade específica. Na segunda situação, o negócio seria vedado ${ }^{289}$. Para Pontes de Miranda, sequer há exceção ${ }^{290}$.

Parece-nos justificada a diferença proposta por Philomeno J. da Costa. Isso porque, retomando nossa premissa de inexistência de saldo de lucros e reservas na companhia adquirente, em uma situação em que a companhia emitente receba previamente do comitente os recursos necessários para a aquisição, não haveria maior esvaziamento do patrimônio social, que, de outro modo, já estaria totalmente vinculado à manutenção do capital. Neste caso, há, efetivamente, não uma redução ilícita do patrimônio social, mas um

\footnotetext{
${ }^{289}$ In op. cit., p. 48 a 50.

290 "Pretende-se que a lei não proíbe que a sociedade por ações negocie as próprias ações em nome de terceiros, ou por conta de terceiros; mas seria explícita permissão da fraude à lei”. Cf. Pontes de Miranda, Tratado de Direito Privado, op. cit., p. 89.
} 
incremento dele, na medida em que a companhia receba sua remuneração depois de cumprida a comissão: defendemos, aqui, a existência de uma exceção ao princípio de que apenas o saldo de lucros ou reservas pode ser usado nestas aquisições.

Por outro ângulo, entendemos que a companhia não poderia efetuar a operação sem o adiantamento dos recursos pelo comitente, uma vez que, nessa situação, deveria ela dispor de saldo de lucros ou reservas para possibilitar a aquisição, de acordo com a vedação genérica da Lei das S.A.. Reconhece-se que esta posição é mais conservadora do que aquela prevista na Europa (onde não há essa diferenciação), mas não visualizamos possibilidade de distinta intepretação no Brasil: não obstante poder-se alegar a situação de "intermediária" da companhia na estrutura, existe o risco concreto de o comitente não cumprir sua obrigação contratual; se isso ocorrer, tendo a companhia adiantado os recursos para a compra sem possuir lucros, tal situação a deixará em estado ainda mais prejudicial do que o anterior. Ademais, é prudente notar que, no contrato em comento, a companhia estaria agindo em nome próprio, o que significa que ela estaria vinculada ao contrato com os alienantes das ações, e de seu patrimônio devem sair os recursos para cumprir a obrigação contratual assumida. Em outras palavras, mesmo que transitoriamente e com caráter de intermediação, são os recursos da companhia que serão destinados a honrar a compra e, salvo se recebidos previamente, há o risco de que o comitente não honre a sua obrigação contratual de pagar o valor à companhia-comissária.

Por final, nossa opinião é a de que esse regime do contrato de comissão seja aplicado a todas as companhias, exceto às instituições financeiras (sobre as quais teremos um item específico abaixo). Diferentemente da posição adotada na União Europeia, não nos parece justificado excluir a modalidade contratual da comissão para empresas não financeiras, desde que observadas as regras prudenciais acima.

Passemos ao contrato de mandato, nos termos dos artigos 653 e seguintes do Código Civil. O que ocorre se a companhia recebe um mandato para adquirir ações em nome e no interesse do mandante? Ora, aqui não há que se falar em restrição alguma a ela, eis que, no contrato de mandato com representação, a companhia não age em nome próprio, ela age em nome alheio (e, naturalmente, também no interesse alheio), conforme a indisputável redação do artigo 653 do Código Civil. Isso significa que (assumindo que os atos deram-se dentro da extensão do mandato) o patrimônio social nunca será atingido por conta do negócio jurídico celebrado por ela nessa qualidade: a parte no negócio jurídico será diretamente o terceiro envolvido, o mandante, e não a companhia, que agiu apenas em cumprimento do mandato. Portanto, a liquidação financeira do negócio dar-se-á 
diretamente com recursos oriundos do patrimônio do terceiro, que será o único responsável pelo ato praticado em seu nome pela companhia-mandatária, conforme precisa regra do artigo 663 do Código Civil. Não há, aqui, qualquer razão que justifique a restrição deste tipo de estrutura, assumindo que a companhia aja dentro dos poderes do mandato e sempre em nome do mandante.

Com relação ao contrato de corretagem, previsto nos artigos 722 e seguintes do Código Civil, temos que são operações plenamente permitidas para todas as companhias. Ora, a corretagem nada mais é do que um contrato por meio do qual uma pessoa (o corretor) faz uma mediação em decorrência da solicitação de alguém. Ele apenas aproxima as partes contratantes, que, a partir daí, contratarão em nome e no interesse próprios, pagando uma comissão de corretagem a ele. A conclusão não é diferente no caso de intermediação e corretagem de ações de companhias abertas, hipótese na qual as sociedades corretoras de títulos e valores mobiliários podem intermediar as operações de seus clientes junto aos sistemas das bolsas de valores, mesmo em relação a ações de companhias que sejam suas controladoras. Enumeramos inúmeras razões que justificam essa conclusão: (i) pelo contrato de corretagem, a sociedade corretora apenas executa a ordem de compra ou venda das ações nos sistemas de negociação da bolsa de valores, sempre com a identificação do cliente final, que é juridicamente o contratante, (ii) mesmo que as normas operacionais da BVMF (hoje a única plataforma de negociação de ações do Brasil) prevejam uma responsabilidade subsidiária da sociedade corretora pelo inadimplemento de seus clientes finais, ela não passa a ser titular das ações, apenas passa a poder adotar medidas de tratamento de inadimplência (como a liquidação de posições do cliente faltoso que estejam em sua custódia), para seu ressarcimento.

Passemos ao polo inverso, o das situações em que um terceiro age em nome ou no interesse da companhia.

Na Alemanha, a matéria vem regulada no §71a, Abs. 2 da Aktiengsetz de 1965, que trata genericamente dos casos de "fraude à lei" (Umgehungsgeschäfte). Segundo esse artigo, são nulos os negócios jurídicos entre a companhia e um terceiro, de acordo com o qual tal terceiro seja legitimado ou obrigado a adquirir ações da companhia por sua conta/interesse, ou, ainda, por conta/interesse de uma sociedade coligada à emitente, desde que tal aquisição esteja em desconformidade com os requisitos gerais do $§ 71$ (que menciona as regras gerais da aquisição).

A fattispecie aqui tratada pelo legislador alemão, como se nota, comporta uma série de situações que carregam o traço comum de usarem uma interposta pessoa: um terceiro 
age em nome próprio, mas por conta da sociedade emitente das ações. É importante fazer essa observação, pois em negócios jurídicos nos quais o terceiro aja em nome e por conta da própria sociedade, não há que falar-se da aplicação de regras sobre o uso de interposta pessoa; na realidade aplicar-se-iam a esse caso as regras gerais direcionadas à própria companhia.

\section{A aquisição será feita "no interesse" ou "por conta" da sociedade, quando o} resultado econômico da aquisição seja absorvido pela própria companhia ou, também, quando ela assumir integralmente o risco derivado de tais operações.

Dos três contratos mencionados acima, apenas o contrato de comissão merece uma análise um pouco mais detalhada, já que, no mandato com representação e na corretagem é a própria companhia a pessoa vinculada ao negócio jurídico, em seu próprio nome e sob sua responsabilidade exclusiva, submetendo-se tais contratos, necessariamente, às regras gerais de aquisição das próprias ações pela companhia. Entendemos ser possível a realização de uma comissão de compra por um terceiro, no interesse da companhia, apenas na hipótese de esta possuir saldo de lucros ou reservas (e no caso de companhias abertas, observado o limite de $10 \%$ ) em montante suficiente para realizar a aquisição - como se ela estivesse negociando diretamente. No limite, mesmo que não figure como parte no negócio jurídico diretamente, é a companhia que deverá, em cumprimento às suas obrigações oriundas da comissão, honrar a operação com o comissário.

\subsubsection{Acionista Remisso, Ações Caducas e Ações Caídas em Comisso}

Como forma de garantir à sociedade mecanismos eficientes para cobrar dos acionistas subscritores aqueles valores a que se obrigaram, a Lei das S.A., da mesma forma que o fizeram várias leis de outros países (na Alemanha, por exemplo, o $\$ 64$ da Aktiengesetz de 1965 estipula uma pena de perdimento em favor da sociedade, "für verlustig erklärt"), garante dois mecanismos de ação, nos termos do seu artigo 107. O primeiro deles é o mais intuitivo, qual seja, o de possibilitar à companhia, verificada a mora de seu acionista, a promoção de uma ação de execução contra ele para buscar em juízo o valor dos aportes de que é devedor. Trata-se, nada mais, do que o mecanismo de direito comum para cobrar obrigações inadimplidas pelo devedor.

O segundo inciso do mesmo artigo traz interessante mecanismo alternativo para que a companhia busque os capitais a ela devidos pelo acionista subscritor em mora, que se consubstancia em uma hipótese permitida pela lei de negócio da companhia com as ações 
de sua emissão não expressamente excetuada pelo artigo 30 da Lei das S.A.: a venda, pela companhia, das ações do acionista em mora, por conta e risco deste. Esta hipótese configura, com acerto, uma espécie de venda permitida pela companhia de ações de sua emissão.

Cabe, neste momento, nos debruçarmos mais detidamente sobre a estrutura do artigo 107. Em verdade, existem três momentos distintos no mesmo artigo: (i) um primeiro, no qual a companhia procura vender as ações do acionista em mora caídas em comisso, que, ressalte-se, ainda lhe pertencem de direito (venda por ordem e risco do acionista faltoso, cf. redação do artigo 107, II), (ii) outro, em que a companhia expropria o acionista faltoso (que se torna, então, ex-acionista) e declara as ações caducas, podendo integralizá-las com lucros e reservas de lucros, exceto a legal, que tenha contabilizado (redação da parte inicial do artigo $107, \S 4^{\circ}$ ), e (iii) um último, em que a companhia, em não tendo saldo de lucros e reservas suficientes para a integralização, busca vender as ações em seu próprio nome, já tendo sido expropriado o ex-acionista (parte final da redação do artigo $107, \S 4^{\circ}$ ).

Portanto, verificada a mora do acionista, poderá a companhia mandar vender as ações, por conta e risco do mesmo, em bolsa de valores. Cumpre notar que, hoje, diferentemente do que ocorria na vigência do DL $2.627 / 40^{291}$, as opções da companhia não são mutuamente excludentes. Assim, mesmo optando pela cobrança judicial de seu crédito (art. 107, I) contra o acionista e seus cessionários (sempre solidários com ele, a teor do art. 108), a companhia ainda assim poderá, em momento posterior, mandar vender as ações em bolsa e poderá, igualmente, cobrar eventual diferença a menor em juízo, caso a venda das ações não atinja valor suficiente para saldar os débitos do acionista (artigo 107, $\S 3^{\circ}$ ).

Não encontrado um comprador depois de colocada a ação para venda em leilão especial da bolsa de valores, poderá a companhia declará-las caducas, expropriando, então, o ex-acionista e "fazendo suas" as entradas já realizadas. Ela pode também optar por não declarar as ações caducas e reduzir diretamente o capital social em montante equivalente. A partir dessa declaração de caducidade, e em não havendo saldo de lucros ou reservas suficientes, a companhia terá o prazo improrrogável de um ano para tentar encontrar um comprador para as ações ${ }^{292}$, findo o qual será obrigatória a redução do capital social.

\footnotetext{
${ }^{291}$ Cf. Philomeno J. da Costa, op. cit., p 68.

${ }^{292}$ Entendemos que, apesar da letra da lei prever uma espécie de procedimento linear, a companhia poderia optar por tentar encontrar novos compradores para as ações mesmo que tenha saldo de lucros suficientes para integralizá-las; não vemos prejuízo em que isso seja feito, especialmente considerando as necessidades patrimoniais e políticas de cada sociedade em determinado momento.
} 


\subsubsection{Sucessão Universal: Incorporação, Fusão e Cisão}

As operações de fusão, cisão e incorporação, técnicas de concentração societária, encontram-se reguladas nos artigos 223 e seguintes da Lei das S.A. Uma incorporação é, como se sabe, uma operação por meio da qual uma companhia absorve todos os ativos e passivos de uma (ou de mais de uma) sociedade, nos termos do artigo 227 da mesma lei, sucedendo-a em todos os direitos e obrigações. Já uma fusão pode ser definida como uma operação por meio da qual duas ou mais sociedades se unem para formar uma sociedade nova, passando esta, igualmente, a ser a sucessora universal de todos os direitos e obrigações das sociedades envolvidas (art. 228). É possível, e ocorre com certa frequência na prática, que uma das companhias envolvidas no processo detenha ações da outra (a incorporanda, por exemplo, detendo ações da incorporadora), o que levará ao surgimento de ações em tesouraria em algum momento do processo. Podemos classificar estes tipos de aquisição das próprias ações como aquisições a título secundário, classificação esta que abrange, além das aqui descritas, todas as demais situações em que "a aquisição não surge como querida de forma imediata e principal, mas como consequência necessária de uma operação mais vasta, cujo objeto excede a aquisição em si" ${ }^{293}$.

Decidimos separar a cisão das duas operações societárias acima, porque, diferentemente daquelas, nesta, as partes envolvidas devem efetivamente relacionar, no ato de cisão, os direitos e obrigações que serão cindidos do patrimônio de uma sociedade para serem vertidos para outra (a sucessão não é "universal" e opera apenas para essa parcela cindida - art. 229 da Lei das S.A.). Em outras palavras, há um elemento volitivo muito claro no ato de cisão, o que lhe retira o caráter de "aquisição secundária" que está presente nas outras duas formas de reorganização societária.

Segundo Philomeno J. da Costa, tratando apenas da incorporação: "essas ações, na passagem, na mudança, na 'transferência', fazem o papel de frações resgatadas da anônima incorporadora..."294 . Esse autor defende que uma companhia incorporadora não poderia receber, em decorrência da operação, ações de seu próprio capital, pois o faria contra o texto legal (do DL 2.627/40). Segundo ele, por mais que o objeto da operação seja uma universalidade de direitos (ou seja, o patrimônio da incorporada) e não apenas determinados ativos e passivos (o que seria o caso em uma cisão), seria possível

\footnotetext{
${ }^{293}$ Cf. Maria Victória Rodrigues, op. cit., p. 33.

${ }^{294}$ In op. cit., p. 47.
} 
identificar-se esses ativos "proibidos" para possibilitar que a companhia objeto da incorporação possa, antes de concretizada, desfazer-se dos bens em questão.

Data venia, não podemos concordar com a opinião do ilustre Philomeno J. da Costa. Em nosso entendimento, nas operações de incorporação ${ }^{295}$, o princípio da sucessão universal deve ter total prevalência sobre questionamentos acerca da existência de ações próprias; exigir que as companhias envolvidas, no atual cenário de desenvolvimento do nosso mercado de concentração empresarial, primeiramente se desfaçam dessas ações, para então possibilitar a conclusão da operação, não nos parece ser a solução mais adequada. Este tipo de pensamento não se coaduna com a melhor interpretação técnica, e nem mesmo com uma interpretação mais ampla, de favorecimento dos negócios no Brasil. Operações envolvendo companhias fechadas, por exemplo, poderão ser retardadas pela falta de compradores (terceiros) para as ações detidas por uma das companhias envolvidas (incorporanda ou uma das envolvidas na fusão) no capital da outra (incorporadora ou a outra sociedade a ser fundida). Na legislação comparada, diga-se de passagem, a sucessão universal é tratada de forma absolutamente privilegiada: na Aktiengesetz, todos os requisitos restritivos da lei são excepcionados para os casos de sucessões universais, até mesmo o requisito de que as ações estejam integralizadas (\$71, Abs.1 S.5 da Aktiengesetz de 1965). Entendemos a exceção e com ela concordamos: o objeto do negócio jurídico é outro, as ações próprias são uma consequência de menor relevância. Adicionalmente, entendemos que, nas operações de incorporação e fusão, a existência de ações da incorporadora no patrimônio da incorporanda deverá ser levada em consideração quando for calculado o patrimônio líquido desta última (art. $227, \S 1^{\circ}$ da Lei das S.A.). Não devem ser consideradas nesse cálculo as ações que ela detenha no capital da incorporadora. Seguinda a sugestão da $2^{a}$ Diretiva, uma vez concluída, o correto seria a lei estabelecer um prazo para que as ações próprias resultantes da transação, que excedam o volume dos lucros e reservas da adquirente ou da nova sociedade ou o limite de 10\% - para as abertas , sejam alienadas.

Para a cisão, temos entendimento diverso. Isso se deve ao fato de que a companhia que irá absorver a parcela cindida deverá efetuar um aumento de seu capital, para refletir o valor da nova parcela patrimonial, atribuindo as novas ações oriundas desse aumento aos acionistas da que foi cindida. Ora, em um exemplo extremo, se a sociedade cindida decidir

\footnotetext{
${ }^{295}$ Optamos por não nos aprofundar no estudo da fusão propriamente dita, já que, nesta, as ações de todas as sociedades previamente existentes serão extintas e substituídas pelas ações emitidas pela nova sociedade que nasce da fusão. Nessa circunstância, o estudo possui menor relevância. Cf. Antonio Albanese, Operazioni..., cit., p. 362 .
} 
elencar no ato de cisão apenas as ações de emissão da sociedade para a qual o patrimônio será vertido, o aumento de capital se faz absolutamente inútil, pois a companhia "incorporadora" já possuiria, em seu patrimônio social, os bens utilizados originalmente para integralizar as ações que lhe seriam ora vertidas por força da cisão - o mesmo efeito seria atingido por meio de uma redução de capital da companhia cindida, com entrega das ações da companhia "incorporadora" aos seus acionistas. Não faz sentido, neste caso, sequer cogitarmos sobre a cisão, pois o seu resultado final seria idêntico à situação anterior a ela.

\subsubsection{Compra e Venda com Pacto de Retrovenda ou Reporte}

Outro negócio jurídico de que se cogita quando se debatem os negócios com as próprias ações é aquele por meio da qual uma pessoa compra determinado bem, assumindo, concomitantemente, a obrigação de revendê-lo no futuro à mesma pessoa que originalmente lho vendeu, por preço predeterminado. Neste tipo de operação, assumem as partes o compromisso recíproco de revender e recomprar o mesmo bem (ou bens de quantidade e qualidade iguais, se fungíveis) no futuro, a um preço previamente estabelecido por elas (ou ao menos com parâmetros objetivos para sua quantificação). A doutrina mais antiga, espelhando-se no nome que este contrato recebe nos países europeus, denomina-o de "contrato de reporte".

Philomeno J. da Costa assim o define: "pelo reporte ativo o reportador fica com os títulos ou a mercadoria adquiridos à vista e ao mesmo tempo vende outros ou outra da mesma espécie a prazo ao reportado" ${ }^{296}$. Segundo este autor, no ordenamento jurídico brasileiro, estaria o "reporte" de ações, tendo como reportadora a própria companhia, proscrito, em virtude da vedação genérica a que a companhia negocie com as próprias ações.

Não defendemos que a eventual vedação decorra simplesmente da regra geral proibitiva, carecendo o contrato de análise mais profunda do ponto de vista dos interesses resguardados, para assim chegarmos a uma conclusão aceitável. Em primeiro lugar, é preciso dizer que, no Brasil, o Código Civil não reconhece a estrutura europeia conhecida como "contrato de reporte" (veja-se, por exemplo, que ele é um contrato definido no Código Comercial Português, no artigo 477) como um tipo contratual autônomo. Aqui, a única estrutura contratual que poderíamos visualizar seria o de um contrato de compra e

${ }^{296}$ In op. cit., p. 45. 
venda com pacto de retrovenda, nos termos do artigo 505 do Código Civil, muito embora esse artigo faça menção apenas à retrovenda de coisa imóvel.

Temos, com isso, uma situação peculiar, pois, de um lado, não há tipificação civil da estrutura de "reporte" e, de outro, não prevê o Código Civil a possibilidade expressa de retrovenda de coisas móveis, como as ações. Naturalmente, isto não impede que os participantes de um negócio de compra e venda de coisa móvel pactuem, no momento da conclusão do contrato original, outra compra e venda, esta a preço pré-ajustado e de cumprimento diferido (o adimplemento das obrigações de entregar a coisa e pagar o preço são diferidos no tempo). Esta última possibilidade nos aventa ser a estrutura típica de contratos coligados, em que cada um dos contratos tem tipificação e existência autônomas, mas onde o segundo é logicamente dependente da conclusão do primeiro.

Não é isto o que acontece no "contrato de reporte", devido à sua função econômica peculiar, que lhe situa em uma posição de encontro entre o mercado de capitais e o mercado de crédito ${ }^{297}$.

Explicamos, trazendo à tona uma breve descrição dos "repurchase agreements" (conhecidos pela abreviação "repo"), extremamente utilizados no mercado financeiro internacional $^{298}$ (e nacional, como veremos). Nessa estrutura, o titular de determinados valores mobiliários (ações, por exemplo) os venderá para um banco ou outro intermediário financeiro por um preço de US\$X (o preço de venda) e, no mesmo ato, assumirá a obrigação de recomprar dessa mesma pessoa os mesmos valores mobiliários ou títulos (ou instrumentos equivalentes, se fungíveis) em uma data especificada no futuro por um preço de US\$Y (o preço de recompra) ${ }^{299}$. Este valor de recompra (US\$Y) será equivalente ao preço de venda acrescido de uma taxa de juros acordada entre as partes, que servirá como remuneração do comprador original.

A estrutura assemelha-se, em termos econômicos (mas nunca jurídicos), à realização de um empréstimo, pelo comprador original ao vendedor original, com garantia dos títulos adquiridos, pois: (i) o vendedor original recebe uma quantia em dinheiro, que ele se obriga a repagar ao comprador original no futuro, (ii) o comprador original pode

\footnotetext{
${ }^{297}$ Maria Victória Rodrigues, op. cit., p. 28 e 29.

${ }^{298}$ Em junho de 2012, a International Capital Markets Association estimava, apenas na Europa, que houvesse EUR5.6 trilhões em contratos de reporte (repo) em vigor e, no mundo todo, o tamanho desse mercado poderia chegar a US\$15 trilhões. Ver European Repo Market Survey - Number 24, December 2012, disponível em www.icma-group.org.

${ }^{299}$ É importante notar que o preço de venda (US\$X) não equivale exatamente ao preço de mercado dos títulos vendidos, mas, sim, a um valor inferior a ele: ou seja, os títulos ou valores mobiliários adquiridos pelo comprador têm valor superior ao que ele paga ao vendedor, sendo a diferença usada como margem de garantia para ele, no caso de o vendedor não adimplir sua obrigação de recompra na data futura.
} 
vender os títulos comprados no mercado caso o vendedor não cumpra a obrigação de recompra, e (iii) o preço de recompra (US\$Y) equivale ao preço de venda original, US\$X, acrescido de juros sobre US\$X.

Por que existe esta estrutura? De maneira muito simplificada, pode-se dizer que as partes nesse tipo de operação não têm por escopo final a troca de bens por dinheiro, de modo definitivo. Muito pelo contrário, a estrutura do repo, ou reporte, tem finalidades subjacentes que, muitas vezes, não são percebidas. Para o vendedor original, a utilidade de realizar um negócio desta natureza é a de arrecadar, pela venda de ativos seus de longo prazo, recursos em dinheiro de curto prazo e, para o comprador original, a vantagem é receber os juros da operação. A função econômica do repo ou reporte, portanto, está longe de ser a de uma troca definitiva de bens por dinheiro, o que levou certos autores a defender que se trata, de fato, de um contrato de mútuo garantido ${ }^{300,301}$.

Tudo visto, há ao menos três correntes jurídicas que versam sobre a natureza do contrato de reporte: (i) a primeira o classifica como uma espécie de mútuo garantido, negando a existência de efeitos transalativos da propriedade em decorrência da compra e venda, (ii) outra enxerga no reporte tão-somente duas compras e vendas simultâneas e coligadas, e (iii) uma última, mais atual, que o descreve como um todo indissociável, uma única estrutura contratual típica, e não como um somatório de vários contratos. Hoje, é pacífica na doutrina portuguesa, por exemplo, a adoção da última posição: “enfatizando a estrutura unitária do reporte, o considera como um todo orgânico e, portanto, negócio autônomo, típico, ou sui generis, com regras específicas e objetivos financeiros"302.

O Conselho Monetário Nacional (“CMN”), por meio da Resolução n. ${ }^{\circ} 3.339$, de 26 de janeiro de 2006, regulamentou o que aqui se denominou de "Operações Compromissadas", que equivalem, pode-se dizer, ao contrato de reporte português, ou ao repo inglês, e cuja utilização pelas instituições financeiras é, inclusive, bem frequente (disponível como forma de investimento até para pessoas físicas). Contudo, se no mercado

\footnotetext{
300 “(...), as partes que recorrem ao reporte não pretendem, por definição, uma transferência de títulos: tudo se passa de modo diverso, uma vez que a titularidade do reportador é efêmera. E, pela mesma ordem de ideia, tão-pouco está em causa uma transferência definitiva de fundos. Tudo visto, joga-se no reporte um mútuo especialmente garantido". Cf. Antônio Menezes Cordeiro, Do Reporte: subsídios para o regime jurídico do mercado de capitais e da concessão de crédito apud Maria Victória Rodrigues, op. cit., p. 29.

301 "Although assets are sold outright at the start of a repo, the commitment of the seller to buy back the assets in the future means that the buyer has only temporary use of those assets, while the seller has only temporary use of the cash proceeds of the sale. Thus, although repo is structured legally as a sale and repurchase of securities, it behaves economically like a secured deposit (and the principal use of repo is in fact the borrowing and lending of cash)" - grifos nossos. Cf. International Capital Markets Association in http://www.icma-group.org/Regulatory-Policy-and-Market-Practice/short-term-markets/Repo-

Markets/frequently-asked-questions-on-repo/1-what-is-a-repo/.

${ }^{302}$ Cf. Maria Victória Rodrigues, op. cit., p. 29, nota de rodapé 54.
} 
internacional não há limitação para a utilização de ações neste tipo de estrutura contratual, no Brasil, o CMN proscreve a utilização de quaisquer instrumentos de renda variável como objeto do negócio e, em assim sendo, não será possível às instituições financeiras a realização de reportes com as próprias ações (ou, esclareça-se, com qualquer ação). Mesmo tendo o CMN regulado a estrutura no âmbito de sua competência, entendemos que, na ausência de tipificação civil, seria esta um clássico exemplo de coligação contratual de dois contratos de compra e venda - estes, por sua vez, típicos. Ou seja, a "operação compromissada" consiste na coligação de dois contratos de compra e venda entre as mesmas partes, que assumirão polos opostos (comprador ou vendedor) em cada um deles $^{303}$.

À vista do exposto, podem sociedades não financeiras adquirir suas próprias ações, com o compromisso simultâneo de revendê-las no futuro a preço pré-determinado e ao acionista vendedor original? Em caso positivo, em que condições? Ao revés, poderia uma companhia vender suas ações em tesouraria, assumindo o simultâneo compromisso de recomprá-las no futuro a preço certo? Em que termos?

No primeiro caso (compra, pela companhia, com compromisso de revenda), tendo em vista os efeitos translativos inegáveis da estrutura, não podemos afastar o fato de que a companhia adquire suas próprias ações, o que conduz a uma situação de autoparticipação não permitida de forma incondicional pela Lei das S.A.: esse negócio deve ser submetido, em sua inteireza, ao regime das ações próprias. A aquisição de suas próprias ações, mesmo que efetivada com compromisso de revenda a preço certo (inclusive com potenciais ganhos para o patrimônio social decorrentes dos juros cobrados da contraparte), deve ser feita com o saldo de lucros ou reservas da companhia e as ações, enquanto não revendidas, devem ser tratadas como em tesouraria.

Poder-se-ia argumentar que a operação, no fim e ao cabo, não acarretaria riscos ao patrimônio social (nem ao capital social) já que existiria o compromisso firme e irrevogável de revenda/recompra após certo prazo. $\mathrm{O}$ argumento não convence devido ao risco de inadimplemento do vendedor original - e comprador a termo - de sua obrigação de recomprar as ações. Em uma situação limite, poderia restar desfalcado efetivamente o patrimônio social pelo valor da aquisição original, em que pese a possibilidade de a companhia vir a aliená-las para cobrir o valor originalmente desembolsado (o que só seria

\footnotetext{
${ }^{303}$ No âmbito das sociedades reguladas pelo CMN e pelo Banco Central do Brasil, poder-se-ia cogitar de um tipo contratual regulatoriamente estabelecido.
} 
rápido e eficaz em um contexto de companhias abertas e, mesmo neste caso, não haveria garantia de que o seu valor seria suficiente para tal reposição).

Na segunda situação (venda, pela companhia, com compromisso de recompra), entendemos plenamente possível a operação. De fato, se a Lei das S.A. permite que a companhia aliene suas ações que estejam em tesouraria (cf. redação irrefragável do artigo $30, \S 1^{\circ}$, “d”), também precisa permitir que elas sejam alienadas com compromisso de recompra a preço certo, situação que apenas restabeleceria a companhia ao status quo ante. Desde que seja útil e do interesse da companhia a realização da operação (ex.: necessidade premente de caixa ou liquidez), entendemos que a operação seria permitida. O preço de recompra, contudo, deverá necessariamente ser oriundo do saldo de lucros e reservas livres da companhia, com um único, e relevantíssimo, detalhe: a existência ou não desse saldo de lucros deverá ser apurada uma única vez, qual seja, no momento da efetiva recompra e não no momento da celebração dos contratos coligados. Esta visão baseia-se no seguinte pensamento: se fosse obrigatória a verificação da existência de lucros apenas na data de celebração dos contratos coligados (e não na data estipulada para a recompra), então existiria a clara possibilidade de a companhia descumprir uma direta obrigação legal a ela imposta pela Lei das S.A., que é a manutenção da integridade do capital social a qualquer tempo durante a sua existência. Ainda que se possa argumentar que essa interpretação gera insegurança jurídica na contratação desses negócios (uma vez que a contraparte da companhia não terá como garantir a existência de lucros suficientes na data de recompra futura para permitir o adimplemento da obrigação desta), não conseguimos defender a possibilidade de um descumprimento direto da Lei das S.A. - a ilegalidade será manifesta caso a companhia adquira as ações sem possuir saldo de lucros suficiente para tanto.

Se, no entanto, houvesse a participação de uma contraparte central garantidora da operação, como a Companhia Brasileira de Liquidação e Custódia, administrada pela BVMF, por exemplo, que retirasse da operação praticamente todo o risco de crédito da contraparte (i.e., a contraparte central torna-se garantidora da liquidação da operação), entendemos que a compra, pela companhia, com compromisso de revenda, poderia ser feita mesmo à custa do capital social. Isso porque: (i) não há risco (ou há risco ínfimo) de a companhia não vir a receber os recursos de volta, com os juros, pois a estrutura financeira de salvaguardas da bolsa de valores e/ou da contraparte central garantirá a liquidação, 
mesmo que a contraparte esteja inadimplente ${ }^{304}$, e (ii) a operação é vantajosa ao patrimônio social, considerando o recebimento de juros pelos recursos entregues ao vendedor original. Para maior segurança jurídica, neste caso, seria útil, de lege ferenda, que se visse na estrutura do reporte (ou operação compromissada, como a chama o CMN) um contrato típico e sujeito a regras particulares. Obviamente, seria igualmente aconselhável que a bolsa de valores previsse em seus regulamentos a garantia de contraparte central das operações. As considerações sobre a venda, pela companhia, com compromisso de recompra não seriam alteradas.

\subsubsection{Instituições Financeiras}

É natural que toda interpretação sobre a admissibilidade ou não de cada um destes negócios com ações próprias leve em conta a natureza da atividade desenvolvida pela companhia, eis que é possível que a compra e venda de valores mobiliários seja parte do objeto da companhia emitente, como no caso de instituições financeiras. Aliás, existem diversas operações que uma instituição financeira poderia praticar com as próprias ações dentro do seu objeto social (ex.: compra ou venda de valores mobiliários por comissão em nome próprio, mas por solicitação de cliente -, atividades de formador de mercado, arbitragem e trading com as próprias ações, etc.). Nestes casos, apesar de o objeto do negócio ser as ações de sua própria emissão, as instituições financeiras assim o fazem no âmbito regular de suas atividades, e não como algo extraordinário e possivelmente duvidoso em sua essência.

No exercício de suas atividades bancárias/financeiras, essas sociedades anônimas requerem uma especial regulamentação, pois elas, diferentemente de companhias de objeto não financeiro, tradicionalmente engajam-se em atividades de compra e venda de valores mobiliários. Assim, elas deveriam poder, por exemplo, realizar a compra e venda de seus papeis em cumprimento de ordem dada por seus clientes nesse sentido (que esperam que os bancos possam desempenhar essas atividades para eles) - que equivale ao contrato de comissão visto acima.

\footnotetext{
304 A probabilidade de a contraparte central garantidora do mercado de valores mobiliários não possuir recursos suficientes para honrar as obrigações cursadas em seu ambiente é praticamente nula, considerando as exigências da Lei 10.214, de 27 de março de 2001 (reforma do Sistema de Pagamentos Brasileiro). Nos termos dessa lei, essas entidades devem constituir mecanismos e salvaguardas que podem compreender, entre outros, dispositivos de segurança adequados e regras de controle de riscos, de contingências, de compartilhamento de perdas entre os participantes e de execução direta de posições em custódia, de contratos e de garantias aportadas pelos participantes.
} 
O exemplo alemão, de que é sempre válida a lição, é claro no sentido de diferenciar o regime jurídico aplicável a sociedades não financeiras e a companhias com objeto financeiro. A Aktiengesetz de 1965, no §71, abs. 1, Nr. 4, elenca a compra por instituição financeira em comissão (Einkaufskomission) como uma forma permitida de negócio da companhia com as próprias ações não sujeita aos requisitos da lei (saldo de lucros e limite de $10 \%)^{305}$. O $\$ 71$, Abs. 1, Nr. 7, acrescentado posteriormente, complementa a regra, prevendo ampla possibilidade de negócios pela instituição financeira com ações de sua emissão (o que afastou a discussão sobre a venda em comissão - Verkaufskomission, não prevista no Nr. 4), desde que de acordo com autorização da assembleia geral (cujo prazo máximo é de 5 anos) e observado um limite diário especial de $5 \%$ das ações. Salta aos olhos a existência de uma sistemática separação legislativa entre o regime destinado às companhias não financeiras e o destinado às financeiras, já que, como vimos, a própria lei alemã veda a compra e venda de valores mobiliários como um "fím em si mesmo" ( $\$ 71$, Abs. 1, Nr. 8, S. 2) $)^{306}$ - restrição que não se estende às instituições financeiras, que podem atuar, inclusive, como formadores de mercado (market makers) das próprias ações, nos termos da regra específica aplicável a elas, lex specialis (\$71, Abs. 1, Nrs. 4 e 7).

A $2^{\text {a }}$ Diretiva também contém dispositivos específicos para as atividades de instituições financeiras, como já se viu, especialmente no tocante: (i) àquelas situações de concessão de empréstimo ou financiamento para aquisição das próprias ações expressamente excetuada a vedação para instituições financeiras (art. 23, 2), (ii) à aceitação das próprias ações em garantia (art. 24, 2), e (iii) à comissão de compra (Art. 20, 1, "c").

Atualmente, as instituições financeiras nacionais estão em situação de clara desvantagem em comparação às de outros países. Nossa regulação societária é bastante rígida e não contém nenhuma previsão expressa de um regime jurídico apropriado para que elas possam atuar, o que, não nos restam dúvidas, as prejudica. Veja-se um exemplo bastante corriqueiro e simples dessa distorção. É comum na prática financeira que um cliente solicite ao banco que adquira no mercado um determinado valor mobiliário para,

\footnotetext{
305 "Em uma compra e venda por conta e ordem de terceiro (banco adquire ações próprias no mercado, para, então, revendê-las ao cliente), existe apenas uma aquisição passageira, que, portanto, não leva a uma efetiva distribuição de liquidez". No original: "Bei einer Einkaufskommission (Bank erwirbt für den Kunden, um Aktien dann an ihn weiterzureichen) liegt ein blosser Durchgangserwerb vor, der also nicht zur endgültigen Ausschüttung von Liquidität führt". Alexander Kitanoff, op. cit., p. 36.

306 “Com o $\$ 71$, Abs. 1, Nr. 8, S. 2 AktG, é deixado claro que esse é um privilégio apenas das instituições financeiras e prestadores de serviços financeiros". Ou "Mit \$71, Abs. 1, Nr. 8, S. 2 AktG wird klargestellt, dass dies das Privileg von Kreditinstituten und Finanzdienstleistern ist". Cf. Alexander Kitanoff, op. cit., p. 89.
} 
então, revender-lhe; ou, ao contrário, que adquira do cliente um determinado lote de valores mobiliários e depois aliene esses ativos no mercado.

A prática é conhecida como "client facilitation". Com a edição da Instrução CVM n. ${ }^{\circ}$ 533, de 24 de abril de 2013 (“Instrução CVM 533”), a CVM, respondendo a clamores do mercado, alterou o famoso artigo 48 da Instrução CVM 400, que estabelece, grosso modo, as hipóteses nas quais uma instituição intermediária de uma oferta pública de valores mobiliários pode ou não negociar com os papeis que estão sendo distribuídos na oferta. A regra geral é a de vedação de qualquer negócio no período em que as ações fiquem restritas, nos termos da Instrução CVM 400, excetuadas algumas circunstâncias previstas no art. 48, II (agora felizmente complementadas pela Instrução CVM 533). Entre elas, encontra-se a "aquisição de valores mobiliários solicitada por clientes com o fim de prover liquidez, bem como a alienação dos valores mobiliários assim adquiridos" - art. 48, II, "h": eis aí o reconhecimento regulatório da existência deste tipo de operação. Os clientes dos bancos usualmente esperam que as grandes instituições financeiras possam realizar esse tipo de operação também quando envolverem as ações de emissão do próprio banco. O ponto é particularmente relevante no Brasil, onde, como se sabe, as instituições financeiras são emissoras de algumas das ações mais líquidas do mercado, respondendo por significativo volume de negócios e compondo até mesmo o Índice Bovespa - citamos os exemplos do Itaú Unibanco Holding S.A., do Banco do Brasil S.A. e do Banco Bradesco S.A.

No entanto, quando a solicitação envolve ações do próprio banco, não há previsão na Lei das S.A., nas regras da CVM e tampouco nas do Banco Central do Brasil que prevejam um regime jurídico diferenciado para estes casos, de forma semelhante ao que acontece na Europa. Pelo contrário, as normas do Banco Central do Brasil tendem a ser ainda mais restritivas que as da Lei das S.A. e da CVM, como se nota na redação da Resolução do CMN n. ${ }^{\circ} 2.723$, de 31 de maio de 2000, que veda, em absoluto, no artigo $7^{\circ}$, a existência de participações recíprocas entre instituições financeiras, quando a Lei das S.A. as permite (sujeitando-as a condições, evidentemente), conforme artigo 244. Uma subsidiária de uma instituição financeira que seja companhia aberta, portanto, não pode, hoje, realizar nenhuma operação com ações de sua controladora, nem mesmo em situações onde inexiste risco palpável à instituição, como no caso de compras ou vendas para cumprir ordens de clientes. Nem mesmo a própria instituição emitente tem suas algemas afrouxadas para fins de persecução de seu objeto social, devendo observar sempre 
o conjunto proibitivo resultante da sobreposição das normas da Lei das S.A., da CVM, do CMN e do Banco Central do Brasil.

Entendemos ser exagerada a opinião de que existe risco substancial para os credores ou acionistas das instituições financeiras em negócios como esses, especialmente se forem levadas em consideração a robustez de controles e níveis de adequação patrimonial, a existência de limites operacionais e a presença de regras detalhadas de capital regulatório $^{307}$ e gerenciamento de riscos (de crédito, de mercado e operacionais inclusive jurídicos) que o próprio $\mathrm{CMN}$ a elas impõe. O nível adequado de proteção aos credores nas instituições financeiras não será atingido por meio do controle das ações próprias em situações como a compra ou venda em comissão, mas, sim, por meio da observância das regras estruturais sobre a solidez e funcionamento do próprio mercado financeiro - que são, notadamente, muito mais robustas do que as normas de proteção do capital social.

Também vê-se como extremamente prejudicial a submissão das instituições financeiras às consequências tradicionalmente apontadas pela doutrina para o caso de “concessão de empréstimos para aquisição de ações próprias”. Ora, a instituição financeira tem por objeto justamente a concessão de empréstimos; seria absurdo solicitar que ela controlasse a destinação que o mutuário dará aos recursos, mormente quando ela for companhia aberta - obviamente, uma situação de evidente dolo poderia ser averiguada no caso concreto.

De todo o exposto, avaliamos que, de lege ferenda, devem ser permitidos de forma mais ampla esses negócios jurídicos para as instituições financeiras, sujeitando-os a regras mais ou menos robustas que venham a ser definidas na lei e nas normas do CMN. O que se nos afigura muito restritivo é a não existência de nenhuma condição específica para suas atividades financeiras. A aplicação conjunta da Lei das S.A., que não faz referência expressa a um regime específico, da dura Instrução CVM 10, para as companhias abertas, e, ainda por cima, de regras mais severas do que as aplicáveis a todas as demais companhias, nos parece resultar em um ambiente totalmente inóspito para a atuação das instituições financeiras.

\footnotetext{
${ }^{307}$ As duras normas de Basileia III entraram em vigor em 01 de outubro de 2013 no Brasil e regulamentam de maneira extremamente minuciosa e abrangente a forma e as limitações de risco das instituições financeiras, estabelecendo um regime de tutela de credores - aqui incluídos os depositantes - muito mais robusto, detalhado e específico à sua atividade do que a tutela do capital social que, para instituições financeiras, tem menor relevancia, considerando-se o conceito de "capital regulatório" ou "patrimônio de referência".
} 


\subsection{Regime Contábil das Ações em Tesouraria}

A definição do regime contábil das ações em tesouraria passa necessariamente por uma análise de seu valor. As regras contábeis, em essência, são destinadas a refletir numericamente o valor intrínseco de ativos e passivos da sociedade nas suas demonstrações financeiras. Portanto, a pergunta fundamental para este item de nosso estudo é: qual o valor intrínseco das ações em tesouraria para a companhia?

Em uma perspectiva patrimonial abstrata, pode-se afirmar que o valor das ações é um reflexo do fato de que aos seus titulares é garantida uma participação no acervo social. Isso porque as ações, nesta concepção, têm valor porque se referem a bens reais do patrimônio da sociedade: são, na acepção de Ascarelli, "bens de segundo grau”, já que elas, apesar de representarem um bem distinto daqueles de propriedade da sociedade e de serem separadamente negociáveis, não operam uma milagrosa duplicação dos bens econômicos. Nesta acepção, as ações valem enquanto tiverem um suporte físico real.

À vista disso, o valor pago pela companhia, oriundo do patrimônio social, pelas ações de sua emissão anularia o valor intrínseco das ações, pois elas deixariam de representar uma quota-parte do acervo social em caso de liquidação, o que lhes daria, então, valor zero. "Se a sociedade emitente adquire as suas próprias ações, estas, ao permanecerem integradas ao patrimônio social, substituem os valores reais que até esse momento haviam representado. As acções próprias, porque reenviam para o patrimônio já existente da sociedade, nada lhe acrescentam de novo, comparando-as a generalidade da doutrina a espelhos que duplicam, mas não engrandecem, o patrimônio social. Enquanto forem detidas pela sociedade, não têm qualquer valor patrimonial autônomo"308.

Existe, no entanto, espaço para travarmos uma discussão teórica sobre isso: é bem verdade que o preço da ação reflete a consistência patrimonial e financeira de uma companhia, mas reflete igualmente outros fatores da sua atividade, como sua produtividade potencial futura (fluxo de caixa futuro) e até mesmo questões subjetivas ${ }^{309}$. Assim, o pagamento pela sociedade pela aquisição de suas próprias ações não extinguiria o valor destas, o que se poderia comprovar, v.g., pelo fato de que a companhia pode aliená-las e realizar o valor da venda, inclusive auferindo lucros. De todo modo, como as ações em

\footnotetext{
${ }^{308}$ Cf. Maria Victória Rodrigues, op. cit., p. 84. "Não sem razão formulou Thiel que as ações em tesouraria não incorporam mais um valor patrimonial. O valor patrimonial que outrora representavam foi pago pela companhia a título de preço de aquisição" Ou, no original: "Nicht ohne Grund formulierte Thiel, dass eigene Anteile keinen Vermögenswert mehr verkörpern. Das Vermögen, das sie einmal repräsentierten, wurde von der Gesellschaft beim Erwerb als Kaufpreis ausgezahlt". Cf. Alexander Kitanoff, op. cit., p. 56.

${ }^{309}$ Cf. Maria Victória Rodrigues, op. cit., p. 37, nota de rodapé 73.
} 
carteira remetem a uma situação de "papel contra papel" e não "papel contra bens" (como é a situação natural das ações em circulação), elas não podem possuir um valor patrimonial autônomo, mas apenas um valor futuro de realização (valor econômico ou valor de mercado), que apenas se concretiza no momento de sua alienação e que, como veremos abaixo, não pode ser economicamente contabilizado - as ações tornam-se, enquanto em poder da sociedade, "não-bens".

Na Alemanha, ainda que a Aktiengesetz de 1965 mencione, como já vimos, que uma operação legal de recompra de ações não configura um retorno indevido das entradas dos sócios, a discussão continuou em relação ao preço de sua aquisição: estabeleceu a doutrina que a situação excluída pela lei do regime da intangibilidade do capital social apenas seria aplicável caso o preço de aquisição das ações fosse "justo", ou seja, não existisse o pagamento de uma mais-valia às ações, o que, argumenta-se, representaria novamente um retorno ilegal de entradas aos acionistas, em contrariedade à vedação do $\$ 57$ da Aktiengesetz de 1965. Está aí o ponto de contato entre as duas discussões (valor da recompra e contabilização de ações em tesouraria): qual seria o "valor justo" da compra de ações próprias que possibilitaria o enquadramento na exceção ao $\$ 57$ e, portanto, que permitiria entender que não houve retorno indevido das entradas dos acionistas? A premissa do pensamento deve ser a de que as ações compradas devem necessariamente representar um bem dotado de valor à sociedade, pois, caso contrário, qualquer valor despendido seria considerado um irregular retorno de capital $^{310}$. A outra posição defendida na doutrina alemã é a de que essas ações não são bens econômicos aptos a serem contabilizados no ativo social, pois: (i) a mera expectativa de venda futura não seria passível de contabilização, (ii) um adquirente da companhia não estaria disposto a pagar por esses ativos, e (iii) a ausência de valor seria facilmente verificável em caso de liquidação da sociedade.

Tendo em vista essa discussão de valor, são duas as formas pelas quais se podem contabilizar as ações em tesouraria: (1) como uma forma redutora das disponibilidades livres da companhia, ou seja, em uma conta redutora de seu patrimônio líquido (o que

\footnotetext{
310 “A permissão de um negócio jurídico oneroso [entre a companhia e seus acionistas com as ações próprias] pressupõe que as ações detidas pela companhia representem um ativo patrimonial, um bem econômico. Se esse não fosse o caso, então qualquer ínfimo preço de aquisição seria considerado excessivo e apenas os negócios gratuitos seriam permitidos". No original: "Die Annhame eines Umsatzgeschäftes bedingt, dass eigene Aktie in der Hand der AG ein Vermögens- bzw. Wirtschaftsgut darstellen. Wäre dies nämlich nicht der Fall, wäre jeder noch so geringe Erwerbspreis bereits zu viel und nur der unentgeltliche Erwerb wertädaquat". Segundo o autor, a literatura e a jurisprudência aceitam que as ações em tesouraria possuem valor autônomo para a companhia, especialmente considerando o seu potencial de alienação. Cf. Alexander Kitanoff, op. cit., pp. 51 e 52.
} 
reflete, a nosso ver, com maior clareza a sua natureza, devido ao valor intrínseco que - não - possuem para a companhia), ou (2) podem ser refletidas nas demonstrações financeiras como ativos. Neste último caso, o valor financeiro do balanço permanece idêntico, há apenas uma troca de um bem por outro (dinheiro por ações). Na primeira forma, há uma efetiva redução do valor contábil do balanço. A opção por uma ou outra maneira de contabilização pode ser mais ou menos eficiente na proteção dos interesses dos credores.

A contabilização no ativo do balanço é a forma clássica. $\mathrm{Na}$ ausência de limites objetivos pela lei, a mera contabilização como ativo da companhia, expressando que a recompra de ações equivale à troca de um bem por outro, poderia gerar uma série de inconvenientes práticos, mormente o de esgotar totalmente seu patrimônio apenas por meio de recompra de ações, tornando-se a companhia uma casca desprovida de valor em situação de falência que, no entanto, continuaria demonstrando em sua contabilidade a existência de ativos. Não foi por outra razão que surgiu na Alemanha, em 1931, o limite objetivo de detenção de, no máximo, $10 \%$ do capital social em tesouraria. Na época, não havia a regra da utilização apenas do saldo de lucros e reservas disponíveis, de modo que seria possível a ela o esgotamento completo de seu patrimônio por meio de aquisições de ações próprias $^{311}$. Dessa discussão exsurgiu a técnica contábil compensatória de, além de contabilizar esses valores no ativo, criar-se uma reserva indisponível no passivo, deduzindo-se da conta de lucros e reservas disponíveis valor equivalente ao das ações “ativadas”, limitando o saldo de valores passíveis de distribuição aos acionistas. O saldo dessa nova reserva tinha uma destinação muito limitada.

A mera contabilização como ativo social (sem criação de reserva indisponível em montante equivalente) traria algumas incongruências. Isto pode ser demonstrado por meio de um simples exemplo numérico: uma sociedade com $\mathrm{R} \$ 1.000,00$ de capital social, dividido em 1.000 ações de $\mathrm{R} \$ 1,00$ de valor nominal, $\mathrm{R} \$ 500,00$ de lucros acumulados e $\mathrm{R} \$ 1.500,00$ de caixa decide adquirir 250 ações de sua emissão, pelo valor nominal. Os balanços, antes e depois da operação, poderiam ser assim demonstrados:

BALANÇO

\begin{tabular}{llllll} 
Antes: & Ativo & Patrimônio Líquido & Depois: & Ativo & Patrimônio Líquido \\
Caixa & $1.500,00$ & & $1.250,00$ & - \\
Ações em Tesouraria & - & - & 250,00 & - \\
Capital Social & - & $1.000,00$ & - & $1.000,00$ \\
Reserva de Lucros & - & 500,00 & & - & 500,00 \\
\cline { 2 - 3 } Total & $\mathbf{1 . 5 0 0 , 0 0}$ & $\mathbf{1 . 5 0 0 , 0 0}$ & & $\mathbf{1 . 5 0 0 , 0 0}$ & $\mathbf{1 . 5 0 0 , 0 0}$
\end{tabular}

${ }^{311}$ Alexander Kitanoff, op. cit., p. 97. Posteriormente, foi introduzida a exigência da utilização de lucros e reservas, mas não foi excluído o limite de $10 \%$, que existe até hoje, muito embora a Diretiva Alteradora o tenha facultado. 
Se as ações acima fossem contabilizadas no ativo social, teríamos uma efetiva diminuição do capital social, sem que isso fosse adequadamente evidenciado nas demonstrações financeiras, pois as ações contabilizadas no ativo são também elementos do capital social, de que fazem parte por definição. Elas seriam contadas duas vezes nas demonstrações financeiras. Isso se verifica com clareza caso fosse inserida no balanço da sociedade acima uma redução de capital no valor de $\mathrm{R} \$ 250,00$; essa operação seria efetuada com meros ajustes contábeis, sem fluxo de caixa, o que indica que o capital social já estava efetivamente reduzido:

\begin{tabular}{lll} 
BALANÇO & Ativo & $\begin{array}{l}\text { Patrimônio } \\
\text { Líquido }\end{array}$ \\
Caixa & $1.250,00$ & - \\
Capital Social & - & 750,00 \\
Reservas & - & 500,00 \\
\cline { 2 - 3 } & $\mathbf{1 . 2 5 0 , 0 0}$ & $\mathbf{1 . 2 5 0 , 0 0}$
\end{tabular}

A $2^{\text {a }}$ Diretiva, no artigo 22, n. ${ }^{\circ}$, alínea (b), impunha aos Estados-Membros da União Europeia que optassem pela ativação das ações próprias, para compensar esse efeito negativo, que criassem uma reserva indisponível no patrimônio líquido da companhia em montante equivalente. Na prática, a norma visava a desestimular que as ações fossem contabilizadas como ativos, aptas, assim, a cobrirem o vínculo de indisponibilidade representado pelo capital social nominal. No entanto, essa medida pretendida pelo legislador comunitário poderia provar-se inócua aos fins a que se propunha, eis que uma reserva indisponível, por mais que efetivamente aumentasse o vínculo de indisponibilidade dos ativos sociais, seria consumível por perdas e prejuízos correntes. A Lei das S.A., nesse sentido, é bastante clara ao prever que as reservas (sejam elas disponíveis ou indisponíveis) sempre serão utilizadas para cobrir prejuízos correntes da sociedade: (i) no artigo 200, I, consta essa previsão para a reserva de capital, (ii) o artigo 189, parágrafo único, contém a regra máxima de que o prejuízo do exercício será obrigatoriamente absorvido pelos "lucros acumulados", pelas reservas de lucros e, até mesmo, pela intocável reserva legal (absorver prejuízos é uma de duas situações em que essa reserva pode ser usada - a outra é a incorporação ao capital social, conforme artigo $193, \S 2^{\circ}$ ), nessa ordem. Ou seja, a reserva indisponível prevista na $2^{\text {a }}$ Diretiva pode (e deve) ser integralmente consumida por prejuízos que a sociedade sofra, anulando o seu efeito. A saída seria a contabilização 
dessas ações fora do ativo social ou a criação de uma conta específica (não denominada de reserva), que não fosse sujeita à delapidação por prejuízos sociais ${ }^{312}$.

$\mathrm{Na}$ Alemanha, a regra de contabilização anterior à atual contemplava esta primeira concepção (ativo social com concomitante criação de reserva indisponível), o que era visto como uma forma incoerente de contabilizar o "valor nulo" dessas ações. A regra atual do Handelsgesetzbuch, modificada pela Gesetz zur Modernisierung des Bilanzrechts (Bilanzrechtsmodernisierungsgesetz - BilMoG), de 25 de maio de 2009, alterando a anterior, prevê, no novo \$272, Abs. 1(a), que o valor das ações recompradas seja efetivamente reduzido da cifra nominal do capital social, e não mais contabilizado no ativo social. Essa mesma lei retirou as ações próprias da lista de contas do ativo estabelecida no $\S 266$ do Handelsgesetzbuch.

A segunda forma conhecida de contabilização de ações próprias é aquela que prevê uma redução, no montante e valor da aquisição, diretamente de contas do patrimônio líquido, ao invés de serem postas no ativo as ações recompradas. Dois são os métodos de dedução desses valores: o cost method e o par value method. O primeiro, mais simples, reproduz a contabilização das ações em tesouraria pelo seu custo de aquisição, ignorando o valor nominal ou o preço de emissão original da ação, por meio da criação de uma conta redutora de patrimônio líquido chamada "ações em tesouraria". O método do par value, um pouco mais complexo, traduz também deduções de contas do patrimônio líquido, mas de maneira distribuída entre as contas respectivas: deduz-se o valor nominal da conta de capital social e o restante do saldo de lucros e reservas.

No Brasil, de acordo com o art. 178, $2^{\circ}$, III, da Lei das S.A., divide-se o patrimônio líquido da companhia nas seguintes contas: capital social, reservas de capital, ajustes de avaliação patrimonial, reservas de lucros, ações em tesouraria e prejuízos acumulados. Já o artigo $182, \S 5^{\circ}$, reza que as ações em tesouraria deverão ser destacadas no balanço como dedução da conta do patrimônio líquido que registrar a origem dos recursos aplicados na sua aquisição (exceto, é claro, no caso de recebimento das ações por negócio gratuito ${ }^{313}$ ). Portanto, vê-se que a Lei das S.A. adota o conceito de

\footnotetext{
${ }^{312}$ No mesmo sentido, Maria Victória Rodrigues, citando Ianuzzi, op. cit., pp. 64 e 65, nota de rodapé 126.

${ }^{313}$ Para estas, a Lei das S.A. não dá orientações quanto à sua contabilização. Segundo alguns autores, as ações em tesouraria recebidas por negócio jurídico gratuito deveriam ser contabilizadas no ativo da companhia, sem dedução de seu custo de aquisição, e seu valor passará a integrar o patrimônio social. Preferimos que todas as ações sejam contabilizadas em conta redutora de patrimônio líquido, e não como ativo social, em decorrência de que, mesmo não tendo havido saída de recursos da companhia, as ações em tesouraria ainda assim possuem a mesma natureza de "não-bens" para a sociedade, o que dificilmente se coaduna com a sua contabilização no ativo social. Discordamos, portanto, de Carlos Eduardo Bulhões, op. cit., p. 36.
} 
contabilização das ações em tesouraria como dedução direta do patrimônio líquido refletindo a visão de que não há, na operação, uma efetiva troca de "bens contra bens" -, por meio do método de custo de aquisição ${ }^{314}$, mantido inalterado o capital social. Se uma companhia decide, por exemplo, utilizar uma reserva estatutária de lucros para realizar uma recompra de ações, então o balanço fictício dessa sociedade poderia ser assim representado:

\begin{tabular}{|c|c|c|}
\hline \multicolumn{3}{|l|}{ PATRIMÔNIO LÍQUIDO } \\
\hline \multicolumn{2}{|c|}{$\begin{array}{l}\text { CAPITAL SOCIAL } \\
100.000 \text { ações de valor nominal de } \mathrm{R} \$ 10,00 \text {, integralizadas }\end{array}$} & $1.000 .000,00$ \\
\hline \multicolumn{2}{|c|}{ RESERVAS DE LUCROS } & $450.000,00$ \\
\hline Reserva Legal & & $300.000,00$ \\
\hline $\begin{array}{l}\text { Reserva Estatutária } \\
\text { Ações em Tesouraria - } 10.000 \text { ações ao } \\
\text { custo de aquisição de } \mathrm{R} \$ 150,00 \text { cada }\end{array}$ & $\begin{array}{l}300.000,00 \\
(\mathbf{1 5 0 . 0 0 0 , 0 0 )}\end{array}$ & \\
\hline \multicolumn{2}{|l|}{ PATRIMÔNIO LÍQUIDO } & $\mathbf{1 . 4 5 0 . 0 0 0 , 0 0}$ \\
\hline
\end{tabular}

Para as companhias abertas, o artigo 17 da Instrução CVM 10 complementa a Lei das S.A., prevendo, igualmente, que as ações em tesouraria devem ser destacadas no balanço como dedução da conta do patrimônio líquido que registrar a origem dos recursos aplicados na sua aquisição (redação igual à da lei), exceto na hipótese de doação (rectius: qualquer negócio gratuito - art. 20, “d”, da Instrução CVM 10), e contabilizadas pelo valor do custo desta operação (redação complementar e que reflete o cost method de que falamos).

A contabilização da alienação de ações em tesouraria não possui tratamento na Lei das S.A., apenas na Instrução CVM 10, mas sua disciplina é aplicada indistintamente para companhias abertas ou fechadas.

A operação gerará um ganho ou uma perda, dependendo do valor que as ações possuam no momento da alienação, comparado com o custo de sua aquisição. No entanto, essas operações não interagem com a demonstração de resultados da companhia, esclarecendo o artigo 18 da Instrução CVM 10 e a doutrina contábil que a referida alienação não deve ser contabilizada como lucro ou prejuízo do exercício ${ }^{315}$. Havendo "lucro" na alienação, então esse sobre-valor deverá ser contabilizado como "reserva de capital”, em conta específica (art. 18, “a”, da Instrução CVM 10), pois ele se assemelharia

\footnotetext{
314 “A operação de compra de ações pela própria companhia é como se fosse uma devolução de patrimônio líquido, motivo pelo qual a conta que as registra (devedora) deve ser apresentada como conta redutora do patrimônio". Cf. Sérgio de Iudícibus et al., Manual de Contabilidade Societária, Atlas, São Paulo, 2010, pp. 361 a 363.

${ }^{315}$ Cf. Sérgio de Iudícibus et al., op. cit, p. 363.
} 
a um ágio na emissão de ações novas ${ }^{316}$. Havendo "prejuízo", "tal diferença deverá ser debitada na mesma conta de reserva de capital que registrou lucros anteriores, até o limite de seu saldo, e o excesso (prejuízos apurados nas transações superiores aos lucros já registrados) deverá ser considerado a débito da própria conta de reserva que originou os

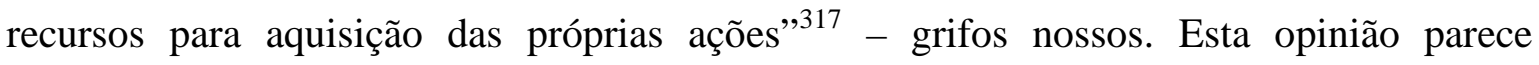
contradizer a letra do art. 18, "b”, da Instrução CVM 10, segundo o qual o saldo negativo deverá ser contabilizado sempre a débito das contas de reservas de lucros que registrarem a origem dos recursos aplicados em sua aquisição.

A companhia aberta (não há semelhante obrigação para as fechadas) deverá, nos termos do art. 21 da Instrução CVM 10, evidenciar, em notas explicativas às suas demonstrações financeiras, diversos dados a respeito das aquisições de suas próprias ações. O escopo da existência de um grau de disclosure maior sobre estas operações, é o de permitir que os investidores tenham informações detalhadas sobre os objetivos, prazos, volumes e valores envolvidos, fazendo seu juízo de valor quanto às motivações e eficácia das recompras para a companhia em que investem, sem contar que poderão avaliar a presença de algum tratamento privilegiado a acionistas.

Na nossa visão, apesar de ser possível imaginarmos um valor futuro nas ações em tesouraria (pela sua alienação no mercado), é igualmente verdade que, sob diversos prismas, as ações em tesouraria não podem representar um ativo social: (i) no comércio, essas ações terão valor zero, pois nenhum adquirente racional iria considerar qualquer desembolso de dinheiro para aquisição das ações em tesouraria da sociedade, (ii) na liquidação da companhia, é impossível cogitar-se de uma distribuição do acervo líquido para as ações em tesouraria, o que afasta a determinação de um valor de liquidação para esses papeis, (iii) do ponto de vista do cálculo do valor da ação, considerando seu fluxo de dividendos futuro, também não seria possível a identificação de um valor à ação em tesouraria, já que ela tem os seus direitos aos dividendos suspensos pela lei, (iv) ademais, admitir valor autônomo a esses papeis nas demonstrações contábeis seria permitir que, pelo cancelamento das ações em tesouraria, existisse uma destruição autófaga de patrimônio social, o que não seria racional. Por fim, como argumento fatal, nem mesmo a

\footnotetext{
${ }^{316}$ Apesar de já termos esclarecido que não há que se falar em extinção das ações em tesouraria, devido à teorização da sociedade sócia de si mesma, não é de todo descabida a comparação contábil ao ágio na emissão de novas ações. Nos Estados Unidos da América, o §6.31(a) do Revised Model Business Corporation Act estabelece que as ações em tesouraria sejam equiparadas ao que nos pareceria corresponder a um capital autorizado: "\$6.31. A corporation may acquire its own shares, and shares so acquired constitute authorized but unissued shares" - grifos nossos. A alienação dessas ações, portanto, equivaleria a uma nova emissão.

${ }^{317}$ Cf. Sérgio de Iudícibus et al., op. cit, p. 363.
} 
possibilidade de alienação futura pode ser usada como argumento a favor da contabilização desses papeis como ativo social: ora, se até hoje ninguém se propôs a contabilizar o capital autorizado como ativo social, o argumento de que as ações em carteira representariam um "potencial capital futuro" não poderia, por si só, prevalecer - além do que, seria extremamente difícil avaliar economicamente essa expectativa. De todos esses ângulos, essas ações não representam um bem econômico apto a ser contabilizado como ativo social.

Como conclusão, podemos afirmar, portanto, que as ações em tesouraria são bens jurídicos existentes, mas desprovidos de valor econômico para a companhia, apenas papel emitido sem substrato fático real, e que, desse modo, a forma de contabilização mais adequada a elas não é no ativo, mas por meio de uma conta redutora de patrimônio líquido, que é efetivamente como hoje são tratadas no Brasil e em outros países ${ }^{318}$.

Todo o afirmado, em hipótese alguma, pode ser confundido com uma suposta total ausência de valor das ações entesouradas: para terceiros, elas podem possuir valor, assim como qualquer outra ação. $E$ isso se verifica de forma muito clara quando analisamos os casos em que a companhia utiliza suas ações em tesouraria como moeda de pagamento, ou em permuta, por ações de outras companhias em operações de concentração societária - situação que, como se verá oportunamente, já foi avaliada no Brasil em alguns casos concretos. Se as ações em tesouraria fossem desprovidas de qualquer valor, para quaisquer pessoas, essa moeda de pagamento certamente não seria aceita pelas contrapartes. Ademais, reconhecida a existência de valor econômico das ações em tesouraria na perspectiva de terceiros, as ações permanecem, igualmente assim, com um valor “organizativo", uma vez que se prestam a reestabelecer o vínculo jurídico-societário com futuros acionistas que venham a adquirir essas ações ${ }^{319}$.

Este pensamento tem uma consequência interessante: a companhia pode dar as suas ações em garantia de uma dívida sua a terceiros - como em alienação fiduciária, por exemplo -, que aceitarão essa garantia por sua conta e risco (o objeto desta garantia e o seu valor estão diretamente ligados à saúde da própria devedora). Caso a companhia descumpra qualquer obrigação, então os credores poderão simplesmente tomar as ações e

\footnotetext{
318 "Quindi, l'acquisto si resolve sempre nell'attribuzione a un azionista di fondi sociali, senza corrispondente entrata, nel patrimonio della società, di valori (beni) idonei alla copertura del capital (ed è in tal senso che esattamente si è affermato che le azioni proprie acquistate dalla società "non hanno più alcun valore per sé stesse”". Cf. Scotti Camuzzi, Acquisto delle..., cit., pp. 624 e 625.

319 “(...) a me sembra che la prospettiva ricostruttiva più corretta, perché, ripeto, indotta dal Legislatore del codice, sia quella di attribuire alle azioni proprie in portafoglio prima ed innanzitutto un valore 'organizzativo' (...), piuttosto che non un concreto valore essenzialmente o prevalentemente patrimoniale". Cf. Paolo Ferro-Luzzi, L'<<autopofagia〉>..., cit., p. 1287.
} 
vendê-las no mercado, onde elas terão valor intrínseco e patrimonial como qualquer outra, retomando sua eficácia plena (enquanto não houver inadimplemento, as ações permaneceriam em tesouraria). Novamente, este caso não nos parece ferir, a priori, os grupos de referência e interesses protegidos (uma aprovação da assembleia geral resolvendo sobre a forma da garantia, o preço e a maneira de alienação das ações em caso de inadimplemento, parece suficiente para a tutela dos acionistas), merecendo ser acolhida a possibilidade.

\subsection{Consequências Civis das Operações da Anônima com Ações de Seu Capital em Infração à Lei}

A realização de um negócio, pela companhia, com ações de sua emissão em situação não expressamente permitida pela lei é sempre nula ou, ao contrário, sempre anulável ou, ainda, nula ou anulável dependendo da situação concreta que se vislumbre? Esta é a pergunta que trataremos de explorar neste item.

Parte da doutrina, aqui incluída a opinião de Philomeno J. da Costa, entende que seriam sempre nulos esses negócios ${ }^{320}$. Argumenta-se que o Código Civil dispõe no (atual) artigo 166, II, que: "É nulo o negócio jurídico quando: II - for ilícito, impossível ou indeterminável o seu objeto;" - redação muito semelhante àquela do artigo 145, II, do Código Civil de 1916. Segundo Philomeno J. da Costa, todos aqueles negócios que as sociedades fizerem com as próprias ações, salvo aqueles que a própria lei admite, são ilícitos e, portanto, nulos.

O que se dá, por outro lado, quando da operação, ainda que formalmente descumprindo a lei, não resulte nenhum prejuízo para a companhia ou, melhor dizendo, quando da operação decorram até mesmo lucros para ela? Sabe-se, a esta altura, que a ratio legis de todas estas proibições é a de proteger (primeiramente) a intangibilidade do capital social enquanto garantia dos credores e, nestes casos, não haveria ofensa ao objetivo que inspirou a lei, já que o capital social permaneceria íntegro - fomentou-se, inclusive, aumento patrimonial. Então, a pergunta justifica-se: se não há, ao menos à primeira vista, afronta à ratio legis defendida pelo preceito normativo, por que haveria de lhe ser culminada a pena de nulidade nestes casos?

Parte da doutrina tradicional obtempera que, tal qual nos delitos formais, a lei não exige a existência de efetivo prejuízo para sancionar com a nulidade o negócio e, assim,

\footnotetext{
${ }^{320}$ Philomeno J. da Costa, op. cit., p. 38.
} 
mesmo em situações em que haja lucro para a companhia, dever-se-ia defender a nulidade do negócio, tendo em vista que, em essência, estaria sendo atacada a intangibilidade do capital social no exato momento em que retirada parcela do patrimônio social, em prejuízo da cifra de retenção mínima, para pagar pela aquisição das ações. Independentemente de serem auferidos lucros em momento futuro, naquele intervalo temporal entre a aquisição e a venda (apenas na venda se aufere o lucro), existiria um prejuízo para os credores sociais. Philomeno J. da Costa utiliza até mesmo a expressão "prática arriscada e amoral"321, referindo-se aos negócios, defendendo sempre a sua nulidade, fundamentando-se no fato de que não é condição para a nulidade de um negócio jurídico a existência de prejuízos efetivos.

O tema é realmente sujeito a muitas discussões, inclusive do ponto de vista histórico. Na Itália, até a promulgação do Codice Civile de 1942, havia um vácuo jurídico neste ponto: o Código Comercial Italiano de 1882 não previa explicitamente qual seria a consequência civil em caso de irregularidade na aquisição das próprias ações (cujas condições de validade estavam no art. 144, como dissemos), previa apenas uma sanção penal direcionada aos administradores (no art. 247). Nessa situação, coube à doutrina a exegese. E ela foi extremamente diversificada. Alguns autores da época sustentavam que não haveria consequências civis para essa irregularidade, dado que, textualmente, a lei dava apenas uma consequência de caráter penal. Segundo outros autores, de outra sorte, essas operações seriam sempre nulas ${ }^{322}$.

Quando a Itália publicou o Codice Civile de 1942, cujas linhas gerais de tratamento da problemática já vimos acima, as consequências civis em caso de irregularidade/ilegalidade, não foram, novamente, abarcadas pela lei (permaneceu apenas a sanção penal), retornando, mais uma vez, à doutrina italiana o ônus de enfrentar a espinhosa questão. Entendia-se, majoritariamente, que as operações praticadas em desconformidade com as condições da lei (que estavam originalmente apenas no art. 2.357) seriam sempre nulas, já que contrariariam norma imperativa ${ }^{323}$. Todavia, não faltaram

\footnotetext{
321 "[I]sto é, o patrimônio da sociedade responsável ou devedora decresceu na exata medida do total do valor das ações próprias figurantes no ativo social". Philomeno J. da Costa, op. cit., p. 40. Releva advertir que a redação comentada pelo autor é a do artigo 15 do DL 2.627/40, que não permitia expressamente as compras de ações para manutenção em tesouraria. Isso faz com que sua argumentação perca força, pois não é verdade que qualquer saída de parcela patrimonial da companhia destinada à compra de suas ações represente um prejuízo para as garantias de credores, mas apenas aquela parcela que saia em prejuízo do montante mínimo de ativos necessário para cobrir a cifra nominal do capital social.

${ }^{322}$ Cf. Barbara Pozzo, op. cit., p. 185.

323 “(...) il vecchio art. 2357 non prevedeva nessuna specifica conseguenza civile. La letteratura largamente prevalente - constatata l'indubbia natura imperativa del disposto nell'art. 2357 - trovava naturale rifarsi all'instituto generale della nullità ex art. 1418, comma 1, c.c. con il conseguente richiamo alla disciplina
} 
vozes defendendo que a consequência civil deveria ser de anulabilidade ou de "nulidade relativa" ou "nulidade virtual", posto que não poderia, tecnicamente, falar-se em nulidade absoluta por violação a norma imperativa, quando a norma do Codice Civile não o era pelo contrário, silenciava. No Judiciário, relata-se uma decisão de 1968 na qual o juiz avaliou as sanções civis de acordo com o requisito que não fora observado: ocorrido o negócio sem autorização da assembleia, então seria ele anulável, por falta de poderes da administração, enquanto seria nulo se não observasse os requisitos objetivos impostos à sociedade (como a utilização de saldo de lucros) ${ }^{324}$.

Em 1974, antes, portanto, da introdução da Segunda Diretiva, a Itália sofreu uma minirreforma do direito societário, tendo sido introduzido o então art. 2.359-bis (hoje art. 2.359-ter), que tratava principalmente das participações recíprocas, mas que introduzia, de maneira interessante, a inusitada consequência civil da "obrigatoriedade de alienação" das ações adquiridas em desconformidade com os preceitos estabelecidos pela lei - nenhuma outra lei nacional continha essa previsão até esse momento, nem mesmo a alemã. "L'acquisto illegittimo veniva dunque sanzionato non nei modi tradizionali della nullità o dell'annulabilità, ma mediante un obbligo di alienazione, da realizzarsi se del caso coativamente" - grifos do original ${ }^{325}$. Alguns autores passaram a estender esse tratamento a qualquer operação envolvendo ações próprias, não apenas àquelas inseridas em um contexto de participações recíprocas. Dois anos depois, para felicidade do legislador italiano, a Segunda Diretiva acolheu este mesmo conceito de consequência civil, nos art. 20 e 21. Em ambos os casos, passado o prazo ali mencionado para a venda dessas ações, a consequência é o seu cancelamento (artigo $21 \mathrm{c} / \mathrm{c}$ artigo 20, n. ${ }^{\circ}$ 3), que será obrigatoriamente acompanhado de redução do capital social, na hipótese em que essas aquisições tenham sido feitas em prejuízo do capital social.

Talvez o assunto mais interessante tratado na Segunda Diretiva seja este. De fato, as regras que essa norma comunitária desenhou a respeito são profundamente diversas daquelas que os vários ordenamentos nacionais continham até aquele momento, não tendo

pure di ordine generale propria di tale sanzione". Cf. Aldo Angelo Dolmetta, Sulle Conseguenze Civilistiche dell'Acquisto di Azioni Proprie Compiuto in Violazione dei Divieti di Legge, in Rivista delle Società, Vol. 41, n. ${ }^{\circ} 2 / 3$, março-junho de 1996, p. 340, citando extensa bibliografia.

${ }^{324}$ Cf. Barbara Pozzo, op. cit., pp. 189 a 192.

${ }^{325}$ Cf. Barbara Pozzo, op. cit., p. 194. Assim se manifestou Antonio Albanese sobre o tema: "[s]e una delle quattro condizioni citate à violata, l'atto di acquisto rimane valido: in tal modo, si salvaguarda l'interesse del mercato alla rapida e sicura circolazione dei titoli azionari. Le conseguenze dell'operazione illegittima sono pertanto diverse e peculiari: le azioni acquistate devono essere alienate (secondo modalità da determinarsi dall'assemblea) entro un anno dal loro acquisto". Cf. Antonio Albanese, Operazioni..., cit., p. 357. 
o legislador comunitário se valido do tradicional regime das invalidades dos negócios. Ele criou regime alternativo, ao estabelecer como sanção civil para as aquisições em contrariedade à lei, a obrigação de realizar um ato inverso àquele que foi realizado de forma ilegítima, cuja validade não seria contestada. "L'eliminazione degli effetti dell'atto di acquisto illegitimo non si persegue più intervenendo sulla sua validità, ma imponendo di compiere, entro un dato termine, un nuovo atto in senso inverso" ${ }^{, 326}$. O artigo $21 \mathrm{da}$ Segunda Diretiva estipula a consequência de que as ações adquiridas contrariamente ao permitido nos artigos 19 ou 20 devam ser alienadas no prazo de um ano a contar da data da aquisição ilegítima. Afirmamos que este é talvez o assunto mais interessante da Segunda Diretiva, pois nenhuma outra legislação europeia previa consequência semelhante - todas lidavam com o regime tradicional das invalidades, em maior ou menor extensão. É, portanto, de reconhecer-se que, no tocante a este assunto, está-se diante da criação de uma regra europeia em sentido próprio, criada ad hoc, que visava a harmonizar os efeitos de tais negócios ilegítimos em diversos países, que claramente o disciplinavam de formas múltiplas $^{327}$.

Na Alemanha, a lei de adequação à $2^{a}$ Diretiva, de 1978, recepcionou o regime de sanções estabelecido na norma comunitária, introduzindo essa categoria de consequências civis na sua legislação. A mudança mais decisiva sobre a legislação alemã anterior foi, sem dúvida, no quesito das sanções ${ }^{328}$. A partir daqui, o sistema alemão de sanções passou a prever que, tanto as ações adquiridas licitamente, mas em excesso ao limite de 10\%, quanto aquelas adquiridas em contrariedade à lei (ex.: à custa de capital), estariam sujeitas à obrigação de alienação. Em ambos os casos, se não forem alienadas nos prazos prescritos pela lei (um ano para as ações ilegitimamente adquiridas e 3 anos para as que superem o limite), então serão elas canceladas pela companhia, com a consequente redução do seu capital (nos termos do §71c, introduzido por esta lei de 1978). Releva o aprofundamento: o §71a, Abs. 4 da Aktiengesetz (cuja redação é a mesma desde 1978) declara que os negócios obrigacionais de aquisição das próprias ações em contrariedade à lei serão nulos ("ein schuldrechtliches Geschäft über den Erwerb eigener Aktien ist jedoch nichtig, soweit der

\footnotetext{
${ }^{326}$ Cf. Barbara Pozzo, op. cit., p. 235.

${ }^{327}$ Cf. Barbara Pozzo, op. cit., p. 248. No Reino Unido, por exemplo, o Companies Act de 1985, promulgado pouco depois da entrada em vigor da $2^{\text {a }}$ Diretiva, continuou prevendo a sanção de nulidade, cumulada com multa à companhia e consequências penais aos administradores (cf. Section 143(2) da norma, dizendo que a aquisição em contrariedade à lei seria void).

${ }^{328} \mathrm{O}$ que é reconhecido pelo próprio legislador alemão: "A decisiva diferença em comparação ao direito alemão vigente é, no entanto, relacionada às sanções". No original: "Der entscheidende Unterschied zum geltenden deutschen Recht liegt jedoch in den Sanktionen". Cf. Gesetztezentwurf der Bundesregierung zur Durchfürung..., cit., p. 14.
} 
Erwerb gegen die Absätze 1 oder 2 verstö $\beta t ”)$. Como conciliar as duas disposições? Segundo a doutrina alemã, o que se criou com a lei de 1978, no que tange às sociedades anônimas foi um sistema dual de sanções: a companhia pode escolher o retorno ao status quo ante (de acordo com a regra de que o negócio obrigacional é nulo e conforme as disposições do Bürgerliches Gesetzbuch), mediante devolução das ações ao acionista que as queira receber, ou ela pode optar pela alienação delas, nos termos do §71c da Aktiengesetz ${ }^{329}$.

A conceituação de uma nova modalidade de revogação dos efeitos desses negócios jurídicos, desligada das tradicionais categorias das invalidades, tem como motivação o fato de que os efeitos da invalidade do negócio jurídico são, geralmente, representados pela aplicação do princípio geral de retorno das partes ao status quo ante (art. 182 do Código Civil). Transposto o princípio para nosso objeto de estudo, vislumbramos um sem-fim de questionamentos extremamente complexos e de difícil, ou impossível, resolução. Tradicionalmente, entendia a doutrina que o princípio do retorno ao status quo ante deveria ser observado também nestes casos ${ }^{330}$, ou seja, a companhia devolveria as ações adquiridas contra a lei ao acionista que as vendeu e receberia de volta o preço das ações pagas. Em se defendendo esta posição, perguntar-se-ia se o estado de espírito do acionista teria, então, o condão de afastar a sua responsabilidade por devolver o preço recebido; afinal, ele nem sempre teria condição ou conhecimento da saúde financeira da companhia suficiente a ponto de entender se ela poderia ou não adquirir as próprias ações - hoje, especialmente, deveria o acionista ter conhecimento contábil para avaliar a composição do patrimônio líquido dela. Muito embora se possa argumentar com a existência dos instrumentos técnico-jurídicos necessários para que os acionistas façam tal avaliação, é inegável que a vasta maioria deles não conseguiria, do ponto de vista prático, valer-se de tais instrumentos. Em outras palavras, surgiria a pergunta sobre se a lei deveria proteger o acionista vendedor de boa-fé, como o protege com relação à distribuição de dividendos, nos termos do art. $201, \S 2^{\circ}$, da Lei das S.A.

Para mais, a aplicação do regime geral das invalidades nos levaria a enfrentar a questão sobre quem deveria arcar com eventuais prejuízos ou se beneficiar de eventuais ganhos na diferença de cotação das ações, entre um e outro momento. Exemplificamos: um negócio de recompra de ações de uma companhia é declarado nulo, sendo a sociedade condenada a devolver aos acionistas as ações que comprara a $\mathrm{R} \$ 10,00$ (com consequente

\footnotetext{
${ }^{329}$ Cf. Barbara Pozzo, op. cit., p. 311.

${ }^{330}$ Philomeno J. da Costa, op. cit., p. 41.
} 
saída patrimonial no valor de $\mathrm{R} \$ 10,00$, multiplicados pela quantidade de ações adquiridas) e os acionistas vendedores, por sua vez, a restituírem a ela os $\mathrm{R} \$ 10,00$ por ação que venderam. Hoje, na data de "retorno" ao status quo ante, as ações estão valendo $\mathrm{R} \$ 50,00$ no mercado. Pergunta-se: os acionistas deveriam ser beneficiados por este aumento de valor ou deveriam "recompor" o valor a ser devolvido à companhia com a diferença das duas cotações (em outras palavras, devolver à companhia não só os $\mathrm{R} \$ 10,00$ recebidos originalmente, mas também os $\mathrm{R} \$ 40,00$ de diferença)? A pergunta é muito capciosa e de difícil resposta, pois afinal, é possível, nesta esteira, que a decretação de nulidade de uma compra de ações pela companhia resulte em perda patrimonial a ela de ainda maior vulto (pela devolução de ações em tesouraria a um preço muito abaixo do de mercado no momento), hipótese que a decretação da nulidade, em tese, busca exatamente evitar! Ao mesmo tempo, do ponto de vista do acionista vendedor, especialmente se estivesse de boafé desde o início, não deveria a ele ser imposto qualquer prejuízo.

E ainda, especificamente no caso das companhias abertas, como defender a aplicação irrestrita da teoria geral das invalidades quando o acionista vendedor, em bolsa, sequer tem condições de saber quem é sua contraparte - no caso, a companhia emissora? Realmente, podem-se visualizar situações patológicas bastante bizarras, nas quais os acionistas vendedores em bolsa seriam chamados a devolver os recursos recebidos e aceitar de volta as ações de que se haviam desfeito. É imprescindível que a doutrina e a jurisprudência levem todos estes pontos em consideração na estruturação dos efeitos das invalidades no que tange às operações com as próprias ações.

É, aliás, justamente na tutela dos acionistas alienantes de boa-fé que a Segunda Diretiva parece ter encontrado a sua fundamentação para a introdução do novo regime das consequências civis. Segundo Barbara Pozzo: "la validità del contratto d'acquisto consentirebbe di eliminare in maniera probabilmente più profícua l'annacquamento patrimoniale provocato da un acquisto illegittimo, tutelando in tal modo le ragioni dei creditori sociali. Dovendo scegliere tra il tentativo di recuperare in via giudiziale la somma versata per l'acquisto di azione proprie, e la possibilità di vendere tranquillamente tali azioni sul mercato (...) non vi sarebbero dubbi: la seconda soluzione potrebbe senz'altro tutelare maggiormente i terzi creditori”, ${ }^{331}$. E ainda, segundo Dolmetta: “al fondo [da adoção de nova categoria de consequências civis] sta evidentemente il convencimento (il suo emergere e rafforzarsi) che non sempre (oppure: non in determinate

${ }^{331}$ Cf. Barbara Pozzo, op. cit., p. 238. 
situazioni) la sanzione della nullità si manifesta il remedio migliore, ma finisce per essere eccessivo, se non controproducente" ${ }^{332}$.

O exame desta questão tem importância fundamental para as companhias abertas, pois a teoria das nulidades no direito societário apresenta aspectos de grave complexidade. Como se sabe, mas nunca é demais rememorar, nem sempre o regime jurídico das nulidades e anulabilidades estabelecido para o direito comum (Código Civil) pode ser facilmente replicado para o direito societário. As questões que precisam ser respondidas, portanto, são: (i) os negócios com as próprias ações, realizados em desconformidade com as regras da lei, são nulos, anuláveis ou apenas ineficazes? Ou, ainda, válidos, mas sujeitos a procedimentos especiais de anulação (aqui em sentido vulgar) dos efeitos produzidos? (ii) qual a consequência jurídica (efeitos) da nulidade ou anulabilidade desses atos - o retorno ao status quo ante, a indenização em caso de impossibilidade de retorno ou uma consequência especial?

A noção de que o direito societário pode, por vezes, adotar um regime jurídico de invalidades diferente do regime comum não é nova. É absolutamente firme a doutrina, por exemplo, no sentido de que um regime especial de anulabilidades, diverso do regime comum do Código Civil, se deve ao interesse que precisa existir, e que o ordenamento deve perseguir, da estabilidade das assembleias, suas deliberações (art. 286 da Lei das S.A.) e, em geral, da atividade societária. Os prejuízos que poderiam ser causados à sociedade e demais interessados em decorrência da instabilidade jurídica das deliberações é muito claro e está ligado à aplicação da já mencionada sanção aos atos nulos e anuláveis do Código Civil, que é o retorno ao status quo ante. Justamente por essa razão que, por exemplo, os prazos de prescrição - corretamente identificados por Erasmo Valladão Azevedo e Novaes França como de decadência - previstos na lei são mais curtos, se comparados aos do regime comum do Código Civil (quatro anos pelo disposto no artigo 178 do Código Civil, 2 anos na Lei das S.A.) ${ }^{333}$.

Enfocando novamente a nossa matéria, e procurando responder à primeira das perguntas acima: os negócios jurídicos da companhia com suas próprias ações são nulos, anuláveis ou ineficazes?

Diferentemente do caso das assembleias e suas deliberações, a Lei das S.A. não contém nenhum dispositivo que leve ao entendimento de que a esses negócios jurídicos

\footnotetext{
${ }^{332}$ Cf. Aldo Angelo Dolmetta, Sulla..., cit., p. 344.

${ }^{333}$ Cf. Erasmo Valladão Azevedo e Novaes França, Apontamentos sobre a Invalidade das Deliberações Conexas das Companhias, in Temas de Direito..., cit., pp.68 e ss.
} 
tenha sido atribuído um regime de invalidades distinto daquele estatuído pelo Código Civil. O art. 286 não traz, entre as situações ali descritas, nenhuma norma especial acerca da anulação dos negócios praticados pela companhia com suas ações. O artigo 30 da Lei das S.A., de seu turno, não contém nenhuma disposição geral sobre o ponto.

Para as companhias abertas, em vista da cristalina redação da Lei das S.A., não restam dúvidas de que trata-se de hipótese de nulidade: o seu artigo $30, \S 2^{\circ}$, dispõe que a aquisição das próprias ações por companhias abertas obedecerá, sob pena de nulidade, as determinações da CVM. Desde logo, vê-se que a lei atribui a nulidade a estas hipóteses de maneira expressa, de modo que, conforme a irrefutável redação do artigo 166, VII, do Código Civil, que declara serem nulos os negócios jurídicos quando a lei taxativamente assim os declarar, é exatamente esse o caso para as companhias abertas.

Para as companhias fechadas, de outra sorte, precisaremos recorrer ao regime geral do Código Civil. Segundo o mesmo artigo 166, VII, são nulos os negócios jurídicos quando a lei proibir-lhe a prática, sem cominar sanção. Este parece realmente ser o caso: a Lei das S.A. proíbe taxativamente a companhia de realizar as operações com as próprias ações, abrindo as já avaliadas exceções. Entendemos que, para as companhias fechadas, serão nulos os negócios jurídicos por ela celebrados, caso eles afrontem, no mínimo, um dos grupos de referência tutelados: não basta, cabe o reforço, que o negócio não seja listado no art. 30 da Lei das S.A., é mandatória a avaliação sobre os interesses protegidos. Assim, realizadas operações em desacordo com os requisitos genéricos que as permitiriam (em prejuízo do capital social, em desacordo com o princípio de tratamento igualitário dos sócios ou em afronta a normas de proteção do mercado de capitais), seriam esses negócios, também, nulos.

Muito embora se chegue à conclusão de que os negócios com as próprias ações, praticados em afronta à lei, sejam nulos, defendemos que os efeitos decorrentes dessa nulidade não tenham a aplicação do regime comum. $O$ afastamento da aplicação irrestrita dos efeitos da nulidade no campo do direito societário já foi defendido pelos autores de maior peso na doutrina nacional. Waldirio Bulgarelli mencionava, em parecer datado de 1977, que “(...) a verdade é que a tendência dominante é a de minorar o radicalismo da nulidade absoluta, no campo societário, inclinando-se para reconhecer os efeitos dos atos ditos nulos ou inexistentes, impedindo a sua retroatividade e permitindo a sua retificação, a que os espanhóis chamam de subsanación do vício"334 - grifos do

${ }^{334}$ Cf. Waldirio Bulgarelli, Anulação de Assembleia Geral de Sociedade Anônima, in Manual das Sociedades

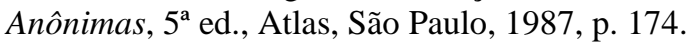


original. Também Alfredo Lamy Filho ${ }^{335}$, Trajano de Miranda Valverde ${ }^{336}$ e Erasmo Valladão Azevedo e Novaes França ${ }^{337}$ já se manifestaram de modo concreto no mesmo sentido.

Aliás, cabe enfatizar, como último ponto deste item, que a CVM não desconhece totalmente essa consequência civil. O artigo 14 da Instrução CVM 10 esclarece que a companhia deve alienar as ações em tesouraria que "execederem o saldo de lucros e reservas" no prazo de 3 meses a contar da aprovação do balanço em que se apurar tal excesso. A consequência estipulada para a irregularidade não será a nulidade da operação.

Defendemos, assim, a adoção de um regime especial quanto aos efeitos da nulidade. Portanto, a declaração de um negócio jurídico da companhia com suas próprias ações como nulo: (i) não deve necessariamente restituir as partes ao status quo ante, (ii) deve proteger o acionista de boa-fé que tenha contratado com a companhia e a ela vendido suas ações, por analogia com o disposto no art. $201, \S 2^{\circ}$, da LSA, e (iii) deve ter como consequência primordial a alienação das ações adquiridas contra a permissão legal, em prazo determinado pela lei e, não sendo isso possível, deverá ser reduzido o capital social em montante equivalente.

\subsection{Participações Sociais Recíprocas}

As participações de uma companhia controlada no capital de sua controladora são chamadas de "recíprocas", justamente por entender-se que a sociedade controlada estaria negociando, indiretamente, com as suas próprias ações. Esse "paralelismo", mencionado por Carvalhosa, é recente no Brasil: o DL 2.627/40 não abordou especificamente o tema,

335 “Com efeito - e vale como esclarecimento - no âmbito do direito societário não tem aplicação irrestrita a teoria das nulidades do direito civil, regida pelo principio 'quod nullum est, nullum producit effectum"” Cf. Alfredo Lamy Filho e José Luiz Bulhões Pedreira, A Lei das S.A., cit., p. 545.

336 "O regime comum das nulidades dos atos jurídicos não se ajusta, sem graves desvios, aos organismos que, sob a denominação de sociedades, associações, corporações, fundações, surgem por obra da energia dos homens e atuam, como sujeitos de direito, na vida social". Cf. Trajano de Miranda Valverde, Sociedades..., Vol. III, cit., p. 97, item 811.

${ }^{337}$ Cf. Erasmo Valladão Azevedo e Novaes França, Invalidade das Deliberações de Assembleia das S.A., Malheiros, São Paulo, 1999, pp. 21 a 27. Referindo-se, embora, à invalidade das assembleias e suas deliberações, o autor assim se manifesta: "Dessa forma, ante a evidente necessidade de estabilidade das deliberações assembleares, concebeu-se um sistema especial de invalidades no direito societário, que se caracteriza pelos seguintes principais tópicos: a) prazos de decadência, curtíssimos, para anulação de assembléia ou das suas deliberações; b) irretroatividade da invalidade, em certos casos; c) ampla possibilidade de sanação do vício, mesmo em se tratando de hipótese de nulidade absoluta, quando possível; d) diverso enfoque da distinção entre atos nulos e anuláveis; e) inatingibilidade, em princípio, de terceiros de boa-fé, salvo os casos de nulidade ostensiva”. In Erasmo Valladão Azevedo e Novaes França, Temas..., cit., pp. 101 a 103. Ver também, do mesmo autor, Lineamentos da Reforma do Direito Societário Italiano em Matéria de Invalidade das Deliberações Assembleares, in Revista de Direito Mercantil, Industrial, Econômico e Financeiro, n. ${ }^{\circ}$ 134, Malheiros, São Paulo, 2004, pp. 12 a 24. 
em parte porque não era comum à época de edição de tal diploma a convivência com a concentração empresarial por meio de complexas estruturas financeiras e de participações acionárias $^{338}$ - não faziam parte da preocupação do legislador e da doutrina nacional ${ }^{339}$, naquele momento, os grandes grupos empresariais ${ }^{340}$. O problema das participações sociais recíprocas, cujas regras vêm inseridas usualmente dentro da disciplina específica dos "grupos de sociedades", apenas com a edição da Lei das S.A. mereceu tomada de posição do direito brasileiro ${ }^{341}$, que acolheu, como norma geral, a sua proibição genérica, salvo as exceções mencionadas no artigo 244 e seus parágrafos ${ }^{342}$. As exceções são exatamente aquelas situações nas quais a lei permite a negociação, pela companhia, com suas próprias ações.

Na Exposição de Motivos da Lei das S.A., vê-se que "o Projeto, depois de regular, até o capítulo XIX, as companhias como unidades empresariais distintas, disciplina, nos capítulos XX a XXII a nova realidade que são as sociedades coligadas e o grupo de sociedades. No seu processo de expansão, a grande empresa levou à criação de constelações de sociedades coligadas, controladoras e controladas, ou grupadas - o que reclama normas específicas que redefinam, no interior desses agrupamentos, os direitos das minorias, as responsabilidades dos administradores e as garantias dos credores" ${ }^{243}$. Ainda na Exposição de Motivos, quando comentam sobre o artigo 244, os autores do anteprojeto assim o justificam: "Com o objetivo de preservar a integridade do capital social na sua função de garantia dos credores, o artigo 245 - hoje 244 - proíbe a participação recíproca entre sociedades coligadas, salvo se uma delas observa as condições em que a lei autoriza a aquisição das próprias ações" - grifos nossos. De plano, duas conclusões

\footnotetext{
${ }^{338}$ Modesto Carvalhosa, op.cit., p. 19.

339 Trajano de Miranda Valverde, na introdução a seus comentários ao DL 2.627/40, tratava com vigor da oposição entre a publicação do novel diploma legal sobre as sociedades por ações e a existência de normas especiais aplicáveis àquelas sociedades anônimas controladas pelo Estado, de modo que se discutia muito sobre a intervenção deste na economia, e seu condão de relativizar as normas que a ele se aplicam. In Sociedades..., Vol. 1, cit., pp. 35 e ss.

${ }^{340}$ Daí também ter o professor Philomeno J. da Costa escrito sobre as operações da companhia com ações de seu próprio capital, e ter dedicado apenas um capítulo de sua tese às participações sociais recíprocas.

341 Tal se justifica, como expõe Arnoldo Wald, em consonância com Modesto Carvalhosa, "pelo desenvolvimento relativamente recente das grandes empresas nacionais em nosso país, que ocorreu no momento em que as sociedades anônimas saíram do regime antigo de empresas familiares fechadas para, sob o efeito catalisador da legislação do mercado de capitais, abrirem as suas portas e receberem ampla contribuição do público". Arnoldo Wald, Das Participações Recíprocas das Sociedades Comerciais no Direito brasileiro, in Estudos e Pareceres de Direito Comercial, RT, São Paulo, 1972, pp. 3 - 16.

342 Outros artigos fazem referência a este, como, por exemplo, o artigo $265, \S 2^{\circ}$, ao tratar do grupo de sociedades, afirmando que a participação recíproca das sociedades do grupo obedecerá ao disposto no artigo 244.

${ }^{343}$ Desde logo, nota-se que a questão da garantia dos credores é tema recorrente das disposições legais atinentes a esses capítulos, onde se inclui o artigo das participações recíprocas. Alfredo Lamy Filho e José Luiz Bulhões Pedreira, A Lei das S.A., cit., pp.245 e ss.
} 
importantes podem ser extraídas desses comentários iniciais feitos ao instituto: (i) seu fundamento foi, sem dúvida, o de proteção dos interesses subjacentes dos credores (intangibilidade do capital social); e (ii) as participações recíprocas foram incluídas como modalidade de negociação com as próprias ações.

Limitar-nos-emos, neste momento, apenas a afirmar o quanto precede, indicando que as participações sociais recíprocas são uma forma indireta de negócios com as próprias ações. Não caberá, nesta dissertação, nos delongarmos sobre as características específicas desse intrincado assunto (que, aliás, merece estudo aprofundado e monográfico urgente no Brasil), nem sobre como os interesses dignos de tutela devem merecer acolhida. Para uma introdução acerca dos contundentes, profundos e complexos problemas que as estuturas de participações cruzadas apresentam, referimo-nos à obra de Ulrich Wastl e Franz Wagner, concisa e precisa $^{344}$.

${ }^{344}$ Ulrich Wastl e Franz Wagner, Das Phänomen der Wechselseitigen Beteiligungen aus Juristischer Sicht, Peter Lang, Frankfurt am Main, 1997. 


\section{ASPECTOS ORGANIZATIVOS: O INTERESSE DOS ACIONISTAS}

Nas relações internas, o capital social desempenha uma função estrutural, que tradicionalmente se denomina de função organizativa ou de participação. Ele constitui o parâmetro jurídico das relações entre os sócios, no exercício em comum da atividade econômica. Traduz-se, como é sabido, numa cifra capaz de representar percentualmente os riscos que cada acionista corre com a empresa social, de modo a, dentro da concepção capitalista da sociedade anônima, estruturar as relações internas de poder e influência da sociedade, quer economicamente, quer em termos de direitos de sócio. A realização de negócios jurídicos pela sociedade com ações de sua emissão pode, mantendo inalterada a cifra do capital social, afetar sua função organizativa, funcionando como expediente para alterar a medida participativa das ações "quer em termos administrativos, quer patrimoniais, distorcendo o princípio da repartição de competências, ou afectando princípios estruturais da sociedade anônima, como sejam o princípio democrático, o princípio da paridade de tratamento ou princípio de tutela das minorias" ${ }^{\text {345 }}$.

Se as ações em tesouraria não sofressem nenhuma modificação em seu regime jurídico, elas poderiam efetivamente, em determinadas condições, representar uma subversão do sistema de distribuição de poderes, dando à administração ou aos sócios majoritários a possibilidade de alterar as regras de formação da vontade social. Não é por acaso, portanto, que a maioria das legislações estudadas preveja uma alteração no regime jurídico dessas ações, conforme será visto abaixo, especialmente relacionada à suspensão do direito de voto.

Ainda que suspenso o direito de voto dessas ações, nem por isso estão afastados outros riscos organizativos inerentes às ações em tesouraria. Com a detenção, pela sociedade, de suas próprias ações, podem ser alteradas as forças internas da sociedade, ao aumentar-se proporcionalmente a medida de participação dos demais acionistas titulares de ações em circulação. Em uma sociedade, por exemplo, o capital social está subdividido entre os acionistas nas seguintes proporções: o sócio A detém 43\%, o sócio B 26\%, o sócio C 7\%, o sócio D $9 \%$ e os restantes $15 \%$ estão dispersos entre acionistas diversos, totalizando, portanto, $100 \%$ do capital social. Se a sociedade decidir adquirir dos sócios atomísticos os $15 \%$ das ações em circulação, "produzem-se duas ordens de modificações

\footnotetext{
${ }^{345}$ Cf. Maria Victória Rodrigues, op. cit., p. 93.
} 
substanciais nas relações entre os sócios: o sócio A passa a deter maioria absoluta das ações $(50,59 \%)$ porque a nova base para medir as relações de força é de 85 (100 - 15). O sócio D passa a poder exercer os direitos que a lei só conceda aos sócios que possuem pelo menos $10 \%$ do capital social $(10,58 \%)^{, 346}$.

Também do ponto de vista econômico as ações em tesouraria podem impactar os interesses dos acionistas. De forma introdutória, já que pretendemos desenvolver cada um destes pontos nos subitens deste capítulo, podemos argumentar que a aquisição de ações próprias, com a correspondente suspensão de seus direitos aos dividendos (ou a todos os direitos econômicos, conforme a legislação de cada país), deveriam beneficiar os demais acionistas, uma vez que o lucro distribuível seria concentrado nas participações sociais remanescentes.

Além disso, a aquisição de ações próprias pode representar, mesmo que liquidadas com valores oriundos de saldo de lucros e reservas, um injustificado tratamento diferenciado entre acionistas, quando, por exemplo, os acionistas não vendedores sejam prejudicados pelas vendas feitas a preços "injustos" ou com a exclusão da participação de determinados grupos de acionistas (minoritários, em regra), situação na qual vemos um eventual abuso de poder de controle por parte de grupos majoritários, esvaziando, ainda, os lucros sociais que de outro modo caberiam a todos os sócios. Em um exemplo extremo, um acionista controlador poderia usar todo o lucro líquido de um exercício para fazer com que a sociedade adquira ações de que ele próprio seja o titular, nulificando os lucros da companhia, sem perder o poder de controle. Os demais sócios não receberão nada. Neste contexto, é de relevância o estudo sobre o preço de aquisição dessas ações, as maneiras por meio das quais é possível concretizar os negócios (operações em bolsa e privadas) e como será possível evitar, ou mitigar, a ocorrência de situações de tratamento não equitativo entre os acionistas.

\subsection{A Sociedade Sócia de Si Mesma}

Trata este item de um ponto fundamental da nossa dissertação: a evolução teóricodogmática da possibilidade de uma sociedade ser sócia de si mesma. Obviamente, a evolução da doutrina e do pensamento jurídico acerca das justificativas para a operação não foi rápida, como não foi rápida a evolução do instituto da sociedade por ações, cuja transformação institucional no decorrer dos anos foi tremenda. Quem poderia defender na

\footnotetext{
${ }^{346}$ Cf. Maria Victória Rodrigues, op. cit., p. 95.
} 
época das colonizações que devesse existir um regime de proteção aos credores? Ou às minorias acionárias? Ou mesmo que uma sociedade pudesse ser sócia de outra, na época em que o conceito de pessoa jurídica estava em fase embrionária? Quem poderia, dentro da filosofia contratualista dominante no início do pensamento acerca das companhias, defender que ela devesse se ocupar também dos trabalhadores e da comunidade em que atua? Ou, ainda para nos atermos ao contratualismo, defender a juridicidade da sociedade de um único sócio?

\subsubsection{Da Estrutura para a Função: da Incompatibilidade Absoluta para a Teoria da Confusão}

A exegese desta questão ocupou, historicamente, um papel de destaque para as correntes doutrinárias que visaram a vetar os negócios com as próprias ações. Na legislação do século XIX, era um discurso de estrutura que buscava impedí-los: "In quest'ottica l'acquisto di azioni proprie veniva inquadrato come problematica strutturale all'interno del diritto delle società anonime, analizzando se fosse di per sé ed in teoria compatibile con la stessa struttura sociale e con la configurazione di uma personalità giuridica distinta da quella dei diversi soci l'ammissibilitá dell'acquisto di azioni proprie. Per cui il tutto si riconduceva al quesito ontologico: può la società essere socia di se stessa?" - grifos do original ${ }^{347}$. Aqui, cabe uma observação relevante: tanto as exposições de motivos das primeiras leis que sobre a matéria versaram (como a Aktienrechtsnovelle de 1870), quanto os textos teóricos iniciais sobre ela, debruçavam-se em esforços para tentar entender esta lógica - e esse foi um esforço comum aos sistemas de common law (que superaram a dificuldade com muito mais facilidade) e aos de civil law.

Por exemplo, no leading case inglês (Trevor v. Withworth) é extremamente interessante a afirmação de Lord Watson, segundo o qual seria incompatível com a natureza da sociedade tornar-se sócia de si mesma, dado que não seria possível inscrevê-la no registro de titularidade de ações, e porquanto a ela nada seria devido em caso de liquidação da companhia: "[I]t is inconsistent with the essential nature of a company that it should become a member of itself ${ }^{348}$.

No direito norte-americano, apesar da raiz comum com o direito inglês, as primeiras decisões a respeito já tinham um caráter muito mais flexível em relação a estas operações (caráter esse que predomina até hoje), sendo a legislação norte-americana,

\footnotetext{
${ }^{347}$ Cf. Barbara Pozzo, op. cit., p. 14.
}

${ }^{348}$ Cf. Barbara Pozzo, op. cit., p. 16. 
indubitavelmente, mais tolerante do que qualquer outra no mundo, mesmo a inglesa (o que se deve, em parte, também em decorrência da obrigação assumida pelo Reino Unido de coordenação jurídica em âmbito comunitário europeu). No caso Ex Parte Holmes, de 1826, já anteriormente mencionado, a decisão foi a de permitir o recebimento pela companhia de suas próprias ações, criando, sobre elas, um trust, e evitando, com isso, a confusão e extinção dos papeis ${ }^{349}$. Com efeito, em textos doutrinários do início do século XX nos Estados Unidos da América já não se nota mais sequer menção ao argumento lógicoestrutural, mas adquire a discussão um caráter eminentemente funcional, pela análise da proteção dos credores e da solvabilidade da companhia ${ }^{350}$, em contraposição à evolução inglesa, que se ateve, originalmente, à formalidade da estrutura da companhia para julgar a operação ilegal, independentemente das circunstâncias do caso concreto. Escrevendo em 1901, Frederick H. Clark critica a posição adotada pelos Lords ingleses no caso Trevor vs. Witworth, ao dizer que ela "seems however to go very far in the direction of upholding the broad proposition that such a purchase is inherently illegal without reference to circumstance $^{, 351}$. Outro autor norte-americano chamou a preocupação de Lord Watson no caso Trevor v. Witworth de "metafísica"352.

Em resumo, foram três as correntes doutrinárias que procuraram justificar a possibilidade ou a impossibilidade de a companhia vir a figurar como acionista de si própria na Europa: (i) uma, minoritária, defendia a aceitação total, sem que ocorresse qualquer alteração no regime jurídico das ações pelo fato de serem adquiridas pela companhia emissora, (ii) outra, majoritária, propagava a negação absoluta da possibilidade, exceto para os casos em que a aquisição implicasse a extinção das ações, e, ainda, (iii) uma

\footnotetext{
349 "No doubt the company may,..., take their own stock in pledge or payment; and keep it outstanding in trustees, to prevent its merger...”. Ex Parte Holmes, 5 Cow. 426 (N.Y. 1826), citado por Barbara Pozzo, op. cit., p. 17. Em outros casos do início do século XIX, as decisões também eram tendentes a não invocar o argumento estrutural.

${ }^{350}$ Cf. Power of a Corporation to Acquire its Own Stock, Columbia Law Review, Vol. 13, n. ${ }^{\circ}$ 2, 1913, pp. 148 a 150, citando a jurisprudência. "Hence the objection to the practice [recompra, pela companhia, das suas ações] instead of resting on a lack of power must find its logical basis in the disadvantages to other shareholders and to corporate creditors which may result from such transactions." - grifos nossos. Cf. Right of a Corporation to Purchase its Own Stock, Harvard Law Review, Vol. 27, N. ${ }^{\circ}$ 8, 1914, pp. 747 a 750 , citando casos.

${ }^{351}$ Frederick H. Clark, Legality of Purchase by a Coporation of its Own Stock, in The American Law Register (1898 - 1907), Vol. 49, N. ${ }^{\circ}$ 7, Vol. 40 New Series, 1901, p. 402. Cf. também Barbara Pozzo, op. cit., p. 17, nota de rodapé 12.

352 "From the standpoint of metaphysics, it is difficult to conceive of a corporation - a legal personality being a member of itself. This logical difficulty troubled Lord Watson in Trevor v. Whitworth, (1887) 12 A. C. 409. And if a corporation purchased all of its shares (which it might theoretically do in some states if it had no debts), we should have a case of a corporation dissolving itself into nothingness by the device of swallowing its viscera and leaving perhaps a surplus of assets in vacuo without an owner. The practice offers considerable food for fantastic speculation". Cf. Irving J. Levy, Purchase..., cit., p. 30, nota de rodapé 142.
} 
terceira, mais recente, propunha a aceitação das operações, embora sob certos condicionalismos e impondo um regime jurídico diferenciado a essas ações. Hoje, podemos afirmar com convicção, após analisar diversos ordenamentos jurídicos, que a única corrente que prevalece é a terceira - as demais servem como interessante contraponto teórico aos dogmas que muitas vezes nos apresenta a teoria jurídica e valem a pena, em razão disso, serem mencionadas ${ }^{353}$.

A primeira corrente doutrinária mencionada, que defendia a "teoria da sociedade acionista de si mesma", teve seu berço no início do século XX, na Alemanha, com a publicação, em 1906, da obra "Die Folgen des Erwerbs eigener Aktien”, de autoria de Runkel-Langsdorff. Para os defensores desta teoria, não se opera qualquer modificação pelo fato de uma sociedade adquirir as suas próprias ações. O conteúdo dos direitos e deveres das ações permanece intacto, mesmo quando adquiridas pela própria companhia, sendo que a "sociedade pode perfeitamente ficar investida na qualidade de membro da corporação por ela formada, acionista de si mesma" ${ }^{354}$. Nestes termos, à companhia seria permitido exercer prerrogativas de acionista (representada, evidentemente, por seus administradores) como, v.g., o direito de voto nas suas assembleias gerais, o direito de preferência na subscrição de ações, o direito ao dividendo e até mesmo o direito de impugnar as próprias deliberações.

$\mathrm{Na}$ posição exatamente oposta encontram-se aqueles autores que negam, em absoluto, a possibilidade de a companhia adquirir ou negociar com as ações de sua própria emissão, argumentando que é impossível conceitualmente a sociedade ser sócia de si mesma. Inclusive, relata-se que foi esta a razão da introdução, na Alemanha, em 1870, da proibição absoluta da recompra de ações, até então largamente utilizada com lucros da companhia. A garantia de credores foi tema apenas subsidiário ${ }^{355}$. Esta foi, cronologicamente, a primeira corrente a prevalecer (a tese de Runkel-Langsdorff surgiu apenas em 1906).

O argumento (da impossibilidade teórica de uma sociedade ser sócia de si mesma) resultava da aplicação do princípio de que ninguém pode ser obrigado para consigo mesmo (nemo potest apud eundem pro ipso obligatus esse), somada à da teoria da personalidade jurídica, criada justamente como forma de distinguir as esferas jurídicas dos sócios e da companhia, como dimensões não apenas separadas, mas contrapostas. Tendo a companhia

\footnotetext{
${ }^{353}$ Cf. Maria Victória Rodrigues, op. cit., p. 34.

${ }^{354}$ Cf. Maria Victória Rodrigues, op. cit., p. 35.

${ }^{355}$ Cf. Alexander Kitanoff, op. cit., p. 18, nota de rodapé 18.
} 
personalidade jurídica distinta, destarte, da personalidade dos sócios, a aquisição das suas próprias ações implica a reunião, no mesmo sujeito, das posições ativas e passivas em relação a cada direito e dever que a ação atribui ao sócio em face da companhia e viceversa. Segundo os defensores deste pensamento, a contradição, in casu, está no fato de que ninguém pode ser credor e devedor de direitos e deveres de si próprio, razão pela qual a operação seria juridicamente impossível e, assim, vedada absolutamente. Como vimos logo acima, esta foi a posição originalmente concebida pelo direito positivo europeu, tendo sido a teoria adotada pela Aktienrechtsnovelle alemã de 1870. A tese é a de que um todo não pode simultaneamente ser sua parte, assim como uma casa feita de pedras não pode simultaneamente ser uma dessas pedras.

Avançando um pouco no tempo, a teoria da impossibilidade absoluta ganha novas feições quando passa-se não mais a questionar a possibilidade jurídica da sociedade sócia de si mesma, mas acerca a sobrevivência ou não das ações uma vez realizada a operação. Aplicar-se-ia, nesta hipótese, o mesmo princípio de que ninguém pode ser devedor de si próprio. Segundo relata Maria Victória Rodrigues, “esta posição, largamente divulgada em França em período anterior à lei de 1966, traduzia-se na defesa de que as acções próprias se devessem considerar anuladas ou extintas de pleno direito a partir do momento da aquisição, por força do instituto da confusão" ${ }^{, 356}$ - grifos nossos. Estando os polos ativos e passivos da mesma relação jurídica reunidos em uma mesma pessoa, extinguiam-se por confusão e, consequentemente, extinguiam-se as ações que davam suporte a essa relação jurídica $^{357}$.

Ambos os argumentos pecam, a nosso ver, por entenderem excludentes pensamentos que não o são. Assim, admitir que a companhia adquira suas próprias ações e mantenha-as em carteira não significa admitir que ela possa exercer todos os direitos, poderes e deveres que a titularidade de uma ação traz consigo. E foi visualizando exatamente que esses extremos não se justificavam para a prática comercial, ora engessando demasiadamente o quadro de liberdade da companhia, ora permitindo a ocorrência de situações no mínimo curiosas, que se desenvolveu a terceira corrente de pensamento, que predomina até hoje. Reconhecer a diferença entre a existência do direito e a possibilidade de seu exercício foi a saída encontrada para o impasse, desenvolvendo-se

\footnotetext{
${ }^{356}$ In op. cit., p. 37.

${ }^{357}$ Essa teria sido a teoria defendida largamente em França e mantida também pela jurisprudência desse país até uma sentença do Tribunal de Comércio do Havre em 1930, que admitiu, pela primeira vez, que a sociedade adquirente das suas próprias ações as pudesse conservar em carteira. Cf. Maria Victória Rodrigues, op. cit., p. 37, nota de rodapé 72 .
} 
um regime jurídico diferenciado para as ações nesta situação, a que comumente se chama de regime jurídico das ações em tesouraria.

Diga-se também que o instituto da confusão, como forma de extinção das obrigações diferente de seu adimplemento comum (artigo 381 do Código Civil), não tem aplicação automática ao caso da reunião das ações nas mãos da companhia emitente. "A confusão é o modo de extinção da obrigação que se dá quando se reúnem em uma única pessoa o credor e o devedor da mesma dívida" ${ }^{358}$; essa é a explicação da eficácia extintiva da confusão, pois o propósito da existência da relação obrigacional é cumprido quando o credor e o devedor passam a ser a mesma pessoa; não existe mais razão para a subsistência do liame obrigacional, já que não há mais necessidade de suporte jurídico para a constrição do patrimônio do devedor pelo credor, para cumprimento da obrigação. Por outro lado, é forçoso lembrarmos que o próprio Código Civil prevê a hipótese de restabelecimento do liame obrigacional original quando cesse a situação de confusão (artigo 384 do Código Civil), o que indica claramente a presença de uma eficácia latente, uma paralisia temporária de direitos.

Saindo do campo civil e colacionando, a nosso ver, o argumento invencível para afastar a aplicação do instituto da confusão, lembre-se que, societariamente, a relação jurídica entre acionista e sociedade não é uma relação bilateral obrigacional pura (crédito e débito). Nada mais falamos do que o hoje já óbvio para os estudiosos do direito societário: com Ascarelli ${ }^{359}$ e seu brilhante trabalho, sabe-se que a relação jurídica societária é plurilateral e associativa, de forma que, nesse tipo de liame, não se pode visualizar uma relação estrita de crédito e dívida entre a companhia e seus acionistas, o que se reflete num regime jurídico muito diverso do obrigacional (Ascarelli, com o brilhantismo que lhe é peculiar, cita 23 diferenças entre os dois). A ação, mais do que uma relação de débito e crédito, transmite a "socialidade" (Mitgliedschaft), uma situação jurídica - o estado de sócio -, que abrange um sem número de prerrogativas, direitos, expectativas de direito, deveres, poderes, faculdades e sujeições entre a companhia, o acionista titular e os demais acionistas. A ação consubstancia a "membridade" de uma pessoa (entenda-se: qualquer pessoa, já que a companhia é, via de regra, independente das pessoas que a

\footnotetext{
${ }^{358}$ Cf. Paulo Luiz Netto Lôbo, op. cit., p. 248. Afigura-se-nos útil trazermos a observação do próprio autor, feita pouco mais à frente em seu texto, citando Pontes de Miranda, de que a confusão não ocorre, tecnicamente, apenas na relação crédito-dívida, mas também na relação pretensão-obrigação.

${ }^{359}$ Tullio Ascarelli, O Contrato Plurilateral, in Problemas..., cit., pp. 372 e ss.
} 
compõem - Körperschaft) dentro de uma coletividade: a aplicação da confusão civil não é possível $^{360,361}$.

A única exceção que faríamos à nossa linha de argumentação acima seria pela aplicação da confusão para aqueles efetivos direitos de crédito contra a companhia, como é o caso, ad esempio, dos dividendos declarados e não pagos, dos valores pendentes de reembolso após exercício do direito de recesso e dos valores devidos após resgate de ações.

\subsubsection{Superando a "Confusão”: a Teoria da Ineficácia ou Suspensão dos Direitos}

Dando prosseguimento, vê-se que nenhuma das duas teorias mais radicais logrou aceitação nas legislações modernas, que, genericamente, permitem determinadas operações pela companhia com ações de sua emissão e, igualmente, a detenção dessas ações em carteira. A terceira teoria, defensora de um discurso de moderação, leciona que as ações não só podem ser adquiridas pela sociedade, como também defende que isso não acarreta, ipso facto, a sua extinção, mas apenas a suspensão de determinados direitos que lhes são inerentes, que ficam como que em estado de hibernação, "suspensos, privados de eficácia, como paralisados ou inertes" ${ }^{362}$, durante o tempo em que a situação de autoparticipação durar, ressurgindo no momento em que cessar a auto-titularidade das ações.

Doutrinariamente, essa suspensão de direitos, no Brasil, poderia ser enquadrada como uma hipótese de suspensão de eficácia, de maneira semelhante ao que acontece com a inserção de condições, seguindo a teoria dos planos do negócio jurídico, da existência, validade e eficácia. As ações em tesouraria, portanto, ficam sujeitas a um "fator de atribuição de eficácia em geral", que se traduz no ato de sua alienação (recolocação em circulação). Esta, por sua vez, representa um fator externo à condição de titularidade das ações, sem o qual não é possível a irradiação dos efeitos do status socii ${ }^{363}$.

\footnotetext{
360 "Na verdade, não sendo a ação o título de um crédito, mas da qualidade ou estado de membro da corporação - estado esse que por seu turno se analisa e desdobra em direitos e deveres de variada natureza, uns patrimoniais, outros de caráter pessoal -, não há que aplicar aí os princípios da "confusão", válidos em matéria de obrigações". Cf. António Ferrer Correia, op. cit., p. 123.

361 "Aggiungere che, nel caso ora contemplato, si riuniscono, nel medesimo soggeto (società per azioni), due qualità opposte (e, qualche volta, complementari), creando una situazione giuridica, che, tuttavia, non coincide con lo schema che sbocca nell'estinzione del rapporto per confusione, in quanto, nella specie, non si trata di rapporto obligatorio (debito e credito) (...) Si trata, invece di un diverso rapporto, che intercorre fra società e socio - lo se qualifichi associativo, o di partecipazione (...)" - grifos do original. Cf. Francesco Messineo, Spettanza dei Dividendi sulla Propria Azione, Acquistata dalla Società, in Rivista delle Società, Vol. 11, maio-junho de 1966, p. 418.

${ }^{362}$ Cf. António Ferrer Correia, op. cit., p. 124.

${ }^{363}$ Maria Victória Rodrigues dá notícia da "teoria da quiescência ou paralisação de direitos" em Portugal, que consiste em uma "temporária paralisação do exercício do direito que resulta da existência de um obstáculo à possibilidade de actualizar tal exercício". Na Itália, Barbara Pozzo fala em "stato di quiescenza, che consiste
} 
Segundo António Ferrer Correia, resumindo a discussão: “[a] sociedade, em suma, não adquire (...) a qualidade de accionista - não se pode ser accionista de si mesmo -, antes se limita a incorporar no seu patrimônio, eventualmente para futura realização, o valor que essas acções representam"364 . Esta é a corrente doutrinária vigente no Brasil já há algum tempo (positivamente, desde a Lei 3.150/1882, como vimos) e, para nós, a melhor das três correntes de pensamento, que consegue equilibrar os perigos com os benefícios da operação, de forma a garantir uma visão pragmática do instituto, com uma única ressalva: não vemos nenhum problema conceitual em reconhecer que a companhia pode tornar-se, sim, acionista de si mesma ${ }^{365}$; o que ela não pode adquirir é a possibilidade de exercício de alguns dos direitos normalmente atribuídos ao acionista em virtude do estado de sócio $^{366,367}$.

\subsubsection{A Sociedade sem Sócios}

Finalizamos este item com a análise de uma situação interessante. A Lei das S.A. não menciona um percentual máximo de ações do capital social que uma companhia pode deter em tesouraria - ela não faz qualquer limitação -, de modo que, no limite, poder-se-ia imaginar uma companhia com $100 \%$ das próprias ações em tesouraria, surgindo então uma sociedade sem sócios. Para as companhias abertas, a Instrução CVM 10 reduz o interesse prático da pergunta, ao limitar o montante de ações passíveis de serem adquiridas pela

in una temporanea paralisi dell'esercizio del diritto" - mesma expressão usada por Messineo (“(...) la sospensione temporanea di una delle situazioni, che è, in sostanza, quiescenza; (...)" - grifos do original). Veja-se, ademais, como já mencionado, que essa suspensão de eficácia é muito semelhante àquela que ocorre quando há a confusão com posterior cessação do estado que a originou, nos termos do artigo 384 do Código Civil. Cf. Maria Victória Rodrigues, op. cit., p. 43, Barbara Pozzo, op. cit., p. 26 e Francesco Messineo, Spettanza..., cit., p. 419. No Brasil, entendemos que a teoria de Antônio Junqueira de Azevedo pode ser aplicada às ações em tesouraria, mesmo que sejam necessárias algumas adaptações teóricas, pois é difícil conceber a ação como um negócio jurídico, mesmo que a elas se atribua o caráter de títulos de crédito: a ação da companhia não representa, na essência, uma declaração de vontade apta a produzir efeitos jurídicos. Cf. Antônio Junqueira de Azevedo, Negócio Jurídico - Existência, Validade e Eficácia, 2a ed., Saraiva, São Paulo, 1986, p. 63.

${ }^{364}$ António Ferrer Correia, op. cit., pp. 124 e 125.

${ }^{365}$ Em outros países, é mais nítido que a companhia adquire a propriedade das suas ações. O Codice Civile italiano, por exemplo, deixa claro que o nomen iuris da titularidade da companhia em relação às ações entesouradas é a propriedade (cf. redação do art. 2.357-ter: "Finchè le azioni restano in proprietà della società..." - grifos nossos). Contudo, seria leviano deixar de reconhecer que, diferentemente da Itália - onde a propriedade, via de regra, transmite-se com o contrato -, no Brasil a propriedade das ações adquire-se mediante o registro da sua titularidade no livro de registro de ações nominativas da companhia, nos precisos termos do art. 31 da Lei das S.A. Como afirmamos no texto, não vemos um problema conceitual em a companhia ser sócia de si mesma - adquirindo a propriedade das ações -, mas não podemos ignorar a previsão de tal artigo. Com isso, registrando-se a transferência das ações no livro de "Transferência de Ações Nominativas", será possível defender a existência do direito de propriedade da companhia sobre as ações entesouradas. Não vemos ilegalidade alguma no procedimento.

${ }^{367}$ Alfredo Lamy Filho e José Luiz Bulhões Pedreira (coords.), Direito das Companhias, cit., p. 556. 
companhia emissora a $10 \%$ das ações de uma mesma classe ou espécie em circulação. Entendemos o posicionamento majoritário da doutrina, ainda fortemente influenciado pelo contratualismo clássico, de que uma sociedade não poderia adquirir a totalidade das ações por ela emitidas, pois isso seria conceber uma sociedade sem sócios (uma "Kein-MannGesellschaft" para nos atermos à similar terminologia adotada na Alemanha para a sociedade unipessoal - Ein-Mann-Gesllschaft" $)^{368}$. As críticas desses autores baseiam-se na relação essencial da sociedade e do sócio: a ausência dessa relação desnatura a companhia e a transforma em uma entidade de natureza quase fundacional. Argumenta essa parte da doutrina, portanto, que numa situação dessa natureza, a reunião de todas as ações da companhia na sua tesouraria acarretaria sua dissolução de pleno direito, de modo que sempre deveria subsistir ao menos um acionista, afastando um "suicídio das sociedades" 369 .

Outro argumento usado para criticar a possibilidade de uma sociedade sem sócios é de caráter econômico. Argumenta-se que, na ausência de acionistas, as companhias pertenceriam a si próprias, e, nesse caso, perderiam um centro de interesses claro e bem definido. Nesses termos, o mercado da livre concorrência seria prejudicado em suas premissas mais básicas, já que teríamos agentes de mercado agindo sem um interesse próprio a perseguir: “(...) Uma constituição econômica a que pertençam os princípios da livre iniciativa privada, livre concorrência e controle do poder econômico pela descentralização [entendida como ausência de concentração de mercado], perde, com uma evolução nesse sentido, de maneira substanciosa a sua base real. Supondo que o desenvolvimento tivesse ocorrido como se desenhava em 1930, então hoje teríamos uma situação em que as grandes empresas, que não fossem, elas próprias, subordinadas a um grupo de empresas, pertenceriam a 'si próprias'. O fundamento da concorrência é, no entanto, que as empresas individuais que participam do mercado representem interesses diversos. Se os interesses dos acionistas saem do jogo, então faltará às empresas a essencial diferença específica de interesses, que são, por sua vez, as características que justificam sua independência e sua concorrência. (...) Deve ser chamada a atenção ao fato de que o problema não possui apenas uma dimensão técnico-jurídica, mas concomitantemente um aspecto de impacto na constituição econômica" ${ }^{370}$.

\footnotetext{
${ }^{368}$ Por exemplo, cf. Maria Victória Rodrigues, op. cit., p. 46, nota de rodapé 98.

${ }^{369}$ Cf. Maria Victória Rodrigues, op. cit., p. 47, nota de rodapé 98.

370 No original: “(...) Eine Wirtschaftsverfassung, zu derem Grundprinzipien Privatunternehmertum, Wettbewerbsfreiheit und Machtkontrolle durch Dezentralisierung gehören, verliert bei einer solchen Entwicklung zunehmend ihre reale Basis. Stellt man sich vor, die Entwicklung wäre so weitergegangen, wie
} 
Usualmente, tem-se mencionado um argumento de natureza societária para restringir a viabilidade prática de uma companhia adquirir todas as suas ações: se o direito de voto das ações em tesouraria fica suspenso no período em que elas estejam em carteira, fica impossibilitado o funcionamento da assembleia geral, uma vez que não haveria nenhuma ação com direito de voto e, portanto, a assembleia restaria impossibilitada de instalar-se. O fato de que não existam, no momento, ações com direito de voto para votar na assembleia, não deveria, por si só, ocasionar a dissolução de pleno direito da companhia. Considerando uma sociedade com conselho de administração e diretoria, a companhia poderia sobreviver apenas com seus órgãos de administração, ao menos até a obrigatoriedade de realização da assembleia geral ordinária do ano seguinte, momento no qual, em não havendo nenhum sócio, não vemos alternativa que não a dissolução e liquidação da sociedade, dado que seria impossível a ela cumprir com a obrigação da lei.

Na primeira edição de seu livro "O Novo Direito Societário”, de 1998, Calixto Salomão Filho escreveu um artigo primoroso intitulado "A Sociedade sem Sócios", onde aprofundou, pela primeira vez, o assunto sob a ótica do direito brasileiro. Em um determinado trecho desse trabalho, o Professor se depara com a mesma perplexidade, “aparentemente paradoxal, mas não insuperável"371, de impossibilidade de instalação da assembleia geral. Segundo o autor: "novamente a solução é organizativa. Basta que a competência para representar a sociedade perante ela própria seja atribuída a órgão nãocoincidente com o de representação da sociedade" ${ }^{, 372}$. Essa separação seria atingida, em nosso sistema jurídico - que reconhece a bipartição dos órgãos da administração -, ao se atribuir ao conselho de administração uma parte das competências (aquelas não indelegáveis) da assembleia geral - o que é, por si só, uma tarefa extremamente complexa-, enquanto à diretoria incumbiria, como de costume, a representação da sociedade perante terceiros.

De qualquer forma, por pouco ou muito tempo que dure a situação, essa ausência de sócios faz surgir o seguinte problema ulterior: aquele referente a definir qual a destinação a

sich um 1930 abzeichnete, so hätten wir heute den Zustand, dass diejenigen Grossunternehmen, die nicht selber Konzernabhängig sind, 'sich selbst' gehörten. Grundlage des Wettbewerbs ist aber, dass die selbständigen Unternehmen, die am Markt agieren, unterschiedlieche Interessen repräsentieren. Fallen die Aktionärinteressen weg, so fehlt es zwischen den Unternehmen an jener spezifischen Differenz der Interessen, die ihrer Unabhängigkeit und ihrem Wettbewerb erst den Sinn geben (...) Es soll nur darauf aufmerksam gemacht werden, dass das Problem nicht nur reine rechttechnische Dimension hat, sondern zugleich einen unternehmensverfassungsrechtlichen Aspekt". Cf. Ulrich Huber, Zum Aktienerwerb durch Ausländische Tochtergesellschaften, apud Maria Victória Rodrigues, op. cit., p. 48, nota de rodapé 98.

${ }^{371}$ Calixto Salomão Filho, Sociedade sem Sócio, in O Novo Direito Societário, $1^{\text {a }}$ ed., Malheiros, São Paulo, 1998, p. 131.

${ }^{372}$ Calixto Salomão Filho, Sociedade sem Sócio, cit., p. 131. 
ser dada aos valores apurados na liquidação. A doutrina, aqui, tende a defender duas possibilidades teóricas, sempre por analogia: (i) a primeira saída seria equiparar a companhia a uma fundação, ou seja, um patrimônio personificado, e (ii) a segunda seria a aplicação analógica da regra do direito das sucessões, que estabelece que, na ausência de outros sucessores legais, ao Estado deverá ser vertido o patrimônio ${ }^{373}$.

A se adotar a equiparação com uma fundação, regula o nosso Código Civil (art. 69) que, extinta a mesma, o juiz deverá decidir, salvo se o estatuto ou o ato de constituição tiverem previsão diversa, sobre a versão do patrimônio da fundação para outra fundação de natureza semelhante. Aplicando a analogia, seria o caso, então, de o magistrado decidir para qual outra entidade seria vertido o patrimônio da companhia-fundação. Parece-nos que seria ideal atribuir o patrimônio líquido a entidades privadas, que seriam as mais legitimadas a dar continuidade à empresa social anteriormente desenvolvida. A versão do patrimônio ao erário público deve, a nosso ver, ser efetivamente a última opção a ser adotada. Vale uma observação final: é até possível que seja adotado o regime da fundação, por analogia, no caso de liquidação de uma sociedade sem sócios, mas é inadmissível a equiparação entre as duas figuras. Enquanto a ausência de titularidade do patrimônio, na fundação, faz parte de sua essência, na qualidade de patrimônio personificado destinado a um fim, na sociedade essa ausência é meramente eventual. E mais, a estrutura orgânica da sociedade é estruturada para permitir que seja automaticamente reacesa em sua integralidade, na ocasião da admissão de um novo sócio.

A outra saída seria adotar o regime subsidiário do direito das sucessões. No nosso entendimento, isso significaria a aplicação do regime jurídico da herança vacante ao patrimônio da companhia liquidada, nos termos dos artigos 1.819 a 1.823 do Código Civil: a companhia seria dissolvida e liquidada na forma da Lei das S.A. e, uma vez apurado o patrimônio líquido, seria ele absorvido pelo poder público (art. 1.822). Não há espaço para permitir que se abra um prazo, uma vez finalizada a liquidação, para a habilitação de acionistas desejosos de receber o patrimônio vacante: ao invés de zelar pela "justiça" na transferência do patrimônio, a permitir-se tal prazo, inúmeras serão as ações de anulação das aquisições das ações pela companhia, para permitir a habilitação daqueles acionistas em sua liquidação - e aqui, novamente, a adoção de um regime de nulidades diferenciado teria o condão de evitar esta situação.

${ }^{373}$ Cf. Mario Stella Richter Jr, op. cit., p. 819. 
É inegável que uma sociedade sem sócios causa perplexidade ao estudioso, conforme pode-se depreender resumidamente das discussões acima, mas acreditamos que, observada a companhia pelo prisma e função da teoria organizativa, o contrato de sociedade, de maneira ainda mais contundente na companhia, tem o intuito primordial não apenas de vincular pessoas ao exercício de uma atividade, mas o de criar e assegurar a manutenção no tempo de uma organização. Aqui, mais uma vez, fazemos referência às lições de Herbert Wiedemann: se a sociedade não tem sócios, é bem verdade que lhe falta a pluralidade de pessoas, mas a sua organização patrimonial e da empresa [criadas por meio do vínculo societário] permanece intocada ${ }^{374}$. Segundo Calixto Salomão Filho, defendendo a aplicação da teoria do contrato organização como forma de explicar a independência da sociedade em relação aos acontecimentos e mudanças existentes no grupo de sócios, "é essa independência que faz com que uma sociedade possa existir sem nenhum sócio atual, mas apenas com a simples perspectiva de um sócio futuro" ${ }^{\text {375. }}$.

Veja-se, também, que há muito tempo a companhia tornou-se absolutamente independente das pessoas que a compõem, conforme já tivemos oportunidade de analisar extensivamente neste trabalho. A estrutura de Körperschaft (também citada por Calixto Salomão Filho no mencionado texto) pode justificar a ausência de acionistas, uma vez que eles já são ausentes, na prática, da organização. A evolução, nos países anglo-saxônicos, da pulverização extrema do capital e do fenômeno do absenteísmo societário, que viabiliza o surgimento do controle gerencial da companhia, também é um reflexo da modernidade, que permite olhar a discussão da sociedade sem sócios de forma menos agressiva: o controle da companhia e da organização pela administração não é novidade, mas, hoje, esse controle se perpetua por guerra de procurações de acionistas totalmente ausentes da vida da companhia.

É possível, apesar de inicialmente inquietante, cogitar juridicamente uma sociedade sem sócios, pois não se trata de uma situação insuperável. A nosso ver, o pensamento jurídico e o desenvolvimento histórico da companhia moderna já demonstraram que as perplexidades de outrora se tornam lentamente realidade patente da técnica jurídica. Não negamos que, do ponto de vista prático, dificilmente conseguir-se-ão superar as dificuldades postas, mormente com relação ao funcionamento de uma companhia sem nenhum sócio, que elimina por completo a dicotomia de atuação fiduciária dos

\footnotetext{
${ }^{374}$ Cf. Herbert Wiedemann, op. cit., pp. 6 e 7. Fazemos referência também ao capítulo de pressupostos teóricos e dogmáticos deste estudo.

${ }^{375}$ Cf. Calixto Salomão Filho, Sociedade sem Sócio, cit., p. 127.
} 
administradores: o único interesse remanescente seria o da empresa em si, retomando as discussões controversas da doutrina da Unternehmen an sich, de Walther Rathenau ${ }^{376}$. Além disso, reconhecemos também que o interesse prático na existência de uma estrutura organizacional desta natureza é muito reduzido. A sociedade sem sócio, tudo visto, pareceria enquadrar-se, do ponto de vista de sua estrutura, como um meio termo entre uma fundação e uma sociedade, já que o seu objetivo seria indubitavelmente o de perseguir o lucro (como toda sociedade), mas, na ausência de propriedade (existindo apenas o controle), esse lucro não seria distribuível: essa forma de sociedade seria "uma forma jurídica capitalística destinada exclusivamente à auto-preservação e ao crescimento" $^{, 377}$, fazendo surgir a forma mais institucionalzada possível de organização, com desvinculação absoluta em relação aos sócios ${ }^{378}$.

\subsection{Tratamento Igualitário dos Acionistas}

\subsubsection{Considerações Gerais}

A recompra de ações próprias pode, como demonstramos, ser comparada, em certos aspectos, com uma distribuição de dividendos, mas isso não significa que não seja possível sublinharmos algumas diferenças substanciais entre ambas as formas de distribuição de recursos, a partir da perspectiva da paridade de tratamento dos acionistas.

\footnotetext{
376 Cf. Walther Rathenau, Vom Aktienwesen - Eine Geschäftliche Betrachtung, traduzida por Nilton Lautenschleger Jr., Do Sistema Acionário - Uma Análise Negocial, in Revista de Direito Mercantil, Industrial, Econômico e Financeiro, n. ${ }^{\circ}$ 128, Malheiros, São Paulo, 2002.

${ }^{377}$ Cf. Calixto Salomão Filho, Sociedade sem Sócios, cit., p. 132.

378 A propósito, cite-se o insuperável Fábio Konder Comparato que, escrevendo em 1970 (!), reproduziu um diálogo imaginário idealizado por Andrew Hacker, no contexto das "máquinas societárias" do futuro - as sociedades sem sócios. Em resumo, dispunha a fábula criada por Hacker sobre uma companhia americana, a American Electric, cujo único acionista era o fundo de pensão dos seus próprios funcionários. Em determinado ano, termina tal companhia seu processo de total automação industrial (por meio de máquinas), tornando desnecessários seus funcionários. Assim, com a demissão ou aposentadoria desses, a American Electric compra todas as ações detidas pelo fundo de pensão (pagando-lhe o preço correspondente), dissolvendo-o. A partir desse momento, torna-se essa companhia uma "máquina" sem acionistas e sem funcionários. Chamada a sua diretoria a depor no Senado americano por força do patrocínio, pela companhia, da aprovação de uma lei restringindo a importação de certos equipamentos elétricos, Hacker imaginou um maravilhoso diálogo entre o diretor e o Senador, que reflete justamente a busca pelo interesse da American Electric. Vale a transcrição da parte final do diálogo: "Senador: E por 'companhia' o Sr. não designa nem acionistas nem empregados, pois os Srs. não os possuem. E o Sr. também não designa os dez diretores, porque os Srs. parecem ser exatamente dirigentes assalariados que a máquina emprega para gerir os seus negócios. Na realidade, quando essa máquina faz política - ou qualquer outra atividade - ela tem interesses próprios que podem ser completamente diferentes dos interesses pessoais dos seus dirigentes. Sinto dizer que acho tudo isto bem confuso. Diretor: Pode lhe parecer confuso, Senador, mas eu posso dizer que tudo isto tem sido totalmente honesto para nós, na American Electric. Nós estamos fazendo exatamente o trabalho para o qual fomos contratados - cuidar dos interesses da companhia". In Fábio Konder Comparato, Aspectos Jurídicos da Macro-Emprêsa, RT, São Paulo, 1970, pp. 29 e 30.
} 
O princípio do tratamento igualitário destes não está presente de forma explícita na Lei das S.A. ${ }^{379}$, mas não se pode deixar de reconhecer a sua existência implícita, pois a lógica de tal tratamento - no sentido de que nenhum acionista poderá, dentro das mesmas circunstâncias, sofrer tratamento diferenciado - fornece à estrutura da anônima um arcabouço de proteção, necessário para que ela possa captar recursos do público investidor. Como as ações de uma mesma classe e espécie são homogêneas entre si, todas devem garantir os mesmos direitos e expectativas para seus titulares, inclusive as expectativas relacionadas aos seus direitos econômicos e de participação no acervo social, seja na liquidação, seja por meio da distribuição de lucros. Esta é uma premissa básica da estrutura da sociedade anônima.

Desse modo, nas situações de pagamento de dividendos, assim como nas recompras, a existência de um tratamento diferenciado, cristalizado em uma distribuição desproporcional dos lucros entre os acionistas da mesma classe, pode gerar comoções graves. "As a general proposition, a rule that assures substantive equality of dividend payments offers common stock investors a higher return per unit of risk, and society a less costly vehicle for obtaining capital, than a rule that permits indeterminately differential payments of common stock dividends. It also can reasonably be said to conform to public investors' expectations" - grifos nossos ${ }^{380}$. Apesar de a Lei das S.A. não dispor explicitamente sobre a distribuição proporcional dos dividendos de acordo com a titularidade do capital social, ela determina expressamente que as ações de cada classe conferirão aos seus titulares iguais direitos (art. 109, $\S 1^{\circ}$ ), o que necessariamente deve corresponder à distribuição proporcional dos lucros (que é um dos itens listados no próprio artigo 109): não vemos razões minimamente aceitáveis que justificassem uma distribuição desproporcional. O mesmo vale para negócios da companhia com as suas ações, não há regra manifesta na Lei das S.A. que obrigue a companhia a realizar os negócios de maneira proporcional entre todos os acionistas, ou a estender-lhes igual oportunidade de participação no negócio.

De toda sorte, o mecanismo da recompra de ações pode representar, do ponto de vista substancial, uma tentativa de transferir valor e patrimônio da sociedade para um ou

\footnotetext{
${ }^{379} \mathrm{O}$ que não significa que a Lei das S.A. não contenha dispositivos claros no sentido de conceder proteção contra o tratamento diferenciado ou privilegiado. Assim é que, em nossa opinião, uma recompra de ações em que apenas o acionista controlador se visse na posição de alienante, em prejuízo e exclusão dos demais, violaria o seu dever de lealdade - previsto no artigo 116 -, bem como constituiria abuso do poder de controle, nos termos do artigo 117, os quais seriam mecanismos eficientes de proteção aos interesses dos minoritários, no sentido de receber um tratamento equitativo. Cf. também Calixto Salomão Filho, Sociedade sem Sócios, cit., p. 129.

${ }^{380}$ Victor Brudney, op. cit., p. 1077.
} 
para determinados sócios, como os controladores, em detrimento dos demais: "either because controllers know favorable corporate information not known to the market, or because management views the stock as its best investment opportunity"381 - existe um perigo tangível na estruturação destes negócios jurídicos, que se traduz na possibilidade de que sejam usados como forma de garantir uma distribuição desproporcional de recursos da companhia para os seus acionistas, e, igualmente, de que a administração possa influenciar a composição do círculo societário, em detrimento do interesse social ${ }^{382}$.

Na compra proporcional de ações de todos os membros da coletividade não existe diluição ou concentração injustificada da participação acionária, mas em aquisições ou alienações direcionadas a determinados acionistas existe a potencial influência da companhia sobre quem efetivamente comporá seu círculo societário. Nestas, a preocupação premente da lei deve ser a de evitar negócios evidentemente ilícitos, que tenham por finalidade prejudicar dolosamente um ou um grupo de sócios, em benefício não da sociedade, mas, por exemplo, do controlador - como pode ocorrer, v.g., quando a sociedade pretenda desfazer-se de um determinado grupo minoritário de acionistas tradicionalmente opositores ao controlador; ou, ainda, quando determinado acionista, detendo informação privilegiada sobre a companhia, retira seus investimentos antes da informação tornar-se pública, vendendo suas ações a ela: "[i]mplicit in the cases is the concept that the distribution of corporate assets embodied in the repurchase should not result in selling stockholders being treated more, or less, favorably than surviving stockholders",383.

Na Alemanha, por exemplo, o §71, Abs. 1, Nr. 8, S. 3, ao fazer referência ao §53a, ambos da Aktiengesetz de $1965^{384}$, impõe, concretamente, a observância do princípio do tratamento igualitário dos acionistas nas operações de compra e de venda ${ }^{385}$ pela companhia de suas ações. A Diretiva Alteradora, muito depois da edição da Aktiengesetz, acolheu de forma inequívoca o princípio para as operações com as próprias ações, ao modificar a redação do art. 19 da $2^{\text {a }}$ Diretiva, que passou a assim estar redigido: “1. Sem

\footnotetext{
${ }^{381}$ Victor Brudney, op. cit., p. 1107.

382 Esta última perspectiva mostra gravidade ainda mais evidente em países como o Brasil, onde a figura do acionista controlador é uma realidade histórica e presente.

${ }^{383}$ Victor Brudney, op. cit., p. 1108.

384 "§53a. Tratamento Igualitário dos Acionistas. Os acionistas deverão, sob as mesmas condições, serem submetidos a tratamento igualitário". No original: " $\$ 53 a$. Gleichbehandlung der Aktionäre. Aktionäre sind unter gleichen Voraussetzungen gleich zu behandeln".

${ }^{385} \mathrm{Na}$ Itália, o art. 132 do Decreto Legislativo 58, de 24 de fevereiro de 1998 ("testo unico delle disposizioni in materia di intermediazione finanziaria") determina que "gli acquisti di azioni proprie (...) devono essere effetuati in modo da assicurare la parità di trattamento tra gli azionisti (...)" - grifamos. A norma parece limitar a aplicação desse princípio, portanto, apenas às compras de ações próprias.
} 
prejuízo do princípio da igualdade de tratamento de todos os acionistas que se encontrem na mesma situação (...)" - o que, na realidade, representou mais uma "declaração de esclarecimento" (deklaratorische Klarstellung) ${ }^{386}$ do que uma inovação, uma vez que o art. 42 da Segunda Diretiva, talvez não de maneira tão irrefutável, já previa o tratamento igualitário como regra geral para a norma como um todo: "para a aplicação da presente diretiva, as legislações dos Estados-Membros garantirão um tratamento igual aos acionistas que se encontrem em condições idênticas".

\subsubsection{O Preço como Fonte de Discriminação: As Formas de Aquisição como Mitigadores}

Não apenas pela exclusão de alguns acionistas da possibilidade de realizar o negócio jurídico, mas também pela estipulação do preço de aquisição acordado, poderá haver indícios de um tratamento diferenciado entre acionistas. Pode-se dizer que uma inflação exagerada do preço de aquisição de uma recompra (assim como um preço excessivamente baixo em uma alienação) tende a caracterizar uma forma ilegítima de transferência de patrimônio a determinados acionistas, que acabariam recebendo, pela sua participação social, mais recursos (ou ações a menor preço) do que de outra forma teriam direito, dilapidando o patrimônio social de forma injustificada. Para dar o tom do raciocínio, gostaríamos de fazer referência à discussão na doutrina alemã, que expusemos no item referente ao tratamento contábil das ações em tesouraria, sobre a natureza da recompra como retorno ilegítimo das entradas dos sócios, ou não, a depender do preço pago pela aquisição: um preço de aquisição "inflado" poderia, então, ser considerado como uma maneira ilegítima de tratamento diferenciado entre acionistas e, concomitantemente, um retorno ilegal de capital aos sócios ${ }^{387}$ ?

Na Lei das S.A., o artigo $30, \S 1^{\circ}$, “b”, estipula ser possível a aquisição para permanência em tesouraria, mas não baliza sob quais condições de preço essa aquisição deve ser feita.

\footnotetext{
${ }^{386}$ Cf. Andreas Cahn, Die Auswirkungen der Kapitaländerungsrichtlinie auf den Erwerb Eigener Aktien, in Institute for Law and Finance Working Paper 61, Goethe Universität, Frankfurt, 2007, p. 3.

387 "Ainda pior é o caso no qual determinados acionistas influentes vendem as suas ações a um preço demasiadamente alto. Tal significa um prejuízo aos demais acionistas pelo deferimento de tratamento diferenciado a alguns, e, ao mesmo tempo, um prejuízo aos credores, uma vez que uma compra nesses moldes equivale, economicamente, a uma devolução do capital social, que deve servir como proteção destes". No original: "Noch schlimmer ist es, wenn einzelnen einflußreichen Aktionäre die Aktien noch zu hohen Preisen abgekauft werden. Das bedeutet eine Schädigung der übrigen Aktionäre durch Bevorzugung einzelner, es bedeutet zugleich eine Beeinträchtigung der Gläubiger, da ein solcher Erwerb wirtschaftlich einer Rückzahlung des Grundkapitals gleichkommt, das der Sicherung der Gläubiger dienen soll'. Cf. Alfred Hueck, Gesellschaftsrecht - Ein Studienbuch, 3ª ed., Beck, Munique, 1951, p. 150.
} 
Em uma companhia aberta, a intuição levaria a crer que o preço da aquisição devesse ser sempre o de bolsa, independentemente de indagar se a compra foi em bolsa ou privada, para evitarmos discussões acerca de prejuízo aos demais acionistas. Com efeito, prevê o artigo 12 da Instrução CVM 10 que a aquisição das ações próprias pela companhia aberta nunca pode ser realizada por valor superior ao valor de mercado das ações. Mesmo que exista uma ordem de compra por preço muito superior ou inferior ao da média dos últimos pregões, a BVMF irá submetê-la a leilão, permitindo a interferência entre ordens compradoras e vendedoras (nos termos da Instrução CVM 168), na tentativa de ajustar o preço original àquele de mercado. No caso de ofertas públicas de aquisição de ações, realizadas pela própria companhia, a Instrução CVM 361 exige preço uniforme e determinado, mas não impõe que seja ele necessariamente o valor de bolsa; até porque, se assim fosse, não haveria razão econômica racional para que os acionistas aceitassem a oferta - poderiam simplesmente vender suas ações no mercado. Dessa forma, entendemos que é legítima a interpretação de que o artigo 12 da Instrução CVM 10 não se aplica aos casos de ofertas públicas voluntárias de aquisição das próprias ações (valendo, no entanto, os demais limites, como o de $10 \%)^{388}$. Ainda que seja essa efetivamente a intuição, nada impede, teoricamente, que uma companhia possa optar por realizar uma venda ou compra de seus papeis a preços diferentes dos de mercado, quando, por exemplo, isso for favorável a ela, o que pode ocorrer quando ela utiliza ações em tesouraria como moeda de pagamento em uma operação societária de aquisição ou incorporação, sendo atribuído às ações preço superior ao de mercado (e a CVM já decidiu em sentido semelhante, como veremos) ${ }^{389}$. Neste caso, não há prejuízo aos acionistas (que não teriam sequer interesse econômico em adquirir as ações a preço maior do que o disponível em bolsa), muito menos à companhia, que estaria utilizando de maneira extremamente eficiente suas ações em tesouraria - o ponto, aqui, será a transparência das condições do negócio e a aprovação da assembleia (por tratar-se de uma negociação privada, que, por essa razão, não poderá ser estendida irrestritamente a todos os acionistas), como esclareceremos.

Nas companhias fechadas, de outra sorte, não há nenhuma regra. Nestes casos, entendemos que a companhia detém total liberdade para estipular o valor das ações para a

\footnotetext{
${ }^{388}$ Cf. Alexander Kitanoff, op. cit., p. 63.

${ }^{389} \mathrm{Na}$ Alemanha, em se tratando de exclusão de direito de preferência em aumento de capital quando o preço de emissão for próximo ao de mercado e o volume inferior a $10 \%$ do capital social, parece ter-se mencionado, nas discussões legislativas do Bundestag e não no texto legal final, um percentual de prêmio de $3 \%$ a 5\% sobre o valor de bolsa como permitido, sem justificativa, no entanto. Cf. Entwurf eines Gesetzes für kleine Aktiengesellschaften und zur Deregulierung des Aktienrechts, BT-Drucksache 12/7848, p. 9. Comparar com a redação do correspondente §186, Abs. 3, S. 4 da Aktiengsetz de 1965.
} 
recompra (que poderão ser apenas privadas, nitidamente), observados dois fundamentais requisitos: (i) a recompra apenas pode ser feita com saldo de lucros ou reservas (art. 30, §1, "b”, da Lei das S.A.), e (ii) os acionistas devem ser tratados de maneira igualitária, assim entendida uma situação na qual, sob as mesmas premissas, todos os acionistas tenham tido a mesma oportunidade de acesso à operação ${ }^{390}$ ou tenham tido oportunidade de aprovar a exclusão de sua participação no negócio jurídico ${ }^{391}$. Sendo atendidas essas duas premissas, não há razão para preocupação em relação à possibilidade de prejuízo aos acionistas ou credores, já que o capital social estará mantido, por força da utilização do saldo de lucros ou reservas, e tendo em vista que todos os acionistas terão tido acesso à operação (ou aprovado o seu "não-acesso"), não havendo tratamento privilegiado. Inexistem, nesta visão, limites objetivos máximos ou mínimos, até porque, havendo-lhe sido estendida a possibilidade de negociar com a companhia naquelas condições, cumpre ao acionista decidir se contrata ou não. Em outras palavras, atendidos esses dois requisitos primordiais, o preço de aquisição passa a ser assunto de importância secundária ou mesmo de nenhuma importância - o principal é a uniformidade de informações entre companhia e todos os acionistas, permitindo que cada um deles tome a decisão de vender/comprar ou não as ações ao preço que a companhia está oferecendo a todos eles indistintamente ${ }^{392}$.

Assuma-se uma companhia fechada com 10 acionistas, titulares de 100 ações ordinárias de mesma classe e espécie cada um, sem valor nominal, de patrimônio líquido de $\mathrm{R} \$ 150$ mil, sendo que desse valor o saldo de reserva de lucros é de $\mathrm{R} \$ 100$ mil e o capital social de $\mathrm{R} \$ 50$ mil. O valor de patrimônio líquido das ações, neste exemplo, seria de R \$150 por ação (R \$150 mil / 1000 ações emitidas) - este preço seria, quiçá, o mais

\footnotetext{
${ }^{390}$ Avaliando em profundidade o assunto, do ponto de vista da alienação de ações representativas do controle de uma sociedade (e do direito de venda conjunta, nas mesmas condições, pelos demais acionistas), cf. William D. Andrews, The Stockholders' Right to Equal Opportunity in the Sale of Shares, Harvard Law Review, Vol. 78, N. ${ }^{\circ}$ 3, 1965, pp. 505 e ss. Avaliando o caso Pearlman v. Feldman, o autor alude a que " $[t]$ he right violated, then, is simply the right of all stockholders to have an equal opportunity to participate ratably in a sale of stock pursuant to an offer to purchase controlling shares at a favorable price" - o debate atingia o direito de tag along, que parte de uma discussão um pouco distinta (a de se as ações de controle têm valor maior do que as demais ou não) da deste caso.

${ }^{391}$ É justamente nesta alternativa, que encontramos razão para, data venia, discordar da opinião de Luiz Gastão Paes de Barros Leães, para quem: "se a aquisição em tela é um processo voluntário, como falar em obrigatoriedade de estender essa compra a todos os demais acionistas, como forma de manutenção do princípio da isonomia acionária? Deveríamos estender essa operação à totalidade das ações da sociedade, a ponto de atingir a sua liquidação?". Em verdade, se for impossível, pela sua natureza, a extensão da possibilidade teórica (como ocorre nas operações de bolsa) de que todos os acionistas participem do negócio privado, então se tem na aprovação da assembleia o contraponto necessário. Cf. Luiz Gastão Paes de Barros Leães, Pareceres, Singular, São Paulo, 2004, p. 647.

392 "Onde evitare che alcuni soci vengono privilegiati rispetto ad altri, sono estate elaborate especifiche disposizioni affinché venga garantito da parte dei managers un dovere di informazione nei confronti di tutti gli azionisti dei dettagli che caratterizzano il piano di riacquisto". Cf. Barbara Pozzo, op. cit., p. 107.
} 
óbvio para uma recompra. No entanto, a nosso entender, nada impede que a companhia adquira uma ação de cada acionista a $\mathbf{R} \mathbf{\$ 1 0}$ mil. Isso porque o requisito legal de proteção aos credores estará atendido (o saldo de lucros, de $\mathrm{R} \$ 100$ mil reais, é suficiente para comportar o valor total da recompra) e porque todos os acionistas tiveram oportunidade de participar da operação proporcionalmente (sendo adquirida uma ação de cada), não havendo tratamento privilegiado. É verdade que, nesse caso, o valor das ações remanescentes diminuiria, considerando a utilização de todo o lucro social, mas é igualmente verdade que todos os acionistas, de maneira equitativa, receberiam compensação financeira, consubstanciada no pagamento do preço de aquisição ${ }^{393}$.

À vista do exposto, ressalta como de importância ímpar o reconhecimento de que as variadas formas de aquisição das próprias ações pela companhia (em bolsa, em oferta pública, ou por meio de operações privadas) podem ser mais ou menos propensas a ofender o princípio do tratamento equitativo entre acionistas.

Em bolsa, além da possibilidade de interferência nas ordens (mecanismo que busca equalizar o preço das ações), o anonimato das operações garante a possibilidade teórica de todos os acionistas, indistintamente, aceitarem as ofertas de compra ou venda feitas pela companhia - esta peculiaridade enfraquece o problema de tratamento diferenciado, dado que a companhia não terá como antever suas contrapartes e, portanto, não terá como, deliberadamente, prejudicar ou favorecer acionistas específicos. Estas especificidades das transações bursáteis, aliás, fizeram com que a Aktiengesetz de 1965 previsse, no §71, Abs.1, 8, S.4, que as operações de compra e venda de ações, se realizadas em sistema de bolsa, automaticamente supririam o comando de igualdade de tratamento a que o mesmo artigo faz referência (esta forma de aquisição é vista como um "porto seguro") ${ }^{394}$.

Em operações fora de bolsa, cujos exemplos são as ofertas públicas de aquisição e os negócios privados, a situação não é tão simples. Mesmo em uma situação de oferta

\footnotetext{
393 "Em uma recompra de ações pro rata não tem qualquer relevância, de acordo com a posição aqui defendida, o preço de aquisição, desde que todos os acionistas, proporcionalmente à sua participação no capital social, tenham as mesmas chances de negociar com a companhia. Quando, no entanto, apenas alguns acionistas podem negociar, existe a preocupação de que os demais possam financiar a recompra por meio da diluição do valor de suas participações". No original: "Bei einem Aktienrückkauf pro rata spielt nach der hier vertretenen Ansicht der Kaufpreis keine Rolle, solange jedem Aktionär gemäß seiner Beteiligungsquote die gleiche Andienungschance eingeräumt wird. Wenn aber nur bestimmte Aktionäre ihre Aktien andienen können, besteht hier die Besorgnis, dass die anderen Aktionäre den Rückkauf über die Verwässerung ihre Anteilsscheine finanzieren". Cf. Alexander Kitanoff, op. cit., p. 164.

${ }^{394}$ Cf. Alexander Kitanoff, op. cit., p. 37. Por conseguinte, entendemos a razão pela qual a Instrução CVM 10 veda, no art. $2^{\circ}$, "d", a participação do controlador como contraparte da companhia nos negócios: a presunção é a de que ele estaria inclinado a beneficiar-se com a operação, em detrimento dos minoritários. Contudo, não podemos admitir que essa proibição seja aplicável mesmo quando o negócio ocorrer em bolsa: nesta hipótese, inexiste forma de concretização da presunção acima exposta, uma vez que não há certeza de que será ele quem contratará com a companhia e os demais acionistas poderão, coincidentemente, intervir.
} 
pública de compra das próprias ações pela companhia, dirigida a todos os acionistas de uma mesma classe e ao mesmo preço fixo, surgem dúvidas quanto ao tratamento equitativo, como, por exemplo, no caso de escolha de algum critério de rateio a ser utilizado pela companhia na verificação de um excesso de demanda pelos acionistas. Como deveria a companhia efetuar o rateio de forma equitativa? As duas principais teses são as de que ela deve ratear a aceitação das ofertas de venda: (i) de acordo com a participação do acionista vendedor no capital da companhia, ou (ii) de acordo com a participação proporcional de cada oferta de venda no volume total de ofertas de venda, atribuindo mais peso àqueles acionistas que tenham se disposto a alienar, proporcionalmente aos demais, mais ações pelo mesmo preço. A escolha de um ou outro método pode gerar significativas diferenças numéricas, de modo que somos da opinião de que a primeira opção de rateio deveria prevalecer: esta recompra, tal qual o pagamento de dividendos, corresponde economicamente a uma extensão do direito do acionista de participar no lucro da sociedade e, sendo este último repartido de acordo com a participação social, não deveria ser diferente a conclusão no caso das recompras, que são genericamente, como se afirmou, uma forma de distribuição de lucros aos acionistas ${ }^{395}$.

\subsubsection{Aquisições Privadas}

A compra privada, por sua vez, é genericamente vista como a operação particularmente mais apta a ofender o princípio do tratamento equitativo entre acionistas, por razões naturais, basicamente refletidas no fato de que são operações bilaterais, cursadas fora do ambiente de bolsa - e, justamente por isso, muito propensas à discriminação de quais acionistas poderão ter acesso ao negócio -, além de possuírem um caráter muito forte de negócio jurídico plenamente dispositivo, cujos termos são maleáveis de acordo com a vontade das partes contratantes (preço, por exemplo). Existe, com relação a ela, uma presunção de lesividade aos acionistas, por poder resultar em uma transferência implícita de valor (implied wealth transfer) da companhia para o acionista. Em estudo empírico realizado por M. Bradley e L. M. Wakeman com diversas operações de recompra de ações no mercado norte-americano entre 1974 e 1980, foram testadas diferentes formas e justificativas de recompras de ações de companhias abertas, bem como seus efeitos sobre o valor da companhia após a operação: em alguns casos, foram verificados efeitos positivos sobre o valor das ações (confirmando a teoria da sinalização e os estudos de Theo

${ }^{395}$ Cf. Alexander Kitanoff, op. cit., p. 144. 
Vermaelen de 1981, que apontavam aumento do preço das ações remanescentes) e, em outros, efeitos negativos sobre o valor da companhia. Uma das hipóteses em que foi identificada uma perda de valor para os acionistas foi justamente nas operações de recompra "direcionadas" (single block repurchase); ou seja, naquelas operações privadas negociadas com um ou um grupo específico de acionistas, com exclusão dos demais, que seriam situações nas quais a justificativa do negócio não seria necessariamente o interesse da companhia: "The evidence presented in this paper is consistent with the hypothesis that a single block repurchase (...) is used by the managers of the repurchasing firm to eliminate a threat to their control over the firm. In a sense, they use the repurchase premium to bribe the selling stockholder into giving up his interest in the firm and, by implication, cease monitoring the firm's activities. As a result, the managers of the repurchasing firm are able to pursue an operating strategy that is more in line with their own interests and less in line with those of their stockholders" 396.

Seria o caso, então, de vedá-las por completo por afronta formal ao princípio do tratamento igualitário? Especialmente para as companhias fechadas, uma interpretação que proibisse, genericamente, essa forma de contratação seria extremamente prejudicial, e até mesmo incompatível com o fato de que as ações dessas companhias não são negociadas em bolsa. Ademais, lembramos que existem algumas situações nas quais as recompras, mesmo privadas e mediante pagamento de prêmio ao vendedor, podem perseguir finalidades legítimas da companhia, como, por exemplo, ao permitir um caminho de saída da sociedade a um sócio descontente, de forma rápida e benéfica à atividade social (eliminando a incerteza de terceiros sobre o futuro da sociedade). Por essa razão, não vemos como impedir, nem mesmo como atribuir uma presunção relativa de ilegalidade, a essas operações: o princípio do tratamento igualitário dos acionistas admite que as situações fáticas possam justificar a adoção de critérios diferenciados, tendo em vista sempre o interesse da sociedade.

Poderiam os acionistas, por exemplo, reunidos em assembleia, autorizar a realização de um negócio jurídico privado com as próprias ações pela companhia com um acionista ou grupo especificado (i.e., poderiam eles justificar, em sede de assembleia, o tratamento diferenciado, consubstanciado na ausência de acesso ao negócio jurídico)? Conceitualmente, a resposta a essa pergunta impende ser afirmativa, uma vez que os acionistas são soberanos para decidirem, no âmbito da assembleia, sobre qualquer assunto

\footnotetext{
${ }^{396}$ Michael Bradley e L. Macdonald Wakeman, The Wealth Effects of Targeted Share Repurchases, Journal of Financial Economics, Vol. 11, p. 327.
} 
de interesse da companhia. A primeira dúvida que surge é qual o quórum de aprovação necessário. Impor um quórum de unanimidade, sob a alegação de que a aprovação de um tratamento diferenciado entre acionistas dependeria de uma renúncia individual, além de exagerado, seria evidentemente impraticável em muitas companhias, mesmo nas fechadas. Não nos parece justificado tal quórum, pois a Lei das S.A. o adota apenas em casos isolados, plenamente circunstanciados ${ }^{397}$. Na ausência de especificação pela Lei das S.A., ou pelo estatuto social da companhia, deve prevalecer o quórum genérico de maioria absoluta dos acionistas, nos termos do artigo 129 da Lei das S.A.

Nessa assembleia, parece-nos, poderá votar também o acionista que contratará com a sociedade (contrariamente, por exemplo, à lei inglesa, que veda essa participação, por impedimento de voto): é um caso de conflito substancial, e não formal, de interesses $^{398,399}$.

Como se sabe deste já tão debatido, e ainda assim controverso, tema, a vexata quaestio está na redação do artigo $115, \S 1^{\circ}$ da Lei das S.A., que usa a expressão "não poderão votar", indicando a existência de uma hipótese de proibição de voto. Na realidade, grande parte da doutrina brasileira já chegou ao consenso de que se trata de hipótese de conflito substancial de interesses, devendo ser analisado ex post, mesmo em se tratando de hipótese de deliberação sobre um contrato bilateral, pois a mera existência de interesses duais não acarreta, ipso facto, o conflito de interesses: o acionista pode, ainda, exercer seu direito de voto no interesse da companhia, sacrificando o seu próprio. Ou mais, o contrato

\footnotetext{
${ }^{397}$ Quais sejam: (i) a transformação da companhia, nos termos do art. 221 da Lei das S.A., e (ii) a aprovação de cisão desproporcional, nos termos do art. 229, $\$ 5^{\circ}$ da mesma lei. Além disso, o art. 1.127 do Código Civil prevê quórum de unanimidade para a mudança de nacionalidade da companhia (aplicável às anônimas tanto pelo uso da expressão "acionistas", no próprio artigo, quanto pelo disposto no art. 1.089 do mesmo diploma).

${ }^{398}$ Leães nos lembra sobre a diferença entre o conflito formal (divieto di voto, no direito italiano, Auschlu $\beta$ des Stimmrechts, na Alemanha) e conflito substancial de interesses (conflito di interessi, na Itália, Stimmrechtsmissbrauch, na Alemanha): "Daí a distinção feita pela doutrina e jurisprudência peninsulares entre proibição de voto (divieto di voto) e conflito de interesses (conflitto di interessi). Trata-se de hipóteses diversas, com pressupostos diferentes e distintas conseqüências jurídicas. No caso de proibição de voto em assembléia, mais do que a incompatibilidade entre o interesse do sócio e da companhia, há um controle ex ante da legitimidade do voto com base em precisos indícios formais (...). Da infringência dessa abstenção, decorreria a consequentia iuris da nulidade do voto e anulabilidade da decisão decorrente do voto contaminado com vício de legitimação. Já no caso de conflito de interesses, cabe uma indagação relativamente ao mérito da deliberação da assembléia, para a qual foi decisivo o voto do acionista, para se apurar se há ou não a incompatibilidade entre os interesses do acionista e da companhia, manifestada no voto do acionista (vale dizer, cabe apurar se há abuso no exercício do direito de voto). Nessa hipótese, o controle é ex post, de onde se deduz que deva ser apurado caso a caso, para efeito de sua eventual anulação". In Luiz Gastão Paes de Barros Leães, Conflito de Interesses e Vedação de Voto nas Assembléias das Sociedades Anônimas, Revista de Direito Mercantil, Industrial, Econômico e Financeiro, Malheiros, São Paulo, $\mathrm{n}^{\circ}$ 92, pp. 107 a 110.

${ }^{399}$ Como nos ensina Erasmo Valladão: "Já no que tange ao conflito de interesses, há um controle ex post: torna-se necessária uma indagação relativamente ao mérito da deliberação, para a qual foi decisivo o voto do acionista, a fim de apurar se efetivamente ocorreu incompatibilidade entre os seus interesses e o interesse da companhia”. In Conflito de Interesses..., cit., pp. 77-78.
} 
bilateral pode, até mesmo, ter sido celebrado sob condições equitativas de mercado, como, a contrario sensu, permite a própria Lei das S.A. no artigo $117, \S 1^{\circ}$, "f"400,401 . Não nos restam dúvidas, à luz disso, de que todos os acionistas podem votar nessa assembleia e, se houver estipulação, por exemplo, de um preço abusivo em benefício da maioria deliberante (e isto vale igualmente para as companhias abertas), então o voto será anulável e assim também a assembleia, se tal voto tiver sido decisivo para a formação da maioria - a regra geral do conflito de interesses é uma boa régua para a avaliação da legalidade destes negócios privados, mesmo que aprovados em assembleia.

Para as companhias abertas, a atual Instrução CVM 10 veda qualquer tipo de negócio privado, devendo cada situação de exceção ser submetida à prévia aprovação da CVM, conforme artigo 23 da Instrução CVM 10. A norma deveria prever, no entanto, que as operações privadas de compra sejam precedidas sempre por deliberação da assembleia geral de acionistas - e não do regulador -, que são efetivamente os maiores, mas não os únicos, interessados no negócio.

Em resumo, a saída, parece-nos, é condicionar essas operações à deliberação da assembleia geral, soberana para decidir sobre as operações, submetendo a análise sobre eventual abuso de direito de voto, abuso de controle ou quebra do dever de lealdade à avaliação a posteriori.

\subsubsection{Alienações Privadas: Vendas, Operações Societárias, Planos de Opção de Compra, Doações}

Usualmente, quando se discute a questão do tratamento igualitário ou equânime entre os acionistas, tem-se em mente a situação de recompra das ações, para entesouramento. Nos parágrafos acima, quando defendemos que o requisito do tratamento igualitário seria atendido com a garantia de possibilidade de acesso ao negócio, ou aprovação do "não-acesso" em assembleia, discorremos apenas acerca da situação de compra privada. Novamente, as operações em bolsa de valores não nos preocupam - elas

\footnotetext{
400 "Entendemos, dessa forma, que, ao fazer referência a 'interesse conflitante com o da companhia', no $\S 1^{\circ}$, do artigo 115, a lei não está se reportando a um conflito meramente formal, mas sim a um conflito substancial, que só pode ser verificado mediante o exame do conteúdo da deliberação", in Erasmo Valladão Azevedo e Novaes França, Conflito de Interesses..., cit. p. 97 - os grifos são do original.

${ }^{401}$ Nunca é demais relembrar, inclusive, no tocante a este tema, que a proibição de voto dos acionistas em matéria que tratasse da conclusão de negócio entre o acionista e a sociedade foi retirada do rol expresso de proibições de voto do § 252 do Código Comercial (Handelsgesetzbuch) alemão de 1897, exatamente porque essa proibição expressa dava margem a uma série de abusos dos minoritários e impedia a celebração de contratos úteis à sociedade. A Aktiengesetz de 1937, seguindo a orientação da própria doutrina (desenvolvida antes mesmo da edição de tal norma), no §114, 5, já não mais previa esta hipótese. In Erasmo Valladão Azevedo e Novaes França, Temas de Direito Societário..., cit., p. 336 e, adiante, pp. 572 - 575.
} 
atendem automaticamente ao requisito da lei -, apenas as operações de alienação privadas, realizadas por companhias abertas e fechadas, é que ganham em interesse.

Entendemos que, nestas, a lógica aplicada às compras privadas tem igual aplicação - talvez com evidência ainda mais marcante, considerando a variedade de possibilidades de alienação, não resumidas à venda. Ou seja, não só na compra, mas também na alienação privada, deve a companhia garantir tratamento igualitário aos acionistas existentes, consubstanciado ou na possibilidade de que todos possam participar do negócio (adquirindo as ações ao preço oferecido pela companhia), ou na aprovação, por eles, de uma operação da qual não lhes será permitido participar $^{402}$.

Não convencem os argumentos que negam esse raciocínio sob o pretexto de que as ações em tesouraria passam, uma vez adquiridas, a ser bens da companhia, como máquinas e equipamentos, e que, dessa maneira, teria ela a prerrogativa, inerente ao seu direito de propriedade, de delas dispor da forma, e no preço, que melhor lhe conviesse. Em primeiro lugar, sequer podem ser consideradas as ações em tesouraria como "ativos" da sociedade; elas representam, como vimos, apenas uma semente de realização futura de valor - sequer contabilizam-se como ativos. Em segundo lugar, inapelavelmente, é forçoso reconhecer que o objeto do negócio jurídico tem natureza jurídica diferenciada: no caso das ações em tesouraria, negocia-se, em conjunto com a ação (bem singular), também o estado de sócio, diferenciando-a de um ativo comum da companhia ao atribuir uma situação jurídica ao adquirente. No caso da alienação de ativos comuns (como uma máquina), a garantia de proteção aos acionistas está no tratamento dos negócios com partes relacionadas (se houver venda dessa máquina a um sócio), do abuso do poder de controle, dos deveres fiduciários da administração e do dever de lealdade do controlador (quando o bem seja vendido a terceiros por preço vil ou abaixo de mercado, em prejuízo do interesse social). Já no caso de alienação de ações próprias, modifica-se a esfera societária da companhia: conjuntamente com a saída das ações da tesouraria, admite-se novo sócio ou aumenta-se a participação de um já existente, influenciando, assim, todo o ordenamento societário, patrimonial e da empresa da companhia envolvida. Neste cenário,

\footnotetext{
${ }^{402}$ Reforça-se: o princípio do tratamento igualitário, de forma mais evidente nas alienações, não requer que a companhia, em qualquer caso, abra a possibilidade de contratação do negócio a todos os acionistas, o que seria, evidentemente, impossível em muitos casos. Diferentemente das aquisições, que se concretizam basicamente por meio de um contrato de compra e venda, as alienações podem adotar diversas formas algumas delas são impraticáveis aos acionistas da companhia, como na hipótese de uma permuta de ações (chegaremos ao tópico). O princípio de que se cuida neste item é atendido, também, com a adoção dos procedimentos de transparência e aprovação da assembleia.
} 
além das proteções acima, afigura-se o princípio do tratamento igualitário como adequado balanceamento desses riscos.

Note-se bem: o tratamento igualitário não impõe, neste caso, como tampouco o faz no caso de compras privadas, que todos os acionistas necessariamente tenham a possibilidade de celebrar o negócio jurídico em substituição à contraparte pretendida, mas que eles tenham ao menos tomado conhecimento da operação e deliberado sobre seu "não-acesso". Não reconhecer esse princípio seria permitir que uma companhia alienasse ações em tesouraria a um terceiro (ou a acionistas determinados) a preços muito baixos permitindo a entrada de um novo sócio, ou aumentando a influência dos já existentes -, enquanto os demais acionistas continuariam obrigados a pagar preço mais alto para poderem adquirir essa mesma quantidade de ações no mercado.

É bastante clara a fonte de descontentamento dos acionistas que não participarem dessa alienação, de tal modo que é justificável a imposição de alguma forma de transparência e controle desse tipo de negócio. A que ora se sugere é o envolvimento da assembleia geral, fórum adequado para a publicidade da operação à generalidade dos acionistas (por força dos procedimentos de convocação e de estabelecimento da ordem do dia) e, simultaneamente, órgão deliberativo máximo da companhia, onde todos os acionistas concorrerão para a formação de uma única vontade social.

Reconhece-se, por outro lado, que o envolvimento da assembleia geral, como condição para a realização de qualquer negócio privado, de alienação ou de compra, pode configurar um engessamento excessivo à companhia, além de significar um aumento de seus custos (é patente o custo envolvido na convocação e realização de assembleias, especialmente em companhias abertas). Adicionalmente, mencione-se que nem sempre os acionistas reunidos em assembleia conseguirão, efetivamente, definir se a operação privada (e o preço estipulado para as ações) está sendo contratada nos melhores termos possíveis à companhia. Isso se torna muito nítido em companhias abertas, nas quais os acionistas muitas vezes sequer à assembleia comparecem: existe um grau elevado de desinteresse por parte deles nos negócios sociais, o que tornaria o requisito da submissão à assembleia tãosomente custoso, porém não benéfico. Tudo visto, ainda assim defendemos maior envolvimento da assembleia geral na contratação das compras e vendas privadas, uma vez que este é um procedimento que garantirá mecanismos de controle mais nítidos por parte dos acionistas: (i) uma vez submetida a operação à assembleia, vale o que deliberar a maioria, sujeitando os demais acionistas a essa decisão (princípio majoritário), (ii) nenhum acionista poderá alegar desconhecimento da operação (caso tenha sido regularmente 
convocada e instalada a assembleia), (iii) eventual abuso no exercício do direito de voto poderá ser levantado pelos acionistas que se sentirem prejudicados, mediante a utilização dos tradicionais remédios jurídicos disponíveis (conflito de interesses, abuso do poder de controle, etc.), (iv) será mais simples anular uma assembleia, ou impedir a sua realização, do que buscar a anulação do negócio jurídico celebrado pela companhia (uma vez que, para tanto, o acionista precisaria munir-se de elementos que comprovassem a razão do pedido de anulação do negócio do qual não participou e sobre o qual dificilmente conseguirá detalhes, além da problemática questão de sua legitimação para tanto), e por aí vai $^{403}$.

Dando prosseguimento ao raciocínio, a lógica desenvolvida nos parágrafos antecedentes (participe ou aprove a não participação), ao que nos parece, pode ser aplicada para qualquer tipo de negócio privado. Citamos, em primeiro lugar, a alienação privada das ações em tesouraria como pagamento de uma aquisição societária realizada pela companhia.

Neste caso, imaginemos que uma companhia negociou a aquisição de controle de uma sociedade e, como forma de pagamento, contratou a entrega de ações em tesouraria ao vendedor como parte, ou como a totalidade, do preço. A situação, não rara, a depender de como for estruturada, assemelha-se societariamente a uma incorporação de ações ou a uma incorporação da companhia, pois os acionistas da sociedade adquirida passam a ser acionistas da companhia que negocia com as próprias ações. Assim, na nossa visão, muito embora não haja previsão expressa nesse sentido, seria necessária a submissão da operação à assembleia geral de acionistas por duas razões: (i) em primeiro lugar, é patente que esta é uma das típicas operações privadas que não poderão ser contratadas por todos os acionistas indistintamente, de forma que, em linha com o nosso raciocínio, devem eles dela tomar conhecimento e aprovarem seus termos em assembleia, (ii) como se não bastasse essa razão, nessa assembleia seria possível a apresentação aos acionistas do laudo de avaliação da sociedade adquirida e do laudo que corrobora o valor atribuído às ações em tesouraria a serem utilizadas (se a operação fosse estruturada como uma incorporação de ações ou

\footnotetext{
${ }^{403}$ Como meio termo a ambas as opiniões, poder-se-ia cogitar o estabelecimento de um regime híbrido, no qual a regra geral seja a de aprovação pelos acionistas das operações, mas em que determinadas operações privadas fossem isentas da obrigatoriedade de tal submissão à assembleia: caso, como exemplos, (i) o preço estipulado para as ações em tesouraria no negócio jurídico não desvie de um predeterminado percentual em relação aos preços de mercado (se houver), para mais ou para menos, (ii) a operação seja aprovada pelo conselho de administração, desde que este seja composto por maioria de conselheiros independentes evitando o recurso constante à assembleia, etc. A dificuldade seria, notoriamente, o estabelecimento de um regime jurídico coerente e a definição dos elementos capazes de dispensar o recurso à Assembleia de acionistas.
} 
como uma incorporação, esses seriam requisitos necessários, conforme art. 224 c/c 252 e até o 256, todos da Lei das S.A.). Essa assembleia, por sua vez, se aprovar a operação e a relação de troca, será suficiente para o atendimento do princípio do tratamento igualitário entre acionistas.

A CVM já teve a oportunidade de julgar variados casos em que as companhias pretendiam alienar as suas ações em tesouraria no contexto de negócios privados (lembrese que, na atual Instrução CVM 10, qualquer negócio privado com as próprias ações a ser realizado por companhias abertas requer prévia aprovação da CVM).

No Processo Administrativo n. ${ }^{\circ}$ RJ2011-3859, julgado em 08 de novembro de 2011 pelo Colegiado da CVM, a Minerva S.A. ("Minerva”) solicitou autorização à CVM para alinear privadamente suas ações em tesouraria como forma de pagamento parcial do preço de aquisição de participação acionária na sociedade uruguaia Pulsa S.A. No caso, o valor das ações em tesouraria foi estipulado acima do valor de mercado médio dos 22 meses anteriores ao negócio, e superior até mesmo ao maior valor que elas tiveram nesse período. Ainda assim, segundo o voto da Diretora Luciana Dias, como houve negociação entre duas partes independentes e como o preço por ação em tesouraria foi ratificado em assembleia geral, deveria ser permitida a fixação do preço acima do de mercado. $O$ tratamento equitativo na alienação de ações em tesouraria, como se disse, decorre ou do acesso igualitário à operação ou da sua aprovação em assembleia; neste caso, optou-se pela aprovação societária. Além disso, outro bom argumento, reconhecido também pela CVM, é que o preço por ação estava situado acima do de mercado, não abaixo dele, de forma que (i) nenhum acionista da companhia iria querer participar do negócio jurídico, e (ii) não há que se falar em transferência de riqueza entre a companhia e o acionista adquirente, pois, na realidade, seria mais certo falar-se no inverso. Também no Processo Administrativo CVM RJ-2008-4169, de relatoria do Diretor Sérgio Weguelin, a JBS S.A. pretendia alienar privadamente suas ações em tesouraria em pagamento parcial da aquisição da totalidade do capital social da National Beef Packing Company LLC (a outra parte seria em dinheiro). Neste caso, o preço de alienação foi obtido por meio da média ponderada por volume das negociações com ações da JBS nos últimos 20 pregões da BVMF anteriores à transação, e tais critérios foram todos submetidos à aprovação prévia da assembleia geral, junto com o laudo de avaliação da companhia adquirida, cumprindo, desse modo, o princípio de tratamento igualitário acima elaborado. Já no Processo Administrativo CVM RJ2013/565, também envolvendo pedido da JBS para utilizar suas ações em tesouraria como moeda de pagamento de aquisições, julgado pelo Colegiado em 09 de julho de 2013, a Diretora 
Luciana Dias parece ter atribuído ao preço dado às ações em tesouraria uma importância primordial no tocante à observância do interesse social, apenas, e não ao tratamento igualitário dos acionistas. Segundo ela: “[e]m relação ao processo de determinação de preço, os precedentes da CVM, em geral, autorizam a alienação privada de ações de emissão própria quando ela é feita a valor de mercado ou sob a condição de que ela seja feita a valor de mercado. Isto porque, conforme já mencionado, a formação transparente do valor de mercado protege a companhia de maus negócios". A afirmação não deixa de ser verdadeira, mas o principal ponto acerca dos negócios privados, a nosso ver, não é o de se inquirir se o negócio é ou não proveitoso para a companhia (interesse social), mas é o de não permitir tratamento diferenciado entre acionistas, ao comprar mais caro ou vender mais barato para um ou um grupo de acionistas privilegiados.

Outro exemplo são as alienações privadas de ações em tesouraria em decorrência do exercício de opções outorgadas pela companhia, nos termos do art. 168 , $\S 3^{\circ}$, da Lei das S.A. Como esses planos são aprovados em assembleia, a forma de alienação em cumprimento do exercício das opções poderá ali ser aprovada, e isso afasta questionamentos de tratamento não igualitário. Tanto isso é verdade que o art. $13, \S 6^{\circ}$, da Instrução CVM 358 e o artigo $3^{\circ}$, II, da Instrução CVM 390 permitem a alienação privada das ações em tesouraria da companhia dentro do contexto desses planos, sem a necessidade de sua prévia aprovação (da CVM) - o que nos parece plenamente justificável, já que a assembleia geral aprovou o plano anteriormente, tendo conhecimento da forma de alienação privada dessas ações e dos critérios de determinação do preço das mesmas no momento das alienações.

No caso de planos de remuneração, que não sejam configurados como planos de opção de compra nos termos da Lei das S.A., mas que consubstanciem doações de ações em tesouraria para os administradores e funcionários, estaria estendido o tratamento benéfico dado pelas normas aos planos de opção? A redação do art, 30, §1 , "b”, da Lei das S.A., prevê apenas que a companhia poderá receber as ações por doação, mas não parece permitir que ela doe essas ações ${ }^{404}$. Seria o caso? Não se deve concordar sempre com a possibilidade, pois a doação, pela companhia, das ações em tesouraria poderia configurar um ato de liberalidade (vedado, por si só, pelo art. 154, §2, "a”, da Lei das

\footnotetext{
404 Impossível negar a possibilidade, no entanto, de venda de ações recebidas em doação. Sem razão, portanto, Fran Martins, para quem as ações recebidas em doação não poderão ser recolocadas no mercado, apenas canceladas, por não ter sido o patrimônio social desfalcado com a sua aquisição. Cf. Fran Martins, Comentários..., cit., p. 185. Entendendo ser possível a venda das ações recebidas em doação, cf. Modesto Carvalhosa, Comentários..., cit., p. 312.
} 
S.A.) em prejuízo do interesse social, haja vista que ela poderia, alternativamente, alienar onerosamente esses papéis para terceiros, obtendo lucro inegável na operação (uma vez que seu custo de aquisição foi zero, qualquer valor recebido será concebido como resultado positivo) - isso sem contar com a possibilidade de doação de ações para determinados acionistas em prejuízo de outros, que poderão não ter tido acesso às ações gratuitamente. Entendemos, assim, não ser possível à companhia ser doadora das próprias ações, exceto, naturalmente, quando a doação esteja inserida dentro de um contexto visivelmente positivo à companhia e sua atividade. Mesmo em tal contexto, ou a doação é objeto de aprovação da assembleia geral ou todos os acionistas devem estar legitimados a receber, proporcionalmente, as ações distribuídas gratuitamente. Uma das circunstâncias que justificam que a sociedade doe suas ações em tesouraria é aquela que se insere no contexto de programas de remuneração para administradores e funcionários da companhia. Tais doações não poderiam ser vistas como contrárias ao interesse social, ou como um ato de liberalidade, eis que correspondem à remuneração do trabalho que foi prestado à companhia. Desde que o plano de remuneração seja aprovado em assembleia de acionistas, em que conste expressamente que as ações em tesouraria serão doadas privadamente para os funcionários e administradores elegíveis e em que seja deliberada a forma de determinação do número dessas ações a serem doadas, entende-se lícita a operação. Inclusive, o regime benéfico estabelecido para as alienações privadas de ações em tesouraria em conexão com planos de opção de compra (art. 168, §3º da Lei das S.A.), estipulado pela CVM no art. 13, §6 $6^{\circ}$, da Instrução CVM $358 \mathrm{c} / \mathrm{c}$ art. $3^{\circ}$, II, da Instrução CVM 390, deveria, de lege ferenda, ser estendido a estes planos de remuneração: não há diferenças substanciais entre eles que justifique uma disparidade de tratamento.

As doações privadas de ações em tesouraria foram alvo de apreciação da CVM, por exemplo, no Processo CVM RJ 2011/5238, julgado em 27 de janeiro de 2012, no qual era consulente a Cielo S.A. e cujo objeto era justamente avaliar a possibilidade de estruturar um plano de remuneração dos administradores da Cielo não baseado exclusivamente na opção de compra de ações, mas na doação de ações com circulação restrita. No caso, a Superintendência de Relações com Empresas, SEP, julgou que tal plano "não representa uma liberalidade por parte da Companhia, mas, antes, uma forma de remuneração dos administradores e executivos", de forma que seria possível a doação das ações em tesouraria, desde que sempre fosse precedida de autorização da assembleia geral (o 
que seria obrigatório, desde logo, por força do artigo 152 da Lei das S.A. $)^{405}$. Não obstante, a CVM entendeu que os planos de incentivo, estruturados na forma de doação de ações, não podem ser equiparados aos planos de opções para fins de dispensa do pedido prévio de alienação privada das ações em tesouraria (dispensa aplicável apenas aos planos de opções, cf. normas já mencionadas acima) - entendeu, por outro lado, que uma única aprovação do plano de incentivo seria suficiente para permitir todas as doações privadas oriundas dele, cf. voto do Diretor Relator Otávio Yazbek ${ }^{406}$.

A alternativa à necessidade de submissão das operações privadas à assembleia, como se disse, é a de oferecer a possibilidade de acesso ao negócio jurídico para todos os acionistas indistintamente. Tal poderia ser alcançado por meio de uma oferta pública secundária das ações em tesouraria (possível apenas para as companhias abertas, naturalmente), que garantiria acesso irrestrito dos acionistas às ações, ao preço oferecido.

A CVM também já enfrentou a questão da possibilidade da realização de uma oferta pública secundária, pela companhia, de suas ações em tesouraria. No Processo CVM RJ-2010-7731, o Banco do Brasil S.A. (“BB”) questionou a CVM sobre a possibilidade de alienação de ações ordinárias de sua emissão, mantidas em tesouraria, em mercado de balcão não organizado (o que é vedado pelo artigo $9^{\circ}$ da Instrução CVM 10, que, no caso de companhias com ações listadas em bolsa, apenas permite negociá-las nesse ambiente e não privadamente ou no mercado de balcão). Neste caso, o $\mathrm{BB}$, em conjunto com determinadas instituições intermediárias, havia protocolizado na ANBIMA um pedido de registro de oferta pública de distribuição primária e secundária de suas ações ordinárias. Ou seja, nessa oferta, o BB iria emitir ações, em busca de novo capital, e, concomitantemente, iria ser acionista vendedor na oferta secundária, ao ofertar publicamente ações até então mantidas em tesouraria. De acordo com o pedido do BB, as ações haviam sido adquiridas, originalmente, nos termos da Instrução CVM 10 para

${ }^{405}$ É válido ressaltar que a aprovação ora mencionada deve existir em qualquer situação de doação das ações em tesouraria, mesmo que não inseridas no contexto de um plano de remuneração (para os quais o art. 152 da Lei das S.A. prevê a aprovação de qualquer forma), dada a nossa tese de que o tratamento equitativo pode basear-se na aprovação da assembleia dos termos do negócio privado.

${ }^{406}$ No contexto das doações como forma de remuneração, cf.: (i) voto do Diretor Otávio Yazbek no Processo Administrativo CVM RJ 2009/3983 (EDP Energias do Brasil S.A.), julgado em 04 de agosto de 2009, requerendo a aprovação do plano de incentivo mediante doação em assembleia geral, à semelhança do que seria exigido para os planos de opção, (ii) Processo Administrativo CVM RJ 2011/2942 (Itaú Unibanco Holding S.A.), julgado em 06 de setembro de 2011, requerendo que os critérios para determinação do número de ações a serem doadas sejam aprovadas em assembleia geral, (iii) Processo CVM RJ 2011/6574 (Valid Soluções e Serviços de Segurança em Meio de Pagamento e Identificação S.A.), julgado em 06 de setembro de 2011, também pressupondo a aprovação do plano em assembleia geral (data venia, não há que se falar em risco de diluição, como faz o voto - a necessidade de aprovação dos acionistas decorre do risco de tratamento não igualitário entre eles), (iv) voto da Presidente Maria Helena Santana e do Direitor Eli Loria no âmbito do Processo CVM RJ 2011/4494 (HRT Participações em Petróleo S.A.), julgado em 27 de janeiro de 2012. 
permanência em tesouraria, para posterior alienação - que deveria ocorrer, via de regra, em bolsa, conforme regra da Instrução CVM 10. Interessante o argumento utilizado pelo BB, neste ponto, que coloca em perspectiva a necessidade de alienação em bolsa com a de transparência e fiscalização da CVM acerca das operações de recompra. Como uma oferta pública, que é registrada na CVM, garantiria tanto, ou mais ${ }^{407}$, publicidade e potencial de fiscalização da CVM do que uma recompra comum na bolsa, não haveria razão para não autorizar-se o BB a alienar suas ações em tesouraria na oferta pública secundária, ainda que ela ocorra formalmente no mercado de balcão não organizado, e não em bolsa.

$\mathrm{O}$ argumento convence, considerando que o risco de interferência na correta formação de preço e na manipulação de mercado dificilmente poderão ser invocados nesta situação, eis que o preço da venda será formado por ocasião da verificação da demanda externa ao emissor (os potenciais adquirentes das ações), de acordo com suas intenções de investimento na forma da Instrução CVM 400. Isso sem contar que a oferta pública estará sujeita a registro e acompanhamento próximo do regulador, nos termos da Lei 6.385/76 e dos princípios que as regem, como o de tratamento equitativo e o da adequada e transparente divulgação de informações sobre a oferta, os valores mobiliários ofertados e a companhia emissora (art. $1^{\circ}$ da Instrução CVM 400). Por derradeiro, vê-se que esse tipo de situação aumenta a liquidez das ações da companhia, que passará a contar também com as ações outrora em tesouraria, e garante indubitável tratamento igualitário entre os acionistas, que terão todos, ao menos em tese, igual acesso a poder adquirir as ações ao preço que vier a ser definido na oferta pública. Efetivamente, em 25 de maio de 2010, o Colegiado da CVM aprovou a alienação das ações do BB no âmbito da oferta secundária de suas ações ${ }^{408}$.

407 O que foi efetivamente reconhecido no âmbito do Processo CVM RJ/2009/10511, de teor substancialmente similar ao do BB, por meio do qual a EDP - Energias do Brasil S.A. ("EDP") solicitou autorização prévia da CVM para alienar ações em tesouraria em âmbito de oferta pública de distribuição secundária de suas ações ordinárias. No item "aa" do Relatório de Análise /CVM/SEP/GEA-3/nº 103/09, a analista da Superintendência de Relações com Empresas menciona que: "diante de tais características, resta preenchido o requisito da publicidade da operação, de maneira muito mais extensiva do que ocorre no ambiente de bolsa" - grifos nossos. O Colegiado da CVM aprovou o pedido da EDP em 03 de novembro de 2009. O mesmo foi dito no âmbito do Processo CVM RJ/2004/7266 (Unibanco - União de Bancos Brasileiros S.A.), mas que, no tocante a esse ponto, não chegou a ser julgado, pois o pedido perdeu o objeto, conforme mensagem do Superintendente de Registro de Valores Mobiliários MEMO/SER/GER$2 / \mathrm{N}$. ${ }^{\circ} 13 / 2005$, de 24 de janeiro de 2005. Os demais pedidos do Unibanco foram julgados pelo Colegiado da CVM no dia 25 de janeiro de 2005.

${ }^{408}$ A mesma decisão foi tomada pelo Colegiado da CVM no âmbito do: (i) Processo CVM RJ/2009/10511 (caso EDP, de que falamos), (ii) Processo CVM RJ/2004/4232 (WEG S.A.), julgado em 18 de agosto de 2004, (iii) Processo CVM RJ/2009/12985 (Banco Cruzeiro do Sul S.A.), julgado em 22 de dezembro de 2009 - com voto do analista pelo indeferimento do pedido, com base no fato de que apenas investidores institucionais participam da formação de preço no processo de coleta de intenção de investimentos. Isso é 


\subsection{Esvaziamento do Poder de Supervisão da Assembleia Geral de Acionistas}

Juridicamente, é também interessante a indagação sobre se seria lícito, ou desejável, que a administração da companhia tivesse a possibilidade de influenciar a composição do círculo de acionistas, já que isso poderia subverter a lógica de distribuição interna de competências societárias.

Nos termos do artigo 121 da Lei das S.A., a assembleia geral representa o órgão deliberativo dos acionistas, e a instância tomadora de decisão máxima da companhia, podendo deliberar e decidir sobre todos os negócios relativos ao seu objeto e tomar as resoluções que julgar convenientes à sua defesa e desenvolvimento. Na estrutura orgânica da sociedade anônima, desde há muito tempo em termos de direito continental europeu, a administração é subordinada ao interesse da coletividade de acionistas reunidos em assembleia geral, e não o contrário, o que decorre, normativamente: (i) da possibilidade de eleição e destituição da administração pela assembleia geral ad nutum, conforme os artigos 122, II, c/c 140, caput, c/c 143, caput (princípio da supervisão) da Lei das S.A., (ii) do fato de que a administração tem poderes para decidir somente sobre o dia a dia da atividade, sendo os princípios e decisões estruturais de competência privativa da assembleia geral (princípio da separação dos poderes), e (iii) das normas e deveres de conduta atribuídos pela lei aos membros da administração. Essa lógica organizacional sofreria uma indevida interferência, caso fosse permitido à administração, direta ou indiretamente, esvaziar o poder da assembleia geral, tornando-a, nessa situação, imune ao poder de fiscalização que a lei atribui ao conclave dos acionistas.

Podemos, por exemplo, cogitar uma dita interferência, se das ações em tesouraria não fossem tolhidos os direitos políticos (voto) e, adicionalmente, se a administração pudesse, em nome da companhia, votar na assembleia geral com essas ações - podendo, com isso, aprovar as próprias contas, eleger-se (por meio do conselho ou diretamente), alterar o estatuto social e deliberar sobre a distribuição de lucros. A corrente doutrinária que defendia esta linha de raciocínio, hoje abandonada, era aquela defendida em 1906 por Runkel-Langsdorff, conforme se expôs no item referente à sociedade sócia de si mesma. Antônio Ferrer Correia salienta que essa construção "é inconveniente e bizarra"409 e, por

verdade, mas não prejudica a correta formação de preço; ao contrário, esses investidores são muito mais aptos a defini-lo do que os de varejo.

${ }^{409}$ Cf. António Ferrer Correia, A representação dos menores sujeitos ao pátrio poder na assembleia geral das sociedades comerciais: Apêndice II: acções adquiridas pela própria sociedade emitente e direito de voto 
isso, estaria desde logo ultrapassada. O autor português levanta vários argumentos que tornariam a aceitação da teoria acima extremamente complicada: com efeito, como permitir que a sociedade possa participar da assembleia destinada a formar a sua vontade, votando em determinado sentido? Seria a admissão de uma manifestação de vontade da sociedade dirigida ao processo social destinado à sua própria formação, de modo que a vontade quase que pre-existiria a si própria. Acrescente-se outro argumento: a permitir-se que os administradores representem a companhia em sua própria assembleia, ela passaria a representar um alter ego da administração, que poderia, assim, dominar o poder legislativo da companhia ao exercer o direito de voto das ações em tesouraria, esvaziando a separação entre as funções da administração e da assembleia geral ${ }^{410}$.

Herbert Wiedemann ensina que, em uma típica sociedade anônima, existem sempre dois centros de poder: a assembleia geral de acionistas e a administração, sendo que as competências decisórias devem necessariamente ser subdivididas entre eles. A administração exerceria um "mandato político-empresarial" (mandato aqui usado em sentido político e não jurídico), já que seus membros possuem poder de decisão sobre os negócios da sociedade, mas exercem esse poder necessariamente no interesse dos titulares do capital, para os quais respondem e aos quais se subordinam ${ }^{411}$. Se a administração pudesse votar com as ações em tesouraria, além da evidente incompatibilidade societária, ter-se-ia apenas um centro de poder societário, a administração, e, paralelamente, uma assembleia geral oca e desprovida de função ${ }^{412}$.

É por isso que, hoje $\mathrm{e}^{413}$, o assunto encontra-se superado: a totalidade das legislações analisadas retira das ações em tesouraria o direito de voto, como é o caso também da Lei

in Estudos Jurídicos II - Direito Civil, Comercial e Criminal, Atlântida, Coimbra, 1969, p. 122. Também encontra-se em Messineo a defesa da suspensão do direito de voto das ações em tesouraria, no sentido de que esse mecanismo legal impede uma "influência nociva" no interesse dos acionistas: "con i divieti descritti e brevemente analizzati qui sopra (e dei quali finisco di chiarire la ratio), la legge si è proposta di neutralizzare taluni poteri, connessi a quelle azioni, nel senso di impedirne un uso che non sia correto, e di evitare che gli amministratori possano acquistare in assemblea un'influenza nociva agli interessi altrui'. Cf. Francesco Messineo, Spettanza..., op. cit., p. 420.

${ }^{410}$ António Ferrer Correia, A representação..., op. cit., pp. 122 e 123.

${ }^{411}$ Cf. Herbert Wiedemann, op. cit., p. 298.

${ }^{412}$ Cf. Alexander Kitanoff, op. cit., p. 149.

${ }^{413}$ Alexander Kitanoff relata que, por mais que a doutrina alemã anterior à reforma de 1931 se posicionasse pela suspensão da eficácia dos direitos das ações em tesouraria, como a lei silenciava, muitas companhias utilizaram-se da prerrogativa para fazer com que a administração efetivamente absorvesse os poderes deliberativos da assembleia geral de acionistas. Menciona o autor: "Considerando a controvérsia existente, muitas companhias decidiam custodiar as suas ações em um consórcio de bancos, que se vinculavam contratualmente a exercer o direito de voto dessas ações conforme orientações da administração. As ações utilizadas com esse intuito ficaram conhecidas como 'ações de administração'. Por meio delas era possível aos administradores da sociedade anônima, e aos acionistas majoritários a que eram vinculados, enfraquecer o grau de influência da assembleia geral de acionistas na decisão sobre os destinos da sociedade". No original: "Daher gingen viele Gesellschaften dazu über, neue Aktien bei einem Bankkonsortium zu platzieren, 
das S.A., no artigo 30, $4^{\circ}$. Dessa forma, as ações em tesouraria não são aptas a garantir à administração um canal de interferência indevida na formação da vontade social.

\subsection{Influência da Administração na Composição Societária}

Existe também uma forma mais sutil de a administração da sociedade exercer uma influência subversiva na distribuição de poderes internos da companhia, enfraquecendo o poder da assembleia geral. Ela poderia, por exemplo, por meio de compras e vendas de ações da companhia, efetivamente excluir da composição de sócios aquelas pessoas de posição discordante da atuação dos administradores, e manter, por outro lado, apenas aqueles acionistas que vissem a administração, e seus membros, com bons olhos - o que se daria, pela necessidade de direcionamento do negócio jurídico, provavelmente em operações privadas.

Assumindo que os negócios privados são permitidos, a pergunta adicional que precisa ser respondida é quanto ao grau de neutralidade que a administração é obrigada a ter com relação à composição dos membros da sociedade. Em outras palavras, se existe, e em que medida atua, um dever de neutralidade da administração com relação à composição acionária da companhia que administram.

Há uma corrente doutrinária que responde a essa pergunta simplesmente negando toda e qualquer competência da administração na definição de quem serão os acionistas da companhia. De onde deriva a interpretação da existência de um dever de neutralidade da administração? Alguns autores indicam que seria um dever inerente ao princípio de que ela age em prol de interesses alheios aos dela, ou seja, os membros da administração atuam como fiduciários dos acionistas. Outros autores derivam esse dever de neutralidade não de regras organizativas internas da sociedade, mas do ponto de vista externo, dos potenciais acionistas futuros: segundo esta corrente, a troca da composição societária se dá no âmbito do mercado secundário de ações, na esfera dos acionistas compradores e vendedores, portanto. A administração, e a companhia, não têm qualquer ingerência nessa esfera e, ademais, se tivessem, exerceriam influência perversa no "mercado de controle societário", que tem como função primordial garantir a maximização de eficiência na gestão dos recursos sociais, em prol da maximização da riqueza: ou seja, uma administração

das sich vertraglich dazu verpflichtete, das Stimmrecht nach Weisung des Vorstands auszuïben. Solchermaßen verwendete Anteilspapiere nannte man 'Verwaltungsaktien'. Mitells der sog. Verwaltungsaktien war es dem Vorstand der AG um den mit ihm verbündeten Großaktinären möglich, den Einfluss der Hauptversammlung auf die Geschicke der Gesellschaft entscheidend zu schwächen". Op. cit., pp. 21 e 22, nota de rodapé 38. 
ineficiente deveria estar sujeita ao risco de, com a queda no valor da companhia decorrente de sua má gestão, ser substituída por outra mais eficiente, eleita por um novo controlador que tenha adquirido esse poder no "mercado de controle acionário"414.

De qualquer forma, é difícil defender um dever de neutralidade absoluta e sujeito a nenhuma exceção, haja vista que a administração, justamente como titular de deveres fiduciários perante a companhia e seus acionistas, deveria poder, por exemplo, buscar uma oferta concorrente de aquisição de controle em situação em que ela entenda ser a oferta existente contrária ao interesse da companhia. Deveria ela, ademais, não só ter a possibilidade, como o dever de se manifestar com relação a essa oferta de aquisição, justificando aos acionistas a sua opinião sobre a sua conveniência. A regra geral deve, portanto, comportar algumas exceções.

A corrente contrária a essa defende a possibilidade irrestrita de a administração exercer influência sobre quem deve ou não compor o círculo acionário da companhia. Genericamente, apontam os seus defensores o fato de que os administradores têm deveres fiduciários para com a própria companhia antes do que para com seus acionistas, discussão que naturalmente nos levaria a debater se estes divergiriam daqueles, mas, igualmente, nos levaria a extrapolar o limite deste trabalho ${ }^{415}$. Assim, os administradores poderiam considerar outros interesses no escopo de sua atuação, como o dos trabalhadores, dos credores, dos acionistas futuros e até mesmo da comunidade em que atuam (ver artigo 116, parágrafo único, da Lei das S.A.).

Afigura-se impossível atribuir um dever de neutralidade absoluto aos administradores, mas tampouco é recomendável que a discricionariedade da administração seja mantida em seu patamar mais alto. Esta última opção insere-se melhor no modelo de direito norte-americano, no qual a "business judgement rule" aparece no centro das discussões sobre os padrões de comportamento dos administradores, mas dificilmente poderia ser implementado em um sistema de direito continental-europeu, no qual as classificações e os institutos não têm a tradicional característica de serem abertos e posteriormente preenchidos pelo Judiciário. Para mais, é preciso levar-se em conta a diversidade de companhias que se apresentam em sua dimensão real (não teórica): existem diferenças profundas na avaliação dos deveres, e limites, de conduta dos administradores em sociedades anônimas com milhares de acionistas atomizados (e que dificilmente

${ }^{414}$ Cf. Alexander Kitanoff, op.cit., p. 152.

${ }^{415}$ Para mais, e com farta doutrina, Erasmo Valladão Azevedo e Novaes França, Conflito de Interesses nas Assembléias de S.A., Malheiros, São Paulo, 1993. Ver também Calixto Salomão Filho, O Novo Direito Societário, $3^{a}$ ed., cit. 
conseguiriam organizar-se entre si para substituir um administrador) e em companhias familiares ou com um acionista controlador bem determinado. Em uma e em outra, os deveres da administração, e a quem ela efetivamente deve satisfações e se subordina, ganham tons diferentes ${ }^{416}$.

Não se pode deixar de notar, no entanto, que o regime dos deveres da administração, na Lei das S.A., possui semelhanças fundamentais com a doutrina dos "fiduciaries duties" do direito norte-americano, notadamente porque a própria lei arrola uma série de deveres, a partir do seu art. 154, que os membros da administração precisam observar no exercício de sua função, como o dever de lealdade, de informar e de diligência. Parece-nos, portanto, que um discurso de moderação é, mais uma vez, o adequado. Apesar de a regra geral dever ser a de neutralidade dos administradores em relação à composição acionária, há situações em que os seus deveres, impostos pela lei, determinam que eles efetivamente ajam de forma a proteger o interesse da companhia, evitando, de outra sorte, a sua responsabilização. A discussão não é simples, é fervorosamente discutida na doutrina e foge ao nosso escopo ${ }^{417}$.

\subsection{Regime Jurídico das Ações em Tesouraria: o Fenômeno da Concentração de Direitos e não da Titularidade do Capital Social}

\subsubsection{Cálculo de Quóruns de Instalação e Votação}

Como já afirmado, as ações em tesouraria têm a eficácia de determinados direitos e deveres a que dão direito, suspensa. Se essas ações não contam para fins do exercício do direito de voto em assembleia geral, contarão porventura para efeitos de cálculo de quórum estatutário e de maiorias especiais que os estatutos ou a própria lei exigem em determinados casos? Digamos que uma determinada companhia fechada tenha um capital social nominal de $\mathrm{R} \$ 1.000 .000,00$, dividido em um milhão de ações com direito de voto de valor nominal de $\mathrm{R} \$ 1,00$ cada, sendo que duzentas e cinquenta mil ações (um quarto do

\footnotetext{
416 Wiedemann, nesse sentido, contrapõe os tipos ideais dos tipos reais de companhias. Cf. Herbert Wiedemann, op. cit., pp. 108 e ss.

${ }^{417}$ Cf. Erasmo Valladão Azevedo e Novaes França, Conflito de Interesses de administrador na incorporação de controlada in Temas de Direito Societário..., cit., pp. 334 a 360; Cf. também a completa monografia de Luis Felipe Spinelli, Conflito de Interesses..., cit.; Erik Oioli, Ofertas Públicas de Aquisição do Controle de Companhias Abertas, Vol. 1, Quartier Latin, São Paulo, 2010, pp. 115 a 117 e também mais adiante nas páginas 198 a 216; Roberta Nioac Prado, Desconcentração do Poder de Controle e Poison Pills: Evolução no Mercado de Capitais Brasileiro in Rodrigo R. Monteiro de Castro e Luis André N. de Moura Azevedo (coords.), Poder de Controle e Outros Temas de Direito Societário e Mercado de Capitais, Quartier Latin, São Paulo, 2010, pp. 375 a 421; Paul Davies e Klaus Hopt, Control Transactions, in Reinier Kraakman et. Al. (coords.), The Anatomy of Corporate Law, 2a . Ed., Oxford University Press, Reino Unido, 2010.
} 
capital social) estão em tesouraria. Nestas circunstâncias, qual será a base para o cálculo do quórum de instalação da assembleia e das maiorias: "o capital correspondente à totalidade das acções emitidas, ou apenas o capital correspondente às acções em circulação?"418 Um milhão de ações ou setecentos e cinquenta mil?

Temos por mais acertado que, em ambos os casos, as ações em tesouraria não devam ser contadas, porque o entendimento contrário levaria ao truncamento total das atividades da sociedade. Voltando ao nosso exemplo, qualquer deliberação que exigisse aprovação de, no mínimo, 3/4 do capital social, ficaria virtualmente impossível de ser tomada, considerando que as ações em tesouraria não votam (art. 30, §4 da Lei das S.A.): a companhia teria um veto sobre a formação de sua própria vontade, o que não pode ser concebido. Assim, no exemplo dado, a base de cálculo para a averiguação de quórum de instalação e de maioria seriam apenas as ações que não estejam em poder da sociedade. António Ferrer Correia enuncia, ainda, um segundo argumento, citando De Gregorio, segundo o qual: "só os acionistas em certo momento existentes são os destinatários do patrimônio social e, por conseguinte, só eles representam, real e efetivamente - em 'substância' -, a totalidade do capital da sociedade"419. Segundo esse argumento, apenas aos reais acionistas da sociedade em determinado momento é que incumbe a participação no processo de definição da vontade social e somente a eles seria, em hipótese fictícia de liquidação da sociedade, devolvido eventual acervo líquido remanescente.

É, ademais, o que se interpreta da Lei das S.A., quando dispõe, no art. 125, que a assembleia geral instalar-se-á com a presença de um quarto do capital social com direito de voto. Apesar de reconhecermos que as ações ordinárias em tesouraria são ações com direito de voto, não podemos deixar de lembrar que elas estão momentaneamente sem direito de voto, o que nos leva a crer que elas não devam ser computadas no cálculo dos $25 \%$ necessários para instalação da assembleia em primeira convocação. O artigo 136 da Lei das S.A., em outro exemplo, traz o mesmo conceito: requer maioria qualificada de metade, no mínimo, das ações com direito de voto para aprovação de determinadas matérias. Se mantivermos as ações em tesouraria dentro do cálculo das ações totais com direito de voto, então poderíamos chegar a uma situação onde nenhum acionista conseguiria aprovar a matéria, mesmo que todos votassem no mesmo sentido. Basta elevarse o quórum para, por exemplo, $90 \%$ das ações com direito de voto, ou mesmo para unanimidade (como conseguir unanimidade das ações com direito de voto se for

\footnotetext{
${ }^{418}$ Cf. António Ferrer Correia, op. cit., p. 125, nota de rodapé 2.
}

${ }^{419}$ Cf. António Ferrer Correia, op. cit., p. 126, nota de rodapé 2. 
considerada a existência de ações em tesouraria, que não votam?), para perceber-se que outra interpretação não cabe, por uma questão de ordem prática e conceitual: as ações em tesouraria não votam e não pertencem a nenhum acionista, são, jurídica e contabilmente, bens sem valor algum para a companhia. Abre-se um parêntese: a questão não é sempre de proteção do minoritário, pois o desconto das ações próprias dos cálculos de quóruns não os beneficia, em prejuízo do majoritário ou controlador; esse artifício matemático apenas reequilibra as forças de poder internas com base em novas realidades, concentrando os direitos econômicos e políticos de todos os acionistas indistintamente.

Voltando ao exemplo dado no início deste item: se a companhia emitiu 1.000.000 de ações com direito de voto e detém 250.000 delas em tesouraria, então existem apenas 750.000 ações nas mãos de acionistas efetivamente, pessoas interessadas no andamento da coletividade societária: é sobre este número que se devem fazer todos os cálculos de poder interno da sociedade. Assim, não será necessário o comparecimento de titulares de 250.000 ações para instalação da assembleia em primeira convocação (um quarto de 1.000.000), mas apenas de 187.500 ações (um quarto de 750.000). O mesmo raciocínio vale para o cálculo de quóruns de votação: uma matéria que requeira aprovação de metade das ações com direito de voto não precisará contar com o voto favorável de 500.000 ações, mas apenas de 375.000; uma aprovação unânime contará apenas com 750 mil ações votando a favor.

E isto, por sua vez, significa que é necessário diferenciar alguns conceitos relevantes para o correto entendimento dos efeitos de concentração das ações em tesouraria. Um determinado percentual de titularidade do capital social total emitido, ou mesmo do capital emitido com direito de voto, não necessariamente equivale ao mesmo percentual de poder político do acionista na assembleia geral. Desconsiderando a questão das ações preferenciais sem direito de voto, que têm igual efeito no poder intrassocietário, é possível que um acionista que detenha $20 \%$ do capital social emitido, possua, de fato, mais poder político proporcional na assembleia. Este fenômeno de separação do poder político da titularidade do capital não é novidade, mas é importante ter-se em mente que é um fenômeno também desencadeado pelos negócios ora objeto de nosso estudo: as ações em tesouraria provocam a concentração do poder político e econômico dos acionistas remanescentes, mas não da sua respectiva titularidade do capital social total ${ }^{420}$.

${ }^{420}$ Cf. Alexander Kitanoff, op. cit., p. 199. 
Este conceito é extremamente importante, pois o capital social total emitido continua o mesmo, exceto se as ações forem canceladas depois de adquiridas. Os acionistas continuarão a deter a mesma titularidade proporcional formal do capital social (em termos percentuais), mas suas ações passarão a lhes atribuir maior fatia de direitos econômicos e políticos, uma vez que parte do capital social (e dos direitos a essa parte atinentes) estará letargicamente repousando na tesouraria da companhia - os direitos econômicos e políticos atrelados a essas ações em hibernação serão, ipso facto, redistribuídos entre aqueles que efetivamente permanecem como acionistas da companhia e a quem - abstraída a questão da personalidade jurídica - ainda pertencem os bens sociais ${ }^{421}$. $\mathrm{Na}$ Itália, por exemplo, o artigo 2.357-ter do Codice Civile determina este fenômeno expressamente, ao dizer que os direitos econômicos das ações em tesouraria passam a ser distribuídos proporcionalmente entre as demais ações (muito embora esse mesmo artigo preveja que as ações em tesouraria continuam sendo computadas para a definição de qualquer quórum da lei) ${ }^{422}$.

Por fim, cabe mencionar que a Lei das S.A. estipula também situações em que o conceito não é o de "ações com direito de voto", mas sim de "capital social", como é o caso do artigo $141, \S 4^{\circ}$, II, que indica que acionistas sem direito de voto, mas que representem $10 \%$, no mínimo, do "capital social" - total, leia-se - poderão eleger um membro do conselho de administração, e seu suplente, em separado. Como devem ser tratadas as próprias ações neste caso? Como visto, as ações em tesouraria concentram os direitos políticos (voto) e econômicos (dividendos, por exemplo) entre os acionistas remanescentes, de forma proporcional entre todos eles, mas não alteram a titularidade percentual proporcional de cada acionista sobre o capital social total da companhia. Este

\footnotetext{
${ }^{421}$ Trazemos o exemplo do Processo Administrativo RJ2004/3666, apreciado pelo Colegiado em 23 de junho de 2004, tendo como requerentes o Unibanco - União de Bancos Brasileiros S.A. e o Unibanco Holdings S.A. (em conjunto, "Unibanco"). O Unibanco procurou a CVM para que ela o autorizasse a alienar ações preferenciais mantidas na tesouraria de ambas as companhias para permitir a aquisição, pelo Unibanco, do controle acionário do BNL do Brasil S.A. ("BNL"). Tal aquisição seria viabilizada mediante permuta das ações de propriedade dos acionistas do BNL por units de emissão do Unibanco, que representavam as ações preferenciais em tesouraria de ambas as sociedades deste último, funcionando estes (units) como "moeda de permuta". O parecer da área técnica da SEP nesse caso menciona o fenômeno da concentração dos direitos econômicos: "Esse dispositivo [o artigo 16 da Instrução CVM 10] elimina as ações em tesouraria da base total de ações, por espécie, que compõem o denominador da fração de distribuição de lucros da companhia. No momento em que parte das ações em circulação são retiradas do mercado, o efeito imediato é a potencial valorização das remanescentes, que passam a gozar da possibilidade de auferir maior remuneração a seus titulares. Por outro lado, o retorno das ações em tesouraria ao mercado implica, em última análise, numa relativa redução da remuneração distribuída aos acionistas, o que nada mais é do que um retorno ao status anterior à aquisição dessas ações pela companhia" - grifos nossos. O parecer é inatacável.

422 "Art. 2357-ter. Finchè le azioni restano in proprietà della società, il diritto agli utili e il diritto di opzione sono attribuiti proporzionalmente alle altre azioni. Il diritto di voto è sospeso, ma le azioni proprie sono tuttavia computate ai fini del calcolo delle maggioranze e delle quote richieste per la costituzione e per le deliberazioni dell'assemblea. Nelle società che fanno ricorso al mercato del capitale di rischio il computo delle azioni proprie è disciplinato dall'articolo 2368 , terzo comma".
} 
exemplo de que tratamos (do art. $141, \S 4^{\circ}$, II) menciona justamente o conceito de capital social total, da onde se deveria concluir que as ações em tesouraria também fossem computadas para o atingimento dessa minoria qualificada (afinal, elas também fazem parte do capital total). Essa interpretação, contudo, não deve prevalecer, pois o intuito da lei, nesse ponto, é o de garantir que acionistas minoritários tenham ingerência na administração da companhia: com esse objetivo, criou a lei um mecanismo que lhes dá a aptidão de enfrentar o poder do majoritário, a eleição em separado. Se fossem consideradas as ações próprias em tesouraria no cálculo do atingimento dos $10 \%$ do capital total, então teríamos como consequência que, quanto mais ações a companhia detivesse em tesouraria, maior seria a dificuldade prática enfrentada pelos acionistas minoritários para conseguirem formar o conjunto de acionistas necessário pela lei, pelo simples fato de que serão em menor número tais acionistas, prejudicando a sua coordenação política - o que, por sua vez, contraria o próprio intuito de proteção da minoria estipulado nesse artigo.

Numericamente, poderíamos exemplificar da seguinte forma: uma companhia fechada com 10 acionistas e 3000 ações emitidas, sendo 2250 com direito de voto e pertencentes a um único acionista controlador (Acionista Controlador) e 750 ações divididas entre os demais 9, sendo 260 ações para o Acionista A e 70 para cada um dos outros 7. Nesta situação, o Acionista A detém originalmente apenas 8,6\% do capital social total (260 / 3000). Se essa companhia recompra 490 ações sem direito de voto (dos outros 7 acionistas), então o acionista A, com 260 ações, representativas de 8,6\% do capital total emitido - incluindo as ações entesouradas -, passaria a deter, no entanto, 10,3\% do capital total se fossem desconsideradas as ações em tesouraria (260/(3000-490)), permitindo-lhe o exercício do direito de eleger membro do conselho, em separado, individualmente.

Nossa posição, portanto, é a de que as ações próprias, mantidas em tesouraria, não devem ser consideradas nos casos em que a lei exija a titularidade de um determinado percentual do capital social total para possibilitar o exercício de um direito de minoria, ou em uma votação, pois essa inclusão, na prática, tornaria cada vez mais difícil a formação da respectiva quota (ou mesmo a impossibilitaria) - aqui, sim, em prejuízo dos minoritários e em benefício do majoritário ou controlador (que, de um ponto de vista concreto, é quem comandará a administração a recomprar as ações). Portanto, quando a lei menciona algum percentual do "capital social total" que seja necessário para legitimar o exercício de algum direito de minoria, ou para aprovar alguma matéria, deve ser lido orequisito como o "capital social que não esteja em poder da companhia"; evita-se, desse modo, essa distorção, sem se perder de vista que a titularidade percentual do 
capital social mantem-se inalterada: o Acionista A, do exemplo, continuará, formalmente, titular de $8,6 \%$ do capital social total (já que as ações recompradas não foram formalmente canceladas).

\subsubsection{Direitos das Ações em Tesouraria}

Quando discorremos acerca da evolução da teoria da sociedade sócia de si mesma, falamos sobre as correntes doutrinárias que buscaram justificar a possibilidade da aquisição das próprias ações pela companhia. Vimos que, de uma forma geral, a aquisição das próprias ações foi sendo legitimada com o passar dos anos tendo por base uma série de ajustes teóricos na própria noção de sociedade e na concepção de titularidade de direitos e obrigações decorrentes das ações. A solução teórica desenvolvida historicamente foi, de forma genérica, a da suspensão de eficácia de determinados direitos oriundos das ações (ou oriundos da titularidade das ações). Elas permanecem em estado de catalepsia, na feliz expressão de Philomeno J. da Costa ${ }^{423}$.

Na época que antecedeu a reforma de 1931 na Alemanha (em que vigia o já comentado e controverso $\$ 226$ do Handelsgesetzbuch), o assunto era avaliado, de um lado, por juristas que defendiam a suspensão dos direitos inerentes às ações e, de outro, por doutrinadores que defendiam a manutenção da eficácia desses direitos, devido à ausência de dispositivos legais que regulassem o problema no Handelsgesetzbuch. Já naquela época, no entanto, muito embora a esmagadora maioria dos doutrinadores negasse direitos às ações nessa condição ${ }^{424}$, a controvérsia não estava pacificada, o que ocorreu, a nível normativo, apenas com a reforma de 1931; hoje, continua positivada a suspensão dos direitos (\$71b). Entre nós, reza o artigo 30, $\$ 4^{\circ}$, da Lei das S.A. que as ações adquiridas nos termos do artigo $30, \S 1^{\circ}$, "b", enquanto mantidas em tesouraria, não terão direito a dividendo nem a voto ${ }^{425}$. É situação de ineficácia dos direitos, como já defendemos. A questão que passaremos a enfrentar agora é outra: a Lei das S.A. menciona tão somente o direito ao dividendo e o de voto, mais nenhum. E os demais direitos, prerrogativas, poderes e pretensões que uma ação dá ao seu titular, como a possibilidade de exercer direitos de

\footnotetext{
${ }^{423}$ Philomeno J. da Costa, op. cit., p. 149, nota de rodapé n. ${ }^{\circ} 134$.

${ }^{424}$ Cf. Alexander Kitanoff, op. cit., p. 21.

${ }^{425}$ Este dispositivo reflete a adoção, pela nossa lei, da teoria moderada da "sociedade sócia de si mesma" que, como visto, propaga que a sociedade pode adquirir ações de sua emissão e que elas não são extintas automaticamente, mas os (ou melhor, alguns dos) direitos inerentes à condição de membro da sociedade ficam com sua eficácia suspensa. Esta doutrina foi adotada em várias legislações da Europa da segunda metade do século passado (\$71b da Aktiengesetz alemã de 1965, Art. 2.357-ter do Codice Civile italiano) e genericamente é a única que prevalece hoje. Ver António Ferrer Correia, op. cit., p. 125, nota de rodapé 1.
} 
minoria (como, v.g., o direito previsto no art. 126, $\S 3^{\circ}$, da Lei), o recebimento de bonificações decorrentes de incorporação de reservas e o direito de preferência em aumentos de capital? Qual a melhor forma de interpretar este ponto: ampliação da ineficácia a todos os direitos (em contrariedade teórica com o dogma interpretativo de que regras restritivas de direito, ou normas excepcionais, não podem ser interpretadas extensivamente ${ }^{426}$ ) ou avaliação em cada caso concreto?

A solução, no caso brasileiro, é diferente para as companhias fechadas e para as abertas, para as quais a Instrução CVM 10 é aplicável: esta vai além do que prescreve a lei, ao prever, no seu artigo 16, que as ações, enquanto mantidas em tesouraria, não terão direitos patrimoniais ou políticos. Em outras palavras, teria a Lei das S.A. efetivamente se limitado a restingir textualmente apenas os dividendos e o voto, ou também outros direitos inerentes ao estado de sócio são igualmente submetidos à vedação? E, por outro lado, haveria a Instrução CVM 10 efetivamente barrado qualquer tipo de direito das ações em tesouraria, usando a prerrogativa a ela atribuída pelo artigo $30, \S 2^{\circ}$ (que submete a validade das operações às regras da CVM), ou teria a CVM excedido a sua competência legal?

Não nos parece que a Lei das S.A. tenha querido retirar das ações em tesouraria apenas o direito ao dividendo, dentre o espectro dos direitos patrimoniais atribuídos aos titulares das ações. Para chegar-se a essa conclusão, precisa-se inquirir a razão pela qual o esse direito é suspenso pela lei, que está ligada ao fato de que a companhia não pode desviar a destinação dos lucros que tenha auferido para si própria, pois os lucros e reservas de lucros da companhia são juridicamente de titularidade dos acionistas (conforme deixa claro o artigo $202, \S 6^{\circ}$, da Lei das S.A.). Se se permitisse que às ações em tesouraria fossem pagos dividendos, na prática, estar-se-ia permitindo um desvio dos lucros distribuídos pela companhia para si própria, por meio da redução das suas reservas - e, consequentemente, do seu patrimônio líquido (a contrapartida dos dividendos pagos seria caixa para a companhia). Assim, o pagamento de juros sobre o capital próprio, em que pese a denominação distinta dada a eles pelo ordenamento jurídico, também é vedado pela Lei das S.A., pois trata-se de um direito patrimonial de distribuição obrigatória: reduz-se o tamanho do patrimônio líquido (e, também, dos ativos sociais) para acrescer ao patrimônio

\footnotetext{
${ }^{426}$ Francesco Messineo, escrevendo em 1966, chegou a defender que as ações em tesouraria deveriam ter direito aos dividendos, justamente pelo fato de que a redação original do Codice Civile suspendia apenas o direito de voto, e que das "norme eccezionali" "non può farsi applicazione analogica, per aggiungere, a quei divieti, altri che, comunque, non siano espressamente contemplati”. Cf. Francesco Messineo, Spettanza..., cit., p. 420. Já à época, contudo, era posição minoritária, e que foi definitivamente superada pela redação dada ao art. 2.357-ter na reforma de 1986.
} 
dos sócios. Há uma mudança de titularidade da riqueza decorrente da distribuição do lucro - é esta a razão pela qual o direito aos dividendos é suspenso. Portanto, de acordo com esse pensamento, devem ser entendidos como suspensos, não apenas os dividendos em si, mas todos os direitos patrimoniais que possuam a mesma natureza dos dividendos, ou, em outras palavras: qualquer forma de distribuição do lucro da empresa, que ocasione a redução do patrimônio líquido e dos ativos sociais, tendo por consequência a transferência efetiva da riqueza da companhia para os acionistas é vedada.

Já no caso das companhias abertas, precisamos enfrentar a redação do atual artigo 16 da Instrução CVM 10, tendo em vista a previsão da Lei das S.A. de que as "aquisições" pela companhia das suas ações estão sujeitas, sob pena de nulidade, às normas da CVM

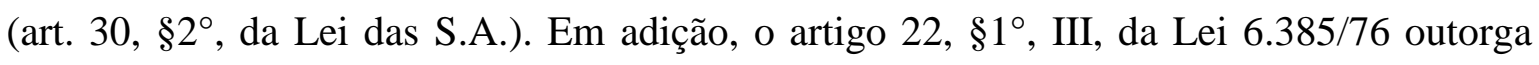
competência à CVM para publicar normas sobre as compras de ações emitidas pela própria companhia "e sobre a alienação das ações em tesouraria", estendendo o âmbito da competência da CVM também para tais alienações. Para José Edwaldo Tavares Borba, a CVM teria, com a edição da Instrução CVM 10, se excedido no seu poder regulamentar: “Determina, ainda, a Instrução, que as ações de tesouraria não terão 'direitos patrimoniais'. Nesse passo, ao que me parece, a CVM se excedeu em sua função regulamentar, pois contrariou a própria lei das sociedades anônimas, a qual apenas privou essas ações do dividendo e não dos demais direitos patrimoniais, sem a natureza de dividendo, como é o caso das bonificações" ${ }^{, 427}$. Na nossa visão, houve efetivamente excesso de competência da CVM (muito embora a norma esteja positivada há mais de 30 anos, sem que tenha sido contestada judicialmente sua legalidade), pois a Lei das S.A. condiciona a validade das aquisições (e das alienações, pela interpretação conjunta com a Lei 6.385/76) às normas emitidas pela CVM, que, portanto, tem amplo espaço para regular o assunto dentro, apenas, desse contexto - podendo fazê-lo, inclusive, de forma mais conservadora do que a lei. $\mathrm{O}$ que não poderia ter feito, como fez, seria regular os direitos inerentes às ações em tesouraria, de forma mais ou menos conservadora do que a Lei das S.A., pois nenhuma lei lhe outorgou competência específica para modificar ou complementar a lei nesse aspecto.

Passemos a avaliar alguns direitos específicos, para vermos como devem ser tratados.

\section{Aumentos de Capital}

427 José Edwaldo Tavares Borba, in Direito Societário, cit., p. 231. No mesmo sentido, cf. Carlos Eduardo Bulhões, op. cit., pp. 44 e 45. 
Iniciaremos pelos casos envolvendo aumentos de capital, que podem gerar controvérsias relacionadas às ações em tesouraria sob diversos ângulos. O primeiro deles, por exemplo, não se refere ao quórum necessário para aprovar o aumento de capital (que deve obedecer, quanto às ações em tesouraria, às regras de que falamos acima), mas sim, se haveria algum conflito conceitual entre a companhia deliberar um aumento de capital enquanto houver ações em tesouraria que pudessem, facilmente e sem maiores burocracias, ser alienadas novamente em troca de dinheiro. Seria válida, assim, a visão de que o aumento de capital deveria ser a ultima ratio e que, enquanto houvesse mecanismos alternativos de capitalização, como precisamente a alienação das ações em tesouraria, devesse a companhia optar por esgotá-los de antemão?

É claro que, do ponto de vista teórico, uma nova emissão de ações, mediante aumento de capital, pode ter funções das mais diversas, e que não seriam atingidas pela alienação de ações em tesouraria: (i) as ações em tesouraria podem não ser líquidas e, assim, não haver comprador, (ii) a companhia pode não querer colocar uma pressão de queda no preço de suas ações, mediante a oferta de venda de um grande lote delas (aumento da oferta), (iii) as ações em tesouraria podem estar reservadas para objetivo específico (cobrir o exercício de opções outorgadas pela companhia no âmbito de um plano de opções de suas ações), (iv) a companhia pode querer emitir ações sem valor nominal, e dedicar maior parte dos recursos à reserva de capital, e não à conta de capital social (a alienação de ações em tesouraria não muda o saldo contábil do capital social, como afirmamos). Enfim, a companhia pode deliberar aumento de capital ao invés de alienar as ações em tesouraria, e há inúmeras razões que justificam esta opinião.

Outro argumento, derivado da lógica de que o aumento de capital deveria ser considerada a última opção de capitalização da companhia, nos traz o artigo 170 da Lei das S.A., que permite o aumento de capital mediante deliberação da assembleia geral "depois de realizados $3 / 4$ do capital social”. Ou seja, apenas é permitida a deliberação de aumento de capital pela companhia após ter sido integralizado $75 \%$ do capital social anteriormente emitido (o DL 2.627/40 exigia, no art. 108, a totalidade). As ações em tesouraria podem ser consideradas como ações "não integralizadas", já que os valores aportados originalmente pelos acionistas foram a eles devolvidos no processo da recompra? A resposta a essa pergunta poderia dificultar uma deliberação de aumento de capital, e gerar dúvidas quanto à natureza da alienação dessas ações. 
Tangenciamos esta questão no início de nosso trabalho, quando afirmamos, com os argumentos que nos pareceram convincentes, que uma recompra de ações não pode ser equiparada juridicamente - ao menos uma recompra feita nos termos em que a lei a permite -, a um retorno do capital social aos acionistas, ou a uma redução do capital social, mas sim, a uma forma de distribuição de lucros. Isso porque, e agora retomamos o ponto, se não fosse essa a interpretação, então as ações em tesouraria deveriam ser consideradas não integralizadas, ou mesmo não emitidas. A consequência deste pensamento (equivocado) para o caso de aumento de capital é que elas poderiam impedir a deliberação do aumento, caso o quórum de $3 / 4$ do capital social "integralizado" não fosse atingido em decorrência das ações encarteiradas. Cabe lembrar: quando a Lei das S.A. exige um alto percentual de integralização do capital para possibilitar o aumento, segue ela uma lógica de que, enquanto houver créditos da companhia contra os seus acionistas pela integralização das ações emitidas, então não deveria ser utilizado o canal do aumento para reforçar as entradas de capital; a Lei das S.A. estabelece mecanismos para que a companhia cobre os acionistas faltosos, ou reduza seu capital se não conseguir fazê-lo (acionista remisso). Note-se bem, ações em tesouraria não indicam valores que os acionistas subscreveram, porém não integralizaram: os valores devidos pelos subscritores foram pagos, não há que se falar em relação jurídica de débito e crédito em relação aos valores de integralização; essas operações dão-se no mercado secundário dessas ações, justamente porque a recompra feita na forma da lei não representa um retorno de capital aos acionistas. Na integralização de novas ações, portanto, trata-se do princípio da veracidade do capital social, enquanto os princípios que regem a recompra de ações orbitam em torno da manutenção desse capital.

Dessa forma, não há razão para argumentar no sentido de que não seria possível o aumento de capital sem antes serem as ações em tesouraria alienadas; esse pensamento, inclusive, seria completamente anti-econômico e oneroso para as companhias.

\section{Direito de Preferência (dos Demais Acionistas e da Própria Companhia)}

A pergunta consequente, argumentatis argumentandis, seria: se a ação em tesouraria representa uma ação não integralizada, ou mesmo não emitida (em decorrência da suposta devolução de capital aos acionistas ou da sua equiparação jurídica a uma redução de capital), a sua alienação daria ensejo ao direito de preferência dos demais acionistas, ao ser comparável com um aumento de capital, nos termos do artigo 171 da Lei 
das S.A.? Alguma doutrina estrangeira defende a existência do direito de preferência também na alienação de ações em tesouraria, baseando-se no fato de que os acionistas existentes em determinado momento seriam tão legitimados à proteção na situação de alienação de ações em tesouraria como o são em casos de emissão de novas ações ${ }^{428}$. Nesta concepção, a alienação de ações em tesouraria deveria ser oferecida primeiro aos acionistas existentes, na proporção de suas ações, para que eles não tenham a sua participação "diluída".

Divergimos profundamente dessa visão. Em primeiro lugar, a participação societária no capital social total emitido, mantidas as demais condições constantes, não é alterada pela existência das ações em tesouraria, apenas há um fenômeno de concentração dos direitos e deveres dos acionistas, enquanto a titularidade percentual total permanece a mesma. Daí ser de fácil compreensão que, na alienação de ações em tesouraria, o que ocorrerá será, no máximo, um retorno da distribuição dos direitos e deveres à proporção existente antes da conclusão da recompra de ações, mantida, de qualquer forma (antes, durante e depois da aquisição), a titularidade do capital social total. Em outras palavras, não há que se falar em diluição dos acionistas, que é precisamente o que justifica o direito de preferência nos casos de aumento de capital (direito esse, aliás, que nem sempre é atribuído pela Lei das S.A., nem mesmo em casos de aumento de capital - veja-se, v.g. a hipótese de incorporação de sociedades do art. 227 da Lei das S.A.). Some-se a esse argumento que, não é demais reforçar, a aquisição de ações próprias nos termos da lei não pode ser equiparada a um retorno de capital social aos acionistas, de forma que as ações em tesouraria jamais podem ser equiparadas a ações não integralizadas ou, o que é pior, a ações não emitidas; essas operações de compra e venda pela companhia dão-se, como mencionamos, exclusivamente no mercado secundário das ações, e não no primário, sendo inadmissível a existência de direito de preferência aos demais acionistas na alienação das ações em tesouraria.

A CVM reconheceu expressamente a ausência de preferência na alienação das ações em tesouraria no julgamento do Processo Administrativo CVM RJ 2004/3666, em que eram partes requerentes o Unibanco - União de Bancos Brasileiros S.A. e o Unibanco Holdings S.A.: versava o caso sobre uma permuta de ações em tesouraria como forma de aquisição do controle de outro banco. Nos termos do (excelente) parecer da area técnica da SEP: “Com relação aos efeitos da operação junto aos atuais acionistas das Requerentes,

${ }^{428}$ Cf. Alexander Kitanoff, op. cit., p. 186. 
podemos concordar, de início, que [a] utilização dessas ações afasta a possibilidade de diluição das atuais participações acionárias, dado que não ocorrerá aumento de capital nas companhias. Na mesma linha, não há que se falar em direito de preferência para aquisição das ações em tela, na forma do art.171 da Lei das S.A.” - grifos nossos ${ }^{429}$. Parece-nos inabalável esta opinião.

Partindo para a segunda discussão: às ações em tesouraria é garantido o direito de preferência na subscrição de um aumento de capital ordinário deliberado pela companhia, mediante emissão de novas ações? Ou é este também submetido à ineficácia dos direitos das ações em tesouraria?

O direito de preferência (ou opção de preferência, como seria melhor denominado ou, ainda, direito formativo gerador ${ }^{430}$ - aqui, falaremos em direito de preferência) já foi amplamente estudado na doutrina. Sua função, inegavelmente, é a de preservar a porcentagem de participação dos acionistas no conjunto de todas as ações em que se divide o capital social, garantindo a eles a manutenção do objeto de seus direitos de participação $^{431}$, evitando que sofram uma diminuição da sua participação proporcional nas reservas da sociedade ou na gestão $\operatorname{social}^{432}$. Isso porque, naturalmente, a divisão dos lucros sociais, do acervo líquido (em caso de liquidação) e do poder político da companhia se dá em função da titularidade percentual do capital social.

José Luiz Bulhões Pedreira e Alfredo Lamy Filho argumentam, a nosso ver de forma não sustentável, ser “inconcebível” o exercício da preferência pela companhia, defendo sua opinião ao afirmarem: "se a companhia integralizasse as ações subscritas com lucros ou reservas do seu patrimônio haveria uma capitalização desses recursos sem acréscimo ao patrimônio da companhia" ${ }^{\text {433 }}$ - o que é verdade, mas que por si só não nos parece justificar a impossibilidade da preferência. O fato de que não haverá ingresso de novos recursos ao patrimônio social não justifica a exclusão do direito de preferência, pois isso ocorre também em outras situações nas quais a lei permite o aumento de capital, ainda

\footnotetext{
${ }^{429}$ Apesar disso, a Diretora Norma Jonssen Parente, sem razão, votou por indeferir o pedido do Unibanco tendo em vista um alegado caráter "anti-democrático" da operação pretendida, justamente por privar os acionistas de suposto direito de preferência, no que ficou vencida pelo excelente voto do Diretor Luiz Antônio de Sampaio Campos: "De fato, não entendo que 'a operação é em tudo similar a uma emissão de ações', como afirmado pela Ilustre Diretora Relatora, uma vez que tanto a aquisição quanto a alienação das ações de emissão da companhia por ela própria se dá no mercado secundário, sem a emissão de novas ações, mercado este [em] que somente existe direito de preferência por convenção das partes, sob pena de se desrespeitar princípio basilar das sociedades anônimas, a livre circulação das ações (art. 36)" - grifos nossos.

${ }^{430}$ Cf. Pontes de Miranda, Tratado..., Vol. 50, cit., p. 357.

${ }^{431}$ Cf. Alfredo Lamy Filho e José Luiz Bulhões Pedreira (coords.), Direito das Companhias, cit., p. 1426.

${ }^{432}$ Cf. Cf. Tullio Ascarelli, Problemas..., cit., p. 728.

${ }^{433}$ Cf. Alfredo Lamy Filho e José Luiz Bulhões Pedreira (coords.), Direito das Companhias, cit., p. 555.
} 
que apenas o nominal (sem alteração do patrimônio líquido, portanto). O exemplo, aqui, é o de um aumento de capital por incorporação de reservas, que tem justamente o efeito de não capitalizar a companhia com novos recursos oriundos de uma subscrição externa de ações - há apenas um reajuste contábil entre as contas de reservas de lucros e de capital social, com o respectivo aumento do vínculo de indisponibilidade -, de forma que o ingresso de novos recursos não é condição sine qua non de um aumento de capital ${ }^{434}$.

O raciocínio, neste item, precisa adotar outro caminho, que é justamente aquele que dialoga com a função que o direito de preferência exerce no seio da sociedade. Como mencionamos brevemente, a ideia da existência desse direito é garantir aos acionistas que o seu estado de sócio, e o exercício dos direitos dele derivados, será mantido proporcionalmente estável, mesmo com a emissão de novas ações. Caso contrário, um aumento de capital significaria uma redução imediata da participação desse acionista nos lucros sociais e nos votos em assembleia (se as ações tiverem voto). Nessa linha, entendemos que o direito de preferência baseia-se na titularidade do capital social total emitido, e não na titularidade (temporária ou não) de direitos econômicos e políticos em determinado grau. Justificamos a diferença: as ações em tesouraria têm como efeito indireto a concentração dos direitos econômicos e políticos das ações remanescentes, pois os lucros sociais, quando de sua distribuição, serão repassados apenas àquelas ações em circulação naquele momento (o mesmo ocorrendo com o voto, uma vez que as ações em tesouraria não votam), mas não têm como efeito a alteração na titularidade do capital social total, para o qual as ações em tesouraria continuam contribuindo. O direito de preferência, portanto, não tem a mesma natureza do direito ao dividendo, não podendo ser subsumido, nem por analogia ou interpretação extensiva, ao art. $30, \S^{\circ}$, da Lei das S.A.

Estas passagens nos levam a algumas conclusões.

Em primeiro lugar, e reconhecemos que a ideia é inovadora no Brasil ${ }^{435}$, não deveria ser principiológicamente considerado inconcebível a companhia exercer a preferência com relação às ações em tesouraria, ainda que todos os países que pesquisamos condenem qualquer tipo de participação da companhia no mercado primário de suas ações

\footnotetext{
${ }^{434}$ Tullio Ascarelli, Problemas..., cit., pp. 625 e ss.

${ }^{435}$ Carlos Eduardo Bulhões parece defender a possibilidade, mas advoga que seria necessária regulação expressa da Lei das S.A., com o que não pactuamos. A forma como atualmente é regulada a matéria já permite a interpretação que faremos. Cf. Carlos Eduardo Bulhões, op. cit., pp. 51 e 52.
} 
(subscrição de capital, cf. restrição da Segunda Diretiva ${ }^{436,437}$ ). Essa opinião justifica-se porque, no limite, se a companhia subscrevesse o aumento de capital em decorrência da preferência, deveria integralizar o aumento com o seu saldo de lucros e reservas e, assim, estar-se-ia diante de uma situação praticamente ${ }^{438}$ idêntica a de capitalização de lucros e reservas, na forma do permitido pelo art. 169 da Lei das S.A. Além disso, por mais que possa ser aventado que as ações em tesouraria não participam dos lucros sociais e não votam e, dessa forma, não tem "objeto de direitos de sócio" ou "direitos de primeira ordem" cuja diluição precisa ser tutelada pelo exercício da preferência, podemos mencionar que não permitir à companhia a manutenção da sua proporção no capital total poderá causar prejuízos a ela no futuro, seja porque efetivamente terá menor número de ações para alienar ao público em troca de recursos financeiros, seja porque poderá ver-se na necessidade de ir a mercado para comprar mais ações em decorrência de, por exemplo, um plano de opção de ações que tenha aprovado, o que a sujeitará às condições de liquidez e preço do mercado.

Enfocando o interesse dos acionistas, também não vemos situação de absoluta incompatibilidade: a eles continuará a ser garantida a preferência com base na sua titularidade total do capital social (contando as ações em tesouraria), o que não acarretará uma diluição de sua participação percentual total (que é o critério usado pela Lei das S.A.) e, ademais, continuarão eles a se beneficiarem de uma distribuição de lucros e votos em maior proporção, enquanto durar o entesouramento, por força do fenômeno já tratado da concentração dos direitos econômicos e políticos ocasionado pelas ações em tesouraria. Se os acionistas reunidos em assembleia permitirem o exercício da preferência (e eles precisarão fazê-lo, pois esse exercício diminuirá as reservas distribuíveis e as intangibilizará como capital social), não vemos razões plausíveis para não se permitir que isso seja feito. No exercício da preferência pela companhia, nessa linha, não visualizamos riscos incontornáveis aos acionistas (que aprovarão a preferência em assembleia, de

\footnotetext{
${ }^{436} \mathrm{O}$ que não afasta, cabe rememorarmos, o fato de que a Itália permitiu, por 7 anos, que a assembleia geral deliberasse sobre o exercício do diritto di opzione pela companhia, nos termos do art. 2.357-ter do Codice Civile - a possibilidade foi, é bem verdade, revogada na reforma de 2010, por conta da incompatibilidade teórica com o direito comunitário.

${ }^{437}$ Messineo também entendia possível esse exercício, tendo em vista a falta de exclusão expressa desse direito pelo Codice Civile vigente em 1966, e considerando que: "I divieti non si presumono, né si sottointendono". Cf. Francesco Messineo, Spettanza..., cit., p. 421.

${ }^{438}$ Não é absolutamente idêntica, pois o aumento de capital por meio de subscrição de novas ações efetivamente tem por intuito teórico a capitalização da sociedade mediante ingresso de novos recursos ao patrimônio social. Não se descuida deste detalhe, mas ele, por si só, não nos parece ser suficiente para excluir juridicamente a possibilidade da preferência; outros argumentos precisariam ser defendidos em conjunto com este.
} 
maneira similar a uma capitalização de reservas, além de conseguirem manter sua titularidade percentual e, igualmente, sua participação concentrada em decorrência das ações em tesouraria permanecerem sem dividendos e voto), nem aos credores (que, muito pelo contrário, terão, em tese, um benefício decorrente do aumento do vínculo de indisponibilidade do capital social), nem ao mercado, para quem essa operação deveria ser neutra, desde que bem explicada nas demonstrações financeiras.

A mesma lógica deveria valer para as companhias abertas, ainda que haja previsão, no art. 16 da Instrução CVM 10, de que a elas não será atribuído direito patrimonial algum, pois o direito de preferência não representa verdadeiramente um direito patrimonial; não se relaciona diretamente com a participação nos lucros sociais (apesar de garantir, em segunda ordem, que ela não seja impactada e diluída), de maneira que podemos afirmar que ele não tem a mesma natureza do dividendo e também não carrega o mesmo risco de desvio dos lucros sociais.

Aliás, se não for permitido à companhia exercer a preferência sobre essas ações (seja nas fechadas ou abertas), o que ocorre com esse direito? É ele acrescido automaticamente às demais ações em circulação ou não? É um caso de renúncia do direito de preferência ou de cessão?

Se não for concebida a existência do direito de preferência, então esse direito, por inexistente, não poderá ser "renunciado" ou "cedido". Mas tampouco será o caso de mero acréscimo lógico às demais ações ("Anwachsung” ou "preferência nas sobras" "439), pois a preferência está baseada exclusivamente na titularidade percentual do capital social total, e não na titularidade de direitos econômicos e políticos. Como já afirmamos, a titularidade do capital social não se altera com a aquisição de ações para permanência em tesouraria, apenas os direitos econômicos e políticos sofrem uma concentração. Por isso, não há que se falar em "direito de acrescer" da preferência atribuída às ações em tesouraria para as demais ações; elas exercem a preferência usual que lhes for atribuída e nada mais.

Se, por outro lado, for concebida a existência da preferência para as ações em tesouraria, caberá a indagação sobre a sua renúncia ou cessão, em casos em que não possa ser exercido, seja porque os acionistas não o aprovaram, seja porque não há saldo de lucros suficiente para a integralização ou seja, ainda, por falta de interesse da companhia. O tratamento a ser dado nessa situação poderá ser aquele estipulado para as sobras em aumentos de capital, conforme art. $171, \S \S 7^{\circ}$ e $8^{\circ}$, da Lei das S.A. (falando de "rateio") ou,

${ }^{439}$ Cf. J.C. Sampaio de Lacerda, Noções Fundamentais sobre Sociedades Anônimas, Ed. Nacional, Rio de Janeiro, 1956, pp 47 e ss. 
ainda, poderá ser cedido o direito de preferência nos termos do art. $171, \S 6^{\circ}$ - neste último caso, também devem ser considerados os princípios de tratamento igualitário entre os acionistas: a cessão deveria ocorrer pro rata, de acordo com a participação de cada acionista no capital.

Concluindo o raciocínio, (i) defendemos a possibilidade de a companhia fechada subscrever suas próprias ações em aumento de capital, na proporção da sua titularidade do capital social em tesouraria, tendo em vista que a Lei das S.A. não retira das ações em tesouraria esse direito (art. $30, \S 4^{\circ}$ ), (ii) as companhias abertas também devem ter esse direito assegurado, ou permitido, pois o direito de preferência tem natureza distinta daqueles que garantem a participação nos lucros distribuídos, e não são, por isso, direitos patrimoniais propriamente ditos, e (iii) em ambos os casos, a ausência de riscos para os grupos de referência (acionistas, credores e mercado), observados certos cuidados, atrelada à presença de potenciais riscos para a própria companhia, em caso de não exercício, devem ser fatores importantes para a defesa da existência desse direito às ações em tesouraria.

\section{$\underline{\text { Bonificação }}$}

Assunto intimamente relacionado ao que acabamos de expor é aquele atinente à situação das ações em tesouraria nas hipóteses de capitalização de reservas, conforme art. 169 da Lei das S.A. Segundo esse artigo, a capitalização de lucros por meio da incorporação de reservas: (i) importará aumento do valor nominal das ações, caso possuam, (ii) se não possuírem, não acarretará nenhuma alteração, exceto o aumento do valor nominal do capital social, ou (iii) poderá ocasionar a emissão de novas ações, correspondentes ao aumento, distribuídas entre os acionistas na proporção das ações que possuírem no capital social. No último caso, costuma-se falar em bonificação.

Parece-nos forçoso reconhecer que, em todos esses casos, as ações em tesouraria

\section{devem ser contempladas.}

Em referência ao aumento do valor nominal das ações sem alteração do seu número, a necessidade de extensão dessa consequência às ações em tesouraria remonta à própria Lei das S.A., que impede a existência de ações com valores nominais distintos (art. $\left.11, \S 2^{\circ}\right)$. No caso de inexistência de ações com valor nominal e na ausência de emissão de novas, as ações em tesouraria acabam inexoravelmente sendo incluídas, pois, na prática, nada ocorre com elas, nem mesmo uma mudança de seu valor patrimonial, haverá apenas uma reclassificação contábil. 
Já no caso de emissão de novas ações em bonificação das existentes, entendemos que também as ações em tesouraria devam ser contempladas com as novas ações, mas o pensamento, neste caso, requer uma digressão um pouco mais longa.

Em primeiro lugar, qual a natureza do direito à bonificação? É ela um direito patrimonial ou um benefício do acionista, decorrente da sua mera titularidade dos papeis?

A bonificação de ações, de acordo com o art. 169 da Lei das S.A., visa a evitar o mesmo problema que vimos a respeito do direito de preferência: busca-se manter a proporção de cada acionista no capital social total, de forma a tutelar os seus direitos de primeira ordem, como a participação nos lucros da companhia e na gestão da vida social, evitando sua diluição injustificada. Mas há uma diferença fundamental entre um aumento de capital comum e um aumento de capital via capitalização de reservas, dado que a deliberação de um aumento de capital ordinário difere, no tempo, da subscrição das novas ações emitidas, de forma que o acionista tem a prerrogativa de subscrevê-las ou não quando for deliberado o aumento (a participação no aumento assenta no consentimento individual de cada subscritor). No caso de aumento mediante capitalização de reservas, por outro lado, não há um elemento de vontade do acionista envolvido, pois a deliberação do aumento mediante capitalização implica a necessária e imediata realização deste, participando obrigatoriamente todo acionista no aumento. Assim, as ações emitidas em contrapartida da capitalização das reservas com aumento do número de ações poderão ser entregues aos acionistas mesmo à sua revelia, e apenas para garantir a sua participação proporcional nas ações totais emitidas; fala-se, inclusive, em ações gratuitas ${ }^{440}$. Não há que se falar em distribuição dos lucros, pois estes já haviam sido retidos, destinados, para a composição da reserva e, agora, por deliberação da assembleia, foram simplesmente revestidos de outro regime jurídico, o do capital social, sem haver qualquer alteração no patrimônio líquido ou no ativo da sociedade, que permanecem intocados e imutados: não há, em momento algum, transferência de riqueza da companhia para os acionistas, cujas ações, agora bonificadas, passam a representar em maior número o mesmo patrimônio líquido.

Assim, parece-nos inegável que as ações bonificadas, a par de servirem como forma de não diluir a participação total dos acionistas no capital da companhia, são ações compulsoriamente e gratuitamente distribuídas a todos, na proporção da participação de cada um, não podendo ser equiparada a uma distribuição de lucros, como o dividendo e,

${ }^{440}$ Cf. Tullio Ascarelli, Problemas..., cit., p. 634. 
assim, não podendo ser subsumida ao regime do art. 30 , $\S 4^{\circ}$, da Lei das S.A.: na lei, a bonificação das ações em tesouraria é permitida, até porque, caso assim não fosse, os demais acionistas veriam sua participação percentual aumentar em decorrência da bonificação, o que certamente não é o intuito da operação.

Passando para a seara das companhias abertas, a Nota Explicativa CVM n. ${ }^{\circ}$ 16, de 1980, editada em conjunto com a Instrução CVM 10, determina, textualmente, que não seria possível garantir a bonificação das ações em tesouraria, pois isso "importaria permitir que a companhia participasse dos lucros sociais", dentro de um raciocínio linear de que a bonificação representa participação nos lucros por derivar dos lucros e reservas capitalizados, que seriam justamente dos acionistas e não da companhia. $O$ argumento da CVM visa a equiparar as bonificações a uma participação nos lucros e, portanto, a um dividendo, o que seria vedado tanto pela Lei das S.A. quanto pela Instrução CVM 10. Estamos em total discordância com o argumento usado pela CVM nessa Nota Explicativa, pois a bonificação de ações em nenhum momento aumenta ou diminui o patrimônio social, apenas reclassifica-se um lucro disponível para uma conta de reserva não distribuível (que tem impacto jurídico expressivo, não se ignora), não se alterando, portanto, o valor patrimonial dessas ações, apenas o seu número ou valor nominal: não há que se falar, portanto, em distribuição de lucros. Aliás, não há distribuição de qualquer natureza, apenas uma operação que tem impacto zero no patrimônio da sociedade. É impossível qualquer equiparação da bonificação a um dividendo, ou a uma participação nos lucros.

Ainda assim, o texto da Instrução CVM 10 fala em não atribuição de qualquer "direito patrimonial" às ações em tesouraria e a Nota Explicativa fala expressamente na vedação das bonificações: "[c]om efeito, uma manifestação tão expressa, de parte provavelmente de quem redigiu a Instrução n. ${ }^{\circ}$ 10/80, naturalmente conduz todos os futuros leitores da Instrução 10/80 e de sua exposição de motivos a respeitar aquela manifestação" ${ }^{441}$. No entanto, como já procuramos demonstrar, o raciocínio empregado pela CVM na Nota Explicativa não sobrevive a uma análise mais detalhada, pois bonificação de ações não pode ser equiparada a uma distribuição de lucros.

A CVM tem posicionamento no mesmo sentido, apesar da redação da Nota Explicativa. Em intrincado caso julgado em 25 de novembro de 2008 (Processo Administrativo RJ2008/6446), no qual eram requerentes o Unibanco - União de Bancos Brasileiros S.A. e Unibanco Holdings S.A. (em conjunto, "Unibanco"), o Colegiado da

${ }^{441}$ Voto da Diretora Presidente Maria Helena Santana, nos autos do Processo Administrativo RJ2008/6446, julgado em 25 de novembro de 2011, de que falaremos mais adiante. 
CVM entendeu que as ações em tesouraria devem também ser bonificadas, vencido o Diretor Eli Loria, que havia votado contrariamente.

Em 23 de setembro de 2008, foi ele, inclusive, o primeiro a votar. Relata o Diretor que, em julho daquele ano, o Unibanco havia realizado assembleia geral e decidido bonificar todas as suas ações emitidas, em circulação e em tesouraria, na proporção de uma para cada dez, condicionada a bonificação à aprovação da CVM e do Banco Central do Brasil. O argumento básico (e correto) do Unibanco era o de que o artigo 169 da Lei das S.A. permitia a capitalização de lucros e reservas mediante aumento do valor nominal das ações ou de emissão de novas ações a serem distribuídas aos atuais acionistas da companhia na proporção de ações que possuírem. Se as ações em tesouraria não fossem contempladas na bonificação, os demais acionistas teriam sua participação proporcional aumentada, de forma oposta ao que determina a lei. A área técnica da CVM manifestou-se contrariamente à possibilidade e solicitou parecer da Procuradoria Federal Especializada da CVM, que se manifestou igualmente de forma contrária, sempre na linha de que a bonificação das ações seria um direito patrimonial das ações, que a Instrução CVM 10 retira por completo, em linha com a Nota Explicativa. Notificado para prestar esclarecimento, o então denominado Banco Itaú Holding Financeira S.A. manifestou-se no sentido de que sempre bonificava suas ações em tesouraria (exceto se ela ocorresse em dinheiro $^{442}$ ), pois o efeito patrimonial da operação seria zero, vez que não existe, na hipótese, patrimônio sendo distribuído aos acionistas.

Eli Loria, em excelente voto, defendeu a natureza da ação como o liame entre a companhia e seus acionistas, de forma que todos os direitos e obrigações das ações em tesouraria derivam do status socii, que a companhia, por incompatibilidade conceitual de a sociedade ser sócia de si mesma, não pode ter. Destrinchando as três dimensões da ação, concluiu que: "as ações em tesouraria passam a não mais apresentar a primeira e a segunda dimensão de seus sentidos, conforme acima apontado (conferir participação acionária e servir como bem móvel que compõe o patrimônio de seu titular). Restaria a tais ações, portanto, apenas a sua existência enquanto certificados ( $3^{\text {a }}$ dimensão do sentido de 'ação'), ou seja, enquanto títulos representativos de uma parcela potencial do capital social, que voltarão a ser plenos tão somente no momento em que forem alienados a outras pessoas,

\footnotetext{
${ }^{442}$ O que é óbvio, pois uma "bonificação em dinheiro" não é uma bonificação da forma como vem prevista na Lei das S.A.; ou bem se capitaliza o lucro ou as reservas de lucros e se emitem ações gratuitas em troca, ou se pagam os lucros ou reservas a título de dividendos. Bonificações em dinheiro são distribuições de lucros e têm, portanto, natureza similar aos dividendos - vedados pela Lei das S.A. para as ações em tesouraria.
} 
físicas ou jurídicas”. Concluiu, por fim, que a ação em tesouraria rompe o elo entre sócio e sociedade, sendo impossível a atribuição de direitos e deveres a ela.

A Diretora Presidente, à época, Maria Helena Santana, votou em 04 de novembro de 2008 em sentido oposto, argumentando que as ações bonificadas são ações gratuitas e não equiparáveis aos dividendos ou a qualquer forma de distribuição de lucros, propondo, inclusive, a alteração da Nota Explicativa: “[s]endo a operação de bonificação em ações mero remanejamento contábil que não possui a característica de transferir rendimento da companhia para o acionista (ou, dito de outra forma, de incrementar de fato o patrimônio do acionista), fica claro que as ações em tesouraria devem ser bonificadas”. Ela foi seguida pelo Diretor Marcos Barbosa Pinto, que votou por autorizar a operação no caso concreto, embora subsumindo a bonificação a um direito patrimonial vedado pelo art. 16 da Instrução CVM 10, e também pelo Diretor Eliseu Martins.

\section{$\underline{\text { Desdobramentos e Agrupamentos }}$}

Os desdobramentos e os agrupamentos, cuja previsão legal está no artigo 12 da Lei das S.A., ainda com mais razão, devem ser permitidos às ações em tesouraria, pois, aqui, sequer há remanejamento contábil do saldo de lucros. Com efeito, o desdobramento é uma prática societária que ocasiona, compulsoriamente, a conversão de uma ação em várias outras, como forma de aumentar o número de ações em circulação no mercado, fomentado a liquidez das companhias e diminuindo o valor para sua negociação (o grupamento é o exato inverso) - sem alterar o valor do capital social ${ }^{443}$.

Não há nenhuma forma de distribuição de lucros vedada; não há, nem mesmo, um “direito” das ações, tão-só uma consequência aritmética de sua titularidade.

${ }^{443}$ Cf. Roberto Papini, Parecer sobre Desdobramento de Ações, in Sociedade Anônima e Mercado de Valores Mobiliários, $2^{\mathrm{a}}$ ed., Forense, Rio de Janeiro, 1988, p. 65. 


\section{ASPECTOS DE MERCADO: INTERESSES DOS INVESTIDORES}

As bolsas de valores surgiram como entidades particulares, onde seus membros se encontravam para negociar os ativos que possuíam, antes mesmo da formalização de qualquer autoridade governamental de controle do mercado de capitais ${ }^{444}$. Nesse sentido, sua função era inicialmente a de um ponto de encontro para determinados membros trocarem suas mercadorias. A sua função regulatória se limitava a determinar algumas práticas de conduta para tornar o ambiente comercial mais atrativo para novos integrantes. Essa função evoluiu no decorrer do tempo, mas o princípio norteador continua o mesmo: a bolsa de valores é responsável, grosso modo, por regular as condutas, a formação correta do preço de troca e garantir a liquidação das operações (muitas vezes por meio de uma contraparte central).

Os objetivos de política pública na regulação das bolsas de valores e do mercado de capitais são razoavelmente comuns em qualquer lugar do mundo, resumindo-se a garantir a proteção dos investidores, assegurar que os mercados sejam justos, eficientes e transparentes, e reduzir riscos sistêmicos ${ }^{445}$. Argumenta-se que o objetivo subjacente da regulação das bolsas de valores e do mercado de capitais seja assegurar que os agentes de mercado tenham confiança em usar o mercado de capitais, por meio da adoção de processos que resultem em sua transparência, em seus participantes serem tratados de forma equitativa, na formação de preço ser objetiva e confiável e em que o mercado seja blindado contra ataques manipulativos ou condutas abusivas ${ }^{446}$.

A aquisição pela companhia de suas próprias ações listadas no mercado de bolsa pode constituir um meio particularmente significativo de ameaça a alguns desses objetivos, por meio, exemplificativamente, da criação de condições artificiais de demanda e oferta de

\footnotetext{
444 Jennifer Elliot, Demutualization of Securities Exchanges: A Regulatory Perspective, in IMF Working Paper, WP/02/119, 2002, pp. 1-30, 2002. Disponível para consulta em http://ssrn.com/abstract=879869. Consulta realizada em 18 de maio de 2013. Para mais informações a respeito da evolução institucional das bolsas de valores, ver Marcelo Lorena Dutra, A Nova Forma de Propriedade das Bolsas de Valores, Tese (Doutorado em Direito), Universidade de São Paulo, 2008, principalmente pp. 13 - 56.

445 "The fair and efficient functioning of an exchange is of significant benefit to the public. The efficiency of the secondary market in providing liquidity and accurate price discovery facilitates efficient raising of capital for commercial enterprises, benefiting both the wider corporate sector and the economy as a whole. The failure of an exchange to perform its regulatory functions properly will have a similarly wide impact". OICV-IOSCO, Regulatory Issues Arising from Exchange Evolution - Final Report, 2006, p.5. Disponível para consulta em http://www.cnmv.es/publicaciones/IOSCOPD225.pdf. Consulta realizada em 18 de maio de 2013.

${ }^{446}$ Cf. William Pearson, Demutualization of Exchanges - The Conflicts of Interest (Hong Kong), in Shamshad Akhtar (coord.), Demutualization of Stock Exchanges - Problems, Solutions and Case Studies, publication n. ${ }^{\circ}$ 100602, Asia Development Bank, 2002, p. 85 e ss.
} 
suas ações, consubstanciada no aumento de demanda criado por suas próprias ordens de compra ou venda - o que, por sua vez, poderá prejudicar a correta, e isenta, formação de preços no mercado.

A história, especialmente do final do século XVIII e início do século XIX, tem exemplos abundantes de casos em que a aquisição das ações próprias foi empregada para influenciar o mercado bursátil de ações, levando muitas vezes à quebra da sociedade e a crises gravíssimas na economia. Existem notícias de bancos franceses sofrendo bruscas falências em decorrência das operações já em $1882^{447}$.

Segundo relata Maria Victória Rodrigues, no âmbito da crise da bolsa de Nova Iorque de 1929, companhias abertas norte-americanas teriam procurado aumentar a cotação de seus papeis por meio de aquisições das próprias ações e, após a eclosão da crise, teriam tentando limitar a queda vertiginosa das cotações por meio também de recompras, tudo com recursos da companhia ${ }^{448}$. Foi o caso da Trading Corporation, por exemplo, que, em 14 de março de 1929 (7 meses antes do “crash”), havia adquirido 560.724 ações próprias, das 1.000 .000 que formavam o seu capital (aproximadamente $56 \%$ do total, portanto), com um dispêndio de mais de US\$57 milhões (um valor bastante elevado em 1929). Com essas manobras, a cotação das ações da Trading Corporation teriam atingido um valor que representava o dobro do seu patrimônio líquido à época. Com a eclosão da crise, o que se verificou foi uma tentativa ainda mais acentuada de utilização dos recursos da sociedade para tentar frear a queda das cotações por meio da compra de suas ações (sem valor algum, a esta altura), o que levou, em última análise, à completa falência da sociedade. Por outro lado, essas companhias não poderiam alienar as ações em tesouraria para fazer caixa, pois isso aceleraria ainda mais a queda dos preços, gerando uma nefasta espiral da morte (death spiral).

A Europa traz exemplos semelhantes ocorridos no mesmo período. Na Alemanha, foram utilizadas tantas operações de aquisição de ações próprias com finalidades especulativas, e em tão grandes proporções, que as autoridades se viram forçadas a, em 1931, reformar a legislação então bastante permissiva (o §226 do Handelsgesetzbuch), por meio da promulgação da Aktienrechtsverordnung, de 19 de setembro de 1931. Relata-se que, entre os anos de 1929 e 1931, os grandes bancos alemães chegaram a ter mais de 50\% de seu capital social em tesouraria, o que trouxe graves prejuízos para a economia real e a situação da moeda. O Berliner Tageblatt de 23 de fevereiro de 1932 referia, por exemplo,

${ }^{447}$ Cf. Arthur Nussbaum, Acquisition..., cit., p. 971.

${ }^{448}$ Cf. Maria Victória Rodrigues, op. cit., p. 98. 
que o Dresdner Bank possuía RM (Reichsmark) 58 milhões em ações próprias em tesouraria, frente a um capital social de RM100 milhões, representando impressionantes $58 \%$ do total ${ }^{449}$. Alexander Kitanoff, na mesma esteira, descreve que o ponto mais severo da crise bancária alemã de 1931 deu-se com a desastrosa quebra do Danat-Bank, que revelou (na ausência de normas de publicidade sobre as aquisições) o mesmo percentual de ações próprias contabilizadas como patrimônio da sociedade (35 milhões de Reichsmark em ações em tesouraria, em face de um capital social nominal de 60 milhões de Reichsmark) ${ }^{450}$.

A história demonstrou, dessa forma, que há um perigo muito real de a sociedade utilizar a operação com a única finalidade de simular uma maior cotação das suas ações, afetando interesses tanto privados quanto públicos. Para o público investidor em geral, a sustentação artificial de altas cotações das ações pode levá-los a acreditar que a companhia possui robusta situação econômico-financeira, demonstrando pujança da sociedade (e a aquisição das ações próprias pode, longe de melhorar, contribuir decisivamente para piorar essa situação). Para a sociedade adquirente os riscos também são substanciais. Haverá sempre um momento em que ela se verá em uma encruzilhada que já não pode resolver: por um lado, não terá recursos em dinheiro disponíveis para continuar as aquisições das próprias ações no mercado, e, por outro lado, não poderá vender a sua carteira de ações em tesouraria, já que isso acarretaria um aumento da oferta e consequente queda na cotação das ações: ciclo vicioso que, frequentemente, pode levar à quebra da sociedade.

Do ponto de vista do interesse público, a interferência das operações na correta formação de preços, influenciando os dados supostamente objetivos fornecidos pela bolsa de valores, é de extremo interesse do poder público, por conta até da interação entre o desenvolvimento de um eficiente mercado de capitais e o desenvolvimento da economia real de um país. Veja-se que as bolsas de valores são atualmente uma das maiores fontes de liquidez e são o lugar propício para os agentes de mercado captarem recursos de terceiros, dando continuidade ao fluxo de mercadorias, bens e capitais na economia. Entre outros fatores que conectam o grau de desenvolvimento do mercado de capitais ao desenvolvimento econômico, podemos mencionar: (i) ampliação na mobilidade de capital na economia; (ii) existência de mecanismo eficiente de alocação de poupança para

\footnotetext{
${ }^{449}$ Cf. Maria Victória Rodrigues, op. cit., p. 100.

${ }^{450}$ Cf. Alexander Kitanoff, op. cit., p. 23.
} 
investimentos; (iii) melhoria na eficiência da realocação de riscos financeiros ${ }^{451}$; (iv) oportunidade para o financiamento por meio do capital estrangeiro; (v) complementaridade com o sistema bancário; (vi) oferecimento de mecanismos de venda de participações societárias que facilitam os desinvestimentos dos fundos de private equity e venture capital, entre outros ${ }^{452}$. Afora estas correlações econômicas entre desenvolvimento do mercado de capitais e crescimento econômico, grande papel foi atribuído ao Direito ${ }^{453}$.

Assim, os itens que exporemos neste capítulo têm o intuito de relacionar as operações da companhia com as suas ações com os interesses dignos de tutela no mercado de capitais.

\subsection{Defesa contra Ofertas Hostis de Aquisição de Controle Societário}

A administração da companhia e seus acionistas podem, muitas vezes, ser colocados em uma situação onde será necessária a tomada de alguma atitude defensiva contra uma oferta pública de aquisição do controle da companhia. Sem querer esgotar o assunto neste item, considerando a vastíssima literatura jurídica e econômica sobre ele, limitamo-nos a afirmar que existem razões plausíveis para que essa atuação seja legitimamente desejada: para conseguir um preço melhor por ação ou mesmo para impedir o sucesso de uma oferta visivelmente prejudicial à companhia. Qualquer que seja essa motivação, ao lado do desenvolvimento do market for corporate control, um arsenal de

\footnotetext{
${ }^{451}$ É o fundamento básico da ampliação dos mercados de derivativos no mundo. O Professor Otávio Yazbek, ao tratar dos arranjos institucionais do mercado de capitais para lidar com a alocação dos riscos, menciona que há dois: alocação de riscos por meio do mercado (com a sua comercialização via mercado, sendo o melhor exemplo, sem dúvida, os instrumentos derivativos) e a alocação de riscos fora dele (a partir de estruturas organizacionais complexas do próprio mercado). Citando Arrow, defende o autor, com clareza, que "ao tratar dos tais mecanismos de mercado, Kenneth J. Arrow se refere a relações negociais, instrumentos ou dispositivos contratuais pelos quais determinados riscos inerentes a uma atividade - ou pelo menos os efeitos econômicos de tais riscos - são repartidos ou transferidos entre os agentes econômicos". A partir da instrumentalização do risco é que surgem verdadeiros mercados para ele, sendo que determinados terceiros recebem uma remuneração para assumir os riscos de outra parte, seja porque tal terceiro tem melhor estrutura financeira ou seja porque ele possui melhores condições de arcar e administrar tais riscos. In Regulação do Mercado Financeiro e de Capitais, Elsevier, Rio de Janeiro, 2007, pp. 25 - 37.

${ }^{452}$ Benn Steil, Creating Securities Markets in Developing Countries, apud Marcelo Lorena Dutra, op. cit., pp. $63-65$.

${ }^{453}$ Para uma breve introdução a essas discussões, remetemos o leitor ao estudo de La Porta, Lopez de Silanes, Schleifer e Vishny, de 1998, no qual se debateu qual a relação entre os sistemas jurídicos (basicamente common law e civil law) e o desenvolvimento do mercado de capitais, devido a fatores como diferentes graus de proteção aos minoritários e maior dispersão do controle acionário. In Flora Pinotti Sano, O Modelo de Supervisão baseada em risco e o Papel da Auto-Regulação, na obra coletiva Auto-Regulação e Desenvolvimento do Mercado de Valores Mobiliários Brasileiro, Saraiva, São Paulo, 2009, pp. 6 -9. Ver também estudo de La Porta, Schleifer e Lopez de Silanes, no qual os autores analisam a legislação de 49 países, verificando o grau de envolvimento entre elas e o desenvolvimento do mercado de capitais. Cf. Rafael La Porta, Andrei Schleifer, Florêncio Lopez de Silanes, What Works in Securities Laws?, Tuck School of Business at Darmouth Working Paper N. 03-22, 2003. Disponível para consulta em www.ssrn.com/abstract $=425880$.
} 
mecanismos de defesa se desenvolveu: uma das usualmente citadas é justamente a utilização de recompras de ações pela companhia-alvo.

De maneira bastante genérica, uma oferta pública de aquisição de controle de uma companhia aberta ocorrerá quando o ofertante tiver o entendimento de que, sob seu comando, o valor da companhia aumentaria. Em outras palavras, a visão do adquirente é de que a administração atual da companhia é ineficiente, resultando, assim, em um baixo valor de mercado das ações, relativamente ao potencial da companhia caso tivesse uma administração eficiente. Essa forma de aquisição de controle atua, portanto, como um constante incentivo de mercado aos administradores de companhias sujeitas a este tipo de operação de sempre buscarem aumentar a eficiência de sua gestão e o valor da companhia, protegendo, com isso, a sua própria condição de administrador ${ }^{454}$.

Uma oferta pública de aquisição pode ser vista positivamente pelos acionistas, devido à existência de um prêmio pelas ações em relação à sua cotação em bolsa (refletindo a visão do adquirente de que há mais valor na companhia do que atualmente precificado e que, com o controle, poderá ele modificar essa situação e explorar esse valor intrínseco). Essa mesma oferta poderá ser vista pela administração da companhia como lesiva aos seus interesses, já que seus membros temerão, se bem sucedida a oferta, a sua imediata substituição por uma nova, e mais eficiente, administração. O "conflito de agência" entre administradores e acionistas está circunscrito neste jogo de interesses: a administração, detentora do controle, mas desprovida do capital, desejará enfrentar a oferta e defender a companhia, enquanto os proprietários do capital, desprovidos de controle, desejarão dar boas-vindas à ela ${ }^{455}$. Por outro lado, é possível que os acionistas, por impossibilidade prática de coordenarem seus interesses, vejam-se no meio de um dilema do prisioneiro, reflexo da teoria dos jogos, sentindo-se quase que forçados a aceitar a oferta, sob o risco de tornarem-se acionistas minoritários de uma companhia com menor liquidez. Esses acionistas devem assumir, racionalmente, que os demais também possuem o mesmo sentimento e que, assim, tenderão a aceitar a oferta. Adicionalmente, a própria

\footnotetext{
${ }^{454}$ Eduardo Secchi Munhoz, Transferência de Controle nas Companhias sem Controlador Majoritário, in Rodrigo R. Monteiro de Castro e Luis André N. de Moura Azevedo (coords.), Poder de Controle e Outros Temas de Direito Societário e Mercado de Capitais, Quartier Latin, São Paulo, 2010, p. 298. Não se descarta, com isso, que muitas vezes a intenção do ofertante seja outra, qual seja, simplesmente a de saquear os ativos da companhia alvo (looting).

${ }^{455}$ Alexander Kitanoff, op. cit., p. 169.
} 
oferta pode ter um caráter coercitivo, quando, por exemplo, ofereça melhor preço para os que primeiro aderirem a ela ${ }^{456}$.

No seio dessa discussão é que se controverte sobre a função de o administrador poder ou não intervir no processo da oferta pública, equilibrando e fazendo a intermediação entre todos esses interesses ao adotar medidas de defesa contra ela ${ }^{457}$. A literatura sobre o assunto, em geral, discute se sequer seria lícito ou desejável que a administração ou os acionistas tenham esse poder para enfrentar uma oferta de aquisição de controle, e se essas defesas levariam, em qualquer caso, a uma perda de valor para a companhia. A contenda doutrinária usualmente adota uma abordagem um tanto extremista, ora julgando as defesas todas como desvantajosas ${ }^{458}$, ora julgando-as todas bem-vindas ${ }^{459}$. Se, de um lado, o administrador poderá coordenar os dispersos acionistas da companhia, de forma a aumentar a eficiência da oferta, poderá ele, por outro lado, agir não no interesse deles, mas de si próprio, protegendo seu cargo. Como vimos acima, existe uma forte corrente que defende um dever absoluto de neutralidade da administração na composição da esfera societária da companhia, o que levaria também a um dever de abstenção de utilização de mecanismos de defesa em caso de uma oferta pública de aquisição, já que ela, em essência, nada mais é do que uma forma de alterar o círculo societário da companhiaalvo.

Uma rejeição ou aceitação irrestrita da possibilidade de utilização de mecanismos de defesa, no entanto, tem pouca aplicabilidade prática e pouco contribui para um entendimento sobre o assunto que efetivamente ajude a melhor proteger os diversos interesses em jogo. O melhor caminho em termos de política legislativa deve ser o de que os mecanismos de defesa sejam permitidos, mas submetidos igualmente a escrutínio e formas de contrabalanceamento. Nos países de tradição romano-germânica e mesmo na Inglaterra, esse poder de atuação é tradicionalmente atribuído aos acionistas, reunidos em assembleia (e não à administração, como ocorre nos EUA), que devem, então, deliberar sobre a interferência ou não na oferta em andamento - são os acionistas, como soberanos da companhia, que decidirão como e se irão defender-se dela. Análise judicial posterior sobre a existência de conflitos de interesse nessa deliberação é sempre possível.

\footnotetext{
${ }^{456}$ Cf. Lucian A. Bebchuck, The Pressure to Tender: An Analysis and a Proposed Remedy, Delaware Journal of Corporate Law (DJCL), Vol. 12, pp. 911-949, 1987, disponível em http://ssrn.com/abstract=480301.

${ }^{457}$ Cf. Fábio Konder Comparato e Calixto Salomão Filho, O Poder de Controle..., cit., pp. 247 e ss.

458 "Our investigation leads to the conclusion that shareholders' welfare is maximized by an externally imposed legal rule severely limiting the ability of managers to resist a tender offer even if the purpose of resistance is to trigger a bidding contest". Cf. Frank H. Easterbrook and Daniel R. Fischel, The Proper Role of a Target's Management in Responding to a Tender Offer, in Harvard Law Review, Vol. 94, 1981, p. 1164. ${ }^{459}$ Martin Lipton, Takeover Bids in the Target's Boardroom, in The Business Lawyer, Vol. 35, 1979-1980.
} 


\subsubsection{Eficácia das Recompras como Tática de Defesa}

Isso posto, independentemente da posição que se entenda mais adequada sobre o dever de neutralidade da administração, entendemos necessário discorrer sobre a utilização das recompras de ações como estratégia de defesa contra uma oferta pública de aquisição das ações da companhia. E, igualmente, cumpre indagar se esse mecanismo representa um meio útil a esse fim. É o que segue.

Em primeiro lugar, uma aquisição de ações de sua emissão pela companhia tem o efeito de diminuir a quantidade de ações efetivamente em circulação no mercado secundário (o artigo $3^{\circ}$, III, da Instrução CVM 361, por exemplo, exclui as ações em tesouraria do conceito de ações em circulação) e, assim, diminui também a quantidade de acionistas disponíveis para aceitarem a oferta de aquisição. Por outro lado, é certo também que, com o entesouramento, diminui o volume de papeis necessários para que o proponente possa exercer a maioria dos votos em assembleia, dado que essas ações passarão a não ter mais direito de voto, enquanto em tesouraria.

Em segundo lugar, podemos mencionar novamente o "efeito de sinalização": se, durante uma oferta pública, a administração utiliza o mecanismo de recompra de suas ações a um preço atrativo (concomitantemente com o compromisso de que o controlador ou os administradores não participarão da oferta), isso tenderá a fazer com que os agentes percebam uma subvalorização crível, fidedigna, das ações: isto provocará a atuação das forças de mercado no sentido de buscar um novo equilíbrio no seu preço, que poderá ser igual, próximo ou mesmo superior ao oferecido pelo proponente, reduzindo, assim, o incentivo econômico para que os acionistas a aceitem. De fato, o sinal poderá ser tão forte, que indicará ao mercado a avaliação da administração e do controlador de que as ações valem mais até do que o preço oferecido pela companhia na recompra (daí a existência concomitante do compromisso de que eles não alienarão as suas próprias ações à companhia durante a oferta de recompra - inclusive, a teoria da sinalização, nesta seara, funciona melhor com o lançamento de uma oferta concorrente do que com uma recompra a $\underline{\text { mercado, }}$ pois, naquelas, a definição do preço acima do de mercado é mais flexível ${ }^{460}$ ). A realidade é que as recompras de ações agem em ambas as pontas das curvas responsáveis pela formação do preço do papel: na ponta da oferta (ao reduzir a quantidade de papeis em circulação, que passam a estar em tesouraria) e na ponta da demanda (ao aumentá-la com

${ }^{460}$ Criticamente, cf. Jesse M. Fried, op. cit., pp. 446 e ss. 
as suas próprias ordens de compra) - o efeito no preço, portanto, é mais acentuado do que uma mera demanda de terceiros, existe um fator potencializante.

Ainda com relação aos efeitos das recompras no preço do papel, ao lado da teoria da sinalização (que indica que o preço subirá pelos atos de terceiros, receptores do sinal), vimos que há um fator potencializante nessas operações, que pode modificar as curvas de oferta e demanda em ambas as pontas. Aprofundemos ainda mais a exegese de como a recompra exerce pressão sobre o preço da ação (price pressure). É equivocado o entendimento de que o preço de mercado da ação, em um determinado momento, reflete o valor que todos os acionistas da companhia entendiam adequado. Teorias recentes apontam para a existência de heterogeneidade entre os acionistas: eles atribuem diversos valores intrínsecos à ação que possuem, de modo que o valor de mercado da ação equivaleria ao menor valor intrínseco atribuído entre todos os acionistas (dito de outra forma: seria o valor que o "acionista marginal" aceitaria vender a ação). Acionistas com mais reserva de valor não estão dispostos a vender ao preço corrente de mercado, enquanto acionistas com menor reserva de valor já o fizeram. Essa diferente atribuição de valor aos papeis pode decorrer de uma série de fatores: (i) assimetria de informações entre eles, (ii) expectativas heterogêneas, (iii) efeitos fiscais diferentes ou distintos custos de transação ${ }^{461}$. Dessa maneira, uma oferta de recompra da companhia a um determinado preço (seja por meio de recompra a mercado, seja pelo lançamento de uma oferta pública concorrente) incentivará que os acionistas com os menores "valores de reserva" vendam as ações, reforçando, por outro lado, a base acionária com aquelas pessoas que acreditam mais na companhia e que valorizam as ações em patamar mais elevado do que aquele oferecido pela companhia. Ceteris paribus, o "acionista marginal", aquele que estaria disposto a vender ao preço corrente de mercado, passaria a ser um acionista marginal com maior expectativa de valor do que o acionista marginal pré-recompra. É a isto que se denomina "price pressure". Este mecanismo será ainda mais eficiente em um cenário de oferta pública de aquisição na modalidade leilão holandês (ao invés de a preço fixo), mas é válido para qualquer recompra de ações. A pressão de preço faz com que seja mais custoso ao proponente o sucesso da oferta hostil.

Adicionalmente, a recompra de ações envolverá necessariamente a utilização de lucros e reservas de lucros da companhia, para concretizá-la (esse é um requisito basicamente uniforme em todos os países analisados), o que significa, de seu turno, um

\footnotetext{
${ }^{461}$ A descrição é de Jesse M. Fried, op. cit, p. 436.
} 
dispêndio de recursos, uma distribuição de liquidez não utilizada pela companhia e que, de outra sorte, poderia ser justamente o fator preponderante na decisão do proponente de lançar a oferta de aquisição. Sem contar a possibilidade de que essa aquisição seja financiada por meio de capital de terceiros, o que, além de diminuir o saldo de lucros e reservas da companhia, ainda aumenta o seu endividamento.

Por outro lado, esses argumentos não são unânimes e isentos de contraargumentação. Precisamos considerar que, eventualmente, o ofertante já seja acionista da companhia-alvo e, neste caso, uma recompra de ações poderá ter o efeito de concentrar os direitos de voto proporcionais desse acionista, favorecendo a sua intenção de ganhar o controle da companhia ${ }^{462}$. Além disso, o efeito de sinalização, de que falamos, poderá não ter o mesmo grau de eficácia, neste momento, que em outros momentos poderia ter. Recorda-se, aqui, uma característica importante do efeito de sinalização: ele depende do grau de credibilidade do sinal que se envia ao mercado. Muitos poderão questionar a razão pela qual essa demanda pela companhia de suas ações, a preços maiores do que os praticados então na bolsa, não foi lançada antes da oferta hostil, mas apenas depois dela, o que poderá gerar uma incerteza por parte dos investidores sobre a credibilidade do sinal enviado pela companhia.

Tomando todos esses parâmetros em consideração, parece-nos que a pergunta sobre se a aquisição de ações de sua emissão, pela companhia, no decorrer de uma oferta pública de aquisição de seu controle, representa um método propício de defesa deve ser respondida afirmativamente. Quão eficaz o mecanismo se mostrará no caso concreto, entretanto, não é uma pergunta capaz de ser respondida em teoria, dependerá de uma série de fatores do caso concreto, como, por exemplo, o grau de atratividade e dependência da oferta (do ponto de vista do adquirente-proponente) ao volume de lucros e reservas existentes na companhia alvo, ou, ainda, em que grau uma oferta de recompra pela companhia enviaria um sinal crível ao mercado sobre sua sub-precificação ${ }^{463}$. Particularmente eficiente seria uma recompra de ações que conseguisse manter na companhia apenas aqueles acionistas que nela enxerguem potencial, e que, portanto, estariam menos tendentes a vender suas posições: isso pode ser atingido, entre outros

\footnotetext{
462 "[D]efensive stock repurchases may represent a somewhat risky strategy, even though repurchases also increase the percentage of target stock in the hands of target managers or their loyalists. The riskiness of the repurchase strategy will in fact turn on the relative holdings of the outside bidder and target managers and loyalists. Because SEC tender offer rules require the bidder to reveal its pre-offer stake in the target (...) target managers can avoid defensive stock repurchases when that strategy would be particularly risky". Cf. Michael Bradley e Michael Rosenzweig, Defensive Stock Repurchases, in Harvard Law Review, Vol. 99, 1986, p. 1379, nota de rodapé 2.

${ }^{463}$ Cf. Alexander Kitanoff, op. cit., p. 172.
} 
meios, com a aquisição das ações no mercado e revenda delas a sociedades coligadas ou mesmo controladas da companhia (nos limites do permitido pelas regras de participações recíprocas), ou para o(s) acionista(s) controlador(es). Essas pessoas, obviamente, não estariam dispostas a aceitar a oferta, o que daria maior eficiência ao mecanismo ${ }^{464}$.

\subsubsection{Conveniência das Recompras de Ações como Tática de Defesa: Recompras a Mercado vs. Ofertas Públicas Concorrentes}

De qualquer forma, retomando o nosso raciocínio, a recompra de ações pode ser vista, em princípio, como uma forma útil de defesa contra ofertas de aquisição de controle. A dúvida que passaremos a responder agora é se é legalmente permitido ou desejável o uso dessa ferramenta.

Nos EUA, a discussão remete ao debate sobre a business judgement rule e a sua relação com os deveres fiduciários da administração. Grosso modo, as operações de recompra de ações como mecanismo de defesa contra aquisições hostis de controle são permitidas nos EUA, dentro da lógica de que o administrador tem um campo de atuação maleável e permissivo, desde que obedeça a seus deveres fiduciários de lealdade, etc., nos quais a business judgement rule se apoia. Assim, a questão, lá, circunscreve-se à indagação sobre qual o "primary purpose" da operação de recompra. Segundo esse teste jurisprudencial, a decisão da administração de efetuar uma recompra de ações nessas condições deve ser considerada legítima se não tiver sido realizada com o objetivo principal de perpetuação do seu próprio poder na companhia; cabe aos administradores o ônus de provar que agiram em boa-fé e após "reasonable investigation" sobre os perigos e a conveniência das recompras como mecanismo de defesa ${ }^{465}$. O leading case que definiu esses critérios foi o caso, julgado pela corte de Delaware, Unocal Corp. v. Mesa Petroleum Co., de 1985, em que a corte julgou que os administradores deveriam provar que, na decisão de utilizar o mecanismo de defesa, não agiram exclusivamente ou

\footnotetext{
${ }^{464}$ Não ignoramos o fato de que, no Brasil, essas vendas pela companhia aberta deveriam dar-se em bolsa, com a capacidade de intervenção de terceiros; discorremos sobre possibilidades teóricas.

465 "Where the target issues stock to a big brother, buys a company to create an antitrust block, purchases its shares from a raider at a premium or takes similar action, the standard seems to be a primary purpose rule the action will be sustained unless the primary purpose was to keep the management in office rather than to serve the best interests of the company and its shareholders". Cf. Martin Lipton, Takeover Bids...,. cit., p. 124. "Relying on the business judgment rule, courts typically have held that the target's management has the right, and even the duty, to oppose a tender offer it determines to be contrary to the firm's best interests." Cf. Frank H. Easterbrook and Daniel R. Fischel, The Proper Role...,. cit, p. 1163. "The result of this decision is that purchases which may involve preservation of control are outlawed unless management can prove that the purchases are primarily in the corporate interest". Cf. W. McNeil Kennedy, Transactions by a Corporation In its Own Shares, in Business Lawyer, Vol. 19, 1963-1964, p. 336.
} 
preponderantemente (primarily) nos seus próprios interesses de manutenção de seus cargos, mas que a sua decisão foi motivada por uma preocupação de boa-fé acerca do bem da companhia e de seus acionistas. Neste caso, Mesa Petroleum, acionista minoritária da Unocal, iniciou uma oferta pública de aquisição das ações da Unocal, tendo sido considerada pela administração desta como coercitiva e, ademais, a preço vil. Com isso, a administração da Unocal lançou uma oferta pública concorrente, pela própria companhia, e que foi considerada válida pela Supreme Court of Delaware.

No Reino Unido, à semelhança do teste jurisprudencial norte-americano, existe o conceito dos "improper purposes", que visa a qualificar a ação da administração durante, ou na iminência, de uma oferta pública de aquisição. Por outro lado, o Take Over Panel Code, no item 21.1, contém uma regra estrita de que a administração não pode tomar nenhuma atitude "which might result in any offer or bona fide possible offer being frustrated or in shareholders being denied the opportunity to decide on its merits". É a consagração da "no frustration rule", que reflete a ideia geral de que são os acionistas, e não a companhia, que devem decidir sobre a conveniência da oferta. Segundo Gower: "this is a particularly strict rule. Unlike the common law relating to improper purposes, Rule 21 requires shareholder approval for any action proposed by the directors of the target company, which could have the result of preventing the shareholders of the target company from deciding on the merits of the bid (...) The Rule looks to consequences, not to purposes" ${ }^{\prime 66}$. Na doutrina comunitária europeia, essa regra inglesa é traduzida na discussão do dever de neutralidade da administração (board neutrality), mas que alguns autores preferem denominar de "no frustration", já que não frustrar não significa necessariamente uma atitude absolutamente neutra e passiva da administração: ela pode, por exemplo - e deve, em muitos casos -, orientar os acionistas sobre a conveniência da oferta. Não frustrar a oferta não significar ser passivo com relação a ela ${ }^{467}$.

No Brasil, até muito pouco tempo atrás, sequer poderia cogitar-se da existência deste tipo de oferta, dado que elas dependem de um determinado grau de dispersão do capital da companhia para ao menos terem as condições de surgir, o que ainda é pouco

\footnotetext{
${ }^{466}$ Cf. Gower and Davies, op. cit., p. 986.

${ }^{467}$ Cf. Paul Davies e Klaus Hopt, Control Transactions..., cit., pp. 235. O artigo 32-D da Instrução CVM 361 permite, porém não determina, que o conselho de administração se manifeste favorável ou contrariamente a uma oferta pública. Isso propositalmente: no Brasil, discutiu-se se a CVM teria competência para regular e criar esse dever de conduta, que outrora era obrigatório, mas que foi tornado facultativo após a reforma promovida pela Instrução CVM 487, de 25 de novembro de 2010. Para um resumo das discussões, ver o Relatório de Análise da SDM Processo no RJ-2007-14749 - Audiência Pública SDM 02/2010, disponível no site da CVM. Acresça-se ao debate que o Regulamento do Novo Mercado, da BM\&FBovespa, contém regra mandatória nesse sentido, no seu item 4.8 .
} 
comum, apesar de ser uma crescente realidade ${ }^{468}$. Calixto Salomão Filho, em suas notas ao trabalho de Comparato, afirma que "trata-se de técnica evidentemente nociva" e comemora a redação da Instrução CVM 10, que proíbe a prática por completo ${ }^{469}$.

Essa vedação, no entanto, não lhe retira toda a utilidade prática, uma vez que nos parece plenamente possível a realização de uma oferta pública concorrente, pela própria companhia-alvo, para aquisição de suas ações, nos termos da Instrução CVM 361. Esta norma claramente permite que a própria companhia seja a ofertante em uma oferta pública, e aí devemos, portanto, incluir a concorrente, assim definida como "a OPA formulada por um terceiro que não o ofertante ou pessoa a ele vinculada, e que tenha por objeto ações abrangidas por OPA já apresentada para registro perante a CVM, ou por OPA não sujeita a registro cujo edital já tenha sido publicado, nos termos do art. 11 ” - artigo $2^{\circ}$, VI, da Instrução CVM 361, grifos nossos. Dito de outra forma: entendemos possível que uma companhia, em face de uma oferta de aquisição de seu controle, possa, ela própria, lançar uma oferta concorrente a seus acionistas, observadas as condições da Instrução CVM 361, alinhadas, no que for possível, com as da Instrução CVM 10 (prática conhecida como self-tender offer ou self-tender).

Essas duas modalidades de utilização do mecanismo da recompra como forma de defesa contra aquisições hostis, recompras a mercado e via oferta concorrente, encontram seu paralelo nas regras dos EUA, que permitem, como estratégia de defesa contra uma oferta hostil, ora a utilização do mecanismo das recompras a mercado (open market repurchases), ora o lançamento de uma oferta pública concorrente (a self-tender offer) - as modalidades estão sujeitas a diferentes regras procedimentais e de transparência. Ambas as alternativas são apenas formas de efetivação das recompras, servindo a um único propósito, que é a defesa contra a oferta hostil: ambas são, assim, espécies do gênero "recompras defensivas de ações" ou "defensive stock repurchases" 470 .

Então, por qual razão o Brasil veda as aquisições a mercado (na Instrução CVM 10) e permite as ofertas concorrentes (na Instrução CVM 361)? Temos que entender, por amor à boa técnica interpretativa, que as duas normas devem possuir motivos e teleologia distintas, apesar de aparentemente regularem o mesmo objeto.

\footnotetext{
${ }^{468}$ Cf. Erica Gorga, Changing the Paradigm of Stock Ownership from Concentrated towards Dispersed Ownsership? Evidence from Brazil and Consequences for Emerging Markets, Cornell Law School Working Papers, setembro de 2008, disponível em http://ssrn.com/abstract=1121037. Ver também Eduardo Secchi Munhoz, Transferência de Controle..., cit., pp. 285 a 324.

${ }^{469}$ Fábio Konder Comparato e Calixto Salomão Filho, O Poder de Controle..., cit., p. 249.

${ }^{470}$ Cf. Michael Bradley e Michael Rosenzweig, Defensive..., cit., p. 1379.
} 
A primeira diferença entre uma e outra situação é a autonomia que a administração possui em cada caso para efetuar os negócios jurídicos, e as salvaguardas normativas existentes; a segunda é o grau de transparência envolvido em cada uma. No caso de aquisição para permanência em tesouraria, a autonomia da administração é ampla, já que ela agirá, autorizada pelo estatuto social e pelo conselho de administração (este último, inclusive, identificando os objetivos e os limites das operações, e não a assembleia), dentro de um quadro maleável em termos de decisão sobre o momento e a razão da aquisição. Já em uma oferta concorrente haverá prévia deliberação da assembleia de acionistas (ou, ainda que seja defensável a ausência desta aprovação, haverá severos requisitos de transparência impostos pela CVM).

Acrescentamos outra distinção que nos parece fundamental: a regra de "não frustrar" e o dever de neutralidade da administração, que permeiam a interpretação desse dispositivo da Instrução CVM 10, não impedem, normalmente, que a administração possa aumentar o escopo de decisão dos acionistas por meio, exemplificativamente, da busca de outro ofertante, um "cavaleiro branco" como se os denomina comumente (White Knight), que poderá aparecer no curso da oferta mesmo que a administração não tenha saído em sua busca. Se aparecer um novo concorrente, ainda que este seja a própria companhia, o fundamento lógico continua sendo o de que os acionistas não foram privados de sua decisão - muito pelo contrário, aumentou-se o leque de opções submetido à sua apreciação. Note-se, ainda, que a Instrução CVM 361 não contém uma regra expressa de "no frustration", abrindo, dessa maneira, espaço para a atuação mais flexível da administração, desde que o conceito maior do direito brasileiro, de que cabe aos acionistas a decisão sobre a conveniência da oferta, seja observado.

Por final, o ponto que se nos apresenta fundamental é o de que as recompras a mercado e as ofertas públicas concorrentes diferenciam-se substancialmente no tocante aos requisitos procedimentais e de transparência. Qualquer oferta pública de aquisição de ações deve ser submetida a uma série de regras de publicidade previstas na Instrução CVM 361, mesmo que tais ofertas não sejam de registro obrigatório na CVM, o que garante o acesso dos acionistas a um amplo rol de informações sobre o adquirente, a recompra, as interações do adquirente com as ações da companhia no decorrer da oferta, as atitudes dos administradores, as condições da oferta e da formação do preço, etc. Isso atribui uma dimensão de segurança ao procedimento, que não encontra paralelo nas aquisições a mercado, cujos requisitos de transparência, por mais que existentes, são bem menos detalhados e exigentes. 
Do ponto de vista da efetividade, a doutrina (mormente norte-americana) ocupou-se de dar as bases teóricas para responder à indagação acerca de qual dos mecanismos cumpre melhor o objetivo de defesa contra uma oferta hostil de aquisição de controle: recompras a mercado ou ofertas públicas concorrentes? E, neste último caso, qual modalidade de oferta pública concorrente é a mais indicada, a preço fixo ou por leilão holandês? Genericamente, entende a literatura que as recompras a mercado seriam menos eficientes como tática de defesa, pois o preço fixado pela companhia para a recompra poderá não corresponder ao mínimo necessário para a aquisição de quantidade de ações suficiente. Além disso, o risco de imputações de manipulação de preços quando a companhia adquire muitas ações a mercado em um curto período é maior, sendo preferível a utilização de ofertas públicas concorrentes. John C. Persons estudou as duas tradicionais formatações das ofertas públicas de recompra sob a perspectiva da formação de preço, e as comparou com as recompras a mercado, chegando à conclusão que, mesmo dentro da categoria das ofertas públicas concorrentes, "fixed price repurchases are better suited to signaling undervaluation and Dutch auctions are better suited to deterring takeovers "471 - inclusive, para substanciar sua tese (o que também foi feito por meio de robustos cálculos matemáticos e estatísticos), o autor menciona que o maior número de ofertas públicas concorrentes na modalidade de leilão holandês, dentro do seu período de avaliação, foi verificado no ano de 1989, mesmo ano em que as ofertas hostis de aquisição de controle alcançaram (ao menos até o ano em que o estudo foi conduzido) número recorde nos $\mathrm{EUA}^{472}$.

Ou seja, enquanto não houver uma oferta pública de aquisição do controle de uma companhia, poderá a sua administração fazer uso, nos termos da Instrução CVM 10, da recompra de ações para manutenção em tesouraria, desde que observem as regras de tratamento igualitário e proteção dos credores de que já falamos, cristalizadas no texto da Instrução CVM 10. Depois de anunciada a oferta pública hostil, a utilização das recompras de ações nos termos da Instrução CVM 10, outrora permitida, poderia ser entendida como uma forma ilegal de dificultar ou evitar a formação de novas maiorias ou minorias de acionistas no seio da sociedade, o que configuraria uma interferência vedada da administração na composição da esfera societária da companhia, uma violação do seu dever de neutralidade, restando possível apenas, diante da ausência de vedação de atuação, a realização de uma oferta concorrente nos termos da Instrução CVM 361 e da Lei das S.A.

${ }^{471}$ Cf. John C. Persons, op. cit., p. 1374.

${ }^{472}$ Cf. John C. Persons, op. cit., p. 1392. 
Estas últimas seriam lex specialis com relação às situações ordinárias de administração da companhia, o que está em linha com o pensamento de que as ofertas públicas concorrentes são mecanismos mais eficientes de defesa contra uma oferta hostil, além de ser um procedimento mais controlado, regulado e transparente para o mercado e os acionistas. Por fim, a literatura aponta que ofertas públicas sob a modalidade de leilão holandês são as mais eficientes para deter uma oferta hostil.

\subsubsection{A Rule $13 e-1$ vs. Rule $13 e-4$}

Nos EUA, houve discussão bastante semelhante, refletida na positivação, pela SEC, de duas normas diferentes para regular, de um lado, as recompras de ações no decorrer de uma oferta pública hostil - o que foi feito pela edição da Rule 13e-1 - e, de outro, qualquer oferta pública de aquisição, inclusive aquelas realizadas pela companhia para adquirir suas ações, como mecanismo de defesa ou não - positivada pela Rule 13e-4. A diferença de regime entre uma e outra norma é significativa e suscitou bastante discussão na doutrina norte-americana. Antes de chegarmos a elas, uma breve introdução sobre a Section 13(e) do Exchange Act, sob a qual ambas foram promulgadas, faz-se desejável.

Em 1968, ocorreu a reforma da Section 13 do Exchange Act pelo Williams Act (cujo objetivo primário, no entanto, foi o de regular todas as tender offers, como veremos), pela inclusão do poder da SEC de normatizar as formas sob as quais as companhias poderiam recomprar suas ações no mercado, inclusive fomentando a ideia de que a SEC pudesse desenhar um regime destinado a "razoavelmente prevenir práticas abusivas" - o que foi feito por meio da inclusão da Section 13(e) no Exchange Act. O Congresso norteamericano tinha por intenção garantir que os acionistas de uma companhia, e outras pessoas interessadas no seu preço, tivessem acesso a informações completas sobre as atividades de recompra, bem como sobre seus propósitos ${ }^{473}$. Ainda assim, muitos se questionaram se essa inclusão seria realmente necessária, dada a expansão das investigações e condenações com fundamento na Section 10(b) e da Rule 10b-5 (promulgada com base nessa seção), que já garantiriam a base coercitiva necessária ${ }^{474}$.

\footnotetext{
${ }^{473}$ Cf. Michael Bradley e Michael Rosenzweig, op. cit., p. 1384.

${ }^{474}$ Cf. Mark R. Moskowitz, Corporate Stock Repurchases under the Securities Exchange Act of 1934, in Nebraska Law Review, Vol. 51, 1971, p. 196.
} 
Seja como for, a nova seção incluída no Exchange Act trouxe preceitos anti-fraude relacionados às compras e vendas de ações pela companhia a mercado ${ }^{475}$. Uma observação interessante sobre a inclusão dessa seção é a de que ela não é "auto-eficaz": não proíbe ou obriga que a companhia, desejosa de adquirir suas ações, faça ou se abstenha de fazer qualquer coisa. A norma do Exchange Act se apoia totalmente na competência regulatória atribuída à SEC, que ficou responsável por publicar as rules and regulations necessárias para controlar as recompras de ações pelas companhias de uma maneira condizente com a lógica anti-fraude dessa seção. E a competência normativa da SEC nesta situação era basicamente direcionada a dois pontos de atenção: (i) definir quais as situações que poderiam ser vistas como operações manipulativas ou fraudulentas, e (ii) definir regras prescritivas e criar um regime tendente a diminuir a probabilidade de ocorrência dessas manipulações e fraudes, dentre as quais o insider trading ${ }^{476}$.

A primeira regra publicada sob a Section 13(e), após a reforma de 1968, foi justamente a Rule 13e-1, que tem como objeto a imposição de controles (não a vedação, como ocorre no Brasil) à negociação pela companhia com suas ações quando estiver em andamento uma oferta pública, lançada por terceiros, de aquisição das mesmas. A regra, em essência, é de transparência; ela requer que a companhia divulgue aos acionistas e à SEC uma declaração (statement) informando: (i) o tipo e o volume de ações a serem adquiridas, os nomes das pessoas de quem serão adquiridas e o mercado por meio do qual ocorrerão as operações, (ii) o objetivo da recompra e os planos futuros do emissor com relação às ações assim adquiridas, e (iii) a fonte contábil e o valor total dos recursos a serem utilizados. O objetivo é deixar às claras para os acionistas que a companhia irá intervir no mercado das suas ações e possibilitar, com isso, que os acionistas possam tomar

\footnotetext{
475 "As initially proposed by the Senate, 13 (e) could have been construed as going beyond the prevention of fraud, thereby permitting the SEC to adopt rules 'necessary or appropriate in the public interest or for the protection of investors' which are not designed solely for the prevention of fraudulent, deceptive or manipulative practices. The House picked up this ambiguity in construction and revised the section so as to limit its scope to the prevention of fraud". Cf. Mark R. Moskowitz, Corporate..., cit., p. 246.

${ }^{476}$ Section 13(e)(1) do Exchange Act: "It shall be unlawful for an issuer which has a class of equity securities registered pursuant to section 12 of this title, or which is a closed-end investment company registered under the Investment Company Act of 1940, to purchase any equity security issued by it if such purchase is in contravention of such rules and regulations as the Commission, in the public interest or for the protection of investors, may adopt (A) to define acts and practices which are fraudulent, deceptive, or manipulative, and (B) to prescribe means reasonably designed to prevent such acts and practices. Such rules and regulations may require such issuer to provide holders of equity securities of such class with such information relating to the reasons for such purchase, the source of funds, the number of shares to be purchased, the price to be paid for such securities, the method of purchase, and such additional information, as the Commission deems necessary or appropriate in the public interest or for the protection of investors, or which the Commission deems to be material to a determination whether such security should be sold" grifos nossos.
} 
uma decisão informada sobre se aceitam ou rejeitam a oferta em andamento, ou, ainda, se nada fazem ou se aceitam vender à companhia os seus títulos.

Já as normas que regulam o procedimento e a transparência de ofertas públicas, incluindo aquelas defensivas e lançadas pela companhia emitente (defensive self-tender offers) são outras (algumas delas inclusive promulgadas sob esta mesma seção - mormente a Rule 13e-4), mais detalhadas, complexas e, indubitavelmente, mais custosas para a companhia. Alguns autores, inclusive, defendem que uma estrutura regulatória no modelo da brasileira é a mais correta: considerando o menor grau de transparência nas recompras a mercado, a efetiva proteção dos investidores estaria não na proibição de uso da recompra como tática de defesa, mas na obrigatoriedade de ser sempre feita por meio de uma oferta pública concorrente ${ }^{477}$. Assim é que o mesmo Williams Act, que modificou a Section 13 para outorgar à SEC a competência e o dever de regular as recompras de ações, introduziu a Section 14(d) no Exchange Act, regulando a forma e os procedimentos para a realização de qualquer oferta pública de aquisição de ações. No entanto, essa mesma seção excetua de seu âmbito de aplicação as ofertas públicas realizadas pela própria companhia (cf. Section 14(d)(8)(B)). A SEC deveria regular as self-tender offers não sob a seção 14(d), e sim sob a 13(e), que trata sobre quaisquer tipos e mecanismos de recompra de ações.

Em 1979, a SEC, fazendo uso de sua competência, publicou a Rule 13e-4, regulamentando as ofertas públicas lançadas pela companhia para adquirir suas ações, nos moldes das regras já existentes para as ofertas públicas lançadas por terceiros (interfirm bids). De forma geral, a norma positivada pela SEC impunha ao emissor que fosse realizar uma "issuer tender offer", como a norma a denomina, o dever de cumprir com três macrorequisitos: registre, divulgue e dissemine (file, disclose and disseminate). Sob o ponto de vista do registro, a companhia é obrigada a protocolizar junto à SEC uma vastidão de documentos, inclusive um Tender Offer Statement, incluindo todos os seus anexos. Além disso, deverá também divulgar uma série de informações aos seus acionistas, por meio de publicações em jornais (que podem, em certos casos, ser de circulação nacional). Existe uma miríade de outros procedimentos e formas de atuação que são exigidos da companhia, a depender de alguns fatores específicos da oferta (como, por exemplo, se ela consiste

\footnotetext{
${ }^{477}$ A falta de transparência nas operações de recompra a mercado como mecanismo de defesa, associada à análise de que os incentivos econômicos e as pressões de uma e outra forma de recompra são iguais, levou uma parte da doutrina a propagar que a única modalidade de recompra permitida em âmbito de defesa contra ofertas hostis fosse a self-tender offer, considerando o regime mais robusto de transparência aplicável a elas, sugerindo a vedação absoluta da possibilidade de recompras "defensivas" a mercado, exatamente como ocorre no Brasil. Cf. Michael Bradley e Michael Rosenzweig, op. cit., p. 1383 e, mais à frente, p. 1407.
} 
apenas na possibilidade de pagamento de dinheiro, ou se ela envolve permuta de valores mobiliários). Um importante artigo dessa norma é aquele que estipula o mecanismo de rateio entre os acionistas, caso mais acionistas tenham aceitado vender suas ações à companhia, do que aquele volume que ela estava disposta a adquirir (a norma tem por intuito permitir uma fair opportunity de participar na oferta). "Plainly, the rules governing self-tender offers are significantly more onerous than those that apply to defensive open market repurchases. While the latter transactions are subject only to disclosure obligations, self-tender offers must comply with a scheme, roughly comparable to regulation $14 D$, that includes rigorous substantive regulations, as well as disclosure obligations ${ }^{, 478}$.

\subsubsection{Algumas Conclusões}

As normas da CVM merecem algumas melhorias pontuais. $\mathrm{O}$ ideal seria, de lege ferenda, que ela imponha a criação dos programas de recompra não ao conselho de administração, como ocorre hoje (artigo $8^{\circ}$ da Instrução CVM 10), mas à assembleia geral, que deverá, então, definir preços máximos e mínimos e os objetivos da operação, podendo, inclusive, permitir o uso do programa como forma de defesa contra ofertas públicas de aquisição, eliminando a dicotomia de tratamento que hoje existe (já defendemos em outro capítulo, com vistas às discussões sobre tratamento não equitativo entre acionistas, a inserção da assembleia geral como principal órgão para a discussão e aprovação das recompras - o que, agora, se reforça ainda mais). Ora, se é a assembleia geral de acionistas que permitiu o uso do programa para a persecução desse objetivo específico, então o administrador estará apenas dando cumprimento a uma determinação dos acionistas ao utilizar o mecanismo, o que deveria ser entendido como plenamente possível. Na Alemanha, a doutrina tem o mesmo entendimento (desde que o objetivo seja expresso nesse sentido, não se admite qualquer interpretação extensiva), com a diferença de que, por lá, a assembleia já é, hoje, a legitimada para a criação e delimitação do âmbito de abrangência desses programas cf. §71, Abs. 1, S 8, da Aktiengesetz de $1965^{479}$. Existem, no entanto, discussões sobre se a assembleia geral poderia dar uma autorização genérica, anteriormente à oferta, para que a administração usasse mecanismos de defesa, ou se

\footnotetext{
${ }^{478}$ Cf. Michael Bradley e Michael Rosenzweig, op. cit., p. 1387.

${ }^{479}$ Cf. Alexander Kitanoff, op. cit., p. 176. Ressalte-se: a Segunda Diretiva cria, no ambiente comunitário, a regra de que é a assembleia que autorizará a criação dos programas de recompra. Tal autorização vigorará, após a alteração promovida pela Diretiva Alteradora, por 5 anos.
} 
apenas aprovações ad hoc seriam permitidas. Segundo Paul Davies e Klaus Hopt, existe a possibilidade de atuação da administração quando autorizada pelos acionistas, mesmo com a presença da "no frustration rule". No entanto, segundo esses autores: "it is clear in both the City Code and the [takeover] directive that shareholder approval means approval given during the offer period for the specific measures proposed and not a general authorization given in advance of any particular offer". Segundo eles, uma aprovação genérica da assembleia geral seria inapropriada (e potencialmente contestável), já que não daria oportunidade aos acionistas de deliberarem sobre as condições específicas oferecidas por algum proponente no caso concreto, reconhecendo que esse é um mecanismo permitido na Alemanha e também no Japão ${ }^{480}$. Concordamos com estes autores, essa autorização deveria ser permitida, mas deveria ser dada apenas $a d h^{481}$. Se fosse adotada a possibilidade de aprovação prévia pela assembleia geral (“aprovação branca”) poder-seia cogitar da imposição de uma série de requisitos específicos para tal, na linha do disposto pelo §33, Abs. 2 da Wertpapiererwerbs- und Übernahmegesetz da Alemanha, que impõe período máximo de aprovação de 18 meses e quórum qualificado e, ainda, aprovação do conselho de administração para que a diretoria possa agir em decorrência dessa autorização.

Indo mais além, o artigo 32-E, §2 , I, da Instrução CVM 361 estende à própria companhia objeto de uma oferta pública de aquisição de controle as obrigações impostas ao ofertante e às pessoas a ele ligadas (caput desse artigo) de, durante o período da oferta, comunicar ao mercado os negócios realizados, direta ou indiretamente, com valores mobiliários "da companhia objeto". Ou seja, a Instrução CVM 361 parece implicitamente admitir que a companhia pode negociar com ações de sua emissão mesmo no decorrer de uma oferta pública de aquisição de seu controle (em situação de recompra para manutenção em tesouraria, não como oferta concorrente), o que é vedado pela Instrução CVM 10. Quer-nos parecer que esse reconhecimento implícito reforça nosso argumento de que a Instrução CVM 10 deve ser alterada neste ponto, transferindo a autorização do

\footnotetext{
${ }^{480}$ In Control Transactions, cit., p. 234.

${ }^{481}$ Comentando a redação de uma proposta de norma comunitária de 1990, assim se manifestou Giuseppe Carcano sobre o tema: "Il testo della Proposta modificata del settembre 1990 (...) segna un più accentuate distacco dal principio di neutralità verso una presa di posizione a favore di chi lancia l'offerta: vengono limitate le potenzialità di azione degli amministratori attraverso la previsione che l'autorizzazione dell'assemblea debba essere concessa 'durante il periodo di accettazione'; qualsiasi autorizzazione anteriore dell'assemblea deve essere dalla stessa confermata e, a tale scopo, l'organo di amministrazione può convocare l'assemblea 'prima che termini il periodo di accetazione"”. Cf. Giuseppe Carcano, Acquisto di Azioni Proprie come Tecnica di Difesa dalle Scalate: la CEE Rafforza il Divieto, in Rivista delle Società, Vol. 37, n. ${ }^{\circ}$ 5/6, setembro-dezembro de 1992, p. 1312.
} 
programa, e seus limites, à assembleia geral e não ao conselho de administração. Com esta alteração, poderá ser conciliada a interpretação da Instrução CVM 361 com a Instrução CVM $10^{482}$.

Ainda nesta discussão sobre a relação entre as duas normas: o preço de aquisição de uma oferta concorrente deverá ser necessariamente superior ao de bolsa, por requisito expresso da Instrução CVM 361 (que impõe, no artigo 13, §3º, uma sobrevalia mínima de $5 \%$ sobre o valor da oferta original, que necessariamente já garantirá um prêmio sobre o valor de bolsa, por mera lógica econômica), ao contrário do requisito da Instrução CVM 10, que impõe a observância do valor de mercado. Ou seja, ainda que, em nossa visão, essa interpretação já seja a única possível, a regra do preço de aquisição das próprias ações deve ser expressamente excepcionada pela CVM para o caso de ofertas concorrentes, nos termos da Instrução CVM 361. De outra sorte, o limite de $10 \%$ e a obrigatoriedade de utilização de saldo de lucros e reservas, previstos pela Instrução CVM 10, devem ser aplicados para as ofertas públicas lançadas pela própria companhia nos termos da Instrução CVM 361, apesar de não ser um requisito claramente colocado por esta última norma. Por fim, é obrigatória a observância do requisito, comum a qualquer oferta de aquisição, de tratamento equânime entre os destinatários da oferta (artigo $4^{\circ}$, I e II, da Instrução CVM $361)$.

Em suma, nossa visão é a de que deveria ser permitido à companhia a utilização desse mecanismo de defesa, seja por meio das recompras a mercado, seja por meio do lançamento de uma oferta concorrente, desde que, em ambos os casos, a assembleia geral tenha aprovado essa modalidade de defesa ( $a d$ hoc) e que, no caso concreto, o conselho de administração dê um parecer acerca da conveniência da sua utilização.

\subsection{Manipulação de Mercado, Insider Trading e Transparência}

\subsubsection{A Doutrina da Imputação do Conhecimento: a Companhia como Insider de Si Mesma}

O ilícito de insider trading desenvolveu-se historicamente como uma forma de coibir a prática de negociação de ações por determinados agentes com base no conhecimento, por parte deles, de informações relevantes e não públicas sobre a

\footnotetext{
${ }^{482}$ Por outro lado, a manutenção da situação atual, que permite apenas as ofertas públicas concorrentes como forma de defesa, não é ruim, considerando os estudos que vimos e que realçam a eficiência das ofertas concorrentes como forma de defesa, quando comparadas com as recompras a mercado.
} 
companhia emissora, que pudessem afetar o preço ou a cotação dos papeis uma vez publicadas. A premissa básica que impõe a regulação do problema é a de que a decisão de compra e venda de valores mobiliários deve ser um processo racional, que permita ao investidor tomar uma decisão informada sobre o negócio, com base na análise de todas as informações relevantes e materiais sobre a companhia. Os requisitos de transparência são, portanto, uma forma preventiva de equalizar a disponibilidade de informações entre todos os participantes do mercado de capitais, diminuindo a assimetria de informações e fomentando a correta formação de preços; a disponibilidade uniforme (simultânea) da informação para todo o mercado decorre dessa lógica de formação de preços e de equidade de tratamento. Interferências neste processo tendem a ter efeitos nefastos, abalando a confiança do público no funcionamento do mercado de capitais e afetando a correta formação de preços.

A Section 10(b) do Exchange Act define como ilegal a utilização de qualquer estratagema ou mecanismo manipulativo com o intuito de fraude ${ }^{483}$, estabelecendo um amplo regime de responsabilidade das pessoas que agirem em desconformidade com esse princípio geral.

A SEC, agindo de acordo com o poder normativo a ela concedido por essa própria seção, complementou a regra com diversas Rules, sendo uma delas de particular interesse para o estudo das normas sobre insider trading: em 1942 publicou-se a famosa Rule 10b-5, que regula a utilização de mecanismos ou táticas fraudulentas em maior nível de detalhe. A Rule 10b-5 representa uma vedação genérica de utilização de qualquer mecanismo ardiloso, estratagemas e esquemas que tenham por intuito fraudar o público investidor e tem sido utilizada pela SEC e pelo Judiciário como base normativa para a condenação das mais diversas formas de "securities fraud", sendo uma delas o insider trading. No caso In re Cady, Roberts \& Co, de 1961, a SEC buscou definir melhor os conceitos aplicáveis à condenação por insider trading de acordo com a regra da Rule 10b-5. Versava o caso sobre os administradores de uma companhia aberta que compartilharam com seu corretor de ações (broker) a informação de que eles pretendiam reduzir seus dividendos em 40\%, o que levou esse intermediário a vender milhares de ações da companhia, antes que a informação se tornasse pública. A SEC considerou que o broker atuou em violação da

\footnotetext{
483 "To use or employ, in connection with the purchase or sale of any security registered on a national securities exchange or any security not so registered, or any securities based swap agreement any manipulative or deceptive device or contrivance in contravention of such rules and regulations as the Commission may prescribe as necessary or appropriate in the public interest or for the protection of investor".
} 
regra 10b-5, criando os contornos do princípio que ficou conhecido como divulgue ou abstenha-se de negociar (disclose or refrain from trading, também conhecido como CadyRoberts-rule): (i) a existência de uma relação que permita o acesso a informações ainda não divulgadas ao público, e (ii) a presença de uma injustiça inerente (inherent unfairness) da conduta.

Foram diversos os casos que desenvolveram e aprofundaram o princípio criado em In re Cady, Roberts \& Co., assim como os limites e a forma de atuação da SEC, e que não nos cabe mencionar em profundidade, bastando, neste momento, delinearmos esses elementos básicos, para podermos nos aprofundar na questão de como essa experiência influencia a discussão sobre as recompras das próprias ações: está, ou deveria estar, a companhia sujeita à mesma regra de transparência (disclosure) e vedação à negociação imposta a qualquer insider, quando ela tenha a intenção de adquirir suas próprias ações no mercado?

Segundo a reconstrução clássica da doutrina, também a companhia como tal é subordinada aos deveres de informação e transparência tradicionalmente impostos a terceiros considerados "insiders": "these underlying principles...apply...equally to corporations themselves when acting through their officers, directors or agents" Considera-se que, do ponto de vista dos investidores ou dos acionistas, não faz diferença alguma que alguém tenha vendido ou adquirido as ações de um insider terceiro, conhecedor de uma informação relevante e não pública, ou da própria companhia, conhecedora dessa mesma informação. A justificativa para submeter a companhia a esses mesmos deveres é a de que não faria sentido, em termos de política regulatória, impor todos os deveres e sanções aplicáveis ao insider trading às hipóteses em que, por exemplo, o administrador negocia os papeis com terceiros, e deixar de impô-los quando o administrador esteja presentando a própria companhia ${ }^{485}$ na concretização dos mesmos negócios jurídicos. "Ora, questa concezione [de igualdade de condições no mercado market egalitarism] non solo consente, ma exige che anche e, andrebbe detto, soprattutto la società emitente sia destinataria del dovere di disclose or abstain. Invero la società,

\footnotetext{
${ }^{484}$ Kohler v Kohler 319 F2d 638. Cf. Barbara Pozzo, op. cit., p. 424. "Although the Cady, Roberts decision did not itself deal with an issuer's transactions in its own shares, other recent cases make it unmistakably clear that a corporation will be subject to the same prescriptions". Cf. W. McNeil Kennedy, Transactions..., cit., p. 322.

485 "Whatever the present boundaries of the term "insider", it seems self-evident that the corporation itself should be considered to fall therein so as to subject the corporation to an affirmative duty of disclosure". Cf. Mark R. Moskowitz, Corporate..., cit., p. 198.
} 
quando entra, con le più varie motivazioni, sul mercato delle proprie azioni, deve obbedire alle medesime regole del gioco che valgono per qualsiasi altro operatore ${ }^{, 486}$.

Concordamos com o raciocínio de que as regras de insider trading devem aplicar-se igualmente às companhias que negociam suas próprias ações. Teoricamente, ao menos, é difícil de conceber alguém que represente melhor a definição de insider do que a própria companhia com relação às suas informações ${ }^{487}$. Ela é a "ultimate insider" 488 .

Um ponto interessante nesta conclusão é a discussão sobre a imputação de conhecimento da informação privilegiada: é a pessoa física do administrador que é o insider ou é a companhia? A questão deriva do fato de que o administrador age, na sua função de órgão da companhia, como se a própria companhia fosse: a teoria orgânica da sociedade impõe a conclusão de que ele não a representa por mandato, mas ele é a própria companhia na medida em que a administra. Em assim sendo, a pergunta inquietante é, na realidade, acerca da imputação do conhecimento da informação privilegiada: uma pessoa jurídica pode ser titular de informação privilegiada? E mais: ela pode conhecer qualquer tipo de informação?

A nosso ver, a única forma de conhecimento é pela pessoa humana que, de fato, detém a informação privilegiada e age com base na informação que possui para cometer o ilícito de insider trading. Se essa pessoa física, no caso, age presentando a companhia, ainda assim entendemos que o insider é o administrador, não a companhia que ele presenta. Tecnicamente, portanto, entende-se que a companhia, enquanto pessoa jurídica, não poderia ser considerada insider de si própria, mas, por ficção jurídica, o ordenamento pode equipará-la ao titular da informação, com o intuito de condená-la a reparações de natureza civil/administrativa por insider trading, em solidariedade com a pessoa física faltosa.

O questionamento que decorre desse reconhecimento, e da discussão sobre a imputação do conhecimento à companhia, é o seguinte: em que momento deve ser

\footnotetext{
${ }^{486}$ Cf. Francesco Carbonetti, Acquisto di Azioni Proprie e Insider Trading, cit., p. 1019.

${ }^{487}$ Cf. W. McNeil Kennedy, op. cit., p. 328. Sem razão, a nosso entender, Franzo Grande Stevens, para quem a pessoa física que produzir uma informação ("il padre de la notizia") no exercício de uma função: "la può sfruttare nell'interesse della persona - fisica o giuridica - per la quale ha svolto la sua funzione o l'attività professionale ma non per sè ". A seguir-se essa lógica, o administrador da companhia estaria proibido de negociar, em seu próprio nome, com informação privilegiada de que tenha conhecimento em virtude de seu cargo, podendo fazê-lo, no entanto, como presentante da companhia. Essa conclusão é insustentável do ponto de vista dos interesses tutelados pelas normas repressoras do insider trading. Cf. Franzo Grande Stevens, Questioni in Tema di Insider Trading e di Compravendita di Azioni Proprie, in Rivista delle Società, Vol. 36, $\mathrm{n}^{\circ} .4,1991, \mathrm{p} .1008$.

${ }^{488}$ Conforme citação de Goldberg, feita por Carbonetti. Cf. Francesco Carbonetti, Acquisto di Azioni Proprie e Insider Trading, in Rivista delle Società, Vol. 34, n. ${ }^{\circ}$ 5, setembro-outubro de 1989, p. 1011.
} 
considerada possível a imputação (por ficção) do conhecimento sobre uma determinada informação à companhia? Por exemplo, se considerarmos um caso no qual os administradores tenham, eles próprios, acesso a alguma informação considerada material e relevante, então a imputação do conhecimento à companhia deve ser mais fácil, já que essas pessoas são órgãos da companhia, membros de sua administração. Mas existirão situações onde será mais difícil a alegação de conhecimento da informação pela companhia. Damos um exemplo: um químico, funcionário de uma companhia que desenvolve produtos de limpeza, desenvolve uma nova fórmula que revolucionará a forma de produção da companhia, mas que ainda está sujeita a novos testes. Se assumirmos que essa informação seja relevante e material, poderia ela ser imputada, desde logo, à companhia? Em essência, se levarmos o argumento ao extremo, qualquer mínimo ato ocorrido dentro da atividade desenvolvida pela companhia deve ser atribuído a ela: sua atividade é necessariamente de seu conhecimento. Isso, obviamente, não tem como ser aplicado na prática. Sabe-se que, dependendo da dimensão da companhia e de suas atividades, é possível que determinadas informações não cheguem ao conhecimento de seus órgãos oficiais, mas fiquem perdidas nos tecidos, veias e células que compõem o restante do corpo social.

Uma das saídas para esse dilema seria afirmar que a informação não poderia ser imputada à companhia caso nenhum membro de seus órgãos de administração tenha tido acesso ou conhecimento a ela. O problema deste pensamento, a nosso entender, é que ele privilegia a quebra de comunição intrassocietária, de forma a que possa ser utilizada a defesa do desconhecimento pela administração. Além disso, restaria sempre uma discussão sobre a hierarquia da pessoa que efetivamente tinha conhecimento da informação e algumas situações um tanto complexas de responder: por exemplo, a informação chegou ao superintendente de pesquisa e desenvolvimento, que não é membro da administração estatutária da companhia - haveria conhecimento da informação por ela? $\mathrm{Ou}$, assumindo que ele fosse administrador estatutário, mas que não fosse membro do comitê executivo, haveria aqui imputação do conhecimento? E se ele participasse de todos os comitês e fosse membro da administração, mas tivesse se abstido de comparecer em uma determinada reunião e, com isso, não tivesse compartilhado a informação relevante com os demais: o que ocorreria caso uma recompra fosse efetuada pela companhia nesse interim? Admitidamente, não há uma resposta óbvia para essas perguntas, remanescendo a teoria da imputação do conhecimento com contornos bastante turvos. 
Nos EUA, a tese que parece ter sido adotada em larga escala é aquela segundo a qual uma informação pode ser imputada à companhia quando um seu "agent", em qualquer nível, tiver recebido uma informação material relevante e que, devido à sua posição hierárquica na companhia, seria razoavelmente esperado dele que transmitisse a informação por meio dos canais internos de comunicação. De acordo com Mark R. Moskowitz: “[u]nder this standard an agent's knowledge of material information will be attributed to the corporation when the agent, in light of his position in the corporation, would be expected to pass the information up through the channels of intracorporate communication or when he is apprised of the repurchase transaction which is 'materially affected' by such information through the intervention of the federal securities laws $" 489$. Esta teoria tem o problema de imputar conhecimento de uma informação à companhia, mesmo que seus órgãos não tenham tido acesso a ela, o que, de certa forma, significa reconhecer que a pessoa jurídica tem capacidade de conhecimento distinta da capacidade de retenção de informações das pessoas humanas que compõe seus órgãos.

Ainda mais complexa se torna a resolução do problema quando pensamos em grandes companhias, cujo objeto seja justamente o de participar na compra e venda de valores mobiliários, ou, ainda, quando imaginamos a configuração real das grandes companhias, nas quais é virtualmente impossível que a diretoria possa efetivamente estar presente em todas as declarações de vontade da pessoa jurídica. Em uma instituição financeira ${ }^{490}$, por exemplo, sabe-se que não são os administradores que ordenam as compras e vendas dos valores mobiliários, mas sua tesouraria, composta de diversos empregados com o mandato funcional de comprar e vender os valores mobiliários em nome da pessoa jurídica para a qual trabalham, com o intuito de lucro. Nesta configuração, se esse operador tiver autonomia para comprar e vender as ações da própria instituição financeira (companhia aberta) para a qual trabalha, não seria razoável acusar a companhia de insider trading caso os altos membros da administração estejam discutindo informação material e não pública no comitê executivo, enquanto o operador, ignorando a existência da informação, esteja comprando e vendendo os papeis da companhia na mesa de operações.

A nosso entender, a melhor teoria sobre o assunto é a que imputará o insider trading à companhia caso: (i) as pessoas físicas que tenham dado a ordem de compra ou venda, em seu nome, independentemente de sua hierarquia interna, sejam elas

\footnotetext{
${ }^{489}$ Cf. Mark R. Moskowitz, op. cit., p. 206.

${ }^{490} \mathrm{O}$ mesmo raciocínio vale para qualquer companhia com estrutura semelhante.
} 
próprias insiders (titulares de informação privilegiada), ou (ii) qualquer membro da administração da companhia tenha acesso a alguma informação material e não pública e tenha sido negligente em orientar a cessação da conclusão de transações pelas pessoas que efetivamente negociam os papeis, até que seja tornada pública a informação.

Esta posição é compatível com o fato de que a companhia, por si própria, não tem capacidade de conhecimento de informação alguma, apenas as pessoas que trabalham para ela ou compõem seus órgãos funcionais. Por outro lado, também evita a circunscrição do problema ao âmbito da administração orgânica, estendendo a teoria para quaisquer pessoas que ajam em nome da companhia, enquanto em posse de informação privilegiada. É claro que, no caso concreto, se houver indícios de que a administração da companhia não foi diligente em informar aos operadores da tesouraria (ou a quem quer que seja o responsável por negociar as ações da companhia) sobre a existência de uma informação privilegiada (e, portanto, da vedação à negociação), então poder-se-á estar diante de um caso de insider trading por falta de procedimentos prudentes de comunicação da informação. Dificilmente será possível basear uma defesa da companhia na fórmula da chinese wall, pois isso seria admitir que a administração da companhia esteja separada funcionalmente da atividade que ela desempenha e/ou de sua tesouraria, o que é um contrassenso.

Se, todavia, tanto a pessoa responsável pelos negócios, quanto a administração da companhia, desconhecessem alguma informação material específica, deveria a companhia poder continuar a negociar os seus papeis, sob o argumento de que nem a administração orgânica, nem a pessoa específica, operaram com base em informação material e de desconhecimento da outra parte ${ }^{491}$. O caso concreto ditará os detalhes da imputação da responsabilidade, não há como pensarmos em fórmulas estanques e predefinidas.

A Lei das S.A. já regulava o insider trading, de forma bastante acurada, desde 1976, prevendo o dever de informar da administração da companhia no art. 157, que dispõe sobre a obrigação de os membros da administração declararem a sua própria titularidade de ações da companhia. $\mathrm{O} \S 4^{\circ}$ desse mesmo artigo prescreve, em adição, a obrigação dos administradores da companhia de comunicarem, imediatamente, e de

\footnotetext{
491 "It may be, for example, that the board has not yet been informed of a startling discovery just made by the company's research department. In cases where the board is unappraised of such information, it should be able to authorize the purchase of corporate shares without violating Rule l0b-5. For in this situation, the board, who is acting for the corporation, is not utilizing information unavailable to the selling shareholders. A stricter standard would not only be impractical but would be unreasonable in light of the design of Rule lob-5 which is to prohibit a party from trading in securities on the basis of inside information unavailable to the other party" - grifos nossos. Cf. W. McNeil Kennedy, op. cit., p. 328.
} 
divulgarem pela imprensa qualquer deliberação da assembleia geral ou dos órgãos de administração da companhia, ou, ainda, a ocorrência de um fato relevante nos seus negócios, “que possa influir, de modo ponderável, na decisão dos investidores do mercado de vender ou comprar valores mobiliários emitidos pela companhia”. Complementa essa norma aquela estabelecida no art. $155, \S 1^{\circ}$, da Lei das S.A. que, ao regular o dever de lealdade, impõe ao administrador o dever de manter sigilo sobre qualquer informação que ainda não tenha sido divulgada ao mercado, obtida em razão de seu cargo e capaz de influir de modo ponderável na cotação de valores mobiliários, sendo-lhe vedado valer-se da informação para obter, para si ou para outrem, vantagem, por meio da compra ou da venda de valores mobiliários.

A Lei das S.A., note-se, concentrava-se originalmente nos negócios realizados apenas pelos administradores da companhia. Em 2001, foi incluído o $\S^{\circ}$ no art. 155 da Lei das S.A., que ampliou a vedação "a qualquer pessoa" que à informação tenha tido acesso o intuito não nos parece ter sido, no entanto, o de incluir a companhia neste conceito de "qualquer pessoa" 492 .

A Instrução CVM 358, que é a norma administrativa básica sobre insider trading, dispõe sobre a obrigação de a companhia aberta divulgar ao mercado, imediatamente depois de ocorridos, "atos ou fatos relevantes" acerca dos seus negócios, assim definidos como aqueles que possam influir de modo ponderável: (i) na cotação dos valores mobiliários de sua emissão ou a eles referenciados, (ii) na decisão dos investidores de comprar, vender ou manter aqueles valores mobiliários, e/ou (iii) na decisão dos investidores de exercer quaisquer direitos inerentes à condição de titular de valores mobiliários emitidos pela companhia ou a eles referenciados (art. $2^{\circ}$ da Instrução CVM 358). O parágrafo único desse mesmo artigo lista uma série de exemplos. Já o artigo $3^{\circ}$ da norma determina que cumpre ao Diretor de Relações com Investidores zelar pela ampla e imediata disseminação dessa informação, simultaneamente em todos os mercados onde os valores mobiliários sejam negociados. $\mathrm{O}$ artigo 13 dessa norma, por sua vez, acolhe a regra administrativa que veda a negociação com as ações da companhia, inclusive e expressamente pela própria companhia aberta, na pendência de divulgação de tal ato ou fato relevante. A CVM, portanto, ampliou a abrangência da vedação aos negócios com base em informação privilegiada para além dos administradores e demais "terceiros",

\footnotetext{
${ }^{492}$ Segundo Eizirik: "deve haver um nexo profissional entre o vazamento de informações e os terceiros, para que possam ser enquadrados na norma”. Cf. Nelson Eizirik et al., op. cit., p. 540. Devendo haver um nexo profissional entre o terceiro e a companhia, não podemos facilmente enquadrar ela própria no preceito.
} 
abarcando a própria companhia emissora - reconhecendo, indubitavelmente, que ela pode ser considerada insider de si mesma.

Nossa conclusão, à vista de tudo o quanto exposto nos últimos parágrafos, é a de que a teoria da "dupla via de imputação do conhecimento", conforme a delineamos, é plenamente compatível com o ordenamento jurídico brasileiro.

Com relação ao canal de conhecimento oriundo da administração, o mencionado art. $155, \S 1^{\circ}$, da Lei das S.A. decididamente nos fornece o embasamento jurídico necessário à defesa da tese de que a sociedade seria considerada como conhecedora da informação privilegiada, caso algum membro de sua administração estivesse de posse dela, mas fosse negligente em orientar a cessação da negociação pelos departamentos responsáveis: este dever de comunicação/orientação decorre, pensamos, do dever de lealdade estabelecido nesse dispositivo, que proíbe a negociação, pelos administradores, com ações da companhia, antes de divulgada a informação privilegiada, para si ou para outrem. Este dever, por sua vez, deve ser estendido, por analogia, às negociações da própria pessoa jurídica que eles presentam, na pendência da publicação da informação $^{493}$.

Já quanto à via de conhecimento oriunda das pessoas que ordenam as compras e vendas em nome da sociedade (independentemente do seu grau de hierarquia interna), a conclusão não poderia ser outra, eis que elas efetivamente estão agindo em nome da pessoa jurídica, seja por mandato civil, seja por mandato intrínseco ao vínculo trabalhista e objeto de seu trabalho: negar a imputação do conhecimento à companhia neste caso, em que o seu agente é titular da informação, seria negar que ele tenha atuado em nome da companhia, com o que não podemos concordar - a companhia deve ficar obrigada pelos atos de seus representantes legais.

Em ambos os casos de imputação (sem prejuízo de eventual imputabilidade penal que recaia sobre as pessoas físicas), entendemos que, tanto a pessoa física - administrador ou não -, quanto a companhia emissora das ações podem ser responsabilizados no âmbito civil e administrativo pelo ilícito de insider trading.

Quanto à repressão penal, criminaliza o art. 27-D da Lei 6.385/76 o uso indevido de informação privilegiada por parte de qualquer pessoa que dela "deva manter sigilo". Pela

\footnotetext{
493 “Art. 155. (...) $\S 1^{\circ}$ Cumpre, ademais, ao administrador de companhia aberta, guardar sigilo sobre qualquer informação que ainda não tenha sido divulgada para conhecimento do mercado, obtida em razão do cargo e capaz de influir de modo ponderável na cotação de valores mobiliários, sendo-lhe vedado valer-se da informação para obter, para si ou para outrem, vantagem mediante compra ou venda de valores mobiliários.". A própria companhia, não descuidamos, é um "terceiro" bastante especial neste contexto, mas parece-nos plenamente justificável a sua inclusão na expressão “para outrem”.
} 
leitura do dispositivo, conclui-se que este é crime próprio, cujo sujeito ativo são apenas as pessoas que tenham dever legal ou contratual de manter sigilo sobre as informações confidenciais, relevantes e não públicas, recebidas em função do exercício de tal cargo ou contrato. Por ser crime próprio, as pessoas que tenham agido na qualidade de administradores da companhia, e, portanto, presentantes da pessoa jurídica, podem ser abrangidos pelo tipo do art. 27-D da Lei 6.385/76, ainda que não tenham agido, juridicamente, em nome próprio? Parece-nos que a imputabilidade penal dos administradores está mantida, mesmo no caso em que eles negociam as ações como presentantes da companhia, e não em nome próprio, pois eles poderão estar objetivando vantagem "para outrem" - a companhia que presentam -, conduta que também é tipificada como crime no mencionado artigo ${ }^{494}$. Quanto aos demais insiders internos que agem em nome da companhia (ex.: funcionários da tesouraria), que não os administradores, entendemos que também poderão ser incriminados pelo tipo em comento, pois também têm o dever de manter sigilo, ainda que não decorrente da Lei das S.A., mas certamente decorrente de sua função na companhia e potencialmente das suas normas internas de confidencialidade ${ }^{495}$.

Retomando um pensamento que já se expôs em outro momento deste estudo, mas que vale, aqui, ser repetido em função de sua pertinência temática: a companhia, com frequência, se verá na difícil posição de avaliar se uma determinada informação que a sua administração possua (assumindo que tal informação possa efetivamente ser imputada à companhia) deve ou não ser divulgada como ato ou fato relevante ou se, por outro lado, a companhia pode usá-la para sinalizar ao mercado uma falha de precificação das suas ações. Conforme menciona W. McNeil Kennedy: "From the corporation's standpoint, moreover, the disclosure requirement is even more onerous to satisfy because theoretically the corporation is acquainted with essentially all the information concerning itself and because it is in no position, because of competitive reasons, to disclose a substantial portion of this information" - grifos nossos. No limite, a discussão aqui é a mesma que se

\footnotetext{
${ }^{494}$ Adicionalmente, ressalte-se que o crime ocorrerá apenas para o administrador que efetivamente utilizou-se da informação privilegiada ao presentar a companhia no negócio. Os demais, mesmo que tenham participado de algum fórum colegiado no qual a estratégia de aquisição tenha sido traçada, não poderão ser acusados do crime, pois não "agiram”, seja em nome próprio, seja em nome da sociedade. De forma contrária, entendendo que a natureza colegial da decisão não seria incompatível com o regime criminal, assim se manifestou Carbonetti: "pertanto, la natura collegiale delle decisioni societarie in materia di acquisto e vendita di azioni proprie e la circonstanza che le decisioni stesse siano solitamente eseguite da persone estranee al consiglio di amministrazione non sembrano a me elementi incompatibili con l'applicazione della disciplina dell'insider trading". Cf. Francesco Carbonetti, Acquisto di Azioni Proprie e Insider Trading, cit., p. 1015.

${ }^{495}$ As mesmas considerações cabem com relação ao crime de manipulação de mercado do art. 27-C.
} 
trava quando se está diante da difícil tarefa de identificar, entre a imensidão de informações não públicas da companhia, aquelas que são “privilegiadas". Essa informação, para ser relevante e digna de divulgação, deve ser, no entanto, minimamente concreta e de caráter razoavelmente preciso, apresentando um mínimo de materialidade e consistência, para que possa ser considerada relevante e capaz de alterar significativamente a cotação das ações. Genericamente, informações cuja perspectiva de materialização seja de longo prazo ou, ainda, informações esparsas sobre a atividade da companhia que, tomadas em conjunto, possam ter impactos positivos nos resultados da companhia em algum momento futuro já previsível, mas que ainda não passem em uma avaliação de probabilidade/materialidade, poderiam não ser divulgadas como fatos relevantes, apenas sinalizadas ao mercado por meio de recompras.

Reconhecemos que a linha de distinção entre as situações em que uma informação poderá ser base para a teoria da sinalização e em que ela será base para o insider trading é bastante tênue - os fatores envolvidos em cada caso concreto são de tal maneira variados e diversos que a aplicação de uma fórmula predeterminada é praticamente impossível. Na dúvida sobre a materialidade da informação, o ideal é abster-se de negociar.

As breves linhas expostas neste item têm a limitada função de sublinhar como uma matéria per se já complexa, como é a disciplina do insider trading, pode apresentar aspectos de delicadeza e incerteza adicionais, quando confrontada com a dos negócios com as próprias ações.

\subsubsection{Recompras e Manipulação de Mercado}

Demais disso, outro terreno de incertezas no âmbito do mercado de capitais, atinente às recompras, é aquele da manipulação de mercado. Em que medida a companhia poderia ser acusada de ter praticado atos manipulativos (como se os definirá) por meio de suas recompras de ações?

Se o mercado de capitais está em seu funcionamento ideal, então o preço de mercado das ações de uma companhia será dado pela intersecção entre as curvas da oferta e da demanda que, por sua vez e de acordo com a tese da ECMH, refletirão as informações disponíveis sobre a companhia. As compras e vendas da ação, é óbvio, influenciam o seu preço, na medida em que são indicadores de oferta e demanda por ela. Um aumento no volume das ordens de compra, refletindo um aumento de demanda, se não for acompanhado de um aumento de igual porte nas ordens de venda, tende a aumentar o preço 
da ação, independentemente de quem seja o adquirente - se um terceiro ou a própria companhia. As recompras de ações podem ter, por conseguinte, um impacto significativo na formação de preços e das curvas de oferta e demanda, o que certamente trará consequências negativas para o mercado de capitais, encarado amplamente, desde o surgimento da teoria econômica clássica, como uma força autônoma.

Nos EUA, a vedação a práticas abusivas e tendentes a falsear ou manipular os preços dos valores mobiliários no mercado vem contida na Section 9(a)(2) do Exchange Act, que coíbe qualquer conduta que tenha por objetivo criar uma situação de liquidez, aparente ou real, sobre um valor mobiliário, ou, ainda, aumentar ou reduzir o seu preço, com o intuito (purpose) de induzir alguém a comprá-lo ou vendê-1o ${ }^{496}$. A Section 9(f) desse mesmo diploma estabelece uma obrigação de reparar o dano sofrido por qualquer pessoa em decorrência de atos em violação desses princípios anti-manipulativos.

Em que medida a utilização do instituto da recompra pelas companhias pode ser considerada uma forma de manipulação do preço das ações, tendo em vista o inegável fato de que é justamente na interferência nos preços das ações que o mecanismo ganha em utilidade?

Como se afirmou, a manutenção de cotações altas das ações de uma companhia tem benefícios diversificados, tanto para a própria pessoa jurídica emitente dessas ações, quanto para os seus administradores e funcionários. Logo, considerando o potencial efeito das recompras no preço, a companhia pode ver-se tentada a recomprar as ações de sua emissão com o intuito de induzir um aumento artificial no seu preço, favorecendo-a. Em tal situação, há uma chance concreta de essas operações serem consideradas ilegais, por falsearem o mecanismo da formação de preço da ação - e, com isso, "manipularem" os preços dos papeis -, bem como por criarem condições artificiais de demanda e/ou de oferta (a recompra de ações aumenta a demanda e, concomitantemente, diminui a oferta: o impacto no preço ocorre em ambas as pontas).

Não nos parece razoável supor que a mera existência de um aumento no valor das ações em decorrência da recompra possa ser subsumida ao ilícito de manipulação de preços, pois, caso assim se entendesse, tais recompras deveriam ser proibidas por completo: em alguma medida a interferência da companhia no mercado de suas próprias

\footnotetext{
496 "To effect, alone or with 1 or more other persons, a series of transactions in any security registered on a national securities exchange, any security not so registered, or in connection with any security-based swap or security-based swap agreement with respect to such security creating actual or apparent active trading in such security, or raising or depressing the price of such security, for the purpose of inducing the purchase or sale of such security by others".
} 
ações influenciará a cotação dos seus papeis, isso é inevitável. Nos EUA, portanto, a discussão caminhou para o entendimento de que não basta que o preço do papel tenha aumentado ou diminuído por força das recompras: o intuito específico das operações deve necessariamente ser o de induzir alguém a negociar os papeis, algo que depende de extensa dilação probatória em cada caso concreto ${ }^{497}$.

No Brasil, a Lei 6.385/76 contém previsão (art. $4^{\circ}, \mathrm{V}$ ) outorgando competência ao CMN e à CVM para exercerem suas atribuições com a finalidade de evitar ou coibir modalidades de fraude ou manipulação "destinadas a criar condições artificiais de demanda, oferta ou preço dos valores mobiliários negociados no mercado". A Instrução CVM 8, editada justamente como forma de regulamentar esse artigo, estabelece uma série de ilícitos administrativos, todos eles conjugados em uma única redação, preceituando que "é vedada aos administradores e acionistas de companhias abertas, aos intermediários e aos demais participantes do mercado de valores mobiliários, a criação de condições artificiais de demanda, oferta ou preço de valores mobiliários, a manipulação de preço, a realização de operações fraudulentas e o uso de práticas não equitativas". São previstos nessa redação, portanto, quatro ilícitos administrativos diferentes, sendo eles: (i) a criação de condições artificiais de demanda, oferta ou preço de valores mobiliários, (ii) a manipulação de preço, (iii) a realização de operações fraudulentas e (iv) o uso de práticas não equitativas. Apesar de a instrução aparentemente não mencionar a própria companhia como sujeito passivo da obrigação, a expressão "demais participantes do mercado de valores mobiliários", contida no texto, certamente deve ser interpretada como a tendo incluído. A norma ainda define e conceitua cada um desses elementos distintamente; especialmente, no que nos interessa neste item, distingue-se a "criação de condições artificiais de demanda, oferta ou preço" da definição de "manipulação de preço", o que se justifica, em certa medida, pelo fato de que pode ocorrer a criação de oferta e demanda de maneira uniforme nas duas pontas da curva, fazendo com que a cotação dos valores mobiliários não seja influenciada, apenas sua liquidez. Esta seria uma situação não abrangida pelo conceito de "manipulação de preço", apenas pelo de "criação artificial de oferta e demanda" - a única coisa que não se justifica é a existência, no texto da regra, da expressão "condições artificiais de preço", pois necessariamente esse elemento está

497 "The key to illegality under 9 (a) (2) is the requirement of purpose (...) The purpose requirement of 9 (a) (2) should not be satisfied unless the prohibited end, inducing others to trade, is the primary objective to which the activity is directed" - grifos nossos. Cf. Mark R. Moskowitz, op. cit., p. 227. 
inscrito no conceito de "manipulação" (criar artificialmente preços é sinônimo de manipulá-los).

Em nossa opinião, alterações artificiais na corrente de demanda e oferta e as manipulações de preço devem ser encaradas sob o gênero de "operações fraudulentas", podendo ser reunidas, para fins didáticos, no conceito de condutas manipulativas de mercado. Essa interpretação teve acolhida com a reforma do mercado de capitais de 2001, uma vez que o tipo penal do artigo $27-\mathrm{C}$ da Lei $6.385 / 76$ possui o nomen iuris justamente de "manipulação de mercado", descrevendo em seu texto a vedação a "manobras fraudulentas" que tenham por finalidade alterar artificialmente o funcionamento dos mercados e o fluxo regular de formação de preços (neste conceito incluiríamos as alterações nas curvas de demanda e oferta e, também, a manipulação de preço em si) - o único tipo administrativo previsto na Instrução CVM 8 que não foi unificado neste dispositivo é o do tratamento não equitativo.

A grande questão que se coloca é a de como diferenciar as compras e vendas feitas pela companhia com um objetivo legítimo (mesmo que especulativo ${ }^{498}$ ) daquelas que possuem objetivos manipulativos. Por exemplo, a teoria da sinalização estabelece que a companhia possa intervir no mercado para corrigir uma distorção no preço das suas ações: isso não configuraria, a rigor, uma alteração das condições da oferta, da demanda e do preço da ação, vedadas nos termos da Instrução CVM 8? Ainda que se entenda que qualquer das proibições dessa instrução estão condicionadas à configuração do propósito de induzir terceiros a negociar (para a manipulação de preços esse requisito é expresso, mas não para os demais ilícitos), a “indicação” de subvalorização já não seria, por si só, uma indução à negociação?

Na definição de manipulação de preço, a Instrução CVM 8, seguindo o exemplo dos EUA, impõe uma condicionante de propósito, ao defini-la como "a utilização de qualquer processo ou artifício destinado, direta ou indiretamente, a elevar, manter ou baixar a cotação de um valor mobiliário, induzindo, [sic] terceiros à sua compra e venda". A mesma condicionante não existe na definição do ilícito estipulado no inciso II, "a" dessa norma: "II - Para os efeitos desta Instrução conceitua-se como: a) condições

\footnotetext{
${ }^{498}$ Especulação com ações próprias não pode ser confudida com manipulação de mercado. Na especulação, a companhia que está recomprando seus papeis acredita que está fazendo um bom negócio, seja porque está enviando um sinal ao público, seja porque acredita que as ações irão subir no futuro e que ela poderá, então, aliená-las e lucrar com a diferença. Mas pode ocorrer que essa previsão não se materialize e ela sofra perdas. $\mathrm{Na}$ manipulação e na fraude (como o insider trading), "o manipulador objetiva eliminar os riscos da operação, transformando em certeza a esperança de obter lucros; para tanto, modifica as regras de funcionamento do mercado e da formação de preços, enganando os investidores, que desconhecem o caráter artificial das cotações dos títulos". Cf. Nelson Eizirik et al., op. cit., p. 522.
} 
artificiais de demanda, oferta ou preço de valores mobiliários aquelas criadas em decorrência de negociações pelas quais seus participantes ou intermediários, por ação ou omissão dolosa provocarem, direta ou indiretamente, alterações no fluxo de ordens de compra ou venda de valores mobiliários". Nestes dois ilícitos administrativos, contudo, o bem tutelado é o mesmo, a regularidade e transparência do mercado de capitais, assegurando que o processo de formação de preços seja regido de forma independente pelas forças da oferta e da demanda. Por conseguinte, ambos os ilícitos administrativos devem possuir um elemento doloso específico, ou, dito de outra maneira, as intervenções no mercado devem ter por objetivo, como intenção primordial (elemento volitivo ou elemento subjetivo especial), a formação de preços artificiais ou de condições de liquidez artificiais para induzir alguém a operar no mercado com base nessas falsas situações (resultado). Não basta, frise-se, que haja um aumento ou baixa da cotação de uma ação, ou que haja um repentino aumento de liquidez por conta da atuação da companhia - o que pode ocorrer (e muitas vezes efetivamente ocorre) com a realização de algumas operações com lotes significativos de ações (block trades) que causam um "impacto no mercado". Nestas hipóteses, não há que se falar em manipulação, devido à ausência da intenção específica de induzir alguém a erro.

Por fim, cumpre dizer que ambos os ilícitos administrativos aqui mencionados são de mera conduta ${ }^{499}$, não cabendo indagação sobre a efetiva existência de prejuízos ou danos para terceiros, ou de lucro para a pessoa que agiu, devendo apenas ser demonstrado o nexo causal entre a conduta e o resultado.

Buscando atacar esses inquietantes pontos, o exame das leis comparadas aponta para duas formas de lidar com eles, uma direcionada aos casos de manipulação - por meio da adoção do conceito de presunções de legalidade - e outra aos de insider trading - por meio da adoção de planos de negociação pré-aprovados.

No primeiro caso, o regulador estabelece um quadro regulatório determinando condições sob as quais será presumida a ausência de manipulação de mercado: volumes e preços máximos, momento de conclusão do negócio, frequência e intermediários permitidos. No segundo, ele determina as condições (que podem não ser as mesmas definidas para as hipóteses de manipulação) sob as quais será presumida a ausência de uso

\footnotetext{
${ }^{499}$ A observação vale também para o tipo penal do art. 27-C da Lei 6.385/76. Cf. Arnaldo Malheiros Filho, Crime de Manipulação do Mercado de Capitais, in Marcelo Vieira von Adamek (coord.), Temas de Direito Societário e Empresarial Contemporâneos, Malheiros, São Paulo, 2011, p. 893, reconhecendo, no entanto, que essa conclusão é relevante mais no "mármore da mesa de dissecção em laboratório hermenêutico" do que na vida real, pois a prova da mera conduta seria praticamente impossível.
} 
de informação privilegiada: mormente por meio da criação de planos (ou políticas) de negociação ou recompra, previamente aprovados, tornados públicos e sujeitos a diversos níveis de escrutínio. São duas normas distintas, que podem coexistir em relação a uma mesma companhia, como ocorre nos EUA. O Brasil, atualmente, dispõe apenas da política de negociação, como se verá.

\subsubsection{EUA: Porto Seguro para Recompras sob a Visão da Manipulação de Mercado}

Havendo estabelecido que as regras de manipulação de mercado se aplicam à companhia emissora das ações, passou a ser preocupação do legislador norte-americano o estabelecimento de regras de conduta e de transparência que garantissem aos investidores acesso a informações completas e fidedignas sobre a atividade de recompra das companhias. Desde 1968, com a reforma da Section 13(e) do Exchange Act pelo Williams Act, a atenção do Congresso norte-americano com as recompras de ações tornou-se mais marcante, como já tivemos oportunidade de mencionar, sendo que a SEC, usando da competência a ela outorgada por essa seção, desde logo desejou fazer uso de tal poder regulatório. Foi assim que, em 1970, foi proposta a Rule 13e-2, que por alguns anos regulou o assunto nos EUA, estabelecendo alguns critérios prescritivos obrigatórios e limites quantitativos, além de um regime de transparência ${ }^{500}$.

Em 1982, no entanto, a SEC, obtemperando que os programas de recompra eram utilizados em sua maior parte para fins legítimos, abandonou a ideia de regulá-los minuciosamente, tendo a autarquia norte-americana se dedicado, então, a elaborar um regime claro e unívoco, dentro do qual as recompras das próprias ações poderiam ser efetuadas com a presunção (relativa) de não violação das regras anti-manipulação (Section 9(a)(2)) e anti-fraude (Section 10(b)) do Exchange Act: promulgou-se a Rule 10b-18 (vigente até hoje). As regras da Rule 10b-18 têm por finalidade orientar os administradores da companhia e, assim, assegurar que as operações de recompra por eles conduzidas, dentro das margens sugeridas pela SEC, não serão, prima facie, consideradas manipulativas ou fraudulentas. Em particular, a Rule 10b-18 possui quatro critérios concernentes a alguns elementos das auto-aquisições (e que devem ser observados

\footnotetext{
${ }^{500}$ Cf. Securities and Exchange Commission 17 CFR Part 240 [Release No. 34-61414; File No. S7-04-10], p.
} 2. 
diariamente): (i) maneira de aquisição (manner of purchase), (ii) momento (timing), (iii) preço (price), e (iv) volume (volume) ${ }^{501}$.

Em outras palavras, um emissor não será suspeito de violação das normas antimanipulação e anti-fraude das seções relevantes do Exchange Act em consideração, exclusivamente, a esses quatro critérios - desde que eles atendam, obviamente, aos parâmetros da Rule 10b-18. É interessante notar alguns detalhes da norma, que a tornam bastante peculiar e criativa: (i) suas regras de conduta não são prescritivas, de forma que não obrigam as companhias a efetuar as recompras de determinada maneira, apenas estabelecem algumas condições, de observância voluntária, segundo as quais as recompras daquele dia terão o benefício da presunção de legalidade, (ii) a realização de recompras que não atendam a todas essas restrições, de maneira oposta, também não importará em uma presunção de que elas foram manipulativas ou fraudulentas ${ }^{502}$, (iii) mesmo as recompras realizadas dentro das fronteiras da Rule 10b-18 não garantem uma presunção absoluta de legalidade - o que a norma estabelece é que, se levados em consideração exclusivamente esses quatro critérios, dentro dos limites nela previstos, não haverá imputação de manipulação ou fraude, mas, quando vistas as operações no contexto da totalidade dos fatos e circunstâncias que as circundam (com a avaliação de outros critérios, adicionais àqueles), então poderia ser verificada tal manipulação ou fraude, e (iv) não se aplica a presunção se realizadas as recompras durante certos períodos "suspeitos": para qualquer aquisição realizada durante o curso de uma oferta pública dos valores mobiliários da companhia, durante uma oferta pública de aquisição de suas ações e durante o período de anúncio de uma fusão ou aquisição, com algumas exceções (Rule 10b-18(13)(i) a (vii)).

É importante reforçar que nenhuma destas condições tem por objetivo a criação de uma proteção contra o insider trading pela própria companhia. Longe disso, estas regras asseguram uma moldura de proteção apenas contra atividades de manipulação, mas não contra a negociação com informações privilegiadas (o desenho regulatório para isto está

\footnotetext{
501 "Before Rule 10b-18 was adopted, issuers effecting repurchase programs were uncertain about their potential liability under the anti-manipulation provisions of the Exchange Act. Those provisions offer little practical guidance with respect to the scope of permisible issuer market activity. Since 1967, the Commission has considered periodically whether, and how, to regulate an issuer's market repurchases of its securities. The Commission determined that a safe harbor rule would prevent fraudulent, manipulative, and deceptive acts or practices by issuers and others without imposing unnecessarily complex and intrusive restrictions on issuer market repurchases." Cf. Securities and Exchange Commission 17 CFR Part 240 [Release No. 3440617; File No. S7-27-98], p. 59912.

${ }^{502}$ Cf. Rule 10b-18(d): "no presumption shall arise that an issuer or an affiliated purchaser has violated the anti-manipulation provisions of sections 9(a)(2) or 10(b) of the Act, if the Rule 10b-18 purchases of such issuer or affiliated purchaser do not meet the conditions specified in paragraph $(b)$ or $(c)$ of this section".
} 
em outro conjunto de regras, como veremos): "Some issuer repurchase activity that meets the safe harbor conditions may still violate the anti-fraud and anti-manipulation provisions of the Exchange Act. For example, Rule 10b-18 confers no immunity from possible Rule 10b-5 liability where the issuer engages in the repurchases while in possession of material, non-public information concerning its securities, or where purchases are part of a plan or scheme to evade the federal securities laws" - grifos nossos ${ }^{\mathbf{5 0 3}}$.

À vista do exposto, o primeiro critério é o da maneira de aquisição (Rule 10b18(b)(1)). Ele requer que um emissor use apenas um intermediário para realizar as suas recompras em um dia. O objetivo desta previsão é prevenir que um emissor possa criar uma percepção de que existem ofertas de compras e vendas advindas de vários diferentes intermediários, o que pode afetar a ideia do mercado sobre a liquidez dessas ações. De fato, a utilização de vários intermediários de mercado pode mais facilmente camuflar o fato de que a liquidez gerada por ordens de compra e venda estão, na realidade, direcionadas ao mesmo comitente (a companhia) - se a companhia é obrigada a utilizar apenas um intermediário, então a verificação da ocorrência deste tipo de operação "casada" é mais simples.

O segundo critério é o do momento da aquisição (Rule 10b-18(b)(2)). Esta condição especifica que uma recompra pelo emissor não pode ser a primeira operação na abertura do mercado, e que as recompras pela companhia tampouco podem ocorrer nos últimos trinta minutos (dez, no caso de ações com grande volume de negociação) anteriores ao fechamento do sistema de negociação. Genericamente, entende-se que as operações celebradas na abertura e no fechamento do mercado tendem a sugerir a "força" da demanda pela ação e, assim, são elas consideradas largamente como uma indicação significativa do seu valor de mercado. A regra impede que a companhia recompre no início do pregão, para evitar que ela induza o restante das negociações do dia; impede as mesmas operações no final do pregão para evitar que ela influencie o preço de fechamento das suas ações naquele dia (prática conhecida como "mark the close").

A condição de preço (Rule 10b-18(b)(3)) especifica qual o maior preço que um emissor pode oferecer para comprar as suas próprias ações. Como a regra impede, grosso modo, que a companhia possa oferecer a compra de seu papel por um preço superior à última oferta de compra independente publicada, ou por preço superior ao do último

${ }^{503}$ Cf. SEC Division of Market Regulation, Answers to Frequently Asked Questions Concerning Rule 10b-18 ("Safe Harbor" for Issuer Repurchases), pergunta 1. 
negócio fechado entre partes independentes, essa regra assegura que o emissor não condicionará a formação do preço de suas ações por meio de suas recompras. Tal como estruturada, a condição usa um preço de referência independente e que não foi estabelecido pelo emissor das ações.

Por fim, a condição de volume (Rule 10b-18(b)(4)) foi desenhada para prevenir que um emissor possa dominar o mercado de suas ações através de uma substancial atividade de recompra e revenda. Com efeito, um emissor pode interferir no volume de negociação diário de suas próprias ações até o limite máximo de $25 \%$ do volume médio diário de negócios (average daily trading volume - ADTV) verificados em suas ações nas quatro semanas que antecedem o pregão no qual as recompras são efetuadas (daí serem estas regras inaplicáveis para companhias estreantes na bolsa de valores - elas precisam aguardar ao menos quatro semanas para poderem valer-se do porto seguro da Rule 10b-18). Alternativamente, a regra permite que seja feita, uma vez por semana, uma recompra em volume superior ao dos $25 \%$ diários (e, no dia eleito para tal operação, a regra dos $25 \%$ não pode ser cumulada), exceção conhecida como "one block per week" e que visa a garantir às companhias com volume de negociação médio moderado ou baixo (ADTV baixo) maior flexibilidade na concretização de seus programas ${ }^{504}$.

A Rule 10b-18 está em constante desenvolvimento. Em 1998, por sugestão da New York Stock Exchange - NYSE, foi solicitada à SEC uma alteração em uma das condições da norma, notadamente uma flexibilização na sua condição de momento da aquisição, em ocasiões nas quais haja ocorrido uma suspensão generalizada de negociação (market-wide trading suspension), como no caso de acionamento de circuit brakers ou no caso de grave instabilidade (em 2001, por exemplo, com o atentado às torres gêmeas, foi suspensa a negociação na NYSE diversas vezes, o mesmo ocorrendo na eclosão da crise de 2008). Nesses termos, a sugestão era a de permitir que as companhias pudessem, observadas as demais condições (preço, maneira e volume), realizar ofertas ou recompras no início do pregão seguinte a um pregão no qual tenha havido suspensão generalizada de negociação. A NYSE justificava seu pedido com base em pesquisas realizadas entre seus membros, segundo os quais era consenso que, em uma situação de grave crise, permitir a ampliação do "safe harbor" a essas recompras "could offer an important source of liquidity

\footnotetext{
${ }^{504}$ A Rule 10b-18(a)(5) define o conceito de "block". Adicionalmente, vale notar que a Rule 10b-18(b)(4)(ii) exclui o volume de ações adquiridas por meio da exceção do "one block per week" do cálculo do ADTV das quatro semanas antecedentes para fins do cálculo dos $25 \%$, o que se justifica, pois esse anormal volume de recompra poderia influenciar os limites de volumes das semanas seguintes.
} 
and provide balance to selling activity ${ }^{״ 505}$. Inclusive, mencionou-se que, na crise de 1987, as recompras de ações representaram um movimento visto positivamente, já que garantiram uma onda constante de demanda pelas ações que, no seio da crise, se encontravam com uma pressão de venda muito elevada. Do lado da companhia, isso pode permitir que ela adquira suas ações a um bom preço, ao mesmo tempo em que proporciona liquidez para elas. A SEC concordava com o mérito do pleito ("the Commission weighed its concerns about potential manipulative activity by issuers against the benefits of facilitating short-term liquidity during periods of severe market turbulence. We found that the balance tips in favor of enhanced liquidity") e adotou a alteração por meio da inclusão, em 1999, da nova Rule 10b-18(c), sob o título de "condições alternativas de mercado" (alternative market conditions) $^{506}$ - o volume máximo de $25 \%$ do ADTV permaneceu intocado, mesmo na ocorrência das tais "condições alternativas".

No ano de 2003, a norma sofreu grande e robusta alteração. Estas modificações tiveram por objetivo simplificar e atualizar o regime do "safe harbor" criado em 1982, tendo em vista o desenvolvimento do mercado de capitais desde o ano de seu nascimento. Ao lado de alterações materiais no conteúdo da regra, a SEC também fortaleceu as normas de transparência das companhias acerca de toda e qualquer operação de recompra de ações (mesmo as realizadas dentro dos limites da Rule 10b-18), por meio de modificações pontuais em várias normas norte-americanas ${ }^{507}$. As principais alterações da reforma de 2003 foram: (i) a adoção de dois parágrafos introdutórios à rule, esclarecendo que sua observação é voluntária e que as recompras realizadas fora dos limites sugeridos não são, per se, consideradas manipulativas ou fraudulentas, (ii) uma moderada liberalização das condições sob as quais as recompras podem ocorrer, dentro do quadro da presunção de legalidade, quando efetuadas em períodos suspeitos (assim definidos como aqueles em que as companhias emissoras têm particular interesse em inflar artificialmente o valor de suas ações), (iii) a permissão de que determinadas companhias com alta liquidez possam efetuar recompras até 10 minutos antes do fechamento do pregão (em contraposição à regra geral dos 30 minutos), já que a grande liquidez das ações tende a dificultar atos de manipulação pelo emissor ${ }^{508}$, (iv) a extensão da margem de segurança da norma para o período pós-

\footnotetext{
${ }^{505}$ Cf. Securities and Exchange Commission 17 CFR Part 240 [Release No. 34-40617; File No. S7-27-98].

${ }^{506}$ Cf. Securities and Exchange Commission 17 CFR Part 240 [Release No. 34-41905; File No. S7-27-98].

${ }^{507}$ Cf. Securities and Exchange Commission 17 CFR Parts 228, 229, 240, 249, 270, and 274 [Release Nos. 33-8335; 34-48766; IC-26252; File No. S7-50-02].

508 "These modifications allow issuers of more actively traded securities, which are considered to be less susceptible to manipulation, to stay in the market longer". Cf. Securities and Exchange Commission 17 CFR
} 
fechamento do mercado regular (after-hour trading), observadas algumas condições especiais de preço, (v) o aumento do volume de recompras permitido após uma suspensão generalizada das negociações com aquelas ações, de 25\% para 100\% do ADTV (em 1998, o volume havia sido mantido em 25\%), e (vi) o aperfeiçoamento das regras de transparência dos emissores com relação à sua atividade de recompra.

Por fim, em 2010, a SEC colocou em audiência pública uma nova reforma da Rule 10b-18, com vistas a clarificar e modernizar ainda mais o regime ali estabelecido ${ }^{509}$. Um dos principais pontos da proposta de reforma era o de adequar a condição de preço à circunstância de que, com o desenvolvimento de maneiras mais rápidas e automatizadas de negociação, restava praticamente impossível aos emissores garantir que cada negociação de compra e venda, individualmente considerada, estava em conformidade com os quatro critérios definidos pela SEC; e, lembre-se, se uma única operação está desenquadrada, todos os negócios daquele dia não gozarão do benefício da presunção de legalidade. A discussão do material era se seria desejável a expansão da condição de preço para incluir métodos mais modernos de apreçamento, como, v.g., o preço médio ponderado por volume (volume-weighted average price ou VWAP) - que calcula o preço médio das ações adquiridas em um dia por meio da soma dos valores financeiros de cada operação (preço da ação x quantidade adquirida em cada negócio) e posterior divisão desse valor pelo volume total de ações adquiridas. Dessa maneira, o preço médio final seria determinado "passivamente".

Na parte final dessa proposta de alterações à regra, a SEC buscava receber também informações sobre diversos outros pontos, não expressamente relacionados à rule, envolvendo a extensão (e sob quais condições) da regra para outros valores mobiliários que não as ações, como os títulos conversíveis em ações (convertible bonds). Entre outros, estava também interessada em receber subsídios acerca de quais seriam as preocupações relevantes, do ponto de vista da manipulação de mercado, nos casos em que uma companhia adquire suas ações com o uso de derivativos complexos.

As dúvidas da SEC são bastante pertinentes e inquietantes, mas a regra final ainda não foi publicada.

\subsubsection{EUA: Ações Próprias e Insider Trading: os “Trading Plans”da Rule 10b5-1}

Parts 228, 229, 240, 249, 270, and 274 [Release Nos. 33-8335; 34-48766; IC-26252; File No. S7-50-02], p. 64957.

${ }^{509}$ Cf. Securities and Exchange Commission 17 CFR Part 240 [Release No. 34-61414; File No. S7-04-10]. 
O quadro protetivo da Rule 10b-18 não estabelece nenhuma proteção, ou presunção de legalidade, para o caso de uso de informação privilegiada pelo emissor das ações que efetua recompras ou alienações de ações próprias. Esse quadro regulatório vem estipulado em outra regra: a Rule 10b5-1, publicada dentro do pacote de normas aprovado pela SEC em 15 de agosto de 2000, em conjunto intitulados como Selective Disclosure and Insider Trading $^{510}$. Tal regra foi proposta, e adotada, com o objetivo principal de tentar esclarecer ao mercado as bases sob as quais a SEC buscaria a imposição de responsabilidade por insider trading: apenas provando o conhecimento da informação privilegiada pela pessoa ("knowing possession" ou "awareness" da informação), ou provando também o seu efetivo uso na negociação ("use the information for trading"); optou-se pela "awareness theory", de forma que poderá ser imputada a responsabilidade por uma negociação "com base em" informação privilegiada, se a pessoa que ordenou a compra ou a venda "was aware of the material nonpublic information when the person made the purchase or sale" (Rule 10b51(b)). A adoção do critério do conhecimento da informação, ao invés do seu "uso efetivo", foi defendida sob o fundamento de que um operador que faz uma compra ou venda tendo conhecimento da informação privilegiada, inevitavelmente faz uso dessa mesma informação - não há presunção de uso, há efetivo reconhecimento.

A Rule 10b5-1, no entanto, procura contrabalançear a adoção do critério do mero conhecimento positivando, ao mesmo tempo, uma série de "defesas afirmativas" que as companhias (na realidade, a regra vale para qualquer pessoa, física ou jurídica, nós nos referiremos apenas aos próprios emissores das ações) que recompram ações e os seus operadores (traders) podem utilizar para se defenderem de acusações de negociação "com base em" informação privilegiada. Uma das possíveis formas de defesa é justamente a adoção de um plano escrito para negociar com os seus papeis: este é o chamado "Rule 10b5-1 Trading Plan, que garante, de certa forma, um porto seguro contra acusações de insider trading pela companhia com suas próprias ações.

Contudo, para que o Trading Plan satisfaça os requisitos das defesas afirmativas, é preciso que (Rule 10b5-1(c)(1)(i)(A)): (i) a pessoa o adote antes de ter conhecimento da informação privilegiada, (ii) o plano especifique o preço (de mercado em determinada data, um preço limite ou um preço em dólares preestabelecido), o volume (em número de ações ou em dólares) e as datas (em dias específicos do ano) em que as ações serão compradas ou

${ }^{510}$ Cf. Securities and Exchange Commission, 17 CFR Parts 240, 243, and 249, [Release Nos. 33-7881, 3443154, IC-24599, File No. S7-31-99]. 
vendidas. Alternativamente, é possível que ele contenha uma fórmula ou algoritmo (inclusive de computador) para determinar o preço, volume e data de aquisições. $\mathrm{Na}$ ausência de quaisquer desses parâmetros, é necessário que o plano delegue para um terceiro a decisão sobre a recompra ou revenda, não permitindo que a pessoa que aprovou o plano exerça influência sobre a conveniência, o momento e a razão da aquisição ou venda, e (iii) a compra ou venda seja realizada de acordo com o plano aprovado.

Para as pessoas jurídicas, existe uma defesa adicional e específica (em relação à defesa do parágrafo anterior), que poderá ser alegada quando for demonstrado que: (i) a pessoa física que tomou a decisão de comprar ou vender a ação, agindo em nome da pessoa jurídica, não estava ciente da informação, e (ii) a pessoa jurídica mantinha procedimentos e controles internos, de acordo com a natureza de seu negócio, que garantiam que tais pessoas físicas não poderiam ter agido com base em informação privilegiada.

A regra garante efetivamente uma segurança para as companhias de que elas poderão negociar as suas ações em momento futuro, mesmo que de posse de informação privilegiada, de acordo com o plano pré-aprovado. Conforme desenhados, esses planos cobrem situações bem detalhadas, em que é razoável afirmar que a informação material e não pública, ainda que existente, não teve uma influência significativa na decisão de recomprar ou vender as ações próprias, pois o grau de discricionariedade da companhia é praticamente inexistente. Por exemplo, uma companhia pode estruturar, nos termos dessa norma e desde que não esteja de posse de informação material nesse momento, um plano de recompra de ações sem obrigatoriamente especificar os volumes, datas e preços de acordo com os quais irá recomprar ou vender suas ações, desde que tal plano contenha fórmulas escritas para derivar automaticamente os volumes, preços e datas. Poderá esse plano, igualmente, delegar toda a discricionariedade relacionada à definição de volumes, preços e datas de recompras, para outra pessoa que não esteja de posse da informação privilegiada - desde que o emissor, obviamente, não tenha e não exerça influência sobre tal pessoa: "we believe this provision will provide appropriate flexibility to those who would like to plan securities transactions in advance at a time when they are not aware of material nonpublic information, and then carry out those pre-planned transactions at a later time, even if they later become aware of material nonpublic information" $" 511$.

\footnotetext{
${ }^{511}$ Securities and Exchange Commission, 17 CFR Parts 240, 243, and 249, [Release Nos. 33-7881, 34-43154, IC-24599, File No. S7-31-99].
} 


\subsubsection{Brasil: Política de Negociação de Ações de Companhias Abertas e Insider Trading}

Passemos à análise das disposições da CVM concernentes ao insider trading e à manipulação de mercado, tendo em vista as recompras de ações.

O artigo 13, caput, da Instrução CVM 358 veda qualquer negociação pelas pessoas ali mencionadas (incluindo administradores, controladores e a própria companhia) com ações de emissão da sociedade antes da divulgação ao mercado de atos ou fatos relevantes ocorridos nos seus negócios: é a consagração administrativa da proibição do insider trading $^{512}$. O art. $13, \S^{\circ}$, I, da mesma norma estende a proibição de negociação, por qualquer das pessoas listadas no caput, se existir a intenção, ainda não divulgada ao mercado, de promover incorporação, cisão, total ou parcial, fusão, transformação ou reorganização societária da companhia - o art. 14, de seu turno, estende a vedação caso exista intenção de alienação do controle -, e, mesmo depois de divulgada essa intenção, a restrição poderá prevalecer, caso a negociação com as ações puder interferir nas condições dos referidos negócios, em prejuízo dos acionistas da companhia ou dela própria, nos termos do art. $13, \S 5^{\circ}$.

Dando prosseguimento às vedações, o art. $13, \S 4^{\circ}$, proscreve por completo a negociação, pelas pessoas mencionadas no caput, no período de 15 (quinze) dias que anteceder a divulgação das informações financeiras da companhia, ressalvado o disposto no $\S 3^{\circ}$ do art. 15 . Por último, o art. $13, \S 6^{\circ}$, cria uma exceção permanente ao caput (e apenas a ele) para alienações de ações em tesouraria, privadamente (que dependerão, de qualquer forma, de prévia aprovação da CVM, nos termos da Instrução CVM 10), decorrente do exercício de opção de compra, de acordo com plano de outorga de opção de compra de ações aprovado em assembléia geral.

O artigo $13, \S 7^{\circ}$, por outro lado, estabelece que as vedações do art. 13, caput, e dos parágrafos $1^{\circ}$ a $3^{\circ}$ (note-se: não ao $4^{\circ}$ ) "não se aplicam" às negociações realizadas pela própria companhia aberta (e pelas demais pessoas atingidas), de acordo com política de negociação aprovada nos termos dessa norma (art. 15).

\footnotetext{
${ }^{512}$ Marcelo Trindade esclarece que a Lei das S.A., após a reforma de 2001, adota a teoria do efetivo uso da informação privilegiada com o intuito de auferir lucro ou vantagem (cf. art. 155 da Lei das S.A.), o que o art. 13 da Instrução CVM 358 não faz. Isso indica que a Instrução CVM 358 presume que as pessoas ali listadas, ao ter a posse da informação, a utilizarão para auferir vantagem indevida - de certa forma, a presunção da norma a aproxima da teoria do conhecimento do fato (awareness) seguida pela regulação dos EUA. Ainda assim, é obrigatório que a CVM prove, como condição da acusação, a existência da informação privilegiada. Cf. Marcelo Fernandez Trindade, Vedações à Negociação de Valores Mobiliários por Norma Regulamentar: Interpretação e Legalidade, in Marcelo Vieira von Adamek (coord.), Temas de Direito Societário e Empresarial..., cit., p. 458.
} 
A política de negociação de ações de companhias abertas, estipulada no artigo 15 da Instrução CVM 358, segue, em linha principiológica, o 10b5-1 Trading Plan dos EUA, representando uma maneira de isentar a companhia de responsabilidade por insider trading. Tal isenção de responsabilidade é corporificada em uma prova previamente elaborada pela companhia, que se contrapõe à presunção (criada pelo artigo 13, caput, dessa instrução) de utilização da informação privilegiada com intuito de lucro ${ }^{513}$.

Nos precisos termos do art. 15 da Instrução CVM 358, é lícito à companhia (e a Instrução CVM 480, de 07 de dezembro de 2009 - "Instrução CVM 480" - tornou isso obrigatório para os emissores de Categoria A), por deliberação de seu conselho de administração (que também é o órgão competente para aprovar as condições sob as quais serão feitas as recompras, nos termos do artigo $8^{\circ}$ da Instrução CVM 10), aprovar uma política de negociação de suas ações, cuja observação seja obrigatória para administradores, controladores e, inclusive, para a própria companhia. A aprovação dessa política de negociação não poderá ser feita na pendência de divulgação de um ato ou fato relevante ${ }^{514}\left(\operatorname{art} .15, \S 1^{\circ}\right)$, deverá contar com a adesão das pessoas que queiram dela se beneficiar ( $\left.\operatorname{art} .15, \S 1^{\circ}, \mathrm{I}\right)$ e incluir a vedação absoluta aos negócios no período de 15 dias que antecedem a divulgação de suas informações financeiras (cf. art. 13, §4%). O art. 15, $\S 3^{\circ}$, permite ainda aos administradores negociarem nesse período de 15 dias, exclusivamente em conformidade com um detalhado plano de investimentos pessoais aprovado pela sociedade, desde que sejam obedecidas as formalidades e condicionantes desse parágrafo (cronograma definido para as divulgações de informações financeiras, compromisso de investimento de valores pré-estabelecidos e em datas pré-acordadas, etc.).

Pois bem, aprovada a política de negociação, seu grande benefício é o de garantir à companhia uma prova previamente elaborada contra alegações de que tenha se utilizado de informações privilegiadas na sua atividade de recompra - a companhia continuará detendo a informação privilegiada, mas terá uma prova de que dela não se utilizou para auferir vantagem.

À companhia que aderir à política será facultado, pelo exposto, negociar com as suas ações mesmo: (i) na pendência de divulgação de ato ou fato relevante (art. 13, caput),

\footnotetext{
${ }^{513}$ Marcelo Fernandez Trindade, Vedações à Negociação..., cit., p. 459.

${ }^{514}$ Pois, como se verá, a existência da política concede benefício de presunção de que as operações efetuadas sob seu manto não foram feitas em contrariedade às vedações de negociação com informação privilegiada. A se permitir que uma política fosse aprovada às pressas na pendência de um ato ou fato relevante, estaria aberta à porta para que companhias, controladores e administradores pudessem negociar com as ações contando com o "benefício", mesmo já de posse de informação privilegiada.
} 
inclusive eventual alienação de controle ${ }^{515}$, e (ii) se existir a intenção não divulgada ao mercado de promover incorporação, cisão total ou parcial, fusão, transformação ou reorganização societária da companhia (art. $13, \S 3^{\circ}$, I), podendo utilizar a política aprovada como defesa afirmativa contra a presunção relativa do art. 13, caput.

Poderá também sempre, independentemente da política, alienar ações em tesouraria por força do exercício de opções outorgadas no âmbito de planos aprovados em assembleia geral (art. $\left.13, \S 6^{\circ}\right)$ e não poderá nunca, mesmo que tenha aderido à política, negociar com suas ações no período de 15 dias que antecederem a divulgação de suas informações financeiras ( $\operatorname{art} .13, \S 4^{\circ}$ ) - na realidade, a companhia conseguirá negociar mesmo neste último período, mas a prova de que não usou informação privilegiada precisará se basear em outras circunstâncias, que não a existência da política de negociação.

Entendemos e concordamos com o raciocínio, mas é necessário dizer que a forma como hoje está detalhada a política de negociação no Brasil deixa muito a desejar, pois o ponto fulcral que permite a sua utilização como defesa afirmativa (do ângulo do insider trading) é a ausência de discricionariedade (retirada do elemento intencional da negociação) por parte da companhia em efetuar os negócios, em termos de seu preço, volume e datas. A Instrução CVM 358, com efeito, não traz nenhum parâmetro ou conteúdo mínimo que deva constar dessa política e, ao mesmo tempo, atribui a ela o condão de provar que as operações não foram feitas com base em informação privilegiada. Realmente, o que nos parece ser o mais correto do ponto de vista de política regulatória é o estabelecimento de maior rigor de detalhes do que os atualmente constantes na Instrução CVM 358, nos moldes realizados pela Rule 10b5-1 Trading Plan, de modo que se consiga justificar a sua utilização como prova de não utilização da informação privilegiada pela ausência do elemento volitivo da companhia. Assim, a estipulação do conteúdo mínimo das políticas de negociação poderiam abranger: (i) as datas, volumes e valores específicos das operações a serem realizadas pela companhia, (ii) critérios passivos para sua determinação, ou, ainda, (iii) a delegação da decisão de recompra ou revenda a um terceiro não vinculado à companhia ou à sua administração, sem que lhes seja possível influenciar a tomada de decisão desse terceiro (o que já parece ter norteado a definição do plano de investimentos pessoais da administração do art. $15, \S 3^{\circ}$ ).

\footnotetext{
${ }^{515}$ Para sermos precisos, o art. 14 da Instrução CVM 358 estabelece a impossibilidade de negociar com as próprias ações na pendência de divulgação da informação sobre alienação de controle, situação não excepcionada pelo art. $13, \S 7^{\circ}$, que ao art. 14 não se refere, apenas ao 13 (onde constam as reorganizações societárias, mas não a alienação de controle). No entanto, a potencial alienação de controle é, obrigatoriamente, fato relevante, de forma que pode ser enquadrada no art. 13, caput e, por consequência, incluída na exceção do art. $13, \S 7^{\circ}$.
} 
Aliás, estabelecida uma política de negociação nos termos em que sugerimos acima, razões não haverá para que a companhia não possa adquirir ou vender suas ações também dentro do período de 15 dias a que se refere o art. $13, \S 4^{\circ}$, dessa norma. Ora, qualquer alegação de insider trading, em qualquer período (por mais suspeito que seja), poderá ser afastada pela prova da ausência de discricionariedade da companhia: se ela, v.g., delegou competência a um terceiro, independente, para que este negocie com as suas ações, por qual razão lhe seria proscrito negociar no período de 15 dias a que fazemos referência? Mas não é só: ainda que a companhia não delegue a competência, mas a mantenha consigo, é possível que ela estruture determinados negócios de tal forma, que alegar a utilização de informações privilegiadas seria absurdo. Por exemplo, ela poderia estipular, em seu plano, data específica para a aquisição de determinada quantidade de suas ações, a preço previamente estipulado: essa data poderia, inclusive, estar inserida no período de 15 dias (desde que a companhia não possua, de antemão, informação privilegiada). Enfim, não apenas parece-nos saudável a alteração da forma como o Brasil trata da política de negociação (detalhando-a), como também se nos afigura salutar que seja repensado seu fundamento, a fim de que seja possível a coerência de tratamento (afinal, os administradores já podem negociar nos 15 dias anteriores à publicação das demonstrações da companhia, nos termos de seus planos de investimento pessoais).

Marcelo Trindade resume bem a discussão: “[p]ortanto, se a decisão negocial for tomada em momento anterior - o da aprovação da política e for meramente cumprida quando da negociação futura, sem a tomada de uma decisão negocial no momento em que o agente já detém a informação privilegiada, a presunção ficará afastada, porque o elemento subjetivo estabelecido na norma legal - de finalidade de obter vantagem indevida com a negociação - não estará presente" ${ }^{\text {516. }}$.

Agora, se por um lado a política de negociação visa a atribuir proteção contra o risco de caracterização do insider trading, ela, por outro, não garante à companhia proteção contra alegações de manipulação de mercado - por meio de criação de condições artificiais de oferta, demanda ou preço -, tão somente porque lhe falta previsão nesse sentido.

A Instrução CVM 8 é omissa quanto a qualquer forma de "safe harbor". Nessa configuração, as companhias estão sujeitas a um constante risco de terem suas operações de recompra classificadas como manipulativas sob o auspício dessa norma. O Brasil, até

\footnotetext{
${ }^{516}$ O autor refere-se ao artigo 13, caput, da Instrução CVM 358. Cf. Marcelo Fernandez Trindade, op. cit., p. 468.
} 
hoje, não possui nenhuma regra que possa dar mais segurança às companhias com relação a esse tema, o que deveria ser feito urgentemente pela $\mathrm{CVM}^{517}$.

\subsubsection{Outros Períodos de Restrição para os Quais a Política não é Defesa Afirmativa}

Mesmo se considerarmos uma companhia com uma política de negociação aprovada, garantindo, com isso, a possibilidade de negociação sob contornos mais seguros, existem determinados períodos previstos em alguns normativos da CVM que não permitem a sua utilização como prova de não utilização da informação privilegiada, o que se observa pela leitura do art. $15, \S 1^{\circ}$, III, que requer que a política contenha "procedimentos que assegurem que em nenhuma hipótese a companhia negociará com as próprias ações nos períodos de vedação estabelecidos nesta Instrução e na própria política de negociação".

Esses períodos de restrição fundamentam-se ora em preocupações contra o uso de informações privilegiadas, ora com a possibilidade de maiores incentivos para os emissores manipularem o preço de suas ações. A esses períodos é atribuída uma diversa valoração pela CVM: são intervalos de tempo nos quais a autarquia houve por bem não permitir a possibilidade de criação de mecanismos de defesa prévia, como a política de negociação, tendo em consideração que, neles, é mais provável a existência de informações privilegiadas e, ao mesmo tempo, de incentivos para que o emissor interfira na cotação de suas ações.

O primeiro deles vem estabelecido na própria Instrução CVM 358, no já citado art. $13, \S 4^{\circ}$. Este dispositivo busca seu fundamento não na preocupação com a manipulação de mercado, mas na ocorrência e no uso de informação privilegiada de conhecimento da companhia e/ou de sua administração. Nos termos desse artigo, é vedada a negociação pela companhia com suas ações no período de 15 (quinze) dias que anteceder a divulgação das suas informações trimestrais (ITR) e anuais (DFP): este período é comumente denominado de “black out period". Nesse curto espaço de tempo que antecede tal divulgação, há duas presunções relativas: a primeira é a de existência e conhecimento, pelos "insiders natos" aí incluída a companhia em si -, de informações materiais sobre a situação financeira da

\footnotetext{
${ }^{517}$ A audiência pública da CVM atualmente em andamento, já por nós referida, cujo propósito é o de substituir a Instrução CVM 10, contém um capítulo denominado de "Presunção de Regularidade de Operações Realizadas em Mercados Organizados", segundo o qual "as aquisições de ações de própria emissão realizadas em mercados organizados de valores mobiliários presumem-se em conformidade com as normas que vedam a criação de condições artificiais de demanda, oferta ou preço, manipulação de preço, operações fraudulentas e práticas não equitativas, se atendidas as seguintes condições (...)". As condições ali listadas são praticamente idênticas àquelas da Rule 10b-18. Voltaremos a essa audiência pública em nossas conclusões, onde tangenciaremos novamente este tópico.
} 
companhia, desconhecidas pelo público, e a segunda é a de que qualquer negócio realizado nesse período será feito "com base" nessa mesma informação. Justifica-se: é extremamente plausível que os membros da administração e os controladores tomem ciência de um lucro ou prejuízo exorbitante realizado em determinado trimestre ou exercício social, antes que as informações financeiras da companhia tenham sido aprovadas e divulgadas ao mercado. $\mathrm{Na}$ posse dessa informação, que pode afetar substancialmente a cotação das ações (observa-se, na prática, que o mercado aguarda ansiosamente a divulgação dos resultados trimestrais e anuais das companhias, e que as ações respondem rapidamente a uma informação positiva ou negativa que seja veiculada em seus números), fica vedada por completo a negociação com as ações da companhia pelas pessoas suspeitas. O já aventado art. $13, \S 7^{\circ}$, dessa mesma norma não permite sequer a utilização da política de negociação como prova contra tais presunções - se houver qualquer negócio pela companhia com suas ações nesse período, ela deverá adotar outras formas de defesa ${ }^{518}$.

Adicionalmente, nos termos da Instrução CVM 10, há, como mencionado, imposição de limites à negociação durante o período no qual esteja em andamento uma oferta pública de aquisição das ações da companhia (art. $2^{\circ}$, "e") - neste caso, a preocupação do regulador é evitar, precipuamente, a manipulação de mercado e não o insider trading, uma vez que a oferta de aquisição será, por definição, pública. Já tivemos oportunidade de avaliar os motivos e as consequências dessa restrição, inclusive defendendo a possibilidade de lançamento de uma oferta concorrente pela companhia, mas o fato é que a restrição existe, sendo probido à companhia realizar operações de compra ou venda de ações, mesmo que sob o amparo de uma política de negociação aprovada, no caso de estar em andamento uma oferta pública de aquisição de suas ações.

A Instrução CVM 400 prevê mais um exemplo de período de restrição praticamente absoluta de negociação, que é aquele durante o qual esteja em andamento a estruturação e o processo de distribuição de uma oferta pública de ações da companhia, em atenção ao risco de manipulação de mercado e também de insider trading. $\mathrm{O}$ artigo 48, II, dessa instrução, cuja função é "proteger os interesses dos investidores, nas hipóteses de negociação de posse de informação privilegiada e de negociação que possa influenciar na

\footnotetext{
${ }^{518}$ É claro que sempre será admitida prova em contrário; seria inconstitucional que a CVM pudesse impor presunções absolutas de existência e utilização de informação privilegiada, sem permitir a produção de provas em contrário (o que deriva do direito ao contraditório e à ampla defesa, nos termos da Constituição Federal, art. $\left.5^{\circ}, \mathrm{LV}\right)$.
} 
precificação dos valores mobiliários ofertados" ${ }^{\text {, }} 19$, prevê, grosso modo, que a emissora (bem como as instituições intermediárias e quaisquer outras pessoas que estejam trabalhando ou assessorando a oferta pública) abstenha-se de negociar, até o encerramento da oferta, com "valores mobiliários do mesmo emissor e espécie daquele objeto da oferta pública". Está-se diante de outra presunção relativa de existência de informação privilegiada e de sua indevida utilização (veja-se: a presunção, aqui, alcança não só a utilização, como também a existência de informação privilegiada ${ }^{520}$ ): a dificuldade de se separarem as operações realizadas sem a posse de tais informações (ou sem o objetivo de influenciar o preço do valor mobiliário ofertado), daquelas que dela tenham feito uso, levou o regulador a restringi-las por completo.

Objetiva a instrução evitar que as instituições participantes do sindicato de distribuição e a própria companhia emissora possam influenciar o mercado por meio da negociação dos valores mobiliários a serem ofertados, antes e no curso da oferta pública: essa influência indevida poderia, por exemplo, forçar um aumento na cotação de bolsa das ações envolvidas, de forma que o preço por ação nova a ser ofertada - um dos principais objetivos dentro do contexto da oferta - seja artificialmente elevado, em benefício da companhia e em prejuízo dos subscritores (haveria transferência de riqueza indevida dos acionistas subscritores para a companhia). No entanto, a própria Instrução CVM 400 enumera, no mesmo art. 48, II, determinadas situações nas quais a negociação pelos envolvidos é permitida; elas têm por fundamento comum a noção de que são transações não motivadas pelo domínio de informação privilegiada e nem pelo intento de manipular o mercado. O rol de exceções, felizmente ampliado por meio da edição da Instrução CVM 533, de 24 de abril de 2013, inegavelmente aplica-se à companhia emissora que deseje negociar suas ações no período da restrição, uma vez que ela está listada no caput do art. 48 como um dos destinatários da proibição. A verdade é que muitas das possibilidades ali relacionadas não são endereçadas à companhia, mas aos intermediários. É o caso, por exemplo, da "alienação total ou parcial de lote de valores mobiliários objeto de garantia firme” (art. 48, II, “b”) que, à obviedade, não é destinada à companhia. Por outro lado, não deixa de ser verdade que muitas das demais exceções podem ser de grande valia para ela, sendo talvez o melhor exemplo desta utilidade a hipótese do art. 48, II, “j”: esse inciso permite que a companhia possa, mesmo no período da restrição, comprar ou vender as

\footnotetext{
${ }^{519}$ Cf. MEMO/SRE/n. ${ }^{\circ}$ 215/2004, de 22 de outubro de 2004, examinado pelo Colegiado da CVM em 25 de outubro de 2004.

${ }^{520}$ Cf. Marcelo Fernandez Trindade, op. cit., p. 461.
} 
próprias ações para cumprimento de obrigações assumidas antes do período da vedação, decorrentes do exercício de opções de compra ou venda por terceiros ou, ainda, de contratos de compra e venda a termo ${ }^{521}$.

Outra hipótese é aquela prevista no art. 13, §5 , c/c 14 da Instrução CVM 358: anunciada uma operação de alienação de controle, fusão, transformação, cisão ou incorporação envolvendo a companhia, ficará ela impedida de negociar seus papeis caso "a negociação com as ações puder interferir nas condições dos referidos negócios, em prejuízo dos acionistas da companhia ou dela própria". Aqui, não estamos diante de uma situação de insider trading, pois a informação (da reorganização societária) já é de domínio público, mas de uma situação onde a intervenção da companhia no mercado de suas próprias ações poderá interferir nas condições dos referidos negócios - há presunção relativa de que ela tem interesse especial em fazê-lo. De fato, uma vez anunciados tais fatos, terá o emissor um considerável incentivo para sustentar ou aumentar o preço de mercado de suas ações, de forma a influenciar os termos da operação societária. Por exemplo, uma companhia poderá tentar inflar artificialmente o preço de suas ações para torná-la mais valiosa dentro do contexto da relação de troca com a outra companhia envolvida (a ser incorporada, por exemplo).

\subsubsection{Algumas Conclusões}

A política de negociação de ações da própria companhia estipulada na Instrução CVM 358 merece, de lege ferenda, algumas reformas.

Em primeiro lugar, deve ser mantida a lógica de que a política de negociação aprovada possa servir de prova contra as presunções regulamentares de utilização de informação privilegiada, mas defende-se a alteração do art. 15 da Instrução CVM 358 para que ele preveja em maiores detalhes o conteúdo dessa política, em consonância com a máxima de que quanto menor a discricionariedade da companhia para realizar as aquisições, tanto menor será a probabilidade de que uma informação privilegiada tenha influência na tomada de sua decisão de negociar - a eficácia na perseguição desse objetivo será tão mais acentuada, quanto menor for o elemento volitivo deixado a cargo das companhias dentro das políticas aprovadas. Da forma como está hoje

\footnotetext{
${ }^{521}$ Em verdade, esclareça-se desde já, estas hipóteses deveriam encontrar aplicação mais ampla, não apenas no contexto de uma oferta pública das ações da companhia. Com efeito, por que motivo seria ilícito à companhia, fora de uma situação de oferta pública de suas ações, negociar seus papeis em cumprimento de contratos celebrados com terceiros antes do período da vedação? Há uma incoerência manifesta nas regras da CVM, decorrente da cumulação de restrições à negociação em diversas normas distintas.
} 
regulamentado, em um exemplo evidentemente ad absurdum, uma companhia poderia ter uma política aprovada que lhe permitisse recomprar até $10 \%$ de suas ações, a qualquer tempo e sem condições de volume diário. Essa companhia, embora nunca tendo realizado uma operação de recompra, poderia, de sopetão e no período de uma semana, passar a adquirir indiscriminadamente suas ações em bolsa - de acordo com o "permitido pela política" -, até que se atingisse o percentual de 10\%. Na semana seguinte, divulga fato relevante que faz com que suas ações subam de cotação vertiginosamente. Da maneira como atualmente descrita, a política poderia ser usada na defesa dessa companhia - muito embora tenhamos convicção de que a CVM não se ateria apenas à sua existência para excluir necessariamente a utilização da informação privilegiada de forma ilegal ${ }^{522}$.

Em segundo lugar, é nossa opinião que as exceções aos períodos de restrição sejam, na medida do possível e desejável, uniformizadas: se o fundamento que as justifica é o mesmo, então a existência de disparidade de tratamento regulatório gera apenas confusão e insegurança jurídica. Por exemplo: a Instrução CVM 358 permite, como se viu, que a companhia possa alienar de forma privada suas ações em tesouraria a qualquer tempo, mesmo que pendente a divulgação de um ato ou fato relevante (art. $13, \S 6^{\circ}$ ), desde que em decorrência do exercício de opção de compra outorgada no âmbito de um plano adrede aprovado em assembleia (art. 168, §3º da Lei das S.A.). Já a Instrução CVM 400 abre um leque bastante interessante de situações, cuja contratação/realização é permitida à companhia no decorrer de uma oferta pública das suas ações: lembre-se, por todas, aquela que permite que a companhia negocie as ações em cumprimento de um contrato celebrado com terceiros anteriormente à restrição. O fundamento de ambas as normas, como já se viu, é o mesmo: a CVM deveria, portanto, passar a permitir, no texto da Instrução CVM 358 (à luz do que fez com relação aos planos de opção), que a companhia negociasse livremente suas ações (em que pese haver a imposição de eventual obrigação de controle de sua ocorrência) nas mesmas situações em que já lhe permite fazê-lo no decorrer de uma oferta pública. Não se trata, aqui, de inclusão dessas possibilidades no plano de negociação (o que as tornaria, apenas, uma defesa afirmativa), mas de um amplo reconhecimento regulatório de que essas operações não têm o condão de infringir os

\footnotetext{
522 Aliás, dentro do contexto da política de negociação reformulada nestes termos, poderia encontrar aplicação a teoria da imputação dupla do conhecimento, que delineamos acima. Explica-se: se a companhia decidir negociar dentro do aprovado em sua política, então estará configurada a sua defesa contra alegações de insider trading. Operando, todavia, fora dela, a defesa poderia assentar-se na utilização de tal teoria, podendo-se provar, por exemplo, que a pessoa que negociou em nome da companhia não era conhecedora da informação privilegiada ou, ainda, que não seria razoável supor que a administração da companhia (conhecedora da informação) a pudesse ter informado sobre a vedação a tempo de impedir o negócio.
} 
princípios que inspiram a proibição de negociação nesses períodos (utilização de informação privilegiada e manipulação de mercado). Mantida a atual situação, a companhia poderia furtar-se a cumprir uma obrigação contratualmente assumida com terceiros (ex.: oriunda de uma opção de compra/venda outorgada a um parceiro estratégico, porém fora do contexto de um plano de opções) em virtude do surgimento de uma informação material ainda não divulgada ou, ainda, em virtude de sobrevir o black out period. Não é razoável.

Tampouco é razoável que a administração não possa dar continuidade às operações usualmente adotadas como forma de administração ordinária da companhia; não deveria ser incentivada uma ruptura na forma como a sociedade é gerida, tão-só em virtude de existir uma informação material e não pública, ou somente por força da estruturação de uma oferta pública de suas ações (ou de aquisição delas), ou, ainda, por se encontrar a companhia dentro do black out period: assim, se a companhia possui determinados volumes médios históricos de negociação com as próprias ações (mesmo que não tenha aprovado uma política), ela deveria poder continuar a operar dessa maneira e dentro desses volumes $^{523}$.

Por final, deveria ser estruturado um safe harbor, de adesão voluntária pelas companhias, dentro do qual haveria presunção relativa de ausência de manipulação de mercado (i.e. não ocorrência de criação de condições artificiais de demanda, oferta ou de manipulação de preço). A CVM poderia estudar a possibilidade de criação de algumas condições de tempo, maneira de aquisição, preço e volume, nos moldes da Rule 10b-18, para que as recompras, prima facie, ficassem isentas de suspeitas manipulativas; tais critérios poderiam ser individualmente inseridos nas políticas de negociação de cada companhia, a critério delas, ou poderiam, ainda, ter aplicação automática, independentemente de sua aceitação (afinal, estas normas têm funções bem delineadas e não coincidentes). No entanto, a previsão deveria ser clara o suficiente para deixar transparente, como mínimo absoluto, que: (i) a observância das "presunções de regularidade" não atribui presunção absoluta de ausência de manipulação, que poderá ser alegada pela CVM com base em outras circunstâncias do caso concreto, incumbindolhe, ainda, o ônus da prova, (ii) não haverá presunção de ato manipulativo para as

\footnotetext{
${ }^{523}$ Poderia ser estabelecido, exemplifica-se, que a companhia pudesse continuar a negociar com as suas ações no decorrer de períodos de "restrição" e mesmo na pendência de divulgação de ato ou fato relevante, caso ela se limitasse a operar dentro do mesmo volume médio diário de negócios por ela realizados nos 3 meses antecedentes à restrição. Esta imposição retiraria a discricionariedade de a companhia optar por, subitamente, triplicar o volume desses negócios.
} 
recompras realizadas fora dessa moldura (retornando, no entanto, o ônus da prova à companhia, que não poderá argumentar com a observância de tais critérios em sua defesa).

\subsection{As Ações Próprias e as Modernas Estruturas e Instrumentos Financeiros}

O artigo 30 da Lei das S.A., como a esta altura já visto à exaustão, proíbe a negociação pela companhia com as próprias ações, mas não menciona quaisquer outros títulos de sua emissão, por mais similares que sejam economicamente a elas. É irrefutável, portanto, que a proibição mestra gira em torno da realização de negócios pela companhia com títulos que garantam ao seu titular o estado de sócio: é esta, em verdade, a preocupação do legislador. Quaisquer títulos que não confiram ao seu titular o status socii não estariam, em primeira análise, abrangidos pelo aspecto objetivo da regra proibitiva. José Alexandre Tavares Guerreiro, de maneira similar e avaliando situação envolvendo um contrato de swap (ao qual nos referiremos a seguir), ensina que: "o contrato de swap, por sua vez, tem por objeto não a substância econômica intrínseca das ações da companhia (...)"-grifos nossos ${ }^{524}$.

À luz do exposto, a lei não proíbe, em princípio, negócios da companhia com instrumentos de dívida por ela emitidos, como, por exemplo, as debêntures (cuja aquisição pela companhia emissora é permitida textualmente pela Lei das S.A., no artigo $\left.55, \S 3^{\circ}\right)$. Sem entrar no já tão cristalizado discurso de diferenciação entre ações e outros instrumentos de financiamento da atividade empresarial, pensamos que a justificativa parece ser, mais uma vez, a de que instrumentos que caracterizem um direito de crédito contra a companhia (como as debêntures), bem assim quaisquer outros instrumentos que não garantam o status socii ao titular, estão excluídos do regime dos negócios com as próprias ações ${ }^{525}$. A observação deste parágrafo não é tão óbvia: em Portugal, como exemplo, o artigo 354 do Código das Sociedades Comerciais atribui à negociação, pela companhia, com títulos obrigacionais de sua emissão o mesmo regime atribuído para os

\footnotetext{
${ }^{524}$ Referindo-se justamente ao fato de que tal contrato tinha por objeto apenas o valor de mercado das ações, mas não o status socii delas decorrente. Cf. José Alexandre Tavares Guerreiro, Contratos Coligados, Swap, Vedação de Negociação com as Próprias Ações e Proibição de Comportamento Contraditório, in Flávio Luiz Yarshell e Guilherme Setoguti J. Pereira (coords.), Processo Societário, Quartier Latin, São Paulo, 2012 , p. 377.

525 "Infatti mentre l'azionista è un socio, il portatore dell'obligazione è un creditore che fece un prestito alla società. Il primo ha tutti i diritti e gli oblighi derivanti dal contratto di società: quindi ha diritto ai dividendo solo quando vi sono utili da ripartire, non può esigere la sua parte di capitale sociale se non dopo che furono pagati i creditori sociali. Il secondo invece ha diritto agli interessi anticipadamente fissati, sianvi o non sianvi utili sociali; può esigere il rimborso del suo credito alla scadenza convenuta". Cf. Cesare Vivante, Istituzioni di Diritto Commerciale, 6ª ed., Real Casa, Milão, 1905, p. 100.
} 
negócios com as próprias ações, prevendo, inclusive, suspensão de direitos desses títulos, enquanto permanecerem em tesouraria ${ }^{526}$. Não é, no entanto, o que ocorre no Brasil: se a lei não é clara nesse sentido (aliás, ela é bem clara, mas no sentido de permissibilidade) devem-se entender permitidas essas operações, observadas as condições de preço e transparência nas demonstrações financeiras impostas pela Lei das S.A.

Nem sempre, todavia, a distinção é tão clara. Quando escreveu em 1965, Philomeno J. da Costa não poderia ter antevisto a evolução pela que passariam os instrumentos do mercado financeiro nos anos que se seguiram e, por essa razão, restringiu-se o renomado Professor à análise de institutos clássicos do direito societário, como o resgate, a amortização e o reembolso, os quais são ainda elencados como exceções formais à regra proibitiva. Surgem, em tempos mais modernos, diversos outros instrumentos, cujas características geram dúvida a respeito de sua subsunção ao preceito proibitivo da Lei das S.A. Vejam-se, nesse sentido, as debêntures conversíveis, os derivativos envolvendo ações (incluindo as opções) ou mesmo os fundos de investimento listados em bolsa que, passivamente, replicam uma carteira teórica de ações - representada por um índice específico (como, por exemplo, o Ibovespa). Nenhum desses instrumentos é uma ação, o que os excluiria, do ponto de vista formal, do âmbito de aplicação das proibições veiculadas pelo artigo 30 da Lei das S.A.

A CVM, à guisa de exemplo, computa na participação social total detida por uma pessoa também instrumentos que não sejam efetivamente ações. Assim o faz, por exemplo, nos artigos 12, III, 12, IV, e também no art. 12, §2 , todos da Instrução CVM 358. Esses dispositivos tratam da divulgação, por qualquer pessoa, de titularidade de "participação acionária relevante" e incluem entre os instrumentos a serem computados em tal cálculo não apenas as ações, mas também os bônus de subscrição, as opções, as debêntures conversíveis, os direitos de subscrição de ações e quaisquer outros direitos sobre ações que uma pessoa detenha. É nítido que a CVM não equipara a titularidade de ações à titularidade de meros direitos sobre elas, mas considera relevante que o mercado avalie também a titularidade potencial de ações de uma pessoa, e não apenas a titularidade efetiva em determinado momento; seu objetivo é resguardar o mercado contra a disponibilização, pelos agentes, de informações potencialmente mal direcionadas, o que se configuraria na hipótese em que determinada pessoa fosse titular de poucas ações de uma companhia, mas

526 "Porque a aquisição destas pela sociedade a que vão referidas pode fazer perigar a sua função de fonte de financiamento societário, prescreve o legislador, no art. 354, que a sociedade só poderá adquirir as próprias obrigações em três hipóteses: nas mesmas circunstâncias em que poderia adquirir acções próprias, para conversão, ou para amortização”. Cf. Maria Victória Rodrigues Vaz Ferreira da Rocha, op. cit., p. 16. 
detivesse uma titularidade potencial alta (por meio de opções com significativa probabilidade de exercício, debêntures conversíveis e outros direitos). O elemento comum a todos esses instrumentos é o de que não garantem o status socii, ao menos no momento de sua emissão ou lançamento, mas apresentam um elemento societário capaz de se materializar em algum momento futuro, com maior ou menor grau de probabilidade.

O desenvolvimento de complexas e modernas estruturas, institutos e instrumentos financeiros faz com que o regulador esteja sempre atento à nova realidade que deve normatizar, envidando esforços para acomodar os riscos que tais novidades representam para a estabilidade do mercado e da economia. Parece-nos desnecessário retomar a discussão sobre como a regulação financeira evoluiu após a eclosão da crise mundial de 2008, bastando apenas relembrar a intensidade da produção legislativa desde tal ano; o mundo vivencia um verdadeiro tsunami regulatório sem precedentes, apenas comparável, talvez, à introdução das securities laws nos EUA, após a crise de 1929. A preocupação pública e da sociedade civil acerca da evolução e da adequada regulação desses mecanismos e instrumentos, para garantir a estabilidade econômica, tornou-se a questão central de discussão regulatória dos últimos 5 anos, sem dúvida alguma. Isso nos traz a um momento propício para inquirirmos sobre como o clássico tema dos negócios da companhia com as ações de sua emissão se relaciona com o desenvolvimento destas novas formas de realização desses negócios.

Neste item de nossa dissertação, nos ocuparemos, portanto, dos negócios com ações próprias realizados pela companhia: (i) por meio do uso de alguns tipos de contratos derivativos, e (ii) indiretamente, por meio de fundos de investimento, negociados ou não em bolsa de valores.

A despeito de reconhecermos que esses problemas já tenham, em certa medida, chegado ao conhecimento da CVM - e avaliaremos um pequeno número de suas decisões a respeito -, houvemos por bem analisar algumas de suas peculiaridades, procurando contribuir para o entendimento das relações (nem sempre óbvias) desses instrumentos com a estrutura protetiva desenvolvida para regular os negócios com as próprias ações. Os fundamentos de tal estrutura protetiva, a esta altura, já foram devidamente explorados, cumprindo agora avaliar como eles interagem com os modernos instrumentos financeiros.

\subsubsection{Derivativos de Ações}


Os contratos derivativos, em suas diversas formas e configurações, são também instrumentos que, em não sendo ações, podem garantir ou gerar direitos futuros e potenciais sobre elas, de forma que é vital que se avalie em que medida a regulação deveria encarregar-se deles no contexto dos negócios com ações próprias. A Associação Internacional das Comissões de Valores Mobiliários (International Organization of Securities Exchange Commissions - IOSCO) realizou, no ano de 2004, uma pesquisa com diversos países participantes (inclusive o Brasil), observando, no documento publicado, que o uso de instrumentos derivativos havia crescido em importância como forma de materializar um programa de recompra de ações, considerando algumas vantagens que tais instrumentos propiciam à companhia, uma vez que eles: (i) são genericamente vistos como mais flexíveis que operações à vista feitas em troca de dinheiro, (ii) são possivelmente mais baratos para a companhia, que pode até auferir receita com o lançamento de alguns instrumentos derivativos (como o prêmio pago à ela pelas opções que tenha lançado), e (iii) possibilitam uma forma eficiente de fixar um preço futuro para as recompras de ações (o que pode ser peculiarmente útil em um cenário de aumento de preço das ações no mercado, podendo a companhia assegurar um preço fixo futuro para suas recompras) ${ }^{527}$. Este mecanismo de recompra de ações suscita os mesmos problemas de que já falamos, como o tratamento igualitário entre os acionistas, a proteção dos credores e a manipulação do mercado, além de problemas próprios, derivados da natureza do instrumento em si, que merecem tratamento diferenciado pela regulação (o Princípio 4 da IOSCO trata justamente da forma de controlar e regulamentar o uso de derivativos nas recompras de ações).

Passemos, então, a considerar o uso dos seguintes instrumentos derivativos no contexto de recompra de ações: as opções e os swaps de ações próprias.

\section{Opções de Ações: a Instrução CVM 390/2003}

O único contrato derivativo que é hoje objeto de regulação expressa pela CVM, no que diz respeito ao regime jurídico das ações próprias, são as opções referenciadas em ações da própria companhia. Uma opção, no âmbito das ações de companhias abertas, é um negócio jurídico por meio do qual uma pessoa, a lançadora da opção, outorga uma prerrogativa unilateral a outra pessoa, a titular da opção, de poder comprar ou vender compulsoriamente determinada ação do/para o lançador em data futura (vencimento) e a

527 Technical Committee of the International Organization of Securities Commissions, Report on "Stock Repurchase Programs", fevereiro de 2004, p. 20. 
preço previamente determinado (preço de exercício) - o exercício do direito conferido pela opção depende de manifestação de vontade de seu titular. No momento do lançamento, o lançador da opção recebe um valor (prêmio da opção) em contrapartida da outorga da prerrogativa unilateral dada ao seu titular.

Pois bem, a Lei das S.A. prevê expressamente a possibilidade de a companhia outorgar opções de compra referenciadas em ações de sua emissão, ao estabelecer, por exemplo, no art. $168, \S 3^{\circ}$, que o estatuto pode estipular que a companhia, dentro do limite de capital autorizado e de acordo com plano aprovado pela assembleia geral, outorgue opção de compra de ações a seus administradores ou empregados, ou a pessoas naturais que prestem serviços à companhia ou a sociedade sob seu controle. Esta é uma forma bastante comum de complementar a remuneração dos administradores ou de determinados funcionários-chave, pois, grosso modo, entende-se que a vinculação de uma parcela da remuneração dessas pessoas ao valor das ações da companhia outorga-lhes um maior senso de compromisso com o sucesso da atividade social, que será refletido no aumento da cotação das ações que são objeto das opções com que foram gratificados, permitindo, por sua vez, incremento de seu patrimônio pessoal.

Ao prever um regime jurídico específico para os negócios da companhia com opções de sua emissão apenas no contexto dos planos de opção que acabamos de mencionar, a lei deixa aberta a via para o questionamento a respeito de como esses instrumentos interagirão com o regime previsto no artigo 30 da mesma lei. Por exemplo, apesar de a Lei das S.A. dar a entender que a opção de compra, uma vez exercida, gera uma obrigação de emissão de novas ações - ao prever, v.g., que elas serão outorgadas no limite do capital autorizado -, aproximando o instrumento a um bônus de subscrição, a verdade é que eles são instrumentos bastante distintos. A opção de compra opera no âmbito do mercado secundário das ações, enquanto o bônus de subscrição necessariamente implicará a subscrição (e não a "compra") de novas ações. Assim, exercida a opção de compra, a companhia será obrigada a vender ao titular da opção as suas próprias ações.

Adicionalmente, em que pese o silêncio da Lei das S.A., entendemos ser plenamente possível que uma companhia participe do mercado de opções de suas ações também de maneira desvinculada dos planos de opção estipulados no art. $168, \S^{\circ}$, podendo, igualmente, valer-se de qualquer tipo de opção disponível no mercado financeiro (não apenas as de compra referidas na lei), como: (i) lançando opções de venda, (ii) adquirindo opções de compra, ou (iii) adquirindo opções de venda de suas ações. Todas essas modalidades poderiam ser consideradas no contexto do mercado de opções 
referenciadas em ações próprias da companhia. No caso previsto na Lei das S.A. (lançamento de opção de compra) e na situação (iii) acima (aquisição de opção de venda), a companhia figurará na ponta de alienante de suas ações próprias, e, nos casos (i) e (ii) deste parágrafo, ela figurará como adquirente de suas ações.

As opções ganham relevância dentro do contexto de nosso estudo por força da peculiaridade de seu objeto mediato, que são as ações de emissão da própria companhia que com elas negocia. A presença desse elemento atrai a aplicação da disciplina especial atinente à fattispecie abstrata individualizada pelo art. 30 da Lei das S.A., uma vez que a tutela dos interesses dos grupos de referência, almejada pela lei, faz-se presente nestes negócios, de forma marcante. Silvia Vanoni assim se manifesta sobre a interação do instituto geral dos negócios com as próprias ações com os contratos derivativos (referindose exatamente às opções): “(...) la disciplina stabilita dagli artt. 2357 ss c.c. impone all'interprete, ogni volta che afronta um simile contratto, di verificare se le sue caratteristiche tipologiche elo la sua ratio non richiedano un'applicazione, paziale o integrale, estensiva o analogica, della regola prevista espressamente per diverse tipologie di operazioni su azioni proprie, ${ }^{, 528}$.

O grande desafio nestas estruturas contratuais (que fique claro: muitas das discussões que teremos neste item podem e devem, em larga medida, ser aplicadas também em outras modalidades de derivativos, como os swaps) é o de entender em que ponto temporal estarão sendo ameaçados os interesses dos grupos de referência. Em que momento, à vista disso, deverá encontrar aplicação o art. 30 da Lei das S.A.: no momento da contratação da operação ou no momento de sua liquidação? Quais critérios e condicionantes devem ser aplicados: todos ou apenas alguns?

Cabe aqui uma exploração minuciosa da Instrução CVM n. ${ }^{\circ} 390$, de 8 de julho de 2003 (“Instrução CVM 390”), que regula, no âmbito das companhias abertas, justamente a negociação com opções referenciadas em ações de sua emissão. Essa norma permite que uma companhia aberta negocie opções de compra e/ou de venda (como adquirente ou lançadora) referenciadas em ações de sua emissão, para fins de cancelamento, manutenção em tesouraria ou alienação, abarcando, portanto, a hipótese do plano de opções prevista na Lei das S.A.

$\mathrm{O}$ artigo $3^{\circ}$ dessa instrução traça um paralelo entre os negócios realizados diretamente com ações próprias e aqueles realizados por meio destes derivativos, ao

\footnotetext{
${ }^{528}$ Silvia Vanoni, Contratti Derivativi su Azioni Proprie: Profili di Disciplina Societaria, in Rivista delle Società, Vol. 49, n. ${ }^{\circ}$ 2/3, março-junho de 2004, p. 459.
} 
estabelecer que o total das ações em tesouraria determinado na Instrução CVM 10 inclui aquelas ações que a companhia poderia vir a adquirir mediante o exercício, por si ou pelas contrapartes, de opções de compra ou de venda (art. $\left.3^{\circ}, \mathrm{I}\right)$. Além disso, também obriga que os negócios com opções sejam realizados em bolsa, tal qual determina a Instrução CVM 10 em relação aos negócios à vista, mas permite os negócios privados no caso de opções outorgadas no contexto do já mencionado artigo $168, \S 3^{\circ}$, da Lei das S.A. (art. $3^{\circ}$, II) - ou seja, a companhia pode alienar privadamente ações em tesouraria no caso de exercício das opções de compra por parte dos seus titulares sem precisar de manifestação favorável da CVM (como pareceria indicar a leitura simples do art. 23 da Instrução CVM 10) ${ }^{529}$ e sem observância das regras de insider trading estipuladas na Instrução CVM 358, como se disse.

Para mais, a Instrução CVM 390 condiciona os negócios da companhia com opções de suas ações que lhe imponham uma potencial obrigação de venda futura (lançamento de opções de compra e aquisições de opções de venda) a serem lastreados, necessariamente, em ações em tesouraria (art. $3^{\circ}, \mathrm{V}$ ). Ela evita, com isso, assumir os riscos de alta na cotação de suas ações (ao tê-las encarteiradas desde o início) e de falta de liquidez para a sua compra no momento em que as opções são exercidas - situações que poderiam deixá-la inadimplente em suas obrigações. Já o artigo $3^{\circ}, \S 2^{\circ}$, condiciona a liquidação física das opções à existência de saldo de lucros ou reservas disponíveis constantes do último balanço aprovado, em valor suficiente para fazer frente à operação - entenda-se bem: este requisito aplica-se apenas aos casos em que a companhia deva adquirir suas ações, pois, aí sim, tanto a Lei das S.A., quanto a Instrução CVM 10, exigem a utilização do saldo de lucros e reservas. Por fim, a norma também detalha a contabilização dos prêmios pagos e recebidos pelos negócios com opções, na forma do seu art. $5^{\circ}$ : similarmente ao que ocorre com as ações à vista, os prêmios e resultados decorrentes das opções transitam apenas em contas de patrimônio líquido, nunca em resultado do exercício.

A norma da CVM é bastante esclarecedora em determinados aspectos. Passemos a explorar mais a fundo alguns deles.

\footnotetext{
${ }^{529}$ O que, diga-se de passagem, não dependia da determinação da Instrução CVM 390, dado que o art. 13, $\S 6^{\circ}$, da Instrução CVM 358 já continha previsão em idêntico sentido. A CVM, ainda assim, já se manifestou, em diversos casos, no sentido da desnecessidade do pedido de aprovação prévia nessas situações, conforme, por exemplo: (i) MEMO/SEP/GEA-1/008/2005, Processo CVM RJ-2004-7408, de 19 de janeiro de 2005 (Unibanco - União de Bancos Brasileiros S.A.), e (ii) Processo CVM RJ 2002-3764, de 10 de outubro de 2002 (Santista Têxtil S.A.), ainda antes da publicação da Instrução CVM 390, mas já antevendo que a autorização prévia ali buscada passaria a ser desnecessária.
} 
Primeiro, por considerar que toda vez que a companhia assumir a obrigação de comprar ações próprias por meio de opções, deverá ela levar em conta, objetivamente, todas as acões potencialmente resultantes do exercício da opcão para o cálculo do seu limite de $\mathbf{1 0 \%}$, cuja observação lhe é mandatória pela Instrução CVM 10; não importa, para estes fins, se a opção será ou não efetivamente exercida, nem qual a probabilidade de que isso ocorra. Existe uma discussão bastante fértil no âmbito financeiro sobre como deve ser calculada a exposição real do titular de uma opção ao ativo por ela referenciado. Ocorre que, tendo em vista o prazo da opção e o seu preço de exercício vis-à-vis o preço à vista daquele mesmo ativo objeto, o valor intrínsesco de uma opção pode variar bastante, o que é refletido na teoria das finanças com base no conceito de exposição efetiva ao ativo subjacente. Exemplificamos com dados numéricos: a companhia aberta $\mathrm{ABC}$ possui ações cotadas à vista a R \$10,00, no dia D0. Se uma pessoa decidir adquirir uma opção de compra de ações da companhia ABC no dia D-1, para exercê-la no dia D0, é intuitivo imaginar que uma tal opção, cujo preço de exercício seja de $\mathrm{R} \$ 5,00$, estará cotada a um altíssimo preço (i.e. o prêmio necessário para sua aquisição será alto); por outro lado, uma opção, cujo preço de exercício seja de $\mathrm{R} \$ 15,00$, terá valor próximo de zero. Qual a razão da discrepância? Essa substancial diferença assenta no fato de que a primeira dará o direito de adquirir ações da $\mathrm{ABC}$ no dia $\mathrm{D} 0$ pelo preço de $\mathrm{R} \$ 5,00$, enquanto o seu preço à vista é de $\mathrm{R}$ \$10,00: a proximidade do prazo de exercício e a certeza de que ele será possível (e, muito provavelmente, rentável) fazem com que a exposição real à ação $\mathrm{ABC}$, correspondente à titularidade da opção $\mathrm{ABC}$, equivalha a $100 \%$ do número de ações que a opção dá direito de adquirir. Já a segunda opção certamente não será exercida, pois o preço de exercício está acima do disponível à vista (seria antieconômico o exercício, uma vez que o titular da opção preferiria adquirir as ações no mercado, ao invés de exercer o seu direito) e, assim, a exposição real à ação $\mathrm{ABC}$, correspondente à titularidade dessa opção, equivalerá a $0 \%$ do número de ações que a opção dá direito de adquirir - a pessoa detém a opção de comprar as ações ABC, mas como ela nunca a exercerá, a sua exposição real (para fins financeiros, ao menos) é zero.

A orientação da CVM, neste quesito, é incontornável: consideram-se incluídas no limite de $10 \%$ todas as ações a que o derivativo daria direito, se exercido - adotou-se a lógica da "exposição jurídica" e não econômica. O motivo para a imposição desta regra, ao que nos parece, está na função dada ao limite de 10\%. Como já se disse, não se pode resumir a sua utilidade à proteção dos credores: a imposição de um número máximo de ações que podem estar em tesouraria, atrelado à inclusão nesse percentual de ações que 
possam potencialmente ser adquiridas no futuro, tem por escopo a tutela, precipuamente, do mercado de capitais. Ao impor um limite quantitativo de ações, a CVM limita, também, a capacidade de a companhia utilizar as opções como forma de manipular o mercado. $\mathrm{O}$ raciocínio implícito a essa norma é que a aquisição de opções de compra (que geram o direito de adquirir ações no futuro) pela companhia têm efeitos por si só, independentemente do seu exercício efetivamente ocorrer - daí remonta a necessidade de aplicação de algumas das regras do regime geral das ações próprias de antemão, i.e., mesmo que as ações ainda não estejam em poder da companhia. No caso da imposição da regra dos $10 \%$, evita-se a manipulação de $\operatorname{preços}^{530}$ : “[s]imile contratto, se praticabile in assenza di qualunque limitazione in ordine alla quantità di azioni che il beneficiario delle call avrà diritto di acquistare e al loro prezzo, constituirebbe strumento principe di manipulazione dei mercati finanziari. Posta tale constatazione, non sembra azzardato dedurne che le disposizioni dell'art. 2357 ss c.c., attraverso le quali è posto un limite al numero [o limite de $10 \%$ - na Itália, 20\%] e al prezzo [saldo de lucros e reservas] delle azioni proprie oggeto di acquisto, possano fungere da barriere volte ad impedire che $i$ contratti di acquisto di call options siano impiegati per il predetto fine illecito della manipolazione delle azioni sottostanti".

$\mathrm{O}$ segundo aspecto interessante está intimamente relacionado à discussão acima. Se a norma exige que a companhia compute no seu limite de $10 \%$ aquelas ações que potencialmente venha a adquirir em decorrência das opções, deveria o inverso ser verdadeiro? Ou seja, deveria a companhia computar a sua exposição "negativa", decorrente das ações que potencialmente venha a alienar, como não incluídas dentro do limite? A lógica meramente econômica diria que sim, as ações em tesouraria que sejam lastro de opções de venda lançadas ou opções de compra adquiridas pela companhia deveriam ser descontadas do limite, de forma coerente com a exigência em sentido contrário. Duvida-se seriamente que a CVM tenha um entendimento neste sentido, considerando que a sua preocupação com a detenção de ações em tesouraria é muito maior do que com sua alienação; considerações e decisões valorativas de cunho jurídico serão aptas a desequilibrar a lógica econômica que imporia tratamento idêntico para as duas situações. Portanto, apesar de reconhecermos a utilização de dois pesos e duas medidas, as ações que venham a ser potencialmente adquiridas em decorrência de opções devem ser computadas para o limite, mas as ações que sejam potencialmente alienadas (e que estejam em

\footnotetext{
${ }^{530}$ Cf. Silvia Vanoni, op. cit., p. 472.
} 
tesouraria), não: estas devem continuar sendo consideradas como em tesouraria até a sua efetiva alienação.

Em terceiro lugar, a Instrução CVM 390 veda que a opção possa ser exercida em outra data que não aquela expressamente prevista para seu exercício (art. $3^{\circ}$, IV). Existem, genericamente, duas modalidades de opções no mercado: uma, que permite seu exercício a qualquer momento entre a data de lançamento e a data final de vencimento opções do tipo "americana" - e, outra, em que o exercício pode ocorrer unicamente na data de vencimento estabelecida - opções "europeias", como se sói chamá-las. No caso da Instrução CVM 390, o propósito da norma em não permitir que o exercício pelo seu titular possa ser feito antes da data de vencimento estipulada, ao que nos parece, é impedir, de um lado que, pelo seu exercício a qualquer tempo, se pudesse causar prejuízo à companhia, "fazendo com que a aparência de justiça e adequada formação do preço na venda ou na compra de uma opção fosse superada pela antecipação dos resultados por uma das partes" ${ }^{, 531}$; de outro lado, a norma também impede que a própria companhia possa valer-se de informação privilegiada ou de interesses manipulativos na negociação de suas ações: em havendo discricionariedade total sobre o momento do exercício, ela teria incentivos para estruturar negócios de caráter contundentemente especulativos.

Outro debate interessante decorre do disposto no artigo $3^{\circ}, \S 2^{\circ}$, da norma em comento, que condiciona a liquidação física das opções à existência de saldo de lucros ou reservas disponíveis constantes do último balanço aprovado, em valor suficiente para fazer frente à operação. Existem aí dois pensamentos implícitos: (i) o primeiro, é o de que o interesse pela tutela da integridade do capital social surge apenas no momento da efetiva aquisição das ações (mediante liquidação física da opção), e não no momento da contratação da operação, e (ii) o segundo é que as opções que prevejam liquidação pela diferença - comumente chamadas de "com liquidação financeira" - não ensejam preocupações quanto à eventual ameaça ao interesse dos credores (afinal, a redação da norma é claríssima ao condicionar a existência do saldo de lucros apenas no caso de "liquidação física das opções"). Testemos tais premissas.

A primeira delas é a de que o interesse pela integridade do capital ocorre apenas no momento da aquisição efetiva das ações, uma vez que é nesse momento que haverá desembolso pela companhia. Essa premissa não é inteiramente verdadeira, dado que a

\footnotetext{
${ }^{531}$ Declaração de Voto do Diretor Marcelo Trindade no âmbito do pedido de autorização para negociação privada de suas ações pela então denominada Companhia Vale do Rio Doce - CVRD, julgado em 14 de junho de 2007, Reg. 5522/07.
} 
companhia que compra opções de compra, por exemplo, paga um prêmio por elas no momento de sua aquisição: o prêmio desembolsado não deveria integrar a avaliação sobre a integridade do capital social? Dito de outra forma, o princípio da integridade do capital social não deveria ser observado permanentemente, ao invés de ser previsto apenas na liquidação do contrato?

Na nossa visão, erra a CVM ao estipular que a verificação da existência do saldo de lucros deve ocorrer apenas no momento da liquidação da opção, pois, em primeiro lugar, o prêmio pago pela companhia deveria fazer parte do "custo global" da recompra - afinal, foi o seu pagamento que permitiu à companhia ter o direito de adquirir suas ações no futuro. Em segundo lugar, entendemos, data venia, não ser ideal esta estipulação, considerando que é de interesse do mercado que haja limites de volume e preço dentro dos quais a companhia pode negociar com opções referenciadas em suas ações: a condição de validade, consubstanciada na utilização de saldo de lucros, tem, no âmbito do mercado de capitais, esta consequência acidental (além da imediata tutela dos credores). Não nos parece justificado permitir que a companhia negocie as opções, na data da sua contratação, sem ter qualquer limite de valor (apenas de volume - uma vez que as ações potencialmente adquiridas em decorrência das opções devem ser computadas nos 10\%). A posição mais conservadora seria a de exigir a observância a essa regra tanto no momento da contratação quanto no momento da liquidação; nesta última hipótese como condição do exercício da opção ${ }^{532}$.

A segunda premissa do art. $3^{\circ}, \S 2^{\circ}$, da Instrução CVM 390 é o de que as opções com liquidação exclusivamente financeira (obtida pela diferença entre o preço de aquisição prevista na opção e o preço de mercado na data do exercício) não põem em risco a integridade do capital social. No caso de uma aquisição de opção de compra pela companhia, por exemplo, o valor da liquidação será sempre um valor a receber estabelecido a seu favor, já que ela não teria exercido a opção se o preço de mercado da ação estivesse abaixo daquele estipulado na opção. O "preço da ação", nestes contratos, é um valor de mera referência, não sendo a vontade das partes que haja efetiva transferência de ações para a tesouraria da companhia. Está plenamente justificada, portanto, a escolha de não se sujeitar algumas modalidades de opções com liquidação financeira ao requisito da existência de saldo de lucros. Explica-se: se a companhia adquire uma opção de compra

532 "Si deve quindi ritenere che, al momento dell'acquisto delle call options, il costo globale dell'operazione di acquisto di azioni proprie prospettata non debba superare l'ammontare degli utili distribuibili e delle riserve disponibili della società risultanti dall'ultimo bilancio regolarmente approvato, nell'interesse di um equilibrato andamento del mercato in cui sono negoziate le azioni stesse”. Cf. Silvia Vanoni, op. cit., p. 474. 
de suas próprias ações (com liquidação apenas financeira), sabe-se, de antemão, o maior valor colocado em risco, que é justamente o valor do prêmio pago. A menos que a companhia tome uma decisão antieconômica, a opção apenas será exercida quando lhe for conveniente, ou seja, quando ela tiver uma diferença em dinheiro a receber (e não a pagar $)^{533}$. Em outras modalidades de opção de liquidação financeira, por outro lado, o raciocínio é distinto: com o lançamento, pela companhia, de uma opção de venda de suas próprias ações (que a obrigue a adquirí-las do titular a preço determinado), por exemplo, o potencial desembolso futuro da companhia não pode ser calculado com precisão. Não há uma maneira única de regular este complexo assunto: os interesses dos grupos de referência manifestam-se em momentos e formas distintas em cada uma das estruturas, de modo que cumprirá sempre ao intérprete a realização do exercício que fizemos neste item, a fim de julgar a licitude de uma opção referenciada em ações próprias ${ }^{534}$.

Por fim, uma última dúvida interessante que se coloca é a de como identificar a existência de uma opção em determinados negócios jurídicos. Uma vez identificada, sobre ela recairão todos os requisitos da Instrução CVM 390, mas, caso contrário, terá aplicação apenas a Instrução CVM 10. No dia 14 de junho de 2007, por exemplo, o Colegiado da CVM apreciou um pedido de autorização para negociação privada de ações formulado pela então denominada Companhia Vale do Rio Doce - CVRD, no contexto da emissão, por uma sua subsidiária no exterior, de títulos conversíveis em certificados de depósito de ações (American Depositary Receipts - ADR) lastreados em papeis da CVRD. Ou seja, a subsidiária da CVRD emitiu títulos conversíveis que, grosso modo, obrigavam os seus titulares a converter tais créditos em ADRs lastreados em ações da CVRD. Como forma de proteger essa subsidiária da CVRD em decorrência da obrigação contratual assumida por ela de entregar esses ADRs, a CVRD alienaria privadamente (o que, como se afirmou, não é permitido genericamente pela Instrução CVM 10) suas ações mantidas em tesouraria para a sua subsidiária, que, então, ficaria protegida na ocasião da conversão dos títulos. Neste caso, o Diretor Marcelo Trindade corretamente observou que a natureza da obrigação assumida pela CVRD em favor da sua subsidiária poderia configurar o negócio jurídico como uma "opção" ou como uma "promessa de compra e venda futura", atraindo a aplicação de normas diversas em cada circunstância: "[a] promessa unilateral de venda,

\footnotetext{
533 "Di conseguenza, nell'ottica della tutela degli interessi societari, il limite dei mezzi propri disponibili riveste scarsa rilevanza, quando l'operazione ha una impostazione esclusivamente finanziaria". Cf. Silvia Vanoni, op. cit., p. 481.

${ }^{534}$ Para uma análise bastante detalhada sobre os contratos derivativos e o regime das ações próprias, cf. Silvia Vanoni, op. cit., especialmente pp. 458 e ss.
} 
pela CVRD à Vale Sub [a subsidiária emitente], das ações que se obrigará a entregar no futuro, para que a Vale Sub possa honrar o compromisso assumido quando emitir os Conversíveis no exterior, constitui, induvidosamente, a concessão de uma opção de compra à Vale Sub, o que atrairia a incidência da Instrução 390/03. Se o negócio vier ser estruturado como uma promessa de compra e venda (e portanto promessa bilateral) poder-se-ia discutir se a norma a incidir seria a Instrução 10/80 (que trata da compra e da venda de ações da própria emissão)”. Ao final, o Colegiado acompanhou a declaração de voto do Diretor Marcelo Trindade, apenas informando que a CVRD deveria, no momento da concretização da operação, definir se ela seria desenhada para enquadramento na Instrução CVM 10 ou na Instrução CVM 390.

\section{$\underline{\text { Swaps de Taxa de Retorno Total }}$}

Na revista Capital Aberto de maio de 2013 foi publicada uma reportagem tratando exatamente da existência de publicações de fatos relevantes pelas companhias abertas informando o mercado sobre a existência de contratos derivativos por elas celebrados com bancos, tendo por ativo de referência as suas próprias ações. No Brasil, a forma mais comum de utilização de swaps como forma de criar uma exposição sintética (pois artificial) às próprias ações é a contratação, privada, de um contrato denominado de Swap

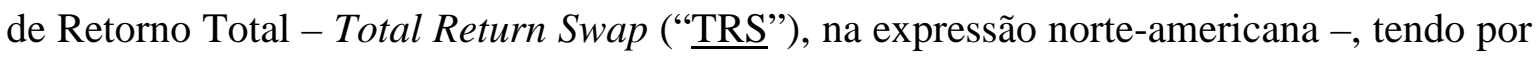
ativo subjacente as ações de emissão da companhia contratante (self-referencing).

Os TRS são genericamente definidos pelo art. $1^{\circ}, \S 3^{\circ}$, I, da Resolução do Conselho Monetário Nacional n. ${ }^{\circ}$ 2.933, de 28 de fevereiro de 2002 ("Resolução 2.933/02”) como "contratos onde as partes negociam o risco de crédito de operações, sem implicar, no ato da contratação, a transferência do ativo subjacente às referidas operações"; a mesma norma estipula, no inciso seguinte, quais os ativos subjacentes passíveis de serem referenciados no derivativo, incluindo, genericamente, os valores mobiliários. Nessa estrutura contratual, uma parte transfere o risco do ativo subjacente referenciado (adquirindo, portanto, proteção contra ele) à outra parte, que o assume (e fornece, consequentemente, a proteção). A parte receptora do risco, em virtude de sua posição contratual, se compromete a ressarcir a parte transferidora na ocorrência de determinados eventos (comumente denominados de "eventos de crédito"), em troca de remuneração. Especificamente, a Circular do Banco Central do Brasil n. ${ }^{\circ} 3.106$, de 10 de abril de 2002 caracteriza o TRS como o contrato no qual a "contraparte receptora do risco for remunerada com base no fluxo de recebimento de 
encargos e de contraprestações vinculados ao ativo subjacente". Estas referências têm por intuito apenas esclarecer a natureza do contrato, uma vez que essas normas do CMN e do Banco Central do Brasil não se aplicam quando o ativo subjacente é uma ação, pois, muito embora sejam valores mobiliários abrangidos pelo art. $1^{\circ}, \S 3^{\circ}$, II, da Resolução 2.933/02, não se pode falar tecnicamente em "risco de crédito" de uma ação - fala-se, notadamente, em risco de mercado.

Assumindo a contratação de um TRS, conforme definido acima, tendo por ativo subjacente uma ação, a análise da estrutura obrigacional decorrente do contrato no contexto de uma recompra de ações seria a seguinte: de um lado, um banco se compromete a repassar à companhia contratante o fluxo financeiro total gerado pelas ações de sua própria emissão, incluindo quaisquer direitos econômicos distribuídos - como dividendos e juros sobre o capital próprio -, e o valor da oscilação das ações em si, em troca de uma taxa de juros - esta última é a remuneração do banco. De forma a se proteger de seu risco, o banco irá, usualmente (mas não obrigatoriamente), comprar as ações subjacentes no mercado à vista (hedge) - assumiremos, para fins de exposição, que o banco contratante sempre adquirirá montante suficiente das ações subjacentes ao TRS para proteger-se de seu risco de mercado. Releva observar que essa é uma das possíveis estruturas envolvendo o TRS (que configura espécie do gênero "swap de ações"), o que certamente não impede a sua configuração com outros contornos. Por exemplo, no parecer já anteriormente citado, de autoria do Prof. José Alexandre Tavares Guerreiro ${ }^{535}$, foi avaliado também um contrato de swap referenciado em ações de emissão de uma das partes contratantes, mas o seu objeto de referência era apenas e tão somente o valor de mercado delas, não as suas distribuições econômicas (ou seja, não era o contrato enquadrado como um swap de "taxa de retorno total", mas, ainda assim, inegevalmente configurava um swap referenciado em ações) - nesse caso, uma vez definido um valor de mercado base para as ações, uma parte, a companhia emissora, comprometeu-se a pagar à outra (o acionista contratante) a diferença a menor entre o valor de mercado das ações à vista e um determinando valor total que as ações deveriam representar; já o acionista pagaria o valor que superasse o que ele teria direito a receber.

Esses contratos geram uma série de dúvidas ${ }^{536}$ : (1) em que medida esse instrumento deve ser computado para o cálculo do limite de $10 \%$ de cada classe ou espécie

\footnotetext{
${ }^{535}$ Cf. José Alexandre Tavares Guerreiro, Contratos Coligados..., cit., pp. 371 e ss.

${ }^{536}$ Muitas das quais já foram tangenciadas no item relacionado às opções. Com efeito, todos os derivativos referenciados em ações de emissão da companhia-contratante possuem elementos comuns que os unem.
} 
de ações imposto pela Instrução CVM 10, uma vez que a companhia não adquiriu nenhuma ação (ao menos na origem do contrato)? (2) Deveria ser aplicável o regime jurídico das ações em tesouraria àquelas ações adquiridas pelo banco como proteção de sua posição contratual? (3) Seria possível suspender o direito de voto e os direitos econômicos de uma ação que, formalmente, não pertence à companhia, mas, sim, ao banco? (4) Poderia (ou deveria) ser controlado o exercício do direito de voto dessas ações, considerando eventual influência da própria companhia na definição desse voto em assembleia? (5) Devem os contratos que tenham previsão de liquidação exclusivamente financeira (i.e. contratos nos quais a companhia não receberá, ao final do prazo, as ações "fisicamente", mas receberá, ou pagará, tão-só um valor financeiro, por diferença), ser submetidos ao seu regime jurídico? (6) Como devem ser verificados os critérios de precificação "justa" destes derivativos, tendo em vista a (já estudada) discussão sobre o preço das ações nestes negócios? (7) Quando deverá ser medida a disponibilidade de lucros ou reserva de lucros que possibilite a contratação do derivativo - na sua contratação ou na sua liquidação? E ainda: qual o valor de lucros a ser exigido? (8) Por serem negócios essencialmente privados, deveriam submeter-se à assembleia geral, conforme se defendeu acima? Seria isso eficiente, dada a complexidade do instrumento e o relativo desinteresse dos acionistas $?^{537}$. Procuraremos responder a pelo menos algumas dessas perguntas adiante.

Em 23 de junho de 2009, o Colegiado da CVM se deparou, pela primeira vez, com um caso envolvendo esses intrumentos ${ }^{538}$. Uma subsidiária estrangeira da Companhia Siderúrgica Nacional (CSN) havia contratado com uma instituição financeira no exterior um total return equity swap, por meio do qual ela pagaria ao banco uma taxa de juros e, em contrapartida, ficaria exposta à variação da cotação de certificados de depósito lastreados em ações de emissão da CSN. Perto do vencimento do contrato de swap (que se daria em setembro de 2009), a CSN procurou a CVM para solicitar que ela própria pudesse adquirir as ações que a instituição financeira havia comprado como forma de proteção contratual, de maneira privada e sem a observância do limite de 10\% imposto pela Instrução CVM 10. Caso o contrato simplesmente chegasse a seu termo final, a instituição financeira iria, muito provavelmente, desfazer-se das ações, por meio de sua venda no mercado à vista, gerando uma corrente de oferta e um possível impacto negativo em seu preço. Por

\footnotetext{
${ }^{537}$ Note-se que muitas dessas dúvidas, em verdade, aplicam-se a outros tipos de derivativos igualmente. Ilustre-se: a problemática do critério de verificação temporal da existência de saldo de lucros ocorre também nas opções (i.e. o saldo de lucros deve ser verificado no momento da contratação ou do exercício da opção?).

${ }^{538}$ Processo Administrativo CVM RJ-2009-5962.
} 
maioria $^{539}$, o colegiado da CVM acatou os pedidos da CSN, mas a decisão não abriu precedentes quanto à estruturação dos derivativos com ações próprias para fins da Instrução CVM 10, uma vez que o contrato derivativo do caso CSN não foi submetido em sua contratação à apreciação do Colegiado - apenas no momento do seu vencimento.

Em 05 de abril de 2011, o Colegiado da CVM apreciou outro pedido de natureza semelhante, desta vez da Braskem S.A. ("Braskem") ${ }^{540}$, que desejava obter autorização da CVM para contratar um swap com uma instituição financeira, tendo como ativo subjacente as suas próprias ações: este caso, sim, pode nos oferecer maiores subsídios de análise. Nos moldes do pedido da Braskem, tal contrato de swap estabeleceria a obrigação de o banco comprar as ações à vista, transferindo todo o risco de mercado delas advindo para a Braskem, por meio do contrato derivativo. Ao final do prazo contratual, a Braskem adquiriria do banco as ações que ele havia comprado ("liquidação física"), pelo preço médio de aquisição das ações pelo banco, acrescido dos emolumentos de bolsa e da remuneração pactuada no swap. A estrutura do caso Braskem facilita a visualização de alguns dos problemas a serem enfrentados neste tipo de discussão. Por exemplo, segundo o relatório do caso: (i) a companhia e o banco confeririam às ações a serem adquiridas o mesmo tratamento que seria conferido caso as ações fossem recompradas diretamente pela Braskem, (ii) no vencimento do contrato, a Braskem compraria do banco apenas as ações para as quais seu saldo de lucros e reservas fosse suficiente - as demais seriam alienadas diretamente em bolsa, (iii) a quantidade de ações detidas pela Braskem, somada àquelas que o banco adquirisse nos termos do contrato de swap, não excederia o limite de $10 \%$ (dez por cento) das ações de mesma classe e espécie em circulação, conforme exigência da Instrução CVM 10, (iv) as compras realizadas pelo banco seriam feitas a preços de mercado, em bolsa, (v) o banco não adquiriria ações não integralizadas, nem pertencentes ao acionista controlador, (vi) o banco não adquiriria ações caso estivesse em curso oferta pública de aquisição das ações da Braskem. Todos esses itens visavam, basicamente, a demonstrar à CVM que o banco, contraparte da Braskem, atuaria nesse caso como longa manus da própria Braskem, e que, por isso mesmo, sujeitar-se-ia aos mesmos requisitos e assumiria as mesmas obrigações que a ela seriam impostas pela regulação.

Em adição a isso, o banco: (i) assumiria a obrigação contratual de não exercer o direito de voto das ações, (ii) renunciaria ao direito de recebimento de dividendos no caso

\footnotetext{
${ }^{539}$ Votaram a favor os diretores Marcos Barbosa Pinto, Eliseu Martins e Maria Helena Santana. Vencidos os diretores Otávio Yazbek e Eli Loria.

${ }^{540}$ Processo Administrativo CVM RJ2010-14060.
} 
concreto, caso fossem distribuídos no período em que ele fosse titular das ações, (iii) renunciaria ao valor a que faria jus caso houvesse uma redução de capital no período. Por fim, a Braskem se comprometeu a dar ampla visibilidade à estrutura, por meio de inclusão de uma descrição detalhada em seu Formulário de Referência e nas suas demonstrações financeiras.

A Diretora Luciana Dias, relatora do processo, analisou a situação precipuamente sob o ponto de vista da manipulação de mercado e do tratamento equitativo entre acionistas, concluindo que a operação poderia ser realizada como proposta, desde que submetida à transparência perante o mercado. A Braskem, recentemente, renovou o seu programa com base nesse contrato de swap, conforme reunião do Colegiado de 31 de julho de $2012^{541}$.

O que se pode depreender desse caso? Analisem-se alguns itens específicos.

Volta-se a atenção, em primeiro lugar, para o seguinte: como se relatou acima, as partes do negócio pretenderam conferir às ações adquiridas pelo banco o mesmo tratamento que a elas seria dado caso tivessem sido recompradas diretamente pela Braskem. Ou seja, foram estabelecidas contratualmente diversas restrições peculiares, a permitirem que, em conjunto, se simulasse uma ação em tesouraria. Assim ocorreu, v.g., quando o banco se comprometeu a não exercer o seu direito de voto e, igualmente, a renunciar aos direitos econômicos que a ele eventualmente viessem a ser distribuídos (dividendos, redução de capital). Ressalte-se, novamente, que este arranjo foi contratual houve aplicação voluntária de parte do regime jurídico das ações em tesouraria.

Entretanto, a CVM, a nosso entender, não teria competência para regular alguns desses pontos da forma como o fizeram as partes. Para citar dois exemplos, igualmente os mais óbvios, entendemos que ela jamais poderia, regulatoriamente, suspender o direito de voto das ações adquiridas pelo banco, pela simples razão de que a Lei das S.A. não o faz. A lei suspende o direito de voto das ações de que seja titular a companhia, não um terceiro; por se tratar de norma restritiva de direito, entendo que não caberia qualquer interpretação extensiva ou analógica: a CVM não poderia retirar o voto dessas ações. Até porque, ela sequer tem competência para tanto, bastando ler a redação do art. 30, §2, da Lei das S.A. (que já estudamos), em conjunto com aquela do art. 22, $§ 1^{\circ}$, III, da Lei 6.385/76: se há discussão acerca da competência da CVM para regular os direitos das ações em tesouraria, dúvida não resta de que ela não tem essa competência para as demais ações da companhia

\footnotetext{
${ }^{541}$ Processo CVM RJ-2012-8129.
} 
- e as de titularidade da contraparte no derivativo são comuns. O argumento é inabalável e vale com ainda mais veemência em relação aos direitos de participação nos lucros (como o dividendo) que, em nenhuma hipótese, sob pena de manifesta ilegalidade, poderiam ser excluídos dessas ações pela CVM, nos exatos termos do art. 109, I, da Lei das S.A. - que encontra uma exceção legal, confirmando a regra, no artigo $30,4^{\circ}$.

Ainda sobre o caso: no vencimento do contrato, a Braskem compraria do banco apenas as ações para as quais seu saldo de lucros e reservas fosse suficiente - as demais seriam alienadas diretamente em bolsa. Ou seja, as partes definiram que a verificação do requisito da disponibilidade de saldo de lucros e reservas (que protege o capital social nominal e os credores, como se viu) seria feita no momento do vencimento contratual, não na data de sua contratação. Ora, quer-nos parecer que a melhor saída, nestes casos, seria a verificação apenas no momento da contratação da operação, e não no futuro. Muito embora se possa argumentar que a ausência de lucros no momento do adimplemento do contrato (mediante compra das ações) possa prejudicar os credores, parece-nos ainda mais temerário abrir o caminho para a insegurança jurídica decorrente do desconhecimento da situação financeira futura dessa companhia. Todavia, não podemos adotar uma interpretação extrema de acordo com a qual a liquidação do contrato derivativo permitisse um cabal descumprimento de lei imperativa, mesmo que em nome da segurança jurídica. É cediço que a segurança jurídica, neste caso, interessa apenas à contraparte contratual da companhia; perante o universo dos demais credores, no entanto, interessa a integridade do capital social. Acreditamos que a saída ideal, que concilia ambos esses problemas, seria obtida por meio da conjugação de duas regras. Em primeiro lugar, poder-se-ia determinar a verificação da existência do saldo de lucros tão-só no momento da contratação da operação - tutelando, aí, a segurança jurídica necessária na estrutura contratual. Em segundo lugar, poder-se-ia estipular que as ações adquiridas em decorrência do cumprimento contratual sejam mandatoriamente alienadas dentro de um prazo estabelecido, quando tiverem sido adquiridas em contrariedade ao princípio da integridade do capital social - protegendo, então, a integridade do capital.

Por último, o caso mostrou que a quantidade de ações que fosse adquirida pelo banco seria somada às ações em tesouraria já detidas pela Braskem para fins de observância do limite de 10\%, conforme exigência da Instrução CVM 10. Esta solução parece-nos bastante acertada e passível de acolhimento regulatório. Como a companhia, no caso, adquiriria as ações do banco "in natura" na data futura, nada mais transparente, para fins de política regulatória e tendo em mente as funções da Instrução CVM 10, que elas 
fossem consideradas para fins de referido limite. A existência do liame jurídico que obrigará a companhia a adquirir essas ações no futuro permite essa interpretação.

Ocorre que essas análises, ainda que extremamente proveitosas, não esgotaram os problemas.

Em primeiro lugar, porque nem todos os direitos econômicos e políticos foram regulados no contrato, se não vejamos: (i) convencionou-se acerca da renúncia aos dividendos declarados, tratamento divergente do estipulado pela Lei das S.A., que dessas ações retira o dividendo, fazendo aumentar os direitos econômicos das demais em valor proporcional. No caso da Braskem, com a renúncia do banco aos dividendos, seriam eles distribuídos aos demais acionistas, ou mantidos pela companhia? Provavelmente retornariam ao caixa da companhia; (ii) em caso de liquidação da companhia, o que ocorreria com essas ações?; (iii) ainda que essas ações tenham integrado o cálculo dos $10 \%$ na contabilidade da Braskem, como foi compatibilizada a contabilidade do derivativo com a contabilidade das ações próprias? Como compatibilizar e harmonizar todos estes problemas?

É importante examinarmos o assunto também pela ótica do regulador. Afinal, por qual razão é tão importante que ele regule os contratos derivativos dentro do contexto das operações com ações próprias? Em primeiro lugar, como se mencionou, a contraparte da companhia no derivativo normalmente será uma instituição financeira que, com quase absoluta certeza, irá adquirir as ações no mercado à vista como forma de proteção de sua exposição. Diz a CVM no Edital de Audiência Pública n. ${ }^{\circ}$ 11/13, da Superintendência de Desenvolvimento com o Mercado da CVM, publicado em 30 de outubro de 2013 ("Edital”): "os efeitos da celebração desses derivativos costumam ser muito similares aos verificados quando a própria companhia emissora adquire tais ações”, pois os efeitos dessa operação sobre o percentual de ações em circulação e sobre a formação da vontade política da companhia são similares aos produzidos pela recompra, o que justificaria o mesmo tratamento para ambas as situações.

Não são, portanto, necessariamente considerações acerca da intangibilidade do capital social que norteiam esta nova fase da regulação, mas, em maior grau, considerações de mercado que permeiam o pensamento: o "enxugamento" artificial da liquidez das ações, o exercício disfarçado do poder político pela companhia (por meio de sua contraparte - 
shadow voting) e a criação de acionistas que, apesar de formalmente titulares das ações, não têm interesse econômico algum na atividade da companhia emissora ${ }^{542}$.

\subsubsection{Fundos de Investimento e Fundos de Índice}

Qual a disciplina aplicável às ações próprias adquiridas por meio de fundos de investimento de que seja cotista a companhia emissora? É esse o objeto deste item.

Como a esta altura já foi exaustivamente visto, a companhia aberta ${ }^{543}$ não pode negociar com as suas ações exceto nos termos em que lhe permite a Instrução CVM 10, que lhe impede de fazê-lo direta ou indiretamente (art. $2^{\circ}$ ). Interpretando essa ampla restrição de acordo com a Lei das S.A., poder-se-ia concluir que o termo "indiretamente" utilizado pela CVM refere-se às operações feitas por controladas ou coligadas da companhia com as ações do capital de sua controladora ou investidora, cf. art. 244 da Lei das S.A. A lei, com efeito, regula as aquisições feitas diretamente pela companhia e aquelas realizadas indiretamente por meio de suas controladas e coligadas. Pois bem, assumindo, então, que a regra da Instrução CVM 10, nesse ponto, tenha adotado o conceito do art. 244 da Lei das S.A.: "indiretamente" significa uma restrição para a companhia negociar suas próprias ações por meio de suas controladas e coligadas.

Poderiam as aquisições de ações realizadas por fundos de investimento de que seja cotista a companhia ser vistas, na perspectiva da Instrução CVM 10, como uma aquisição "indireta" dessas ações pela companhia? Esta pergunta é extremamente traiçoeira e de difícil resposta, pois envolve a avaliação acerca de qual a natureza dos fundos de investimento e se eles podem ser equiparados, para estes fins, a uma controlada ou coligada da companhia - enquadrando-se, dessa maneira, à norma como se a interpretou anteriormente. As regras de funcionamento dos fundos de investimento podem levar o intérprete, por vezes, à conclusão de atribuir-lhes um caráter associativo - equiparando-os às sociedades -, apesar de a regulação defini-los como condomínios especiais.

Precisará ser discutida, igualmente, a situação de um fundo de investimento exclusivo, aquele que é destinado a ter apenas um quotista (nos termos da definição contida no art. 111-A da Instrução CVM 409, de 18 de agosto de 2004 - “Instrução CVM

${ }^{542}$ Cf. Henry T.C. Hu e Bernard Black, The New Vote Buying: Empty Voting and Hidden (Morphable) Ownership, in Southern California Law Review, Vol. 79, N. 4, 2006, pp. 811 e ss. e, dos mesmos autores, Equity and Debt Decoupling and Empty Voting II: Importance and Extensions, in University of Pennsylvania Law Review, Vol. 156, N. 3, 2008, pp. 625 e ss.

${ }^{543}$ Discorreremos apenas sobre as companhias abertas, tendo em vista que os fundos de investimento são, em sua maioria, proibidos de deterem ações de companhias fechadas, exceção feita aos Fundos de Investimento em Participação. Dessa forma, o tema não lhes é de relevância prática. 
409”). Qualquer que seja a conclusão a que se chegue quanto aos fundos de investimento em geral, pode-se estender o entendimento aos fundos exclusivos, considerando que estes tem a companhia emissora como quotista única?

A terceira indagação relaciona-se aos fundos de investimento negociados na bolsa de valores, os Exchange Traded Funds ou ETFs, notadamente aqueles cujo objeto seja o investimento em uma carteira teórica de ações que vise a replicar um determinado índice de ações - por essa razão denominados de "fundos de índice". Aprofundemos a questão.

Existem fundos na BVMF, atualmente, que têm este objeto, como é o caso do ETF negociado sob o código BOVA11, cujo objeto é o investimento em ações que replique a composição do índice Ibovespa. Este índice resulta da variação de uma carteira teórica de ações, elaborada de acordo com os critérios estabelecidos pela BVMF em manual próprio, cujo objetivo é ser o indicador do desempenho médio das cotações das ações de maior negociabilidade e representatividade do mercado de ações brasileiro ${ }^{544}$. O Ibovespa é composto unicamente por ações de companhias abertas brasileiras que atendam a certos critérios de inclusão determinados pela BVMF: a companhia é passiva nessa escolha, em nenhuma momento sua vontade ou concordância é necessária para que ela passe a compor a carteira do índice.

Se uma companhia aberta passa a integrar a carteira teórica do índice Ibovespa, cuja rentabilidade é almejada pelo ETF, o que ocorre quando ela adquire quotas de tal ETF na bolsa? Exemplificamos: uma determinada companhia atinge todos os critérios de elegibilidade da BVMF e compõe a carteria teórica do Ibovespa com um peso de $20 \%$ do total. O ETF, que visa a refletir a rentabilidade do índice, estará obrigado, por regulamento, a deter uma carteira de ações em que as dessa companhia representem esses mesmos $20 \%$ (em uma carteira de 100 ações, 20 devem ser da companhia do exemplo). Caso a companhia viesse a adquirir 50\% das quotas do ETF, qual seria a solução regulatória dada, no que diz respeito ao regime das ações próprias? Deteria ela, "indiretamente", $10 \%$ de suas próprias ações, considerando a composição subjacente da carteira do ETF? A solução seria diferente se esses percentuais fossem alterados - menor participação da companhia nas quotas do ETF e/ou maior peso das ações na composição do índice?

O primeiro passo a ser tomado na busca dessas respostas é descobrir se, de forma geral, a aquisição de ações por meio de fundos de investimento pode ser subsumida à regra de negociação "indireta” estabelecida na Instrução CVM 10: essa avaliação será feita sob a

544 Cf. Metodologia do Índice Ibovespa, Outubro de 2013, disponível na página da rede mundial de computadores da BVMF. 
perspectiva da sua natureza. A Instrução CVM 409 (art. $2^{\circ}$ ) classifica os fundos de investimento como uma comunhão de recursos constituída sob a forma de condomínio. Em verdade, de há muito se controverte sobre a sua natureza jurídica, tendo a doutrina se dividido entre os que viam nele um condomínio efetivamente e aqueles que viam nessas estruturas uma espécie de sociedade ${ }^{545}$. Seja como for, condomínio ou sociedade, poder-seia reduzi-lo, ou equipará-lo, ao conceito de "controlada" ou "coligada" para fins da aplicação do conceito de negócios indiretos com as próprias ações? Ou os negócios indiretos previstos na Instrução CVM 10 independem dessa conceituação e aplicam-se de forma irrestrita?

Temos para nós que seria absolutamente irrazoável a CVM exigir que qualquer estrutura de fundo de investimento que invista em ações possa ser enquadrada como um negócio "realizado indiretamente" por seus quotistas, para fins das normas da Instrução CVM 10. O fundamento para essa conclusão não se encontra na ausência de influência dos quotistas na decisão de investimento do fundo (que é de responsabilidade exclusiva do seu gestor/administrador), eis que em uma sociedade anônima, como regra, os acionistas tampouco possuem tal influência - tanto os gestores do fundo, quanto os administradores da companhia, agem na qualidade de detentores de deveres fiduciários perante os proprietários do patrimônio. O ponto não é este: o argumento é o de que a Instrução CVM 10 não pode adotar uma interpretação muito mais ampla do que a dada pela Lei das S.A.: esta veda os negócios diretos e aqueles realizados indiretamente por meio de coligadas e controladas, apenas, e não de qualquer investida da companhia. Se a interpretação da Instrução CVM 10, no que diz respeito a este quesito, fosse estendida para qualquer participação da companhia, em outras sociedades ou em fundos de investimento, estar-seia indo muito além do que o que pró́be a Lei das S.A.; adentrar-se-ia na seara da irrazoabilidade, pois a propriedade de uma só ação de outra sociedade ou de uma única quota de um fundo de investimento em ações, resultaria em que a companhia precisasse

\footnotetext{
${ }^{545}$ Classificando-os como sociedades: Carlos Fulgêncio da Cunha Peixoto, Sociedades..., Vol. 1, cit., p. 146. Para uma análise profunda das distinções entre sociedade e condomínio ou comunhão, cf. Erasmo Valladão Azevedo e Novaes França, Natureza Jurídica dos Fundos de Investimento, in Temas de Direito Societário..., cit., pp. 187 a 191, citando a primorosa e sempre precisa lição de Ferri, para o qual a distinção está em que, nas sociedades, os bens estão em função da atividade, enquanto no condomínio, a atividade está em função do bem e da sua fruição: "na sociedade a atividade é o 'prius', enquanto na comunhão o 'prius' é o bem". Idem, ibidem, p. 190, grifos do original. O Prof. Erasmo Valladão também defende, nesse parecer, a natureza societária dos fundos de investimento, que têm na sua atividade de investimento, e não nos bens investidos, o seu prius. Idem, Ibidem, p. 192. Para uma análise aprofundada sobre as teses acerca da natureza dos fundos, citando bibliografia, cf. Ricardo de Santos Freitas, Natureza Jurídica dos Fundos de Investimento, Quartier Latin, São Paulo, 2006, pp. 139 e ss.
} 
monitorar diariamente todo o patrimônio social da sociedade ou do fundo investidos, para averiguar a detenção de suas ações nas carteiras respectivas.

Essa interpretação beira o absurdo, pois esse controle é impraticável de maneira eficaz para as companhias, mormente as que investem seu patrimônio em quotas de fundos de investimento. Inclusive, o patrimônio dos fundos de ações regulados pela Instrução CVM 409 sequer é disponibilizado de maneira diária para os quotistas: nos termos do art. 71, II, "b", a divulgação da composição da carteira do fundo é obrigatória em periodicidade, no mínimo, mensal. A situação fica ainda mais grave quando se imaginam fundos que invistam em quotas de outros fundos de investimento.

Temos como mais adequada a interpretação de que os negócios "indiretos" a que faz referência a Instrução CVM 10 devam ser entendidos, no que diz respeito à indústria de fundos de investimento regidos pela Instrução CVM 409, de acordo com o conceito previsto no art. $20, \S 1^{\circ}$, da Instrução CVM 358, que assim reza: "não se consideram negociações indiretas aquelas realizadas por fundos de investimento de que sejam cotistas as pessoas mencionadas nesta Instrução, desde que tais fundos não sejam exclusivos, nem as decisões de negociação do administrador possam ser influenciadas pelos cotistas" - grifos nossos. Ou seja, nenhuma aquisição de ações de emissão de qualquer quotista de um fundo de investimento, realizada por este no escopo de seu objeto, deve ser categorizada como uma forma subreptícia de negociação indireta por esse quotista-emissor, para todos os fins da Instrução CVM $10^{546}$, exceto se tal fundo for exclusivo dele ou tiver suas decisões de investimento "influenciadas" por ele expressão ampla, cuja ocorrência poderá ser avaliada em cada caso concreto. Não há falarse em conceito de controle ou coligamento no caso de fundos de investimento, por sua diversa natureza, de forma que o mencionado artigo atende bem aos anseios da Instrução CVM 10 - que a ele deveria fazer expressa referência.

É difícil conseguir elaborar critérios uniformes de categorização de fundos, a ponto de se que possa fazer uma análise abrangente dos impactos do regime das próprias ações em cada categoria. São tantas as formas, tão numerosas as opções de estruturação, que é virtualmente impossível abarcarmos todas as hipóteses. O que nos parece de importância inegável é que todos os fundos de investimento possuem um caráter instrumental, de forma que a sua estruturação e configuração concretas (não teóricas) é que dão a

\footnotetext{
${ }^{546}$ Aliás, entendemos que não só para fins da Instrução CVM 10, mas também da Instrução CVM 358 (de onde o conceito deriva). Não há, assim, que falar-se em insider trading por negócios realizados por intermédio de fundos de investimento, a menos que sejam exclusivos ou influenciados pelos quotistas, pois, exceto nos dois últimos casos, não há como encontrarmos um elemento volitivo na companhia "adquirente".
} 
melhor base para aferir a existência da "influência do cotista" para fins desta interpretação: é evidente que um fundo de investimento no qual a companhia invista seu patrimônio a título de investimento financeiro, sem sequer interessar-se pela composição da sua carteira, não poderá ser considerado um veículo de fraude à lei, ou de negócio indireto da companhia com suas próprias ações, mesmo que ela detenha um alto percentual das suas quotas. Já aqueles fundos em que um cotista, mesmo com reduzida participação percentual, detenha influência significativa na decisão dos investimentos (por meio de um comitê de investimentos, por exemplo), poderão estar abrangidos pela exegese proposta.

Os únicos fundos que não põem dúvidas de interpretação, portanto, são os exclusivos. Por serem destinados a receber aplicações de um único quotista, a norma presume que os negócios realizados pelos fundos exclusivos são realizados indiretamente pelo próprio quotista único, exegese absolutamente razoável e da qual não vemos como discordar. Seria um absurdo indesculpável permitir-se que a compra de ações de uma companhia aberta não pudesse ser feita por ela diretamente (por qualquer razão), mas pudesse ser realizada por um fundo do qual ela é a única quotista - estaria aberta a porta para as fraudes.

Ressalte-se um ponto importante. Quando defendemos que o critério previsto na Instrução CVM 358 deva ser aplicado, estamos nos referindo à lógica da Instrução CVM 10. Com efeito, quer isso significar que, na nossa visão, não há como justificar a não aplicação das regras prescritivas desta última instrução aos fundos que detenham como único quotista a companhia emissora, ainda que ela não detenha poder de influência sobre a gestão: a lógica do "poder de influência" liga-se mais às regras de prevenção do insider trading do que às regras da Instrução CVM 10, para as quais a efetiva influência da companhia-quotista é irrelevante, bastando que o efeito patrimonial esteja presente ${ }^{547}$. Em outras palavras, as ações adquiridas por esse fundo exclusivo, v.g., passarão a contar para o limite de $10 \%$ da companhia, etc.

Por derradeiro, enfrentaremos em breves linhas o problema dos fundos de índice. Nos termos do art. $2^{\circ}$ da Instrução CVM 359, de 22 de janeiro de 2002, um ETF é "uma comunhão de recursos destinada à aplicação em carteira de ativos financeiros que vise refletir as variações e rentabilidade de um índice de referência, por prazo indeterminado". 95\% da carteira desses fundos deve obrigatoriamente estar investida em ativos financeiros que integrem o índice de referência (ou em futuros desses ativos), como as ações que

\footnotetext{
${ }^{547}$ Traça-se o corte epistemológico, no entanto, nos fundos exclusivos, pelos motivos já expostos.
} 
compõem o Ibovespa. Quanto a estes fundos, entendemos que a utilização do conceito do art. $20, \S 1^{\circ}$, da Instrução CVM 358 também é útil. Até porque eles normalmente são destinados a muitos investidores e constituem somente uma forma eficiente de investimento na carteira teórica completa do Ibovespa (ao invés de adquirirem cada ação do índice, os investidores adquirem apenas as quotas do ETF, que o replica). Portanto, independentemente do peso que determinada companhia possua no índice de ações que o ETF visa a replicar, o investimento por companhias abertas nesses ETFs não deve ser computado para fins da Instrução CVM 10, a menos que eles sejam exclusivos. Sequer cabe, neste caso, a hipótese da "influência do quotista", uma vez que um ETF tem sua política de investimento previamente determinada por força regulatória: ele é obrigado a deter em carteira os ativos que sejam necessários para replicar o retorno do índice que mimetiza - é praticamente impossível haver influência do cotista nessa gestão. 


\section{CONCLUSÃO}

A análise da função que os institutos jurídicos concretamente desempenham em um dado momento histórico faz possível a identificação - como notava Carbonetti, com fulcro em Ascarelli ${ }^{548}$ - de "institutos progressivos e regressivos", em desenvolvimento ou em decadência; institutos cuja utilização é intensificada, encontrando novas funções, e aqueles que gradativamente perdem espaço no ambiente empresarial. Entre as matérias "progressivas", no sentido dado a essa expressão, encontra-se notadamente a dos negócios da companhia com suas ações.

Depois de quase 40 anos de sua entrada em vigor, a Lei das S.A. ainda não sofreu nenhuma reforma no regime jurídico estatuído em 1976 para as negociações com as próprias ações. Tampouco a CVM tinha manifestado interesse em reformular a disciplina regulatória contida na antiga Instrução CVM 10. Ocorre que há um irrefutável movimento prático e doutrinário em torno da matéria, o que se verifica pelas constantes alterações que vem sofrendo do ponto de vista legal em vários países.

Desde a edição da primeira lei que tratou do tema, em 1870, houve um quase inacreditável desenvolvimento teórico, que possibilitou uma cada vez maior flexibilidade nos regimes jurídicos restritivos. Assim, acrescentaram-se, aos poucos, numerosas exceções à proibição originalmente absoluta. A Alemanha foi, e continua sendo em certa medida, o país de liderança na matéria: mesmo a Aktienrechtsnovelle de 1870 merece aplausos por de ter sido a primeira norma a ter reconhecido a existência de um problema inerente a esses negócios - o capital social, e o interesse dos credores, aparecem como primeiro grupo de referência a que se devia proteger.

A regulação das ações próprias constitui, verdadeiramente, a história de um problema, marcada muitas vezes por vontades políticas oriundas da necessidade de se apaziguarem ou controlarem os efeitos de escândalos envolvendo tais negócios. Assim ocorreu, por exemplo, na Alemanha de 1930: com a economia ainda devastada pela Primeira Guerra Mundial, viu suas companhias industriais e financeiras mergulharem em desastrosa crise; muitas delas apelando à bancarrota em curtíssimo espaço de tempo. Averiguando-se os fundamentos da crise, revelaram-se os nefastos usos das ações próprias e propagou-se sua natureza diabólica: o tema ganhou as ruas e bradava-se que o regime em vigor era então muito leniente e permissivo. Positivou o então presidente Hindenburg a Notveordnung de 1931, norma de cunho evidentemente emergencial e de motivação

\footnotetext{
${ }^{548}$ Cf. Francesco Carbonetti, Acquisto di Azioni Proprie e Patrimonio..., cit., p. 1120.
} 
manifestamente política - até hoje é essa reforma legal que dita o núcleo básico da regulação do tema na Alemanha.

Partindo do problema fundamental de escudar o interesse dos credores sociais, o século XX testemunhou o descobrimento de vários outros; passaram a ser dignos de tutela jurídica pelo direito societário os interesses dos credores, dos acionistas e dos investidores do mercado. Debruçaram-se sobre os interesses desses grupos de referência tanto juristas quanto financistas; os primeiros, buscando cunhar teorias e mecanismos jurídicos cada vez mais complexos de controle da liberdade da companhia; os segundos, estudando os impactos de sua utilização no gerenciamento das finanças sociais (strumento utile di finanza aziendale ${ }^{549}$ ), argumentando em favor de sua desburocratização.

Da estigmatização passou-se então à racionalização.

Ao estudar o seu plano de ação para os anos que se seguiriam, por exemplo, a União Europeia, berço da teoria do capital social como se a conhece em todo o mundo jurídico de tradição continental, chegou até mesmo a tangenciar a possibilidade de substituição do capital social como fundamento do regime de vedação! Cogitou-se, à época, introduzir o conceito dos testes de solvência de origem norte-americana (muito embora o estudo não tenha sido concluído e o regime ainda permaneça vinculado ao capital social). A racionalização moderna do instituto é tamanha que até mesmo o legislador comunitário europeu está aberto à ideia de reavaliar o regime do capital como fundamento proibitivo, abalando o núcleo duro do pensamento histórico do tema desde o século XIX. Nos EUA, a SEC constantemente busca aprimorar as suas regras, tendo sua última audiência pública (ainda não transformada em regra) sido feita em 2010 - há apenas 4 anos. Entre os anos de 2006 e 2010, houve na Inglaterra e na Itália semelhante movimento de atualização normativa.

Não passou desapercebido do regulador brasileiro a necessidade de enfrentar a dura tarefa de atualização das normas que regem os negócios com as próprias ações. Como falamos, passados mais de 20 anos da edição da Instrução CVM 10 - tendo sofrido apenas alterações pontuais nesse período -, a CVM colocou em audiência pública uma minuta de instrução que a revogará, substituindo-a por outra de cunho mais moderno.

A minuta de nova instrução prevista no Edital de Audiência Pública SDM n. ${ }^{\circ}$ 11/13 acerta mais do que erra.

${ }^{549}$ Cf. Barbara Pozzo, op. cit., p. 7. 
Sem pretendermos esgotar os temas ali previstos, acerta ao sugerir a inclusão de uma seção inteira dedicada à criação de "presunções de regularidade" (art. 10) nos negócios da anônima com suas ações, sob a perspectiva da manipulação de mercado, nos termos efetuados nos EUA pela Rule 10b-18 - assunto hoje virtualmente não regulado pela CVM. Ainda que se possa argumentar que a utilização de presunções como política regulatória não é frequente no Brasil, enxergamos com bons olhos a sua adoção - ao menos do ponto de vista probatório haverá claro benefício às companhias (seria prudente, por outro lado, dada a novidade dessa forma de regulação, que a CVM esclarecesse a forma de atuação da presunção - esclarecimentos estes que poderiam ter o teor que já mencionamos ao longo do trabalho). Acerta, igualmente: (i) ao colocar fim à discussão sobre a possibilidade de bonificação e desdobramento de ações em tesouraria, corretamente passando a permiti-las (art. $9^{\circ}, \S 1^{\circ}$, I e II), (ii) ao esclarecer o momento da verificação de existência de saldo de lucros e reservas disponíveis para a aquisição (art. $6^{\circ}, \S \S^{\circ}$ e $4^{\circ}$ ), prescrevendo, inclusive, que sua insuficiência não poderá ser alegada pela companhia para adimplir obrigações de liquidação futura que tenha contraído e (Art. $6^{\circ}, \S 5^{\circ}$ ), (iii) ao retirar a bizarra necessidade de submissão dos negócios privados à prévia aprovação da CVM, passando a remetê-los, em alguns casos, à assembleia geral (art. $3^{\circ}$ ).

Erra gravemente, entretanto, ao pretender retirar o voto das ações adquiridas pelas contrapartes da companhia em contratos derivativos referenciados em suas ações e com ela firmados - como já defendemos, a CVM não possui competência para regular o voto de ações comuns, como nitidamente são essas.

Inova, por final, ao criar um complexo e fragmentado sistema de controle do apreçamento das ações próprias (Art. $3^{\circ}, \S 5^{\circ}$ ) no contexto de derivativos. Não temos como afirmar, de antemão, se a solução proposta será adequada aos anseios do mercado. No entanto, parece-nos que a solução proposta, por mais que seja coerente de um ponto de vista de estratégia normativa, é demasiadamente prolixa para que possa gerar a segurança jurídica pretendida. Com efeito, imaginamos ser muito improvável que a CVM consiga regular o preço de derivativos sob a fórmula de "uma regra para todos", dada a inegável presença de milhares de estruturas possíveis.

Tudo visto, é forçoso aplaudir a CVM pelo louvável esforço empreendido na elaboração dessa minuta de instrução; quando positivada, certamente contribuirá para o aprimoramento do mercado de capitais brasileiro.

Por final, do ponto de vista geral, talvez a única conclusão digna de ser repetida neste capítulo é a de que os negócios com ações próprias passem a ser estudados na 
perspectiva das suas condições de validade. Tais condições de validade estão espelhadas nas três colunas de proteção aos grupos de referência de que falamos no decorrer de nosso estudo. Em primeiro lugar, a existência das regras de utilização de lucros e reservas disponíveis e dos critérios de contabilidade das ações próprias, como se viu, evita que negócios com as mesmas possam prejudicar o interesse dos credores. Em segundo lugar, o atendimento ao princípio do tratamento igualitário dos acionistas - por meio de incentivos à participação mais direta (em maior ou menor medida) da assembleia geral de acionistas no processo decisório relativo a tais negócios -, aliado ao regime protetivo do conflito de interesses e do abuso do poder de controle e ao tratamento dos cálculos de quóruns, já garantem uma forma efetiva de proteção dos acionistas. Por último, as regras da CVM sobre manipulação de mercado, transparência e insider trading (além das normas específicas sobre os negócios com as próprias ações pelas companhias abertas) garantem a proteção dos interesses dos investidores e do mercado de capitais.

Atendidas a todas as finalidades perseguidas por essa rede de normas protetivas, não visualizamos razão coerente para vedar qualquer tipo de negócio da companhia com as próprias ações: precisa-se abraçar de vez a racionalização do instituto, abandonando o entendimento acerca do caráter taxativo das exceções previstas no art. 30 da Lei das S.A.

Concordando com Ascarelli, concluímos que o exame de toda e qualquer disposição acerca das sociedades anônimas - e, por conseguinte, da Lei das S.A. - deve ser feito livre de preconceitos, uma vez que os usos e abusos perpetrados por seu intermédio são congênitos à sua própria existência. As anônimas podem representar tanto progressos quanto crises, dependendo do uso que delas se faça ${ }^{550}$. Daí não poder ser acolhida como política legislativa a tendência de adoção de restrições graves em decorrência da máutilização, por poucos, de um instituto que é útil a muitos.

Terminamos, assim, reproduzindo uma máxima proferida por Clodomir Cardoso (na nossa visão, a pessoa que mais se aprofundou no estudo destes negócios no Brasil, depois de Philomeno J. da Costa) ao apresentar à Câmara dos Deputados seu primeiro projeto de lei sobre as sociedades por ações, em 1928: “das leis de sociedades anonymas, tem-se ditto que envelhecem depressa" 551 .

\footnotetext{
${ }^{550}$ Cf. José Luiz Bulhões Pedreira e Alfredo Lamy Filho (coords.), Direito das Companhias, cit., p. 8. Cf. também Luiz Antônio Sampaio Campos, Algumas Notas sobre a Utilização do Lucro do Exercício em Curso: Dividendo e Recompra, in Marcelo Vieira von Adamek (coord.), Temas de Direito Societário..., cit., p. 418.

${ }^{551}$ Cf. Clodomir Cardoso, op. cit., p. 59.
} 


\section{BIBLIOGRAFIA}

1. ADAMEK, Marcelo Vieira von. Abuso de Minoria em Direito Societário (Abuso das Posições Subjetivas Minoritárias), Tese (Doutorado em Direito), Faculdade de Direito da Universidade de São Paulo, 2010.

2. ADESSI, G. Acquisto di Azioni Proprie: Per Conto di Chi?, in Rivista delle Società, Vol. 29, n. ${ }^{\circ}$ 3, maio-junho de 1984, pp. 437 a 466.

3. AKHTAR, Shamshad. Demutualization of Stock Exchanges - Problems, Solutions and Case Studies, publication n. ${ }^{\circ}$ 100602, Asia Development Bank, 2002.

4. ALBANESE, Antonio. Operazioni Sulle Azioni Proprie (e Leveraged Buy Out) nel Nuovo Diritto Societario, in Contratto e Impresa - Dialoghi com La Giurisprudenza Civile e Commerciale, Vol. 23, n. ${ }^{\circ}$, Cedam, 2007, pp. 353 a 386.

5. ANDREWS, William D. The Stockholders' Right to Equal Opportunity in the Sale of Shares, Harvard Law Review, Vol. 78, N. ${ }^{\circ}$ 3, 1965, pp. 505 a 563.

6. ARANGIO-RUIZ, Vincenzo. La Società in Diritto Romano. Napoli: Dott. Eugenio Jovene, 1982.

Eugenio Jovene, 2006.

Instituzioni di Diritto Romano. 14 ed. Napoli: Dott.

7. ARMOUR, John. Legal Capital: An Outdated Concept? Centre for Business Research, University of Cambridge, Working Paper n. ${ }^{\circ} 320$, Março de 2006.

8. ASCARELLI, Tullio. Problemas das Sociedades Anônimas e Direito Comparado, Bookseller, Campinas, 2001.

. Corso di Diritto Commerciale, $3^{\text {a }}$ Ed., Giuffrè, Milão, 1962.

. Problemi Giuridici, vol. 1, Giuffrè, Milão, 1959.

. Saggi di Diritto Commerciale, Giuffrè, MIlão, 1955.

. Studi in Tema di Società, Giuffrè, Milão, 1952.

. Panorama do Direito Comercial, $2^{\mathrm{a}}$ ed., Minelli, Sorocaba,

2007.

9. ASSMAN, Hans Dieter, et. Al. Übernahmeangebote, in Zeitschrift für Unternehmens- und Gesellschaftsrecht, Sonderheft 9, de Gruyter, Berlin, 1990.

Gesellschaftsrecht - Die privatrechtlichen

Ordnungstrukturen und Regelungsprobleme von Verbänden und Unternehmen, $6^{\mathrm{a}}$ ed., C.F. Müller, Heidelberg, 2006.

10. ASQUINI, Alberto, Profili dell'impresa, in Rivista Del Diritto Commerciale, 1943, v. 41, I, in COMPARATO, Fábio Konder (trad.), Revista de Direito Mercantil, Industrial, Econômico e Financeiro, Malheiros, São Paulo, n 104.

11. BAUERMEISTER, Livinston M. Aquisição das Próprias Ações pela Companhia Emissora, Dissertação (Mestrado em Direito), Pós-Graduação em Direito da Pontifícia Universidade de São Paulo - PUC-SP, 2008. 
12. BEBCHUCK, Lucian Arye. The Pressure to Tender: An Analysis and a Proposed Remedy, Delaware Journal of Corporate Law, Vol. 12, pp. 911-949, 1987, disponível em http://ssrn.com/abstract=480301.

. Efficient and Inneficient Sales of Corporate Control, The Quarterly Journal of Economics, novembro de 1994, pp 957 a 966, disponível em http://www.law.harvard.edu/faculty/bebchuk/pdfs/qje.94.pdf.

13. BERTINI, Alessandro. Contributo allo Studio dello Situazioni Giuridiche degli Azionisti, Giuffrè, Milão, 1951.

14. BIERMAN JR. Harold e WEST, Richard. The Acquisition of Common Stock by the Corporate Issuer, in The Journal of Finance, Vol. 21, N. ${ }^{\circ}$ 4, 1966, pp. 687 a 696.

15. BLACKSTOCK, Leo G. A Corporation's Power To Purchase Its Own Stock and Some Related Problems, in Texas Law Review, Vol. 13, 1934/1935.

16. BODIE, Svi; KANE, Alex e MARCUS, Alan J. Investments, $6^{\mathrm{a}}$ ed., McGraw-Hill, New York, 2005.

17. BRUDNEY, Victor. Equal Treatment of Shareholders in Corporate Distributions and Reorganizations, California Law Review, Vol. 71, N. ${ }^{\circ}$ 4, 1983, pp. 1073 a 1133.

18. BUCK-HEEB, Petra, Kapitalmarktrecht, C.F. Muller, Heidelberg, München, Landsberg, Berlin, 2006.

19. BULGARELli, Waldirio. Manual das Sociedades Anônimas, $5^{\mathrm{a}}$ Ed., Atlas, São Paulo, 1988.

Direito Comercial, $8^{a}$ ed., Atlas, São Paulo, 1991.

20. BULHÕES, Carlos Eduardo. Opiniões Jurídicas, Forense, Rio de Janeiro, 2002.

21. BULHÕES PEDREIRA, José Luiz. Finanças e Demonstrações Financeiras da Companhia (Conceitos Fundamentais), Forense, Rio de Janeiro, 1989.

22. BULHÕES PEDREIRA, José Luiz; LAMY FILHO, Alfredo. A Lei das S.A., Renovar, Rio de Janeiro, 1992.

Forense, Rio de Janeiro, 2009.

(coords.). Direito das Companhias, 2 volumes,

23. BRADLEY, Michael e ROSENZWEIG, Michael. Defensive Stock Repurchases, in Harvard Law Review, Vol. 99, 1986.

24. BRADLEY, Michael e WAKEMAN, L. Macdonald. The Wealth Effects of Targeted Share Repurchases, Journal of Financial Economics, Vol. 11, pp. 301 a 328.

25. BRANDÃO LOPES, Mauro. Aquisição das Cotas Sociais pela Sociedade, in Revista de Direito Mercantil, Industrial, Econômico e Financeiro n. ${ }^{\circ}$ 25, RT, São Paulo, 1977.

26. CAHN, Andreas. Die Auswirkungen der Kapitaländerungsrichtlinie auf den Erwerb Eigener Aktien, in Institue for Law and Finance Working Paper 61, Goethe Universität, Frankfurt, 2007.

27. CAMPOS BATALHA, Wilson de Souza. Comentários à Lei de Sociedades Anônimas, vol. 1, Forense, Rio de Janeiro, 1977. 
28. CAMUZZI, Scotti. Acquisto delle Proprie Azioni, Utile e Utile d'Esercizio, in Rivista delle Società, Vol. 15, n. ${ }^{\circ}$ 3/4, 1970, pp. 617 a 658.

Acquisto delle Proprie Azioni e Diritti delle Azionisti, in Rivista delle Società, Vol. 18, n. ${ }^{\circ} 1 / 2,1973$, pp. 1 a 60.

29. CARBONETTI, Francesco. Acquisto di Azioni Proprie e Insider Trading, in Rivista delle Società, Vol. 34, n. ${ }^{\circ}$ 5, setembro-outubro de 1989, pp. 1009 a 1025.

Acquisto di Azioni Proprie e Patrimonio Sociale, in Rivista delle Società, Vol. 27, n. ${ }^{\circ}$ 6, novembro-dezembro de 1982, pp. 1120 a 1150.

30. CARCANO, Giuseppe. Acquisto di Azioni Proprie come Tecnica di Difesa dalle Scalate: la CEE Rafforza il Divieto, in Rivista delle Società, Vol. 37, n. ${ }^{\circ}$ 5/6, setembro-dezembro de 1992, pp. 1310 a 1313.

L'Acquisto delle Proprie Azioni in un Libro Verde Britannico, in Rivista delle Società, Vol. 25, n. ${ }^{\circ}$ 6, novembro-dezembro de 1980, pp. 1292 a 1304.

Opa Ostili e Acquisto "Difensivo" di Azioni Proprie negli Stati Uniti, in Rivista delle Società, Vol. 33, n. ${ }^{\circ}$ 5/6, setembro-dezembro de 1988, pp. 1238 a 1266.

31. CARDOSO, Clodomir. Sociedades Anonymas - Projecto Organizado, Imprensa Nacional, Rio de Janeiro, 1932.

32. CARVALHO DE MENDONÇA, José Xavier. Tratado de Direito Comercial Brasileiro, volumes III e IV, $4^{\text {a }}$ Ed., Freitas Bastos, Rio de Janeiro - São Paulo, 1954 e 1946.

33. CARVAlHOSA, Modesto. Comentários à Lei de Sociedades Anônimas, Vol. 1, $5^{\mathrm{a}}$ Ed., São Paulo, Saraiva, 2007.

A Nova Lei das Sociedades Anônimas - Seu Modelo Econômico, Paz e Terra, Rio de Janeiro, 1976.

34. CHEFFINS, Brian R. Company Law, Theory, Structure and Operation, Clarendon Press, Oxford, 1997.

35. CHIOMENTI, Francesco. Può la Società Esercitare per le Azioni Proprie in Portafoglio il Diritto di Opzione su un Aumento di Capitale? in Rivista del Diritto Commerciale, 1980, I, pp. 407 e ss.

36. CHOPER, Jesse H.; EISENBERG, Melvin Aron. Corporations (Gilbert Law Summaries), $15^{\mathrm{a}}$ ed., Thomson, Chicago, 2005.

37. CLARK, Frederick H. Legality of Purchase by a Coporation of its Own Stock, in The American Law Register (1898 - 1907), Vol. 49, N. ${ }^{\circ}$, Vol. 40 New Series, 1901, pp. 398 a 424.

38. CLARK, Robert Charles. Corporate Law, Brown, Boston, 1986.

39. CODORNIZ, Gabriela Bonini. Aquisição por Companhias Abertas de Ações de sua Emissão, Dissertação (Mestrado em Direito), Faculdade de Direito da Universidade de São Paulo, 2013.

40. COFFEE Jr., John C.; KLEIN, William A. Business Organization and Finance: Legal and Economic Principles, Foundation press, New York, 2004. 
41. COLUMBIA LAW REVIEW. Power of a Corporation to Acquire its Own Stock, Vol. 13, n. ${ }^{\circ} 2,1913$.

Corporate Stock Repurchases under the Federal Securities Laws - Notes, Vol. 66, 1966.

42. COMISSÃO DE VALORES MOBILIÁRIOS. Parecer/CVM/SJU/n. ${ }^{\circ} 91$, de 28/12/1982.

43. COMMISSION OF THE EUROPEAN COMMUNITIES. Modernising Company Law and Enhancing Corporate Governance in the European Union - A Plan to Move Forward, Bruxelas, 21 de maio de 2003.

44. COMPARATO, Fábio Konder. Aspectos Jurídicos da Macro-empresa, RT, São Paulo, 1970.

Forense, 1978.

Ensaios e Pareceres de Direito Empresarial,

Empresarial, Forense, 1981.

Novos Ensaios e Pareceres de Direito

Direito Empresarial: Estudos e Pareceres,

Saraiva, 1990.

; SALOMÃO FILHO, Calixto. O Poder de Controle na Sociedade Anônima, $4^{\mathrm{a}}$ Ed., Forense, Rio de Janeiro, 2005.

45. CORREIA, António Ferrer. Estudos Jurídicos II - Direito Civil e Comercial e Direito Criminal, Atlântida, Coimbra, 1969.

46. CORVO, Erick dos Anjos. Resgate de Ações no Direito Brasileiro - As Operações $e$ suas Funções, Dissertação (Mestrado em Direito), Faculdade de Direito da Universidade de São Paulo, 2004.

47. COSTA, Philomeno José da. Operações da Anônima com as Ações de seu Capital, Tese de Cátedra da Faculdade de Direito da Universidade de São Paulo, São Paulo, 1965 .

Tribunais, São Paulo, 1980.

Anotações às Companhias, Vol. 1, Revista dos

48. COUTO SILVA, Alexandre. Direito Societário: Estudos sobre a Lei de Sociedade por Ações, Saraiva, São Paulo, 2013.

49. CRESPI, Alberto. Acquisto di Azioni Proprie e "Bilancio Regolarmente Approvato” ex art. 2357 c.c., in Rivista delle Società, Vol. 34, n. ${ }^{\circ}$ 6, novembrodezembro de 1989, pp. 1169 a 1187.

50. CUNHA PEIXOTO, Carlos Fulgêncio da. Sociedades por Ações, volumes 1 a 5, Saraiva, São Paulo, 1972.

51. DALMARTELLO, Arturo. Conflito di Interessi nell'Acquisto delle Proprie Azioni ex art. 2357 c.c., in Rivista delle Società, 1959, pp. 189 e ss.

Ammissibilità del c.d. "Trading” di Azioni Proprie, in Rivista delle Società, Vol. 28, n. ${ }^{\circ}$ 3, maio-junho de 1983, pp. 649 a 654.

52. DAVIES, Paul L. Gower and Davies' Principles of Modern Company Law, $8^{\mathrm{a}}$ ed., Sweet \& Maxwell, Londres, 2008. 
53. DE PLÁCIDO E SILVA. Noções Práticas de Direito Comercial, $12^{\mathrm{a}}$ ed., Vols. 1 e 2, Forense, Rio de Janeiro, 1965.

54. DEUTSCHER BUNDESTAG. Gesetzentwurf der Bundesregierung - Entwurf eines Geseztes zur Durchführung der Zweiten Richtlinie des Rates der Europäischen Gemeinschaften zur Koodinierung des Gesellschaftsrechts, BTDrucksache 8/1678, 31 de março de 1978.

Entwurf eines Gesetzes für kleine Aktiengesellschaften und zur Deregulierung des Aktienrechts, BT-Drucksache 12/7848, 14 de junho de 1994.

55. DEUTSCHES AKTIENINSTITUT (DAI). Der Erwerb Eigener Aktien in Deutschland - Ergebnisse einer Untersuchung des Deutschen Aktieninstituts zum Rückkauf eigener Aktien durch die Gesellschaft, Frankfurt a.M., junho de 1999.

56. DODD JR., E. Merrick. Purchase and Redemption by a Corporation of its Own Shares: The Substantive Law, in University of Pennsylvania Law Review, Vol. 89, 1941.

57. DOLMETTA, Aldo Angelo. Sulle Conseguenze Civilistiche dell'Acquisto di Azioni Proprie Compiuto in Violazione dei Divieti di Legge, in Rivista delle Società, Vol. 41, n. ${ }^{\circ}$ 2/3, março-junho de 1996, pp. 338 a 367.

58. DOMINGUES, Paulo de Tarso. Do Capital Social: Noção, Princípios e Funções, $2^{\mathrm{a}}$ ed., Coimbra, Coimbra, 2004.

59. DREYFUSS, Gilbert. Distributions to Shareholders under the New California General Corporation Law, in Loyola of Los Angeles Law Review, Vol. 9, 1976.

60. EASTERBROOK, Frank H. e FISCHEL, Daniel R. The Proper Role of a Target's Management in Responding to a Tender Offer, in Harvard Law Review, Vol. 94, 1981.

61. ELLIOT, Jennifer. Demutualization of Securities Exchanges: A Regulatory Perspective, in IMF Working Paper, WP/02/119, 2002, pp. 1-30, 2002. Disponível para consulta em http://ssrn.com/abstract $=879869$.

62. EISENBERG, Melvin Aron. Corporations and Other Business Organizations, Cases and Materials - Concise $8^{\text {th }}$ Edition, Foundation Press, New York, 2000.

63. EIZIRIK, Nelson. Temas de Direito Societário, Renovar, Rio de Janeiro, 2005. São Paulo, 2008.

et al. Mercado de Capitais - Regime Jurídico, $2^{\mathrm{a}}$ ed., Renovar,

64. ENRIQUEST, Luca e MACEY, Jonathan R. Creditors versus Capital Formation: The Case Against the European Legal Capital Rules, Cornell Law Review, vol. 86.

65. FANELLI, G. Le Partecipazioni Sociali Reciproche, Milão, Giuffrè, 1957.

- Il Regime delle Partecipazioni Reciproche e La Nozione di 'Controllo' e di 'Collegamento' fra Società', in Studi in memorio de Tullio Ascarelli, Milão, 1969, vol. 2.

66. FERRAN, Eilís. Principles of Corporate Finance Law, Oxford University Press, New York, 2008.

67. FERREIRA, Waldemar Martins. Tratado de Sociedades Mercantis, 5 volumes, $5^{\text {a }}$ Ed., Ed. Nacional do Direito, Rio de Janeiro, 1958. 
Tribunais, São Paulo, 1938.

Código das Sociedades Comerciais, Revista dos

68. FERRI, Giuseppe. Le Società, $2^{\mathrm{a}}$ Ed. UTET, Turim, 1985.

69. FERRO-LUZZI, Paolo. I Contrati Associativi, $3^{\mathrm{a}}$ Ed., Giuffrè, Milão, 2001.

L'<<Antropofagia $>>$ Societaria; Riflessioni sulla Natura e sulle Vicende delle Azioni Proprie in Portafoglio, in Rivista delle Società, Vol. 46, n. 5, setembro-outubro 2001, pp. 1276 a 1291.

70. FLUME, Werner. Allgemeiner Teil des Bürgelichen Rechts, vol. 1, Springer, Berlin Heidelberg New York London Paris Tokyo Hong Kong Barcelona Budapest, 1977.

Allgemeiner Teil des Bürgelichen Rechts - Das Rechtsgeschäft, vol. 2, Springer, Berlin Heidelberg New York London Paris Tokyo Hong Kong Barcelona Budapest, 1992.

71. FRANÇA, Erasmo Valladão Azevedo e Novaes. Conflito de Interesses nas Assembleias de S.A., Malheiros, São Paulo, 1993. Paulo, 1999.

Invalidade das Deliberações de Assembleia das S.A., Malheiros, São

Lineamentos da Reforma do Direito Societário Italiano em Matéria de Invalidade das Deliberações Assembleares, in Revista de Direito Mercantil, Industrial, Econômico e Financeiro, Malheiros, São Paulo, nº 134.

- Temas de Direito Societário, Falimentar e Teoria da Empresa, Malheiros, São Paulo, 2009.

. (coord.) Direito Societário Contemporâneo I, Quartier Latin, São Paulo, 2009.

72. FREITAS, Ricardo de Santos. Natureza Jurídica dos Fundos de Investimento, Quartier Latin, São Paulo, 2006.

73. FRIED, Jesse M. Insider Signaling and Insider Trading with Repurchase Tender Offers, in University of Chicago Law Review, Vol. 67, 2000.

74. GABRIELLI, Marcio Fernandes e SAITO, Richard. Recompra de Ações: Regulamentação e Proteção dos Minoritários, in Revista de Administração de Empresas, Vol. 44, n. ${ }^{\circ}$, pp. 54 e ss.

75. GADOW, W., HEINICHEN, E., SCHMIDT, Eberhard, SCHMIDT, W., WEIPERT, O., Aktiengesetz Kommentar, Walter de Grunter \& Co, Berlin, 1939.

76. GADOW, W. e HEINICHEN, E. Aktiengesetz Grosskommentar (herausgegeben von Klaus J. Hopt und Herbert Wiedemann), Walter de Gruyter, Berlin, 1993.

77. GALGANO, Francesco. Diritto Privato, 6a Ed., CEDAM, Pádua, 1990. . Il Nuovo Diritto Societário, CEDAM, Pádua, 2003.

; GENGHINI, Riccardo. Il Nuovo Diritto Societário, I (Le nuove società di capitali e cooperative), $3^{\mathrm{a}}$ Ed., CEDAM, Pádua, 2006.

78. GOLDSCHMIDT, Levin. Storia universale del diritto commerciale. Torino: UTET, 1913. 
79. GOLDSTEIN, Elliott. Revision of the Model Business Corporation Act, in Texas Law Review, Vol. 63, 1984/1985.

80. GORGA, Érica. Changing the Paradigm of Stock Ownership from Concentrated towards Dispersed Ownsership? Evidence from Brazil and Consequences for Emerging Markets, Cornell Law School Working Papers, setembro de 2008, disponível em http://ssrn.com/abstract=1121037.

81. GOWER, Laurence C. B. The Purchase by a Company of Its Own Shares - A Consultative Document, Her Majesty`s Stationery Office, Cmnd. 7944, 1980.

82. GRANDE STEVENS, Franzo. Questioni in Tema di Insider Trading e di Compravendita di Azioni Proprie, in Rivista delle Società, Vol. 36, n. 4, 1991, pp. 1006 a 1009.

83. GRÜNEWALD, Barbara. Gesellschaftsrecht, $6^{\mathrm{a}}$ ed., Moh Siebeck, Tübingen, 2005.

84. GUERREIRO, José Alexandre Tavares; TEIXEIRA, Egberto Lacerda. Das Sociedades Anônimas no Direito Brasileiro, 2 volumes, Bushatsky, 1979.

85. GUERREIRO, José Alexandre Tavares. Aquisição de Quotas pela Própria Sociedade, in Revista de Direito Mercantil, Industrial, Econômico e Financeiro, n. ${ }^{\circ}$ 36, RT, São Paulo, 1979.

Negociação com as Próprias Ações e Proibição de Comportamento Contraditório, in Flávio Luiz Yarshell e Guilherme Setoguti J. Pereira (coords.), Processo Societário, Quartier Latin, São Paulo, 2012.

86. HALPERÍN, Isaac. Sociedades Anónimas, Depalma, Buenos Aires, 1975.

87. HARVARD LAW REVIEW. Right of a Corporation to Purchase its Own Stock, Vol. 27, N. ${ }^{\circ} 8,1914$, pp. 747 a 750.

88. HAUSCH, Donald B. e SEWARD, James K. Signaling with Dividends and Share Repurchases: A Choice between Deterministic and Stochastic Cash Disbursements, in The Review of Financial Studies, Vol. 6, N. ${ }^{\circ}$ 1, 1993, pp. 121154.

89. HU, Henry T.C. e BLACK, Bernard. The New Vote Buying: Empty Voting and Hidden (Morphable) Ownership, in Southern California Law Review, Vol. 79, N. 4, 2006.

Equity and Debt Decoupling and Empty Voting II: Importance and Extensions, in University of Pennsylvania Law Review, Vol. 156, N. 3, 2008.

90. HUECK, Alfred. Aktiengesetz von Adolf Baumbach, Beck'sche Kurz-Kommentare, Band 23, Beck, München e Berlin, 1951. Gesellschaftsrecht - Ein Studienbuch, 3 ed., Beck, Munique, 1951.

91. IGLESIAS, Juan. Derecho romano. 15 ed. Barcelona: Ariel, 2007.

92. INGLEZ DE SOUZA, Herculano Marques. Direito Commercial, $4^{\mathrm{a}}$ ed., Companhia Dias Cardoso, Juiz de Fora, 1926.

93. INTERNATIONAL CAPITAL MARKETS ASSOCIATION. European Repo Market Survey - Number 24, December 2012, disponível em www.icmagroup.org. 
94. INTERNATIONAL ORGANIZATION OF SECURITIES COMMISSIONS, Report on "Stock Repurchase Programs", fevereiro de 2004.

95. ISRAELS, Carlos L. Problems of Par and No-Par Shares: A Reappraisal, in Columbia Law Review, Vol. 47, 1947.

Corporate Repurchase of Its Own Shares - Are There New Overtones? in Cornell Law Review, Vol. 50, 1964/1965.

96. IUDÍCIBUS, Sérgio de; MARTINS, Eliseu; GELBCKE, Ernesto Rubens; SANTOS, Ariovaldo dos. Manual de Contabilidade Societària, Atlas, São Paulo, 2010.

97. JUNQUEIRA DE AZEVEDO, Antônio. Negócio Jurídico - Existência, Validade e Eficácia, $2^{a}$ ed., São Paulo, Saraiva, 1986.

98. JUSTO, A. Santos. Direito privado romano - II (direito das obrigações). $2^{\mathrm{a}}$ ed. Coimbra: Coimbra, 2006.

99. KAKANI, Ram Kumar e JOSHI, Tejas. Cross Holding Strategy to Increase Control: Case of the Tata Group, XLRI Jamshedpur School of Management, Working Paper 06-03 (March 2006).

100. KASER, Max. Direito privado romano. Trad. de Samuel Rodrigues e Ferdinand Hämmerle. Lisboa: Fundação Calouste Gulbenkian, 1999.

101. KENNEDY, W. McNeil. Transactions by a Corporation In its Own Shares, in Business Lawyer, Vol. 19, 1963-1964.

102. KESSLER, Robert A. Share Repurchases under Modern Corporations Laws, in Fordham Law Review, Vol. 28, 1959/1960.

103. KITANOFF, Alexander, Der Erwerb eigener Aktien: Aktienrückkäufe und Interessen der Gläubiger, Aktionäre und des Kapitalmarkts, Peter Lang, Zürich, 2008.

104. KRAAKMAN, Reinier R. e outros; The Anatomy of Corporate Law, $2^{\mathrm{a}}$ ed., Oxford University Press, Reino Unido, 2010.

105. KRAAKMAN, Reinier R. e GILSON, Ronald J. The Mechanisms of Market Efficiency, in Virginia Law Review, Vol. 70, N. ${ }^{\circ}$ 4, Fifty Years of Federal Securities Regulation: Symposium on Contemporary Problems in Securities Regulation, 1984, pp. 549-644.

Efficiency Twenty Years Later: The Hindsight Bias, 2003.

106. LACERDA, J.C. Sampaio de. Noções Fundamentais sobre Sociedades Anônimas, Ed. Nacional, Rio de Janeiro, 1956.

107. LANGEVOORT, Donald C. Taming the Animal Spirits of the Stock Markets - A Behavioral Approach to Securities Regulation, in Georgetown University Law Center, 2002 Working Paper Series in Business, Economics, and Regulatory Law, Working Paper No. 305241, 2002.

108. LAMY FILHO, Alfredo. Temas de S.A., Renovar, Rio de Janeiro, 2007.

109. LARENZ, Karl. Metodologia da Ciência do Direito, tradução de José Lamego, $4^{\text {a }}$ Ed., Fundação Calouste Gulbenkian, Lisboa, 2005. 
110. LAWLESS, Robert M., FERRIS, Stephen P e BACON, Bryan. The Influence of Legal Liability on Corporate Financial Signaling, The Journal of Corporation Law, Vol. 23, 1998, pp. 210 a 243.

111. LEÃES, Luiz Gastão Paes de Barros. Do Direito do Acionista ao Dividendo, Tese de Concurso, 1969.

Anônimas, RT, São Paulo, 1989.

- Estudos e Pareceres sobre Sociedades

. Pareceres, Vol. I, Ed. Singular, 2004.

José Bushastsky, São Paulo, 1976. Direito Comercial : Textos e Pretextos,

- Conflito de Interesses e Vedação de Voto nas Assembléias das Sociedades Anônimas, Revista de Direito Mercantil, Industrial, Econômico e Financeiro, Malheiros, São Paulo, nº 92.

112. LEVY, Irving J. Purchase by a Corporation of its Own Stock, in Minnesota Law Review, Vol. XV, N. ${ }^{\circ} 1,1930$.

113. LIPTON, Martin. Takeover Bids in the Target's Boardroom, in The Business Lawyer, Vol. 35, 1979-1980.

114. LOBO XAVIER, Vasco da Gama. Anulação de Deliberação Social $e$ Deliberações Conexas, Atlântida Editora, Coimbra, 1976.

115. LÔBO, Paulo Luiz Netto. Teoria Geral das Obrigações, Saraiva, São Paulo, 2005.

116. LOPES, Mauro Brandão. Aquisição das Cotas Sociais pela Sociedade, in Revista de Direito Mercantil, Industrial, Econômico e Financeiro, n. ${ }^{\circ}$ 25, RT, São Paulo, 1977, pp. 55 a 66.

117. LORENA DUTRA, Marcelo. A Nova Forma de Propriedade das Bolsas de Valores, Tese (Doutorado em Direito), Universidade de São Paulo, 2008.

118. LORIA, Eli. Estrutura e Função do Capital Social na Companhia Aberta, Dissertação (Mestrado em Direito), Faculdade de Direito da Universidade de São Paulo, 2009.

119. LUTTER, Marcus; HOMMELHOFF, Peter. GmbH-Gesetz Kommentar, $14^{\mathrm{a}}$ Ed., Dr. Otto Schmidt, 2004.

120. MALHEIROS FILHO, Arnaldo. Crime de Manipulação do Mercado de Capitais, in Marcelo Vieira von Adamek (coord.), Temas de Direito Societário e Empresarial Contemporâneos, Malheiros, São Paulo, 2011.

121. MALLEY, Robert J. Corporate Repurchases of Stock and the SEC Rules: An Overview, in Business Lawyer, Vol. 29, 1973/1974.

122. MARTINS, Fran. Comentários à Lei das Sociedades Anônimas, $3^{\circ}$ ed., Forense, Rio de Janeiro, 1989.

123. MARRONE, Matteo. Instituzioni di diritto romano. 3 ed. Palermo: Palumbo, 2006.

124. MASSA, Massimo, REHMAN, Zahid e VERMAELEN, Theo. Mimicking Repurchases, EFA 2005 Moscow Meetings Paper, 26 de fevereiro de 2005, disponível em http://ssrn.com/abstract=67450. 
125. MEISSEL, Franz-Stefan. Societàs - Struktur und Typenvielfalt des römischen Gesellschaftsvertrages, Band 3. Frankfurt am Main: Peter Lang, 2004.

126. MESSINEO, Francesco. Spettanza dei Dividendi Sulla Proprie Azione, Acquistata dalla Società, in Rivista delle Società, Vol. 11, Maio-Junho 1966, pp. 417 a 426.

127. MIRANDA, Pontes de. Tratado de Direito Privado, Parte Especial, Tomo L, $3^{\circ}$ ed., Borsoi, Rio de Janeiro, 1972.

128. MIRANDA JUNIOR, Darcy Arruda. Breves Comentários a Lei de Sociedades por Ações, Saraiva, São Paulo, 1977.

129. MOREIRA ALVES, José Carlos. Direito Romano. 14 ed. Rio de Janeiro: Forense, 2007.

130. MOSKOWITZ, Mark R. Corporate Stock Repurchases under the Securities Exchange Act of 1934, in Nebraska Law Review, Vol. 51, 1971.

131. MUNHOZ, Eduardo Secchi. Transferência de Controle nas Companhias sem Controlador Majoritário in Rodrigo R. Monteiro de Castro e Luis André N. de Moura Azevedo (coords.), Poder de Controle e Outros Temas de Direito Societário e Mercado de Capitais, Quartier Latin, São Paulo, 2010.

132. NEMMERS, Erwen Esser. The Power of a Corporation to Purchase its Own Stock, in Wisconsin Law Review, 1942.

133. NOBILI, Raffaele. Osservazioni in Tema di Azioni Proprie, in Rivista delle Società, Vol. 32, n. ${ }^{\circ}$ 3/4, maio-agosto de 1987, pp. 760 a 806.

134. NUSSBAUM, Arthur. Acquisition by a Corporation of its Own Stock, in Columbia Law Review, Vol. 35, 1935.

135. NUTTALL REVIEW OF EMPLOYEE OWNERSHIP, Julho de 2012.

136. OIOLI, Erik. Ofertas Públicas de Aquisição do Controle de Companhias Abertas, Vol. 1, Quartier Latin, São Paulo, 2010.

137. OTTANELli, Oriana. Acquisto di Azioni Proprie e Conseguente Riduzione del Capitale, in Rivista del Direitto Commerciale e del Diritto Generale delle Obligazioni, n. ${ }^{\circ}$ 3/4, março-abril de 1988, pp. 205 a 232.

138. PASTERIS, Carlo. Il "Controllo" nelle Società Collegate e le Participazioni Reciproche, Milano, Giuffrè, 1957.

139. PAPINI, Roberto. Sociedade Anônima e Mercado de Valores Mobiliários, $2^{\mathrm{a}}$ ed., Forense, Rio de Janeiro, 1988.

140. PENNINGTON, Robert R. Company Law, $7^{\mathrm{a}}$ ed., Butterworths, Londres, Dublin e Edimburgo, 1995.

141. PENTEADO, Mauro Rodrigues. Aumentos de Capital das Sociedades Anônimas, Saraiva, São Paulo, 1988.

142. PERSONS, John C. Signaling and Takeover Deterrence with Stock Repurchases: Dutch Auctions Versus Fixed Price Tender Offers, in The Journal of Finance, Vol. 49, N. ${ }^{\circ}$ 4, 1994, pp. 1373 a 1402.

143. PESSANI, Stefano Cacchi. Le Azioni Proprie nei Pressupposti delle Offerte Pubbliche di Acquisto Obbligatorie, in Rivista delle Società, Vol. 49, n. ${ }^{\circ}$ 2/3, março-junho de 2004, pp. 277 a 329. 
144. PIRES, Gudesteu. Sociedades Anonymas - Subsidios para a Reforma da Lei, Jornal do Commercio, Rio de Janeiro, 1935.

145. PONTES DE MIRANDA, Francisco Cavalcanti. Tratado de Direito Privado, $4^{\mathrm{a}}$ Ed., volumes I, XLIX, L, LI, RT, 1983.

146. POZZO, Barbara. L'acquisto di Azioni Proprie, Milano, Giuffrè, 2003.

147. PRADO, Roberta Nioac. Desconcentração do Poder de Controle e Poison Pills: Evolução no Mercado de Capitais Brasileiro in Rodrigo R. Monteiro de Castro e Luis André N. de Moura Azevedo (coords.), Poder de Controle e Outros Temas de Direito Societário e Mercado de Capitais, Quartier Latin, São Paulo, 2010.

148. RATHENAU, Walter. Vom Aktienwesen: eine geschäftliche Betrachtung, tradução para o português de LAUTENSCHLEGER JR., Nilson. Do Sistema Acionário Uma Análise Negocial, Revista de Direito Mercantil, Industrial, Econômico e Financeiro, n. ${ }^{\circ}$ 128, Malheiros, São Paulo, 2002.

149. REHME, Paul. História universal de derecho mercantil. Madrid: Editorial Revista de Derecho Privado, 1941.

150. REICHERT, Bernhard. Handbuch Vereins und Verbandsrecht, $10^{\mathrm{a}}$ ed., Luchterhand, München, 2005.

151. REPORT OF THE COMPANY LAW COMMITTEE. Her Majesty's Stationery Office, Cmnd. 1749, Londres, 1962.

152. REPORT OF THE HIGH LEVEL GROUP OF COMPANY LAW EXPERTS ON A MODERN REGULATORY FRAMEWORK FOR COMPANY LAW IN EUROPE, Bruxelas, 2002.

153. RICHTER JR., Mario Stella. Novo e Novissimo Regime dell'Acquisto delle Proprie Azioni, in Studi in Onore di Umberto Belviso, Cacucci, Roma, 2011.

154. ROBERT, Bruno. Dividendo Mínimo Obrigatório nas Sociedades por Ações Brasileiras - Apuração, Cálculo e Pagamento, Quartier Latin, São Paulo, 2011.

155. SAlOMÃO FILHO, Calixto. A Sociedade Unipessoal, Malheiros, São Paulo, 1995.

Paulo, 1998.

O Novo Direito Societário, $1^{\mathrm{a}}$ Ed. Malheiros, São O Novo Direito Societário, $3^{\mathrm{a}}$ Ed. Malheiros, São

Paulo, 2006.

"Societàs" com Relevância Externa $e$ Personalidade Jurídica in Revista de Direito Mercantil, Industrial, Econômico e Financeiro, v. 81, 1991, pp. 66 a 78.

156. SAMPAIO CAMPOS, Algumas Notas sobre a Utilização do Lucro do Exercício em Curso: Dividendo e Recompra, in Marcelo Vieira von Adamek (coord.), Temas de Direito Societário e Empresarial Contemporâneos, Malheiros, São Paulo, 2011.

157. SCHMIDT, Karsten, Gesellschaftsrecht, $4^{\mathrm{a}}$ ed., Carl Heymanns, Köln, 2002.

158. SCHULZ, Fritz. Derecho Romano Clásico. Trad. de José Santa Cruz Teigeiro. Barcelona: Bosch, 1960. 
159. SECURITIES AND EXCHANGE COMMISSION. The October 1987 Market Break, Fevereiro 1988, disponível em http://www.sechistorical.org.

. 17 CFR Part 240 [Release No. 34-40617; File No. S7-27-98].

17 CFR Part 240 [Release No. 34-41905; File No. S7-27-98].

17 CFR Parts 240, 243, and 249, [Release Nos. 33-7881, 3443154, IC-24599, File No. S7-31-99].

17 CFR Parts 228, 229, 240, 249, 270, and 274 [Release Nos. 33-8335; 34-48766; IC-26252; File No. S7-50-02].

. 17 CFR Part 240 [Release No. 34-61414; File No. S7-04-10].

. Division of Market Regulation, Answers to Frequently Asked Questions Concerning Rule 10b-18 ("Safe Harbor" for Issuer Repurchases).

160. SPINELLI, Luis Felipe. Conflito de Interesses na Administração da Sociedade Anônima, Malheiros, São Paulo, 2012.

161. STERRET, II, James K.; ACKERMAN JR., Thomas C. California's New Approach to Dividends and Reacquisitions of Shares, in UCLA Law Review, Vol. 23, 1975/1976.

162. STEWART JR. Samuel S. Should a Corporation Repurchase Its Own Stock?, in The Journal of Finance, Vol. 31, N. ${ }^{\circ} 3$, 1976, pp. 911-921.

163. STUBER, Walter Douglas. A Negociação com Opções por Companhia Aberta in Revista de Direito Bancário e do Mercado de Capitais, vol. 23, RT, São Paulo, 2004.

164. TAVARES BORBA, José Edwaldo. Direito Societário, $6^{\mathrm{a}}$ ed., Renovar, Rio de Janeiro, 2001.

165. TRINDADE, Marcelo Fernandez. Vedações à Negociação de Valores Mobiliários por Norma Regulamentar: Interpretação e Legalidade, in Marcelo Vieira von Adamek (coord.), Temas de Direito Societário e Empresarial Contemporâneos, Malheiros, São Paulo, 2011.

166. VANONI, Silvia. Contratti Derivativi su Azioni Proprie: Profili di Disciplina Societaria, in Rivista delle Società, Vol. 49, n. ${ }^{\circ}$ 2/3, março-junho de 2004, pp. 441 a 500 .

167. VALVERDE, Trajano de Miranda. Sociedade por Ações, $3^{\mathrm{a}}$ Ed., 3 volumes, Forense, Rio de Janeiro, 1959.

168. VAZ FERREIRA DA ROCHA, Maria Victória. Aquisição de Acções Próprias no Código das Sociedades Comerciais, Almedina, Coimbra, 1994.

169. VEIGA JUNIOR, Dídimo Agapito da. As Sociedades Anonymas - Commentario, Imprensa Nacional, Rio de Janeiro, 1888.

170. VERMAELEN, Theo. Repurchase Tender Offers, Signaling, and Managerial Incentives, in The Journal of Financial and Quantitative Analysis, Vol. 19, No. 2, 1984, pp. 163-181.

171. VIVANTE, Cesare. Instituzioni di Diritto Commerciale, $6^{\mathrm{a}}$ ed., Real Casa, Milano, 1905.

172. WALD, Arnoldo. Estudos e Pareceres, RT, São Paulo, 1972. 
173. WASTL, Ulrich e WAGNER, Franz. Das Phänomen der wechselseitigen Beteiligungen aus juristischer Sicht, Peter Lang, Frankfurt am Main, 1997.

174. WARDE JÚNIOR, Walfrido Jorge. Responsabilidade dos sócios: a crise da limitação da responsabilidade e a teoria da desconsideração da personalidade jurídica. Belo Horizonte: Del Rey, 2007.

175. WIEDEMANN, Herbert. Gesellschaftsrecht, Band I (Grundlagen), Beck, München, 1980.

Beck, München, 2004.

Gesellschaftsrecht, Band II (Personengesellschaften),

176. WOODS, Donald H. e BRIGHAM, Eugene F. Stockholder Distribution Decisions: Share Repurchases or Dividends?, in The Journal of Financial and Quantitative Analysis, Vol. 1, N. ${ }^{\circ}$ 1, Proceedings of the First Annual Meeting of the Western Finance Association, 1966, pp. 15 a 26.

177. WORMSER, I. Maurice. The Power of a Corporation to Acquire Its Own Stock, The Yale Law Journal, Vol. 24, N. ${ }^{\circ} 3,1915$, pp. 177 a 188.

178. WYMEERSCH, Eddy. Reforming the Second Company Law Directive, WP 200615, University of Gent, novembro de 2006.

179. YALE LAW REVIEW, Buying Out Insurgent Shareholders with Corporate Funds, Vol. 70, 1960/1961.

180. YAZBEK, Otavio. Regulação do Mercado Financeiro e de Capitais, Elsevier, Rio de Janeiro, 2007. 